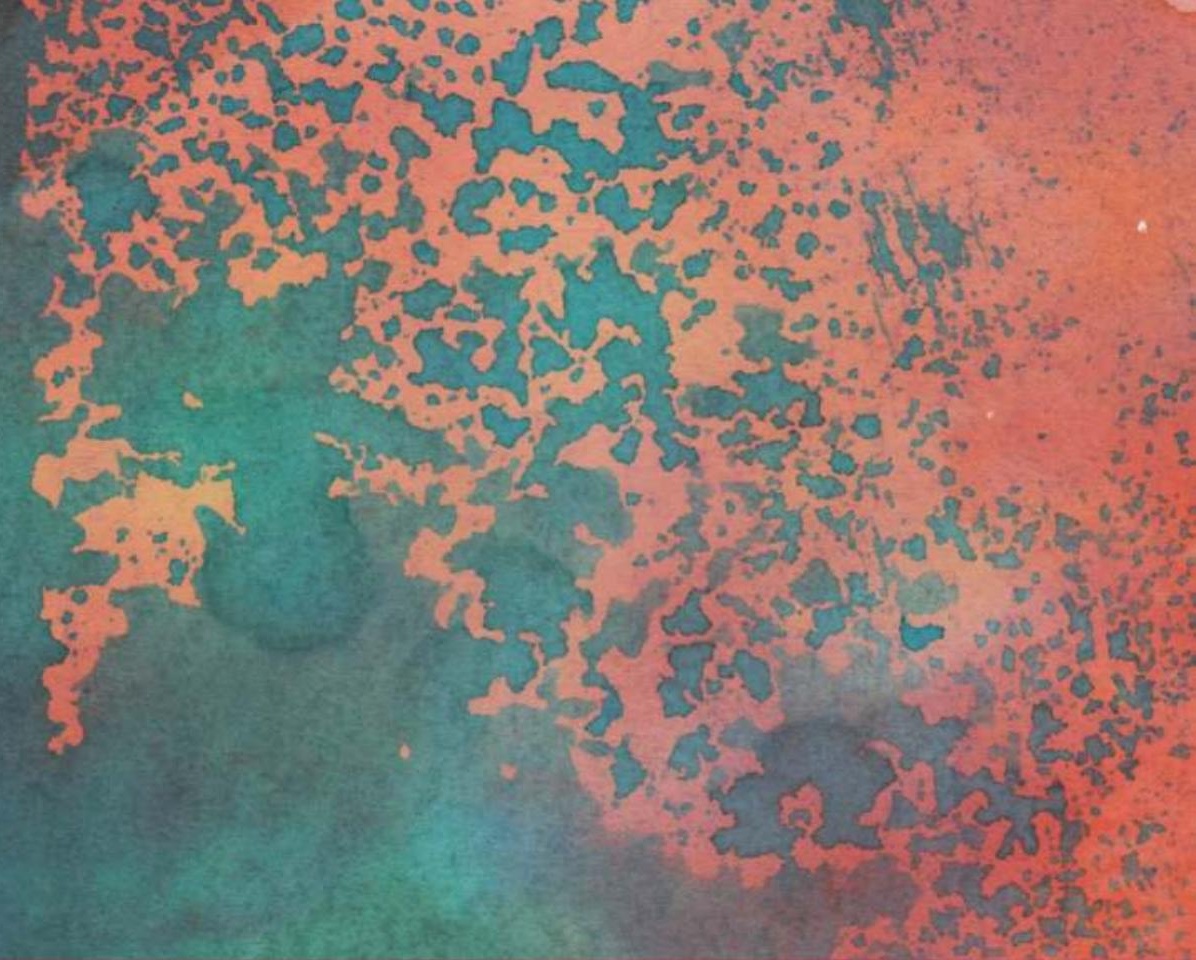

\title{
ANTHOLOGY OF ARABIC DISCOURSE ON TRANSLATION
}

\author{
Edited by
}

Tarek Shamma and Myriam Salama-Carr
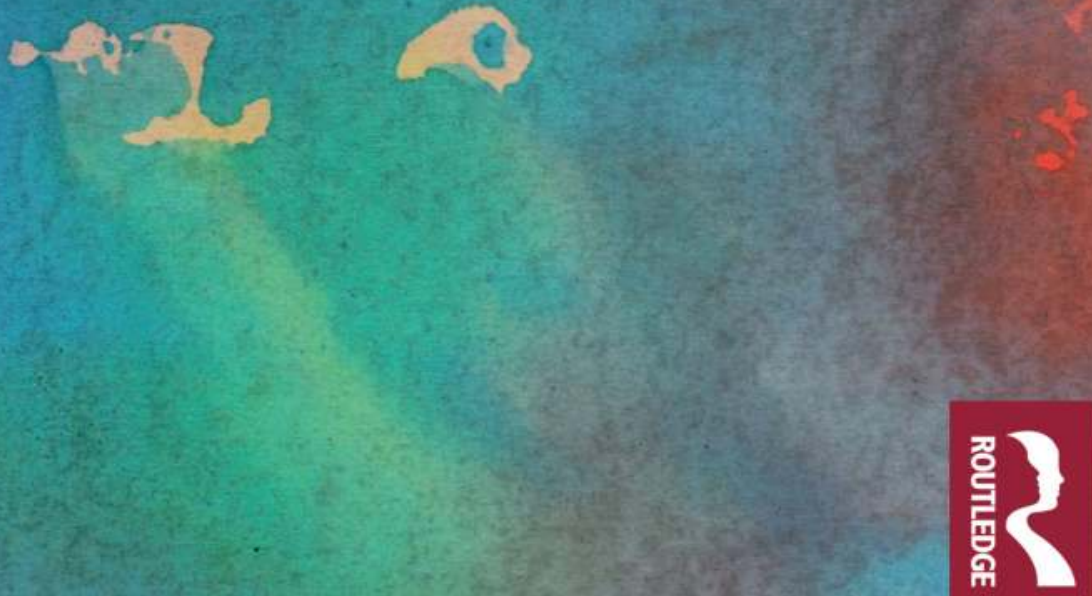


\section{Anthology of Arabic Discourse on Translation}

This anthology brings the key writings on translation in Arabic in the pre-modern era, extending from the earliest times (sixth century CE) until the end of World War I, to a global English-speaking audience. The texts are arranged chronologically and organized by two historical periods: the Classical Period, and the Nahda Period. Each text is preceded by an introduction about the selected text and author, placing the work in context, and discussing its significance.

The texts are complemented with a theoretical commentary, discussing the significance for the contemporary period and modern theory. A general introduction covers the historical context, main trends, research interests, and main findings and conclusions. The two appendices provide statistical data of the corpus on which the anthology is based, more than 500 texts of varying lengths extending throughout the entire period of study. This collection contributes to the development of a more inclusive and global history of translation and interpreting.

Translated, edited, and analyzed by leading scholars, this anthology is an invaluable resource for researchers, students, and translators interested in translation studies, Arab/Islamic history, and Arabic language and literature, as well as Islamic theology, linguistics, and the history of science.

Tarek Shamma is Associate Professor in comparative literature and translation studies at Binghamton University, NY. His recent publications include "In Search of Universal Laws: Averroes' Interpretation of Aristotle's Poetics", in World Literature (2021) and "Universal Wisdom, Islamic Law: Translation Discourse in Classical Arabic", in The Routledge Handbook of Translation History (2021).

Myriam Salama-Carr is Honorary Research Fellow at the University of Manchester, Centre for Translation and Intercultural Studies. She is the author of La Traduction à l'époque abbasside (1990). Her recent publications include "Mapping an Arabic Discourse on Translation" in The Routledge Handbook of Arabic Translation (2020), and "L’École de Bagdad", Équivalences (2020).

Mona Baker is Professor Emerita of Translation Studies, Centre for Translation and Intercultural Studies, University of Manchester, UK. She is the author of In Other Words: A Coursebook on Translation (Routledge, third edition 2018) and Translation and Conflict: A Narrative Account; and editor of the Routledge Encyclopedia of Translation Studies (Routledge, third edition, 2020). 


\section{Translation Studies in Translation}

Series Editors: Brian James Baer and Yifan Zhu

Translation Studies in Translation is a book series dedicated to providing high-quality scholarly translations into English of previously untranslated works on translation- and interpreting-related phenomena primarily from the Global South. Welcoming a variety of formats, ranging from monographs to collections and anthologies, the series seeks to model best practices in scholarly translation while also broadening our understanding of who counts as a translation theorist and what constitutes translation theory.

\section{Translation in the Arab World}

The Abbasid Golden Age

Adnan K. Abdulla

Fedorov's Introduction to Translation Theory

Brian James Baer

\section{Anthology of Arabic Discourse on Translation}

Edited by Tarek Shamma and Myriam Salama-Carr

For more information on any of these and other titles, or to order, please go to www.routledge.com/Translation-Studies-in-Translation/book-series/TST

Additional resources for Translation and Interpreting Studies are available on the Routledge Translation Studies Portal: http://routledgetranslation studiesportal.com/ 


\section{Anthology of Arabic Discourse on Translation}

Edited by

Tarek Shamma and Myriam Salama-Carr

Mona Baker (Consultant) 
First published 2022

by Routledge

4 Park Square, Milton Park, Abingdon, Oxon OX14 4RN

and by Routledge

605 Third Avenue, New York, NY 10158

Routledge is an imprint of the Taylor \& Francis Group, an informa business

(C) 2022 selection and editorial matter, Tarek Shamma and Myriam Salama-Carr; individual chapters, the contributors

The right of Tarek Shamma and Myriam Salama-Carr to be identified as the authors of the editorial material, and of the authors for their individual chapters, has been asserted in accordance with sections 77 and 78 of the Copyright, Designs and Patents Act 1988

All rights reserved. No part of this book may be reprinted or reproduced or utilized in any form or by any electronic, mechanical, or other means, now known or hereafter invented, including photocopying and recording, or in any information storage or retrieval system, without permission in writing from the publishers.

Trademark notice: Product or corporate names may be trademarks or registered trademarks, and are used only for identification and explanation without intent to infringe.

British Library Cataloguing-in-Publication Data

A catalogue record for this book is available from the British Library

Library of Congress Cataloging-in-Publication Data

Names: Shamma, Tarek, editor. | Salama-Carr, Myriam, editor.

Title: Anthology of Arabic discourse on translation / edited by Tarek Shamma,

Myriam Salama-Carr.

Description: London; New York : Routledge, 2021. |

Series: Translation studies in translation |

Includes bibliographical references and index.

Identifiers: LCCN 2021034842 | ISBN 9780367139377 (hardback) |

ISBN 9781032162621 (paperback) | ISBN 9781003247784 (ebook)

Subjects: LCSH: Arabic language-Translating | Translating and

interpreting-Islamic Empire. | Translating and interpreting-

Arab countries-History.

Classification: LCC PJ6170 .A58 2021|

DDC 492.7/802-dc23/eng/20211018

LC record available at https://lccn.loc.gov/2021034842

ISBN: 978-0-367-13937-7 (hbk)

ISBN: 978-1-032-16262-1 (pbk)

ISBN: 978-1-003-24778-4 (ebk)

DOI: $10.4324 / 9781003247784$

Typeset in Times New Roman

by Newgen Publishing UK 
To the memory of my father

(Abd al-Rahman Shamma, 1936-2017)

Tarek Shamma 


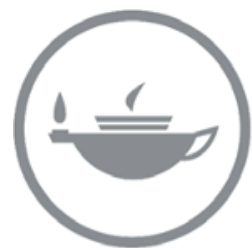

Taylor \& Francis Taylor \& Francis Group http://taylorandfrancis.com 


\section{Contents}

List of contributors $\quad$ xii

Acknowledgments xiv

Transliteration guide $\quad \mathrm{xV}$

Introduction 1

The Classical Period (c. 500 CE-1800 CE) 31

1 From $\underline{\text { Hadith }}$ and Islamic jurisprudence (632) 33

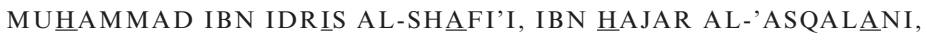

IBN QAIYM AL-JAWZIYA

2 Interpreters in Islamic Conquests (823) 39

ABU 'ABDULLAH AL-WAQQIDI, ABU JARIR AL-T́ABARI,

ABU AL-QASIM IBN 'ASA AKIR

3 Epistle Regarding What Was Translated of Galen's

books (859)

HUNAIN IBN ISHAQ

4 Book of Animals (869)

ABU 'UTHM $\underline{A}$ N AL-J $\underline{A H I D H}$

5 The Letter of 'Abdullah al-Hashimi to 'Abd al-Masih al-Kindi, Inviting him to Islam, and al-Kindi's

Response, Inviting al-Hashimi to Christianity

(ninth-eleventh centuries) 
viii Contents

6 Nabataean Agriculture (930)

ABU BAKR IBN WALHSHIYA

7 Debate on the Merits of Grammar and Logic (935) MATTA IBN Y $\underline{U} N U S, A B U$ SA'ID AL-SIRALFI

8 Explanation of the Torah in Arabic (941) SA'DIYA AL-FAY UMI

9 Meadows of Gold and Mines of Gems (957) ABU AL- $\underline{H} A S A N$ AL-MAS' $\underline{\text { UDI }}$

10 The Index (990)

MULAMMAD IBN ISHAQ IBN AL-NADIM

11 Approximating the Scope of Logic (1063)

IBN HAZM AL-ANDALUSI

12 Commentary on Aristotle's Poetics (1198) ABU AL-WALID IBN RUSHD (AVERROES)

13 History of Wise Men (1248) JAMAL AL-DIN AL-QIFTI

14 The Translation of the Samaritan Torah (The second half of the thirteenth century) ABU SA'ID IBN ABI AL-ḦUSAIN

15 The Chronicles of Time (late thirteenth century) UNKNOWN AUTHOR

16 Classes of Physicians (1270)

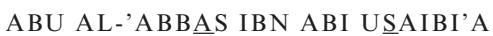

17 Treaties between Islamic States and Italian Cities (fourteenth-sixteenth centuries) ANONYMOUS

18 Collected Fatwas, Refutation of al-Jahmiya, Response to Those Who Have Changed the Religion of Christ (1328) 
19 Commentary on the L-Rhymed Poem (1363) SALAH AL-DIN AL-

20 The Reconciliation of the Fundamentals of Islamic Law (1388)

IBRㅁHIM AL-SHㅗIIBI

21 On the Fundamentals of Jurisprudence, On the Rules of Jurisprudence, On the Sciences of the Qur'an (1392) BADR AL-DIN AL-ZARKASHI

22 Ibn Khaldun's Journey (1406) 'ABD AL-RA $\underline{H M A N}$ IBN KHALD $\underline{\mathrm{U} N}$

23 The Craft of Composition (1418)

24 A Treatise on the Translation of the Qur'an (1542) (c. 1543) YALIA IBN 'ALI AL-RIFA'I

26 The Holy Scriptures in Arabic (1671) SARKIS AL-RIZZI

The Nahda Period (1800-1918)

27 The History of Al-Jabarti (c. 1822) 'ABD AL-RAㅂMㅁN AL-JABARTI

28 Document for Appointing Rifáa al-Tahtawi (1831): Promotion of Al-Tahtawi to the Rank of Amiralay (1846) MULAMMAD 'ALI PASHA

29 Speech Delivered at the Staging of The Miser (1848) 
X Contents

30 Translation of Robinson Crusoe (1861) 216 BUTRUS AL-BUSTANI

31 The Bible, that is the Old and New Testaments, Newly Translated from Hebrew and Greek Languages [The Protestant Translation of the Bible] (1865)

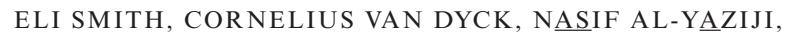
BUTRUS AL-BUSTANI

32 The Seekers' Guide to the Precious Bible (1869) SIMEON CALHOUN

33 Proofs of the Fundamental Truth of Christianity (1877) 230 JAMES SHEPARD DENNIS

34 Revealing the Hidden Arts of Europe (1866) AHMAD FARIS AL-SHIDIAQ

35 The Holy Bible (the Jesuit translation):

First Edition (1876-1881)

Second Edition (1897)

AUGUSTIN RODET, IBRㅁHIM AL-Y $\underline{A Z I J I}$

36 Official Documents about His Service as a Translator (1887-1896)

AHMAD ZAKI PASHA

37 Edifying Plays in the Art of Tragedy (1893) MUHAMMAD 'UTHMAN JALAL

38 The Tale of Qubul and Ward Jinna (1912) MULAMMAD 'UTHMㅁN JAL $\underline{\text { AL }}$

39 "Arabization" (1895) KHALIL BAIDAS, JURJI ZAIDANN

40 "Language and this Age" (1897) IBRAHIM AL-Y $\underline{\text { AZIJI }}$

41 Copyright of authorship and translation (1899-1905) 
42 Translation in Islamic history (1900-1912)

RASHID RIDA, SHIBLI NU'MANI, MUHAMMAD 'ABDO

43 Translation of Les Misérables (1903)

285

HAFIDH IBRAHIM

44 Homer's Iliad (1904)

291

SULAIMAN AL-BUSTANA

45 Celebrating the translator of the Iliad (al-Muqtataf magazine) (1904)

VARIOUS AUTHORS

46 Europe's Crime Against Itself and the World (1906)

A $\underline{H M A D}$ FAHMI

47 Guide for the Modern Translator (1906)

MULAAMMAD AL-SAIYD, MUL्HAMMAD

AWA $\underline{D}$ IBR $\underline{A} H \underline{I M}$, W. H. STEVENS

48 The Gospel of Barnabas (1908)

KHALIL SA'ADDA, RASHID RIDA

49 “Copyright Law" (1910)

ANONYMOUS

50 "Poetry and Poets" (1910)

AMIN AL-RIHANI

51 "Translation Lessons" (1912)

'ALI'UMAR AL-MISRI

52 " "La Marseillaise': History of the French National Anthem and its Translation into Arabic" (1918)

ERNEST NI'MATALLA

Bibliography

Appendices

Index 


\section{Contributors}

Ruth Abou Rached (Author and Translator) is an Honorary Research Associate at the University of Southampton (UK), specializing in teaching Translation Studies, Foreign Languages, and Arabic studies to widen university access to under-represented groups. Her recent book is Iraqi Women's Stories. She is editor for New Voices in Translation Studies.

Ali Almajnooni (Translator) is a published translator, fiction writer, and critic from Saudi Arabia. He is completing his doctoral studies in comparative literature and translation studies from Binghamton University. His Arabic translations include Nella Larsen's Passing, Carson McCullers' The Ballad of the Sad Cafe, and E. L. Doctorow's Ragtime.

Mona Baker (Consultant) is Professor Emerita of Translation Studies at the Centre for Translation and Intercultural Studies, University of Manchester, Director of the Baker Centre for Translation and Intercultural Studies (Jiao Tong University, Shanghai). Author of the Routledge Encyclopedia of Translation Studies (third edition, co-edited with Gabriela Saldanha, 2019).

Adam Gargani (Translator) read Classics with Oriental Studies at St Anne's College, Oxford, before pursuing a $\mathrm{PhD}$ in Applied Linguistics at the University of Salford, where he taught Arabic language, translation and linguistics. He is currently Teaching Fellow in Arabic Translation and Linguistics at the University of Leeds.

Sahar Othmani (Translator) is a Tunisian PhD student at Queen's University Belfast. She is working on an Arabic indirect translation of Han Kang's The White Book. She has made a career as a conference interpreter and content writer for several media and marketing enterprises in English, Arabic, French, and Korean.

Betty Rosen (Translator) is a PhD Candidate in the Department of Middle Eastern Languages and Cultures at the University of California, Berkeley, where she teaches Arabic and Middle Eastern literatures in translation. Her dissertation focuses on theories of language and poetics by Muslim and Jewish thinkers in thirteenth-fifteenth-century Egypt. 
Neil Sadler (Translator) is Senior Lecturer in Translation and Interpreting at Queen's University Belfast. His forthcoming monograph Fragmented Narrative: Telling and Interpreting Stories in the Twitter Age, examines the implications of the fragmentation characteristic of Twitter, and much contemporary communication more broadly, for narrative production and reception.

Lubna Safi (Translator) is a $\mathrm{PhD}$ candidate in the Department of Middle Eastern Languages and Cultures and in the Designated Emphasis Program in Critical Theory at the University of California, Berkeley. Her dissertation examines vision and poetic knowledge in the poetry and poetics of alAndalus and twentieth-century Morocco.

Myriam Salama-Carr (Author and Translator) is Honorary Research Fellow at the University of Manchester, Centre for Translation and Intercultural Studies (UK). Her recent publications include "Mapping an Arabic Discourse on Translation" in The Routledge Handbook of Arabic Translation (2020), and "L'École de Bagdad" in "Démythifier la traductologie", a special issue of Équivalences (2020).

Tarek Shamma (Author and Translator) is associate professor at the Comparative Literature Department and Translation Research and Instruction Program, Binghamton University, NY. He has also taught at universities in Syria, United Arab Emirates, and Qatar. His recent publications include "Translation Discourse in Classical Arabic", The Routledge Handbook of Translation History (2021). 


\section{Acknowledgments}

We would like to thank all our colleagues who have supported this project from its inception over the course of several years: Amal Al-Malki (Dean of the College of Humanities and Social Sciences) and Moneera Al-Ghadeer (former Director of the Translation and Interpreting Institute) at Hamad bin Khalifa University, Doha, Qatar; Luiza Moreira, chair of the Comparative Literature Department at Binghamton University; Routledge Series Editor Brian Baer for his insightful comments on an early draft of this book; and our research assistants (especially Yiyi Zhang and Turki Altamimi from Binghamton University), whose painstaking efforts have been key to the project.

We are grateful to the various libraries that allowed us access to rare and valuable documents.

The funding of different bodies at the University of Manchester, and in particular the Centre for Translation and Intercultural Studies, created the necessary academic and research environment.

Several grants from IASH (The Institute for Advanced Studies in the Humanities) and the Comparative literature Department at Binghamton University provided indispensable funding for the translation of many of the Arabic texts in this volume. These grants, together with a grant from the Center for Translation and Intercultural Studies of Shanghai Jiao Tong University, China, have funded the open-access publication of this book. 


\section{Transliteration guide}

We have used a simplified transliteration system without special characters. However, when Arabic words, especially names of cities, religious terms, dynasties, or historical periods have more or less standardized spellings in English (e.g., Damascus, Sanaa, Umayyad, Souq, Hanafi), we have used the common English forms.

\begin{tabular}{|c|c|}
\hline Consonants & Vowels \\
\hline $\begin{array}{l}\mathrm{l}=\mathrm{c} \\
\dot{ث}=\mathrm{th} \\
\tau=\underline{\mathrm{h}} \\
\dot{\tau}=\mathrm{kh} \\
\dot{j}=\underline{\mathrm{h}} \\
=\underline{=} \underline{\mathrm{s}} \\
ض=\underline{\mathrm{d}} \\
\dot{b}=\underline{\mathrm{t}} \\
\dot{b}=\mathrm{dh} \\
\varepsilon=, \\
\dot{\varepsilon}=\mathrm{gh} \\
\ddot{\theta}=\mathrm{q}\end{array}$ & $\begin{array}{l}\text { 1. Long: } \underline{a} \text { for } ', \underline{i} \text { for } \mathrm{u}, \underline{\mathrm{u}} \text { for } g \\
\text { 2. Short: a for }, \mathrm{i} \text { for }, \mathrm{u} \text { for }\end{array}$ \\
\hline
\end{tabular}




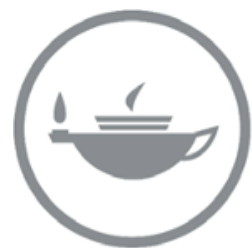

Taylor \& Francis Taylor \& Francis Group http://taylorandfrancis.com 


\section{Introduction}

\section{Translation in Arabic history}

Translation has played a central role in shaping modern cultures and societies. As Delisle and Woodsworth point out in Translators Through History:

Translators have invented alphabets, helped build languages and written dictionaries. They have contributed to the emergence of national literatures, the dissemination of knowledge and the spread of religions. Importers of foreign cultural values and key players at some of the great moments of history, translators and interpreters have played a determining role in the development of their societies and have been fundamental to the unfolding of intellectual history itself.

Arab history is no exception. In fact, it could be argued that - due to the unique geographical position of the region, its rich history, and the multicultural/multi-lingual nature of its communities - translation has played an especially significant part in Arab history.

\section{The early history of Arabic translation}

Arabic emerged and developed in an environment marked by multifaceted forms of interaction among various ethnic, religious, and linguistic communities. Due to its position at the meeting place of Europe, Africa, and Asia, in the same cultural sphere where some of the most ancient civilizations and three world religions emerged, the birthplace of the Arabic language, and later Islam, was characterized by cultural diversity in all stages of its history, stimulating at different at times relations of harmonious cohabitation as well as conflict.

Classical Arabic, the ancestor of Modern Arabic, reached its final stage of development in the pre-Islamic Arabian Peninsula (or simply "Arabia") before it was finally canonized as the vehicle for divine revelation through the Qur'an, and later as the official language of Islam. According to Islamic 


\section{Introduction}

tradition, Muhammad, the Prophet of Islam, was born in Mecca in 570 $\mathrm{CE}$, where he received revelation from God and started spreading the new religion. ${ }^{1}$ Persecuted in his birthplace, he and his followers migrated in 622 to the larger city of Medina, where he established himself as a religious and political leader. This event (the hijra, i.e., "migration") is used as the starting point of the Islamic calendar. From this new location, Muhammad and his followers continued to spread his message, and upon his death in 632, Islam prevailed all across Arabia.

From its earliest stages, and even during Muhammad's lifetime, Islam was a religion of global ambitions. Shortly before his death, Muhammad sent a military expedition into Byzantine-held Syria, and, according to Islamic tradition, dispatched (as early as 628) messengers to the rulers of the most powerful neighboring states of the time, including the Byzantine emperor Heraclius (see al-Bukhari, Chapter 1), the Sassanid Chosroes II, and Armah of Abyssinia, inviting them to convert to Islam. Muhammad's successors ${ }^{2}$ continued this policy, and within 20 years after his death, Muslim armies had conquered and destroyed the Sassanid Empire in Persia and Iraq, and had driven the Byzantines from Syria and Egypt, then North Africa. By the early eighth century, Islam commanded an empire extending from Spain and Southern France to the borders of India.

While relatively removed from the regional centers of power (mainly the Byzantine and Sassanid Empires), the milieu in which Islam arose, even in the heart of Arabia, was not isolated from the cultural and religious life of the Near East. The direct military presence of the Romans and Persians can be attested in Arabia as early as the second century (Fisher 2011: 75). Perhaps more importantly, Roman, then Byzantine, as well as Persian monarchs, established alliances with and exerted influence over local leaders throughout the Peninsula (Ali 1993, vol. 8: 117, 175ff; Fisher 2011: 75; see also Chapter 2). In addition, the Arabs of the Peninsula had strong cultural, political, and commercial links with the Arab communities in neighboring areas, especially with the Lakhmids in Iraq and the Ghassanids in Syria, who founded kingdoms that were allied with and were clients of the Sassanid and Byzantine empire, respectively.

In the Arabian Peninsula itself, significant numbers of Jews and Christians had lived for a long time in Yemen, where Jewish and Christian kingdoms existed through the fifth and sixth centuries (Robin 2012: 294). Jewish, and to a lesser extent Christian, communities also inhabited other parts of Arabia. In Medina itself, there was a well-established Jewish community. In fact, Christianity and Judaism were certainly well known to pre-Islamic Arabs. As Sydney Griffith explains, "Even a brief perusal of the Arabic Qur'ān is sufficient to convince the first-time reader that the text presumes a high degree of scriptural literacy on the part of its audience" (2013: 7), although it is not clear in what ways (e.g., written or oral) this knowledge was acquired.

All these forms of interaction created the need for translation. In fact, some sources mention professional interpreters and translators between Arabic and 
other languages who worked at the service of the monarchs of neighboring kingdoms. One of these was 'Udai Ibn Zaid al-'Abbadi (died c. 590), who was "interpreter and Arabic secretary to the Persian king Khosrow Parviz" (Ibn Qutaiba, al-Ma'arif: 649). According to Jawad 'Ali, "Persians employed some of the Arabs of the Peninsula for their Arabic communications, including the family of 'Udai Ibn Zaid al-'Abbad [...] and an interpreter who translated for Rustam [a Persian commander], called 'Abbud, who was an Arab from Al-Hirah" (1993, vol. 4: 227; see also Ibn 'Asakir in Chapter 2). Other historians mention the less likely possibility (Kaegi 1992: 262-263) of professional interpreters who worked for the Byzantine emperor (see Ibn 'Asakir in Chapter 2). Thus, translation and interpreting in their different forms have been a shaping force for Arabic cultures throughout their history.

\section{The Arabic terms for translation}

The modern Arabic term for translation is "tarjama" (ترجمة), and it has a long and complex history. Contemporaneous with the beginnings of early Arabic, it is bound up with the rich linguistic and cultural diversity that characterized the emergence of this language. While modern Arabic linguists have traced "tarjama" (through a process of back formation) to the root $t$ - $r$ $j$ - $m$, or even $r-j-m$ (Ryding 2005: 63), the word is almost certainly a borrowing from Akkadian (which flourished from the third - eighth centuries BCE), albeit through the mediation of Syriac, another Semitic language with which Arabic has had close affinities. In fact, the Akkadian "targumannu" ("translator") is the source of translation terms in several Semitic languages, including Aramaic and Hebrew (Alexander 1992: 320), even though the Akkadian word is hypothesized to be a borrowing from Luwian, an ancient near eastern language of the Anatolian family, closely related to Hittite (Guth 2017: 58). ${ }^{3}$

The earliest attested occurrence in Arabic of the word tarjama, or one of its derivatives, is found in the poetry of pre-Islamic Arabia in the form of "mutarjim" (c. $525 \mathrm{CE}$ ), which in the context meant "someone who interprets of explains." 4 The earliest occurrence of the word to refer to translation occurs in another poem (c. 600 CE) in the rare plural form "tarajịm" (الترائ). In this context, it referred to "the innkeeper's servants," and also to interpreters, as "wine sellers were non-Arabs who needed someone to explain their speech to people" (al- Mufaddal: 849). ${ }^{6}$ Thus, from the earliest times, tarjama combined other senses beyond translation and interpreting.

This complex genealogy-continued in later uses of the word where it acquired the added sense of "biography" - attests to the multiplicity, not only of the word tarjama, but of the very conceptions of translation in this language. For it is an important fact that in Arabic, well into the early twentieth century, there was no unique term (tarjama or otherwise) to designate the transfer of texts between different languages, nor was this activity itself distinguished from conceivably similar textual practices. As shown above, tarjama and its derivatives covered meanings as varied as "translation," "interpreting" 
(in its two meanings of verbal interlinguistic transfer and explanation), "clarification," and "biography," not to mention the apparently one-off instance of "innkeeper's servant." On the other hand, the activity of translation was covered by several, usually interchangeable, terms (besides tarjama): naql ("moving from one place to another" or "conveyance"), "Arabization," and, less commonly, "tahwill" ("conversion" or "transformation"), as seen in the anthology texts.

The aim of this etymological overview is not only to highlight the great variety in the terms used for translation as well as the perception of the activity itself, but also to point out the limitations of approaches that attempt to capture the supposed conception and function of translation in another culture (usually non-Western) on the basis of the (narrow) etymology of a single word in that language. Hence Maria Tymoczko's account of the Arabic word for translation (i.e. tarjama) as originally designating "biography," and consequently not requiring the faithfulness that is supposedly a feature of Western approaches to translation, as encapsulated in translatio ("carrying across"), the Latin root for the term in many European languages (Tymoczko 2007: 70-71; Fawcett and Munday 2009: 140). As shown here, tarjama has several senses, of which "biography" is only one - and neither the earliest nor the most common at that. ${ }^{7}$ It may be observed, by the way, that "naql" ("moving from one place to another"), one of the most common terms for translation in Classical Arabic, can be mapped to some extent to translatio ("carrying across").

On the other hand, the conceptions of translation's relationship to the original in Arabic were too complex to be captured by a general rejection of faithfulness. Many translators in the Classical age and the Nahda did adapt their sources to native beliefs and customs, sometimes in radical ways, but faithfulness was still a requirement at least in educational contexts (see, e.g., Omar al-Misri, Chapter 51) and in religious translation (see, e.g., discussions of the Qur'anic translation and commentary on Sa'diya). Furthermore, the importance of fidelity was theoretically recognized by some major Classical and Nahda scholars (such as al-Jahidh, al-Sirafi, and Uthman Jalal in this collection), ${ }^{8}$ even if some of them used it to question the very possibility of translation.

\section{Translation in Early Islam}

The emergence of Islam, as well as its later spread, were not divorced from the cultural and linguistic multiplicity of its environment, and the attendant translation activities. In fact, some Islamic scholars claimed that translation itself could be a medium for divine revelation. Sufyan al-Thawri, the eighthcentury muhaddith (complier of the Prophet's hadiths, i.e., "sayings and traditions") says that "Divine revelations were all delivered through Arabic, then every prophet translated for his people in their own language" (qtd. in 
Al-S uyuti, Al-Itqan: 163). On the other hand, the fifteenth-century polymath Al-S uyuti says that "God Almighty sent down sacred scriptures only through Hebrew, which [the angel] Jibril translated for every prophet into the language of his people" (Al-Lughat 19).

Of course, such interpretations were not widely accepted. Most scholars took the Qur'anic verse “And We have sent no Messenger save with the tongue of his people" (Ibrahim 14: 4) at face value. Yet, it is clear that translation was by necessity a matter of great importance for a religion with world-wide horizons, whose message was meant to be delivered to all people of the world, and one which sees itself as the continuation and culmination of a series of divinely inspired faiths (most notably Judaism and Christianity) that had emerged in the same wider region, albeit in different languages and environments.

Translation was certainly no less important for Christianity, which shares Islam's global reach and proselytizing spirit. These common ambitions, combined with different conceptions of translation (as shown below), enriched the study of the purpose and methods of translation, not only in each of these religions, but also in the long interaction between Islam and Arabic Christianity, some instances of which are documented in this anthology in the form of debates, collaborative work, and apologetics.

Even translation as an everyday practice can be attested from the earliest stage of Islam. One Prophetic hadith holds that Wirqa Ibn Nawfal, the cousin of Muhammad's wife Khadija, "used to write in Hebrew; he wrote from the Gospels in Hebrew," or, in another narrative, he "used to write from the Gospels in Arabic." Thus, Wirqa - who according to different sources was a Christian, a Jew, or a Hanif (i.e., someone who rejected polytheism and believed in one God) - either read the Gospels in an Arabic translation or translated it himself. According to Islamic sources, it was Wirqa's knowledge of the Bible and other scriptures that led him to accept the authenticity of Muhammad's revelation, and to affirm that his message was a continuation and revival of previous revealed religions.

The Qur'an itself, delivered to Muhammad though divine revelation, contained words that were recognized to be non-Arabic in origin, although it is a subject of debate whether these can be considered as truly foreign or adapted into Arabic phonetic structures and thus virtually Arabic (e.g., al-Zubaidi: 27). While some theologians have been defensive about these words (see al-Shafi 'i, Chapter 1), others cite them as evidence of the universality of the message of Islam. According to al-Suy $\underline{u t i}$,

The Prophet (Peace Be Upon Him) ${ }^{9}$ was sent to all nations. As God has said that 'We have sent no Messenger save with the tongue of his people,' then the book that was revealed to him must have items from the languages of all nations, even if it is originally in the language of his own people. 


\section{Introduction}

The first translator in Islam is said to be Zaid Ibn Thabit, a Companion of the Prophet, who was commanded by him "to learn the Book of the Jews," so he could "write the Prophet's letters and read the letters they wrote to him" (al-Bukhari, vol. 9: 76). In a different narrative, Zaid is asked to learn Syriac (al-Tirmithi: 365). Besides learning foreign languages, Zaid became the Prophet's official translator, who reportedly handled his communications with kings and heads of states outside Arabia. Zaid, we are told, "wrote to kings and responded to them in the presence of the Prophet (PBUH). He translated from Persian, Greek, Coptic, and Abyssinian, which he had learned in Medina from the speakers of these tongues" (al-Mas'udi, Al-Tanbịh: 245; Ibn 'Abd Rabbih: 244).

\section{Translation in the Classical Age of Islam}

With the spread of Islam outside the Arabian Peninsula, translation gained new momentum. During the Arab conquests themselves, interpreters were instrumental in communicating with the conquered populations, as well as with the opposing Byzantine and Persian armies (see al-Waqidi, al-Tabari, Ibn 'Asakir, Chapter 2). Then, as the nascent Islamic state evolved into a multi-ethnic and religiously diverse empire with international diplomatic relations, translation and interpreting became essential for communication at all levels of administration and government, in intellectual and academic life, and even in daily interactions. In particular, the foundation of fullfledged state institutions during the Umayyad Dynasty (661-750) created new administrative needs, as well as financial and institutional resources for the state patronage of translation.

While the Islamic commonwealth brought a new religion, administrative structures, and worldviews, previous socio-cultural structures and loyalties still obtained to varying degrees in all parts of the empire. Intelligentsia from pre-Islamic civilizations, even those who had converted to Islam, maintained some form of connection with their past heritage, which they drew upon through general references, direct borrowings, and translation. They often used their pre-Islamic heritage as a form of cultural repertoire, tapping it for ancient lore, scientific, literary, and historical knowledge, and for material sources in theoretical and practical disciplines.

On the other hand, the emergence and flourishing of new sciences and intellectual pursuits (including, among others, medicine, astronomy, chemistry, and philosophy) was supported by state sponsorship (especially with regard to access to, and translation of Greek science) under the early Abbasid Dynasty (750-1258). As Adnan Abdulla argues, "No other culture had ever invested so much time, effort, and money in translation" (2020: 134). In fact, this large-scale translation movement has been described as "a major event in the history of world civilization" (Montgomery 2002: 89) and "a truly epoch-making stage, by any standard, in the course of human history" (Gutas 1998: 8). 


\section{Translation in modern Arabic}

The nineteenth century ushered in the second major stage of translation in the history of Arabic. Translation, again as a major social and intellectual phenomenon, came this time from modern European languages. As a result, most notably, of contact with the West, and parallel to similar, often contemporary, historical developments in other non-Western countries (e.g., China and Japan), Arab societies went through a period of intensive intellectual change with the aim of "catching up" with the intellectual and technological advances of the West. Translation was a vital component of the intellectual life of this period, known in Arabic as the Nahda (النهضة), or "renaissance," which extended through the nineteenth and early twentieth centuries. Ttranslation flourished in the Levant, and especially in Egypt, leaving a major imprint on modern Arab societies - not only on their intellectual development but also on many aspects of their social, cultural, and political life. Specifically, translation was a primary vehicle of "modernization" and revival, introducing contemporary European thought and science, as well as new literary genres and techniques that launched a new phase of Arabic literature.

\section{Current research on Arabic translation history}

The outline provided above portrays the history of translation into Arabic as described in most sources on the topic. The texts selected for this book are intended to make available for translation scholars new Arabic sources, most of which never before translated into English and some published for the first time, to facilitate a more nuanced understanding of translation in the Arabic world and, in doing so, to contribute to the project of creating a polyphonic, rhizomatic history of translation.

The one point we need to emphasize here (to be discussed below in further detail) is the continuous relevance of translation in Arabic intellectual life throughout its history. There is no reason to disagree with the conventional wisdom that the Umayyad/early Abbasid and Nahda periods were major landmarks of translation in Arabic history (unprecedented in scope until the twentieth century). However, Arabic translation discourse (if not the practice of translation) persisted at varying levels of intensity and influence in all stages of this history, as evidenced by our collected corpus (see Appendices). Beyond debating its practical aspects, reflection on translation was firmly grounded in the intellectual, religious, and social life of Arab and Muslim communities in ways that warrant further study and analysis.

It is the continuity, versatility, and wider relevance of translation discourse that we aim to reveal through the primary sources presented in this volume. For the study of the history of translation in Arabic still falls short of its full, and very promising, potential. While translation in the golden age (in the Abbasid period, and to a lesser extent during the Nahda) is an important theme in historical accounts of these periods, relatively few studies have tackled the 
primary sources, i.e., the translations themselves and writings about them. Examinations of primary sources usually revolve around canonized and repeatedly analyzed texts (e.g., by al-Jahidh or Ibn al-Nadim), while rich sources of data (translations, paratexts, and writings about translation) that are scattered across all kinds of books, often dealing with topics other than translation, remain largely untapped. In fact, texts by well-known and widely studied authors in other fields (e.g., al-Shatibi, Ibn Taimiya) have yet to be studied from the perspective of modern translation studies (if studied at all). Furthermore, the periods that lie between the two translation movements, of the Islamic Golden Age and the nineteenth/early twentieth centuries Nahda, remain even less explored.

We can illustrate the dearth of primary sources on the translation movement in the Abbasid age with reference to the two systematic, largescale studies of the translation movement in that period: Dimitri Gutas's Greek Thought: Arabic Culture (1998) and George Saliba's Al-Fikr al-'Ilmi al-'Arabi: Nash'atuhu wa Tatawuuruh [Arab Scientific Thought: Emergence and Development] (1998). Gutas's interpretation of the official support of the translation movement (that it advanced the interests of the "Persian faction" by adopting the Sassanid official doctrine of political astrology) hinges on two Arabic translations of a Pahlavi text which had been taken from the Zoroastrian book the Dēnkard (Gutas 1998: 37-40). The first Arabic version, an anonymous translation, was available to Gutas only in a second-hand English translation of a manuscript that he had not seen (Gutas 1998: 37, footnote 16); the second, a translation by the Persian astrologer Ibn Nawbakht, is quoted in Ibn al-Nadim's al-Fihirst (1997: 38, footnote 19; see Ibn al-Nadim, Chapter 110). The same text, as cited in Al-Fihrist, is central to Saliba's own interpretation of the translation movement. Saliba collates ibn Nawbakht's text, cited in two versions in al-Fihrist, with two other narratives, taken from the same book (1997: 49-50 and 52-54; see Ibn al-Nadim), to provide a different account of the emergence of the translation movement. Based on

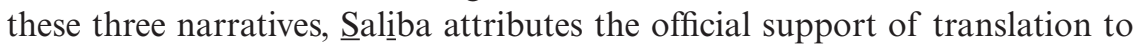
the influence of Syriac scholars who were trying to restore the privileges they had lost after the Arabization of the government administration under the Umayyad Caliphate (661-750) by instigating a translation movement in which, due to their knowledge of Greek, they would be indispensable.

The situation is no more encouraging in studies of translation in the Nahda. It is widely recognized that, throughout the nineteenth and early twentieth centuries, translation was instrumental to the intellectual, as well as material, renaissance of Arab societies. By all accounts, a tremendous number of European (especially English and French) works were translated. The first stage in the translation movement was initiated by Muhammad Ali, governor of Egypt between 1805 and 1848. As part of his efforts to modernize the country, Muhammad Ali sent student missions to Europe-first to Italy, then mainly to France - to acquire modern knowledge, science, and technology. Upon their return, students were instructed to translate European books that 
were needed to modernize the growing army and government administration (Al-Shaiyal 1951: 33ff). Thus, translations in that period focused on books of science, technology, and administration. The second stage in the translation movement spans the second half of the nineteenth, up to the early twentieth century. Most translations in that period did not enjoy official support: they were conducted by individual translators trying to meet the demands of a new and growing market, created by the "mushroom growth of non-governmental journalism" (Cachia 1990: 33).

Still, there has been relatively little research on the translations themselves, or the translators' methods, at least in the field of translation studies (as precious, although scattered information can be found in some philological works). Discussion of the translation movement during this period, as with Abbasid translators, tends to adopt a macro-level approach, investigating its role in the political and social debates of the period, and its contribution (actual or exaggerated) to the emergence of new literary genres, such as the novel and the theater, and the development of a new Arabic style. Little attention has been given so far to the investigation of the translated works, and, more relevant to our purposes, the discussion of translation, which was a major concern in the Nahda. Indeed, many intellectuals in that period engaged in debates on the strategies of translation, and the effect of translated works (negative and positive) on Arab societies in periodical articles, as well as in introductions to and notes on translated works. To illustrate the sheer size of the translation activity that still needs to be examined, we can cite the example of Tanius 'Abdo (1869-1926), a translator who is reported to have produced as many as 700 translations and adaptations (Moosa 1997: 108), including the first published Arabic translations of Shakespearean drama (Hanna 2016: 31). Thus, translated books in many fields, including introductions and commentaries, as well as debates over translation, especially in long-outof-print periodicals, constitute a wealth of data on translation discourse in Arabic that still awaits further study.

This anthology presents Arabic translation discourse from its original sources, sampled in texts that tackle translation from different angles and in various stages of the history of Arabic thought. Our aim is to contribute to a comprehensive survey of these sources, which could bring needed attention to texts that have hitherto been largely unacknowledged and highlight the need for a deeper investigation of this discourse from its original sources.

\section{The anthology}

This book is the outcome of a multi-year research project to locate pre-modern Arabic texts that deal with translation in the form of reflection, commentary, or discussion. The early stage of the project (involving the identification and collection of Arabic texts) was supported with a three-year grant from QNRF (Qatar National Research Fund), which started in 2015. The research team was comprised of Tarek Shamma (Binghamton University) as lead primary 
investigator, Myriam Salama-Carr (Manchester University) as a co-lead primary investigator, and Mona Baker as a consultant, in addition to research assistants from several universities in Qatar, the United States, and the UK. The translation of the Arabic texts into English was supported with a grant from Binghamton University's IASH (Institute for Advanced Studies in the Humanities) and Department of Comparative Literature.

The scope of the study extended from the earliest recorded instances of Classical Arabic (specifically the in pre-Islamic poetry of Arabia) in the early 6th century CE (Versteegh 2014: 8) until the end of World War I, which we set as the conclusion of the pre-modern and the start of the modern periods in the Arab World. Our choice of these dates is not based on a consensus among historiographers about the advent of the "modern age" in the Arab World, for modernity is not an easy concept to define in any discipline. In Arabic, it has often been the subject of heated disputes over ideological as well as methodological differences (see the discussion of the start of the Nahda period below).

While any choice is bound to be somewhat arbitrary, we have settled on this date for the conclusion of our historical scope for several reasons. World War I left profound global effects that in the Arab World were most dramatically represented by the demise of the Ottoman Empire, which had ruled the Arab East since the early sixteenth century. The turn of the twentieth century generally marked the end of the Nahda period with the completion of the profound changes that transformed all aspects of Arab communities throughout the nineteenth century: the traditional forms of government under the Ottoman Sultanate were replaced with modern state institutions; traditional education, based in the early nineteenth century on Qur'anic schools and university mosques, were replaced with modern grade schools and colleges; the judiciary system based on Shari'a [Islamic law] was replaced with modern legal codes; and finally Classical Arabic was replaced with Modern Standard Arabic. To be sure, other researchers with other priorities may have different perspectives. But the choice of exact dates is unavoidable, and one has to settle for the limitations of any option.

When the project boundaries (spatial, linguistic, and temporal) were discussed, it was felt that the Abbasid period and the Nahda were convenient landmarks to start from and finish with, particularly given the constant presence of the earlier period in the translation discourse of the Nahda (see Section 3.5). The texts of the anthology have thus been divided into two broad historical periods: the Classical age (sixth through eighteenth centuries $\mathrm{CE}$ ) and the Nahda (1800 to $1918 \mathrm{CE}$ ). In our initial plan, the anthology was designed to focus on the Nahda and on the "golden age of translation" in the early Abbasid Dynasty, and, to a much lesser extent, in the preceding Umayyad Dynasty, as the two landmark periods of translation activity in the history of Arabic. However, as we progressed further, and as more and more texts accumulated (at a rate we did not quite anticipate), it became clear that translation discourse (if not necessarily translation practice) was present over such long periods and at such a scale that it cannot be limited to two 
discrete stages. Dialogue on translation persisted after the Abbasid age, and practically through all successive periods, albeit at varying levels of intensity. As a result, we had to expand the scope of the first part of the book to span the entire pre-Nahda age, which raises the question of historical periodization (see the further discussion below).

It is this continuity that we aim to represent here. Drawn from a much larger corpus (see below), this anthology is intended to provide a cross section of translation discourse in Arabic, distributed over a variety of subjects and time periods.

\section{Methodology}

Texts were investigated in all contexts, disciplines, and intellectual pursuits, regardless of the author's ethnicity or geographic location. The research team probed translation discourse in all potential sources, including translation pratexts and works that addressed translation as a topic of discussion. Thus, the search covered a substantially wide scope, especially in the pre-Nahda period, in which translation was not seen as an independent discipline for which specialized works could be dedicated (see Initial Findings below). Consequently, works mined for texts in the Classical age (besides translated works, few of which contained any paratexts) included books on literature and linguistics (as the first candidates for inquiries into translation); philosophy, astronomy and medicine (sciences that, to a great extent, were established through translation); religious writings (Islamic, Christian, and Jewish), in which translation was sometimes an important topic of discussion in contexts of scripture translation and religious apologetics; and books of history and travel. Beyond previously published works, we have also examined a limited number of available manuscripts and found texts of great interest, some of which have been included in the anthology.

Translated works played a much larger part in our search in the Nahda period, as a significant number (though still a minority) of translators employed paratexts of varying lengths as introductions, and occasionally footnotes, in their translations. Other sources unique to this period included full works that dealt with translation as the major topic, and official documents that shed some light on the contemporary conditions of translation as a profession.

While our search focused on primary sources, we have also consulted secondary sources-mainly in English and Arabic, to a lesser extent in French, and occasionally in German. For studies of the historical periods under question (general reference works, as well as case studies), whether they deal with translation or other disciplines, such as literature, philosophy, linguistics, and science, sometimes cite or reference instances of translation discourse, even though these were often texts that have been published and discussed widely.

Published works (print and electronic) were identified using bibliographic sources and databases of all kinds. The primary investigators and research 


\section{Introduction}

assistants also consulted major public libraries (especially for rare works and manuscripts), including Qatar National Library in Doha, the Egyptian National Library and Archives in Cairo, the British Library in London, the School of Oriental and African Studies (SOAS) library in London, and the Bibliothèque Nationale de France in Paris.

Digital databases (while not always reliable) were very useful when used with care. These included, among others, the World Digital Library and the Internet Archive, as well as Arabic databases that were useful for Classical works, such as Alwaraq (الوراق) and al-Maktaba al-Shamila (المكتبة الثاملة), or for periodicals, such as Sakhr's Archive for literary and cultural journals. Many of the sources under study have been digitized in recent years, which greatly facilitated and sped up the search process.

Upon the completion of the search process, which spanned several years, the collected corpus was organized for analysis. The collected texts, classified by historical periods, were abstracted by research assistants to facilitate the primary selection process. As the corpus was examined for general trends, the researchers established the selection criteria (see below), as well as the general structure of the anthology and the general guidelines for commentaries. The texts were finally selected for the anthology by the primary investigators, in deliberation with the project consultant.

\section{The Corpus}

Upon completion of the search, the collected texts were combined into a single corpus (see Appendices). The collected material includes 543 texts, of widely varying sizes, ranging from thematic series of articles in the Nahda to brief notes of a few lines (in all periods, but especially in the Classical age).

In classifying the collected texts, we strove for comprehensive criteria. Texts were organized by historical periods of centuries for the Classical age and decades for the Nahda age. This was due to the great imbalance in the number and length of collected texts ( 360 for the 12 decades of the Nahda and 183 for the 11 centuries of the Classical age).

In addition to historical period, the texts were tagged by author and topic; the language(s) translated from/into or discussed in theoretical debates, if at all; and whether the extract was taken from a translated work (i.e., from its paratexts) or from an original work (i.e., an "independent source"). An additional criterion in the Nahda texts was the medium of publication: books, periodicals, and documents, besides a handful of manuscripts.

We have included full statistical tables for the collected texts in Appendices 1 and 2.

\section{Text selection criteria}

The texts having been collected, classified by period, and tagged, the primary investigators had to select the targeted total of 50 texts for the anthology, 
divided evenly between the two historical periods in question. This involved some very tough decisions, due to the magnitude of the collected material and its great diversity in terms of potential research interest. After deliberations about the aim of the anthology and intended uses and audience, we agreed about the following criteria. (We strove to provide a balanced representation of the main trends in the collected material and to connect them as much as possible to contemporary historical problems, literary, political, social, etc., and modern concerns, especially in translation studies):

1. Originality: comprising texts that have not received sufficient attention, especially those dealing with new topics or tackling a common topic from a different angle.

2. Impact and wide recognition: complementing the above criterion. Some texts, though widely known and studied, cannot be left out of an anthology of this kind, due to their influence on contemporaries and/or modern scholars.

We found it necessary to maintain some balance between the above two criteria. While there is little point for the bulk of the material to rely on canonical and extensively discussed texts (albeit within the comparative context of an anthology), it would be misleading to confine the selection to obscure and little-known texts, creating an unbalanced view of the collected material and the intellectual trends reflected in it.

3. Size: While texts considered for selection were only those with a minimum amount of discussion of translation (i.e., beyond a mere reference), their lengths, as stated above, varied considerably. Due to the large size of the collected corpus, we decided to omit extremely short texts (of no more than several lines). Still, some of these were referenced or cited in commentaries on the selected texts when they were deemed to be significant, of special relevance to the issue under discussion, or worthy of further investigation.

4. Connection to significant social, political, or intellectual issues in the historical context of the text, and potential contribution to historical research.

5. Relevance to modern translation studies or related fields, particularly with the aim of de-centering translation studies.

6. Relevance to current problems in Arabic studies - intellectual, cultural, or sociopolitical.

We were careful to maintain a balance among the three criteria above. We strove to underline the immediacy and currency of the issues raised in these texts, without unduly ignoring their historical context or subjecting them to modern perspectives which diminish the historicity of these texts and their embeddedness in specific historical settings.

7. Variety: a principle of the selection process itself, where we tried to maintain a multiplicity of topics, issues, and theoretical approaches, and to reflect as broad a historical range as possible. 


\section{Translation anthology as cultural representation}

Over the course of its rather short history, translation studies has undergone several putative "turns": the "cultural turn," the "audiovisual turn," the "international turn," the "postcolonial turn," the "power turn," among others. While such terms do not point to a major change of direction for the whole discipline (nor were they, one assumes, intended to do so by their progenitors), they do indicate how the field has been actively growing and expanding in various directions. One of the most consistent of these new directions in recent years has been the call to expand theoretical reflection on translation - its historical conditions, practices, and very definition - beyond the dominant Western framework (Gaddis Rose 2000; Hermans 2006; Hung and Wakabayashi 2014; Tymoczko 2007; Baer 2020).

An anthology dealing with a non-Western tradition would seem to fit naturally into these efforts. Hence, Martha Cheung's pioneering Anthology of Chinese Discourse on Translation (2006) was seen as an important contribution to "opening up translation studies to the world outside the West" (Baker and Saldana 2020: xx). Even more, and beyond relativizing "the Eurocentric mode that dominates the present scene" (Cheung 2006: 2), Cheung's project was committed to a more local cultural agenda: highlighting "translation as a form of cultural representation, and not merely as a process of interlingual communication."

To address the second of these potential objectives, this anthology is not intended as a project of cultural representation of Arab or Islamic culturemuch less their identity. Besides the obvious difficulties of applying the broad generalization to such wide populations over such a large span of time, an anthology of theoretical discourse on a specialized topic seems to be a very narrow vehicle for cultural representation. To be sure, cultural representation is not absent from this anthology: the debates and reflections sampled in the following pages could provide illuminating glimpses into the intellectual life of Arab and Islamic cultures, no matter how we choose to define them. Although an important byproduct, this is not an end in itself. Focused as it is on one aspect of intellectual production in Arabic (through tackled from numerous angles), this collection cannot be expected to provide a representative picture of Arabic intellectual heritage, neither in terms of the anthologized authors, nor of the selected texts themselves. For this picture is filtered through the single lens of translation, which is only one dimension of the context of political, intellectual, and literary history. For example, the fact that Bible translation occupies a more prominent position than Qur'anic translation in this anthology does not reflect their relative significance within the contexts of study, but the practical conditions whereby translation was the sole channel for the transmission of Christian and Jewish scriptures into Arabic, while the Qur'an exercised its enormous influence through its original language.

Addressing the Western bias in modern translation studies is less problematic. So, we find it necessary to situate the anthology relative to 
this undertaking and to explain why it is not central to it. While one cannot but appreciate the motives behind the drive to "incorporate non-Western experience" and the promise that it could take translation studies to new horizons, some reservations are in order. In a statement about the basic necessity of this endeavor, Maria Tymoczko explains:

the critique [of current translation research] has been simply that the field in fact includes a broader range of products, processes and contexts than has been explored heretofore and that, hence, translation theory is based on an incomplete sample of the actual data [...] The preponderant use of case studies from European cultures has limited the field's flexibility and acuity in understanding the practice of translation.

(Tymoczko 2014: 104)

Thus, the field, she continues, "needs more data with a broader range in order to evolve a general theoretical framework that will serve present needs, describe past practices and frame future developments" (ibid.).

This seems reasonable enough from a basic common-sense perspective. But singling out the exposition of non-Western views as the primary aim of investigating a translation tradition which happens to be non-Western involves several disputable assumptions - that labels such as "West" or "East" denote somehow homogeneous realities that can be identified objectively, that positions on translation are determined (or at least shaped in crucial ways) by their cultural contexts, that non-Western theories must be different just by virtue of their location, and, most problematically, that it is this difference that justifies our interest in them. Of course, few of these assumptions are stated explicitly, but they are implicit in the very orientation of this endeavor.

If we set the recovery of non-Western views on translation as the primary aim of investigating a translation tradition, we risk limiting our scope, and even our interpretation of phenomena, in serious ways. For even if we concede that we can recognize particular perceptions or practices of translation as characteristic to many (or most) Western linguistic communities, what reason do we have to suppose that their counterparts in other communities throughout the world must necessarily be different? There is no doubt that investigation will reveal important differences, but this should not be the goal of analysis; it cannot take precedence over what should be the main focus of research, which is simply to reveal what translation meant to particular people in this tradition at a particular place and time, regardless of whether it is similar to those in the West or not. If, on the other hand, we have "to watch with an attentive eye, to be sensitive to local customs and traditions, to pick out the unique features, to appreciate differences" (Cheung 2009: 32), we may end up with a partial, perhaps a slanted, image of the translation culture in question, which, in the process, paradoxically reasserts the Eurocentrism of the West as the measure by which other cultures are approached, even if in opposition. Thus, as Salama-Carr explains, "As research on other non-Western traditions 


\section{Introduction}

shows, the challenge to the researcher is to navigate between Eurocentric master narratives and the risks of essentializing given that an anthology will help reinforce an identity and privilege certain voices" (2020: 293). In fact, at least within the historical and geographical scope of this anthology, SalamaCarr argues that "several historians reject the East/ West construct when mapped onto medieval cultural exchanges and that Arab- Islamic historical thought was not entirely cut off from the rest of the world" (2020: 293; see also Kaye 1985). Many historians have questioned the value of "East" and "West" as categories, especially in the study of the premodern world (SalamaCarr 2020: 293; Baer 2020: 235; Baker and Saldanha 2020: xxvi). Within the field of translation studies, Andrew Chesterman (2014) has argued against the Western/non-Western division.

The most contentious aspect of these calls for cultural relativity in translation studies is the rather elusive notion of "culture" which seems to exert some kind of indescribable influence on people's thinking and behavior. To be sure, those who seek to expand the West-dominated theoretical perspective do not assume that certain intellectual positions are inherently and naturally Western, but are the product of political, social, and material conditions that, for several reasons, may have obtained more prominently in the West. But if this is the case, then it would seem far more instructive to investigate translation discourse in the context of these historical and material conditions on a-case-by-case basis, rather than resorting to such overarching and mystifying categories as "the West." What we miss if we persist in this narrow view (besides understanding a translation tradition on its own terms) is the chance to expand our perspective not only through differences, but through continuities and parallels that may seem uninteresting but could be just as important in attaining a wider perspective. This, it is hoped, would allow us to reconfigure translation studies not simply as a space of the "West" and its others, but, in Baer's apt metaphor, "as a rhizomatic plant, a decentralised, non-hierarchical model according to which different cultures crop up from a root system that extends horizontally" (2020: 234).

To be sure, we do not propose to drop culture as a unit of analysis altogether, but only to bear in mind that it is never consistent, homogeneous, or even coherent. We believe that intellectual debates and theoretical positions should be grounded in their historical and socio-political conditions, of which culture is a general encompassing framework, but not very meaningful as a category in and of itself.

\section{On the historical perspective}

\section{Chronological vs. thematic organization}

In the early stages of project, we had to settle on a methodology for organizing the anthologized texts. Two options presented themselves: chronological (by historical phases) or thematic (where texts are grouped by topics, 
such as "Qur'an Translation," "Religious Translation," and "Translating Philosophy").

Each method involves advantages as well as compromises. Thematic threads allow considerable consistency in text selection and commentary. Texts (even when written in different periods) can be linked by similar topics, revealing long-term historical trends, and allowing a more thorough analysis of the issues in question. In addition, duplication and overlap can be reduced in texts that deal with similar topics in different periods. This can be seen, for example, in jurisprudence and theological debates, where each author references and quotes his predecessors in a long chain sometimes extending from the Umayyad period up to the Nahda. Finally, an important advantage of a thematic focus is that it can expand the scope of selection, as a number of texts can be combined to highlight the various aspects of one topic. ${ }^{10}$

However, we concluded that the thematic organization would run into serious methodological and practical hurdles. For one thing, a similarity of topic may mask diverse implications arising from the different contexts. Even the recurrence of the same text through a citation in a later period may give it a different significance in a new environment and from a different authorial perspective. Practical difficulties would also be significant: one text may touch upon multiple topics and may be tackled from various theoretical perspectives, which would make it difficult to classify it under one category. Above all, the main problem with the thematic approach is that it imposes a coherence that may be completely artificial, as it reflects the researcher's own judgment of what issues may be of interest in a certain a group of texts (see also SalamaCarr 2020: 288-289).

Therefore, we eventually decided on a chronological organization, although it limits the selection somewhat and does not register links among chronologically detached texts. For the chronological order allows a better alignment with the texts' historical context, which is of prime importance in an anthology of this type. It was hoped also that this approach would help minimize the researchers' intervention - this while acknowledging that intervention is inherent in the very nature of the anthology as a selection of texts based on preset criteria, no matter how objective and comprehensive we have tried to make them. Still, we have not abandoned thematic connections completely. We have highlighted thematic continuities whenever possible through references or citations in the comments and other paratexts.

\section{Periodization}

The choice of a chronological order raises the thorny question of the periodization of Arab-Islamic history-how to define the major periods, and what historical landmarks may best denote the transition from one stage to another. Choices in this area do not only shape the presentation the texts; they could frame their reading and interpretation. Thus, even as we set the 
two periods of the Classical Age and the Nahda as the general historical backdrop, it proved more difficult than expected to mark their boundaries.

The Nahda seemed generally unproblematic in terms of its overall span. Yet, having decided on the end of World War I, as stated above, as the terminal date, it turned out far more problematic to define its starting point. A date that is bound to be interpreted as the commencement of the age of "modernization" in the Arab World has become a highly controversial question among Arab scholars and intellectuals in recent years. Although it is generally agreed that the late eighteenth and early nineteenth century saw a transition into a new age, divergent views about its genesis and causes have been bound up with conflicting political and intellectual positions.

In their study of the periodization in Arabic historiography, Hirschler and Savant argue that three parameters determine the process of periodization: space and subject matter, as they interact with agency (2014: 6). Hence, if we agree about the space and subject matter of the Nahda, were does the agency lie? What factors, in other words, started this process of "awakening" or modernization? The answer depends, in great measure, on defining the starting point of this period. Pointing to the French Campaign in Egypt and Syria (1798-1801), a position first expressed during the Nahda itself and still widespread today, attributes the start of modernity to contact with the external forces of Europe. Other scholars, however, identify earlier indigenous dynamics, such as the Ottoman Tanzimat reforms, whose genesis is dated as early as the late eighteenth century, although they reached their peak in the nineteenth century (Davidson 1973). In his highly influential Islamic Roots of Capitalism: Egypt, 1760-1840 (1979), Peter Gran argues that the genesis of modernism in Egypt can be traced to even earlier, predominantly internal economic developments. This debate is certainly far from resolved, and it is beyond the scope of this study to partake in it.

Therefore, we have decided on the start of the nineteenth century as a reasonable compromise. Besides being close to the timelines proposed by the various perspectives on this issue, this date is especially significant for the study of translation, as it is also close to the accession of Muhammad Ali as the ruler of Egypt in 1805. In fact, the reign of Muhammad Ali is itself a candidate as the starting point for the start of "modernization," and is undoubtedly a key event of the Nahda. It certainly inaugurated a large-scale, state-supported translation movement (often compared by contemporary and modern scholars to the Abbasid translation movement) and educational missions to Europe, from which students returned with the expertise and training to contribute to Muhammad Ali's modernizing projects, including the translation movement itself (see al-Tahtawi, Chapter 28).

Looking at the period preceding the Nahda, we face another problem of periodization. Conventional historiography divides the classical age of Islam by reigning dynasties - the Umayyad, Abbasid, Fatimid, etc. While this approach is still widely used (especially in educational settings), it has been subject to heated debate. It has become increasingly recognized that the 
cultural, intellectual, and even social, life of the community may not neatly coincide with the rise and fall of political regimes and the mainstream cultural systems they sustain. Thus, since the second half of the twentieth century, the study of history has become more and more pluralized. Moving away from the exclusive concern with political history and high culture, new fields of inquiry have explored "multiple, often overlapping histories, be they social history, cultural history, gender history, or historical anthropology" (Hirschler and Savant 2014: 13). As a result, periodization by dynasties became widely untenable, or at least one option among others. As Hirschler and Savant argue, these developments have been especially pertinent in the "field of Middle Eastern history [...] on account of the prominent position that dynastic periodizations have held" (ibid.: 6). And to be sure, this approach is especially pertinent to this study, which focuses on aspects of cultural, mostly nonpolitical, history without neglecting the close connections between the two.

One direct offshoot of these reevaluations has been calls for new chronological frameworks. In Arabic historiography, proposals have ranged from the integration of Islamic history into broader global frameworks to treating it as a separate process with its own internal dynamics (see Abu Shawk 2017: 83-99). Needless to say, these reevaluations have not resulted in an agreed-upon methodology of periodization; nor are they likely to, since they are inevitably grounded in different approaches to the study of history, not to mention sometimes overt, ideological orientations. The only reliable consensus is that conventional periodizations need serious reconsideration (e.g., see Abu Shawk 2017: 98; Bin Thair 2014: 44-45).

Still, the traditional dynastic periodization remains mostly prevalent in the historiography of Arabic translation, where studies identify specific high points, usually limited to the "golden age" of translation in the early Abbasid (and to a lesser extent Umayyad) Caliphates, and then during the Nahda (see Salama-Carr 2020: 287). In this regard, one of the major questions we have faced in designing and compiling this anthology is the extent to which the traditional periodization, which ties translation to dynasties and political systems, can provide a useable and effective framework for the study of translation discourse in Arabic history. The answer, based on our experience with the material under study, may reveal the strengths and weaknesses of the conventional approach to periodization and could help delimit its areas of applicability.

On the one hand, translation history seems to be relatively in harmony with the political history of the Islamic empire in its early stage. Translation in that period had political, diplomatic, and administrative functions that called for direct governmental interest and patronage. Examples can be found, among other fields, in the role of interpreting in Islamic conquests, the Arabization of the diwans (government departments) during the Umayyad Caliphate, and the patronage of translation by the Abbasids, where political events and the ideologies of the ruling classes were instrumental in directing translation activities. In later stages, the situation became far more complicated. Even 
before the fall of the Abbasid Caliphate in 1258, usually postulated as ushering in an age of decline in all fields, translation activities were far more complex, varied, widespread, and less connected to the central government, to be subsumed under the general heading of "translation in the Abbasid age."

More relevant to our purpose - notwithstanding the cessation of official patronage of translation, and even after the demise of the Abbasid Caliphate - translation discourse persisted (apparently unabated) in different contexts and in extremely varied geographical locales. Indeed, some of the collected texts (including introductions to translated works) are evidence of the continuation of some translation activity. Furthermore, the translation dialogue in these texts reveals links and continuities that transcend political vicissitudes.

The same principle (that translation can be linked to political history only when supported directly by the state) seems to apply to the internal periodization of the Nahda. Dynastic historiography seems to be a viable approach to translation during the reign of Muhammad Ali in the first half of the nineteenth century (1805-1849) when the bulk of translations by far were produced through government intervention. When official patronage ceased under most of Muhammad Ali's successors, the focus shifted to the efforts of individual translators who worked for publishing houses and private periodicals. These new dynamics caused a shift in the nature of translated works themselves, from a preponderance of technical and practical works (usually commissioned by state institutions) to less technical works, especially literary fiction, to meet the popular demand which now determined the selection and implementation of translated texts. ${ }^{11}$

These general observations aside, we have found that the multiplicity of factors that influence periodization are too complex to lend themselves to conventional categories. On the other hand, a new periodization of the history of translation is beyond the realm of this study, especially given the fact that, as indicated by current research and confirmed by our initial findings, research into translation history in Arabic is still in its early stages, whereas a substantial body of primary sources remains untapped (as indicated in Gutas 1998; Saliba 1998; Salama-Carr 2020; Santoyo 2006). Therefore, we have decided to abandon the original framework of the study which identified the early Abbasid age and the Nahda as the primary textual sources. Instead, we have divided the historical range of the study into two broad stages covering the Classical age and the Nahda period of early modernity.

We recognize these categories (especially the first one) to be rather sweeping in range. However, in the current state of research, we believe them to be more reliable than divisions based on clear-cut but artificial boundaries, which may ultimately do more to hinder than to facilitate the investigation of historical trends. Undoubtedly, further research will contribute to the formulation of a more accurate framework of periodization of the history of translation in Arabic. 


\section{A historical approach to translation}

While a historical perspective informed the process of organizing and categorizing the anthologized texts, to what extent is it effective in approaching and analyzing (and, for our purpose, commenting on) the individual texts? And how do we balance grounding in historical research with our grounding in modern translation studies.

Christopher Rundle argues that there are two approaches to the history of translation, depending on whether one's aim is to contribute to translation studies or to historical research. As he explains:

When we carry out research on translation history, we face a choice. Are we going to attempt to extrapolate the translation features we uncover in the historical context we are examining in order to contribute to a wider, general or more global history of translation - thereby also making our work more accessible to Translation Studies (TS) in general—or are we going to address those scholars who share our historical subject and introduce them to the insights which the study of translation can offer? In short, is translation the object of our research, or is it the lens through which we research our historical object?

While this anthology, as stated above, is addressed to translation scholars and those in related fields, we have found it essential to keep track of the historical context of each text. For we do not quite agree with the strict separation between a history-oriented and a translation-oriented approach. The two procedures seem to us to be inseparable. As we cannot arrive at a full understanding of a view of translation as situated practice without considering the historical milieu in which it was produced, so a historical analysis of the political, social, or cultural conditions of the text would be greatly lacking without an informed understanding of the practical and theoretical aspects of translation issues involved in the text.

To take as an example one of the anthologized texts: the late tenth-century debate between Matta Ibn Yunus and Abu Sa'îd al-Sirafi. In their discussion of translation, the two scholars raise linguistic and philosophical issues that are still relevant today, especially the contrast between a "universalist" and "relativist" view of linguistic and cultural difference. From a translation studies angles, it can be argued that this question has played a significant part in formulating translation strategies and shaping the translators', as well as the readers', attitudes toward translated texts. Indeed, the difference between universalism and relativism is at the root of the perennial dichotomy between free and literal translation, which has, in different manifestations, informed much of the debate on the theory and practice of translation. However, as we consider the debate from this side, we cannot overlook the historical situation, in which universalism and relativism reflected (indeed were manifestations of) opposing attitudes 


\section{Introduction}

toward the influence of foreign knowledge, specifically Greek philosophy, on Islamic thinkers. Hence, al-Sirafin's insistence (as a defender of the "traditional" disciplines) on the impossibility of translation (a natural outcome of his extreme relativism) stems as much from his rejection of Greek philosophy as from his views of language and culture per se. Similarly, Matta's staunch advocacy of its possibility is linked to his position as a logician and a translator of Greek philosophy, of which his universalism is possibly more an outcome than a cause.

Therefore, while investigating translation methods and perspectives remains our primary purpose, this should not detract from situating the texts within their immediate social, cultural, and political conditions, which in turn will greatly enrich our understanding of translation. But limiting our reading of the collected texts to a purely historical framework would blind us to their relevance to modern debates in ways that reveal their historical pedigree or enrich our understanding of the sociocultural functions of translation through a variety of historical and modern cases. While these connections may seem contrived to the historian, they are critical goals for the translation scholar's approach to history. At the same time, we should be careful (in pursuit of pioneers and historical precedents) not to project our modern viewpoint in ways that would isolate the texts from their contemporary connections and radically interfere with the nuanced comprehension of their significance. As Dirk Delabastita argues in his response to Rundle's position on the link between history and translation studies,

If history as a discipline (understood as focusing more on the specifics of the translation project being investigated) and translation studies (understood as aiming for more general models of translation) feel like forces pulling in opposite directions, it is still the task of the scholar to keep the dialogue going between the two.

(2012: 246)

\section{Initial findings/observations}

If there is one word to describe the history of translation in the Arabic tradition, as reflected in our collected corpus and, hopefully, in this anthology, it is diversity. Any sweeping generalizations would be problematic, especially at this stage when this tradition is still being explored and analyzed. Yet, the collected corpus constitutes a relatively large sample of Arabic translation discourse, which may allow us to point out trends as well as reflections and debates that may arguably be relevant to modern concerns in translation studies, Arabic and Islamic history, and related disciplines.

Below are our main initial findings/observations which we hope will stimulate further research into existing lines of research or initiate new ones:

- Translation discourse in Arabic continued throughout all historical periods, at an intensity and variety arguably higher than previously 
assumed. There is also evidence of translation practice (at least in some fields), contrary to at least the most pessimistic speculations that it ceased all together (see comment on al-Rifa'i, Chapter 25).

- As explained above, the division into two periods of thriving translation, at least when considering translation discourse as opposed to translation production, seems arbitrary and inaccurate.

- Aside from the translation of the Qur'an, prayer, and Islamic terms, which, due to the swift spread of Islam and the rising numbers of nonArab Muslims, called for immediate and practical solutions, translation thinking in the Classical Period did not start until later in the Abbasid period. Translation discourse flourished subsequent to the flourishing of translation itself. Thus, the Abbasid period was not necessarily the golden period for translation theory or translation conceptualization (as opposed to translation production). Aside from al-Jahidh's widely

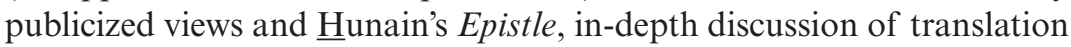
thrived in later times.

A comparable trend can be detected in the Nahda period. The first phase of extensive, state-sponsored translation under Muhammad Ali during the first half of the nineteenth century produced relatively little reflection on translation (most texts we collected from that period are limited to brief notices in introductions or epilogues to translated books). In contrast, translation discourse boomed in the second half of the century. One important difference to note is that the practice of translation, unlike in the Classical age, continued at steady rates through the whole Nahda period.

- One phenomenon that may help explain the above observation is that translators (especially in the Classical Age) do not seem to have themselves engaged in significant theorization about translation. This gap is especially striking in the case of translators who were themselves scholars and made intellectual contributions in other fields of knowledge (Salama-Carr 2000; Faiq 2000). Most discourse on translation was conducted by scholars in other disciplines for various purposes. In this respect, Hunain's Epistle seems to be the exception rather than the rule. A comparable disparity can be seen in the Nahda, where original scholarly works were a far more common vehicle for translation discourse than translation paratexts, which were mostly brief and cursory when used at all (see Appendices).

In this regard, what is absent from our corpus statistics (see Appendices), limited as they are to what is written about translation, is the large number of translations unaccompanied by any paratexts. This is especially apparent in articles and translated fiction in periodicals (the primary publishing venue in the Nahda), which rarely had any introductions or comments, other than the author's name, and occasionally the original venue of publication. In fact, some of these did not have introductory material, or actually any overt indication that the text is a translation. 
As an illustrative example, we examined a random sample of the 24 issues published in the year 1847 of the bimonthly al-Jinan, a well-known periodical edited by Butrus al-Bustani (himself a prominent translator). None of the 30 translated texts published in that year had an introduction longer than a brief notice, such as "a summary of what The Levant Herald said is translated below," "That letter was sent to the emperor of Austria, and it is a fine composition indeed. Below is translation of a part of it, especially the beginning," and "We have read in a European book the following story about the Arab caliph al-Ma'mun, translated below."

It is worth noting as well that many scholars in all ages (but especially in the Classical period) who discussed translation at length were not themselves translators. It may be that translators were more absorbed in the practical aspect of the activity.

- A related phenomenon is that theory and practice were not always closely linked. As stated above, reflection on translation did not necessarily derive from translation experience, nor did it seem to influence its practice. This is especially the case with prescriptive approaches, which subjected translation practice to pre-determined theoretical rules. This trend can be seen most plainly in theological discussions of translation, which drew directly on Qur'anic and Hadith exegeses and analogy with theological principles applied to translation from presumably similar practices. Hence, the disagreement about how many interpreters are required in trials stemmed from different interpretations of the "equivalent" case of court testimony (for which Islamic law requires two witnesses), regardless of the practical limitations which in most cases did not allow for the use of more than one interpreter (see al-Shafi 'i, al-'Asqalani, Ibn Qaiym).

- Rebecca Gould states that "no extant Arabic manifesto specifically adumbrates a methodology for translation" (2013: 85). Apart from the need to define what a "methodology" of translation is, it seems unrealistic to interrogate ancient scholarship for theoretical tools that belong to the modern age. ${ }^{12}$ Besides, Gould's statement overlooks sophisticated discussions of translation practice that can be seen as precursors of a modern translation methodology. In fact, it can be argued that Hunain's

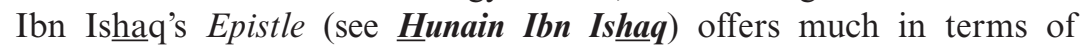
methodology. ${ }^{13}$

However, it is undeniable that translation in Arab-Islamic history was not seen as an independent discipline or an "art" in its own right, which is the case for much of medieval translation. Translation was not treated as such in the literature we have examined. Nor was it designated as an independent discipline in the several encyclopedic works that classified the branches of knowledge, scholarship, and arts in Classical Arabic. This was the case despite the thoroughness with which these works investigate disciplines and arts in all areas; some of them list arts and sciences such as housekeeping, dancing, and "burning mirrors." The only work we found that gives translation a separate classification is 
Abu al-Baqa ${ }^{\prime}$ al-Kafawi's Al-Kuliy $\underline{a}$ t (Totalities) (the second half of the seventeenth century), a dictionary of linguistic terms and distinctions. Here "tarjama" is defined as "the replacement of one word with another that can take its place, apart from explanation" (313). While al-Kafawi limits the scope of tarjama compared with its highly diverse uses in other contexts, his definition is not specific to inter-lingual transfer; it encompasses paraphrase or restatement without additional explanation, i.e., what is termed today "intralingual translation." This confirms our earlier observation that translation as interlingual transfer was grouped with different textual practices such as explanation, exegesis, paraphrase, and other forms of rewording. ${ }^{14}$

- Another period when translation practice was significant (especially politically and socially) is the Mamluk Sultanate (1250-1517) (see al-Qalqashandi, Chapter 23 and Treaties, Chapter 17). Areas of interest in this period include institutional translation at government offices (diwans) and interpreting, especially in the context of commerce, diplomacy, and even tourism (see, e.g., Wolff 2003).

\section{Recommendations for further research}

In our study of the collected corpus, we have identified promising areas in the history of translation in Arabic that have not yet received due attention.

The most significant of these include:

\section{Interpreting}

References to interpreters abound in all periods of Classical Arab history. With the early rapid expansion of Islam out of the Arabian Peninsula, increasing contact with the populations of the conquered countries created new communication needs. Some of the most dramatic of these cases can be found in early Islamic conquests of the larger Near East (see al-Waqidi, Chapter 2).

Interpreting is also a frequently referenced activity in Classical Arabic travelogues, such as those by Ibn Battuta (1304-1368), whose travels stretched between China and the Iberian Peninsula, and Ibn Fadlan (c.879-c.960), who travelled in Eastern and Northern Europe. Interpreting was also essential in multicultural and multilingual environments. Thus, Usama Ibn Munqidh's Al-I'tibar (Learning by Examples), one of the major Arabic accounts of the crusades, contains numerous accounts of daily-life interactions between the Arabic-speaking people of the Levant and the "Frankish" Crusaders, in which interpreting was instrumental. However, in most of these cases, the interpreter is mentioned in passing, without any details about the nature, or, much less, the problematics of their activities.

We also find examples of the widespread use of interpreting in various parts of the Islamic Empire, especially in the newly conquered regions where 
Arabs and non-Arabs (Muslim or otherwise) interacted on all levels of government and administration, not to mention daily life. In fact, there are accounts of interpreters mediating relations between Non-Arabic-speaking rulers and Arab subjects as early as the Abbasid period. The later part of the Abbasid Caliphate saw an increasing presence of non-Arabs in the highest echelons of government, which necessitated the use of interpreters. This was especially the case with Turkic military commanders who were an important force in the Abbasid Caliphate since the ninth century, as most of them did not seem to have mastered Arabic in the same way that Persian statesmen, administrators, and litterateurs had.

As stated above, interpreting was quite important during the Mamluk period, involving new languages in trade relations with Europe, especially Italian cities like Pisa, Florence, and Venice. In addition to Mamluks, at least the Hafsid Dynasty in Tunisia (13th-16th centuries) had trade relations with European cities, in which interpreters were central. In fact, interpreting seems to have been a specialized and often profitable profession in these times, where interpreters could also be assistants, commercial agents, and guides (see Treaties, Chapter 17).

\section{Community translation}

Further research is needed into the role of translation in mediating relations between Arabs and speakers of other languages in the conditions that emerged after the adoption of Arabic as the official language of administration, as well as the legal system, in regions where most speakers knew little Arabic. It is these needs that fueled Islamic legal debates about the possibility of using interpreting and translation in prayer, sermons, and other religious procedures.

Many examples can be found of the influence of interpreting in the communication or miscommunication between Arabic and non-Arabic speakers in daily-life interactions in these regions. To cite one example, the jurist Nur al-Din al-Yusi describes the strife that ensued in the Moroccan city of Sijilmasa from just such a misunderstanding. Some of the jurists of the city were subjecting "Muslim commoners" to interrogation about "the meaning of the word "ikhlas' ${ }^{15}[\ldots]$ It has become established among them that those who do not know the meaning of 'There is no god but Allah' [the opening verse of the sura], that is to say the negation and the affirmation ${ }^{16}$ as determined by scholars, are unbelievers"; as a result, "Muslim commoners were greatly alarmed and agitated" (al-Yussi 227). Al-Yussi then relates how he advised these scholars that literal understanding is hard for non-native speakers, and that it would be enough to have the basic meaning translated for them:

I told them: "This is the meaning of the word "ikhlas" that is required of you as an article of faith, whether you recognize its utterance or not. For 
the word is Arabic, and a non-Arab has no access to its significance. It is enough to have the import of the word translated for him to embrace it as an article of faith'.

(ibid. 228)

\section{Bible translation}

There has been a growing interest in recent years in Christian and Jewish religious writings in Arabic, including translations. While substantial, this heritage is only beginning to be explored, especially in translation studies. ${ }^{17}$ In particular, most studies in Arabic and English have focused on theological and doctrinal questions, sometimes from a modern polemical perspective. Little attention has been given in translation theory to the numerous Arabic translations of the Bible, ${ }^{18}$ which have existed since probably before Islam (see the hadith about Wirqa below), not to mention other religious texts in which translation figures prominently.

A promising line for further research would be to examine translation strategies and their changing implications in all periods, especially in comparison with Qur'anic style. Religious polemics, samples of which have been included in this anthology, also featured debates on translation, often touching on important theoretical issues in translation studies and linguistics. Another important area that the anthologized texts call attention to are the modern Arabic translations of the Bible. In addition to issues of style and rhetoric, which are highly significant in the long history of the Arabic Bible, these translations were linked to the profound social and intellectual developments in the nineteenth century in the Christian communities of the Arab East in, and their broader sociocultural environment.

\section{Qur'an translation}

It may seem surprising at first to include the translation of the Qur'an among areas warranting further exploration, as studies of the Qur'an's translation do not seem to be in short supply. Yet, current research - even in translation studies, and especially in Arabic, but not significantly less so in English ${ }^{19}$ - has been concerned for the most part with issues of $i^{\prime} j \underline{j} z$ (the miraculous nature of Qur'anic rhetoric and the possibility, or usually lack thereof, of translation into other languages), in addition to related linguistic, stylistic, and doctrinal questions (usually difficulties) in the process of translation. But, as even a cursory look at the ongoing debates about the translation of the Qur'an throughout Arabic history would show, the linguistic, stylistic, and cultural issues raised were not limited to i'ijaz and related questions. Some of them actually reveal original reflections on the theoretical and practical aspects of translation. No less interesting, in this regard, are other, less studied Islamic writings dealing with, among other things, prayer, sermons, and Islamic terminology in general. 


\section{Translation teaching}

Although translation instruction and training is a relatively new area in translation studies, several texts from the Nahda point to budding interest in this topic, seen in attempts to establish educational principles and strategies. Two factors seem to have been particularly pertinent here. Dar al-Alsun ("The House of Tongues"), first founded under Muhammad Ali's patronage in 1835 as "The School of Translation," saw the first translator training program in the Arab world. One of its graduates published a translator guide (perhaps the first of its kind in Arabic) that could give us a glimpse into its teaching methodology (see the commentary on al-Saiyd, Ibrahim, Stevens, Chapter 47). More broadly, educational reforms in the nineteenth century established modern public schools, which in due time integrated the teaching of foreign language (alongside, and eventually to the exclusion of Ottoman Turkish), and sometimes translation. Instrumental in this regard was the School Department, established upon Muhammad Ali's orders in 1837. But the transition to formal education was a slow and gradual process (Heyworth-Dunne 1938: 195197). Aside from private schools (specifically those established by European communities and governments in Egypt and the Levant), foreign languages entered educational curricula over a long period of time. First was French (for a long time the foremost foreign language in education, as in other fields), followed by English (Heyworth-Dunne 1938: 434-435). However, English gained rapidly in importance after the British occupation of Egypt in 1882, eventually becoming a mandatory subject in public schools.

A salient, though perhaps unsurprising, feature of early educational methods was the integration of translation with foreign language teaching to such an extent that they became practically indistinguishable. Translator guides and glossaries, which provide little discussion of translation (as opposed to language instruction), reflect a common approach to translation teaching in that period in Arabic, and perhaps in other language as well. Still, we have come upon translation curricula from the early twentieth century that use sophisticated methodology by the standards of the time, addressing translation techniques beyond proficiency in the two languages of translation.

\section{The anthology's divisions and text organization}

As stated above, the selected texts were organized chronologically into two periods (Classical and the Nahda). Naturally, especially with Classical texts, it was not always possible to determine the date of composition, in which case we used the author's date of death. In chapters combining several texts, we used the date of the first text.

Each chapter comprises a biographical note about the author(s) and a brief introduction to the extract, followed by the selected extract, and concluding with a comment by one of the anthology editors. The original title of the selected text is used as the chapter title, on the same page as the introduction 
and biographical note. We have also added titles to the selected extracts that indicate as much as possible the themes of the text and commentary; these are enclosed in square brackets. As explained above, texts from the same period dealing with a similar topic (and occasionally texts by the same author) were grouped together to highlight thematic connections. Sometimes this came out of necessity, as in the first and second editions of the Jesuit translation of the Bible. In these cases, we used a general title for the collection, followed by individual titles for each selection.

To underscore thematic connections, similar approaches, and salient trends, we have used extensive cross-references. For these we usually use the author's name or the title for anonymous works. References to other chapters are marked with italics (e.g., "Treaties," Chapter 17 and "al-Jahidh", Chapter 4).

Naturally, most texts were not excerpted in full. Omissions in the selected texts are marked as usual with ellipsis ("[...]"). Brief remarks, explanations, or connecting phrases inserted into the excerpted texts are marked with square brackets (" $\square$ "). Longer remarks were inserted in footnotes. When footnotes were used in the original texts, these were marked as such; all other footnotes are by the translators or editors.

Quite a few translations of the Qur'an are available in English. We have settled on Arthur John Arberry's version (1937), as it is addressed to the general English-speaking reader, rather than to English-speaking Muslims or academics.

We hope that this selection of texts succeeds in representing the diversity and complexity of Arabic discourse on translation by giving pride of place to both iconic texts and lesser known statements.

\section{Tarek Shamma}

\section{Notes}

1 In the elementary, though necessary, historical overview below, we have followed the conventional version of Islamic history, as accepted in its general outline by most historians. An evaluation of revisionist histories (themselves far from complete or agreed upon among revisionists) is beyond the scope of this book. More importantly, in taking the contemporary narratives at their face value (as in accounts of interpreting with foreign monarchs during Islamic conquests), we do not necessarily accept them as historical facts. We see them as components of the discursive universe on translation that produced the theoretical positions which are the topic of this book, above and beyond their historical authenticity.

2 Caliph, for Arabic "khalifa" ("successor"). Caliphs were supreme leaders of the Islamic polity ("the caliphate").

3 Another, less likely, etymology derives the word from Semitic root r-g-m ("to utter"/“to speak") (Lipiński 1997: 220).

4 Doha Historical Dictionary of Arabic https://dohadictionary.org/dictionary/ $\% \mathrm{D} 9 \% 85 \% \mathrm{D} 8 \% \mathrm{AA} \% \mathrm{D} 8 \% \mathrm{~B} 1 \% \mathrm{D} 8 \% \mathrm{AC} \% \mathrm{D} 9 \% 85$ 
5 Doha Historical Dictionary of Arabic https://dohadictionary.org/dictionary/ $\% \mathrm{D} 8 \% \mathrm{AA} \% \mathrm{D} 8 \% \mathrm{~B} 1 \% \mathrm{D} 8 \% \mathrm{~A} 7 \% \mathrm{D} 8 \% \mathrm{AC} \% \mathrm{D} 9 \% 8 \mathrm{~A} \% \mathrm{D} 9 \% 85$

6 The word also occurs much later in a poem by the Umayyad poet al-Farazdaq (642-732), where it unambiguously refers to interpreters or translators (al-Hawi 1983: 362).

7 With reference to Japanese, for example, Judy Wakabayashi suggests that "etymologically derived implications of certain terms sometimes run counter to translational reality" (Wakabayashi 2009: 175). Here Tymoczko's suggestion of a "cluster" concept (2007: 1085) may be useful.

8 Another example is the astronomer and polymath al-Bairuni. In his monumental account of India, he condemned the Abbasid translator 'Abdullah Ibn al-Muqaffa', who had translated the Pahlavi version of the Panchatantra. Al-Bairuni expressed his wish that he would translate the book himself, as "it was transmitted between Indian and Persian, then between Persian and Arabic by people who cannot be trusted not to change it" (111). Later in the same work, he complements translators who "were competent in language and not known for useless treason" (166).

9 A common term of respect that follows the Prophet's name, usually abbreviated as PBUH.

10 For an example of this approach, see Delisle and Woodsworth (2012).

11 Which does not mean that we can ignore the influence of higher political structures. For example, in the reign of Muhammad Ali's grandson Isma'il Pasha (18631879) restrictions on journalism were relaxed, leading to a surge in periodical and independent translations; under later monarchs, renewed restrictions had the adverse effect. Still, this political effect is only one among several factors that should be seen in conjunction.

12 The risk of mapping existing approaches onto past practices has been pointed out before with reference to medieval translation (see Pym 1998, Ellis and Evans 1994).

13 See, for example, Myriam Salama-Carr 1997. Interestingly, a modern Arab scholar has argued for Hunain's Epistle specifically as a "foundational manifesto" for Arabic translation ('Atiya 2012).

14 Ronit Ricci describes a similar situation in the Southeast Asian literary traditions of Tamil, Malay, and Javanese, where "translation was not necessarily viewed as a separate literary endeavor" (Ricci 2011: 42).

15 Literally "sincerity," this is the title of the 112th sura, chapter, of the Qur'an, which lays out the cornerstone of the Muslim profession of faith: the oneness and eternity of God.

16 i.e. negating the existence of any other god and affirming the existence of One God. "Allah" is literally "the god," as distinguished from "ilahh," literally "god".

17 For a rare approach to Arabic Biblical translation from a modern translation studies perspective, see Hanna 2018.

18 Samir Khalil estimates a number of over a hundred Arabic translations of the Gospels alone (Khalil 1983: 195).

19 See, for example, Abdul-Raof 2013. 


\section{The Classical Period (c. 500 CE-1800 CE)}




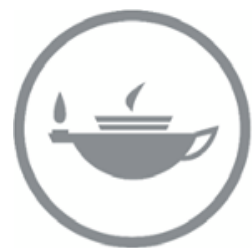

Taylor \& Francis Taylor \& Francis Group http://taylorandfrancis.com 


\title{
1 From $\underline{\text { Hadith }}$ and Islamic jurisprudence (632) ${ }^{1}$
}

\author{
Muhammad Ibn Idris al-Shafi'i, Ibn $\underline{\text { Hajar }}$ \\ al-'Asqalani, Ibn Qaiym al-Jawziya
}

\begin{abstract}
Abu 'Abdullah al-Shafi'i (767-820)
One of the four great Imams [religious leaders] of Sunni Islam, whose legacy on Islamic law gave rise to the Shafi'i school of fiqh (Islamic jurisprudence). $\mathrm{He}$ also wrote on Qur'anic exegesis and Hadith (the sayings and actions of Prophet Muhammad). Al-Shafi'i was also a poet. He wrote more than 100 books, including Kitab al-Umm (The Exemplar), the first exhaustive compendium of the Islamic code of law, and al-Risala (The Epistle).
\end{abstract}

\section{Al-Um (The Exemplar)}

A book on the branches of fiqh, language, Qur'anic exegesis, and $\underline{H}$ adith. It is considered one of the most important works on comparative fiqh, and an authoritative guide by the Shafi'i school.

\section{Ibn Hajar al-'Asqalani (1372-1449)}

A Shafi'i scholar of $\underline{H}$ adith and fiqh. He was born in Cairo and lived in Egypt for most of his life, despite traveling in several countries including Yemen, Hijaz (Iraq), and the Levant. His professional career followed the usual pattern of lecturer, and finally judge.

\section{Fath al-Bari: Sharh $\underline{\text { Sahih }}$ al-Bukhari (explanation of Al-Bukhari's Hadith collection)}

Ibn Hajar's commentary on the $\underline{H}$ adith collection by al-Bukhari, the most canonical $\underline{\text { Hadith }}$ source in Sunni Islam.

\section{Ibn Qaiym al-Jawziya (1292-1349)}

One of the most prominent Islamic jurists of his time. He lived in Damascus and studied under Ibn Taimiya (see below), with whom he maintained a close relationship. A controversial scholar like his mentor, he was imprisoned in 
the Citadel of Damascus along with him in 1326; he was released after Ibn Taimiya's death in 1328. He was best known for his great number of works on fiqh, Prophetic biography, and medicine.

\section{I'lam al-Muwaqqi'in 'an Rabb al-'Aalamin (Guidelines for Those Who Implement the Rules of God)}

The book discusses the fundamentals of fiqh, the purposes of Shari'a, the history of legislation, and the religious foundations of governance. It also includes a detailed study on a range of fatwas (formal legal opinions by qualified Islamic jurists) concerning various issues.

\section{[TRANSLATION/INTERPRETING FOR JUDGES AND RULERS]}

\section{[From al-Bukhari's collection of $\underline{\text { Hadiths] }}$}

\section{A chapter on translating for judges, and if one interpreter is admissible}

- Kharija Ibn Zaid Ibn Thabit said that Zaid Ibn Thabit said: "The Prophet (BPUH) ordered me to learn the writing of the Jews. I even wrote letters on behalf of the Prophet (BPUH) to the Jews and also read the letters they wrote to him.

- 'Umar (Ibn al-Khattab) ${ }^{2}$ said in the presence of 'Ali [Ibn Abi Talib], 'Abd al-Rahman, and 'Uthman [Ibn 'Affan]: "What is this woman [who did not speak Arabic] saying?"'Abd al-Rahman Ibn Hatib said: "She is telling you about her companion who has committed adultery with her."

- Abu Jamra said: "I used to interpret between Ibn 'Abbas [an eminent scholar] and the people." Some people said: "A judge should have two interpreters."

- [a hadith narrated by 'Abdullah Ibn 'Abbas $]$

Abu Sufian Ibn Harb recounted that Heraclius had sent for him, along with the members of a Quraish caravan. ${ }^{3}$ Then he said to his interpreter: "Tell them that I want to ask this [Abu Sufian] a question. If he tells me a lie, you should contradict him." So Abu Sufian related the whole narrative, whereupon Heraclius said to his interpreter: "Say to him, 'If what you say is true, then he [the prophet] will take over the place underneath my feet'."

[COMMENTS BY ISLAMIC SCHOLARS ON THE $\underline{H A D I T H S}$ CITED BY AL-BUKHARI]

\section{Al-'Asqalani, explanation of Al-Bukhari's $\underline{\text { Hadith }}$ collection}

Now al-Bukhari's statement "if one interpreter is admissible" indicates the disagreement on this point [...] Accepting one interpreter as sufficient in 
the opinion of the Hanafi school of fiqh [...] According to Al-Shafi'i (and reflecting the prevalent opinion among the Hanbali school), if the judge does not know the language of a litigant, then only two competent interpreters are acceptable. For the interpreter would convey to the judge what is not accessible to him concerning governance, a case that requires all the conditions of competency, as in giving testimony. ${ }^{4}$ The interpreter would also inform the judge of something that he does not know, as in communicating to him a statement from outside his court.

Then al-Bukhari excerpted part of the narrative of Abu Sufian with Heraclius [...] the purpose of which lies in the part "Heraclius said to his interpreter: 'Tell him'," etc.

Ibn Battal said: "Al-Bukhari did not include the Heraclius narrative as evidence that a non-Muslim interpreter is admissible (as Heraclius' interpreter was an adherent of the faith of his people [i.e., a Christian]), but to show that interpreters in other nations were treated as informers, not as witnesses.

In his al-A $\underline{h}$ kam (Legal Judgments), al-Muhib al-Tabari mentioned using one interpreter as sufficient, referencing the hadith of Zaid Ibn Thabit and the reports about 'Umar and Ibn 'Abbas. He said: "Those who opined for one interpreter used the overt meaning of these narratives as evidence" [...]

As for the narrative of 'Umar with the woman, it seems from the context that it concerned legal judgment, for 'Umar absolved the woman from the legal punishment for adultery, owing to her ignorance that this practice was forbidden, after he had formally charged her and had been about to implement the punishment to her. In this, he relied on the information provided by one person who translated from her language.

The narratives of Abu Jamra with Ibn 'Abbas, and that of Heraclius (where interpreting was purely informative), may have been cited by way of support and confirmation $[\ldots]$

What we can glean from al-Bukhari is that a single interpreter is admissible in cases that do not require a judge. However, this is not the point of dispute, but rather what happens in cases brought before a judge, most of which can be seen as legal judgment. This is especially the case for those who say that the conduct of a judge by itself is judgment.

Ibn al-Munthir said:

Application of qiy $\underline{s}^{5}$ would lead to the necessity for multiple interpreters, for everything that is not readily available to the judge would be accepted only upon full proof, and one person is short of full proof unless complemented by the required minimum number. Still, the hadith, if proven to be authentic, puts an end to all debate; the prophet's relying on Zaid Ibn Thabit alone is a clear proof that should not be challenged.

To this, it can be replied that the Prophet (BPUH) cannot be compared with other rulers, for, unlike them, he could have knowledge through 
divine revelation of what was not readily available to him. Therefore, we can conclude that what is delivered as information can be conveyed by one interpreter, whereas what is delivered as testimony requires the minimum number [of two].

Al-Karabisi reported that the Rashidun Caliphs, ${ }^{6}$ as well as the kings that came after them, had only one interpreter each.

Ibn al-Tin reported of 'Abd al- $\underline{H}$ akam: "No one can interpret save a free and competent man. When the interpreter delivers a statement, then it would be best for two witnesses to hear it and submit it to the adjudicator."

\section{Al-Shafi'i, The Exemplar}

If a non-Arab comes before a judge who does not know his tongue, then interpreting is acceptable only through two competent men of equity who know his language.

\section{Ibn Qaiym al-Jawziya, Guidelines}

If the fatwa issuer does not know the inquirer's language, or if the inquirer does not know the mufti's, one person can interpret between them. For this would be a case of pure information, where one informant would be enough, similarly to reports about other religions, and to medicine.

The rule whereby one interpreter is sufficient has been extended by Abu Hanifa's school to the assessment of the witnesses' competency or lack thereof, messages, claims, admissions and denials before a judge, and identification [...] But on another account, no fewer than two interpreters are accepted in these situations. For they are taken to be testimonies, demanding all their conditions, as they confirm confessions, prove the integrity or lack thereof of witnesses, and would thus be lacking the required number of witnesses. It would be as if only one witness testified to someone's confession, which is insufficient. Such cases would be different from fatwas and inquiries about them; for these are purely informative, and so are treated differently.

\section{Translated by Tarek Shamma}

\section{Commentary}

While the need for administrative and institutional translation became more pressing with the expansion of the Islamic commonwealth, starting with the late seventh century, this type of translation had been an everyday reality since the earliest stages of Islam. As al-Bukhari's hadith demonstrates, the need for translation arose first following the Prophet's move from Mecca to Medina, which marked the transition of the Muslim community from a small number of adherents to a nascent government under the leadership of the 
Prophet. Not only did Muhammad become the undisputed ruler of Medina; the new city enjoyed a relative degree of religious and linguistic diversity. The Jews mentioned here are members of a Jewish community that had settled in Medina long before Islam.

The chief point of contention in the texts under study is whether it was sufficient to use one interpreter in matters of jurisprudence and state administration, which required the highest level of accuracy, as they could become the foundation for legal, political, and religious judgments. As they had no precedents to build upon in practice, scholars resorted to analogy (qiyas), an established principle in Islamic law, deriving judgments either from available instances of interpreting in early Islam or from established legal principles in other (conceivably comparable) practices, such as testimony. The deciding principle here is whether the interpreted text should be treated as a form of court testimony (which according to Islamic law requires two witnesses) or as an informative report (for which one is enough). Opinions varied based on the context and content of the interpreting event: what was the prerogative of the Prophet is not allowed for others, and what is a prerequisite in a court of law is unnecessary in other settings. At any rate, the interest given to this topic by all the major theological schools indicates the crucial importance of legal translation on all levels in all periods of Islamic history.

Given the rather onerous requirements placed on interpreters in these discussions, it is important to consider (especially in future research) the extent to which they found their way into practice. Did rulers and judges actually employ two interpreters in regions and times where prevailing theological schools made this a requirement? Or did logistical difficulties make this condition impractical (considering that finding one qualified interpreter remains a real difficulty in many contexts to this day)? We have simply no evidence to indicate that such practice of using two interpreters ever existed. It is pertinent, in this regard, to consider the quotation that concludes al-' Asqalani's extensive summations of differing opinions on the issue. Even the supreme leaders of Islamic states (in the words of al-Karabisi, a ninth-century theologian) had to content themselves, undoubtedly in the face of practical necessities, with one interpreter, regardless of theoretical theological injunctions.

\section{Tarek Shamma}

\section{Notes}

1 As these texts revolve around Prophetic hadiths, we have used the Prophet's date of death as an estimated date.

2 The second Caliph after the Prophet (c. 584-644).

3 This meeting is supposed to have taken place in Syria while Prophet Muhammad was still alive. Abu Sufian, a chief of the Meccan tribe of Quraish, tells Heraclius about the new prophet spreading his message in Arabia. 
38 al-Shafi'i, al-'Asqalani, Ibn Qaiym

4 In Islamic jurisprudence two witnesses are required in some legal cases.

5 The legal principle in Islamic jurisprudence of applying principles from the Qur'an and $\underline{\text { Hadith }}$ to new circumstances by analogy - in this case, equating the testament given by a witness to that provided by a translator.

6 The four "Rashidun" ("rightly guided") caliphs followed the Prophet Muhammad and formed the first caliphate in Islam (632-661). 


\title{
2 Interpreters in Islamic Conquests (823) \\ Abu'Abdullah Al-Waqidi, Abu Jarir al-Tabari, Abu al-Qasim Ibn' Asakir
}

\begin{abstract}
Abu 'Abdullah Al-Waqidi (747-823)
One of the earliest and most prominent historians in Arabic. Born in Medina, he moved to Baghdad during the reign of the Abbasid Caliph Harun alRashid, and lived there for the rest of his life. Some of Al-Waqidi's works were translated into English, including The Life of Muhammad: al-Waqidi's Kitab al-Maghazi and The Islamic Conquests of Syria.
\end{abstract}

\section{Futuh al-Sham (The Conquests of Syria)}

This famous book was attributed to al-Waqidi for a long time, though most of these attributions are now believed to be mistaken (e.g., al-Zirkli 2002: 311). The two-volume book is a rather dramatic account of the Arab conquest of Syria in the early seventh century CE.

\begin{abstract}
Abu Jarir Al-Tabari (839-923)
One of the most prominent historians and exegetes of the Qur'an in Islamic history. He was born in Tabaristan in Persia, then moved to Baghdad and lived there for the rest his life. Al-Tabari wrote on history, theology and Qur'anic commentaries; his books are distinguished by their encyclopedic range.
\end{abstract}

\section{Tarikh al-Rusul wa al-Mulukk (History of the Messengers and Kings)}

A history of the world from its creation to the end of $910 \mathrm{CE}$, just before the author's death.

\section{Abu al-Qạsim Ibn 'Asạkir (1105-1176)}

An Islamic scholar, historian, and traveler. He wrote more than 60 books, the most famous of which is the monumental History of the City of Damascus. Most of his other books are on $\underline{H}$ adith. 


\section{Tarikh Dimashq (History of Damascus)}

In this 80-volume book, Ibn 'Asakir expounded on the history of the city and Syria generally from ancient times, including biographies of distinguished people who were born or lived there.

\section{[INTERPRETERS IN WARS]}

\section{Al-Tabari, History of Messengers and Kings}

\section{[During the Arab Conquest of Persia]}

Rostam $^{1}$ called in [the Arab commander] al-Mughira [...] then he summoned his interpreter, who was an Arab from Al-Hirah, called 'Abbud. Al-Mughira said: "By God, 'Abbud, you are an Arab. Convey my words to him when I talk, just as you convey his words to me"; Rostam told the interpreter the same. Al-Mughira reiterated the same statements until "We invite you into one of three options: Islam, in which you will have the same rights and duties as we do with no distinctions, paying the tribute in humility" [...]

(Rostam asked what was meant by "humility," and al-Mughira explained that this meant that they should bring the tribute to us and ask to have it accepted, as explained in $\underline{H}$ adi $\underline{i}$ h).

"Islam [al-Mughịra continued] is what we desire the most."

\section{Ibn 'Asakir, History of Damascus}

When Quraish [before Islam] wanted to make 'Uthman Ibn alking, Al-Aswad Ibn 'Abd al-Muttalib said: "Quraish are free people; they cannot be ruled by a king"; whereupon 'Uthman Ibn al-Huairith sought Caesar's support to impose him as king. In an attempt to disrupt his plans, some Quraishi merchants in Syria approached 'Amr Ibn Jafna, ${ }^{2}$ who communicated with Caesar's interpreter, asking him to distort Uthman's words.

Having given audience to 'Uthman, Caesar asked his interpreter: "What did he say?" to which the interpreter replied: "A madman who is badmouthing the king." Caesar decided to have him killed, and ordered him taken away. Being driven out thus, 'Uthman came across one of the king's men reciting a verse of poetry. 'Uthman asked him: "I can see you speak Arabic. So where are you from?" The man answered: "I am from the clan of Asad, and I hate for them to know my ancestry." "But what has turned the king against me?" asked 'Uthman. "It is the interpreter," the man said. "'Amr Ibn Jafna wrote to him to change your words." So 'Uthman said: "Can you devise a way to give me audience with Caesar only once? Then leave the rest to me." "I will," the man said, and he did manage to allow 'Uthman to be admitted into the king's presence. 
When Caesar summoned the interpreter, 'Uthman said: "The most wicked people," which the interpreter delivered to Caesar. Then he said: "The most treacherous people," which the interpreter again delivered to Caesar, and then: "The most untruthful people," which the interpreter delivered to Caesar as well. At this point, 'Uthman seized the interpreter, and Caesar said: "This man has a story. Fetch me another interpreter." So they summoned another interpreter, to whom 'Uthman explained his story. Consequently, Caesar punished the first interpreter [...]

\section{Al-Waqidi, The Conquest of Syria}

\section{[Before the battle outside Damascus, the Muslim Commander has challenged Byzantine Soldiers to a Duel]}

Kulus [a Byzantine commander] said: "This man is a Bedouin. His language is different from mine." So a man called Girgis went forth with him, saying he would interpret for him. Walking along with him, Kulus said: "You should be aware, Girgis, that this is a brave man. If you find him getting the upper hand in the duel, attack him with me, until we pass our day with him. Then tomorrow Azazir [the Byzantine governor of Damascus] will confront him. If he kills him, we will be rid of him, and you will become my friend." "I am not a man of war," Girgis responded. "But I can intimidate him with words." So Kulus fell silent.

As they approached Khalid [the Arab commander], he saw the two of them. Rafi' Ibn 'Umaira [a Muslim warrior] was about to come out to face them, but Khalid said: "Stay where you are. I am equal to the two of them." When they were close to Khalid, Kulus told his companion: "Ask him who he is and what he wants" [...]

\section{[Narrative by 'Amair al-Yashkuri, an Arab Soldier, about the Siege of Baalbek]}

I saw people dropping down on us like birds swooping on seeds. When I attacked one of them to slay him, he screamed: "al-Gauth! Al-Gauth!" [lit. "Help"]. We had learned in the war that this call was a plea for safety, so I said: "You are safe, you wretch. What brought you down from the wall into our midst?" He went on talking to me in Greek, and I did not understand what he was saying.

'Amair continued:

I dragged him into Abu 'Ubaida's tent, and said: "Prince, send for someone who can speak the language of this foreigner. For I saw some of them tossing others [over the wall]." Abu 'Ubaida asked the interpreter who had now been brought in: "Tell us the story of this foreigner? What is behind him? And why are they tossing each other?" The interpreter said: "Poor wretch, we have 
guaranteed your safety. So tell us the truth. Why are some of you throwing others?" $[\ldots]$

\section{[Before the Battle of Yarmuk]}

Khalid and Vahan ${ }^{3}$ did not have an interpreter to convey what the other said: they talked to each other directly. Khalid said: "Vahan, I hate to start before you. Say what you may, for I do not mind, and every statement you make will have its proper response. You can go first, or I can: it is as you please." Vahan said: "I begin by praising God who has made our lord Jesus (the Spirit) his Word, our king the greatest of all kings, and our nation the best of all nations." These words were too hard for Khalid to bear, so he interrupted Vahan. The interpreter said: "Do not interrupt the king, brother of the Arabs. ${ }^{4}$ Mind your manners." But Khalid refused to keep silent. He said: "Praise to God who has made us believe in our prophet, your prophet, and all other prophets [...]"

\section{[During battles in Palestine]}

'Amair walked toward the interpreter sent by Constantine, son of Heraclius, and stood facing him; upon which the interpreter started laughing. 'Amair asked: "Why are you laughing, brother of Christians?" "At your ungainly sight, bearing this weapon," the interpreter said. "For what purpose do you need it? Why do you carry it when we do not mean war?"'Amair said:

A weapon for the Arabs is their emblem; it is their cover and the ground on which they stand. I have borne my weapon for support; I may encounter an enemy, when it would help me protect myself and fight back.

The interpreter said: "Rest assured. Deceit and cunning are only typical of you, Arabs."

Then the interpreter returned to Constantine, and informed him of what he had heard from 'Amr Ibn al-' As; he said: "Sire, the prince of the Arabs has come to us, wearing this and that." The king smiled at the bishop's ${ }^{5}$ words, and said: "Let him come to us." As "Amr was on his way the king prepared himself, donning his royal insignia, with the bishops standing on his two sides and the ushers in front of him. The interpreter returned to 'Amr and said: "Brother of the Arabs, the king has given you his permission." Amr rode in on his horse, with the soldiers of Caesarea in wonder over him and his outfit, until he arrived into the king's tent [...]

\section{[During the Siege of Aleppo]}

Damis [a Muslim soldier] left them and went away. He came back in about an hour with an infidel. "Here you are," he said. "Ask him." 
When they asked him, they did not understand what he said [...] "Wait," Damis said, and went away. Then when midnight came and he had not returned, his companions grew extremely worried [...] While they were thus engaged, Damis came in, leading a Greek man [...] He said:

When I departed from you, I walked close to the wall of the castle. I lay in ambush as people passed by me, gibbering in their own tongue, while I avoided contact with them. All this while, I was seeking someone who could speak Arabic, but it was in vain. I lost hope, and was about to return, when I heard the terrific thump of something that had dropped from the top of the wall. I scurried toward it to find this man, who had thrown himself from the castle to the bottom of the wall. I seized him and brought him here, for you to decide what to do with him.

They approached the man and talked to him, but he replied only in his own language; they also found that his forehead had been cut open. "I tell you that there is great significance to this man's case," Damis said. "I believe he has escaped from his people, and none of you can understand what he says. But wait here, as I go and fetch you someone who can speak his tongue as well as Arabic."

Damis left them, then came back shortly with a man whose turban had fallen down to his neck. He led the man until he was in our presence, and they asked him: "Are you from the city or from the castle?" Damis asked him: "Where do you hail from? Are you a Greek or a Christian Arab?" The man said: "I am a Christian Arab." They said, "Listen, you. Can you lead us to the weaknesses, or one of the weaknesses, of the castle? Then we would set you free, and no one would harm you in any way." The man replied: "I know of no weakness of the castle, nor a route into it. And even if I did, by Christ, neither my faith nor my judgment would allow me to guide you to it." Enraged with him, Damis said: "Ask these prisoners. Is any of them from the environs of the castle? For we have a pact with these people." The man asked them, but found no one from the environ among them. "They are all from the Castle," he said. "I know them all."

[...]

It was reported to me by Sulaiman Ibn 'Abdullah al-Yashkuri, of Ibn Mazin of his grandfather Khaz'al:

We were in Joachim's cavalry ${ }^{6}$ on the orders of [commander] Abu 'Ubaida. As we approached A'zazz [in northern Syria], Joachim addressed us:

You should know, brave Arabs, now that we are so close to the enemy that you should refrain from talking at all, for your language is not unknown to the Byzantines. I will be your interpreter. But you should be on the alert. When you are sure that I have had the better of the commander of the castle, then place your trust in God, and attack. 
As they marched on, Joachim had no knowledge of what fate had in store for him.

\section{[In the narrative of al-Akwa' Ibn'Abbad]}

I was with Malik al-Ashtar among the thousand soldiers under the command of Joachim, the governor of Aleppo. We had arrived at that town [of A'zaz.], and were waiting for dawn, when an army approached from behind, coming from the west of the town. So Malik al-Ashtar headed toward the town; he was not long gone when he returned with a man who was a Christian Arab.

When he was in our midst, he said: "Listen, my friends, to what this man is saying." "What is he saying?" we asked. He said: "Ask him, and he will tell you." When we asked him: "Where are you from?" he answered: "I am from [the clan] of Ghassan, a cousin of Jabala Ibn al-Aiham. ${ }^{7}$ Malik asked him: "what is your name?" and he said: "Tariq Ibn Shaiban." So Malik said to him: "Tariq, in the name of the bond that binds us as Arabs, do not keep from us any secrets you may know of our enemies." "I would not keep anything I know," he said. "Be mindful of yourselves before your enemies are upon you." "How is that?" Malik asked.

Tariq said:

It is because yesterday a spy came to us from your side. He is one of us, and his name is 'Isma Ibn 'Arfaja. He had heard your talk about the ruse that Joachim is planning for the commander of A'zaz. When the spy heard this from you, he wrote about it in a piece of paper, tied it under the wing of a bird, and sent it to the commander of A'zaz. Once he read the letter, the commander sent me to the commander of Riwandat [?], Luca Ibn Shas, to ask for his support against you. I delivered the message to him, and now he is coming at the head of five hundred horsemen. I believe they are about to attack, so be prepared.

\section{[During the Conquest of Armenia]}

Joachim marched at the head of 35 Companions [of the Prophet] and 20 of his people. When they arrived in Ahlat, the Romans and Armenians saw them and knew that they were messengers [...] They took them to the royal palace and informed king Pasagnathes, who had them summoned before him [...] When they were seated, the king's interpreter spoke: "Who are you? And what brings you into our midst?"

Joachim said:

The commander of the Muslim armies at Bitlis has sent us to you as messengers to call you to testify that there is only one God with no partners, and that Muhammad is his servant and prophet. Or else, you do what other people have done by paying the tribute in humility. 
The interpreter conveyed Joachim's words to the king.

[According to another account] there was no interpreter between them, for Joachim conducted the dialogue in Greek, which was those people's language. However, the narrator said: "I have learned from a trustworthy source that there was an interpreter between them. For the king was an Armenian, who knew only this own language, while Joachim was Greek and spoke no other language."

\section{Translated by Tarek Shamma}

\section{COMMENTARY}

These excerpts, taken from some major sources of Classical Arabic historiography, provide illuminating insights into the role of translation (specifically interpreting) in military conflicts, especially in the early stages of Islamic conquests. According to Hilary Footitt, scholarly engagement with translation and interpreting in military conflicts themselves (as opposed to their more benign functions in diplomacy in the aftermath of war) is a recent trend (2020: 616-620).

References to interpreters in wars are far from scarce in historical accounts in Classical Arabic, but they tend to be made offhandedly, confined to a passing reference to the interpreter and the acknowledgement, in parenthesis so to speak, of his role as the conduit of communication, without further details. However, in the excerpted texts (scattered and brief as they are) we can get rare glimpses of the complexity of these operations and their crucial impact, which often go beyond linguistic communication toward cultural mediation, not to mention the problematic situations in which the interpreters often find themselves.

Franziska Heimburger (2012) argues that translation in the context of military conflicts can play two different functions, represented by the metaphors of "go-betweens" and "gate keepers." In the first case, interpreters establish and maintain channels of communication among different languages and cultures, which allows them to formulate and influence these relations: the interpreter "articulates relationships between disparate worlds or cultures by being able to translate between them" (ibid.: xiv). However, this unique situation, made possible by their exclusive knowledge of the two languages and cultures, often places interpreters in an ambiguous, sometimes suspicious, position, with divided loyalties and conflicted identities (Heimburger 2012: 23).

"Gate keepers," on the other hand, have to decide what can, or cannot, be allowed to pass from one side to the other. Their exclusive knowledge gives them this power "to make the decision between 'in' or 'out" (Heimburger 2012: 27). While the interpreter's commission, if implicitly, requires the complete and accurate communication of the other side's message (a common theme in texts in this chapter), gate keepers perform this task selectively. 
Several factors determine this process of selection, including the interpreter's own loyalties, which could consciously or unconsciously, favor on side over the other. Furthermore, the interpreter's informed assessment of the various aspects of the communication event may require different types of interventions to avoid the misunderstandings that could result from accurate and complete translation, due to one side's ignorance of, or indifference to, the other side.

Of course, interpreters may find themselves at any point in the spectrum between these two poles. Indeed, the multifaceted nature of the interpreters' activities in conflicts can be seen clearly in these texts: as they struggle to navigate communication under extreme conditions, interpreters act variously as cultural mediators, local informants, guides on society and geography, victims, and active participants. They may strive to be neutral, but their loyalty could be aligned to a small or great extent with of the two sides, or hopelessly divided between them.

Suspicions about the interpreter's loyalty, or even very identity, arise inevitably in the heated conditions of armed conflicts. But they are certainly not confined to these situations. We have seen a telling example above in the theological debate about whether a non-Muslim translator could be accepted. We will see another example below in al-Qalqashandi's injunction that translators or interpreters should provide a written, officially documented, testimony to their translation, for "most translators belong to the same faith as that of the writer," and so they may resort to suppression or deception.

Another dimension of interpreting in these extracts, and one that is still relevant today, is its often extemporaneous nature. We do hear of professional, full-time interpreters in the service of the state (such as in the Byzantine empire, with its long-established bureaucracies). But in the face of dire emergencies and unexpected needs, military commanders, and sometimes soldiers, have to recruit interpreters on the spot-inexperienced combatants, and even civilians-involving a new array of difficulties and complications. This was especially the case with the armies of conquest, fresh from the nascent Islamic state in the Arabian Peninsula. It was not until a global Islamic empire gradually took root throughout the 8th and 9th centuries with an institutionalized system of government that we find interpreters acting as professional functionaries, as was the case of Basil the interpreter to the Abbasid Caliph al-Mu'tasim (796-842), who accompanied him on his forays into Byzantium (al-Tabari, VII: 247).

\section{Tarek Shamma}

\section{Notes}

1 Rostam Farrokhzad (d. 636) was the commander of the Persian armies during the Arab conquests. 
2 King of the Ghassanids, who established an Arab kingdom in Syria that was a client state of the Byzantines (see Introduction).

3 "Mahan" in the Arabic, a Byzantine general who was the field commander at the battle of Yarmouk, in which the decisive Byzantine defeat opened Syria for the Arab conquest.

4 A polite way of addressing someone using their religious or ethnic affiliation.

5 In Classical Arabic sources, often a generic title for a Christian cleric.

6 Joachim, commander of the Byzantine garrison at Aleppo, had converted to Islam along with the soldiers under his command.

7 The last ruler of the Arab Ghassanid kingdom of pre-Islamic Syria (see Introduction). 


\title{
3 Epistle Regarding What Was Translated of Galen's books (859)
}

\author{
Hunain Ibn Is $\underline{h a q}$
}

\section{Hunain Ibn Ishaq (810-873)}

A famous translator and physician who was born in Basra (in southern Iraq). Besides Arabic, he was fluent in Syriac, Persian, and Greek. He studied medicine and served as the personal physician to the Caliph al-Mutawakkil (847-861). He translated works of Greek philosophers and physicians, such as Hippocrates, Aristotle, and Galen, as well as the Old Testament from the Greek Septuagint (now lost). He also wrote a number of works on medicine, including The Book of the Ten Treatises on the Eye.

Risala Ila 'Ali Ibn Yahia fi Thikr ma Turjima min Kutub Jalinus bi-'Ilmih wa ma lam Yutarjam (Epistle to 'Ali Ibn Yahia Regarding What Was and Was not Translated, to His Knowledge, from Galen's Books)

This is a letter that Hunain Ibn Ishaq wrote to the unknown 'Ali Ibn Yahia when he was 48 years old. The letter addressed what had, or had not been, translated of Galen's books, whether by Hunain himself or his predecessors or contemporaries. Hunain listed an extensive number of Galen's books, summarizing each and commenting on their translations. He also addressed the methods of the translators and the quality of their work, as well as the difficulties of locating and mending the original manuscripts.

\section{[SCIENTIFIC TRANSLATION IN THE EARLY ABBASID AGE]}

You mentioned, May God bless you, that a book was needed that listed all the key books written by the Ancients, the purpose of each of those books, their structure in sections, and their main subjects, in order to help anyone looking for a particular subject and needing to research it and knowing where to look for it, in which chapter or section to find the information. You asked that I undertake this task and I replied that I was unable to remember all those books, since I had lost many in my collection, and that a speaker of Syriac had also asked me to do this with regard to Galen's books and to list the books that I and others had translated into Syriac and other languages. I did write a book for him according to his request. You asked me, God bless 
you, to translate this book for you now until such time when God allows for these books to be returned, with your help, so that I can add any necessary information, and account for the works of the Ancients on medicine that we have found. I intend to do, God willing, what you have requested [...]

You asked me to describe Galen's books - their number, by what they are known, what the purpose of each of them is, how many sections they have and what each of these sections describes. I told you that Galen had written a book along those lines in which he lists the books he wrote, called The Pinax, which I have translated as The Catalogue, and that he had also written a volume on the order in which his books should be read. It is surely much better to get to know Galen's books from Galen himself rather than from me. You replied that even if that was the case, we and all others who want to read those books in Syriac and Arabic need to know as follows: which books have been translated into Arabic and Syriac and which remain untranslated; which books I took on to translate and which have been translated by others; which were already translated by others before I corrected the translation or undertook it again; who were the translators of those books and how skilled they were; for whom I translated the books and how old I was when I did it.

These are important details to know, as the quality of the translation depends on the writing skills of the translator and on the person for whom the text is translated. [You also asked] which of these books still to be translated have a Greek copy available, and which have not been available or are so only in part. This to ensure that the found books are translated and that the missing ones are sought. Your response showed me that you were right and that the task you were asking me to perform was of benefit to me too and to many others.

The explanation for my delay in responding to your request lies in the loss of all my books. I had collected these books throughout my life and from the different countries where I travelled. I have lost all of them. I don't even have the book I mentioned earlier, the one in which Galen lists his works. As you insisted, I feel I had to comply with your request despite having lost what I needed to fulfill it, and having understood that you would be satisfied with what I could remember on the subject. I shall start on this with God's help and your prayers, and keep it as brief as possible, as per your request, whilst at the same time recounting everything I could remember from those [lost] books $[\ldots .$.

\section{Galen's book on Sects in Medicine}

[...] The book was translated into Syriac, before me, by a man called Ibn Sahda of Al-Karakh, who was not a competent translator. Later, when I was a young man in my twenties, I translated it for a physician from Gondishapur, named Shiriashu' Ibn Qutrb, from a very defective Greek copy. When I was about 40 years old, my pupil Hubaish asked me to correct it as I had collected a few copies of it in Greek. I collated the manuscripts in order to establish 
one correct version, which I compared with the Syriac version and corrected the latter. This is how I work with all my translations. A few years later, I translated it into Arabic for Abu Ja'far Muhammad Ibn Musa.

\section{His book on The Art of Medicine}

[...] This volume has been translated by a number of people, among them Sergis al-Ra's 'Aini [Sergius of Reschina] before he had developed his translation skills, Ibn Sahda and 'Ayụb al-Rahawwi [Job of Edessa]. Later I translated it for the physician Daw $\underline{u}$ d. Daw $\underline{u}$ d was sharp and keen on learning, and I was a young man of some thirty years when I translated the book. I had acquired good scientific knowledge through the books I had collected. Later I translated the volume into Arabic for Abu Ja'far Muhammad Ibn Mussa.

\section{Galen's Book on the Pulse addressed to Theuthras and other learners}

[...] This volume was translated into Syriac by Ibn Sahda, then by me for Salmawayh once I had translated the Art of Medicine. Given that Salmawayh was intelligent, well read and interested in books, I took great care with the translations I carried out for him. I later translated the volume into Arabic for Abu Ja'far Muhammad Ibn Musa, together with the Art of Medicine [...]

\section{To Glaucon}

[...] Sergius had translated this book into Syriac before I did. At the time he was quite competent as a translator, but had not reached his peak. I translated the book later into Syriac for Salmawayh after I had translated the book $O n$ the Pulse for him. I recently translated the book into Arabic for Abu Ja'far Muhammad Ibn Mussa.

\section{His book on The Bones}

[...] Sergius had produced a defective Syriac translation of this book. A few years ago, I translated it for Yuhanna Ibn Masawayh, aiming at the utmost accuracy and clarity, as this man is keen on clear style and insists on it. I had also translated it earlier into Arabic for Abu Ja'far Muhammad Ibn Musa [...]

\section{The Elements according to Hippocrates}

[...] The book was translated by Sergius before me, but he did not understand it, and therefore distorted it. Later I translated it into Syriac for Bakhtish $\underline{\text { u' }}$ Ibn Jibril with care and accuracy, which is the way I translated all the other texts for him, and this towards the end of my youth. I later translated it into Arabic for Abu al- $\underline{H} a s a n$ 'Ali Ibn Yahia [...] 


\section{The Book of Natural Faculties}

[...] Sergius had carried out a defective translation of this book. Later, when I was a young man of about 17, I translated it for Jibril Ibn Bakhtishú?. I had translated only another book at the time, which I will mention later. I translated it from a Greek copy which contained errors. When I had acquired more experience, I examined it again and identified errors which I corrected. I wanted to let you know this so that you would understand should you come across different versions of my translation. I translated one of the book's volumes into Arabic for Ishaq Ibn Sulaiman.

\section{The Book of Causes}

[...] Sergius had translated this book into Syriac twice: once before he had learnt from the writers of [the School of] Alexandria, and then a second time following his training. I then translated the book into Syriac for Bakhtishu' towards the end of my youth. Hubaysh translated the six sections into Arabic for Abu Hasan Ibn Yahia [...]

\section{Diagnosis of Affected Places}

Galen wrote this book in six volumes and aimed to show how to diagnose troubles of the affected inner bodily parts [...] Sergius translated this book twice, once for Theodore, bishop of Karkh, and then for someone called Elisha. Bakhtishu' Ibn Jibril had asked me to revise and correct it, which I did after informing him that it would be better and easier to [re]translate. But the copyist did not insert the corrections I had made as he should have, and each other copyist incorporated the changes according to his ability. Thus, the book has remained quite imperfect. I have thought of translating it a second time until Isra íl Ibn Zaharya, known as al-Tayfuri, asked me to retranslate it. I translated it, and Hubaish translated it into Arabic for Ahmad Ibn Mussa [...]

\section{Galen's Book on the Therapeutic Method}

[...] Sergius translated the six first volumes of the book when he was still rather weak and had not developed his translation competence. He then translated the other eight volumes when he was more experienced, and this later translation was better than his translation of the earlier volumes. Salmawayh asked that I correct this second set for a better and more fluent translation. He collated part of the seventh volume with me, as he had the Syriac version, while I had the Greek. He would read it to me, and I would let him know of any discrepancy with the Greek version. He would make corrections [to the Syriac version] until he found this approach very tiresome, and it became clear to him that a [new] translation would be more 
accurate and useful and the process more systematic. He thus asked me to translate these volumes, which I did. We were in Raqqa [in northern Syria] at the time of al-Ma'mun's campaigns, and he gave them to Zakariya Ibn 'Abdullah, known as al-Taifuri, when he wanted to come to Baghdad so that the books could be copied for him there. However, there was a fire on the ship that Zakariya was travelling on, and the book was burnt, with not a single copy left. After a few years I translated the book from the beginning for Bakhtishu' Ibn Jibril. I had several Greek copies of the last eight volumes, which I collated and corrected to produce a single errorfree copy, which I translated as accurately and eloquently as I could. As for the first six volumes I only had one copy available, and this was full of errors. So I was unable to edit these volumes as needed. I then came across another copy, which I collated and corrected as much as I could. It would be better for me to edit it again if I could find another copy, but there are very few copies of this book in Greek, as it was not studied in the School of Alexandria. Hubaish Ibn al- $\underline{H}$ asan translated this book into Arabic for Abu Ja'far Muhammad Ibn Musa from the Syriac version. Later, after he had translated it, Abu Ja'far asked me to examine the last eight volumes of the book for him and to correct any errors I could find. I agreed to this, and completed the work to my satisfaction.

\section{His book on Anatomical Procedures}

[...] Ayyubb al-Ruhawi translated this book into Syriac for Jibril Ibn Bakhtishu’'. I corrected it not so long ago for the physician Yuhanna Ibn Masawayh, striving to correct it very carefully.

\section{His book on Disagreements in Anatomy}

[...] This Book was translated by Ayyubb al-Ruhawi. To correct it was beyond my best efforts, so I translated it again into Syriac for Yuhanna Ibn Masawayh and produced the most accurate edition possible. Hubaish translated it into Arabic for Abu Ja'far.

\section{His book on Hippocrates's Knowledge of Anatomy}

[...] Ayyubb [al-Ruhawi] had translated this book into Syriac. I also translated it along with the books I mentioned before, and I was extremely thorough. The book was translated into Arabic by $\underline{H} u b a i s h$ for Muhammad Ibn Musa.

\section{His book on Erasistratus' Knowledge of Anatomy}

[...] This book had not been translated before when I translated it into Syriac along the other books I have translated and mentioned. However, I could 
only find one copy, and this was full of errors and with the end partly missing. I had to make great efforts to produce a correct version, but in the end it was intelligible. I did my best not to deviate from Galen's meanings. Hubaish translated it into Arabic for Muhammad Ibn Músa [...]

These are his books on anatomy, authentic or attributed to him. They are followed by his books on the activities and functions of bodily organs. I will mention them below, except those already covered, viz. his book on Natural Faculties.

\section{His book on The Motion of the Chest and the Lungs}

I did not translate this book into Syriac, nor had anyone else before me. But Istifan Ibn Bassil translated it into Arabic for Muhammad Ibn Músa. Muhammad Ibn Musa asked me to collate and correct it as appropriate, which I did. Later, Yuhanna Ibn Masawayh asked Hubaish to translate it from Arabic into Syriac, which he did.

\section{His book on The Causes of Breathing}

[...] Ayyubb had carried out an unintelligible translation. Istifan Ibn Basil also translated it into Arabic for Muhammad Ibn Munsa. Muhammad requested the same as he had done for the preceding book, and ordered Istifan to collate his version with mine. So I corrected the Syriac version to make it intelligible and faultless, as I wanted to have a copy for my son, ${ }^{1}$ also with the Arabic translation which was far more accurate than the Syriac version.

\section{His book on The Voice}

I did not translate this into Syriac, nor did anyone before me. But I translated it into Arabic for Muhammad Ibn 'Abd al-Malik, the vizier [minister], some twenty years ago, striving to produce an accurate summary for this intelligent man. Muhammad read it and altered many of its words according to what he deemed to be better. Later Muhammad Ibn Musa looked at it and at the first version and selected the first version for copying. I wanted to point this out to explain why there are differences between the two existing copies. Yuhanna Ibn Masawayh asked Hubaish to translate it from Arabic into Syriac, which he did $[. .$.

\section{His book on The Opinions of Hippocrates and Galen}

[...] Ayyub [al-Ruhawi] translated this book into Syriac, and no one else had translated it. I owned a number of Greek copies, but I was preoccupied with other matters. Later, I translated it into Syriac, adding a volume I wrote in defense of what Galen had written in the seventh volume of this book.

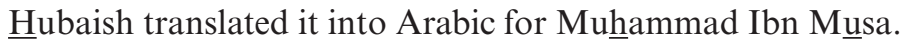




\section{His book on The Uses of the Parts of the Body}

[...] Sergius had translated this book into Syriac, but his translation was poor. I translated it into Syriac for Salmawayh, and Hubaish translated it for Muhammad [Ibn Musa]. I examined some of the volumes and corrected the errors. I am still to correct the rest [...]

\section{His book on Simple Drugs}

[...] The first part of the book, which consists of five volumes, was poorly translated into Syriac by Yüsuf al-Khurii. Later Ayyúb translated it, correcting Yusuf's version, but not as thoroughly as needed. I then translated it into Syriac for Salmawayh, trying my best to produce a correct edition. The second part of the book was translated by Sergius. Yuhanna Ibn Masawayh asked me to collate and correct this second part, which I did, although it would have been better to translate it. Hubaish translated this book into Arabic for Ahmad Ibn Mussa [...]

\section{His book on Repletion}

I had translated it, not long ago, for Bakhtishu', using my usual translator style, that is to say the most elegant I have, and the closest to the Greek, without contradicting the rules of Syriac. Then Bakhtishu' asked me to amend the translation by using a simpler, more fluid and more expansive style, which I did. Istifan translated this book, into Arabic, but I have not looked at his version.

\section{Translated by Myriam Salama-Carr}

\section{Commentary}

This epistle where Hunain Ibn Ishaq, an iconic figure of the translation movement in the Abbasid period, and later known in the West as Johannitus, lists and discusses the Arabic and Syriac translations of Galen's writings, is a key document in the history of Arabic translation. Hunain Ibn Ishaq offers both a genealogy of these translations and their authors, together with an account of his own approach to the translation and revision of earlier versions, ranging from the search for reliable manuscripts to the use of suitable translation methods.

The Epistle lists 25 Arabic translations of Galen's works and 100 Syriac versions. The Arabic translations were usually carried out by Hunain's students on the basis of his own Syriac translations from the Greek originals, but Hunain also translated into Arabic. In addition to this important recording of complex translation activity and knowledge dissemination, the Epistle sheds light on the different stages of the translation process, starting with the 
search for reliable manuscripts to ensure the best possible source text, down to the revision stage and the correction of the translations. With reference to the translation of Galen's Book of the Sects, Hunain writes:

I collated the manuscripts in order to establish one correct version which I compared with the Syriac version and correct the latter. This is how I work with all my translations. A few years later, I translated it into Arabic for Abu Ja'far Muhammad Ibn Mussa.

Throughout the Epistle, the author's comments show that textual analysis, interpretation and subject knowledge were all part and parcel of the translation work.

Furthermore, Hunain's Epistle offers a convincing illustration of the power of patronage as a major factor in the translation movement and the close relation between translation, status, legitimacy and authority, as articulated in Lefevere (1992). In the same way as the translator's approach is determined by the type of texts and their take on the translation process, patronage and its associated constraints also bear upon the translators' work and the selection of texts. Further, the status of patronage means that the patron can confer prestige and recognition on the translators and their work. Lefevere understands patronage as the powerful agents, individuals or groups of people, or even institutions (religious bodies, royal courts, etc.), who have the power to hinder or promote the reading, writing or rewriting of literature (1992: 15). The issue of patronage, whether coming from individual sponsors, wealthy courtiers, or men of science, or from the rulers themselves, underpins the translation movement of the Islamic empire (see Gutas 1998 for a detailed discussion), and indeed much of translated production in general.

\section{Myriam Salama-Carr}

\section{Note}

1 Hubaish Ibn $\underline{H} u n a i n$, mentioned several times here as Hubaish. 


\title{
4 Book of Animals (869)
}

\author{
Abu 'Uthman al-Jahidh
}

\begin{abstract}
Abu 'Uthman al-Jahidh (780-869)
A major literary figure in the Abbasid era, and Classical Arabic in general. Born in Basra, he moved to Baghdad to work in teaching, and was, for a short period, the head of the government correspondence department for Caliph al-Ma'mun (786-833). His works show encyclopedic knowledge and widely varied interests, as well as a keen interest in other cultures and languages. They include the Book of Animals, the Book of Misers, and the Book of Eloquence and Oratory.
\end{abstract}

\section{Kitab al-Haiawan (The Book of Animals)}

The first book on zoology in Arabic, this is a seven-volume encyclopedia covering more than 350 species of animals, complemented with anecdotes, poetic descriptions, and proverbs. It was influenced by Aristotle's books on animals: Historia Animalium, De Partibus Animalium, and De Generatione Animalium (Najm 1985: 86ff).

\section{[ON THE DIFFICULTY AND LIMITATIONS OF TRANSLATION]}

One of the interlocutors said: Poetic excellence is confined to the Arabs and to those who speak their language. Poetry cannot be translated, nor is transmitting it possible. When it is translated into another language, its arrangement becomes fragmented, and its meter void. Its beauty dwindles, and its wondrous quality falls away. It is in this way unlike prose, and prose which began as such is more beautiful and more genuine than prose that has been converted from the metrical verse of poetry.

He said: All nations have a need for maxims in their religion, and in their technical crafts, as well as for anything that establishes for them their livelihoods, opens for them the doors of awareness, and introduces them to various aspects of convenience. In this, their contemporary is like their predecessor, their black like their red, the far like the near; the need for this is general to them all. 
The books of India have been transmitted to us, and Greek wisdom has been translated, along with the literary tradition of the Persians. In the process of translation, some have increased in excellence, while others have been diminished of their original quality. Should the wisdom of the Arabs be translated, it would lose that miracle ${ }^{1}$ which is the meter, though if they were to translate it, they would find nothing of its meanings that has not been mentioned in the books of the non-Arabs which have set down their livelihoods, knowledge, and wisdom. These books have been transmitted from nation to nation, from time to time, and from language to language, until they have come to us. We are the latest to have inherited and looked upon their contents. Thus, it has been confirmed that books are superior to monuments and poetry in recording the glorious feats of civilization.

Then it was said by some of those who are advocates, connoisseurs, and champions of poetry that the translator does not render at all what a philosopher said, in the specificity of his meanings, the truth of his methods, the intricacy of his abridgements, and the subtleties of his definitions. The translator is not able to afford them their due, or render them with fidelity. $\mathrm{He}$ is unable to carry out the duty of a proxy, or what is incumbent upon one who has been delegated a task. For how can he convey and deliver their meanings, or report them in truth and with veracity, unless he is knowledgeable of them - the implications of their expressions and the interpretations of their articulations - as much as the author, the one who first set them down in writing? And since when was Ibn al-Batriq (God have mercy on his soul), Ibn Na'ima, Ibn Qurra, Ibn Fahriz, Thaifil (Theophilus), Ibn Wahịli, or [Muhammad] Ibn al-Muqaffa' comparable to Aristotle? And since when was Khalid [Ibn Yazid] comparable to Plato?

The translator's eloquence in his translation should be equal to his knowledge in the discipline in question. He should be most learned in the two languages - the one translated and the one translated into - attaining the highest mastery possible therein.

Even so, when we find that he speaks two languages, we realize that he has inflicted damage upon each of them, because each of one of the two languages attracts the other, takes from and opposes it. How can his proficiency in the two languages be equal to the mastery he would have in using one alone? For he has only one faculty for language; when he speaks in one language, the capacity of that faculty is exhausted. Such is the case, too, if he speaks more than two languages. The same principles govern translation in all languages. Besides, the more arcane a certain discipline and the fewer the scholars who have mastered it, the more difficult the charge of the translator, and the more prone he will be to error. Hence, you will never find a translator who can fully do justice to one of these scholars.

Such is our assertion for translating books of geometry, astrology, mathematics, and music. Then what could be said were these to be books of religion, containing information about religion, discussing God Almighty 
in ways that may or may not be permissible? What could be said about the translator with regards to his observing the principle of monotheism when establishing the exact meanings in the discussion of the elements? What could we say so that he does not transgress the boundaries of what is and is not permissible to be said concerning God, and what is and is not permissible to be said of man? How shall we put this so that the translator understands the places of general and particular statements, and those too that are general statements that he may render into particular statements, and so that he distinguishes between those reports which are attributed to the Prophet (and his Companions) from those that are reports from the Qur'an. And so that he knows that which is distinguished by reason from that which is specific to custom, or the general mood, which the public has responded to? What can we say so that he knows if a statement is true or false as well as what can be considered truth or falsehood, and until he knows what is meant by "true" and what is meant by "false"-how many properties it embodies, and upon the loss of which of those properties its constitution is transformed?

Likewise, he must know the absurd from the credible, and what can be offered as an interpretation of the absurd, whether it should be branded as falsehood, or whether such a claim might be unlawful. He should know which of the two is more preposterous: for it to be deemed a falsehood or an absurdity, and in which case is absurdity deemed more heinous, and in which is falsehood considered more loathsome? Until he is familiar with analogies and rhetorical embellishments, with intimation and metonymy, and with the distinction between deliberate fallacies and mere incoherence, as well as the distinction between restricted, unrestricted, and abridged speech. And until he knows the syntactic structure of language, and the customs of the people and the bonds of their community.

What we have mentioned are a few of many things to be considered. Whenever the translator does not know this, he commits errors in interpreting religious texts, and to err in religion is more detrimental than erring in mathematics, craftsmanship, philosophy, chemistry, or some of the livelihoods by which mankind earns its sustenance.

Whenever the translator who has translated a text does not fulfill these requisite qualifications, he errs in proportion to the level of his deficiency in these requirements. And what does the translator know of genuine proofs from quasi-legitimate proofs? And of astrological reports? And what does he know of nebulous definitions? What does he know of amending what has been lost from texts, of the omissions of the copyists of those texts? What does he know of some of the delirious ravings that occur in some of the prolegomena? We know already that introductions have to be limited to what is necessary, and must be well organized, being like an unraveled thread. Ibn al-Bitriq and Ibn Qurra did not understand this point from a well-articulated and organized source that was handed down from an erudite, well-versed 
master and enlightening erudite. So then what of a book which has been circulated in different languages, in several pens, and in the scripts of various nations and faiths?

\section{Translated by Lubna Safi}

\section{COMMENTARY}

The development of translation activities during the Abbasid period led a number of contemporary scholars to interrogate the very concept of linguistic and cultural transfer and its boundaries. In this extract taken from the monumental Kitab al- $\underline{\text { Haiawan }}$ (The Book of Animals), the author, AlJahidh (776-868/869), the famed scholar, theologian, and masterful belletrist, contributes to the debate on the nature and (im)possibility of translation by setting out his views on translation and the conditions required for faithful and accurate rendering. Al-Jahidh had access to the Greek-into-Arabic translations and his own writings reflect this through references to Ancient Greek sayings and maxims. The author prescribes objectivity and linguistic skills on the part of the translator who is expected to be as knowledgeable as the translated authors, which brings to the fore the competences expected of the translator, i.e., writing skills and subject knowledge. While these might be familiar expectations, they are, in this context, preparing the ground for Al-Jahidh's own concern with regard to the translation of sacred texts and the possible effects on linguistic interference, in the multilingual context of the time, on the Arabic language, particularly in the context of the shu'ubiya movement, which resisted the supremacy of Arabic. Also mentioned are the risks of manuscript corruption that inscribing will entail. Whereas the bulk of translations carried out at the time focused on scientific and philosophical texts, Al-Jahidh is clearly concerned with the possibility of religious material being translated and addresses the sensitivity of the issue in terms which resonate with current thinking.

Thus, beyond its discussion of translation requirements and the nature of texts to translate, and its foregrounding the particular significance and sensitiveness of religious material, al-Jahidh's text also contributes an important trope to the discourse on translation: That is translation as a dangerous and potentially subversive activity, and not only because of the risk of linguistic interference. This is a narrative which underpins some of the later discussions. One example is found in the words of the linguist al-Sirafi (c. 903-978) who criticizes translation when debating the logician and translator Matta Ibn Yunus (d. 940) (see al-Sirafi and Ibn Yüuus, Chapter 7).

This stance can be traced in other linguistic traditions, be they the medieval or beyond (see for instance the context of the French Renaissance and the 
60 Abu'Uthman al-Jahidh

discussion of the translation of religious texts in the writings of Montaigne, 1533-1592).

\section{Myriam Salama-Carr}

\section{Note}

1 Mu’jez (معج), literally "what causes helplessness," i.e. what is "miraculous" in that it is impossible to perform or emulate. This is a key term in Qur'anic studies (see Introduction above). 


\title{
5 The Letter of 'Abdullah al-Hashimi to 'Abd al-Masih al-Kindi, Inviting him to Islam, and al-Kindi's Response, Inviting al-Hashimi to Christianity (ninth-eleventh centuries)
}

\author{
'Abdullah al-Hashimi, 'Abd al-Masih al-Kindi
}

There is no consensus on the date that this work was written. While the introduction by the (unnamed) author situates the dialogue during the time of Caliph al-Ma'mun (813-833), estimates based on internal evidence range between the ninth and early eleventh century (Troupeau 1986: 120-121). Although the oldest Arabic manuscripts available today date to the seventeenth century, a Latin translation by Peter of Toledo in 1114 has survived; it had a considerable influence on the perception of Islam in Europe during and after the Middle Ages (Koningsveld 2004: 69).

The fact that we do not have any historical information about the two persons to whom the dialogue is attributed has led some scholars, among other factors, to argue that this work is apocryphal (Ehinger 2012: 42; van Koningsveld 2004: 69-70).

Whether the dialogue actually did take place or not, the text as it is provides revealing insights into the opinions prevalent among Christian and Muslim intellectuals about translation and its role in the reception, circulation and interpretations of the scriptures - examples of which can be found across all eras.

\section{[TRANSLATION IN THE FRAMEWORK OF MUSLIM-CHRISTIAN POLEMICS]}

During the time of 'Abdullah al-Ma'mun, there lived a Hashemite nobleman believed to be of the Abbasid family and related to the Caliph al-Ma'mun, who was known for his unswerving belief in the Islamic faith, his depth of knowledge in its tenets and his commitment to his duties as a Muslim in all aspects of his public and private life. He had a friend of great knowledge, piety, and morals who was Kindi of origin ${ }^{1}$ and renowned for his deep unswerving faith in Christianity, and he worked in the service of the Caliph. Both men were great friends, and the trust between them was true and sincere. As the 
Caliph, his companions, and those in his circle knew them both as 'Abdullah Ibn Ismáil al-Hashimi and 'Abd al-Masih Ibn Ishaq al-Kindi, we will not reveal their names for some reason.

Al-Hashimi wrote to al-Kindi a letter which I have scribed down as follows:

\section{Al-Hashimi's letter to al-Kindi}

I begin this letter to you with wishing peace and mercy upon you in the manner of the Prophet (PBUH). We are assured that he did this, as all the accounts that told of him state that so was his custom and that he opened his exhortations by wishing peace and mercy upon all people, making no distinctions between Muslims and non-Muslims, believers and non-believers.

May God deliver you from ignorance of disbelief, and open your heart to the light of faith in Him. You know I am a man who has spent many years devoted to deepening my knowledge and investigation of all faiths and readings their books, and particularly the books of Christianity, the ancient and more recent books which God revealed to Moses, Jesus, and the other prophets, upon them be blessings and peace. The Ancient Books are the Torah, the Book of Joshua, Book of Judges, Book of Samuel, Book of Kings, the Psalms of the Prophet David, the Wisdom of Solomon, Son of David, the Book of Jacob, the Book of the Prophet Isaiah, the Book of the Twelve prophets, the Book of the Prophet Jeremiah, the Book of Prophet Ezekiel, and the Book of the Prophet Daniel. As for the more Recent Books [of Christianity], the first is the Gospel which is made up of four parts, the first being the Gospel of Matthew the Apostle, the second the Gospel of Mark, the Cousin of Simon the Pure, the third the Gospel of Luke the Doctor and the fourth the Gospel of John, Son of Zebedee. Two Gospels came from two of the Twelve Apostles of Christ, (upon Him be Blessings and Peace), Mark and Luke, who were among the seventy Apostles sent out into the World to spread the Word of Christ amongst the nations. The Book of the life and times of the Apostles and their sayings after the Ascension of Christ to the Heavens were written by Luke and in the Fourteen Epistles of Paul. All of these books I have read closely and extensively debated and discussed with Timothy I, Patriarch of the Church of the East, a scholar considered of great wisdom and knowledge in your community [...]

I now call upon you, having gained all of the knowledge of your faith, to join the faith that God chose for me and that I chose for myself to ensure that you are guaranteed a place in Heaven, and safe from the perils of Hell. This would mean that you would worship God, as One and Unified, who has not begotten and has not been begotten, ${ }^{2}$ as One who does not take a woman, or a child, or anyone to stand in for Him. This is the attribute He used to describe Himself, and not one of His Creations could know Him better than he does. I call upon you to worship this One God, whose Attribute as I describe it is none other than what $\mathrm{He}$ has described Himself. Your forefathers and 
my forefathers are both descendants of Ibrahim who was himself a Hanafi Muslim [...]

As I trust that God will guide you as He wills, I call you to respond as you wish and expound clearly and frankly on what could help strongly lead you to make your argument, in the knowledge you can do so in comfort and safety [...] We have been just and fair to you in speech, which is why we have widened your space of safety, content in the knowledge that reason will prevail as "there is no compulsion in religion" [Qur'an, al-Baqara 2: 256]. We only call you to come to us, freely and willingly making known the dreadfulness of your condition.

Peace and the Blessings of God upon you.

\section{The response of Abdul Masih al-Kindi}

In the name of God the Beneficent, the Merciful

May the Lord ease and not burden, and grant success in the completion thereof.

To 'Abdullah Ibn Ismáil al-Hạshimi, from 'Abdul Masih Ibn Ishaq alKindi, the least of all Christ's worshippers

Peace, mercy and greetings to you, and to all people of the world for His Generosity, Amen.

I read the letter that you wrote, and gave thanks to God for all the faculties He has conferred upon me that have gained the attention of the Commander of the Faithful [i.e., the Caliph], and I prayed to God who never disappoints the hopes of those directing toward Him their sincere prayers, that He bestow upon the Commander of the Faithful the best of all blessings. I thank you for the favor and kindness you have shown toward me. I have always known your goodness to be so erstwhile, but you now have confirmed yet further this to be the case $[\ldots]$

Concerning, however, that invitation that you extended me to accept your faith, on the basis that our father Abraham was, according to yourself, a Hanafi Muslim, we must consult with the Lord Christ who promised all a guarantee of Truth in His Holy Gospels. And therefore, I am sure and certain of My Lord Christ's promise as He expounded it in his Holy Gospels [...]

Now tell me how to clarify the saying of your friend: "Say: 'If men and jinn banded together to produce the like of this Koran, they would never produce its like, not though they backed one another" "[Qur'an, al-Isra ' 17: 88]. You say there is nothing more eloquent than the Qur'an? Our answer to it is thus: yes, the most eloquent of languages is Greek according to the Byzantines, al$Z_{\text {Zobah }}^{3}$ within the lands of Persia, Syriac according to the Syriacs and the people of Edessa, as is the Hebrew of Jerusalem for the Hebrews. For all languages have varieties of beauty and eloquence for whomsoever speaks them, all of them appearing as foreign to you, as your Arabic language of beauty and eloquence is foreign to them. This is if we accept your claim that 
your holy book is of more eloquence for being in Arabic. For a possessor of a language of eloquence would not need to borrow or make recourse to that of others in his speech and words, but rather, due to this beauty and eloquence, would avoid making use of any other language. But in the case of your friend, he needed the words of others, even when he stated: "We have sent it down as an Arabic Koran; haply you will understand" [Yusuf 12: 2]. He resorted to Persian for "istabriq" [brocade], "sundus" [silk] "abariqu" [pitchers] and "namariq" [cushions], and to Abyssinian for "mishkat," meaning an alcove for light, as well as many other words. Here we see that Arabic was too narrow, so why was it not broad enough to express these things without having to make recourse to the other languages, particularly as it descended from the Lord of Both Worlds via the Angel Gabriel? Here you see the lack falls on the messenger or the sender of the message $[\ldots]$

Look at Jerusalem in which the nations gather extolling and glorifying the Name of the Lord, that is, the Name of the Father, the Son, and the Holy Spirit, in so many different tongues, night and day, all coming from all countries and regions of the world, near and far [...]

So be fair in your judgment, and to gain God's good-pleasure, consider who is corrupting and changing words: Is it us, those who have taken the book from people who have proved its veracity via divine miracles that no human could ever perform, and upon which so many different nations, faiths and countries, from near and far, have agreed as they have never had upon anything before? Or those who have accepted a book containing no proof or testimony of a prophet or a miracle, which has been transmitted via one person in his tongue and the very same tongue of his people? Can this alone be considered proof? [...]

Let us recall what your friend states himself:

When God said, "Jesus, I will take thee to Me and will raise thee to Me and I will purify thee of those who believe not. I will set thy followers above the unbelievers till the Resurrection Day. Then unto Me shall you return, and I will decide between you, as to what you were at variance on."

[ㅁ1 'Imran 3: 55-58] [...]

Then ten days after His Ascension to the Heavens, the Disciples of Christ were gathered together in one room when suddenly they heard a sound of a violent wind and the Holy Spirit - that is the Paraclete - manifested itself among them. Tongues of fire descended upon each man, which made him able to talk in the tongues of the lands in which he was setting forth to spread the Good News of Christ the Savior of the world, so that they could call upon the nations of the world to accept Christianity in the languages in which they spoke, showing the manifestations of His Miracle. At that point, each of the Disciples parted company and went to the country to which he was headed and imparted the knowledge in the language of each land's people. 
They wrote the Holy Gospels and gathered the parables of Jesus Christ in all the languages in which the Holy Spirit had dictated, so the peoples of these lands could accept their Message. Shunning all the delights of the material world, these peoples turned toward what was manifest and clear and left their previous faiths to enter Christianity.

\section{Translated by Ruth Abou Rached}

\section{COMMENTARY}

Although the names of both scholars (literally translating as "servant" of their respective faiths) suggest the correspondence may have been an apologia compiled by unknown author/s, the introductory paragraph presents this

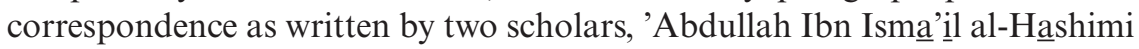
and 'Abd al-Masih Ibn Ishaq al-Kindi. References to historical events in the text frame this correspondence as taking place during the time of Caliph alMa'mun. Opening the debate is al-Hashimi, calling his colleague al-Kindi to embrace Islam on the basis of naskh (Islam abrogating or "updating" the religious laws of the Old and New Testaments).

Al-Hashimi's calls to Islam are based, among other things, on the Qur'an and its language (Arabic) being a miracle. Al-Kindi's response works to refute al-Hashimi's argument from three of the four fields of controversy prevalent in most Muslim-Christian-Judaic debates (Lazraus-Yafeh 1992: 19) during the classical era: naskh (Islamic Sharía abrogating Judaic and Christian laws); tahrif (falsification of the Old and New Testament); lack of tawatur, or reliable transmission. The fourth theological perspective, that of Bible exegesis "missing" Gospels (specifically Barnabas) foretelling the coming of Mohammed, is not covered in this exchange (see Sa'ada and Rida, Chapter 48).

Each scholar "presenting" his theological proof via verbatim citations from all three Holy Books reflects the modes of religious debate of this time: the written word - and its verbatim status - as metamorphosing into attack and defence interchangeably depending on ideological perspective. Striking about this correspondence is each scholar's attention to language, or logos as mediation of divine proofs: for al-Hashimi, Arabic is tautologically "proved" as a miracle by the mere existence of the Qur'an - and vice versa. For alKindi, the veracity of the Bible is marked: one, by fidelity, in that scholars of two (also competing) faiths, Christianity and Judaism, have verified the "truth" of the Old Testament at least; and two, by transformance by the Holy Ghost rendering each apostle able to spread the message directly to different peoples in their own languages.

These different notions of language as Holy proof also set out the different geopolitical loci of power for each faith. For Islam, power is located in Arabic itself, as the language of the Qur'an spoken by the Muslim rulers of this new Empire. For Christianity, the power of language is understood in a much 
more diffuse way: it is the disciple not the language itself who is the source of authority over the message of Christ. Each scholar's conceptualization of language as medium of "proof" and dissemination of his faith seems to be a metonym (Tymoczko 1999: 2001) for their reluctant acceptance of the intertwined nature of their faith with the other. In effect, each scholar is telling "stories" of the other's discourses of faith as well as his own, indicating the intertwined power relations between religious communities; and the intellectual and political status of theologians as agents representing other agencies of power and the political status of their respective religions.

For al-Hashimi, Islam was still in ascendance and able to contend with its "predecessors" by virtue of Muslim scholars' access to discourses of other faiths. He lists the books of the Old and New Testament, which suggests that Arabic versions of the Bible may have existed at least in monasteries (but perhaps later lost) during the ninth century - that is if we accept the historical authenticity of the text. The relative brevity of al-Hashimi's letter to al-Kindi alludes to a confidence in the language of the Qur'an as proof enough of Islam, and in the notion of naskh as abrogating the authority of Christianity.

Al-Kindi also references the presence of foreign words in the Qur'an as further argument against its uniqueness and "miraculous" nature. Muslims scholars such as al-Suyuti, of course, have seen this issues differently.

\section{Ruth Abou Rached}

\section{Notes}

1 Of the ancient Arab clan (erstwhile kingdom) of Kinda.

2 See the Qur'an, al-Ikhlas (112: 3).

3 Zobah or Aram-Zobah, an ancient Aramean state. "Imperial Aramaic" was the lingua franca of the Persian Achaemenid Empire (seventh-fourth centuries BCE), and remained influential in Persia afterward. 


\title{
$6 \quad$ Nabataean Agriculture (930)
}

\author{
Abu Bakr Ibn Wahshiya
}

\begin{abstract}
Abu Bakr Ibn Wahshiya (?-930)
A scientist and linguist, born in Qusain near Kufa in Iraq. His scholarly interests included chemistry, astronomy, agriculture, magic, and languages. He wrote a large number of books in all these fields, the best known of which today are Al-Filaha al-Nabtiya (Nabataean Agriculture), and Shawq alMustaham (an exposition of 89 scripts in comparison with Arabic). The latter contains an early attempt to decipher ancient Egyptian hieroglyphics.
\end{abstract}

\section{Al-Filaha al-Nabatiya (Nabataean Agriculture)}

The book provides an explanation of the Nabateans' methods of farming, and the types and benefits of certain plants, as well as related information about astrology and magic. It is one of the most famous ancient works on agriculture. In the introduction, from which the excerpt is taken, Ibn Wahshiya states that he had translated the book from Syriac into Arabic in 903, and dictated it to his student Abu Talib in 930.

\section{[TRANSLATING THE HERITAGE OF MINORITIES]}

In the name of God, the Beneficent, the Merciful, and Praise be to Muhammad and his Family. This is the book of Nabataean Agriculture, translated from the Kasdanian tongue by Abu Bakr Ahmad Ibn 'Ali, the Kasdanian, known as Ibn Wahshiya in the year 291 of the Arab Hijra calendar [903 CE]. It was dictated by him to Abu Talib Ahmad Ibn al-Husain Ibn 'Ali Ibn Muhammad Ibn 'Abd al-Malik al-Zaiat in the year 318 of the Arab Hijra calendar [930 CE].

He said to him:

My son, I have found this book, among other Kasdanian books that I acquired, translated into a title that in Arabic means "the book of farming land, tending plants, trees, and fruits, and protecting them from disease." 
As the book seemed to me to be too long and bulky, I considered making a summary of it.

However, having lent the matter more thought, I realized that this would be a mistake. For it is my primary intention - indeed my goal - to deliver the knowledge of those folks, viz. the Kasdanian Nabataeans, to the general population and disseminate it among them, so as to educate them as to the magnitude of those people's intellects and the gifts that God bestowed upon them in guiding them to grasp mysterious and useful disciplines of which other nations have fallen short. For I had access to their books at a time when their memory had vanished, their chronicles gone defunct, and their major figures dwindled into nothingness. If they, or their sciences, are mentioned at all, it is as fairy tales, unknown even to their narrators.

Having seen all this, I exerted my efforts in tracking their books, until I found them among people who are the remnants of the Kasdanians, still adhering to their religion, traditions, and language. The books I found among them were kept in extreme secrecy; they denied these books and were afraid to disclose them. Yet, God Almighty has bestowed upon me such a knowledge of their language (namely Ancient Syriac) that I have not seen in anyone else. For I am one of them-that is to say, I am the offspring of one of themhaving, by the Grace of God, also been endowed with financial means. Hence, thanks to Him, I managed to gain access to their books, owing to the reasons I mentioned above - that is knowing their language and being possessed of money. Thus, applying delicacy, generosity, and resourcefulness, I managed to acquire as many of their books as it was within my means.

The one who was in possession of these books came to the realization that he needed to understand what was in them, as the majority of these peopleto be precise, their remnants - were no more able to understand the sciences of their ancestors than cows and donkeys. However, as the man with whom I found these books was distinguished from this majority, and free from the donkey-like state of that lot, I remonstrated him for that excessive caution in suppressing and hiding these books. I told him:

What you do, in your inordinate caution, is, in effect, to erase the memory of your people and conceal their merits. In this, you are following the manner of those who came before. But you, and your predecessors, are mistaken, together with your scholars of the past, who are also my scholars and predecessors, just as they are yours. It is this practice that has led to our ancestors being forgotten, their sciences extinct, and their merits hidden from us. If these books, or some of them, were to be translated into Arabic, so people can read them, they would appreciate the scope of our sciences and benefit from what our ancestors accomplished-which will bring pride to us and attention to our merits.

My addressee was greatly agitated by these words. He said: "Abu Bakr, do you want to deviate from the instructions of our sages and ancestors, and their advice to us to hide our religion and traditions?" "No," I said. 
Their advice was to hide the religion and the practice of our laws because they realized its difference from what was prevalent among the population, thus fearing for their own religion. This kind of secrecy is, indeed, a sound course of action. But this is not the case with useful sciences; if the people who study them were to know of the founders of these sciences, they would highly appreciate them and regard them with great esteem. For these sciences are not in the same category as faith and religious law, and so are not included in the commandment for secrecy.

He said:

What benefit is there in revealing arcane and obsolete sciences, even if they are useful for people? Why spread these sciences among them and let them gain their benefits, with their view of our religion being what you know it to be? Our ancestors were unquestionably right in withholding the books of science as well as religion from them, as they are unworthy of both kinds.

I said:

I disagree with you and our ancestors about withholding sciences, though I agree about religion - if their command was in fact to suppress the sciences. If they had not, then I would certainly agree with them. My friend, don't you know and can see how ignorant people in this age have all become, and the state of negligence and feeblemindedness into which these predominant religions have thrust them, where they have become no better, and sometimes worse or more deplorable, than beasts? By God, it is my concern over people that compels me to disclose some of our sciences to them. Then, I dare hope, they may stop vilifying the Nabataeans. They may, then, awaken from their oblivion - indeed they may somewhat rise from their death. For all people are prepared and formulated by nature to understand all things; some individuals among the ${ }^{1}$ are possessed of intelligence and aptitude. It would be unfair to block knowledge from these people and deprive them of it. If they had become feebleminded despite their aptitude and capacity for understanding, it is because they had no knowledge of the sciences, including methods of their acquisition and development. So, my friend, I implore you to heed my advice and allow me to translate some of these books into Arabic, as I see fit. You are no keener than I am to obey our ancestors, and no more resolute to suppress what should be suppressed. You yourself have an interest in learning those sciences that you did not understand what with your excessive persistence in obeying your ancestors' supposed command to hide them. If you were to look into some of these books, then you would garner great benefits of the most useful applications. If you reflect on what I'm telling you, you will arrive at the same conclusions, and you will judge it to be the right course of action. 
Thereupon, he relented and allowed me access to these books. As I read them to him, he would ask me to repeat the parts that I recited for comprehension, until a day came when he said to me: "You have brought me back to life, Abu Bakr. May God reward you generously on my behalf." "What would one do," I remarked, "with books that he keeps under lock and key, unread and not understood? As far he is concerned, they are as good as rocks or clay. So believe what I told you and continue to follow my advice."

Consequently, I embarked on translating the Nabataean books, one after another, reading each to him, with his understanding and admiration growing more and more. We continued in this manner until he realized the correctness and wisdom of my opinion, and thanked me abundantly for that. It should be noted, however, that my success with him was completed only with the help Dirhams and Dinars. He was prevailed upon through a combination of the desire for money, compelling arguments, appreciation of what he heard, and the benefit he knew it would bring to him.

The first book I translated into Arabic treated of the secrets of astronomy and the rules governing the events proceeding from movements of the stars by Duanay of Babylon. This is a book of great status and value, but I could not translate it in full [...]

After several books, I translated this book with others. By "this book" I mean The Book of Agriculture, which I made sure to translate in full. For I admired this book greatly, having realized its myriad benefits and effective applications in farming land, tending trees, multiplying and improving the quality of fruits, and increasing plants. The book also treats of the properties of materials, countries, and times; the effects of the different seasons; the differences of the natures of climates and their marvelous effects; the grafting, planting, and farming of trees, and parrying diseases thereof; extracting beneficial elements from plants and herbs and using them for medication; keeping maladies away from the bodies of animals; repelling the diseases of trees and plants with each other; the uncommon accomplishments in combining things so as that they produce different ones, either far from or close to the originals.

Having found all these qualities in this book, I completed its translation, which I have now dictated to my son, Abu Talib Aḥmad Ibn al- $\underline{\text { Hu}}$ usain Ibn 'Ali Ibn Ahmad Ibn Muhammad Ibn 'Abd al-Malik al-Zaiyat. I instructed him not to withhold it from anyone who asks for it with the intention of garnering its benefits. For this book is beneficial to all people, of great use to them in their lives. At the same time, I instructed him to withhold other things besides this book.

As I found it, this book is attributed to three ancient Kasdanian sages, the first of whom started it, the second made additions thereon, and the third completed it. Written in ancient Syriac, it is about 1,500 pages. The sage who started this book is reported to have appeared in the seventh of the seven millennia of Saturn, the one in which Saturn was in partnership with the moon, a man by the name of Daghrith. The one who made the additions is 
a man who appeared at end of this millennium, named Yantushar. The third sage who completed the book was a man who appeared four thousand years from the reign of the sun during this cycle of Saturn, viz. the same millennium in which the other two men appeared. Looking at the time span between the two times, I found it to be twenty one thousand years. For as this third sage, named Quthami, is said to have appeared four thousand years from the cycle of the sun (which is seven thousand years), the total interval would be what I have mentioned.

Now the additions made by each of the two sages who followed Daghrith were within the divisions he had already established. They did not alter any of his statements, the categories he formulated, or the plan he made, only appending his material with their subsequent inquiry and analysis. Hence the opening and the first part of the book belong specifically to Daghrith.

The book opens thus:

We extend out exaltation, veneration, prayer, and worship, standing on our feet, to our ancient, living God, who was and still is, commanding Lordship over all things, the great God, the only God with no partner, majestic and permanent in His heaven, his dominion extending everywhere, singular in His might, majesty, and grandeur, all-encompassing and all-powerful, master of the seen and unseen, and everything on earth and above. He breathed His life into the earth, and it was alive, staying as long as He stayed. He imparted his power and capacity into water, and it was preserved, enduring as long as $\mathrm{He}$ endured. He kept the earth in place, and it was steady for time eternal. He bid the water to flow, and it flew, sustained by His life, cold for His dominion over the cold. The enduring earth is stationary and heavy for the greatness of his weight. If He wanted, He would make everything different from what it is; but $\mathrm{He}$ is wise, and active with sagacious power; He is knowing, his knowledge penetrating into all things. Blessed you are, the Lord of the heaven and all else! Holy are Your noble, beautiful names! We worship You, and pray for Your eternity and generosity.

We implore You with your names, eternity, and generosity to keep our minds, as long as we are alive, steady in purpose, and to have mercy on our worn-out bodies after life departs them, keeping worms away from our flesh. For You are an ancient, beneficent Lord! You are ruthless in your severity, hard, and remorseless. You are all-potent, never slow in implementing Your actions. Whomsoever You choose to give cannot be denied his bounty or given anything beyond it. You are singular in Your Lordship, one with Your power, the Lord of the planets and the moving stars, which, as they travel in their orbits, are awed by the sound of Your movement, fearful of Your majesty.

We beseech You to spare us from Your wrath, save us from Your punishment, and have mercy on us in Your ire. We fend off Your anger with Your beautiful names; whoever uses them to intercede for Your mercy will sure have it. So have mercy on us. Have mercy with Your power and Your great, lofty, and glorious name, You highest, greatest, most gracious. By my life I ask You to have mercy on us. Amen. 
Beware of the evil of this God if he is angry, west of the sun, veiled with its rays, or in the midst of his return. Offer to Him this prayer that we have given here. While saying this prayer, burn offerings for His idol: old leather, fat, animal hides. Burn for Him fourteen dead bats and the same number of rats. Then take their ashes and prostrate yourselves before His idol. Prostrate for Him on a black rock with black sand. Seek refuge in Him from his evil, for He alone, my brethren and loved ones, is the cause of the destruction of what is destroyed, the rottenness of what is rotten, the bareness of what is barren, the sorrow of those who are sorrowful, the weeping of the weepers ${ }^{2}$ - of evil, depravity, squalor, filth, and poverty.

This is what He does to humans when $\mathrm{He}$ is angry. When $\mathrm{He}$ is satisfied, He gives them durability, longevity, eminence after their death, a pleasing sight, and mellifluent speech. The sign of His anger is what I described above. The sign of His satisfaction is to be east of the sun, in the middle of his course, and in locations agreeable to his actions, or at full speed, or in the cycle of His ascendance. (Abu Bakr Ibn Wahshiya said: "This means in the sphere of his zenith").

"If you pray to him when He is angry, repeat the prayer and sacrifice when $\mathrm{He}$ is satisfied. Keep reminding Him of this prayer, and recite it time after time. Then you may be spared his spite. Amen!"

\section{Translated by Tarek Shamma}

\section{COMMENTARY}

In Classical Arabic sources, the Nabataeans (النبط) are described as one of the great pre-Islamic civilizations (Ibn Khaldun, I: 507). Yet, it should be noted that the term "Nabataean" was not always precise: it was extended to include Babylonians, Chaldaeans, and other Semitic nations of Mesopotamia, not to mention the vague "Kasdanians," possibly a corruption of "Chaldaeans." Thus, according to Ibn Abi Usaibi'a, "It is claimed that the Nabataeans of Iraq, the Suranians [Syriacs], Chaldaeans, and Kasdanians, and other populations of ancient Nabataeans discovered the principles of the art of medicine" (18). Eventually, "Nabataeans of Iraq" came to designate the inhabitants of the Sawad region in southern Iraq, who spoke the ancient Syriac from which this book is translated. These were distinguished from the "Nabataeans of Syria," who established the Petra kingdom, to whom the modern term "Nabataeans" (Arabic, الأنباط) is usually applied. Nabataeans were known to their Islamic contemporaries for their skill in agriculture (Fahd 1986: 834).

However, as is clear from the introduction, that eminent civilization had become a distant memory by the time this book was translated. It is actually one the goals of Ibn Wahshiya's translation to awaken his fellow Nabataeans 
from the state of ignorance and indolence into which he believed that they had sunk. In fact, it seems that the word "Nabatean" had become something of a slur, synonymous with backwardness, as can be seen in the quotation attributed to Sufian al-Thawri (an 8th-century jurist): "Learning was first the prerogative of Arabs and people of station. But when it was shared by those Nabateans and riffraff, the faith was distorted" (qtd in al-Shatibi, $A l$ I'tisam: 683).

Therefore, this translation, which Ibn Wahshiya had to reason so arduously with his fellow Nabataean to allow, would, he argues, help improve their image and highlight their achievements, which could lead to a re-evaluation of the importance of their native civilization. In this respect, we can place the translation in the context of a significant (and little studied) body of literature that thrived during the Abbasid period, and whose purpose was to compare various nations, weighing (often polemically extolling or denigrating) their assumed virtues and cultural accomplishments. Translation was essential to these efforts, as intellectuals and litterateurs from the various ethnic and linguistic communities within the Islamic empire strove to preserve the legacy of their pre-Islamic cultures and raise their profile by making their cultural and literary products available within the medieval Islamic "republic of letters" (Musawi 2015).

In fact, it has been argued that the celebrated translation movement during the Abbasid period had its roots in this very process-efforts by non-Arab scholars (specifically Persians according to Gutas 1998; 344ff) to integrate their pre-Islamic culture into the new Islamic commonwealth. This was complemented (if not indeed initiated) by the official support of state, sometimes the personal patronage of the Caliphs and their high functionaries, who adopted a policy of Islamic multiculturalism, arguably with the aim of integrating the various ethnocultural communities under their rule within the framework of a universal, but diverse, Islamic culture (Shamma 2009: 83).

When it comes to the translation activity itself, two issues are of special interest. Inevitably, the transmission of the cultural products of ancient, preIslamic civilizations had to be conducted in Islamic terms and concepts (no matter how broad, or even contrived), if they were to be accepted in an intellectual sphere where this religion is the main unifying factor. Consequently, translation involved a practice of unequivocal islamicization, whereby they were refashioned into the molds of the receiving environment. While Ibn Wahshiya, remarkably enough, does not remove all the signs of idolatry from the original text (including references to idols, sacrificial offerings, and astrolatry) as was usually the custom in translating such texts, and while he acknowledges that the differences between his native faith and Islam are so substantial as to invite disdain, he still imbues the religious Nabatean terms with an unmistakable Islamic character. This can be especially seen in the emphasis on monotheism (the recognized foundation of Islam) and the repeated emphases of the majesty of God, even employing Qur'anic terms 


\section{Abu Bakr Ibn Wahshiya}

that deny God's partners and the divine attributes. Some of the terms here are eminently recognizable Islamic terms, coming directly from the Qur'an:

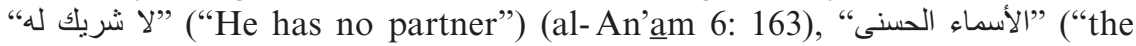
beautiful names" of God) (al-A'raf 7: 180).

The other translation method that enables Ibn Wahshiya to adapt an explicitly pagan text into Islamic terms is his emphasis on innate abilities and the capacity for knowledge as common to all humans. On this principle, he establishes a distinction between the religious doctrine, which has to be occulted (as it openly deviated from the principles of Islam) and universal knowledge that is common to all civilizations and are useful for all people. This universalism underlies Ibn Wahshiya's adaptive strategy, which shows no qualms about acclimatizing the source text to the worldview of the target, as these are seen as surface differences that do not belie the essential similarity of all cultures. It is also the one generally adopted by Muslim translators of the Classical period in their efforts to integrate foreign cultural elements (some of which directly contradicted Islamic beliefs) into mainstream Islamic culture, or even Islamicize them outright, withing the framework of what Hasan Hanafi calls "Islamic universalism" (Hanafi 2000, I: 319).

\section{Tarek Shamma}

\section{Notes}

1 Here Ibn Wahshiya is apparently referring to the Nabateans again.

2 The following part is a little obscure, but the general drift is clear. 


\title{
7 Debate on the Merits of Grammar and Logic (935)
}

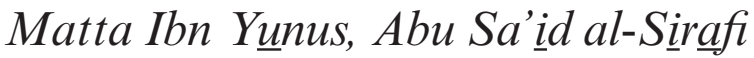

\begin{abstract}
Matta Ibn Yunus (?-939)
A philosopher and a translator who lived in Baghdad during the reign of Caliph al-Radi (934-940). He was the most famous logician of his time and the teacher of the renowned philosopher Abu Nas r al-Farabi. He translated several books of Aristotle, Porphyry of Tyre, and Alexander of Aphrodisias from Syriac and Greek into Arabic. His translations include Aristotle's Poetics and Posterior Analytics and Porphyry's Isagoge.
\end{abstract}

\begin{abstract}
Abu Sa'ịd al-Sịrafi (897-979)
A renowned linguist and literary scholar of his time. Originally from Seraph in Persia, he settled eventually in Baghdad, where he worked as a judge and teacher. His works include Darurat al-Shi'r (The Necessity of Poetry) and Sharh Kitab Sibawaih (Explanation of Sibawaih's Book on Arabic grammar).
\end{abstract}

\section{The debate between Matta and al-Sirafifi (Abu Haian al-Tawhidi's al- 'Imta' wa al-Mu'anasa [Enjoyment and Companionship])}

This public debate was preserved by Abu Haiyan al-Tawhidi, a major tenthcentury litterateur and intellectual, who excerpted it in his two best-known works: al-'Imtá $i$ wa al-Mu' $\underline{\text { anasa }}$ [Enjoyment and Companionship] and alMuquabas $\underline{a}$ [Borrowed Lights].

\section{[ON TRANSLATION AND LINGUISTIC DIFFERENCE]}

I mentioned to the vizier a debate that was hosted by the vizier Abu al-Fath Ibn Ja'far Ibn al-Furat between Abu Sa'id al-Sirafi and Abu Bishr Matta. I had abridged the debate, but the vizier told me to write it down in its entirety, for anything that took place in that eminent gathering, between these two savants, and in the presence of such notables, is worthy of being heard, and its benefits reaped [...] 
When [al-Sirafi] faced Matta he said: "Tell me about logic. What do you mean by it? When we understand your meaning, our discussion of which parts of it are sound, thereby to be accepted, and which are wrong, thereby to be rejected, would be based on principles that are known to us and accepted by us both."

MATTA: In my understanding, logic is an instrument whereby we distinguish sound statements from unsound ones, and faulty meanings from correct ones. It is like scales that I can use to distinguish overweight from underweight and what rises from what sinks.

ABU SA'ID: You are mistaken. Sound statements can be distinguished from unsound ones by familiar patterns and well-known conjugations when we speak Arabic, while faulty meanings can be distinguished from correct ones by the intellect when we use rational inquiry. Besides, supposing you can indeed tell overweight from underweight with your scales, how would you comprehend what you weigh - be it iron, gold, fool's gold, or lead? Obviously, having ascertained weight, you are still deficient in knowing the essence of what is weighed-its value, as well as other numerous qualities. Therefore, the scales on which you have relied and dedicated your efforts to establishing so laboriously are only slightly useful — and this is one of several ways that you have overlooked. It is as the poet said: "If you have preserved one item, you have neglected many." Besides, you have missed an important consideration: not everything in the world can be weighed. Some items are weighed; others are measured by volume; and others are surveyed, scanned, or estimated. If this is the case with visible objects, it is so with things established with reason. For sensory perceptions are the shades of our minds, to a small or great extent, with the resemblance preserved and the similarity still evident.

But let us leave this aside. If logic was devised by a Greek man, following their language, with its own conventions, and established constructions and features, then why would the Turks, Indians, Persians, and Arabs be bound to consider it, or to use it as a judge for them and against them, accepting what it admits and denying what it rejects?

MATTA: This is necessary because logic is an inquiry into conclusions recognized by reason and meanings apprehended by the faculties. It is an investigation of what thoughts may pass through our minds and what notions may occupy our thinking. When it comes to what is recognized by reason, people are one and the same. You surely can see that four added to four would be eight among all nations. One may cite many similar examples.

ABU SA'ID: If it were truly the case that the objects of reason and speech could be reduced, notwithstanding their different categories and diverse derivations, into this obvious level of four and four being eight, then there 
would be no disagreement; we would both in concord. But this is not the case. You have advanced a misleading example, as people of your ilk often do. Still, if conclusions recognized by reason and meanings realized by the faculties can be attained only through a certain language with its own nouns, verbs, and particles, ${ }^{1}$ does it not become necessary to learn this language?

MATTA: Yes.

ABU SA'ID: Then you are inviting us not to study logic, but the Greek language. This is when you do not even know this language. How could you invite us into a language which you do not master-one that became obsolete long ago, the people who used it to communicate with each other and conduct their affairs having died out. But you do translate from Syriac. So what would you say of meanings that were transformed through translation from Greek into Syriac, and then into Arabic?

MATTA: True, the Greeks have died out with their language. Yet, translation has preserved their intentions, conveyed their meanings, and been faithful to their truths.

ABU SA'ID: Let us concede that translation has been truthful rather than false, straight rather than crooked, accurate rather than faulty in measurement; that it never deviated or diverged, added or omitted, never pre-posed or post-posed words; that it has never distorted specific or general meanings, including what is most specific and general-an impossible thing indeed, as it is not in the nature of languages or the characteristics of meaningthen you seem to be implying that we can admit only the arguments made by the Greeks, the proofs they devised, and the truths they elucidated.

MATTA: I am not. But of all nations, they have given special attention to philosophy, the investigation of the visible and hidden truths of this world, and to all that relates to it or originates from it. It is due to their dedication that various disciplines and branches of knowledge have been conceived, propagated, circulated, and established. We have not found the same in other nations.

ABU SA'ID: You are in error. Your judgment is partial and biased. For the knowledge of the world is spread amongst all people of the world. This is why the poet said:

Knowledge is spread in the world

And wise men are ever drawn toward it

and so are disciplines distributed among all those on the face of the earth. This is why a certain science prevails in one area, and a certain art predominates in a certain region over others. This much is evident, and further elaboration is superfluous. Still, your statements would be sound and your claim acceptable if the Greeks had been known of all nations for their constant infallibility, unsurpassable intelligence, and unique constitution. We have to believe that they would not err even if tried, that they could not lie even if they intended 
to, that bliss had favored them, the truth had taken them under his wing, and error had abandoned them; that virtues clung to their origins and branches, and vices were alien to their very essence and nature. But it would be ignorance to assume this about them, and obstinance to claim it for them. Nay, just like other nations, they are correct about some issues, and wrong about others; they know some things, and are ignorant of others; they tell the truth, and they lie; they do well in some situations, and badly in others.

Nor did all the Greeks devise logic, but only a man from them, who borrowed from his predecessors in the same way that his successors borrowed from him. He is not the unquestionable authority over those great masses and vast multitudes; many people, Greek or otherwise, disagree with him. Nevertheless, differences of opinion, judgment, methods of inquiry, and ways of proposing questions and answers are inherent in the very nature of people. So how could one man invent something that would remove, disrupt, or even affect these differences? Far from it: This is, in fact, impossible. The world, before his logic, is the same after. Thus, you have no option but to turn away from what cannot be achieved, being intrinsic in people's nature and temperaments.

However, if you clear your mind and focus your attention on knowing this language in which you converse and debate us (being the medium whereby you study with your colleagues based on the understanding of its speakers and explain the books of the Greeks in its vocabulary), then you will realize that you are needless of the Greeks' meanings, in the same way that you are needless of the Greeks' language.

A question arises here: Would you say that people's intellects are different, and that their shares of reason are unequal?

MATTA: Yes.

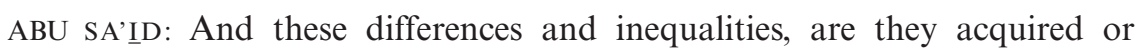
natural?

MATTA: They are natural.

ABU SA'ID: Then how could something be conceived that would obviate these natural difference and original inequality?

MATTA: You have already discussed this.

ABU SA'ID: And did you address it with a definite response and articulate expression? But leave this aside. Let me ask you about a single letter, which is widely used in the Arabic language and whose meanings are distinguished by wise men. Can you extract its meanings through Aristotle's logic, of which you are so proud and admiring? I mean the particle $w a\left({ }^{2} g\right)$ What rules govern it application? Where should it be used? And does it have one meaning or several ones?

Matta was surprised. He said: This is grammar, which I have not considered. The logician does not need grammar, whereas the grammarian greatly needs logic. For logic considers meaning, while grammar concerns itself with 
utterance: it is only incidentally that the logician addresses the utterance, or the grammarian the meaning. Truly meaning is higher than utterance, and utterance is lower than meaning.

ABU SA'ID: You are wrong. Speech and locution, grammar and utterances, sound expression, correct conjugation, statement, narration, predication, interrogation, the conditional, the vocative request, exhortation, invocation, appellation, and petition, all come from the same source by similarity and resemblance [...] Thus, grammar is logic, but is derived from Arabic; and logic is grammar, but is understood through language.

The difference between utterance and meaning is that the utterance originates in nature, while the meaning originates in reason. Hence, utterance becomes obsolescent over time, for time supersedes the products of nature with other products of nature, while meaning is stable throughout time. For the content of meaning comes from the mind, and the mind is divine; while the substance of utterance is clay, and all clay is ephemeral. And so you are left with no name for this discipline of which you claim mastery, and that instrument ${ }^{3}$ of which you are so proud, unless you want to borrow a name for it in Arabic. Now this is, indeed, possible to some extent. However, if you need a little of this language for the translation, then you will need a great deal in order to verify the translation, inspire confidence in it, and avoid potential errors.

MATTA: From your language I only need the noun, the verb, and the particle. These are enough for me to attain the meanings which have been refined for me by the Greeks.

ABU SA'ID: You are wrong. Of the noun, verb, and particle, you still need their definition and construction according to the order inherent in the natures of its speakers. In addition, you need to know the vocalizations of these nouns, verbs, and particles, for error and corruption with vocalization is as serious as with primary words. And here is a subject that you, your associates, and scholars in your field, have completely neglected. For therein a mystery that you have not attained, nor your mind dispelled.

It should be known that no one language is identical to another in all its aspects, or its properties, nouns, verbs, and particles, modes of composition, word order, metaphors and statements of fact, duplication and simplification, prolixity and concision, verse, prose, rhyme, meter, intonations, and other features too numerous to mention. I doubt that anyone with a trace of reason or a grain of justice would deny this judgment or question its validity. Then how can you trust something that was translated under these conditions? Indeed, you may be in need of knowing the Arabic language more than Greek meanings, bearing in mind that meanings are never Greek or Indian, whereas languages are Persian, Arabic, or Turkish. Nevertheless, you profess 
that meanings may be attained by reason, inquiry, and reflection, after which nothing remains but using correct language. So why then do you despise the Arabic language, when you explain Aristotle's books while being ignorant of what truth they hold?

Now suppose someone says to you:

When it comes to the knowledge, investigation, and study of the truth, I am in the same condition as that of people who lived before the invention of logic: I reason and use my judgment just as they did. For language I have known by birth and inheritance, and meanings I have extracted with observation, opinion, emulation, and individual judgment.

Would you tell him that his practice is erroneous and his judgments unsound, only because he did not attain knowledge of the world through your own method? Perhaps you would be happier if he imitated your ways, even when in error, than you would be if he were independent, even when correct - which, indeed, is a sign of patent ignorance and clouded judgment.

Apart from this, tell me about "and" and its rules. I want to demonstrate that your excessive estimation of logic does not avail you, being ignorant of a single letter in this language in which you invite us into Greek philosophy. One who is ignorant about a letter may be so about the entire language. And even if he's not ignorant about the entire language, but only about a part of it, he may be ignorant of what he needs, while knowledge of what he does not need is truly useless for him. Such is the rank of the commoners, or those slightly above it. Then why should he object to what I say and deny it, claiming that he belongs to the elite - nay the choice elite - that he knows the secrets of dialectic, the mysteries of philosophy, the subtleties of syllogism, and correct form of demonstration? This when I only asked you about the meanings of one letter. What if I expound all, asking you about their meanings and their uses, be they mandatory or optional? [...]

MATTA: If I were to expound questions of logic, then you would be in the same position as I am.

ABU SA'ID: You are wrong. If you were to ask me about a certain matter, I would examine it. If I find it connected to the meaning, and is consistent with the correct utterance as commonly established, then I would answer, whether in agreement or denial. If it is not connected to the meaning, I will return it to you. And even if it is consistent with the utterance, but involving one of those fallacies with which you have filled your books, then I will return it to you too. For it is not possible to invent new terms in a language whose conventions are already established among its speakers. Indeed, you claim no terms but what you have borrowed from the Arabic 
language, such as "cause," "instrument," "negation," "affirmation," "subject," "predicate," "generation," "corruption," the "disused," the "special," among other examples, all of which are completely uselessnay, are closer to absurdity and more suggestive of incompetence.

In your own logic you are patently lacking. Your books are not sufficient; nor do you furnish them with explanations. You profess poetry, which you don't know, and rhetoric, from which you are as separated as the earth is from the sky. I heard one of your people say that there was a great need for The Demonstration. If this is the case, then why waste time with books that came before this one? And if we need the books before The Demonstration, then we certainly need those after it. Or else why were books written that are needless and dispensable? This is all confusion, mystification, exaggeration — just lightning and thunder. All you want is to impress the ignorant and vulgarize the noble. The best you can have are grandiose terms, such as "genus" and "species," "property" and "differentia," "accident" and "individual." You boast of "isness," "whereness," "whatness," "howness," and "muchness"; "innateness" and "accidentality"; "substantiality" and "formness"; "negativeness" and "affirmativeness"; "animality." Then you proclaim that you have achieved a marvelous feat in averring that "There is no A in B"; " $\mathrm{C}$ is in some B, therefore some $\mathrm{A}$ is in $\mathrm{C}$ "; Or "A is in all $\mathrm{B}, \mathrm{C}$ is in all $\mathrm{B}$, therefore $\mathrm{A}$ is not in all $\mathrm{C}$ " $[\ldots]$

These are all fabrications and fatuities, riddles and traps. Those whose intellect is sound, discrimination sharp, reflection keen, judgment penetrating, and soul enlightened, can (by God's help and bounty) dispense with all this. But sound intellect, sharp discrimination, keen reflection, penetrating judgment, and enlightened soul are the gracious gifts of God by his exalted bounty, which he bestows upon whom he chooses from among his creatures. So I do not really see why you pride yourselves so much on logic [...]

The he [Abu Sa'id] said: Now tell us. Have you ever dispelled any ambiguities or settled any disputes with your logic? And is it through this power of logic that you believe that God is one among three, that one is more than three, and that the one who is more than one is also one, and that the norm is what you follow, and the truth what you say? Far from it! For here are things that are elevated above the claims and babble of your cohort, and are too sophisticated for their intellects and understanding [...]

Our Sabaean friends have also told us things about [al-Kindi $\left.{ }^{4}\right]$ that would bring laughter to a bereaved mother, that would make your enemies gloat and your friends grieve. And all thanks to the blessings of Greece and the benefits of philosophy and logic. We can only ask God for protection and support that we may be guided to words deriving from true understanding and deeds following from right measures. Verily He hears and answers.

\section{Translated by Tarek Shamma}




\section{COMMENTARY}

This is one of the most extended inquiries into the questions of linguistic difference and translation in Classical Arabic, even if in the form of a debate between logic (represented by Matta, the leading logician of his time) and grammar (represented by al-Sírafi).

However, it should be noted at the outset that the term "debate" is used with a good deal of latitude in describing this exchange as it came down to us. This is mostly a one-sided dialogue, where al-Sirafi, sometimes in a patronizing fashion, does not give his opponent the chance to answer his own questions, and resorts to mockery, including insinuations about Matta's Christian faith. Indeed, the context in which the debate was conducted and recorded is marked by clear bias against Matta: introduced and recorded by al-Tawhidi (a pupil of al-Sirafi's), reported by one of his supporters, attended by his loyal sympathizers, and presided over by a host with no pretenses to neutrality. Still, notwithstanding the gap between al-Sirafin's detailed arguments and numerous examples and Matta's truncated responses, the intellectual foundations and main assumptions of each side can be discerned with reasonable clarity.

The debate has been widely studied in the context of the reception of Greek philosophy in Classical Islam. But it can also afford valuable insight into contemporary positions on translation and intercultural relations. The issues under discussion - the position of Greek philosophy in its new Islamic environment, the link between language and thought, linguistic and cultural difference - are all intertwined with central issues in the understanding and practice of translation in that time, as well as in modern translation theory.

A dialectical confrontation between grammar and logic was of special significance to the contemporary participants and observers, as it represented an intellectual conflict of wide and far-reaching implications. Grammar occupied a central place within the traditional, native sciences (such as theology, Islamic law, and literary criticism), which had been preserved by transmission down the generations since the dawn of Islam. Logic, on the other hand, belonged to the new, rational sciences (such as philosophy), which had been created in Arabic as a result of translation from Greek. Hence, the opposition between reason and tradition, imported and inherited knowledge, is at the center of this debate, informing the two sides' attitudes toward translation, language, and thought.

In al-Sirafifi's rejection of Greek philosophy and its alien logic, he ties it to its specific ancient Greek context with an inextricable bond, which makes it impossible to transmit to a patently different Islamic culture. Naturally, Matta undervalues these differences, arguing that he is concerned only with the basic principles of logic, which transcend the boundaries of geography and time, as they rely on a priori rules of thinking grounded in human nature itself, for "When it comes to what is recognized by reason, people are one and the same." To al-Sirafi, on the other hand, these differences are unbridgeable due 
to the unbreakable unity between thought and language, rooted in the "order inherent in the natures of its speakers." Accordingly, the espousal of logic is an invitation to learn Greek, a language that "had become obsolete long ago" together with the people who had used it. To Matta, however, thought and language are neither inseparably linked, nor equal in value. He distinguishes the utterance, as the subject of grammar, from the sense, as the subject if logic, placing he latter in a higher position. Thus, in al-Sirafi's relativist position, language is a mold that shapes the very structures of thinking, as it determines the semantic, syntactic, and rhetorical structures available to it; in Matta's universalism, language, to use another common metaphor, is a mantle that merely reflects the contours of thought. For Matta, the mindcreated sense comes first, followed by the utterance as an external, auxiliary expression. This position relies on a "logocentric view" which "entails a belief in the existence of a signifying hierarchy, with language subordinated to thought and thought originating from a thinking subject" (Rafael 2015: 86).

These contradictory positions can be seen underlying reflections on translation and cultural/linguistic difference in the works of many classical Islamic scholars, where they lead to different conception of translation and its very possibility (see Shamma 2021b). It is not surprising, then, for alSirafi, who cannot conceive meaning to be separated from language in any of its aspects not only to question if translation may be trusted to be faithful, but to question its very possibility. For Matta, by contrast, the translation of Greek thought is not only possible, but trustworthy, for it "has preserved their intentions, conveyed their meanings, and been faithful to their truths." Language, in his view, is only a medium of expression, of which one needs only the basic building blocks of language: "the verb, the noun, and the particle." Matta's views were shared by intellectuals who embraced the transmission of Greek knowledge for the practice of the rational sciences, including, beyond the translators themselves, philosophers. In his A Survey of the Sciences, Abu Nas r al-Farabi (827-950), a major Islamic philosopher, who was in his youth a student of Matta, expresses a similar universalist perspective: Logic, he argues,

shares a common ground with grammar in that it postulates the laws governing utterances. It diverges from the latter in that, while grammar lays down the laws of the utterances of one nation, logic lays down common laws that apply to all nations.

Thus, while both al-Sirafif and Matta grounded their assessment of translation strictly in linguistic and stylistic perspectives, their positions are rooted in contradictory assessments of philosophy and the new rationalist sciences. This conjunction of linguistics, philosophy, and culture in reflections on translation was not uncommon in Classical Islamic scholarship, and it 
84 Matta Ibn Yunnus, Abu Sa'ịd al-Sịrafi

remains relevant in similar modern debates on translation and cultural transfer in modern Arabic. ${ }^{5}$

\section{Tarek Shamma}

\section{Notes}

1 Al-Sirafi here follows the standard categorization of the parts of speech in Arabic grammar: noun, verb, and particle (i.e., function word).

2 "and," which is a single letter and phoneme in Arabic.

3 Possibly a reference to Aristotle's Organon, literally "instrument" or "tool."

4 Abu Yūsuf al-Kindi (d. 873), considered the first major Islamic philosopher.

5 See, for example, 'Abd al-Rahman 1995: 346ff; al-Harri 2014. 


\title{
8 Explanation of the Torah in Arabic (941)
}

\author{
Sa'diya al-Fayumi
}

\section{Sa'diya (Gaon) Ben Joseph al-Fayụmi (882-941)}

A Jewish philosopher and rabbi, born in Fayum, Southern Egypt, which he left at a young age for Palestine to study under the Torah scholars of Tiberias. In 928, he was appointed Gaon (head) of the Sura Academy in Babylon. He then began to translate the Torah and other books of the Hebrew Bible. One of the most important Jewish scholars of his time, he wrote philosophical and theological works in Hebrew and Arabic, including a Hebrew-Arabic dictionary.

\section{Tafsir al-Tawrat bi al-'Arabiya (Explanation of the Torah in Arabic)}

Al-Fayumi's translation of the Torah was not the first Arabic translation, but it is the oldest extant full version. It gained widespread popularity among Arab Jews in his own age and after.

\section{In the Name of God, We Begin}

Explanation the Torah by the Head of the Yeshiva, Rabbi Gaon (May God have mercy on him)

Being a rendering of the meanings of the Holy Book from the books of prophecy, namely the Torah, from the sacred language into that prevailing in the translator's homeland and time

I have composed this book because one so desirous has asked that I provide the basic text of the Torah in a separate book, free from linguistic discussions of conjugations, reversals and changes of word order, alterations, and metaphors. The book is not intended to address questions raised by atheists or refutations thereof, nor to draw on rational disciplines or oral tradition, but only to extract the meaning of the Torah. I found that the one who made this request wishes the audience to receive the meanings of the Torah, including narratives, commands, and censures, in a systematic and concise manner. 
In this way, the reader, being unburdened by arguments in every discipline, will not take a long time to find a certain story. Those looking for the application of rational disciplines, the processes of oral tradition, and refutations of attacks on the stories of the scripture may find them in the other book, as this brief work draws his attention to this and fulfills his purpose. With this in mind, I composed this accessible exegesis (tafsir ) of the text of the Torah alone, guided only by reason and tradition. Wherever possible, I inserted a word or a letter to clarify the meaning and intention for those who are convinced by variety of expression.

I seek God's help in all my affairs in this world and the hereafter.

\section{Translated by Tarek Shamma}

\section{COMMENTARY}

Sa'diya's translation was the most influential Torah translation in Classical Arabic. Upon its appearance, it became the standard version for Arab Jews in Iraq and Syria, as well as in Egypt, North Africa, and al-Andalus (Islamic Spain) (Zewi 2015 241-244), and was additionally adopted by some Arab Christians, especially in the Coptic Church. As a result, previous translations are sometimes referred to in modern scholarship as "pre-Saadian" (Brody 1998: 241-244). Of these, only fragments in Hebrew script have survived, dated mostly to the ninth century.

The translations produced by Sa'diya and his Jewish predecessors were not the first to appear in Arabic. Copies of the Old Testament were in circulation, at least as excerpts, since ancient times, even before Islam. Jewish translations, however, were significant in that they were made directly from the original Hebrew text, whereas Christian versions were based on Syriac translations, especially the Peshitta (Vollandt 2011: 21-22). Yet, it is a topic of debate whether Sa'diya produced his translation in Judeo-Arabic (i.e., Arabic in Hebrew letters), later converted into the Arabic script; in the Arabic script directly; or in two versions in the two scripts, one for internal use within the Jewish community, and another for the broader Arabic-speaking population (Vollandt 2015: 16).

The first remarkable aspect of the introduction is the use of the word shar $\underline{h}$ (explanation) in reference to the translation (most likely a scribal addition), followed by Sa'diya himself using tafsir (exegesis, paraphrase). This is especially noteworthy considering that Sa'diya's version is essentially a translation. His rendering of the Hebrew text, as he explains it in his introduction, notwithstanding the addition of "a word or a letter to clarify the meaning and intention," can still be accommodated into any except the narrowest views of translation. The use of such cautious terms may reflect the attitude that sacred texts are impossible to translate in full. The only possibility, hence, is an approximation in the form of explanation or paraphrase that cannot 
replace the original in its "sacred language." This, of course, is the position of most Muslim scholars regarding the sacred book of Islam (see al-Shatibi, Chapter 20).

Sa'diya's account of his effort to render his holy book into the language "prevailing in the translator's homeplace and time" is reminiscent of Ibn Wahshiya's project to introduce his Nabatean legacy into the dominant Arabic of his age in an effort to highlight the accomplishments of his people (see Ibn Wahshiya, Chapter 6). To this may be added the fact that Arabic had become the predominant language among Sa'diya's Jewish coreligionists, making translation a practical necessity. No less importantly, transposing religious texts into Arabic, which by then had become a sophisticated medium of scholarly inquiry as well as philosophical debate, enabled Sa'diya and subsequent Jewish scholars to utilize principles and concepts of logic and philosophy, especially Islamic kalam, ${ }^{1}$ for their own religious discourseeventually leading to the development of Jewish kalam, which reached its highest point in the works of Maimonides.

Finally, a palpable (and certainly intentional) Islamic influence can be recognized in Sa'diya's use in the introduction and the text of the translation of Qur'anic, and generally Islamic vocabulary - and even terms of Islamic jurisprudence, such as zakat (Islamic alms giving). Like other members of cultural minorities within the multi-ethnic Islamic empire, Sa'diya was evidently keen to build links with the mainstream culture. Such adaptive methods undoubtedly facilitated his integration of the science of kalam into Jewish theology.

\section{Tarek Shamma}

\section{Note}

1 'Ilm al-kalam, literally "science of discourse." Kalam (translated as "Islamic dialectics") was the discipline of using the concepts and methods of philosophy (especially logic) to defend and prove the tenets of Islam. 


\title{
9 Meadows of Gold and Mines of Gems (957)

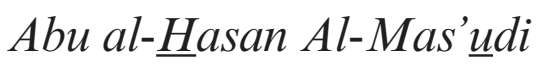

\begin{abstract}
Abu al-Ḧasan Al-Mas'ụdi (896-957)
Al-Mas'udi was a geographer, traveler, and one of the most prominent historians in Classical Arabic. He was born in Baghdad, then settled in Egypt. He was one of the first scholars to compose a universal history and to practice scientific geography in his major work Muruj al-Thahab wa-Ma'adin alJawhar. Al-Mas'udi traveled around the world and gathered anthropological information about the people of the regions he visited. His other major work is al-Tanbih wa al-Ishraf (Admonition and Revision).
\end{abstract}

\section{Muruj al-Thahab wa Ma'adin al-Jawhar (Meadows of gold and mines of gems)}

This is al-Mas'udi's best-known book, considered one of the most significant works of Arabic geography and history. The book presents the history of mankind from the beginning of the world to the late Abbasid Caliphate.

\section{[THE BEGINNING OF TRANSLATION IN THE ABBASID AGE]}

The chronicler Muhammad Ibn 'Ali al-'Abdi al-Khurasanini, who was an intimate of the [Abbasid] caliph al-Qahir (r. 932-934), reported that the caliph one day summoned him to a private meeting and, indicating a lance, insisted on hearing the truth. "It was like staring Death in the face," Muhammad recalled, "so I promised to give him an honest answer."

[Al-Q ahir then demands a frank account of the Abbasid caliphs who preceded him]

"Tell me about al-Mansur," he said.

"The whole truth?" I asked.

"Yes!"

"Before his time," I said, "the house of al-'Abbas and the house of 'Ali had worked as partners. Al-Mansur was the one who drove a wedge between them. 
He was also the first caliph to surround himself with astrologers and heed their counsel. His entourage included Nawbakht (the forefather of the whole Nawbakhti clan), who was originally a Zoroastrian, but had accepted Islam with the caliph as his sponsor. Among the caliph's other astrologers were Ibrahim al-Fazari, author of that long poem about the stars, as well as other works on astronomy and cosmology; and 'Ali ibn 'Isa, who worked with astrolabes.

Al-Mansur was also the first caliph to have books translated into Arabic. These include Kalila and Dimna and Sindhind, as well as the works of Aristotle - the ones on logic, and some others - not to mention Ptolemy's Almagest, Arithmetic, Euclid, and everything else that had been written in Ancient Greek, Greek, Pahlavi [Middle Persian], [New] Persian, and Syriac, in ancient times. The translations were made available to the public and attracted a good deal of attention and interest.

It was in al-Mansur's time that Muhammad Ibn Ishaq composed his Biography of the Prophet, and in so doing, brought together previously unknown reports that had never been collected or organized.

Al-Mansur was also the first caliph to give non-Arab converts and freedmen positions of responsibility, and to promote them ahead of Arabs. In this he was imitated by his successors, with the result that the Arabs, now pushed aside, lost their grip on power and their position of privilege.

Even before al-Mansur succeeded as caliph, he had done some of his own studying, and had learned about the different strains of Islamic thought as well as the variety of opinions on matters of theology and law. He knew about

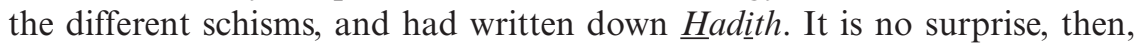
that during his reign, information flowed freely, and learning grew apace.

\section{Translated by Michael Cooperson}

\section{COMMENTARY}

Scholarly debates continue about the translation movement in the Classical age of Islam, which reached a zenith of range and quantity in the early Abbasid period. Particular issues of dispute include its motivations and age of inception. This text situates the start of this movement during the reign of Abu Ja'far al-Mansur, the second Abbasid caliph and the veritable founder of the dynasty. In this, it departs from the majority of scholars who set translation at later stages - specifically during the caliphate of al-Mansur's grandson alMa'mun (r. 813-833) — or even earlier periods during the Umayyad Caliphate (see Ibn al-Nadim, Chapter 10, and Rida, 'Abdo, al-Nu'mani, Chapter 42).

Of special interest in this text is not only the presumed early launch of the translation movement, but also the breadth of the translated material — above all books translated from Greek. It has been long known that this period saw translations from Pahlavi, including al-Nahmatan, ${ }^{1}$ a book on nativities, 
translated by the same Abu Sahl Nawbakht mentioned by al- Mas'udi (see also Ibn al-Nadim, Chapter 10). The most well-known non-Greek translation from that period is perhaps 'Abdullah al-Muqaffa's Kalila wa Dimna, rendered from a Pahlavi text (now lost), which was itself a translation the Sanskrit Panchatantra.

Al-Mas'udi, however, provides an impressive list of works in philosophy, science, and astronomy from Greek (and sometimes the intermediate Syriac), sources that were believed to have been translated only in later periods (e.g. al-Nairizi: 15-16). Perhaps the only other Classical scholar who agrees on timing the start of translation during that period is Sa'id al-Andalusi in The Categories of Nations, where he describes al-Mansur's interest in the sciences, especially astrology; while generally situating translation under the patronage of al-Ma'mun, he still refers to astrological books translated during the alMansur's caliphate.

Al-Mansur's keen interest in astrology and the translation of its books has given rise to speculation about the possible connection to the translation movement in that age. Indeed, a modern scholar (Gutas 1998) has relied mainly on this text by al-Mas'udi, together with two texts excerpted by Ibn al-Nadim (see Chapter 10), to argue that al-Mansur's patronage of astrology stemmed from political motives: the caliph, it is argued, adopted a Sassanid imperial policy, in which astrology played an essential part, in an effort to conciliate his Persian supporters. On this view, the translation movement was based on a revival of an ancient Sassanid myth (translated by Ibn Nawbakht in the Nahmatan; see Ibn al-Nadim, Chapter 10), which attributed the origins of all learning, including Greek sciences, to ancient Persia. ${ }^{2}$

There is little empirical foundation for this interpretation, however. In fact, even the textual evidence seems tenuous and subject to debate. For it is not at all clear that the text identifies a material link between al-Mansur's interest in astrology and his patronage of the translation movement (i.e., aside from the translation of some astrological books). These two events are merely listed among others that characterized the reign of this caliph. In trying to identify a common thread in the narratives cited by al-Mas'udi, the most tangible one seems to be a general negative evaluation. Al-Mansur's espousal of astrology (a pseudo-science rejected by all orthodox Islamic scholars) directly follows (and confirms) al-Khurasani's opening statement of condemnation. Seen in this context, the subsequent narratives only serve to substantiate and rationalize this negative assessment, concluding with the statement that he had appointed non-Arabs for his government, with destructive consequences.

\section{Tarek Shamma}

\section{Notes}

1 Variously "al-Bahmtan" or "al-Yahmtan" (see Ashtiani 2004: 31).

2 For details see Gutas 1998: 34ff, and Ibn al-Nadim, Chapter 10. 


\title{
10 The Index (990)
}

\author{
Muhammad Ibn Ishaq Ibn al-Nadịm
}

\section{Muhammad Ibn al-Nadim (?-990)}

Little is known about his life, except that he was born in Baghdad, where he worked as a bookseller. Al-Fihrist (The Index), is his only surviving work; it probably started out as a bookseller's catalogue.

\section{Al-Fihrist (The Index)}

An extensive bibliography of books written in, or translated into Arabic. Ibn al-Nadim also provides biographical information about the authors, mapping the social and political context of the writing. This is why the book is seen as a window into the culture and knowledge in the Arab-Muslim world in the author's age.

\section{[THE MOTIVATIONS FOR THE TRANSLATION MOVEMENT]}

Chapter Seven: Accounts of the philosophers, the ancient sciences and the books written about them

Section One: On accounts of philosophers of the natural sciences and of logic, with the titles of their books and their translations and commentaries: which are extant, which have been mentioned, which are no longer extant and which used to exist but can no longer be found.

\section{Statements at the beginning of this chapter from the scholars in their own words}

Abu Sahl Ibn Nawbakht in al-Nahmatan said the following:

There has been an increase in the branches of sciences, the types of books and the kinds of questions, together with sources from which are derived what the stars showed. This was due to what existed prior to the reasons for their existence being shown, and people's knowledge about them was described by the Babylonians in their books, learnt from them by the Egyptians and applied 
in their country by the Indians. These dealt with the first created beings before they were tainted with evil, committing sins, and falling into ignorance to the point of confusion and error. As reported in the books dealing with their matters and actions, they became muddled and confused, and their religion was destroyed, which led to bewilderment and incomprehension.

This lasted for a period of time until their successors, their descendants and offspring were helped to remember, to understand, and to acquire knowledge. They also found out about the past, about the context of the world, its condition, the driving force behind its origin, its intermediate stage and its end, the conditions of the world's inhabitants, the positions of the stars and their trajectories, their degrees, minutes and stations, whether high or low, and all of their directions. This was in the time of the king Jam Ibn Awnjihan. Scholars got acquainted with this knowledge and recorded it in books with their explanations. In addition, they described the world's majesty, the origins of its causes, its foundations and its stars, the types of drugs, remedies, and charms, and the things that people use and are seen as suitable to their needs, whether good or bad.

This carried on for a period of time until the reign of al-Dahhak Ibn Qai $[\ldots]$ in the period of Jupiter and its rule and power in organizing the years. Ibn Qai founded a city in al-Sawad [in southern Iraq], named after Jupiter, where he gathered sciences and scholars, and built 12 palaces according to the number and names of the zodiac signs. He stored the scholars' books there and had the scholars live there [...] The people obeyed them and followed their commands and let them manage their affairs as they accepted their superiority in matters of knowledge and modes of living, until a prophet was sent during that time. Due to his arrival and what they learned about him, the people rejected the wisdom [of the past] and many of their ideas became confused and diverging, so each of the scholars looked for a [new] place where to live so as to lead the people there.

One of the wise men was called Hermes. He was the most intelligent, the most discerning in his knowledge, and the most refined. He travelled to the land of Egypt, where he ruled its people, developed the land, improved the life of the inhabitants and showed his knowledge. This situation remained, particularly in Babylon, until Alexander, the king of the Greeks, invaded Persia, coming from the city of the Greeks called Macedonia. When he [the ruler of Persia] refused to pay the tribute that was still imposed upon the people of Babylon and the kingdom of Persia, [Alexander] killed the king Dara Ibn Dar [Darius], took over his kingdom, destroyed the city and the ramparts built by devils and giants. This destroyed all there was of scientific material, engraved on wood or stone, and all that was there was burnt or scattered. The copies that had been collected in the catalogues and libraries in the city of Istakhr he ordered to be translated into the Greek and Coptic languages, before burning the material written in Persian once he had copied what he needed. There was a book entitled al-Kushtaj, of which he took what 
he needed on astronomy, medicine, and natural sciences. He sent this book to Egypt, together with the scientific material, all the treasures and the scholars themselves [...]

People in every time and age encounter different experiences and introduce new disciplines, depending on the measures of the stars and the zodiac, which control the affairs of world with the command of God Almighty [...]

\section{Another account}

Learning in ancient times was forbidden, except for scholars or those who were seen as able to receive it naturally. Philosophers studied the nativities of people who were seeking science and philosophy, and when, and only when, it was ascertained that someone had the gift of learning, they enlisted and taught him. Philosophy appeared among the Greeks and the Romans before the religious law of Christ, peace be upon him. When the Romans converted to Christianity, they prohibited philosophy and burnt some of the books, but stored some others. They also forbade people from discussing anything of philosophy that contradicted the prophetic laws. Later, the Romans returned to the schools of philosophy. This was due to the Romans king Julian who used to stay in Antioch, who appointed as his minister Themistius, the commentator of Aristotle's books [...] Then Christianity prevailed again, and philosophy books were banned and stored away, as it is still the case today. In ancient times the Persians had translated parts of the books of logic and medicine, and later this was translated into Arabic by Ibn al-Muqaffa' and others.

\section{Another account}

Khalid Ibn Yazid Ibn Mu'awiya was called the "Wise Man of the alMarwan." " He was virtuous, interested in, and fond of sciences. As the art of chemistry attracted his attention, he ordered a group of Greek philosophers who lived in a city in Egypt to present themselves to him. He knew classical Arabic and ordered them to translate the books on the art from the Greek and Coptic languages into Arabic. This was the first translation in Islam from one language into another.

Then the Diwan [register], which was in Persian, was translated into Arabic

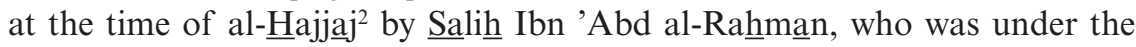
protection of Abu Tamim. Salih's father was a captive from Sijistan [Sistan]

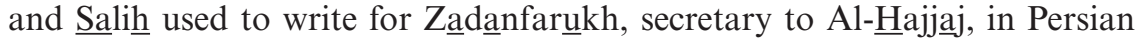
and Arabic under his supervision. As al-Hajjaj grew to like $\underline{\text { Salih}} \underline{\underline{S}} \underline{\text { Salih }} \underline{\underline{h}}$ said to Zadanfarukh: "You are my link to the ruler, who seems to have come to like me. He may want to raise my position above yours and you may lose yours." The secretary replied: "Do not think this. He needs me more than I need

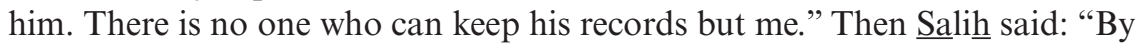


God, if he wants me to change the records into Arabic, I will change it," so Zadanfarukh said: "Do change a few lines for me to see," which he did. Then $\underline{\text { Salih }}$ was asked to pretend that he was sick, and he did, so al-Hajjaj sent him his physician, Tiadrus (Theodorus), who did not find any ailment. This came to the knowledge of Zadanfarukh who ordered him to attend to his job.

Then it so happened that Zadanfarukh was killed during the insurrection of Ibn al-Ash'ath, as he was leaving some place to return to his house. So Al-Hajjaj appointed Salih as secretary in his place. Then Salih informed him of what had happened between him and his partner with regard to the translation of the register, and al-Hajjaj decided on the matter and put $\underline{\text { Salih }}$ in charge [of the translation of the register]. Then Mardan Shah, son of Zadanfarukh asked him: "How will you deal with dahwayh and shashwayh?" and Salih said "I shall write "tenth" and "half-tenth." Mardan then asked: "But how will you deal with "waid," to which he replied "I shall write "In addition." ("waid" means an addition). So Mardan exclaimed: "May God cut your origins from the earth in the same way as you have cut off the

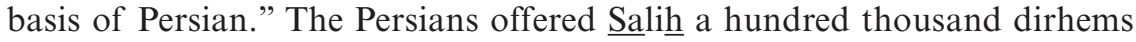
to agree to show inability in translating the register, but he refused and performed the translation [...]

As for the register in Syria, it was in Greek, and the secretary was Sarjun Ibn Mansur for Mu'awiya Ibn Abi Sufyan, ${ }^{3}$ then Mansur, son of Sarjunn. The records were translated during the time of Hisham Ibn 'Abd al-Malik ${ }^{4}$ by Abu Thabit Ibn Sulaiman Ibn Sa'd, a protégé of Husain, who was responsible for correspondence during the rule of Caliph 'Abd al-Malik. It was reported that the register was translated in the days of 'Abd al-Malik who had asked Sarjun to take on duties. When Sarjun showed some reluctance, 'Abd al-Malik became angry. He consulted Sulaiman, who said to him: "I will translate the register and rid you of him."

\section{The reasons why books on philosophy and other ancient sciences have been translated in this land}

One reason for this was that al-Ma'mun saw in a dream what looked like a man of white color with a reddish complexion, a wide forehead and joined eyebrows, bald with a blue streak in the black of his eyes, of pleasant appearance, sitting on his bed.

AL-MA'MUNN SAID: "It was as if I was facing him and I was in awe." So I said: "Who are you?" And he replied: "I am Aristotle." I was pleased and said: "Wise man, may I ask you a question?" and he replied: "ask." SO I ASKED: "What is good?" and he replied: "What is good in the mind." I ASKED AGAIN: "Then what?" and he answered "What is good in the law." THEN I SAID: "Then what?" and he replied: "What is good with the people." SO I SAID: "A then what?" and he said: "Then there is no then." 
According to another account, [al-Ma'mun] said: "Tell me more," and Aristotle replied: "who gives you advice about gold, let him be for you like gold, and let monotheism be your guide."

This dream was one of the major reasons for the acquisition of books, as there had been correspondence between al-Ma'mun and the Byzantine king. Al-Ma'mun had triumphed against him, so he wrote to him to request a selection of ancient [manuscripts of] sciences stored and preserved in Byzantium. After a first refusal, the king agreed and al-Ma'mun sent a group including al-Hajjaj Ibn Matar, Ibn al-Bitriqu, Salman the director of Bait al-Hikma, ${ }^{6}$ and others. They brought a selection of books from what they had found and when they brought them, al-Ma'mun ordered for them to be translated, which was done. It is said that Yuhanna Ibn Masawayh was one of those who travelled to Byzantium.

Among the people who were interested in obtaining the books from the land of the Byzantines were Muhammad, Ahmad and al-Hasan, the sons of the astronomer Shakir (who will be mentioned later). They were generous with gifts, and they sent Hunain Ibn Ishaq and others to the land of the Byzantines in order to bring back rare books and unusual compositions in philosophy, geometry, music, arithmetic and medicine. Qusta al-Ba'albaki brought some material with him and translated it. He also had some material translated for him. According to Abu Sulaiman al-Sijistani (c.912-c.985), the sons of the astronomer paid a group of translators, which included Hunain Ibn Ishaq, Hubaish Ibn al-Hasan, Thabit Ibn Qurra and others, around 500 dinars a month for translation as a salary.

I heard Abu Ishaq Ibn Shahram in a public gathering say that there is in the land of the Byzantines an ancient temple with a large gate as was never seen before, with both doors made of iron. In the past the Greeks worshipped stars and idols, and offered sacrifices. Abu Shahram said:

I asked the Byzantine king to open it for me, but it was impossible for him to do this, as the temple had been closed since the Byzantines became Christians. I continued to be pleasant to him and to correspond with him and to engage in conversation with him when at his court.

\section{Abu Shahram continued:}

Then he agreed to open it, and this edifice was made of marble and stone with colors and inscriptions, which surpassed in their number and beauty anything I had seen before. There were also ancient books in the temple that would require many camel loads.

He even talked of "thousands of camels." Some of the books were somewhat used, others were in good condition and others had been eaten by insects. Abu Shahram then said "I saw gold utensils for offerings and other 
extraordinary objects. Then upon my exit, the door was locked, and I felt embarrassed that he had awarded me this privilege." He added: "This was in the time of Saif al-Dawla." Abu Shahram thought that the temple was a three-day journey from Constantinople.

\section{Translated by Myriam Salama-Carr}

\section{COMMENTARY}

In tackling the translation movement during the Abbasid age, Ibn al-Nadim resorts to the common method of contemporary historians - citing the various narratives of the event one by one as they were available to them. Thus, we are given different (sometimes incompatible) interpretations of the motivations for the emergence and official support of the translation movement.

The first narrative cited comes from the Persian astrologer Ibn Nawbakht (see al-Mas'udi, Chapter 9). Ibn Nawbakht traces ancient sciences to their presumed origins in Babel, Egypt, and India (fabled sources of ancient wisdom in Classical Arabic sources). Then, without any apparent transition, he moves to ancient Persia, whose kings, he explains, revived these sciences, after they had become extinct, and kept them in their cabinets, from which they were (re)introduced into Egypt. The preserved ancient sciences were subsequently transferred to the Greeks, following the Greek conquest of Persia (334 вCE). Alexander's the Great, we are told, seized the books of Persian kings, had their contents translated into Greek, then burnt what was left. In later times, Persian kings, having renewed their practice of patronizing sciences, reassembled the scattered ancient books and (re)translated what had been rendered into other tongues, especially during the reign of Khosrow I (r. 531-579 CE).

Ibn Nawbakht's narrative, while emphasizing the collective and somewhat universal nature of knowledge as it passed through ancient cultures, evidently places Persians at the center of this process, which would situate this narrative in the context of the efforts of members of different cultural communities during the Abbasid period to celebrate their cultural legacy through translation (see Ibn Wahshiya, Chapter 6). Especially significant is the fundamental role given to Alexander the Great in the narrative, bearing in mind that by far that the bulk of translated works in the Abbasid age (especially philosophy and medicine) came from Greek. Thus, Ibn Nawbakht, a recent convert of Persian ancestry and translator of the al-Nahmatan from Pahlavi, seems to be tracing the entire translation movement (including implicitly Greek works) back to Persian sources.

Indeed, in his From Greek to Arabic, Dimitri Gutas finds this narrative to be something of a foundational myth for the translation movement in the Abbasid age, as it was propagated by Persian scholars and adopted by Caliph al-Mansur (Gutas 1998: 73; see also al-Mas'udi, Chapter 9). 
Notwithstanding the strengths and weakness of this interpretation (see the Introduction), there is no doubt that Ibn Nawbakht's narrative involves an unmistakable "national" sentiment. Yet, one should not disregard the other, no less significant, professional element. Ibn Nawbakht - an astrologer at the court of al-Mansur, who succeeded his father Nawbakht and would be succeeded in this position by his son Abu al-'Abbas (Ashtiani 2004: 38) - had a vested interest in confirming the decisive impact of the stars in the rise and decline of civilizations throughout history; his account makes astrologers the sole interpreters of the celestial cycles of history, and thereby indispensable to monarchs. Indeed, the theme of human history as controlled by the stars is repeated throughout the text, from the opening to the conclusion, forming something of a unifying thread. Therefore, one has to conclude that Ibn Nawbakht's career aspirations were no less essential than his ethnic identity. It may be argued, in fact, that the main incentive for this narrative is to introduce his own profession as the arcane art of understanding and predicting human events. Reviving and propagating Persian national mythology was certainly a part of this effort, but there is no reason to assume that it was the main purpose.

Ibn Nawbakht's account of the transmission of ancient knowledge and its preservation in Persian translation underlies a view of translation as an instrument of power, used not only to import, but also to appropriate the cultural products of other nations. The aim may be a universal storehouse of human knowledge accessible to all nations, but this has to be done through the agency of one national language. It's difficult to miss the parallel between this view and the more modern project famously described in 1813 by the German philosopher Fredrich Schleiermacher, who called for establishing a massive translation enterprise whereby major world classics would be translated into German. This project, Schleiermacher argued, would

preserve in the geographical center and heart of Europe, all the treasures of both foreign and our own art and scholarship in a prodigious historical totality, so that with the help of our language everyone can enjoy, as purely and as perfectly as a foreigner can, all the beauty that the ages have wrought.

(quoted in Robinson 1997: 238)

According to Laurence Venuti, Schleiermacher saw "translation as an important practice in the Prussian nationalist movement," enabling "German culture to realize its historical destiny of global domination" (Venuti 2008: 83). ${ }^{8}$ Such a viewpoint is certainly not limited to a particular age or language. If Persian might, according to some of its speakers in the Classical age of Islam, serve as a preserver of different world cultures throughout history, would Arabic not play a similar role in view of the global dimensions of the Islamic state, and Islam as a universal religion, with a massive translation movement from various languages being a one of its main cultural landmarks? A similar 
position was expressed by Ibn 'Arabi, the 12th-13th century Sufi and philosopher. He explained: "Do you not see that this nation has translated the sciences of all nations? [...] This nation, indeed, has acquired the knowledge of all those who came before it, and has invented sciences that were unknown to them" (Ibn 'Arabi: 333).

Ibn al-Nadim's third account dates the start of translation to the earlier Umayyad period by placing it in the context of the major administrative reforms implemented during the reign of the fifth caliph 'Abd al-Malik Ibn Marwan (646-705) or one of his successors. A major component of these

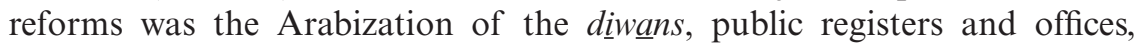
which later developed into full-fledged government departments (see $\boldsymbol{a l}$ Qalqashandi, Chapter 23). In the early years of the Arab conquest, díwans were kept in Pahlavi (ancient Persian) in Iraq and in Greek in Syria and Egypt, and administered, as these texts show, by secretaries who spoke these languages (Persians for Pahlavi and Syriacs for Greek). Group identity is a distinct factor here too, though now linked to language rather than ethnicity. The career aspirations of state employees are also evident, indicating the high stakes involved in translation competency, not only in the scholarly fields of philosophy and medicine (as in Ibn Nawbakht), but also in state administration.

The narrative about the Arabization of the diw wans is the basis of a different modern interpretation of the translation movement. In his al-Fikr al-'Ilmi al'Arabi: Nash'atuhu wa Tatawwuruh (Arabic Scientific Thought: Its Emergence and Development), George Saliba singles the Arabization of the diwans as the social catalyst for the translation from Greek. The vast majority of the translators of Greek works in the Abbasid period (and all of them in the early stages) were, like Sarjunn, Christian Syriacs who had learned Greek, the language of Byzantine learning and administration of the region before the coming of Islam. When the Arabization of diwans deprived them of lucrative careers, they had recourse in their bilingual knowledge to embark on the translation of Greek works in philosophy, medicine, and astronomy, which were available either in their original language or in Syriac versions. Thus, Saliba argues, they managed to return to the coveted state service to reclaim in new roles the positions they had lost due to the Arabization process.

The final narrative, in which the translation movement (at least from Greek) did not start until later during the reign of al-Ma'mun (r. 813-833), is introduced under a separate title, which may suggest that Ibn al-Nadim lends special importance to it. Much has been written about al-Ma'mun's dream that supposedly inspired him to initiate the translation of Greek philosophy, which is beyond the scope of this commentary. It goes without saying that we cannot ascribe a major cultural event adopted by one of the most eminent caliphs to such a narrow personal motive. However, and regardless of the source of this narrative and Ibn al-Nadim's own view of it, we can certainly read it as an attempt to provide an interpretation of the caliph's personal interest in translating Greek philosophy, rooted in its social, political, and 
intellectual conditions, even if presented in the guise of a dream. The narrative links al- Ma'mun's patronage of translation to his well-known interest in philosophy, especially the Greek rationalist school of Aristotle, all in the context of the intellectual conflicts characteristic of his reign, some of which had highly charged political dimensions. ${ }^{9}$ Furthermore, Aristotle's advice that the good can be determined first by reason, before public opinion or even religious law, is a restatement of the principle of the rational basis of good and evil (التحسين و التقبيح العقليان), conceived by al-Mu'tazila, a rationalist school of theology that was officially adopted by al-Ma'mun.

\section{Tarek Shamma}

\section{Notes}

1 A branch of the Umayyad dynasty that later prevailed in the caliphate.

2 Umayyad governor of Iraq (694-714).

3 The first Umayyad caliph (661-680).

4 Umayyad caliph (724-743).

5 Sharín, more specifically Islamic law.

6 "The House of Wisdom," a scholarly establishment supported personally by alMa'mun; according to Arab classical historiography, translation was one of its main functions.

7 Founder of the Hamdanid dynasty, which ruled northern Syria and Mesopotamia through the tenth century (r. 945-967).

8 For a discussion of this view in the context of translation as a form of conquest see Shamma 2020: 101-104.

9 Muhammad 'Abid al-Jabiri argues that al-Ma'mun's support of rationalist philosophy was intended to "combat Manichean Gnosticism and Shi'ite 'irfan (esoteric knowledge), that is the sources of knowledge adopted by, and unique to anti-Abbasid movements" (1993: 242). Adnan Abdulla also argues for a link between the translation of Greek logic and the official effort to quell heresies connected to ancient Persian religions (Abdulla 2021: 35-36). 


\title{
11 Approximating the Scope of Logic (1063)
}

\author{
Ibn $\underline{\text { Hazm al-Andalusi }}$
}

\section{Ibn ㅂazm al-Andalusi (995-1063)}

One of the most eminent jurists and men of letters in al-Andalus, born in Córdoba. He wrote on logic, medicine, theology, history, and comparative religion. Like his father and grandfather before him, Ibn Hazm served as minister to several Umayyad caliphs of al-Andalus. His most prominent

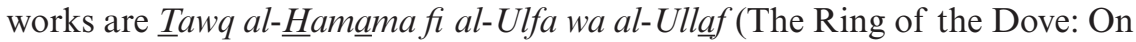
Love and Lovers) and Approaching the Scope of Logic.

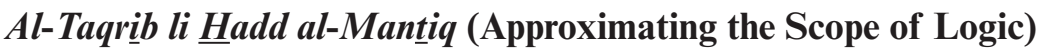

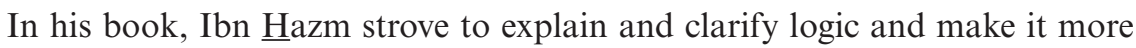
accessible using "common expressions and jurisprudential examples." In addition to the examples from jurisprudence, he also disputed some of Aristotle's ideas.

\section{[THE HUMAN ORIGINS OF KNOWLEDGE AND BARRIERS TO TRANSLATION]}

We find that He, the Almighty, has indeed numbered his blessings upon the one who inaugurated his creation of humankind in that He taught him the names of things. So He says: "And He taught Adam the names, all of them" [the Qur'an, al-Baqara 2:31]. It is through Him that angels, humans, and jinn are known from among the rest of living beings. He is the one who brought to knowledge all existent things in their varying facets and clarified their meanings, which, due to their differences, required different names. He also made known the knowledge of their designation under the category of nouns.

So, whoever is ignorant of the extent of this blessing in himself, and in the rest of his kind, and does not value its importance for him, would not be superior to animals except in form. To God is due gratitude for what He has taught and provided; there is no God but He. And whoever does not know the descriptions of named things, a knowledge that is necessitated by the variance

DOI: $10.4324 / 9781003247784-13$ 
of their names, and defines each of them only by their definitions, then he has ignored the extent of this majestic blessing, and passed it heedless and unaware, and in turning away from it, he does not endure a simple failure, but a great one.

If one without knowledge of the matter says: "Have any of the predecessors spoken of this?" it will be said to him: "This knowledge is firmly established in the soul of every sensible being." For the intelligent mind arrives, with what God has enabled in it of understanding, to the benefits of this knowledge. An ignoramus dawdles like a blind man until he is alerted to it, and so it is with all forms of knowledge. None of the venerable forefathers-may God be pleased with them - spoke in matters of grammar; yet when ignorance spread among people with regards to the different declensions by which meanings are differentiated in the Arabic language, the scholars set down books of grammar. In doing so, they alleviated a substantial problem, which greatly aided in the understanding of God's word and the words of his Prophet (PBUH). The one who is ignorant of this knowledge lacks understanding of his Lord. Thus, the alleviation of this ignorance counts among the scholars' good deeds, procuring rewards for them. This should also be said of the works of scholars in language and jurisprudence, for the honorable predecessors were not in need of them, due to what God had bestowed on them of favor, and honored them in their witnessing of prophecy. Those who succeeded them lacked all this.

It can be sensed and known that the deficiency of one who does not inspect these sciences and read these books affiliates him to beasts. Such is this science, that whoever is ignorant of it, the structure of God's words, and of the words of His Prophet (PBUH), is absent to him, and confusion deceives him in such a way that he is unable to distinguish between it and the truth. He knows his faith only by blind imitation, and would be susceptible to bewilderment. We seek refuge in God from this. It was thus urgent, for these reasons and for what we will mention after this, God willing, to write this book, and to toil in explaining and simplifying the science of logic, by God's power and strength. So we proceed, and in God we seek help.

Among the wise predecessors, who came before our time, were those who compiled books in which they organized the different categories under which the names of designated things fall, those which all nations have agreed upon in meaning even though they differed in the particular expressions. For nature is one, though choices are varied and diverse. They determined how information becomes known from the construction of these names, what is and is not permissible, and they pursued such matters. Thus, they set in these matters certain boundaries of meaning and did away with ambiguity. With these books, God brought great benefit to us, they brought close what was remote, made easy what was difficult, and helped clear barriers in the way to truth. Among them are Aristotle's eight collected books on the scope of logic.

Now we speak the words of one who desires his First and Only creator's protection and safeguard, and who has no power or strength except through 
Him, and no knowledge except that which He has taught him: Among the acts of obedience with which we wish to please our Lord is the clarification of these books for their great benefit. For we have seen that people are with regards to them of four kinds: three of them have embraced repugnant error and a repulsive transgression, and the fourth a shunned and unrecognized truth, an oppressed knowledge. To champion the oppressed is a duty worthy of reward.

One of the four kinds of people is a group that has judged that these books contain disbelief and encourage apostasy. They say this without having attended to their meanings or even perused them. This, while they recite God's word (the Exalted and Glorified), though they are the ones intended when $\mathrm{He}$, the Exalted, says: "And pursue not that thou hast no knowledge of; the hearing, the sight, the heart - all of those shall be questioned of " $[\ldots]$

Thus, we trust in God's great and abundant reward for removing this falsehood from their stubborn souls, which have judged before confirming its veracity, accepted without knowledge of the truth, and decided without argumentative proofs. We sought to lift from them the great offense which in this corrupting belief they have attributed to a group free of ill-repute, with a pure complexion, innocent of what they were accused of [...]

The second kind are a group that consider these books delirious speech and senseless talk. In general, most people are quick to antagonize and to disparage what they do not know [...] So we also found that it would be an act of righteousness to educate those who are unknowing about what we have commended earlier for its excellence $[\ldots]$

The third kind are a group who have read these aforementioned books with disordered minds, destructive inclinations, and unsound perceptions. Their hearts have been drenched with fondness for disdain, they have yielded to helplessness, and they have been averse to the transmission of the prescribed law. They have accepted the statement of the ignorant that these are books of atheism; thus, they have branded themselves as understanding these books, yet they cannot be any further from understanding. What we have just mentioned has contributed to the confusion about, and aversion to these books [...]

The fourth kind are a group who have considered with clear intellect, with thought purified from bias, and a sound mind, and were thus enlightened by these books and devoted to the attainment of their objectives. They were therefore guided by their source of light, and the Oneness of God was confirmed for them through necessary and inescapable proofs. They witnessed the divisions of creation and the effect of the Creator on it and His care for it. They found these superior books to be like the sincere companion, the righteous guard, and the loyal friend who does not give up during hardship, and whose friend finds him whenever he looks for him [...] These books to them are like a touchstone to a goldsmith, and like the things that have within them those particular elements that reveal their secrets.

When we look into the calamities we have just mentioned, we can find that among the ills causing them is the complication of translations and their rendering of the meaning into expressions that are not common or 
in everyday use. For not every expression fits every concept. So, we sought closeness to God, the Exalted and Glorified, by presenting the meanings in simplified and clear expressions, in which the expert and layman, the scholarly and the uneducated, are equal in their understanding of them, according to our understanding of them and with what the Creator, the Blessed and Sublime, granted us of strength and power to act. The reason that drove those translators that preceded us to obfuscate, and to make inaccessible their expressions and to roughen the terrain towards their understanding, is their avarice for knowledge and their hoarding it.

It seems to us that those who sought knowledge at that time were plenty and of keen dedication. Now people have renounced knowledge, to the point that they even harm, frighten, and chase away people who have it. Not content to leave their ignorance for themselves, rather they have started to call to it, thus deterring others from it in both speech and action. [...]

Otherwise, learning would be defunct, except for lip service. Only subtle traces and a few signs would remain of it. God is the one who is sought for help. $[\ldots]$

Our book is of the type which only those of knowledge and sound deliberation compose, falling under the fourth type of books, which is the explanation of the abstruse $[\ldots]$

\section{[Introduction to Logic or Isagoge]}

With this, we begin, God Almighty willing, with His strength and power, what we intended. We undertake to explain the prolegomena of the aforementioned books, what is called in the Greek language the Isagoge. Isagoge in the Greek language means "prolegomenon," which is the work of Porphyry of Tyre. The books that come after this one are among the works of Aristotle.

\section{Translated by Lubna Safi}

\section{COMMENTARY}

The goal of Ibn Hazm's book, as suggested by the title, is to make logic more accessible to the general reader. For this purpose, he uses common and non-specialized terms, supported with examples from Islamic theology. As Ibn Hazm admits in the introduction, logic had become an alien, and even suspected, subject, due, among other things, to its impenetrable style, resulting from "complication of the translations and their rendering of the meaning into expressions that are not common or in everyday use."

The difficult style of philosophical works, caused mainly by translation, was a common complaint among scholars, including some practitioners of philosophy (see Ibn Rushd, Chapter 12; al-Sírafi and Matta, Chapter 7).

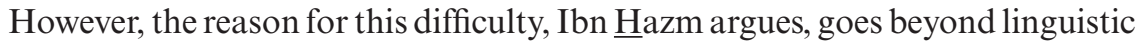
difference and translators' errors; it was a deliberate effort by the practitioners 
of logic to keep it to themselves, which is what "drove those translators that preceded us to obfuscate and to make inaccessible their expressions and to roughen the terrain towards their understanding." Such a course of action was understandable, he says, in earlier times when there was considerable demand for logic among students. But the case is different in his own time, when this art had become all but discarded. Indeed, it had become the target of open hostility. Thus, scholars in the past may have been excused for their reluctance, since logic, as he says later in the same book, is

like strong medicine. If taken by those of sound health and wholesome nature [...] it would help them and improve their wellbeing [...] But if taken by the ill-humored and weak of build, it would cause them harm and worsen their plight — it may in fact be lethal.

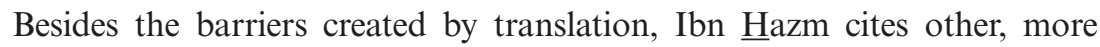
fundamental objections to logic, which calls the very discipline into question, charging it with absurdity or even inciting heresy and apostasy. In response, he traces logic back to its common human origins, as transcending the linguistic barriers which emerge in translation. To him the difference created by translation can be regarded as negligible, since the basic principles of logic are ones that "all nations have agreed upon in meaning even though they differed in the particular expressions. For reality is one, and choices are varied and diverse."

These arguments rely on two assumptions that were accepted by many Islamic scholars who practiced and defended logic. First, as explicitly emphasized here, is the shared human origin of wisdom beyond differences of culture, language, and time. The second is the separation of meaning and utterance with the former given primacy as containing a kernel of knowledge which remains invariable despite the multiplicity of surface expressions in different languages. As a result, translation could be trusted as a preserver of the primary meaning, whereas inevitable distortions are attributed to the human error, rather than to the impossibility of translation as such. This was the line of argument employed by Matta in his defense of logic (see Ibn Rushd, Chapter 12; al-Sirafi and Matta, Chapter 7).

A similar attitude toward translation was expressed by the logician Abu Sulaiman al-Sijistani (d. c. 985). When he is told that "We have found that ancients made many statements that agree in confirming monotheism [...] which indicates that what stems from the divine law is consistent with what is intimated by the soul," al-Sijistani agrees, explaining that any imperfections in the comprehension of wisdom that deviate from pure monotheism must arise from the translators" errors. For "It is no secret that translation from Greek to Hebrew, from Hebrew to Syriac, and from Syriac to Arabic has compromised the properties of meanings in the vessels of truths" (in alTawhidi, al-Muquabasat: 258).

Tarek Shamma 


\title{
12 Commentary on Aristotle's Poetics (1198)
}

\author{
Abu al-Walid Ibn Rushd (Averroes)
}

\section{Ibn Rushd (Averroes) (1126-1198)}

A judge, physician, and philosopher. Born in Córdoba (Islamic Spain) to a family of prominent judges, he studied fiqh (Islamic jurisprudence) and natural sciences with the scholars of his time. He wrote on various topics, including theology, medicine, astronomy, physics, psychology, mathematics, Islamic law, and linguistics. He is known today chiefly as a pioneer of rationalist philosophy, which was influential also in Renaissance Europe. His works include summaries of and commentaries on all Aristotle's works that were available in Arabic in his time, which became well known in Europe through Latin translations.

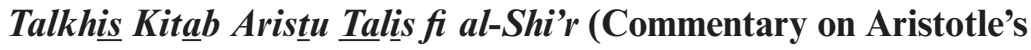 book on poetry)}

Relying most likely on Matta Ibn Yunus's translation, Ibn Rushd's work is a "middle commentary" (Badawi 1953: 55), which does not follow the original word for word, but gives a detailed summary, interspersed with selected citations. He had already written a short comment (jami') on the same book, ${ }^{1}$ in which he confined himself to a synopsis of "poetic statements" and Aristotle's general purpose. As the theater as literary genre was unknown in Arabic (or in Syriac, which was the first language of many translators), Matta Ibn Yunus translated "tragedy" and "comedy" into "panegyric" and "satire," respectively.

\section{[ON THE UNIVERSAL LAWS OF POETRY]}

Our purpose here is to summarize what can be found in Aristotle's book of the total laws that are common to all, or most, nations. For much of this book concerns laws that are specific to their [i.e., the Greeks'] poetry. Their poetic practices either exist to varying extents in Arabic, or in other languages [...] 
This is what this book covers of the features that are common to all, or most, nations. The rest is entirely, or mostly, confined to their own poetry and practices thereof. For he [Aristotle] enumerates the poetic genres common among them, stating the origin of each, and which parts of them preceded the others in genesis. He lends special attention to satire and panegyric, which are eminent among them. In addition, he indicates who established which of these recognized genres, as well as which poets augmented or perfected it. In this respect, he lavishes praise on Homer as the founder of the principles of these genres, considering that no poet before him had produced any worthwhile examples, neither in panegyric or satire, nor in the rest of their recognized arts $[\ldots]$

\section{[From chapter four, on panegyric]}

He said: "Panegyric must have six parts: mythical statements, customs, rhythm, beliefs, insight, and melody" [...]

Customs ${ }^{2}$ and beliefs are the most important parts of panegyric, since this genre does not imitate people as they are perceived to be, but singles out for imitation their righteous customs and good deeds. Now good beliefs include actions as well as disposition; hence, Aristotle made custom one of the six parts, which obviated the need to mention both actions and character in his classification. Insight, on the other hand, involves demonstrating the correctness of thought, which to them was apparently a method of proving the correctness of the praised thought. All this cannot be found in Arabic poetry - only in panegyric religious statements. The Greeks imitated these three things - customs, thoughts, and inference - with the three things with which imitation is effected, namely imaginative statements, rhythm, and song $[\ldots]$

\section{[From chapter five, on panegyric and the nature of imitation it employs]}

He said: "It seems that, considering the purpose of poetic statements, that imitation of falsehoods and fabrications is not the work of the poet." This refers to fables and tales, such as those found in the book of Kalila wa Dimna. Instead, the poet' subject is what exists or is likely to exist, his intention being to deter from, to incite into, or to produce an exact imitation thereof, as was stated in the sections on imitation.

Thus, the activity of those who produce such fables and tales is different from that of poets, even if they produce these invented tales and fables in rhythmed speech. The two have the rhythm in common; however, one of them fulfills his function through fabrication, even if not in rhythm, with what mental improvement can be gleaned from invented statements. The poet, on the other hand, cannot fully achieve his purpose without rhythm. For creators of tales and fabricated examples only invent non-existent people and give them names. The poet, by contrast, names things that exist. A poet may even 
address totalities. Hence, the art of poetry is closer to philosophy than that of inventing fables.

These statements of Aristotle concern their poetic practice, which seems to be the natural custom for natural nations [...]

\section{[From chapter six]}

Panegyric statements should include these two aspects. This happens when the poet turns from imitating virtues to imitating the misfortune or suffering that may befall the virtuous; or when turning from this to imitating the virtuous. This type of imitation softens the soul and prompts it to accept virtues. You will find most imitation employed in scriptural statements of this type, being panegyric statements signifying action. One example is the narrative of Yusuf (May God's blessing be on him) and his brothers ${ }^{3}$ and other similar tales considered moral instruction [...]

He said: "Some poets incorporate into their panegyrics things that are intended only to arouse wonder, without being either fearful or pathetic." You find many of these things in scriptural writings. For praise of virtues is not found in Arabic poetry; in our time they are to be found only in written [religious] traditions [...]

\section{[Types of imitation]}

He said: "The fifth type is used by the sophists among poets," which is mendacious exaggeration. Examples of this are numerous in Arabic poetry ${ }^{4}$ and that of the moderns [...] but are entirely absent from the Noble Book. For they are to this type of statement, I mean poetry, what sophistries are to logical proofs. However, some commendable examples of this type may be found among natural poets $[\ldots]$

\section{[From chapter seven]}

He mentioned the differences between panegyrics and their other poetic genres $[. .$.

All this, however, is specific to them, with no counterparts in our language, either because what he discussed is not common to most nations, or because things occurred to the Arabs that deviated from the natural norm. The latter is more likely, for he would not have included in this book what is unique to them, but only what is common to all natural nations [...]

Now this is the full extent of our understanding of what Aristotle mentioned in that book of those statements common to all genres of poetry, or specific to panegyric - meaning those common to most, or all, nations. The other subdivisions of their poetry between panegyric and the other types that he mentioned are specific to them, and even these he discussed only partly in the book as it came to us. This suggests that the book has not been translated in 
full: there remains the discussion of many other subdivisions of their poetry, which he promised in the beginning of the book to discuss in full. The missing part of what is common is the discussion of satire. It seems, however, that the treatment of this issue is close to what was said on panegyric, for opposites illuminate one another.

\section{Translated by Tarek Shamma}

\section{COMMENTARY}

The Islamic reception of Greek philosophy remains a subject of heated debate. Beyond its impact on Islamic scholarship and society, scholars have explored the aspects of originality in the transmitted Greek thought: were thinkers and men of letters in the new environment able to assimilate Greek philosophy to formulate their own concepts and theoretical approaches? In fact, questions have been raised about the very process of transmission and comprehension: Did Greek works arrive in Arabic intact, or at least without parts of them distorted beyond recognition? What we are concerned with here is the role of translation in these processes: the difficulties the translators encountered in dealing with cultural and linguistic difference, the methods they adopted in dealing with it, and to what extent they shaped and reoriented the Greek heritage into its new context. No less importantly, what were the assumptions and purposes that informed the reading of this translated heritage in its new environment?

Ibn Rushd's commentaries on Aristotle's full canon, as it was available to him, constitute the most intimate textual engagement with Greek philosophy in Arabic. In his work, he usually does not foreground translation as a constitutive factor in his access to Greek philosophy, treating his comments as a direct engagement with Aristotle. Yet, there are moments of reflection, or rather of hesitation, when he pauses to speculate on the opacities of the text. Like Ibn Sina (Avicenna) before him, Ibn Rushd sometimes had to resort to conjecture. It was not only that he could not read Greek. The temporal and cultural gap between the twelfth-century Ibn Rushd and the fourth-century BCE Aristotle-1,600 years between two cultures that did not share many literary forms - was a serious obstacle not only to full transmission, but even to the comprehension, of the source text.

To be precise, the misunderstanding of Aristotle's exposition of the art of Greek drama started with the Arabic translation of the Poetics. The Syriac Matta Ibn Yunus, himself a leading logician and a proponent of Greek philosophy (see above) was faced with the terms and concepts of Greek theater (a genre that was unknown to the Arabs or the Syriacs before them). The challenge that faced Ibn Yunus was not only the complete absence of an equivalence, but, more fundamentally, of any contextual information that could have allowed him to understand the foreign concept in its original 
setting and employ the usual methods of coinage or borrowing, as his fellow contemporary translators did in translating philosophical or scientific works from Greek. What distanced the book even further from its original context was the fact that the Poetics (like Rhetoric, Aristotle's other work of literary criticism) was categorized as part of the Organon, the collection of Aristotle's works on logic, together with Categories, On Interpretation, Prior Analytics, Posterior Analytics, Topics, On Sophistical Refutations. This (mis)classification had become standard practice among commentators on Aristotle in the Hellenistic Alexandrian School of philosophy since at least the sixth century (Vagelpohl 2012: 56). Based on his almost inevitable assumption, as the title suggested, that the work dealt with poetry, Ibn Yunus adapted the book into what he believed were the equivalent terms in Arabic poetics. In trying to make the book comprehensible across this wide chasm, Ibn Yunus had to make a conceptual leap that was as much an act of creativity as it was a misunderstanding. Consequently, "comedy," which represents people as "worse than our normal level" became "satire," while "tragedy," which represents people as better, became "panegyric." 5

Faced with the obscurities of the texts, Ibn Rushd speculates on several possible reasons, including the Arabic translation. Indeed, it is this difficulty, sometimes incomprehensibility, of parts of Aristotle's texts that prompted Ibn Rushd to start his project of a full-scale explanation of, and commentary on, all Aristotle's works available in Arabic. Ibn Rushd's contemporary, the historian 'Abd al-Wahid al-Marakishi, mentions that the Andalusian philosopher Ibn Tufail conveyed to Ibn Rushd that Abu Ya'qub al-Mansur (the Almohad caliph) had complained about "the troubled phrase of Aristotle, or that of those who have translated him, and referred to the obscurity of his purposes" (al-Murakushi: 179). Ibn Tufail asserts that "Were these books to be tackled by someone who would summarize them and clarify their purposes, after he has fully comprehended them, they would be more accessible" (ibid). Thus, he asks Ibn Rushd to undertake this task, which he would have done himself had it not been for his advanced age and heavy duties as minister to the caliph. This, Ibn Rushd says, is "what made me compose these summaries of the books of the philosopher Aristotle" (al-Murakushi: ibid).

Besides the difficulties of reception, Ibn Rushd's reflections (on the original text as well as on the translation) reveal the receiver's approach to the Poeticshis intentions and assumptions, in his attempt to integrate the target text into the receptive culture, and his own philosophy. Like Islamic philosophers before him (specifically Ibn Sina and al-Farabi), Ibn Rushd shows little concern with the meaning or position of the text in its original environment. The aim of his commentary, as he says more than once, is what "total" laws can be garnered from the Greek work, to be applied to all cultures, and thus incorporated into the intellectual horizon of the receivers.

Along the same line, Ibn Sina had concluded in his earlier, far shorter commentary that the general principles formulated by Aristotle can be used as the basis for native developments in "the science of pure poetry (الشعر المطلق ) 
according to the customs of this time" (Ibn Sina 198). Ibn Sina conceived such a project as complementary to Aristotle's own intention, which was not only to describe Greek poetry, but, more importantly, to derive universal laws, even if expressed within the customs of his age.

This was the philosopher's task as Ibn Rushd saw it, and it was the guiding principle of his commentary. As he explains, Aristotle "would not have included in this book what is unique to them, but only what is common to all natural nations." Hence, he set out to elucidate the "total" principles proposed by Aristotle (sifting out what was unique to Greek poetry, and thus limited to its age), which he then applied to Arabic poetry to arrive at general laws that balanced local culture and universal application (see Shamma 2021a).

\section{Tarek Shamma}

\section{Notes}

1 This was published in an English translation by Charles Butterworth (1977). Butterworth used a Judeo-Arabic manuscript (i.e., written in Arabic in the Hebrew script), as no version has survived in the Arabic script.

"العادات" (customs) was Matta's translation of "character."

3 i.e. Joseph. The twelfth chapter of the Qur'an is named after him, and relates a broadly similar narrative to the one in the Bible.

4 Here, as in other places, Averroes refers specifically to pre-Islamic poetry.

5 See Aristotle (1995): 33, Ibn Yunus: 88-89. For a thorough discussion of the circumstances and the context of Ibn Rush's reading of Aristotle through Ibn Yunus's translation, see Shamma 2021a. 


\title{
13 History of Wise Men (1248)
}

\author{
Jamal al-Dịn Al-Qifți
}

\section{Jamal al-Dịn Al-Qifti (1172-1248)}

A physician and biographer, born in Qift in Egypt in 1172. He lived in Aleppo, northern Syria, where he became a judge then minister to the Ayyubid prince al-'Aziz Muhammad. He died in 1248 in Aleppo. Of his many works, only two have survived, including this one.

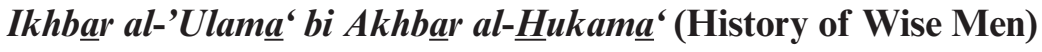

The book includes biographies of 414 philosophers from all over the world, including some of al-Qifti's contemporaries. The "wisdom" of the title refers to philosophy as well as to medicine.

\section{[METHODS OF TRANSLATING GREEK PHILOSOPHY AND SCIENCE]}

\section{Aristotle, son of Nicomachus}

[...] The meaning of "Aristotle" is "of perfect virtue" [...] Because of Aristotle, books of philosophy and other ancient sciences became numerous in Islamic lands.

To explain the reason for this: [Here al-Qifti cites Ibn al-Nadim (see Chapter 10) on al-Ma'mun's dream and his subsequent efforts to acquire books for translation from Byzantium]

When books were delivered to al-Ma'mun, some were found to be complete, and others not. Those which were incomplete have remained so to this day; no one has been able to obtain full copies of them. The logician Abu Sulaiman al-Sijistani, a resident of Baghdad and a notable member of this group [i.e., philosophers], said that al-Munajjim family [ninth-tenth centuries] used to finance a group of translators that included Hunain Ibn Ishaq, Hubaish Ibn al-Hasan, Thabit Ibn Qurra, and others, to the sum of five hundred dinars for translation and for their services. 
Among those interested in obtaining books from the land of the Byzantines in later times were Muhammad, Ahmad, and al-Hasan, the sons of Musa Ibn Shakir, the astrologer, whose activities will be discussed in their respective biographies. Sparing no expenses in this enterprise, they acquired highly sought-after books in philosophy, engineering, music, arithmetic, and other disciplines. When he arrived in Baghdad, Qusta Ibn Luqqa al-Ba'albaki brought some of these with him, which he later translated [...]

Now Aristotle's writings can be divided into four categories: logic, natural sciences, divinity, and ethics. [...]

\section{On Categorias [Categories], its translators and exegetes}

It was translated from Greek into Arabic by Hunain Ibn Ishaq, and was explained and paraphrased by several Greeks, as well as Arabs, including Porphyry of Tyre in Greek; Stephanus of Alexandria; Elias in Greek; Yahia the Grammarian, the patriarch of Alexandria; Ammonius; Themistius; Theophrastus; Simplicus [of Cilicia] in Greek; and by a man known as Theon [of Alexandria] in Syriac and Arabic.

One remarkable commentary is a fragment by Malkhos. ${ }^{1}$ Abu Zakariya Yahia Ibn 'Adi said: "This attribution to Malkhos must be false, because I saw the phrase 'Alexander said' in the text." However, this does not preclude the attribution, as it is possible that some late authors added the words of Alexander to that of the other one [...]

On First Analotiqa [Prior Analytics], which is an analysis of deduction. It was translated into Arabic by Theodorus. It is said that he had it reviewed by Hunain [Ibn Ishaq], who mended it. Hunain translated a part of it into Syriac, while Ishaq [Ibn Hunain, his son] translated the rest into Syriac.

On commentaries on this book:

Alexander of Aphrodisias explained the book up to "good figures" in two commentaries, one of which is more comprehensive. Themistius explained the two books in three. Yahia the Grammarian [John Philoponus] also explained up to "good figures." A bu Bishr Matta [Ibn Yunus] explained the two books. Al-Kindi wrote an exegesis of this book.

On Second Analotiqa [Posterior Analytics], which is demonstration. Hunain translated some of it, and Ishaq translated the rest, into Syriac. Matta translated Ishaq's Syriac version into Arabic.

On those who explained this book:

Themistius wrote a full exegesis of this book. Alexander [of Aphrodisias] also explained it $[\ldots]$

\section{On Sophistiqa [Sophistical Refutations], which deals with specious wisdom}

It was translated by Ibn Nâ'ima [al- $\underline{\text { Himsi] }}$ and Abu Bishr Matta [Ibn Yunus] into Syriac, and by Yahia Ibn 'Adi into Arabic. 
Those who explained the book include Koboi (?). Ibn Na'ima's version was translated into Arabic by Ibrahịm Ibn Bakush by way of repair.

Al-Kindi wrote a commentary on this book.

\section{On Rhetoriqua, that is "rhetoric"}

It can be found in an old translation.

Ibn Ishaq is said to have translated it into Arabic.

It was translated by Ibrahịm Ibn 'Abdullah and explained by Abu Nas r al-Farabi.

The book was also transmitted in the handwriting of Ahmad Ibn al-Tabib in an old manuscript $[\ldots]$

\section{On Coming to Be and Corruption, by him}

It was translated into Syriac by Hunain, and into Arabic by Ishaq. It was also translated into Arabic by ['Uthman] al-Dimashqi, as mentioned by Ibn Bakush.

The book was explained in full by Alexander[of Aphrodisias]. Olympiodorus wrote a commentary that was translated by Estath [Eustathius].

It was also translated by Matta [Ibn Yunus]. Qusta [Ibn Luqqa] translated the first treatise of the book. Matta's version was mended by Abu Zakariya Yahia Ibn 'Adi upon his study of the book, and was explained by Yahia the Grammarian.

A Syriac commentary on the book was found and translated into Arabic. Those knowledgeable in Syriac have said that the Syriac version is superior to the Arabic one. The Arabic translator was undoubtedly not worthy of the task. But God knows best.

\section{Upper Phenomena [Meteorology] by Aristotle}

Olympiodorus wrote an extensive exegesis of this book, translated by Abu Bishr Matta, on which ['Ali Ibn Sahl] al-Tabari wrote a commentary.

Alexander wrote a commentary that was translated into Arabic, but not into Syriac. Yahia Ibn 'Adi later translated this book from Syriac into Arabic.

\section{On the Soul}

This book is in three treatises.

It was translated into Syriac in full by Hunain. Ishaq also translated the book, save a small part; then he made another, improved translation.

Themistius wrote a full exegesis of the book: the first treatise [of the original] in two treatises, the second in two, and the third in three. Olympiodorus wrote a good commentary. Another good commentary in Syriac is attributed to Simplicus. An exegesis was made by Atawals [?]. It is also found in Arabic. 
Alexander [of Aphrodisias] wrote a summary in about 100 pages. [Yuhanna] Ibn al-Bitriq wrote short commentaries on this book. Ishaq translated what Themistius wrote on this book from a bad copy, which he mended 30 years later by comparing the translation with a good copy.

\section{On Sense and the Sensible, by him}

This book is in two treatises.

No reliable translation is known or mentioned. What is available is the very little included in a commentary by Abu Bishr Matta Ibn Yunus.

\section{Animals by Aristotle}

This book is in 19 treatises. $^{2}$

It was translated by Ibn al-Bitriq. It may be found in an older Syriac translation that is better than the Arabic one.

There are also old short commentaries, as stated by Yahia Ibn 'Adi. Nicolaus [of Damascus] wrote a summary of this book, translated into Arabic and corrected by 'Ali Ibn Zar'a, of which (by God's grace) I owned one copy.

\section{Divinity, also Known as Letters and Metaphysics [Aristotle's Metaphysics]:}

This book is organized by the order of the Greek letters, starting with little Alpha. ${ }^{3}$

It was translated by Ishaq. The available part runs up to "Mu"; this letter section was translated by Abu Zakariya Yahia Ibn 'Adi. The "Tau" section may also be found in Greek. These letters were all translated by Eustathius al-Kindi $[\ldots]$

\section{Apollonius the Carpenter [of Perga]}

An ancient mathematician, who preceded Euclid by a long period. He wrote Conics on the science of curved lines, which are neither straight nor arced. When books were brought out from the land of the Byzantines to al-Ma'mun, only the first part of this book was acquired, including seven chapters. However, when the book was translated, the introduction indicated that it contains eight chapters, that the eighth chapter comprises the contents of the seven chapters and more, and that Apollonius laid down useful principles and desirable benefits therein. Since then, and to this day, interested people have been searching for this chapter, but have not found a trace of it. It was undoubtedly kept in the treasuries of kings, for these sciences were highly esteemed by the Greeks.

I have discussed this chapter with a contemporary of mine who practices this science, or claims to do so. He said: "It has been found," and he proceeded 
to describe it. Yet, when his description did not match the author's own account of his chapter, I realized that this man was unaware of minor as well as major issues. So I disregarded him, and left him to his ignorance.

This book (that is Apollonius' Conics) besides another he wrote on the same topic were the reason for Euclid's writing his own book a long time after, as, God willing, we will mention in Euclid's biography, for that would be a more fitting place.

In the beginning of Conics, the Sons of Musa Ibn Shakir say that Apollonius lived in Alexandria, and that his book was corrupted for several reasons. These include the difficulty of copying it and the reluctance to engage in thorough corrections, as well as the fact that the book became defunct and forgotten. The book circulated in fragments among individuals, until there appeared in Ascalon a man called Eutocius, who was an eminent master of geometry. The Sons of Musa say that this man wrote good books in geometry, of which nothing at all has been translated for us. When the fragments of the book that could be collected were put together, four chapters were mended. The Sons of Musa said that the book is in eight chapters, of which seven chapters and a part of the eighth are available. The four chapters were translated for Ahmad

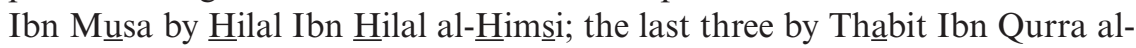
Harrani $[\ldots]$

\section{On Galen's commentaries on Hippocrates' books}

Hippocrates' Oath, explained by Galen. Hunain translated the book from Greek [into Syriac], adding material of his own, and 'Isa Ibn Yahia into Arabic.

Aphorisms [Galen's Commentary on the Hippocratic Aphorisms], explained by Galen. Hunain translated the book into Arabic, and 'Isa the exegesis into Arabic.

Fractures, explained by Galen. Hunain translated the book into Arabic for Muhammad Ibn Mussa. Four chapters.

Acute Diseases [On Regimen in Acute Diseases in Accordance with the Theories of Hippocrates], explained by Galen. In five chapters. This was translated into Arabic by 'Isa Ibn Yahia in three chapters.

Head Surgeries, one treatise.

Epidemia, in seven chapters. It is explained by Galen: the first chapter in three, the second in three, and the third in three; the fourth, fifth, and seventh chapters were not explained by Galen. The sixth, in eight chapters, were translated into Arabic by 'Isa Ibn Yahia.

Humors, by Galen. Three chapters, translated by 'Isa Ibn Yahia for A $\underline{\text { hmad }}$ Ibn Musa.

Kaciteron ["Medical Cast"], explained by Galen. Three chapters. It was translated by Hunain into Arabic for Muhammad Ibn Mussa.

Water and Air, explained by Galen. Three chapters. Hunain translated it into Arabic for Muhammad Ibn Musa. 
On the Nature of Man, explained by Galen. The gist was translated into Arabic by Hunain, and explained by 'Isa Ibn Yahia.

As for [Ptolemy's] The Almagest, it is in 13 chapters. It was first explained and transmitted into Arabic under the auspices of Yahia Ibn Khalid Ibn Barmak. He had an exegesis written for it, but this, being inadequate, was not to his satisfaction. So he commissioned Abu Hassan and Salman, the directors of Bait al- Hikma, who excelled in the task. Having enlisted capable translators, they expended considerable effort in correcting this book. Abu Hassan and Salman tested these translations and selected the clearest and most eloquent ones.

It is said that al-Hajjaj Ibn Matar also translated this book. But al-Nairizi did not translate it.

Thabit [Ibn Qurra] mended the entire book, based on the old translation, which was unsatisfactory. Ishaq translated this first version because it was superior $[\ldots]$

\section{Ptolemy Philadelphus}

One of several kings called "Ptolemy," a Greek monarch who came after Alexander. He was a keen supporter of scholarship, constantly in search of the histories and biographies of kings. He had a deep interest in investigating the history of the first construction of $\mathrm{Babel}^{4}$ and the narrative of the creation of the world, and in Nimrod, his grandfather and ancestry. Having embarked on this quest, he found what he sought among the Israelites of Jerusalem in their Second Kingdom. They translated the Torah for him from Hebrew into Greek, wherein he found a mention of Nimrod. This was the version [of the Torah] translated from Greek into Arabic by Hunain Ibn Ishaq [...]

Hunain Ibn Ishaq was among the translators of philosophical books, which he transmitted into Syriac and Arabic. He was eloquent in Greek and Arabic. [The Caliph] Al-Mutawakkil (r. 847-861) selected him for, and entrusted him with translation. He provided him with skilled scribes, proficient in translation; they would translate, then he would correct their translations. As a translator, he was truly superb.

\section{Translated by Tarek Shamma}

\section{COMMENTARY}

Al-Qifti's History of Wise Men, from which the selected extract is taken, is considered to be the most important work of this historian and biographer and is key to medieval Islamic historiography, being grounded in the Ancient and Islamic traditions. The book focuses on the acquisition and dissemination of knowledge ('ilm) and wisdom ( hikma) in the fields of science and philosophy, and is a precious account of the role played by translation into Arabic from 
Greek and Syriac, not as a mere process of transmission but as a catalyst for further commentaries and the development and expansion of ancient science. Further, the book includes references to works which are no longer extant. The various scholars are listed alphabetically, not chronologically, which helps to bring together successive periods and eras, and a section is allocated to the "physician translators." The text foregrounds the complex genealogy of Arabic versions of Ancient Greek texts. The Arabic translations would sometimes be based on Syriac versions of the Greek texts, or be the outcome of multiple revisions, and efforts to establish the most reliable source manuscript. The reader is reminded of the central part played by the well-known translator of Greek into Syriac, Syriac into Arabic, but also Greek into Arabic, Hunain Ibn Ishaq, himself a physician who was taught by the famed Masawayh, and who also revised others' translations. Al-Qifti's account also shows the centrality of patronage, whether from the caliphs such as al-Ma'mun and al-Mutawakkil in the ninth-tenth-century translation movement, or from rich and learned sponsors, and the framing of the translation activities with reference to Bait al-Hikma (the House of Wisdom). (See also Ibn Abi Usaibi'a, Chaapter 16, and Ibn al-Nadim, Chapter 10).

\section{Myriam Salama-Carr}

\section{Notes}

1 Malchus/Malkhos, possibly the same Porphyry of Tyre, whose first name was Malchus.

2 The Arabic version is actually a compendium of three works of Aristotle's: History of Animals (treatises 1-10 in Arabic), On the Parts of Animals (11-14), On the Generation of Animals (15-19).

3 Actually, Metaphysics starts with "Alpha"; "Little Alpha" is the heading of second book.

4 See the Qur'an, al-Baqara (2:102). 


\title{
14 The Translation of the Samaritan Torah (The second half of the thirteenth century)
}

\author{
Abu Sa'îd Ibn Abi al- $\underline{\text { Husain }}$
}

\begin{abstract}
Abu Sa'id Ibn Abi al-Husain was major Samaritan scholar in the second half of the thirteenth century. He lived in Egypt and issued many religious fatwas, which were widely distributed among the Samaritans of his time.
\end{abstract}

\section{Tarjamat al-Tawrat al-Samiriya (The Translation of the Samaritan Torah)}

We relied on three copies of the French National Library, especially Arabe 6, the most complete manuscript, in comparison with Arabe 5 and Arabe 7. Arabe 6 was published by Abrahamus Kuenen in 1851, but this version was inaccurate, retaining some of the copyists' errors.

\section{[ON THE “TRUE” TRANSLATION OF THE TORAH]}

He who follows the truth, will be rightly guided

This poor servant who is in need of God's mercy, Abu Sa'id Ibn Abi al-Husain (May he be admitted into God's mercy), says:

I saw the translation of the Noble Book circulating among our people (May God multiply them and guide them) to be corrupt in sense and form, due to their ignorance of Arabic. In fact, some of them claim that it is the work of

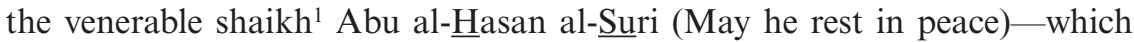
is certainly not true. It would be, indeed, impossible for him to make such a translation, particularly in the rendering of * which is a brazen heresy and the result of confusion. That is actually the translation of [Sa'diya] al-Fayumi, the scholar of the Jews (May God curse him). Accordingly, I have found it to be in the common good to translate this version, including what came before and after it, delivered (God willing) in correct and eloquent idiom.

Then copies of this version can be made to obliterate the untruth on which al-Fay umi and those who accepted his idiom relied. Therein (God willing) will be my claim to an honorable standing with God Almighty and those of his people who follow the truth.

DOI: $10.4324 / 9781003247784-16$ 
[Marginal notes to the introduction on the same page]

All the marginal notes here are my own, and are the outcome of my diligence. Most of them are arcane interpretations that have been bestowed on me by the bounty of God.

[Marginal note to verse 4:24 in Exodus ${ }^{3}$ ]

Know, may God aid you, that al-Fayumi, the scholar of the Jews, May God curse him, committed the grossest error in translating this verse, as he attributed to the prophet (May God's peace be with him) the perpetration of a capital sin. For the death penalty is punishment only for capital sins, from which the minor prophets are immune, not to mention the foremost of them. ${ }^{4}$ I truly marvel at the former generations in our nation who accepted his translation, with the ignorant among them even believing it to be the translation of Shaikh Abu al- Hasan al-Suri, May God have mercy on him. He is far above this. In fact, the reading of this verse by most members of our faith is corrupt in the Hebrew text, in correspondence to this translation. Praise be to God with whose blessing I was able to deliver the correct, eloquent, and refined translation.

\section{Translated by Tarek Shamma}

\section{COMMENTARY}

Classical Arabic historians usually considered the Samaritans a Jewish sect. ${ }^{5}$ However, as Abu Sa'id's introduction makes it clear, while they belong ethnically to the Israelites, the Samaritans see themselves as a separate religion. For their scripture, they recognize as canonical only the first five books (of Moses), rejecting the rest of the Hebrew Bible, as well as Rabbinical traditions, including the Talmud. The Samaritan Torah, besides being written in the different, Samaritan alphabet, contains some significant differences from the Hebrew Bible, including reverence for Mount Gerizim, rather than Mount Zion, as the location chosen by God for a holy temple.

Following the wide circulation of Sa'diya's translation, the Samaritans adopted it, like Jews and some Christians around the Arab World. But growing dissatisfied with what they saw as doctrinal violations, Samaritan scholars felt the need for a new Arabic translation, more consistent with their interpretation of the Torah (Kahle 1960: 54-55). This was first done by Abu al-Hasan al-Suri (eleventh-twelfth century), mentioned in Abu Sa'id's introduction, who is credited with the first known Samaritan version of the Torah (Kahle 1960: 55). Hence, Abu Sa'id's edition is actually a revision of previous copies, rather than a new translation. It is hypothesized that it arrived into this final form through a series of successive revisions, each increasingly deviating from Sa'diya's version (ibid).

Abu Sa'id is one of the few translators in the Classical period to attach an introduction, or any paratexts, to his translation. Like Sa'diya before him, 
he must have felt it incumbent to explain his reasons for a new translation of the central text of his community, placed in its historical and intellectual context. In Abu Sa'id's case, the introduction, though rather short, was perhaps inevitable to promote a new mode of reading and to engage in an (oppositional) dialogue with his predecessors. For his declared aim to remedy the corruption caused by Sa'diya's translation was not limited to linguistic and semantic errors, as is often the case; but to expose and eradicate doctrinal deviations, which he considered heretical.

In his effort to reverse Sa'diya's influence, to produce a "correct" version of the Torah, Abu Sa'id's foremost concern is accuracy, as can be seen in his detailed comments on the translation in marginal notes that surround many pages of the manuscript (especially its early parts), sometimes on all sides. A rare practice in his time, Abu Sai'id's notes discuss the various translation options, the significance of each, and the stylistic and structural differences between Arabic and Hebrew. Other annotations provide explanations of words and parts of the text and general comments of theological nature.

Despite Abu Sai'id's many disagreements with Sa'diya, his translation shows a similar Islamic influence, reflected in repeated Qur'anic terms, even in the space of this short text. Obviously, intellectuals in several ethnic and religious communities of the time (notwithstanding their differences) engaged in deliberate attempts to translate their own culture into the terms of the wider intellectual universe of the Islamic empire, with the attendant "cultural capital" and practical applications.

\section{Tarek Shamma}

\section{Notes}

1 Literally "old man," a title of respect which was applied to religious figures in all faiths. Today it is usually associated with Muslim clergy. Sometimes it is a general title of respect.

2 From Exodus 4:21 (Shehadeh 1989: 494). In the back translation from Abu Sa'id: "On your travel back to Egypt." Abu Sa'id refers here to subsequent verses about Moses (see the margins below).

3 "On the way, at a place where they spent the night, the Lord met him and tried to kill him" (New Standard Version). A back translation of Abu alwas on the way, at the place of spending the night, the Lord went to him, intending to provoke him."

4 In the context God wanted to punish Moses because he had not circumcised his oldest son.

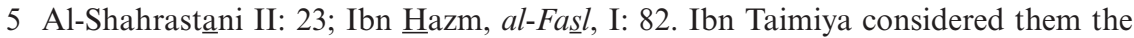
Jewish equivalents of Shi'ite Muslims (Minhaj, Vol. 5: 174). 


\title{
15 The Chronicles of Time (late thirteenth century)
}

\author{
Unknown Author
}

\section{Akhbar al-Zaman (The Chronicles of Time)}

This work has sometimes been attributed to the great historian al-Mas'udi (see above), based on a book by this title that he listed among his writings. However, al-Mas'udi's own Akhbar al-Zaman, an encyclopedic history of the world in 30 volumes, has not survived (Pellat 1986: 784). So the authorship of this book remains uncertain. Its earliest citation is found al-Maqrīzī (d. 1442), and the earliest known manuscript dates to the late 13th century.

\section{[ON THE FIRST LANGUAGE AND THE CONFUSION OF TONGUES]}

And God commanded the four winds to turn upon that tower from all sides and smite it into ruin. Then He cast the earth into shadow and sent a great tremor that shook the mountains. The people of the earth leapt up in terror, unable to see their fellows, and little knowing where to turn; and their tongues lost the power of speech. The accursed Nimrod, enemy of God, perished, along with those who worshipped him, and the people fled on foot into the darkness. After three days and nights they spied clefts in the hills, lit by a feeble light. Each nation clove to a cleft and fled therein, to save themselves, certain strangers having appeared behind them to urge them on, speaking to each nation in a different language, until lo, when each nation came forth in some part of the earth, each spoke its own tongue, and could no longer understand the speech of the others. And to each that found its place there spoke a crier, saying "This is your place, to abide therein; so be fruitful here, and multiply" [...]

And God gave Adam the name "Abdullah" [servant of God] and called him "Father of Muhammad." He was the most beautiful of God's creatures, tall, with curly hair. But when he fell to earth, God took away some of the beauty of his face and form, and shortened his stature. And where formerly he had spoken Arabic, God twisted his tongue to Syriac and took away what he had taught him, though He restored it when Adam repented [...] 


\section{The confusion of tongues}

After the flood, the people of the earth lived all together in Babylon, and their language was Syriac. Then they were scattered. On one path together were the tribes of Qahtan, '서, Thamud, 'Imlaqu, Tasam, and Jadis; and to them God gave knowledge of the Arabic you hear. Then their fortunes led them

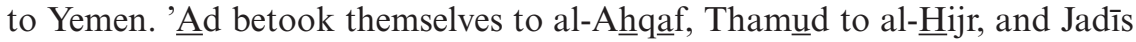
to Yamāma. Then Tasam descended to al-Yamāma and settled among Jadīs, while 'Imlaq went forth and settled in the land of the Sanctuary. ${ }^{1}$ Dakhm of Iram settled in Ta ' if, and Jurhum in Mecca. These tribes and their descendants are called "the true Arabs," while the children of Ishmael are called "Arabs by aspiration," for the Arabic they speak they learned from those tribes.

\section{Translated by Michael Cooperson}

\section{COMMENTARY}

The Biblical story about the multiplicity of languages that resulted from the destruction of the tower of Babel found its way into several Classical Arabic sources, usually under the heading of "the confusion of tongues." It is generally considered part of "Isra iliyate" (literally "of the Israelites"), a term which designated historical narratives and fables considered to have originated from Jewish sources, including the Torah, from which this narrative is usually cited. The common universal language that prevailed before the destruction of Babel is usually Syriac, which was sometimes believed to be the language that Adam spoke in paradise. Sometimes, as in here, Adam's tongue was originally Arabic, but it was turned into Syriac when he came down to

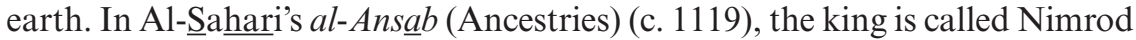
Ibn (i.e., son of) Kan'ạn. Al-Sahari furnishes further details, including the fact that Nimrod "called people to worship idols," which they obeyed.

The story obviously underwent a process of reconceptualization in Arabic sources, seen particularly in explaining the cause of God's destruction of the tower as punishment for idol worship, rather than for the Babylonians' defiance of God (see Genesis 11:6). One important thing is not clear, however: whether the stories cited in these sources came directly from an Arabic version of the Torah, or were adapted indirectly from narratives which were modified as they circulated in their new Islamic environment.

A noteworthy aspect of the inclusion of the Babel narrative in Islamic sources is its striking difference from the Qur'anic view. The Qur'an does not describe this phenomenon as a cataclysmic event. In fact, the diversity of tongues is part of God's plan: "O mankind, We have created you male and female, and appointed you races and tribes, that you may know one another. Surely the noblest among you in the sight of God is the most godfearing of you" (al-Hujurat 49: 13). In this account, the multiplicity of languages 
(like other forms of human multiplicity) is a divine blessing to enrich human experience. This implicit contradiction between the scriptures does not seem to have been of much concern to contemporary Islamic scholars, who usually cited the Biblical story in the course of general histories, with little exploration of its implications. Thus, especially in contrast with its wide-spread influence in translation studies in English, the Babel tower narrative does not seem to have played any significant part in shaping views on translation and linguistic difference in Arabic scholarship, Classical or modern.

\section{Tarek Shamma}

\section{Notes}

1 The area where Islam emerged (specifically Mecca and Medina). Like all other locations in this paragraph, it is in the Arabian Peninsula.

2 Other authors who cite it, albeit in less elaborate detail, include al- $\underline{\text { Sahari in }}$ alAnsab (Ancestries) (c. 1119), Ibn al-Nadim in al-Fihrist, and Ibn Munnabih (d. c. 728) in al-Tijan fi Muluk Himyar (On the Kings of Himyar). 


\title{
16 Classes of Physicians (1270)
}

\author{
Abu al-'Abbas Ibn Abi Us saibi'a
}

\begin{abstract}
Abu al-'Abbạs Ibn Abi Usaibi’a (1200-1270)
Born in Damascus to a family of physicians and belletrists, he followed in the steps of his father to practice medicine at the Bimaristan (Hospital) al-Nuri, which was headed by the famous physician Ibn al-Dakhwar. He also worked at the Bimaristan al-Nasiri in Cairo in 631 before returning to Damascus to practice again at the Nuri hospital. At the request of the prince 'Izz al-Din Aibak, he moved to the city of Salkhad, near Damascus, where he died in 668. $\mathrm{He}$ is the author of several works on medicine and astronomy which are no longer extant.
\end{abstract}

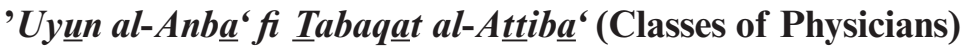

This biobibliography provides a wealth of information on Ancient and medieval physicians in many cultures, from Ancient Greek and Roman times to the year 1252, weaving in the input of Indian and Persian medicine and the development of Arab medicine, and drawing on a number of other Arab chronicles. The chronicle is divided into 15 chapters, with introduction offering philosophical, religious, and social contextualization of medicine as a branch of knowledge, and of the Arab-Islamic medical tradition. The book contains biographies of more than 400 physicians and much information on the translation and translators of medical texts.

\section{[ON MEDICAL TRANSLATION]}

\section{Galen's works}

Galen wrote a high number of books. Here is a list of the ones I found in circulation, translated by Hunain Ibn Ishaq al-'Ibadi and others into Arabic, and the aims of Galen for each of them.

The Book on Medical Terms, in which he introduces the terms that were used by physicians and with what meanings they were used. This book has 
five chapters. The one we found had been translated into Arabic by Hubaish al-Asam, who translated the first chapter.

The Book on Demonstration. Galen divided it into 15 chapters. His aim was to elucidate how to demonstrate what is plainly obvious. And this was the aim of Aristotle in his fourth book on logic. Hunain said: "Until now none of our contemporaries has come across a complete copy of the book. But Jibril [Ibn Bakhtishu'] sought it with great effort, and I myself looked hard for it [...]"

His book on The Structure of Constructions. Hunain said that he could not find this book in Arabic, except for fragments.

The book on How to Diagnose One's Own Faults in two chapters. Hunain said that he only found one chapter in Greek which was incomplete [...]

The commentary on Aristotle's second book called Periermenias, three chapters. Hunain said that he had only found an incomplete copy of this book.

His book on What is Needed for Those with Speech Difficulties, seven chapters. Hunain said that he had found only one chapter of this book, which he did not translate.

Hunain said: "We also found many books that were attributed to Galen but are not his. Some of these were fragments from his writings with which some people fabricated books. Other books were composed before Galen's time but were attributed to him. This is because the person who did this wanted to accumulate books by Galen to surpass others, or because ignorant people could not see the differences and thought that if there were a number of chapters of which the first included a specific name, all the others were by the same author. This is why we find chapters by Rufus [of Ephesus] in many books under Galen's name." Hunain said: "The treatises that we have found attributed to Galen, but whose rhetorical style is not as powerful as that of Galen, and whose strength of meanings is not like that of Galen's, are the following: 'A Treatise on the Heads of [Medical] Sects' [...]"

\section{The Classes of Physicians Who Translated Medical Books and Others from Greek into Arabic, and an Account of Those for Whom They Translated}

Jirjis [Ibn Jibrill]. He was the first to translate medical books into Arabic when he was summoned by al-Mansur, who was very generous to him. He was mentioned earlier.

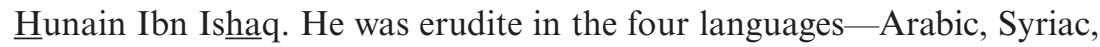
Greek, and Persian - their obscure as well as common usages.

Ishaq Ibn Hunain. He was also erudite in the languages mastered by his father; in translation, he was in the same class as his father.

Hubaish al-A'sam. Hunain's nephew and pupil. A good translator who may be classified with Hunain and Ishaq. He was also mentioned earlier.

'Isa Ibn Yahiya Ibn Ibrahim. Also a pupil of Hunain Ibn Ishaq. He was a man of virtue. Hunain complimented him and approved of his translation, in

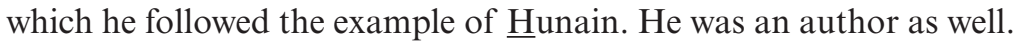


Qusta Ibn Luqqa al-Ba'albaki. A translator who was an expert on languages, distinguished in philosophy and other disciplines. He will be discussed later, God willing.

Ayyub, known as al-Abrash. He did not translate much, and what he translated at the end of his life is comparable in quality to Hunain's work.

Masirjis was a translator from Syriac into Arabic and a well-known physician. One of his books is The Book on the Strengths of Foods, their Benefits and Harms.

'Isa Ibn Masirjis, followed his father. Amongst his books are the Book of Colors and the Book of Smells and Foods.

Shahdi al-Karkhi, from Karakh, was rather a poor translator.

Ibn Shahdi al-Karkhi was like his father with regard to translation. $\mathrm{He}$ surpassed him when older, but was still of average level. He used to translate from Syriac into Arabic and one of his translations is Hippocrates' Book on Embryology.

Al-Hajjaj Ibn Matar translated for al-Ma'munn. Amongst his translations is Euclid's book, and his translation was later corrected by Thabit ibn Qurra al- $\underline{\text { Harranni. }}$.

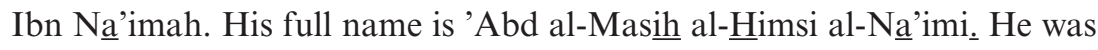
not a particularly distinguished translator, but produced some good work at times.

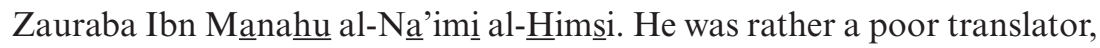
not of the same standard as his predecessors.

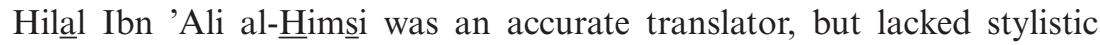
elegance.

Pethion the Translator. I found many grammatical errors in his translations. He did not have any solid knowledge of Arabic to begin with.

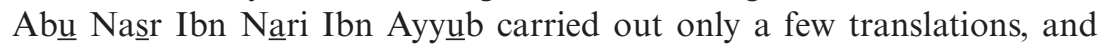
these were not as highly regarded as the work of other translators.

Basil al-Mutran [i.e., The Bishop] translated many books and was a rather good translator.

Istifan Ibn Basil was of nearly the same level as Hunain, but Hunain's style was more elegant and eloquent.

Musa Ibn Khalid the Translator. I came across many of his translations, including the sixteen books of Galen's and others, but he did not measure up to Hunain, or even come close to him.

Ustath [Eustach] was of average competence.

Hairun Ibn Rabita is not famed for being a good translator.

Tadros al-Sanqal. I found some of his translations of philosophical books, and they were of adequate quality.

Serjius al-Ra'si [Sergius of Rechaina] came from the city of Ra's al'Ain. He translated many books, but was an average translator. Hunain did revise his translations. Those that he corrected are good, while the others are of average quality. 
Ayyub al-Rahawi [Job of Edessa]. He is not the same as the abovementioned Ayyub al-Abrash. He was a good translator and a skilled linguist, but his Syriac was better than his Arabic.

Yusuf the Translator, or Abu Ya'qub Ibn 'Isa, physician and translator, also called al-Na'is. He was the student of 'Isa ibn Sahrabakht, and he came from Khuzistan. His language is faulty, and his translations are not particularly good.

Ibrahim Ibn al- $\underline{\text { Salt }}$ was of average competence in translation, and he is in the same class as Sergius al- al-Ra'si.

Thabit al-Naqil [i.e., the Translator] was also of average competence as a translator, although better than Ibrahim Ibn al-Salt. He did not translate much, and one of his translations is Galen's Juices.

Abu Y $\underline{u}$ suf al-Kạtib [i.e., the Secretary] was an undistinguished translator. He translated a number of Hippocrates' works.

Yuhanna Ibn Bakhtishư' translated many books into Syriac, but is not known to have translated into Arabic.

Al-Bitriq [i.e., The Patriarch] lived at the time of [the caliph] Al-Mansur (r. 754-775) who ordered him to translate some of the ancient books. He produced many good translations, although not as good as those of Hunain ibn Ishaq. I found many of his translations of medical books written by Hippocrates and Galen.

Yahia Ibn al-Bitriq belonged to the circle of al- $\underline{H}$ asan Ibn Sahl. ${ }^{1}$ He did not know Arabic very well, nor Greek, as he was a Latin who was fluent in the contemporary form of Greek and knew how to write it in its cursive script instead of the discrete letters of ancient Greek writing.

Qida al-Ruhawi. Hunain Ibn Ishaq would call on him when he had too many books to translate and lacked the time to do it, and then would correct the translations.

Mansur Ibn Banas, of the same level as al-Ruhawi, but his Syriac was better than his Arabic.

'Abd Yashü' Ibn Bahriz, the metropolitan of Mosul, was a friend of Jibril Ibn Bakhtishu' and translated for him.

Abu 'Uthman Sa'idd Ibn Ya'qüb al-Dimashki [i.e., of Damascus], one of the accomplished translators, worked for the vizier 'Ali Ibn 'Isa [...]

Qusta Ibn Luqa al-Ba'albaki. Sulaiman Ibn Hasan said that he was a Christian, a gifted and distinguished physician, a philosopher and an astronomer who was knowledgeable in geometry and arithmetic. He also said that he [Qusta] lived at the time of [the caliph] al-Muqtadir Billah [895932]. Ibn al-Nadim al-Baghdadi the secretary reported that Qusta excelled in many sciences, including medicine, philosophy, geometry, arithmetic and also music, and remained unchallenged. He was eloquent in Greek and mastered the Arabic language. He died in Armenia at the court of one of its kings. He replied to the epistle of Ibn 'Isa the Astronomer on the Prophecy of Muhammad (PBUH), and wrote Kitab al-Fardus fi al-Ta'rikh [The Book of the Paradise on History]. 
I say that Qusta translated numerous books of the ancient Greeks into Arabic. He was a good translator and eloquent in Greek, Syriac, and Arabic. $\mathrm{He}$ corrected many translations the originals of which were Greek. He authored many treatises and books on medicine and other the arts. He was articulate and sound of judgment [...]

\section{The Classes of Syriac Physicians Who Were Active in the Beginning of the Abbasid State}

Abu Zaid $\underline{H}$ unain Ibn Ishaq al-'Ibadi $[$ [...]. [His people] al-'Ibad [...] are tribes who came from Arabia and had converted to Christianity in al-Hirah [...] Hunain Ibn Ishaq was very eloquent and excelled in poetry. He had lived in Basra for a while and was taught Arabic by Al-Khalil Ibn Ahmad [alFarahidi], ${ }^{2}$ prior to moving to Baghdad to practice medicine.

Yuxsuf Ibn Ibrahing said:

Hunain Ibn Ishāq tried to study medicine and the circle of Yuhanna Ibn Masawayh was the one most attended by those wishing to study medicine and attracted many educated men. I was able to see Hunain Ibn Ishāq when he was studying, under the guidance of Yuhanna Ibn Masawayh, the book De Sectis, which is entitled Hareseis in both Greek and Syriac.

Hunain would ask many questions, and this irritated Yuhanna, together with the fact that Hunain was the son of a jeweler and hailed from alHirah. For the people of Gundeshapur, and the physicians in particular, disliked the people of al-Hirah. Furthermore, they were strongly opposed to the entry of merchants' sons into their profession. One day Hunain queried with Yuhanna a passage he was studying with him and which he wished to understand. Yuhanna lost his temper and exclaimed: "What could the people of al-Hirah have to do with the study of medicine? Go to one of them, a relative of yours, and request fifty dirhams from him. With one dirham you can buy some small baskets and with three of them you can get arsenic. Spend the rest on Kufi and Qadisiyyah coins, put them in the baskets, and spread the arsenic over them. ${ }^{3}$ Then sit by the road and shout 'Great coins for alms and expenditure!' Selling those coins will be much more profitable to you than this profession." He then ordered Hunain out, who was upset and in tears. And we did not see Hunain for two years. [...]

[Then at the home of a man called Ishaq al-Khasi, who spoke Greek] I noticed a man whose hair partially covered his face, but I could not see who he was. This man was pacing the room, reciting some Greek poetry by Homer, the greatest of all Greek poets, and the sound of his voice reminded me of Hunain. I had not seen him for over two years, and I said to Ishaq al-Khasi: "This is Hunain," which he denied unconvincingly. So I addressed Hunain, who acknowledged that it was indeed him. He said "That son of the strumpet Risala claimed that no 'Ibadi was capable 
to learn the art of medicine. I would sooner give up the Christian faith than learn medicine before I can master the Greek language more fully than anyone else in my time! No one knows this except my friend here and I would have kept out of your way if I had known that you were to recognize me. But now that my disguise is no longer of use with you, I ask you not to reveal my identity." It was at least three years, may be four even, before I was to see him again.

Once I had called on [the physician] Jibril Ibn Bakhtishu', who had just traveled from Al-Ma'mun's camp, shortly before his death. ${ }^{4}$ Hunain was in his house, and he had translated sections of one of Galen's works on anatomy, a book that a Byzantine editor had divided up into sections. Jibril was addressing him with great respect as rabban (or "teacher") Hunain. As my astonishment showed, Jibril said to me: "Do not think that I am showing undue respect to this young man. Let me tell you that if God preserves him, he will surpass not only Sergius (he meant Sergius of Reshaina, who was the first to translate into Syriac a number of Greek scientific works), but other translators as well." I stayed on for quite a

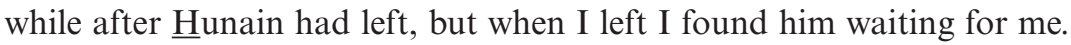
He greeted me and said: "I had asked you before to keep my secret, but now I would like you to divulge it, as well as what Abu 'Isa [i.e., Jibril] has said about me." I said that it would make Yuhanna look rather foolish to hear from me how full of praise Abu 'Isa was for you." taking from his sleeve a copy of the translation he had carried out for Jibrill: "Make him look even more of a fool by showing him this copy, but don't tell him I was the translator and then when he comments on how good it is, tell him!"

I showed the manuscript to Yuhanna on this very day, even before going home. When Yuhanna had read those sections that the Greeks call The Factors, he was most astonished. He exclaimed: "Do you think that it is really possible for someone in our age to receive revelation from Christ?" I replied: "No, neither now nor ever. Christ has never revealed anything to anyone, but he is the one who received revelation." ${ }^{5}$ He said: "Leave such talk aside. This text could only have been produced with the support of the Holy Ghost." So I said: "This was done by Hunain Ibn Ishaq, whom you ordered out of your house and advised to deal in coins." "That's impossible," he exclaimed, before eventually realizing that I was speaking the truth. From then on, he treated him with much respect and generosity, which I could witness until I left Iraq in the year 225 [c.840].

This is everything that was narrated by Yuxsuf Ibn Ibrahim.

I [Ibn Abi Usaybi'a] say that Hunain, from that time on, worked closely with Yuhanna Ibn Masawayah, and became his student to learn about medicine. He translated many books for Masawayah, particularly the books of Galen, some into Syriac and others into Arabic. Hunain's knowledge of Greek, Syriac, and Persian was better than that of any of his contemporaries 
or the other translators of his time. Moreover, he worked hard on practicing and mastering Arabic, until he became highly distinguished in it.

The caliph al-Ma'mun reported that he had seen, in a dream, an elderly respectable looking man who was speaking from a pulpit, and that his name was Aristotle. Once awake, he asked about Aristotle and was told that he had been a wise man among the Greeks. He then called for Hunain Ibn Ishaq, ${ }^{6}$ as he knew of no other translator of his competence, and asked him to translate the books of the Greek philosophers into Arabic, and he bestowed upon him generous payment and presents [...]

Abu Ma'shar said, in his Memoranda [on Astronomy]: "There are four translation masters in Islam: Hunain Ibn Ishaq, Ya'qub Ibn Ishaq alKindi [philosopher, d. 873], Thabit Ibn Qurra al-Harrani [mathematician/ astronomer, d. 826 or 836], and 'Umar Ibn al-Farkhan al-Tabari [astronomer, d. c. 812$][\ldots]$

\section{The Classes of Physicians Who Appeared in al-Maghreb ${ }^{7}$ and Lived There}

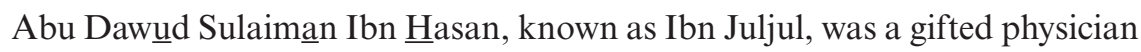
with experience in treatment and great skills in the art of medicine. He lived in the days of [the caliph] Hisham al-Mu'aiyad Billa ${ }^{8}$ and worked for him as physician. He was clever, and he was interested in the efficacy of simple drugs, and explained the names of these drugs in the book of Dioscorides of Anazarbus, unveiling its secrets and clarifying its obscure meanings. At the beginning of his book he writes: "The book of Dioscorides was translated in Baghdad during the Abbasid Caliphate during the reign of Ja'far alMutawakkil [847-861]. It was translated from Greek into Arabic by Istifan Ibn Basil the translator, and his work was revised by Hunain Ibn Ishaq the translator, who corrected and certified the translation. Istifan translated into Arabic the Greek names he knew how to translate; as for those for which he did not know of an Arabic equivalent, he left them in Greek. He trusted that God would send someone after him who would know [these names] and translate them into Arabic. This is because the nomenclature [of drugs] is based on the agreement of the people from each land to name the different classes of drugs as they consider fitting, sometimes by derivation, sometimes by other ways upon which they agree. Istifan trusted that among those who were to follow him some would know those classes of drugs for which he was unable to find a term in his time, and would name them according to what they had learned in their own time, so that these [names] would finally be known.

Ibn Juljul said: "This book made its way to al-Andalus in the translated version produced by Istifan, including the drug names he knew how to translate into Arabic and also those he did not know. The readers benefitted from all that could be understood from it, both in the Mashreq ${ }^{9}$ and in alAndalus, until the days of al-Nasir 'Abd al-Rahman ibn Muhammad, who 
was the ruler of al-Andalus at the time. Armanios [Romanos], the Emperor of Constantinople, presented him with magnificent gifts, in the year 337 [948$949 \mathrm{CE}$ ] I think. Included in those gifts was a copy of the book of Dioscorides illuminated with wonderful Byzantine illustrations of plants; the book was written in Greek. Together with it, he sent the book of Orosius, the author of stories, which contains a wonderful history of the Romans, information about the past, stories about the first kings, and many useful facts.

Armanios wrote to al-Nasir: "You will not benefit from the book of Dioscorides unless you have the help of someone with knowledge of the Greek language, who will recognize the characteristics of those drugs. If there is someone able to do this in your kingdom, then you will enjoy the benefits of the book. As for the book of Orosius, you have in your land, among the Latins, some who can read it in Latin, and if you allow them, they will translate it for you from Latin into Arabic."

Ibn Juljul said that, "at the time, there were no Andalusian Christians in Cordoba who read Greek, so it was not translated into Arabic. The book remained in al-Andalus and the translation that is available is that of Istifan and it comes from Madinat al-Salam [The City of Peace], Baghdad."

When al-Nasir replied to the King Armanios, he asked him to send him someone who would speak Greek and Latin to train some of his subjects as translators. So Armanios sent to the king a priest called Nicholas, who arrived in Cordoba in the year 340 [951-952 CE]. There were at the time physicians in Cordoba who researched and sought Arabic equivalents that were still missing for the names of drugs in Dioscorides' book. The physician who was the keener to study the matter was Hasdai Ibn Shabrut al-Isra' ${ }^{6}$ ili [the Israelite], who was eager to be close to the king, 'Abd al-Rahman al-Nasir. The king gave preference to the monk Nicholas, who explained the unknown names of drugs in Dioscorides' book."

\section{Translated by Myriam Salama-Carr}

\section{COMMENTARY}

The selected extracts from Ibn Usaibi'a's Classes of Physicians illustrate the complex genealogy of the medical Arab-Muslim tradition (see Gutas 1998) and the social and political factors which promoted its development beyond the first translation phase, and prior to its dissemination to European lands through yet another translation movement. Of the fifteen chapters of the book, two are of particular interest to a history of translation: Chapters Eight and Nine focus on translation activities, informing us on the strengths and competence of the listed translators, including the renowned Hunain Ibn Ishaq, who was celebrated for his knowledge of a number of languages and the quality of his translations - an iconic figure of the so-called Golden Age of Islam. 
In addition to the comments made on the translators' skills and output by the author himself, or by the earlier chroniclers he cites, such as Ibn al-Nadim, Al-Qifti in the Mashreq, or Ibn Juljul in the Maghreb, more general issues are raised. Translation here is seen as an activity that requires not only mastery of languages (the translators were working from Greek into Syriac, and Syriac into Arabic, or directly from Greek into Arabic), but also knowledge of the subject matter. It is also clear that translation work, starting with the collection of manuscripts to the collaborative efforts involved, was strongly dependent on the interest and patronage of rulers and other powerful scholars (see Lefevere 1992) and was playing a part in empire building. This is particularly clear when reading the biography of Hunain reported by Ibn Abi Usaibi'a.

The interconnection of translation and terminological work, be it term formation or standardization, underpins the revision work carried out by the leading translators. The example of the Materia Medica of Dioscorides, the Greek physician and pharmacologist (40-90 CE), is of particular interest. The revision work also brings to the fore the shifting concept of the "original text" when translators often had to collate and compare various versions of one original or its earlier translations to establish a reliable "source text," and when manuscripts were particularly vulnerable to scribal errors or material damage.

Finally, the very language used by Ibn Abi Usaibi'a points to the variety of terms that were used to refer to the translator (naqil, mutarjim, or even the later turjuman before the second term became more widely used) contributes to the Arabic medieval discourse on translation.

\section{Myriam Salama-Carr}

\section{Notes}

1 Abbasid governor of Iraq (813-819).

2 This encounter is fictional as al-Farahidi, one of the founders of Arabic linguistics and the author of its first dictionary, had died in c.791, i.e., before Hunain's birth (809).

3 Apparently to give them a golden color.

4 I.e., Ibn Bakhtishụ's death in 828; the Caliph al-Ma'mun died in 833.

5 The speaker is obviously a Muslim. Islam rejects the Christian doctrine of Christ's divinity, regarding him as one of the prophets who received revelation from God.

6 Again, this does not seem very likely. Al-Ma'mun, as stated earlier, died in 833, at which time Hunain was barely 24 years old, and the caliph had initiated the translation movement many years before his death. The narratives linking Hunain with the major figures of his time attest to the legendary status he acquired among Arabic historians.

7 Literally "the west," which refers to areas of the Muslim world west of Egypt, including al-Andalus (Islamic Spain).

8 Umayyad caliph of al-Andalus (976-1013).

9 Literally, "The East," generally the part of the Muslim world that includes Egypt and areas east of it, often up to Persia. 


\title{
17 Treaties between Islamic States and Italian Cities (fourteenth-sixteenth centuries)
}

\author{
Anonymous
}

These texts were published by the Italian orientalist Michele Amari in I Diplomi Arabi del R. Archivio Fiorentino (Arabic Documents in the Royal Florentine Archive) (1863), accompanied by an Italian translation. We have relied on this version in verifying the Italian names cited in the documents.

In the original manuscripts, some words are difficult to read. These are marked in Amari's text with three dots within round brackets: (...).

\section{Translation as a profession \\ [TREATIES BETWEEN THE HAFSID STATE AND ITALIAN CITIES]}

\section{[1313]}

In the Name of God, the Beneficent, the Merciful.

Prayer and Peace be upon our Master Muhammad, the noble prophet, and on his family and Companions.

This document sets forth the auspicious agreement held on behalf of our lord and master, the Caliph and Imam, the custodian of God's work, who is victorious by His grace, the Commander of the Faithful, Abu Yahia Zakariya, son of our master and Prince Abu al-'Abbas, son of the rightly guided princes, may God grant them victory, aid them with his succor, and forever sustain their reign,

With Giovanni Fagioli and Ranieri de Bagno, the emissaries who were sent to the Supreme Presence, may it remain a high beacon and a resplendent light, in Tunis, may God protect it,

by Ticcio de'Conti di Colle, deputy of Federigo conte di Montefeltro, deputy of the comune of Pisa-its patriarchs and chiefs, and those in charge of all its interests and affairs [...]

They wrote this agreement $[\ldots]$ upon the following terms:

[...] 
- That they [i.e., the Pisans] should follow the common custom in paying the weigher who weighs their goods, that they should have their choice of accommodation to their own comfort wherever they travel on the African Coast.

- That they should not be barred from buying whatever food or services they need.

- That they should be free to offer the goods they have for sale or to return them.

- That neither workers at the Diwan in these countries, nor interpreters, nor boat owners should introduce any measures other than those established by custom.

- That no merchant of them should be barred from travel once he has been cleared by the Supreme Presence, may God guard it, and regions under its command.

- That merchants in their company should be treated in the same manner with equal rights and duties, and that their merchants should not be prevented from selling their goods in public following the established custom if they so choose $[\ldots]$

- That defaults on goods they sell in public on testimony should be borne by the Diwan, and defaults on goods they sell through interpreters should be borne by the interpreters [...]

- That if a Pisan sells cotton or linen by weight, he should not have to pay a gratuity or commissions to the Diwan or the interpreter.

- That if a Pisan sells merchandise by himself at the Diwan, he shall have to pay only for one translation [...]

The signing of the agreement by the aforementioned emissaries, Giovanni Fagioli and Ranieri de Bagno, being in full competency, mental capacity, and consent, and authorized by their superiors, was attested in the presence of witnesses, and communicated through the Muslim translators, as established by custom.

The signing was attended by consul Bengiàl Brkan, Giovan K.raia [...] The agents whose responsibility it is to implement the supreme commands of the Noble Port, may God keep his fortune and high position, pledged to enforce the agreement.

\section{Completed on 21 Jumada of 713 [Hijra] September 14 [1313]}

\section{[1353]}

In the Name of God, the Beneficent, the Merciful. Prayer and Peace be upon our Master Muhammad, the noble prophet, and on his family and companions

This document sets forth the auspicious accord held on behalf of our lord and master, the Caliph and Imam, who seeks victory from God and is so 
victorious by His grace, the Commander of the Faithful, Abu Ishaq Ibrahim son of our lord and master, the Caliph and Imam, who seeks aid only in God and is aided by Him, the revered Commander of the Faithful, the late Abu Yahia Abu Bakr, son of the rightly guided princes, may God grant them victory, aid them with his grace and support, forever sustain their reign, make the earth their dominion, and preserve for Muslims their rule and the greatness of their kingdom, and the kingdom of their noble ancestors and close companions - by the trusted, favored, worthy chamberlain to noble kings, fully authorized by them, known for his auspicious leadership at all times, in all forms, and for all purposes [...] Abu Muhammad 'Abdullah, who set conditions aright after they had gone awry, and fulfilled hopes after they had been frustrated. May God keep his name high on all pulpits of glory

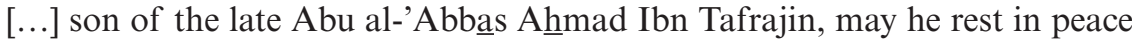
and may God make paradise his eternal abode [...] with Neri Porcellino, the Christian from Pisa, who was admitted on this date into The Supreme Presence in Tunis, may God keep it a high beacon, a resplendent light, as an emissary from the Comune of Pisa - its patriarchs and chiefs, and those in charge of all its interests and affairs. Having been admitted into the supreme presence, may God keep it prosperous, he submitted an authorization written in his foreign tongue.

Upon the permission of him who is authorized to look into this document, the honored, well-starred, glorified, superior, distinguished, notable, foremost shaikh Abu 'Abdullah Muhammad - son of the revered, glorified, superior, auspicious, honored, hallowed shaikh Abu al-'Abbas Ahmad [Ibn Tafragin]may God sustain his distinction and keep him in His favor, a group of Christian merchants, consuls, and priests were summoned. Their authorization was found, through the translation by trusted Muslim interpreters, to be authentic without a measure of doubt, and of the type they customarily use amongst themselves.

It was the wish of the said emissary that the accord for whose conclusion he had arrived should last for ten consecutive solar [i.e., Gregorian] years, starting with the middle of this current May, upon the conditions stated below:

- That they [i.e., the Pisans] should follow the common custom in paying the weigher who weighs their goods, that they should have their choice of accommodation to their own comfort wherever they travel on the African Coast.

- That they should not be barred from buying whatever food or services they need.

- That they should be free to offer the goods they have for sale or to return them.

- That neither workers at the Diwan in these countries, nor interpreters, nor boat owners should introduce any measures other than those established by custom $[\ldots]$ 
- That defaults on goods they sell in public on testimony should be borne by the Diwan, and defaults on goods they sell through interpreters should be borne by the interpreters.

- That if a Pisan flees or defaults on a payment or credit in a transaction with the Excellency or with a Muslim, then neither the Pisans nor their consul shall be held liable unless they have provided a guarantee for him. Only the culprit shall be held liable.

- That if a Pisan sells cotton or linen by weight, he should not have to pay a gratuity or commissions to the Diwan or the interpreter.

- That if a Pisan sells merchandise by himself at the Díwan, he shall have to pay only for one translation.

- That if a Pisan has merchandise that is set aside as fitting for the Noble Excellency, then the merchandise shall be held only for ten days, during which time it is either paid for or returned to its owner.

- That Pisans shall receive an equal amount of support, benefaction, and courtesy as the Genovese.

- That Pisans shall in all matters receive the same amount of benefaction and courtesy as other Christians who have signed pacts with [the Supreme Presence] [...]

The aforementioned, Neri Porcellino, authorized by his superiors mentioned above to conclude this accord, testified, as attested by witnesses, that he is authorized to sign, as stated above, with full competency, mental capacity, and consent, as communicated through translation into Arabic.

His signing of this accord with him who is privy to the affairs of the Sultan's, may God be by his side, in the safely-guarded land of Tunis was attended (...)

Completed on Thursday 11 Rabi' al-Thani of 754 [Hijra], concurrent with May 16 [1353] [...]

[Clauses from a treaty between the Hafsid State and Pisa, signed on October 5, 1421, during the reign of Abu Faris 'Abd al-'Aziz al-Mutawakkil (1394-1434)]

\section{Clause 10}

If a Pisan wants to sell any piece of merchandise by peddling through an interpreter as a witness, then the transaction shall be cleared through the Díwan's representative. The same applies to other parties to this contract.

\section{Clause 11}

If a Pisan sells a piece of merchandise through an interpreter and receives a deposit on the sale and then the buyer withdraws from the sale, the sale shall not be canceled. The buyer shall be required to pay the full price of the merchandise. The same applies to other parties to this contract. [...] 


\section{Clause 13}

All interpreters shall undertake the translation jointly; no one interpreter shall be employed exclusively. Interpreters are paid five dirhams for a hundred dinars.

\section{$[1445]$}

\section{In the Name of God, the Beneficent, the Merciful}

Prayer and Peace be upon our Master Muhammad, the noble prophet, and on his family and Companions

\section{Praised be God, the Lord of the Two Domains}

When he was admitted into the Supreme Presence of the rightly guided sultan, the imam of jihad, our lord and master, the commander of the faithful [...] Abu 'Umar 'Uthman, son of our lord and master, the great martyred sultan [...] the late Abu 'Abdullah Muhammad al-Mansur, son of the rightly guided princes, may God bless his soul and make his abode in heaven, son of our lord and master, the commander of the faithful, blessed by the mercy of the Most Merciful [...] the [late] Abu Faris 'Abd al-'Aziz, may God bless his secret and multiply his rewards, the son of our lords and masters, the rightly guided caliphs, the divinely supported kings, May they all rest in peace,

The esteemed emissary Baldinaccio, son of Antonio degli Erri, of Florence, delegated by the members the comune, revered among their people, principal among their co-religionists, the comunes of Florence and of the Pisa, to ask for an agreement $[\ldots]$

The emissary Baldinaccio attested his consent to the contents of this agreement through gestures and translation by trustworthy interpreters [...] on the middle of Muharram 849 [Hijra] [April 23, 1445].

\section{Translated by Tarek Shamma}

\section{[TREATIES BETWEEN THE MAMLUK STATE AND ITALIAN CITIES]}

\section{[1496]}

In the Name of God, the Beneficent, the Merciful The most exalted, May God multiply his blessings, King Qạitbai

The great prince, the just and the learned [...]

This letter is sent to his Excellency [the Sultan's deputy in Alexandria]. 
After expressing universal compliments and good will, we convey that the Florentine notables and their Doge have sent an envoy to our exalted portals, communicating that in the times of the kings our predecessors, their consuls and merchants frequented Islamic cities for the purpose of buying and selling, as was the custom of the Venetians, and that they desired to return to the Islamic ports as in the past. They sought our charitable permission herefor, asking to have the terms of which written to them as in accordance with the common practice, thus being admitted into the exalted consideration and gracious protection.

Our exalted charity having acceded to their request, and our venerable decrees having been issued to give them permission to send their consuls, merchants, and ships to Islamic ports (May God protect them), we have issued our commands that they be granted in writing the old terms previously given to the Venetians, which are stated herein: [...]

\section{Clause}

It was brought to our attention that one of the terms granted to the Venetians stipulated that when they paid a translator on duty, they were not required to pay for another translation. Thus, in cases when the sold goods were still at the port, or when the Frankish merchant had already shipped out the spices that he had exchanged for his goods, then he was not asked for a second translation. It was decreed that this condition be granted to them, as the Frankish merchant had already paid for the translator, who was now absent.

Accordingly, His Excellency the Deputy shall be in charge of assuring that the said Florentine merchants be subject to the terms of the Venetians, specified herein [...]

On Jumada 7, 901 Hijra [February 22, 1496].

\section{[1507]}

\section{The Exalted Name}

[...] all Florentines to whom it is communicated are required to abide by the contents of this exalted decree and to follow it, as explained.

In the name of God, the Beneficent, the Merciful

It has been ordained by the supreme, most honorable, sovereign decree of

\section{Qansuh}

the royal, most honorable, commanding sultan, May God Almighty favor, preserve, and empower him,

that this most honorable decree be delivered to all Florentines, May God Almighty guide them to success, informing them that the honorable, princely, 
grand, singular, perfect, military, Taghribirdi, the translator and emissary, May God keep his fortunes, was admitted into our exalted portals, stating that he had prepared for your benefit an honorable warrant of safety such that no one is to be interfered with. For our exalted knowledge extends over the ports of Alexandria, Damietta, Berenice, and Rosetta, as well as all inland cities under our exalted rule.

You shall be able to buy and sell like other merchants, under our exalted protection and that of the Prophet (May God's blessings and peace be upon him). We have decreed that all shall be free from harm, harassment, or interference, and that no father shall be held responsible in place of a son, nor a brother in place of a brother, save with a legal document, be it in the city of Alexandria, or any Muslim port.

Consequently, they shall be able to adopt our decrees, as explained in the above rules, so that they can travel to the cities of our exalted kingdom, with carefree minds, and in tranquil spirits, secure in their persons and possessions, safe from harm or maltreatment. This they should be aware of and can trust.

We beseech the gracious and munificent God for success, and trust in His will.

On the 22nd of Jumada, in the year 913 Hijra [October 29, 1507].

Following the exalted decree. Praise be to God Almighty and His blessings and peace be upon our lord Muhammad and his Companions.

\section{Translated by Tarek Shamma}

\section{COMMENTARY}

These treaties, little studied in themselves, shed light on a still obscure chapter in the history of translation in Arabic - interpreting in diplomatic and international relations. The glimpses we have gleaned of interpreting in armed conflicts and Islamic legal translations are complemented here with details about practical conditions of translation, and especially interpreting, at later times, when it had clearly become a full-fledged profession, with its own rules, conventions, and governing regulations. In addition, the texts serve as corollary to al-Qalqashandi's account of written translation of the Mamluk state (see al-Qalqashandi, Chapter 23), where interpreting seems to have been no less significant and regulated. We also get some insights about translation in the even less studied Hafsid court.

One consistently repeated theme is the emphasis on documenting the translated texts and verifying their accuracy and reliability, and the faithfulness of the interpreters, so much that it became necessary to for treaties to be ratified by signed witness testimonies.

A prominent presence in the Mamluk treaties is Taghribirdi, a highly placed translator and interpreter, as well as an emissary and diplomat, who contributed to the preparation of the treaties, as well as to the negotiations 
leading up to them. The grand honorifics bestowed on him (even given the hifalutin nature of the style overall) indicate the high status he enjoyed in the court of Qansuh al-Ghawri (1501-1516). Notwithstanding his Turkish name, Taghribirdi was a European-born Muslim convert in the service of the Mamluk sultans, starting with Al-Ashraf Qaitbai (1468-1496). ${ }^{1}$ Said to have known seven languages, he rose through several positions in the court until he became a "prince of ten" (a military commander with ten knights under his command). Taghribirdi played such a significant part in commercial and diplomatic relations with Italian city states that he was the Sultan's representative in negotiations for commercial agreements with Venice (Wolff 2003: 153-154).

The Hafsid treaties afford more details about the practical side of interpreting as a profession and the regulations that govern it. Obviously, the function of the interpreters went beyond linguistic, or even cultural, communication. They served as mediators and guides, and even contributed actively to the promotion and sale of goods, as well as providing guarantees for some commercial transactions. Further, it seems that some interpreters took advantage of their position to demand extras fees, which compelled the drafters to add specific clauses preventing interpreters, among other parties, to "introduce any measures other than those established by custom," and stipulating that Italian merchants should not have "to pay a gratuity" to anyone, including the interpreters. This is when an interpreter's income was apparently far from meagre. In fact, dragomans' fees were a constant source of complaint by foreign merchants (Bosworth 1986: 237).

Finally, one noteworthy clause in the Hafsid treaties is the stipulation that interpreters should "undertake the translation jointly," without any of them being employed exclusively. This rule was possibly intended as a form of quality assurance, allowing merchants to have access to a variety of interpreters to choose from.

\section{Tarek Shamma}

\section{Note}

1 His birthplace and ethnicity are subject to debate. Speculation ranges from a Spaniard from Valencia (Wolff 2003: 153; Subrahmanyam 1998: 28) to a Jewish Sicilian who converted to Christianity, then to Islam (Behrens-Abouseif 2004: 50). According to Bosworth, he is "probably a Spanish renegade, though whether of Christian, Jewish or Marrano origin is uncertain" (Bosworth 1986: 236). 


\title{
18 Collected Fatwas, Refutation of al-Jahmiya, Response to Those Who Have Changed the Religion of Christ (1328)
}

\author{
Taqi al-Dịn Ibn Taimiya
}

\section{Taqi al-Din Ibn Taimiya (1263-1328)}

Born in $\underline{\text { Harran }}$ in northern Syria, his family fled the city to Damascus when he was four due to an imminent Mongol invasion. He lived the rest of his life in Damascus. A highly influential theologian and jurisprudent of his time, Ibn Taimiya was an uncompromising defender of tradition salaf (past generations) and literalism in Qur'an and $\underline{H}$ adith. Known among his followers as "the Shaikh of Islam," he was controversial in his time, and remains so, due to his fundamentalist and confrontational views. In spite of his open hostility to philosophy, his works show deep familiarity with Islamic and Greek philosophy. He wrote extensively on Islamic law and theology, philosophy and logic, and other religions and Islamic sects.

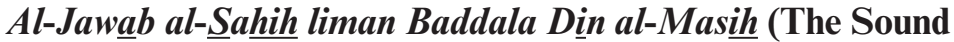 Refutation of Those Who Have Changed the Religion of Christ)}

Written in the context of Christian-Muslim polemics, the book is a rebuttal of the Christian apologetic Letter to a Muslim Friend in Sidon, attributed to Bulus (Paul) of Antioch, Bishop of Sidon. Written in the late thirteenth century, the Letter was reworked in Cyprus in the fourteenth century under the title "Arguments for the Faith of the Christians."

\section{BAIA N TALBIS AL-JAHMIYA FI TA'SIIS BIDA'IHIM $A L-K A L A M I Y A$ (DEMONSTRATION OF THE DECEITFULNESS OF THE JAHMIYA IN THEIR ESTABLISHMENT OF THEIR KALAMM INNOVATIONS)}

Al-Jahmiya are those who deny the principle of a personal God. This charge was especially leveled against rational philosophers, who were accused of being influenced in this position by Greek philosophy. This book was specifically written in response to a book by the famous theologian Fakhr al-Din al-Razi 
(1149-1210), where he denied the anthropomorphic qualities of God, relying on the Islamic science of Kalam.

\section{Majmu' al-Fatawa (Collected Responses)}

A collection of detailed responses to questions directed to Ibn Taimiya as a judge and theologian by lay people.

\section{[THE ROLE OF TRANSLATION IN THE TRANSMISSION OF RELIGIOUS SCRIPTURES]}

\section{From The Sound Refutation}

The refutation of the Christians' claim that the Messengers of God who were sent to them are sufficient, and that they have no need of the prophethood of Muhammad (PBUH).

(Part 2)

\section{The fifth aspect}

One should say that their claim that the prophets bequeathed to them the Torah and the Gospels and all of the other prophecies in 72 different languages, and that these books remain to this day upon a single wording, is a claim whose speaker is known to be talking without knowledge, and is, in fact, a lying slanderer. That belief entails that these books in 72 languages exist now in the world, all of them transmitted from the Apostles, and that all of them agree with each other, not differing in any respect at all. This amounts to four different claims: that they are extant in 72 languages; that they agree with each other; that all of them are transmitted from the Apostles; and, fourthly, that the Apostles themselves were free from error.

One should say: who from among you has already assumed that these books in 72 languages are the ones from the Apostles and that they are still extant today, can attest to their conformity with each other? That could only be possible for one who knows all 72 languages, knows that the books that he has in his possession were the ones passed down by the Apostles, and knows that every copy in the world in this language agrees with the copy which is in his possession. If not, then even if he had collected 72 copies in 72 languages, he still would not know whether every copy was a copy of the one received from the Apostles, even if one were to assume that they had, in fact, passed it down in 72 languages. Moreover, he would not know whether every copy in the world agreed with that copy. Indeed, it is a fact that, both in our time and the past, these books have continued to be transferred from one language to another, such as by being translated from Hebrew to Arabic, or from Syriac, Latin, and Greek to Arabic and other languages. 
Therefore, if a copy in Arabic is found, it is unknown whether it is from what was translated into Arabic after the Apostles or if it is a direct copy of what was taken from the Apostles, assuming that such a copy was taken from them in Arabic. Moreover, it is not possible for one person to collect all the copies translated into Arabic and compare them side-by-side. On the contrary, we have found that the copies translated into Arabic differ from one another in their translation to such a significant degree as to undermine confidence in any one of them. I myself have seen in the Psalms a number of copies translated into Arabic whose differences are practically unconstrained, and that which is seen to have been exchanged and altered cannot be trusted. I have also seen some copies of the Torah in Arabic in the translation of a group of the People of the Book [the Jews and Christians] have lied greatly about. How could one gather all the copies in the 72 languages and compare the copies in each of the languages side-by-side to show that there is amongst them the original copy taken from the Apostles then compare between the copies in all the languages? That is only possible for one who knows all 72 languages completely, and there is no one in the whole of humanity who is capable of that. Even if it were to be demonstrated that there is such a person, it would not be known if the one capable of doing that actually did it and informed us of the copies' uniformity.

If such a person were, in fact, found, then this would constitute only an uncorroborated claim. Or, supposing that someone who knows the soundness of its translation translates each language one by one so that the translation culminates in a single language, such as Arabic, for example, then at that point it would be known whether they agree with each other or not. Otherwise, then, if this book is translated into one language or two or more languages, and the other is translated similarly, whether they agree with each other will only be known if it is also known that the meaning in one language is the same as the meaning in the other, and this will only happen in the case of one who knows the two languages, or for whom the two languages are translated into one language which they know. Moreover, it is well-known that nobody has had the 72 languages translated into one language or the languages he knows, and nobody has command of 72 languages.

Therefore, the certainty that all the books written in the 72 languages agree with each other, or that the copies of all the languages agree with each other, would be a conclusion of unknown soundness even if there were in the world today 72 languages transmitted from the Apostles unadulterated by translated material after that. How could this be when what the people possess now comes from that which was translated after that time into Arabic and other languages up to this day? Moreover, this is a matter which no one could know for sure since there is not today a Torah, or a Gospel or books of the prophets to which someone could testify that they were translated into the Arabic language from the era of the Apostles, let alone into other languages. And even if it could be determined that the Apostles transmitted one of them in 72 languages by having a translation made (and thereafter many other 
translations), it would still be possible for changes to have occurred in some of the translations. Therefore, the knowledge that those original copies contain no changes does not mean that there was no change in some of what was translated after them or in some of what was copied from them. There is no way to know their agreement with each other, seeing as they are currently in 72 different languages.

This is in contradistinction to the Qur'an, which is in the language of the Arabs and the script of the Arabs, so it is possible to know whether what is found within a copy of the Qur'an is in agreement with the original. It is learned by heart and preserved in the heart and does not need preservation in books, as it is transmitted by an overwhelming number of chains of transmission in its wording and its script [...]

\section{(Part two)}

The refutation of their claim of contradiction between the message of the previous prophets and what Muhammad (PBUH) brought.

Concerning their claim that Muhammad's message contradicts that of others, it should be said that he confirms the truth of what the prophets told. However, he did not confirm what words were changed through translation or interpreted differently from their intention. It should be said that Muhammad's prophethood is authenticated by the same means of authenticating the prophets who came before him [...] Consequently, all prophets are truthful, corroborative of each other, and infallible in what they tell of God [...] None of them would tell of something that contradicts what any other has said [...] Nevertheless, abrogation does exist between one revealed law (Sharía) and another, just as abrogation exists in the revealed law of one prophet. Therefore, it is known that all that is transmitted from the preceding prophets which is contradicted by what is known from the message of Muhammad (PBUH) is invalid. This is regardless of whether or not the utterance itself was invalid, either because the prophet himself did not say it, translators of it from one language to another made an error, or the utterance and the translation were both sound, but the error occurred in knowing what that Prophet meant by that speech.

So, everything which is brought as a proof text from the utterances of the prophets which have been transmitted, both from the Tribe of Israel and others who were sent with a language other than Arabic, must only be advanced as an argument on the following preconditions: that one knows the utterance which (the prophet) uttered; knows its translation, and knows the intended meaning of that utterance. The Muslims and the People of the Book agree on the occurrence of mistakes in the commentary of some of the utterances and in explaining the intended meaning of the prophets in them, as well as in the translation of some of them. So, you will find with the Torah that there are a number of translated copies, and there are variations between them in which the understood meaning is different, and likewise in the Gospels and 
elsewhere. This is how all those who believe in Muhammad (PBUH) should answer, generally speaking $[\ldots]$

\section{(Part three)}

The response to their question of how it is possible for their books to have been changed when they were written in 72 languages.

As for their statement: how can it have been possible to have changed our books when there are 1,000 or whatever number of manuscripts in each language, and more than 600 years had elapsed between their composition and the arrival of Muhammad?

One should say: never have the Muslims, nor any known Muslim sect, claimed that the wording of every copy in the world was changed after these versions were disseminated. Rather, the majority of the Muslims, who say that there has been some change in their wording, only claim that some of their wording was changed before the prophethood of Muhammad (PBUH), or that some of the copies were changed after that, not that all the copies were changed. So, some people say that this change happened at the beginning, and some say that some copies were changed after the prophethood of Muhammad (PBUH), but they do not say that every copy in the world was changed. Rather, they say that some copies were changed and not others, and there appear in possession of many people the altered copies instead of those which were not altered, but some people still have the unaltered copies.

This is an incontrovertible fact, so no one can know whether every copy in the world in every language is identical in wording to all other copies in all other languages, except those whose expertise extends to all of the above. And they have already admitted that one person cannot do all that [...] As for their statement that they were written in 72 languages, then it is known by consensus of all Christians that Christ only spoke in Hebrew like the rest of the prophets of the Tribe of Israel, and that he was circumcised-he was circumcised on the eighth day as the Tribe of Israel are circumcised - and that he used to pray in their direction of prayer, did not use to pray towards the East, and did not order his followers to pray towards the East. Anyone who says that his language was Syriac, as some people suppose, is mistaken, as he spoke the words reported from him in the Gospels only in Hebrew, then it was translated from that language into others.

In the translation itself, many mistakes occurred, just as we have found in our time those who translate the Torah from Hebrew to Arabic and make mistakes in the translation, as truthful experts who know the two languages attest $[\ldots]$

Indeed, belief in all that the prophets were given is a necessary truth, but the obligation of bearing witness to the truth of a specific previously unknown prophet rests on two preconditions: (1) that the utterance is one which the Prophet spoke; and (2) that the meaning which they provide as an exegesis for it be an intended meaning of the prophet who made that statement. Therefore, 
the chain of transmission and the meaning of the text must be established, and these two preconditions must be met for everything transmitted from the prophets.

There may be a need for a third precondition regarding one who does not know the Hebrew language, namely that Moses, David, Jesus Christ, and others only spoke Hebrew, so whoever does not know Hebrew, and only knows Arabic or Latin, must find out whether the translator from one language to the other has translated it identically $[\ldots]$

The claim they make to have transmitted [the scriptures] from the prophets - God's blessings be upon them-rests on four preconditions: (1) that the prophethood of the one being transmitted from is known; (2) that the exact wording which he spoke is known; and (3) that it is known that what they report from him is a sound translation, for those prophets did not speak Arabic, nor Latin, Syriac, or Greek, and only spoke Hebrew, as Christ (PBUH) did [...]

The refutation of their claim that God named Himself Father, Son, and Holy Spirit [...]

If this is so, then what they transmit from the prophets can only be proven if: (1) its chain of transmission and its content are known; (2) it is known that it was transmitted from them by a sound transmission; (3) we know that its translation from Hebrew to the other language, such as Latin, Arabic or Syriac, is sound; and, (4) it is known that the Prophet in question meant that particular meaning by it [...]

They have said: the likes of this statement in the books sent by God from the mouths of the prophets and messengers is a universal claim amongst all the Christians, despite differing in their languages and being dispersed throughout the world, adhering to the religion of Christianity, being a single statement and a single text, identical to what was handed down to them from the Apostles when they brought them a divine warning and returned them from the worship of idols to the gnosis of God Almighty. They passed it on to them, every nation in its own language, and it has been in the same form to this day.

The appropriate response to this is from (a number of) points of view [...]

The third aspect: this is indeed an obvious lie, as the speakers of many languages do not have an original gospel, including the language of the Arabs. The Christian Arabs were numerous before Islam. Neither the Arabic Torah, nor the Gospel, nor the books of the prophets were known, except for what had been translated into Arabic from the Hebrew, Latin, and Syriac copies. We should ask them for these books in Hebrew, which existed in the time of the Apostles. Where are they? Who saw them? And if it were demonstrated that the originals had existed in Hebrew, then these extant Hebrew copies today in the hands of the people must be the same ones that were translated into Arabic from what was in their possession [at that time]. At this point, then, their soundness is not known if the soundness of their translation is not known, and their transmission from Christ is not proven. The response should be the same for all the other languages [...] 


\section{(Part five)}

Whoever makes a claim of transmission from a prophet must concede these two preconditions: namely, the chain of transmission; and the textual content. Moreover, there must be proof of its wording, and there must be confirmation of the meaning of the wording. If the transmission were not in the language of the Prophet (in question), but rather in another language, then there must be a sound translation. However, the Christians at large do not have the books of the prophets in the language of the prophets. Moses and Christ and the prophets of the sons of Israel only spoke in the Hebrew language. Christ was Hebrew, only spoke in Hebrew, and some of his followers only spoke other languages, like Syriac, Greek, or Latin. The general population of the Christians do not know Hebrew and so are not skilled enough to read the Torah, the Gospels, or anything else (for that matter) in Hebrew. They only speak one language, be it Latin, Syriac or others, even if there are a few among them who do speak Hebrew, in contrast to the Jews, amongst whom Hebrew is widespread. At this point, then, whoever of the People of the Book makes a claim from the speech of the prophets which has been transmitted in Latin, Syriac, or Arabic must prove the transmission in addition to proving the translation and its soundness. In fact, they are often confounded by the translation (of a text) and the issue of its soundness and differ on its meaning.

\section{Translated by Adam Gargani}

\section{COMMENTARY}

Translation occupied a significant, though not always central, part in religious apologetics in Islamic history, especially between Muslims and Christians. Their practically contradictory views on translation were undoubtedly rooted in the different ways the scripture was transmitted in each religion.

The Qur'an is the literal word of God, delivered through the Prophet, who is the mere conduit of transmission. Hence, the preservation of the Qur'an's text was a foremost concern for early Muslims. For later theologians, this accurate transfer was the foundation of the authenticity of their holy text and the revelation through which it was delivered, and a trustworthy measure against the dangers of distortion (tahrif) which, they argued, affected other religious texts. It was this fear of distortion, besides the overriding principle of the Qur'an's inimitability, that engendered serious doubts about the very possibility of translating the holy text into another language, or, especially, of any translation serving any of the religious functions of the original.

Conversely, the Gospels present a narrative of the life and sayings of Christ as channeled through secondary sources. The sayings of Christ as conveyed in the Greek of the Gospels from their original Aramaic are practically translations. Therefore, the literal translation, or even transmission, of holy 
texts did not have the same impact it did in Islamic thought. This is especially the case in polemical contexts, where Christian arguments (vis-à-vis Islamic assertions of pure, unfiltered access to the word of God) focus on the essence of the message and its core tenets, regardless of the form of expression.

In these excerpts, from a book dedicated to demonstrating the alleged distortions in Christian sacred texts, Ibn Taimiya questions the ability of translation to render the scriptures, considering both the evidence of the texts available in his time and the nature of translation itself. His criterion is a form of perfect equivalence which preserves both the meaning and utterance intact, and from which any deviations would be considered distortions. This can be seen in his response to the claim that the Gospels were rendered by the apostles in numerous tongues. A common narrative in Christian apologetics of the time held that Christ, before his ascension, appointed disciples (70 or 72) and sent them around the world to spread his message (see al-Kindi, Chapter 5). As stated in the polemic attributed to one Anba ${ }^{1}$ Jirji, "the apostles traveled the earth from end to end [...] and they spoke all languages" (Anba Jijri: 10).

In his response to these arguments, Ibn Taimiya's definition of distortion (tahriff) as any disparity that deviates from full equivalence exemplifies the traditional view of fidelity in Islamic theology, which led to serious reservations about the translation of sacred texts, including the possibility of translating the Qur'an into other languages. In the Christian position, on the other hand, with its emphasis on the core message, it is enough to show how all narratives agree on the primary principles, which makes less substantial translation differences mostly immaterial.

\section{Tarek Shamma}

\section{[ON TERMINOLOGICAL INCOMPATIBILITY IN TRANSLATION]}

\section{From Demonstration of the Deceitfulness of the Jahmiya}

Since the Greek books had been translated into Arabic at around the turn of the second century [around the start of the ninth century $\mathrm{CE}$ ], and kalam practitioners had adopted them, and, on the basis of these books, had started to dabble in a range of invalid areas in theology (as well as medical and arithmetical matters in which there is no harm in engaging), the people split into factions on this issue: (1) a group who accepted these books; (2) a group who declared lawful what was in them; (3) a group who subjected what was in them to their own principles and guidelines and accepted what was in agreement with them to the exception of what went against them; and (4) a group who subjected them to the Scripture and the Wisdom that the messengers had brought.

Since these books were translated into Arabic, different types of corruption and disturbance occurred, guaranteeing that there would be diminution and neglect of the knowledge of the Scripture and Wisdom that the messengers 
brought, until what was praised from Scripture and Wisdom began to be classified as "wisdom" as such. Many people thought that scriptural wisdom referred to the wisdom of this or that nation, the nation of India, and so on. They did not know that the noun "wisdom," like "knowledge," "reason," "gnosis," "religion," "truth," "falsehood," "goodness," "honesty," and "love," and all the other nouns the approval and praise of which concepts that human beings have agreed upon, are only disagreed upon in terms of the identification of their referents and the variety of their designations. Therefore, every nation, whether from the People of the Book or others, name what they experience, whether in speech or action, by these names. However, in many or even most things, they only follow doubt and psychological desires [...] Therefore, only a scripture sent from heaven will put an end to the debate amongst human beings. For this reason, Allah Almighty ordered the believers to render judgment to Him in case of a dispute [...]

What is meant here is that those who transmitted these writings and contrarians began to express in an Arabized idiom "sophistiqa," which was taken from Greek, the sense which includes the denial of truth and disguising it with falsehood. Moreover, they took the opinion that this was a real technical term and a general paradigm for a school of thought. This is not the case; on the contrary, it is an obstacle to human beings in many of their affairs. Anyone who has repudiated known truth and gilded it with falsehood is a "sophist" on a particular point, even if he agrees with other things. He would be an obdurate sophist if he knew to be true what he rejected [...] These people would be sophists in this repudiation, even if they agreed with other things. The Almighty and Sanctified said, "it is not thee they cry lies to, but the evildoers - it is the signs of God that they deny" [the Qur'an, al-An'am $6: 33]$. Therefore, the majority of the more distinguished of those who gave the lie to the Truth with which He sent His prophets are from among the obstinate deniers, and they are the worst of the sophists.

\section{From Collected Responsa}

\section{(Part 2)}

As for the prophets and the messengers, these people [i.e., philosophers] do not have a known statement on the issue, whether denying prophecy or affirming it. Then the primordial Abrahamic monotheistic faith prevailedfirst through the prophethood of Jesus when the Christians triumphed in the kingdom of the pagans in Syria, Egypt, Rome, and elsewhere, and then with the prophethood of Muhammad, the Seal of the Messengers, from the light of whose prophethood God made appear a sun which eclipsed the light of the stars, and the righteous forebears lived in it for a long while. But thereafter some of the light of prophecy disappeared, and so some books of the Romans, Persians, Indians, and other foreign philosophers were translated into Arabic during the Abbasid state. Then their books were sought in the reign of 
al-Ma'mun from the Byzantines' lands, and so they were translated, and the people studied them, and therefore some of the blameworthy innovations in religion that appeared did so because of that.

Most translated books were in mathematical sciences, such as arithmetic and astronomy, or natural sciences, such as medicine or logic. As for theology, their speech on it is insignificant, and, besides its paucity, most of what they have does not constitute certain knowledge, while the Muslims have in their theological sciences, inherited from the Seal of the Messengers, that which has filled the world with light and guidance. Even the theologians who have been charged with blameworthy innovations, with their standards which are derivative of scripture, have many, many times over the theological insights that the skilful philosophizers have.

After that there appeared amongst them those who feigned skilfulness in their method in the science of metaphysics, such as al-Farabi and Ibn Sina and others. Ibn Sina composed books in which, by virtue of shared [philosophical] principles, he proliferated things the people of the early generations never even mentioned. He called this "the divine science," and he spoke about prophecies, miracles, and the stations of men of knowledge with a speech containing honour and respect towards what the people of the early generations said, even though the "prophetic divine sciences" had on this topic shortcomings, omissions, hypocrisy, ignorance, misguidance, and disbelief, which is obvious to anyone who has the slightest insight in knowledge and faith [...]

\section{(Part 3)}

As for speaking to the people of a particular terminology in their own terminology and language, this is not blameworthy as long as there is a need for that and the meanings are sound, such as speaking to foreigners, like the Romans, the Persians, and the Turks, in their language and their custom, as this is legitimate due to necessity. However, the Imams disapproved of it if there is no need for it [...] Likewise, the Qu'ran and the Hadith are translated for those who need it to be translated for them to understand it. The Muslim reads what he needs from the books of the nations and their speech in their own language and translates them into Arabic, just as the Prophet ordered Zaid Ibn Thabit to learn the writing of the Jews to read for them and write that for them, as none of the Jews yet believed in him.

\section{(Part 4)}

[...]

During the reign of Abu al-'Abbas al-Ma'mun, hypocrites like the so-called "Khurramiya" and their ilk were prominent. Some of the imported books of the ancients from the lands of the former Roman Empire were translated into Arabic, leading to the spread of the doctrines of the pagans. Al-Ma'mun corresponded with the polytheist kings of India and elsewhere until there was affection between him and them. So when signs of disbelief and hypocrisy 
appeared amongst the Muslims, and the status of the polytheists and the People of the Book was strengthened to the extent that it was, there followed the phenomenon of the rise of the Jahmiya and the Shiites and other groups from the people of misguidance, as well as accommodation to the beliefs of the pagans and their ilk from amongst the "philosophizers." That is the sort of opinion whose holder thinks it to be rational and just, while it is merely ignorance and injustice. Drawing an equivalence between the believer and the hypocrite, or between the Muslim and the infidel, is even more unjust than that $[\ldots]$

If this knowledge had been obtained from believers among the People of the Book, who knew what they had in their language and translated it for us into Arabic, debating them and dialoguing with them would have therefore been beneficial [...] At that point, what they have should be cited in accordance with its correspondence with the Prophet's message, and it can be either proof against them or others, as we have clarified elsewhere.

Similarly, one can read from a translated copy in Arabic which has been translated by trustworthy authorities into the script and spoken language of Arabic-speakers so long as one knows what they contain in both respects by means of authoritative Muslim translators, or from those of us who know their script, like Zaid Ibn Thabit for example, when the Prophet (PBUH) ordered him to learn that [...]

Debating the pagan philosophers and the polytheists and so on is similar to this. So, if a pagan philosopher mentions a statement the ancient pagan philosophers made (which was translated into Arabic) whether faithfully or, which later philosophers engaged in, by addition, omission, extension or specification, rejection of part of it and bringing other meanings from outside it, and so on, then it is acceptable only if he mentioned something which is not related to religion, such as by reporting the statement in medical and purely arithmetical topics, and the books of those who learned from them, such as Muhammad Ibn Zakariya al-Razi and Ibn Sina and other heretical physicians, whose purpose was the utilization of the heritage of the disbelievers and the hypocrites in the affairs of this world [...] So, taking medical knowledge from their books is like requesting guidance from the disbeliever on how to get somewhere or seeking his medical advice. In fact, it is better; since their books were not written with a particular Muslim in mind for them to insert their perfidy therein, none of them had any reason to be perfidious. This is merely making use of their heritage, just as we could make use of their clothes, homes, farms, weapons, and so on. If they mention a religious matter, and if they quoted it from the prophets, they are in this matter like the People of the Book and are in a poor state. But if they transformed knowledge of a religious matter on the basis of rational analogy, then if it agrees with what is in the Qur'an, it is true, and if it contradicts it, then the Qur'an contains the proof of its invalidity [...] So, in the Qur'an is the truth and the clear analogy, which clarifies the invalidity of the analogy they brought. If what they mention is a summary in which there is the truth - and this is true for the greater portion of the pagan Peripatetics, like Aristotle and his followers and others who 
followed them - the truth is accepted, and the falsehood rejected, even though the truth from that source is not the manifestation of the divine attribute of "the Truth" as it is in the Qur'an. Therefore, this issue is dependent upon the knowledge of the Qur'an, its meanings, explanation, and translation.

Now translation and explanation are of three degrees:

The first degree is translation merely by a literal expression, like replacing one word with a synonymous one. So, in this type of translation, you want to know that what is meant by this word amongst one group of people is the same as that which is meant by the same word amongst another group of people. This is useful knowledge, as many people tie the meaning to the word, so then it cannot be stripped from both words at the same time.

The second degree is a translation of the meaning and its elucidation by means of depicting the meaning to the addressee. The depiction of meaning and the making of this meaning understood are of greater scope than translation by word alone, such as explaining to an Arabic speaker an Arabic book whose Arabic words he has heard, but whose meanings he cannot picture when he has not understood them. Depiction of meaning occurs by mentioning the thing itself, or an equivalent, as long as it is a composition of predicates from vocabulary items understood by the addressee and constitute a specific assemblage of images of that meaning, whether precisely or approximately.

The third degree is the elucidation and confirmation of the correctness of meaning by mentioning the evidence and the analogy which confirms that meaning, whether by merely stating the evidence or by stating evidence that indicates the reason for its being. Here, one may need to coin examples and comparisons that convey the confirmation of that meaning to the addressee, just as in the second degree, he needs examples to depict for him that meaning. The same depiction of it may convey the truthfulness of it for knowledge. When the depiction of its meaning suffices to confirm it, he does not need analogy and example, and other evidence. If the Qur'an had known this knowledge, then the theology which is in accordance with it or contradicts it from that of the People of the Book and the pagans and the polytheists must be translated both word for word and also by the meaning [...] It is also known that the Muslims are charged with the communication of the Qur'an, its words, and its meaning, as the Prophet commanded this. The communication of the Message of God can only be like this, and to communicate it to the non-Arabs may require a translation for them, so it was translated for them as much as possible. Moreover, the translation may need to strike comparisons to depict the meanings. So that is the fullest sense of translation.

It is known that most Muslims, or rather most of them who are committed to knowledge, do not engage in translating, commenting on, and elucidating the Qur'an. Hence, the others are even more incapable of translating and elucidating what they have (since the rationality of the Muslims is more perfect, and their writing is more upright in speech and better in conversation, and their language is more encompassing), particularly if those meanings are not beyond doubt, but rather contain much falsehood. Translation of the false meanings and their depiction is difficult because there is not an equivalent to 
them from the truth in every case. So, when we are asked about a statement, they say: is it truth or falsehood? And how are the truth and the falsehood in it made clear? We say: by stating the proof and the evidence for it, just as the polytheists and the People of the Book used to ask the Prophet of Allah (PBUH) about topics or used to debate with him, and just as the other nations used to dispute with their messengers. Many people even say that the Shari $a$ and philosophy are compatible!

An example of this kind of translation is when they mention "the ten intellects" and "the nine souls," and they say that the first intellect is the first emanation from the Necessary Existent and that it is one of the fixed attributes of His essence, and an effect of it, and likewise the second from the first, and that to every celestial body belongs an intellect and a soul. To this, it should be said: their saying of "intellect" and "soul" is their idiom, so it must be translated, and if the utterance is Arabic, then it requires translation by meaning. So they say: the "intellect" is the soul stripped of matter, and the matter is the body and its relations, which they called "intellect," and they call it a separate part, and they call those separate parts of material things because they are separated from bodies, just as the soul of the human being, when it departs his body, is a separate part belonging to matter, which is the body. The "soul" is the directing spirit for the body, like the soul of the human being when it was in his body. When it was in the body, it acted as an agent of motion for it. Then, when the soul separates from the body, it becomes a pure intellect, meaning it understands the objects of knowledge without setting in motion anything from the bodies. These are what the "intellects" and "souls" are.

What we have written is an example of the best translation of the meaning of both "the intellects" and "the souls," and most translators do not achieve this.

\section{Translated by Adam Gargani}

\section{COMMENTARY ON THE TWO TEXTS}

Ibn Taimiya wrote these two texts at a time when the condemnation of "the sciences of the ancients" had become an official ideology among traditional theologians (as well as some rulers). The backlash against philosophy started during the reign of the Abbasid caliph al-Mutawakkil (847-861) with the fall from favor of the Mu'tazilites, whose rationalist philosophy was made a state orthodoxy by al-Ma'mun (see Ibn al-Nadim, Chapter 10). At times, philosophy was banned outright, and its books burned, as in the reign of al-Qadir (991-1031). Thus, in Ibn Taimiya's age, philosophy had become forbidden among most jurists. An injunction against the translation movement, which had been the fountainhead of philosophy in its inception, was the inevitable consequence.

Two issues stand out in Ibn Taimiya's denunciation of the translation from pre-Islamic civilizations. On the one hand, he does not reject translation as 
such: A clear distinction is made between religious disciplines, which deal with divinity and prophethood, and practical ones, such as medicine and mathematics; only the first type is objectionable. In fact, technical, nonreligious material can be translated even from those who are considered disbelievers. As Ibn Taimiya explains in another part of his fatwas:

Aristotle, the First Teacher, is most ignorant when it comes to knowing the Lord of creation. But [philosophers] have good knowledge of natural subjects. This is where the bulk of their learning lies, to which they devoted all their efforts and on which they spent their lives. Of the knowledge of God Almighty, their share is trifling.

This distinction between practical and religious sciences was a common theme among traditional Islamic scholars - either to reject rationalist philosophy (even philosophy as such), or, especially by modern reformers, to argue that "modernization," even through the influence of the West, does not have to impinge on religious values. In his account of Paris published in 1834, Rifa'a al-Tahtawi (one of the founders of the Arab Nahd $\underline{d} a$ ) distinguished between the conventional sciences of his time (such as theology, linguistics, Islamic exegesis) and the "external" (purely scientific and practical) sciences - the latter of which can be translated from European language without compromising the spiritual and moral foundations of Muslim societies. Consequently, al-Tahtawi (who became a prolific translator and the founder of a translator-training school) finds translation to be a necessity for progress and development.

On the other hand, in his denunciation of translated disciplines, Ibn Taimiyya rejects the humanist perspective which underlay the translation from non-Muslim cultures. For Ibn Taimiya, even values designated by the same names in other languages are far from being common to all cultures. While the statements of philosophers, as he concedes, may contain some general truths, these should be assessed by an Islamic standard, which alone would decide what can, and cannot, be accepted. For this purpose, what is required is only the understanding, exegesis, and textual analysis of the Qur'an, rather than rational inquiry based in shared human experience or, in the phrase Ibn Miskawayh (the eleventh-century philosopher), "the eternal wisdom." For, as Ibn Taimiya explains, "the rationality of the Muslims is more perfect, and their writing is more upright in speech and better in conversation, and their language is more encompassing."

\section{Tarek Shamma}

\section{Note}

1 A clerical title in the Egyptian Coptic Church. Anba Jirji supposedly debated three Muslim scholars in the presence of the otherwise unknown prince Mushammar alAyubi in 1216. 


\title{
19 Commentary on the L-Rhymed Poem (1363)
}

\author{
Salah al-Din Al- $\underline{\text { Safadi }}$
}

\section{Salah al-Din Al- $\underline{\text { Safadi (1296-1363) }}$}

A historian, poet, and literary scholar. He was in charge of the government chancery in Safed, Cairo, and Aleppo. His works include Al-Ghaith alMusajjam, Ikhtira' al-Khura (The Invention of Absurdity), a parody of contemporary scholars, and al-Wafi bi al-Wafiyat (Comprehensive Record of Deaths), in 29 volumes, a biographical dictionary of notable people.

\section{Al-Ghaith al-Musajjam (Commentary on the L-Rhymed Poem)}

While centered on a detailed analysis and explanation of the famous Lrhymed poem of al-Tughra ${ }^{6} i(1061-1121)$, the book deals with a wide variety of literary, historical and linguistic topics of the time.

\section{[THE TWO METHODS OF TRANSLATION]}

It was reported that al-Ma'mun, having concluded a truce with a Christian king (of Cyprus, I believe), asked him for a treasure of Greek books which had been kept in a house to which no one had access. The king assembled his highest advisers and asked for their counsel. They all advised him not to send these books, except a patriarch who said: "Send these books today, for never have these disciplines entered a state governed by religious law but corrupted it and caused strife among its scholars."

I was told on reliable authority that Shaikh Taqi al-Din Ahmad Ibn Taimiya (May he rest in peace) used to say: "I do not think that God will neglect al-Ma'mun. He will certainly hold him accountable for what he did to this nation by introducing those philosophical sciences among its people." However, al-Ma'mun did not initiate translation and Arabization; he was preceded by many before him. Yahia Ibn Khalid al-Barmaki commissioned the translation of numerous Persian books, such as Kalila wa Dimna; of Greek books, Almagest was translated for him. It is well known that the first to translate Greek books was Khalid Ibn Yazid Ibn Mu'awia, who had developed a passion for Chemistry. 
Translators follow one of two methods. The first is that of Yuhanna Ibn alBitriq, Ibn Na'ima al-Himsi, and others. Here the translator considers every individual Greek word individually in terms of the meaning it signifies, finds an individual word in Arabic that is synonymous in signifying this meaning, and adopts it. Then he moves to the next word in the same manner, until he has completed what he wants to translate. This method is flawed for two reasons. For you will not find Arabic words that correspond to all Greek words. This is why many Greek words were left as they were in this kind if translation. On the other hand, structural features and syntactical relations of one language are not always identical to those of another. In addition, errors could result from figurative uses, which are abundant in all languages.

The second method of translation is that of Hunain Ibn Ishaq, al-Jawhari, and others. Here the translator approaches a sentence, comprehends its meaning, then expresses it in the other language with a corresponding sentence, regardless of whether individual words are equal. This method is superior. It is for this reason that Hunain's books did not need revising, expect in mathematics, in which he was not versed. Contrariwise, his translations in medicine, logic, physics, and divinity did not require any correction. Euclid was refined by

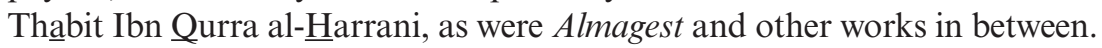

\section{Translated by Tarek Shamma}

\section{COMMENTARY}

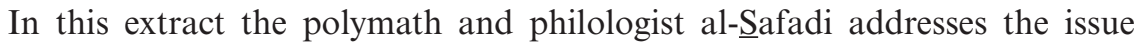
of translation with regard to approaches across the centuries, suggesting a classification or periodization of translators and techniques which has been widely cited in historical accounts of the medieval translation movement into Arabic. In this classification, the work of the iconic translator and scholar Hunain Ibn Ishaq and that of his collaborators is contrasted with the output of earlier translators such as Yahia Ibn al-Bitriq and Ibn Na'ima alWhilst the former are said to focus on meaning and proceed by reading and understanding the whole sentence prior to translating it, al- $\underline{S}$ afadi contends that the latter adopted a literal, word-for-word approach, whereby an Arabic equivalent is found for each and every Greek or Syriac word. Al- $\underline{S}$ afadi

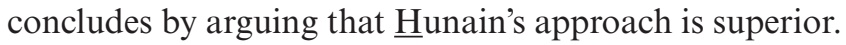

In fact, as a number of scholars have argued (see Gutas 1998 in particular), such a categorization needs to be taken with a degree of caution, as it does not accurately reflect the reality of the earlier translators' work and does not do justice to their achievements. The extract, however, is frequently quoted, and its value resides not only in the insights it provides on the debate on translation in medieval Islam, but in the way it feeds into the narrative of a progress model in translation practice and ensuing reflection, which has been challenged in more recent discussions of the history of translation (D'hulst 2014).

\section{Myriam Salama-Carr}




\title{
20 The Reconciliation of the Fundamentals of Islamic Law (1388)
}

\author{
Ibrahin Al-Shatibi
}

\begin{abstract}
Abu Ishaq Ibrahinim al-Shatibi (1204-1285)
An Andalusian scholar of Islamic law, $\underline{\text { Hadith, }}$ Qur'anic exegesis, theology, and linguistics. He was born in Granada, where he lived and died in 1388 . He is generally considered one of the most important scholars of Islamic law in Classical Arabic. Al-Muwafaqąt $f i$ 'Usul al-Fiqh is his major work.
\end{abstract}

\section{Al-Muwafaqat $f$ ' 'Usul al-Fiqh (The Reconciliation of the Fundamentals of Islamic Law)}

Al-Shatibi's best known book, it is considered to have founded the systematic study of the objectives of the Sharía (Islamic law). It is divided into five parts, the first three of which were published in English in two volumes under the title The Reconciliation of the Fundamentals of Islamic Law.

\section{[TRANSLATION AND THE LEVELS OF SEMANTIC REFERENCE]}

When we say that the Qu'ran was revealed in the language of the Arabs, and that its Arabic is free of foreignisms, it is in the sense that it was revealed in the forms familiar to the Arabs, using their own utterances and modes of meaning. Following the natural disposition of their language, the Arabs may use a general reference intended for an overt signification, a general reference intended for a general signification on one side and a specific signification on the other, a general reference intended for a specific signification, as well as an overt reference intended for other than an overt signification. All these uses can be realized in the beginning, middle, or end of propositions. Arabs may also express propositions in such a way that the beginning refers forward to the ending, or the ending back to beginning; speak of things that are understood though their direct reference, as well as through allusion; and use several names for the same thing, as well as the same name for several things. All this is well known: it is doubted neither by the Arabs, nor by those who pursue the science of their language. 
This being the case, the Qu'ran follows this order in its meanings and stylistic features. Just as some foreign tongues cannot be understood through the Arabic tongue, so the Arabic tongue cannot be understood through foreign tongues, due to the different constructions and styles. It was al-Shafi' 'i, in his treatise on the principles of jurisprudence [known as al-Risala (The Epistle)], who drew attention to these aspects of the question. As many who came after him did not approach the question from this angle, it has become necessary to highlight it. May God guide us all to success.

Second, considering Arabic as utterances signifying meaning, these can be seen from two perspectives: first, as unrestricted words and statements, signifying unrestricted meanings - which is the original reference; second, as restricted words and statements, signifying subordinate meanings - which is the secondary reference.

Now the first aspect of reference, encompassing the purpose of the speaker, is shared among all languages; it is not unique to one nation of any others. If it comes to pass that an agent performed an action such as rising, and the speaker of another tongue wanted to report this action, he would be able to do that without any difficulty. From this angle, it is possible to relate in Arabic the histories of the ancients who are not Arabs and report their sayings. Similarly, it is possible in foreign tongues to report the sayings of the Arabs and relate their histories. This issue is unproblematic.

The other aspect of reference, on the other hand, is unique to the Arabic tongue; it concerns its own manner of relating and reporting. From this angle, every reference necessitates issues that are subservient to it, depending on the referrer, the referent, what is referenced, and the mode of reference, as well the condition and context of reference. Also relevant are stylistic devises-be they direct or indirect expression, concision, circumlocution, and so on [...] These variations, whereby the meaning of one statement may differ, are not the original intention, but are complementary and supplementary to it. With long practice in these modes, one's command of expression can be improved, as long as it is free from objectionable things. It is in this second aspect of reference that statements vary from each other. The same applies to Qur'anic narratives, where the same story may be told in a certain context in some suras (chapters), in another context in others, and in a third context in yet other suras $[\ldots]$

This being established, someone who considers this type of reference cannot translate Arabic statements (not to mention the Qur'an) into nonArabic ones in any way, unless the two tongues are shown to be equal in their use of all the aspects mentioned above [...] If this equality is proven for the other tongue together with Arabic, then each of them can be translated into the other. However, proving this in a convincing manner is very hard indeed. Ancient practitioners of logic (as well as their modern followers) may have pointed to some of this; but it is not sufficient or satisfactory in this regard.

Ibn Qutaiba [ninth-century literary scholar] denied the possibility of translating the Qur'an, that is to say on this second level. On the first level, 
translation is still possible. It is in this mode that the Qur'an has been interpreted and explained without objection the common people, and to those who are unable to comprehend its meanings. It is agreed among Muslims that these practices are permissible. This agreement has become evidence for the appropriateness of the translation of the original meaning.

\section{Translated by Tarek Shamma}

\section{COMMENTARY}

Al-Shatibi's analysis of the modes of semantic significance, though focused on the Qu'ran, moves the discussion of meaning and translation beyond the elementary utterance/meaning dichotomy employed in many contemporary debates (see, for example, al-Jahidh, Chapter 4). His distinction between "unrestricted" and "restricted" ("subordinate) meanings is reminiscent of Chomsky's "deep structure" and "surface structure." This is especially apparent in his account of the unrestricted mode of significance as underlying "the ultimate intention of speakers [...] shared among all languages," and the latter as unique to Arabic, or generally a single language, being confined to "its own manner of relating and reporting."

It is on the first level-where meanings are free from the limitations of space and time, governed by the universal principles of thought and common human activities - that translation is a possible, indeed uncomplicated, activity. Here it is feasible, not only to express in Arabic "the histories of the ancients" and "report their sayings," but also to render the "sayings of the Arabs and relate their histories" to foreign tongues. On the second level, however, we encounter linguistic structures, grammatical and semantic relations, and rhetorical devices limited to specific languages. It is here, al-Shatibi argues, that the miraculous nature of Qur'anic eloquence (i'jazz) resides, inhering in relations and combinations of words that cannot be reproduced intact in any other language.

It should be noted that the resultant impossibility of translation in this area is not limited to the Qu'ran, although it is al-Shatibi's main aim to explain the grounds for i'jaz. Nor is it limited to Arabic, from which all the examples are taken. For, as al-Shatibi has explained earlier, "foreign tongues cannot be understood through the Arabic tongue," just as "the Arabic tongue cannot be understood through foreign tongues." Every language has its singular constructions and styles, which cannot be translated in full.

Especially in his insistence that translation is not acceptable expect when "the two tongues are shown to be equal in their use of the aspects mentioned above," al-Shatibi's position is reminiscent of al-Sirrafi's (see al-Sirrafi and Matta, Chapter 7). The same qualities that make translation impossible for alSirafi are those tied to one language as "complementary and supplementary" to the basic meaning. Ultimately, the defining standard for both scholars is no 
less than perfect equality and sameness for what would count as translation proper. True, al-Shatibi does allow the possibility of translation on the first, "unrestricted," level, but this is designated under "reporting" (i.e., a purely informative function), which preserves the core of meaning but misses the crucial aspects of the mode of expression.

In his final remarks on this question, al-Shatibi considers the remote possibility of languages being equal in their restricted modes of significance, in which case full translation would be feasible. But this is immediately rejected as purely theoretical. Still, it is interesting that he indicates previous efforts to demonstrate this level of equivalence between different languages, which he attributes to logicians, though, again, he dismisses them as "insufficient in this regard." This issue bears further investigation, as Arabic logicians and philosophers were evidently more inclined to linguistic universalism, with its promise of the unrestricted possibility of translation in all cases. ${ }^{1}$

It would be useful in this connection to examine Ibn Qutaiba's argument, employed by al-Shatibi against translating the Qur'an. For the author of Ta'wil Mushkil al-Qur'an (Interpreting the Difficult Passages in the Qur'an), the book cited here, has a much more limited perspective than al-Shatibi. Having elaborated on the rhetorical and figurative methods of the Qur'an (including word order, fronting, inversion, figures of speech, repetition, ellipsis, etc.)all belonging to al-Shatibi's restricted mode-Ibn Qutaiba concludes that "No translator can render [the Qur'an] into any other tongue." However, he goes further than al-Shatibi by singling out Arabic with the impossibility of translation. For "non-Arabs," he says, "were not as expansive in figurative language as the Arabs were"; therefore, the Qur'an cannot be translated, as "the New Testament was translated from Syriac into Abyssinian and Greek, as well as the Torah and Zabur r [Plasms of David]" (Ta'will: 22).

Ibn Qutaiba's attitude invokes a position that recognizes linguistic difference on the restricted level described by al-Shatibi as a barrier to full translation, but sees languages as unequal in this difference, and consequently in their levels of (un)translatability. For the supposedly unequaled figurative richness of Arabic hinders translation from it-but not necessarily the other way round. In fact, to pursue Ibn Qutaiba's argument to their logical conclusions, one may be led to believe that the same multiplicity and productivity that make Arabic a very difficult language to translate from may also make it easier to translate into. This position is stated overtly by the poet and linguist Ibn Sinan al-Khafaji (1032-1073) in Sir al-Fasaha (The Secret of Eloquence), based on the same views of Arabic vis-à-vis other languages:

As for Arabic, its unique distinction, its supremacy over all other languages, is a well-known fact. Its vast capacity is evident. If you investigate all languages, you will not find, as I have heard, one that equals Arabic in the multiplicity of names for the same referent. Conversely, in Greek the same name may designate many referents. Besides its vastness and multiplicity, Arabic is most succinct in conveying meanings - a fact that 
becomes evident in translation into it. Nothing is translated into Arabic but emerges more concise than the original, with meanings preserved and kept intact. This is undoubtedly an eminent advantage and a great merit. For the purpose of speech, and the one for which languages developed, is to reveal and illuminate meanings. If a language can express and reveal one's intentions with brevity and concision, then it is more worthy of usage, being superior to those that need prolixity and periphrasis.

Abu Dawud the Patriarch, who is knowledgeable in Arabic and Syriac, told me that when fine expressions are translated into Syriac, they turn base and ungainly. By contrast, when choice compositions are rendered from Syriac into Arabic, they gain in grace and beauty. The same is said by all foreign speakers about their languages with regard to Arabic [...] On the other hand, our language has such metaphors, and has developed such fine expressions, as have no counterparts in other languages. Meanings do not change; so they can be translated with no alteration. It is as if what is translated from Arabic loses its beauty for this reason, whereas what is translated into it can be improved in elegance, since the translator will find what can be expressed in Arabic better than what he intends and more eloquent than he what he tries.

Al-Khafaji's opinions raise interesting questions about the relationship between meaning (with its different levels) and utterance, and their role in translation, not to mention the standards of fineness, elegance, and beauty, and the extent to which they can be applied as criteria for translation.

\section{Tarek Shamma}

\section{Note}

1 For further discussion of the connection between rationalist Islamic philosophy and cultural/linguistic universalism, see Tarek Shamma 2021b. 


\title{
21 On the Fundamentals of Jurisprudence, On the Rules of Jurisprudence, On the Sciences of the Qur'an (1392)
}

\author{
Badr al-Dịn al-Zarkashi
}

\section{Badr al-Din al-Zarkashi (1344-1392)}

An Islamic scholar of $\underline{H}$ adith and jurisprudence. He was born in Cairo, where he spent all his life. His works include al-Burhan fi 'Ulum al-Qur'an (On the Sciences of the Qur'an), Al-Manthur fi al-Qawa'id al-Fiqhiya (On the Rules of Jurisprudence), and al-Bahr al-Muhit fi 'Usul al-Figh (On the Fundamentals of Jurisprudence).

\section{Al-Burhan fi 'Ulum al-Qur'an (On the Sciences of the Qur'an)}

A comprehensive compendium of Qur'anic sciences, organized in 47 categories. Zarkashi extensively covers the works and opinions of his predecessors. In the seventeenth category, al-Zarkashi examines linguistic issues in the Qur'an, including borrowings from other languages.

\section{[THE POSSIBILITY OF TRANSLATING THE QUR'AN]}

\section{From On the Fundamentals of Jurisprudence}

It is not permissible to translate the Qur'an into Persian or other languages. Rather, it must be read in its original-inimitable-form because any translation will be lacking, and because any other language will fall short of the clarity and elegance that it — and no other language - possesses. For God Almighty has said that the Qur'an is "in a clear, Arabic tongue" (alShu'ara' 26: 195). This would have been the case even had the challenge to produce something like it in composition and style not been issued. Still, since it is not permissible to recite it in an explanatory Arabic paraphrase that is the subject of the challenge, then it is fitting that translating it into some other language be equally impermissible. ${ }^{1}$ Thus, in al-Qaffal's legal ruling, he said, "It is my position that no one may recite the Qur'an in Persian." Some responded, "Then no one may paraphrase the Qur'an." He said, 
No, because in the case of an explanatory paraphrase, it is permissible for a person to convey some of what God intended to be conveyed and leave out some, but if that person intended to recite it in Persian, ${ }^{2}$ then he would not be able to convey everything that God intended to be conveyed.

Others have distinguished between translation [tarjama] and paraphrase, saying, "It is permissible to paraphrase something from one language in another because paraphrase conveys ideas that are necessarily present in the mind."

Translation is substituting one word or expression for another that can take its place in making a certain idea understandable to an attentive listener. It is as if translation conveys what a listener paying attention to the words would understand, whereas paraphrase shows the listener what the translator understands - this is a good way of distinguishing them. So what al-Qaffal conveys regarding reciting the Qur'an in Persian translation is also the same

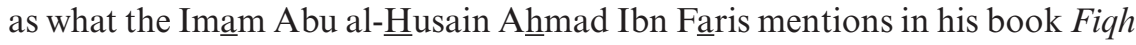
al-'Arabiya [The Science of Arabic].

Al-Qaffal goes on to say:

No translator may translate the Qur'an into another language, as the Gospels were translated from Syriac into Abyssinian languages and Greek, or as the Torah and the Psalms and the other books of God Almighty were translated into Arabic. For non-Arabs did not have the surpassing expressive capacity of the Arabs. What if you wanted to translate the speech of God (the Mighty and Majestic), "And if thou fearest treachery any way at the hands of a people, dissolve it with them equally" (Al-Anfal 8: 58)? Don you not see that you would not be able to convey the true import of the ideas without undoing their interconnectedness, destroying the way they are composed together, and making obvious that which they hold back? You would have to say, "If there were a truce or treaty between you and another people, and they began to take it less seriously, violating it and betraying you, then inform them that those conditions to which you had agreed are now void, and that you are now at war with them, so that both you and they are equally aware that the treaty has been nullified." The case of God's saying: "Then We smote their ears many years in the Cave" (Al-Kahf 18: 11) would be similar.

From all this, it becomes clear that the dissenting opinion transmitted of Abu Hanifa - that reciting the Qur'an in Persian is permissible - cannot be acceptable, since it is inconceivable. It has also been verified that Abu Hanifa changed his position on this matter, as transmitted by 'Abd al-'Aziz [alBukhari] [...] Even those of his followers who are not aware of this retraction say that by this he meant only when it is necessary, and when one cannot recite it in Arabic; when this is not the case, it is prohibited, and whoever does it is considered a heretic. 


\section{From On the Rules of Jurisprudence}

Regarding translation from Arabic into another language, there are several types of cases. First, there are those in which it is absolutely forbidden to substitute one of the languages for the other, both for one with the ability to read or recite it in the original and for one without that ability. This is what is meant by the word "inimitability" (' $i$ ' $\underline{j} \underline{z}$ ), and it refers to the Qur'an, which consensus has established may not be translated into another language. As for what Abu Hanifa-may God have mercy on him-reportedly said about the permissibility of reciting the Qur'an in Persian, it is known from reliable sources that he retracted it. Other cases in this first category include supplications improvised during prayer in a language other than Arabic; doing so is absolutely forbidden, according to Imam al-Shafi'i.

The second category comprises those cases when it is absolutely permissible for both, one with the ability and one without it, like sale, divorce (whether initiated by the husband or the wife), and so forth. Yes, scholars have disagreed about the status when a husband utters the oath of divorce in a language other than Arabic - does this qualify as a direct, explicit divorce? - but the most correct response is yes.

The third type comprises those cases in which it is absolutely forbidden (in its most correct form) for one with Arabic abilities, but not one without them, to perform the act [in another language]: for example, reciting the call to prayer, or pronouncing God's greatness to initiate prayer. Saying the testimony of faith in a language other than Arabic is also considered correct for someone who does not speak Arabic well, but not for one who does, because it relies upon the idea of devoted worship. The same is true of standard recommended appeals for God and traditional supplications that are said during prayer, as well as the salutation "peace be upon you," preaching, and Friday prayers - to be considered most correct, they must be performed in Arabic. Thus, if no one present has strong Arabic, then the sermon may be given in another language - but each person present should subsequently undertake to learn to preach in Arabic. The same applies to one who cannot perform the pronouncement of God's greatness in Arabic.

The fourth type comprises those cases in which both one with Arabic abilities and one without them may perform an act in the "most correct" way: for example, uttering the wedding vow, the words of return to one's divorced wife, accusation of adultery against one's spouse, or declaration of conversion to Islam [...] Along these lines, we have determined that the marriage oath will be considered correct as long as each party understands what the other is saying - in fact, one need not understand the other's words if a reliable interpreter is present to convey their meanings.

Ultimately, there are two sides to the acceptability [of translation]. The criteria are as follows: When both the meaning and utterance are intended, then [using another language] is forbidden for all people in the case of $i^{\prime} j \underline{j} z$; otherwise, it is forbidden only for those who know Arabic (as in supplications). 
But when the meaning, rather than the utterance, is intended, then [using another language] is permissible.

\section{From On the Sciences of the Qur'an}

A chapter on the categories of Qur'anic sciences.

Category 17: Arabized Words in the Qur'an:

Recognizing what it contains that does not come

from the language of the Arabs

Know that God revealed the Qur'an in the language of the Arabs, and it is only permissible to recite it [in a religious context] in that language; as God Almighty has said, "We have sent it down as an Arabic Qur'an" (Yusuf 12: 2). Furthermore, when He says, "If We had made it a non-Arabic Koran" (Fussilat 41: 44), this indicates that there is nothing in it that is not Arabic, for God Almighty caused it to be a miracle of linguistic inimitability that would be witness to His Prophet - peace be upon Him - and function as a definitive sign of his truthfulness, one that would challenge even the poets and the most eloquent of the Arabs to try to produce something like it, and ultimately to recognize the signs of its wondrousness. Thus, its containing language that was not Arabic would be of no benefit. This was the position of al-Shafi' $i$ - may God be pleased with him - and also the position of the majority of scholars [...]

In the fifth chapter on the science of Qur'anic eloquence and clarity in his Epistle [al-Risala], al-Shafi'i said the following on this topic:

Some have spoken about this science who should have abstained from saying as much as they did; for had they done so, their abstention would, in fact, have been more in keeping with its tenets. One such person has said, "In the Qur'an, there is language that is Arabic, and there is language that is not Arabic," even though the Qur'an clearly indicates that there is nothing in God's Book that is not in the tongue of the Arabs [...].

Thus said al-Shafici.

Ibn Faris reported that Abu 'Ubayda said: "The Qur'an was undeniably revealed in clear Arabic, so whoever has claimed that there are instances of languages other than Arabic in it - such as the Nabatean languagehas spoken presumptuously." He said, "The meaning here is of great consequence: if there was something in the Qur'an that was not in the Arabic language, then one might mistakenly believe that the Arabs were unable to produce anything like it because it contained languages they did not know-a very problematic claim indeed. This being the case [that the Qur'an only has Arabic words], there is no grounds for considering recitation of the Qur'an in Persian to be permissible in prayer, for this translation would lack $i^{\prime} j \underline{a} z$. If this were permissible, then it would be permissible to pray simply by reading from books of exegesis, which is something no one would argue to be the 
case" [...] For their part, Ibn 'Abbass, 'Ikrima, and others took the position that the Qur'an contained words that were not part of their language, among them "al-tur" "the name of the eponymous sura], the word for "mountain" in Syriac, and "tafiqa" (al-A'raf 7: 22), which means "began to" or "set off to" in Greek [...]

Al-Zamakhshari preferred the interpretation that the words "al-tawra" [The Torah] and "al-injill" [The Gospels] (시 'Imran 3: 3) are non-Arabic, favoring the reading of the latter as "anjill." But others disagreed; as al-Tabari said,

These examples are attributed to many different languages, but they actually demonstrate how languages can happen to have some identical words. Thus, the Arabs, Persians, and Abyssinians all express each of these things with a single shared expression, as Ibn Faris reported of Abu 'Ubayd.

Ibn 'Atiya said: "Even the pure language of the Arabs, in which the Qur'an was revealed, had mixed somewhat with other languages [before Islam] through trade and through the two commercial travels of the tribe of Quraish [annually to Syria in summer and Yemen in winter] [...] By means of their travels, the Arabs acquired foreign words, some of which they altered to make fit the Arabic alphabet or to lighten cumbersome foreign sounds. Then they used these words in their poetry or conversation until they became part of proper and eloquent Arabic, and thus were contained in the Qur'an when it was revealed. Hence, if an Arab did not know them, it was because he was so pure of language that he did not know any words that originated with other tribes or peoples [...] Ibn 'Atiya said: "The truth of the matter regarding these words is that they were originally foreign, but the Arabs employed them and Arabized them, and in that sense, they are Arabic." He went on: "What al-Tabari opined about two languages' coincidentally sharing a word is farfetched; most of the time, one of the two is the original and the other derived from it. We only find such coincidences plausible in very rare cases."

The jurist Abu al-Ma'ali ’Aziz Ibn 'Abd al-Malik said:

These words were found in the Arabs' speech, for it was the most capacious of all languages and the one containing the most words. It may be that others preceded the Arabs in using these words, for the Prophet (PBUH) was sent to speak to all mankind; as God Almighty has said, 'And We have sent no Messenger save with the tongue of his people' (Ibrahim 14: 4)

Ibn Faris reported that Abu 'Ubaid al-Qạsim Ibn Salam transmitted a disagreement about these words, attributing to the jurists the view that they are not Arabic and to the linguists the view that they are. Abu 'Ubaid went on to say, 
The position that I believe to be correct condones both of these views: these arrangements of letters were originally foreign, as the jurists say, but they came to the Arabs, who Arabized them and altered their foreign soundsand so they became Arabic. By the time the Qur'an was revealed, these arrangements of letters had already been mixed into the Arabs' speech. Thus, whoever says that they are Arabic is telling the truth, and whoever says that they are foreign is also telling the truth $[\ldots]$

From this, it becomes evident that this dispute over the permissibility of reciting the Qur'an in Persian is not real, for it is inconceivable. In the works of several later major scholars, I have found the statement that the impermissibility of translation is specific to the context of recitation accompanied by reflection, and that as for translating the Qur'an for practical daily purposes, this is possible if it is necessary. What is meant is that the one doing so should restrict himself to elucidating straightforward verses with decisive meanings and explaining unique ideas - only to the degree necessary for someone to assert the oneness of God, for instance, or expound the pillars of worship. But otherwise, it is not to be done; rather, anyone who wishes to do more than this is instructed to learn the Arabic language. Therefore, when God's Prophet - peace be upon Him — wrote to the Byzantine emperor, he included only one clear Qur'anic verse with one decisive meaning, which was the oneness of God and the repudiation of idolatry. This was because translation fails to render something in one language fully in another, as previously discussed. Still, since what is to be translated had just one meaning, it was possible to minimize the translation's shortcomings. This would not have been the case for a verse with multiple meanings. Thus, the Prophet (PBUH) did what was necessary in order to communicate, or else he chose this verse because its rough meaning was echoed in the Byzantines' own holy books, even if they did not act in accordance with it.

In his exegesis on the Qur'anic sura al-Dukhkhan, al-Kawashi said:

Abu Hanifa permitted the recitation of the Qur'an in Persian under one condition, and this was that the reader convey each and every one of the ideas contained in it, without omitting anything at all. And others have said, 'This condition bears witness to the fact that he is permitting something in a way that actually does not permit it because the speech of the Arabs - and especially the Qur'an because it is miraculously inimitable - contains myriad subtle ideas and eloquent modes of expression that no other language, Persian or otherwise, can convey'.

But al-Zamakhshari said: "Abu Hanifa's Persian was not strong, so his argument here was not truly based on rigorous examination or deep reflection.

\section{Translated by Betty Rosen}




\section{COMMENTARY}

\section{On the Fundamentals of Jurisprudence}

Unlike many of his contemporaries who wrote on the topic, al-Zarkashi bases his discussion of the translation of religious terms on a systematic definition of translation: "substituting an utterance for another that can take its place in in the understanding of an attentive listener." In this way, translation encompasses, but it is not limited to, semantic equivalence. Especially in contrast with paraphrase in another language (which is based only on the meaning), it depends on the listener's attentiveness to utterances through which his understanding is realized. Meaning and utterance are thus an inseparable unity - a common theme in traditional theological views of the Qur'an and its translation.

However, al-Zarkashi's incorporation of the receiver's understanding introduces a potential hermeneutic element into the discussion. In a different context, it may be possible to argue that this expanded definition opens up the horizon of the translator beyond the strict linguistic and stylistic aspects of the text. Translation, then, becomes a creative activity, informed by the translator's agency and individual reading. This, however, is not al-Zarkashi's intention. In fact, the recognition of the individual influence of the translator only introduces a new barrier to translation. To the differences between the languages and the unique meaning-utterance symbiosis in each is added the uncertainty of human intervention, which cannot be trusted in dealing with a divine text.

As a result, translation for al-Zarkashi has the same status as paraphrase, that is to say it cannot be treated as a sacred text, since it is impossible to preserve the original unchanged. This was the general consensus of Classical theologians, who allowed the translation only of the meaning of the Qur'an, as long the translation is not treated as a sacred text in itself.

\section{On the Rules of Jurisprudence}

In On the Rules of Jurisprudence, al-Zarkashi discusses the translation of a variety of religious texts from Arabic, including the Qur'an and other Islamic texts. He identifies different cases that call for different methods of translation, whose permissibility is determined, above all, by the receivers' competence in the source language. In other words, translation remains an ersatz, if necessary, measure, allowed when the ideal, and only fully satisfactory, procedure of directly reading the source is impossible.

As in the previous text, it is established that permissibility, or lack thereof, concerns the substitution of the source text with one that serves the same purpose, not textual transmission as such. Otherwise, translation is again acceptable for comprehension and exegesis, as al-Zarkashi acknowledges in Fundamentals of Jurisprudence. But translation can never attain complete 
equivalence, which alone can be acceptable in rendering Islamic texts, as preserving the indispensable unity of meaning and utterance. If some measure of equivalence is possible in translating these terms, it is only an exception for those who do not know Arabic. But there are cases when no equivalence should ever be attempted, even for those who do not know Arabic. Specifically when the Qur'an is concerned, treating the target text as fully equivalent to the original (and thus serving the same function) is tantamount to heresy. Otherwise, judgments vary according to one's knowledge of Arabic, how sacred the text in question is, and its relevance to the practical pursuits of daily life.

The most problematic category seems to be the third, where translated texts are permitted for those who do not speak Arabic, but forbidden for those who do. Does al-Zarkashi's reference to those who do not know Arabic encompass only clerics conducting a ceremony or everyone involved? In other words, does a cleric have to use Arabic even if he is the only one, or among a small minority, who knows Arabic? This seems to be the drift of al-Zarkashi's argument; otherwise, using other languages would be allowed practically in all non-Arab communities, where only a minority would know Arabic, which is certainly not his purpose. So one can only wonder at the practical difficulties involved in requiring Arabic in such essential transactions as the Friday sermon and the call to prayer in a setting where most speakers do not know the language. What is the practical point, one may ask, for the imam to read an entire sermon in Arabic for an audience most of whom cannot understand it? Is it a satisfactory solution to have the speech delivered first in Arabic, then translate it into the congregation's language, as sometimes happens in non-Arab Muslim countries, or in Arab countries with large foreign Muslim communities? Or is it better simply to deliver the whole sermon in the community's language? These questions have been the subject of debates in several Muslim countries, with varying solutions proposed.

\section{On the sciences of the Qur'an}

Here, al-Zarkashi reviews various opinions regarding translating the Qur'an and judgments on its permissibility. He briefly summarizes the legal opinions of a number of jurists and judges, as well as the main issues they raise and the subsequent opinions that have been advanced in response to them. The general consensus is that translations cannot replace or be substituted for the original due to the impossibility of complete equivalence. For the translation will deviate from the form "that gives rise to the original's miraculous inimitability," which consists, as al-Zarkashi says in the other two texts, in the inextricability of form and content, or idea and expression. Likewise, alZarkashi insists that other languages "fall short of the clarity and elegance that Arabic possesses," although he does not specify whether this is due to qualities intrinsic to Arabic itself, as Ibn Faris, whom he quotes here, says, or to languages differences in general. Still, translation to him is confined to 
the elucidation of the most basic principles of faith, while those who aspire to do any more than this - to engage in full exegesis and interpretation of the Qur'an, as the basis for legal rulings- have to learn Arabic to read the original text directly.

Finally, it is worthwhile to examine at some depth an opinion by Abu Hanifa which was cited, if only to be refuted, in almost all debates on Qur'anic translation, undoubtedly due to his status as the founder of one of the four major schools of Sunni jurisprudence. Abu Hanifa, it was reported, had permitted the recital of prayer in Persian in all cases without any restrictions, an opinion which most scholars rejected, and the authority of which was disputed for several reasons. In the most common account, Abu Hanifa retracted from this position. Others have claimed that his permission was given on the ostensibly impossible condition that meanings be conveyed in full without any omissions. For, according to what had become a prevalent orthodoxy, Arabic, especially that of the Qur'an, "is miraculously inimitablecontains myriad subtle ideas and eloquent modes of expression that no other language, Persian or otherwise, can convey."

Others conceded that Abu Hanifa did make this judgement, but dismiss

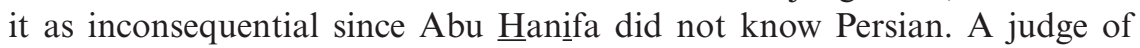
translation, it is argued, should master the two languages in question. This objection is certainly not without merit. But one cannot help noticing that most (if not all) those who asserted that foreign languages are no match for Arabic in translation do not seem to have known other languages themselves. One illustrative example is Ibn Sinan al-Khafaji (cited in al-Shatibi), who candidly admits that he does not know a language other than Arabic, and that his conclusions about the superiority of Arabic were based on "conjecture and intuition" (51).

\section{Tarek Shamma}

\section{Notes}

1 The Qur'an challenged human beings to write something like it (equaling its eloquence and rhetorical perfection) in Arabic. It is assumed that the challenge is impossible to meet, hence the inimitability ( $i^{\prime} j \underline{j} z$ ) of the Qur'an.

2 i.e. as a sacred text, especially in prayer. 


\title{
22 Ibn Khaldun's Journey (1406) 'Abd al-Rahman Ibn Khaldun
}

\begin{abstract}
'Abd al-Raḥman Ibn Khaldụn (1332-1406)
A major Arab historian and sociologist. He was born in Tunisia, and studied at al-Qarawiyyin, sometimes considered the oldest ongoing university in the world, ${ }^{1}$ but lived all over the Arabic-speaking world of his time. After serving at state chanceries in the North Africa and al-Andalus, he settled in Egypt, where he was appointed judge of the Maliki school of jurisprudence. His best-known work is the introduction to his universal history, known simply as al-Muqaddima (The Introduction), considered an early foundational work in sociology and the philosophy of history.
\end{abstract}

\section{Al-Ta'rif bi Ibn Khaldun wa Rihlatuh Sharqan wa Gharban (Introducing Ibn Khaldun and his Journey East and West)}

In this book, Ibn Khaldun relates his family background and upbringing, then discusses how he carried out his quest for knowledge throughout the Islamic world. In the following section, he recounts the details of his meeting with the Moghul conqueror Timur when his armies were besieging Damascus. Ibn Khaldun was asked by the people of the city to act as intermediary.

\section{[IBN KHALDUNN: A TRANSLATOR OF CULTURES]}

[During Timur's siege of Damascus, $1400 \mathrm{CE}$ ]

In the early evening, I went to the Court and requested that I may go out or look over the wall as soon as I was able. At first, they refused my request, then they relented and showed me to the wall. At the gate was the entourage of Timur and the Deputy who Timur had designated in charge of Damascus. His name was Shah Malik and of the Beni Jaqtai tribe. I greeted them, and they 
returned the greeting. I bowed, and they bowed in return. Shah Malik offered me a horse and sent someone from the entourage of the Sultan to fetch it for me. Whilst I was standing at the gate, permission from the Sultan was granted for me to sit at the tent positioned at the site of where he was seated. When it was made known that I was the Maghrebi Maliki Judge, I was invited to enter the tent where he was sat $[\ldots]$

He called from his entourage the jurisprudent 'Abd al-Jabbar Ibn alNu'man, an expert in the Hanafi legal school in Khwarazm to sit down and translate what would be said between us. He asked from whence I had come in al-Maghreb and why I came here. I said:

I have come from my country in order to fulfill the religious duty [of pilgrimage to Mecca]. I set out to travel by sea and docked in the port of Alexandria on the first day of Eid in the [Hijri] year of 784 [1382 CE], where the pageantries on the walls celebrating the ascension of al-Dhahir $[\text { Barquq }]^{2}$ to the throne had been held for the past ten days.

He said to me: "How did he treat you?" I replied:

Very well. He welcomed me, granted me hospitality, attended to all my needs and provided me for the pilgrimage journey. When I returned [to Egypt], he granted me a stipend, so I resided where I did in his kind auspices, may God grant him His rewards and blessings [...]

He asked me: "Where is your son?" I said: "In al-Maghreb al-Juwwani, serving as a secretary to the great king there." He asked: "What is 'al-Juwwani' in the context of al-Maghreb?" I said, for those who speak their language, it means 'inner,' that is the far-out areas, as all of al-Maghreb is on the coast of the Syrian [i.e., Mediterranean] Sea from the south [...] the farthest from here being Fez and Marrakech, and that's what "al-Juwwani" means.

[Ibn Khaldun proceeds to describe different parts of al-Maghreb, based on Timur's request]

He then stated: "I am not satisfied with this. I would like you to write me about the whole of the Maghreb land, from its most remote to the closest of points, with all of its mountains, rivers, villages and cities, so that it would be as if I saw it." I then replied: "I will gladly do so this with your good-pleasure." I penned the most important points after I took leave of the sitting. I inserted what I could of a very simple schematic into 12 small folded brochures" $[\ldots]$

I then returned to my house in the town after requesting from him permission to do so. I stayed in a corner of my house, working on what was requested: a description of al-Maghreb. In the course of a few days, I penned and displayed it to him. He took it from me and commanded it to be translated into the Mongolian language.

\section{Translated by Ruth Abou Rached}




\section{COMMENTARY}

Ibn Khaldun's iconic al-Muqaddima (The Introduction) is considered one of the most important chronicles of history of the Islamic world for its detailed insights on the loci of commercial, scholarly and political influence. As noted by Mamdani (2017: 9), Ibn Khaldun seems to move between different languages, such as Greek and Arabic, and through different regions of the Mediterranean and Africa, with equally astonishing fluidity. His work communicates how regions within the Islamic Empire were conceptualized in ways which were politically defined but did not preclude either the likelihood of political, social and linguistic dynamics of change occurring, or the diversities of different peoples and their histories living within them. As explained by Ibn Khaldun, his work is divided into three parts: the first is historical-political in that it works to "unveil the situations of current generations by unveiling those of the past"; the second aims to impart to Arabs knowledge of peoples such as "the Nabateans, Syriacs, Persians, Israelites, Copts, Greek, Turk, and Frankish" (al-Muqaddima: 6); the third is to impart knowledge of the North African civilizations, such as the Berbers and Egyptians.

It is Ibn Khaldun's brief anecdote on translation which reveals important insights not only on the extent of cultural diversity that, as a scholar of famous al-Qarawiyyin University, he was uniquely exposed to, but his habitus (Bourdieu 1996) as a travelling scholar within the prevalent networks of patronage. So when he explains that he meets with Timur, the Sultan of the Moguls and Tatars, in Damascus, it becomes clear that the Sultan wants to glean from Ibn Khaldun detailed descriptions on North Africa, a geopolitical location known to him conceptually but impossible to imagine in his Levantine location. Not only is a high-level jurisprudence scholar, 'Abd al-Jabbar Ibn al-Nu'aman, summoned to mediate the language difference between the Sultan and Ibn Khaldun, but Ibn Khaldun is then requested to summarize his verbal descriptions in writing. Here we see 'Abd al-Jabbar's verbal interpreting or mediation of Ibn Khaldun's own act of cultural translation on his part: transmitting knowledge about and between different peoples and languages. In other words, Ibn Khaldun also is a "translator" in the eyes of the Sultan - but not in the linguistic sense. Ibn Khaldun transmits to him cultural and geopolitical knowledge of North Africa which he could not access otherwise and records them in writing. In this passage we can read Ibn Khaldun as a historian who made a record of this meeting to transmit his insights and knowledge on his travels in his own history book.

In effect, this episode highlights the role of translation as a dynamic and transformative conduit of knowledge, where individual interventions of translators really count within wider networks of power (Baker 2014). The interjectory questions by Timur, asking for further information on Ibn Khaldun's homeland, highlight the epistemological implications of the microactions of one translator being connective to his habitus: the questions resulted in expanding knowledge exchange. These interjections were significant enough for Ibn Khaldun to record in the chronicle. In this short passage alone, Ibn 
174 'Abd al-Rahman Ibn Khaldun

Khaldun thus offers insights on how the role of the translator, within an elevated habitus, could actively facilitate transmissions of knowledge within systems of political patronage made up of different languages during the Islamic Empire era.

\section{Ruth Abou Rached}

\section{Notes}

1 http://whc.unesco.org/en/list/170.

2 Mamluk sultan of Egypt (1382-1399). 


\title{
23 The Craft of Composition (1418) \\ Abu al-'Abbas al-Qalqashandi
}

\begin{abstract}
Abu al-'Abbas al-Qalqashandi (1355-1418)
A historian, littérateur, and clerk in the Mamluk bureaucracy. He was born in the village of Qalqashanda in Egypt, then moved to Alexandria, where he studied literature and Arabic grammar. Besides teaching and writing, he worked at the state chancellery of Sultan al-Dhahir Barququ, and continued until the end of his reign around in 1399. He died in Cairo. His most famous work is Sub $\underline{h}$ al-A'sha fi Sina'at al-Insha in 14 volumes.
\end{abstract}

\section{Subh al-A'sha fi Sina'at al-Insha (On the Craft of Composition)}

Al-Qalqashandi composed this comprehensive administrative encyclopedia for the clerks of the Egyptian Mamluk diwans. The book covers topics ranging from religious sciences and belles-lettres to geography, history, state administration, calligraphy, librarianship, and even codes and ciphers.

\section{[TRANSLATION IN THE MAMLUK CHANCELLERY]}

\section{(Part One)}

Second objective: explaining the foreign language knowledge required of a clerk

Know that the degree to which a clerk must learn foreign languages is dictated by his needs in communication and correspondence.

With regard to communication, foreign language knowledge is necessary when the ruler does not speak Arabic or favors a foreign language despite also knowing Arabic [...] Moreover, the ruler's army will follow his lead, adopting whatever language he favors. The clerk needs to know the language in which the ruler (as well as his army) speaks in order to best comprehend his intention. He must be able to understand the ruler's speech and make it understandable to those present, grasping quickly what is being said, 
conveying what ought to be conveyed, and demonstrating his own skill and competence in the language - for people are inclined to think favorably of someone who speaks to them in their own language, especially if that person is not of their ethnicity [...]

As for correspondence, foreign language knowledge is necessary for the clerk inasmuch as he must know the language of the official letters received by the ruler. This enables him to translate them for the ruler and reply to them in the language in which they were written, which makes an attractive impression on the heart and soul while shielding confidential information from the eyes of a translator. The command issued by the Prophet (PBUH) to Zaid Ibn Thabit, that he learn Syriac or Hebrew (as previously discussed), must inspire this prerequisite for clerks and spur them to fulfill it to the best of their abilities.

There are two types of foreign languages. The first are those that are written in one specific script, such as Persian, Greek, Frankish, and others. Each of these languages is written in a particular script. The second type are those that do not have a particular script in which they are written; these are the languages of peoples of nomadic nature, such as the Turkic people and people of the Sudan. ${ }^{1}$ Thus, the clerk should reply to missives from the Khans - the kings of the Turks in the northern regions, formerly known as the Horde of Berke and now called the Sultanate of Öz Beg - in the Mongolian language written in the Arabic script. Likewise, missives sent by the kings of Sudan are written in Arabic in the Arabic script. As for languages written in their own script, the clerk should respond to letters from them in their language and in that script. This is the case for those that arrive from the rulers of the Byzantines, the Franks, and other peoples like them - that is, those whose languages have their own distinctive scripts that differentiate them from other languages $[\ldots]$

\section{CATEGORY ONE-CORRESPONDENCE}

\section{(from Part One)}

$[\ldots]$

\section{Number seven: a clerk who maintains the chancellery's records and registers}

(Abu al-Fadl) al-Suri says: "Therefore, the clerk selected for this undertaking must be reliable, patient, and able to withstand fatigue."

He then went on: "There are several administrative duties within the chancellery that will be incumbent upon him [...]

Sixth: Indexing and cataloging all the translations-from Greek, Frankish, and other languages - of official correspondence received by the chancellery in languages other than Arabic, clearly indicating the main subject of each letter 
and the name of the translator, as previously discussed." Al-Suri said: "If these regulations are observed, then the clerk's affairs will remain in order, scarcely anything will be amiss, and every document requested from him will be available with the least possible effort and in the least amount of time" [...] [from Part Six]

\section{Second type: writing summaries and responding to reports from the royal Diwans}

I have already discussed the matters that ought to concern the head of the chancellery, and the fact that time is too limited for him to manage all of the correspondence that arrives in the kingdom, due to the sheer number of incoming letters, as well as the vastness of the realm. Thus, another clerk may be assigned to leaf through the newly arrived correspondence, then identify and summarize the main points. In his memorandum, Abu al-Fadl al-Suri says:

The normal procedure for this is that a clerk appointed by the head of the chancellery will receive all incoming messages. He will then extract the main ideas and write a synopsis on the back of each letter in which he summarizes many words in one-without sacrificing or distorting the meaning at all-but leaves out that which is extraneous, such as the opening supplication and the preface, as well as any repetitive language.

\section{Al-Suri then said:}

This clerk should also extract any information that falls under the treasury's purview from within the letter, writing this information down word for word on a sheet of paper on which he also notes which document it is from, that date on that document, and where it arrived from. These sheets he should pass on to the treasury, requesting that the person responsible for such tasks reply to whoever sent the dispatch. Then the clerk should present all this to the king, pointing out that which concerns him and then passing the letter on to him or someone else.

If the message is in a non-Arabic script-such as the Greek, Frankish, or Armenian-he should summon someone reliable who knows that script to translate it on the back of the document. Supposing this translator writes well in the Arabic script, he should write on the back of the original document something like:

So-and-so says: 'I came to the chancellery, where I was given this excerpt or the entire piece of correspondence written in such-and-such a script on the reverse of this page, and I was asked to explain what it said, and I said such-and-such'. 
Then he should recount what it said, concluding with: "And to all this I bear witness," and two witnesses should also testify that "this is what it said, no more and no less."

If the letter has writing on the two sides of the sheet, he should copy it in its original script and calligraphic style onto new sheets on the backs of which he should write the Arabic translation. But if he does not write well in Arabic, then he should do this in the presence of two witnesses-who can give their approval or disapproval, or change the text or cut it down-as well as swearing before them that it is accurate. After all, most of those who work as translators come from the same community as the original writer or share some affiliation with him, and therefore might be inclined to conceal things or change them. But he may be intimidated into maintaining fidelity with witnesses present to testify to what he has written, fearing that someone may read the letter differently from that to which he has sworn. Once the summaries have been written on the backs of the pages, the letter should be submitted to the appropriate chancellery official, so that he can compare what is written on the back and the front. If it is found to be flawed in any way, he may then add a note in his own handwriting, reproaching the translator for his carelessness and instructing him to be more mindful in the future.

If it is free of errors, he will present it to the king and do as he commands. This includes writing below each paragraph his response to it in the best possible phrasing. Then he should submit the letter to the one responsible for writing the response to it, after which he should compare this response to what was written after each paragraph, fixing any errors he finds and adding anything that has been left out. Once he sees that the response has been written in the best and most precise fashion possible - with not a single idea altered or a single word added unless it serves to elevate the prose and emphasize what is being said - he should present it the king for his inspection. Next, he should summon the person responsible for sealing the letter, who will seal it in his presence and place a card on it indicating its contents; otherwise, if someone were to inquire about it after it had been sealed, it would be impossible to know what it was. Finally, he should submit the letter to those responsible for dispatching it to the appropriate recipient. Furthermore, he should give the copies of the content summary to the one responsible for organizing and filing them $[\ldots]$

[from Part Eight]

\section{Fourth type: correspondence arriving from the Christian Kings in al-Andalus, the northern regions, and other territories in those parts}

These letters are usually written in the Frankish language, typically on rectangular Frankish paper about the same size as (or a bit smaller than) our paper, with close-set lines, and in the Frankish language and script. They are 
folded once, after which the address is written in the center, and then they are folded from both sides such that the address is left visible. Next, a thin strip of leather is attached, and the letter is sealed with a red wax seal, similar to that which appears on letters from the kings of the West [i.e., al-Maghreb]. When such a letter arrives at the royal gates, the seal is broken, and the document is translated by one of the translators stationed at the gates. He then writes out the Arabic on a single sheet of paper; this will be attached to the original piece of correspondence once the response to the Arabic version has been written, as I have previously discussed.

This is a copy of a missive that arrived from Doge Michele [Steno] of Venice, by means of his messenger Nicola the Venetian on the sixteenth day of the blessed month of $\underline{S} a f a r$, in the year 814 [1411 CE]. It was translated by Shams al-Din Sanqar and Saif al-Din Sudun, the two translators at the royal gates, on rectangular Frankish paper with close-set lines. It reads:

To the Great Sultan, the King of Kings, and the Victorious Ruler over the Islamic Lands, May God perpetuate His reign. Nicola, the Doge of Venice, ${ }^{2}$ kisses the ground before the Sultan and asks God to increase His greatness, for $\mathrm{He}$ is the aid and deliverer of truth and justice and the refuge of all the Islamic kingdoms. He sends his esteem and affection to Our Lord the Sultan and relays that even the greatest of the Frankish merchants remain humbly grateful for our lord the Sultan's justice and fairness and that they pray for the continuance of his kingdom. By his awesome nobility, and for the sake of the peace and friendship that exists between us, they wish to return again and again to His noble kingdom.

News has reached us of what happened last year: the blockade at the port of the divinely-preserved city of Damietta. It has also reached us that our lord the Sultan seized the Venetian consulate and detained some of our more highly-respected merchants at the port of the divinely preserved city of Alexandria, where he had them bound in chains and brought to Cairo [...]

Indeed, it is as if what was done to these people had been done to us, and we are astonished at it since our community has committed no offense. All this, despite the manifold justness which our lord the Sultan displays within his own kingdom; and despite our affection and esteem for Him, and our many proclamations - in all of our lands - of his justness and of his benevolence and hospitality toward our community; and despite the fact that we have instructed all our agents and deputies: "Honor all those you encounter who hail from the kingdom of our lord the Sultan, treating them with respect and deference. The Consul, the merchants, and the rest of the Venetians at the consulate are the ones responsible for treating them hospitably, looking after them, making them feel welcome, seeing to their affairs when a situation like this one arises and thwarting those who would create such a situation. All this, in order to set the 
merchants at ease, and ensure that they return time and again to your kingdom.

\section{Translated by Betty Rosen}

\section{COMMENTARY}

In Classical Arabic, the k $\underline{a} t i b$ (plural kutta $\underline{b}$ ) was a secretary whose functions included writing official correspondence and administrative documents of all kinds. A katib was thus an employee in administrative services, whose rank ranged from a mere "book-keeper" to a "chief clerk or a Secretary of State, directly responsible to the sovereign or his vizier" (Islam 1986: 754). Thus, the diwans, i.e., "offices" or "registers" where they worked, were responsible for conducting the various administrative functions of the state, parallel to modern "departments" or "ministries." Dịwan al-Insh $\underline{a}$ ' described here by al-Qalqashandi is equivalent in function to a chancery.

Translation clearly occupied an important and permanent position within the diwan, given an independent filing system whereby translated texts are archived, attached to their originals, following well-established protocols. Significantly, translators' names are also included, together with signed testimonies to the accuracy of the translation. Translation was an institutionalized and well-regulated profession in the departments of the Mamluk state, as also indicated by other documents from the same period, which was undoubtedly due to the wide range, and often complexity, of the Mamluks' international relations. In fact, translators and interpreters played such an important role in navigating diplomatic relations that some of them acquired considerable influence in the court and official quarters (see Treaties between Islamic States and Italian Cities, Chapter 17).

\section{Tarek Shamma}

\section{Notes}

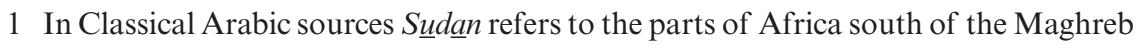
and Egypt (see, for example, Kaye 1986: 752).

2 This is obviously an error. Nicola is only the emissary. 


\title{
24 A Treatise on the Translation of the Qur'an (1542)
}

\author{
Muhammad Ibn Bilal
}

\section{Muhammad Ibn Bilal (1471-1550)}

A jurist and theologian. He was born in Aleppo, where he worked as an Islamic legislator and taught at the Great Mosque of Aleppo.

\section{Risala fi Tarjamat al-Qur'an (A Treatise on the Translation of the Qur'an: On al-Razi's Injunction against Prayer in Translation)}

This short treatise is a detailed response to the eminent scholar Fakhr alDin al-Razi's Mafatih al-Ghaib (Keys to the Knowledge of the Unseen), where he argued that it is not permissible to pray using translation into any other language, using Persian as an example. In support of his opinion, Al-Razi cited 15 arguments, to which Ibn Bilal provides a point-by-point rebuttal. His choice of this text undoubtedly stems from the detailed presentation and the status of its author. The extracts are taken from a manuscript at al-Azhar University library in Cairo, Egypt.

\section{[ON PRAYER IN TRANSLATION]}

This is a treatise on what al-Razi said in the fourth chapter of his "Great Exegesis" [...] that the translated Qur'an is not adequate for prayer.

Now this question deserves to be examined from several angles. My intention is to provide a commentary thereon in service of our lord and master, the great sultan and the honorable Khagan ${ }^{1}[. .$.$] submitted by my$

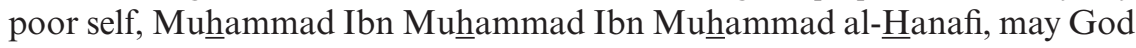
Almighty treat them (and all Muslims) with his constant kindness [...]

On this question, Imam al-Razzi said:

Imam al-Shafi' $i$ said that a translation of the Qur'an is not adequate for prayer, whether one can read Arabic or not. Abu Hanifa said that it is adequate equally for those capable or incapable of reading. Abu Yusuf 
[al-Ansari] and Muhammad [Ibn al- $\underline{H}$ asan al-Shaibani] said that it is adequate for those who are incapable, but not for those who are capable.

Now Abu Hanifa's position on this issue is very untenable, which is why the theologian Abu al-Laith al-Samarqandi and the judge Abu Zaid al-Dabusi stated that it could be disregarded.

We have several arguments to support our position on this question: ${ }^{2}$

The first argument: The Prophet (PBUH) conducted his prayer using the Qur'an that had been revealed from God in Arabic words, continuing in this fashion for his entire life. It is imperative, then, that we should follow his example.

Al-Razi's first argument is not convincing. For one should consider the opinions of some other scholars. In the debate on whether the Message was revealed to the Prophet in meaning or in utterance, some have adopted the latter, ${ }^{3}$ citing as evidence the Qur'anic verse "it is the speech of a noble Messenger" (al-Haqqa 69: 40) [...] But this is only a verbal disagreement [...] for "speech" can be used to refer to the sense of speech, as well as the letter of it. It is the sense of speech, rather than its letter, that is intended here, and what was revealed is in fact the sense, rather than the letter, of the divine message. Therefore, the judgment would depend on the meaning, not the utterance as al-Razi [May God Almighty have mercy on him] mistakenly believed [...]

In fact, if one were to pray in Persian, to the exclusion of Arabic (which has the priority over all other languages), then his prayer would be acceptable in Abu Hanifa's opinion. For it is the meaning, rather than the Arabic utterance, that is a condition for prayer. But even if we concede that the utterance is a condition for the prayer, then it will not be a necessary one, for prayer is acceptable through other means. At worst, this type of prayer would be undesirable. ${ }^{4}$ Undesirability does not preclude its acceptability; for every undesirable act is still permissible, but not the reverse [...]

The Fifth Argument: It is God's command for verses from the Qur'an to be recited in the prayer. As someone reciting in Persian would not be reciting the Qur'an, so he would not have fulfilled this obligation.

To elaborate: reciting the Qur'an is an obligation, as dictated by God's words: "recite of it so much as is feasible. [And perform the prayer]"5 [al-Muzammil 73: 20], as well as in the Prophet's injunction to a Bedouin: "[When you get up to pray ...] recite whatever you can from the Qur'an."

Now we hold that words in Persian cannot be considered as part of the Qur'an for several reasons:

1. God Almighty said:

"Truly it is the revelation of the Lord of all Being, brought down by the Faithful Spirit 
upon thy heart [Muhammad], that thou mayest be one of the warners, in a clear, Arabic tongue" (al-Shu'ara ${ }^{6}$ 26: 192-195).

2. God said: "And We have sent no Messenger save with the tongue of his people" (Ibrahin 14: 4).

3. He said: "If We had made it a non-Arabic Qur'an, they would have said, 'Why are its signs not distinguished? What, non-Arabic and Arabic?" (Fussilat 41: 44) [...]

This verse shows that God did not make the Qur'an non-Arabic. Consequently, whatever is non-Arabic is not part of the Qur'an."

4. He said: "If men and jinn banded together to produce the like of this Qur'an, they would never produce its like, not though they backed one another" (al-'Isra' 17: 88).

Now words in Persian can be said to be either exactly the same as the Arabic ones, like them, or neither. The first possibility is patently false. The second one is also false: if this Persian configuration of words is like the Arabic one, then what is stated in it would be the likeness of the Qur'an - which would belie God's statement that "they could not produce the like of it." Therefore, as it has become clear that words in Persian are neither the same as the Qur'an, nor like them, then it can be established that a recital of Persian in prayer is not a recital of the Qur'an-which is what was to be proved.

What he said in the Fifth Argument is not convincing either. If someone does not recite the Qur'an when commanded, this lack of compliance can be understood with regard either to the Qur'an as sense or the Qur'an as letter. In the first case, the reciter cannot be said to have fulfilled the obligation, since he has not recited the true Qur'an. In the second case, however, he can be said to have fulfilled the obligation, even if not in a perfect manner, nor in the one most in keeping with the Prophet's example [...] It is for this reason that Abu Hanifa (May God have mercy on him) considered reciting the Qur'an in Persian undesirable [...] In other words, his statement cannot be interpreted as an unlimited generalization, as it is wrong to generalize what is tied to a specific condition $[\ldots]$

As for the negation in his statement that "words in Persian cannot be considered as part of the Qur'an for several reasons," this is not convincing either. Each of these reasons demands further consideration:

1. These Qur'anic verses cannot be cited as proof in this connection. That the Prophet (PBUH) received the revelation in Arabic does not necessitate that what is configured in Persian is not Qur'an. For the Prophet's revelation is called Qur'an considering that it signifies the words of God Almighty as coming from His Holy Self. As this meaning is common to all languages, limiting this property to some Qur'anic languages in 
preference to others would be a classification under a wrong class, which is unanimously agreed to be erroneous.

2. The same as above. Only because every prophet is chosen as a messenger to his own people in their own language, it does not follow that what is configured in Persian is not Qur'an. For all these share the same rationale, and a common rationale necessitates a common ruling, as stated by the scholars of the principles of jurisprudence.

3. The same as above. Only because what is revealed to the Prophet (PBUH) is wholly Arabic, it does not follow that what is configured in Persian is not Qur'an, based on the same proof we cited above. A shared proof leads to a shared conclusion.

4. We can reject the second part of al-Razi's statement [that words in Persian are not like those in the Arabic Qur'an], not in all cases, but only considering the signification of these words (for one should not lie about the word of God). His argument would be sound if the likeness in question is intended for the purpose of $i$ j jaz ${ }^{6}$ which is not the case. The meaning of the Qur'anic verse is that they could not produce the like of it in $i^{\prime} \underline{j} \underline{a}$. However, the inability to produce similarity for $i^{\prime} j \underline{a} z$ does not entail the inability to produce similarity in the absolute.

\section{The twelfth argument}

A translation of the Opening Chapter of the Qur'an would not go beyond the following: "Praise God, caretaker of the universe, who is merciful on the needy, who controls the Day of Judgment. You are the One that we worship and the One we ask for help. Guide us to the path of the knowledgeable, not to the path of those who failed."'

If it is the case that the translation of this chapter would be limited to this much or something close to it, then it is a well-known fact that no sermon lacks the same. Consequently, one has to concede that a prayer would be correct by reciting any sermon. As this conclusion is absurd, it follows that the original claim is also absurd.

What he said in the twelfth argument is not convincing either. For the Opening Chapter can be translated in one of two ways: either by a primary method or by an auxiliary method, of which the first, but not the second, would be sufficient for a correct prayer. The translation found in sermons belongs to the second, not the first type, so it is not acceptable for prayer at all. It is certainly not the one under discussion, so the absurdity that he mentions cannot be deduced from it, as our discussion has shown. This argument would be valid if prayer with sermons were allowed, but this is not the case [...]

\section{The fifteenth argument}

As the Qur'an should be read for its meaning, so it should also be read for its utterance. This can be proved in two ways: 1. The Qur'an's i’jaz 
resides in its eloquence, which in turn resides in its utterance, 2. To make the recital of the utterance of the Qur'an a condition for acceptable prayer requires that these utterances be memorized, which memorization, when accomplished in abundance by multitudes of people, guarantees the preservation of the Qur'an free from distortion for eternity. Such is necessary to guarantee the fulfilment of God's promise that "It is We who have sent down the Remembrance, and We watch over it." [al-Hijr 15: 9]. Thus, to claim that the acceptability of the prayer is not dependent upon reciting the Arabic configuration of words subverts this intention [...]

What he said in his fifteenth argument is not convincing either. For there are two aspects to the Arabic Qur'an: that it should be recited for its meaning, and that it should be recited for its utterance. Now the first is particular to prayer, as no prayer is acceptable without the meaning. The second, on the other hand, is particular to challenge and refutation, ${ }^{8}$ which are both tied to $i^{\prime} \underline{j} \underline{a} z$. As $i$ ja $\underline{a} z$ resides in the utterance rather than the meaning, then the Qur'an, in this case, has to be recited in its utterance.

Accordingly, it can be shown that what he said in 1) and 2) is quite erroneous. For the second part, the matter is clear: The acceptability of the prayer is not dependent upon reciting the Qur'an in its utterance for the purpose of $i^{\prime} j \underline{j} z$. For $i^{\prime} j \underline{j} z$ is intended for challenge and refutation. But this is not the purpose of prayer, which is meant to seek the approval of God Almighty and to glorify Him in obedience of His orders. The second part of his argument is wrong for the same reason.

This is also the case regarding his statement that recital in another language "subverts this intention," etc. For the intention here is eloquence for the sake of $i^{\prime} \underline{j} \underline{a} z$, which is necessary for challenge and refutation, not the acceptability of the prayer. This is self-evident; to deny it is a form of stubbornness that should not be heeded.

In conclusion, it has been established that prayer in a language such as Persian is acceptable, albeit not without restrictions. It is so only undesirable. However, undesirability does not preclude permissibility, as affirmed in the beginning of this treatise.

\section{Translated by Tarek Shamma}

\section{COMMENTARY}

Ibn Bilal's treatise represents what can be called the dissenting opinion on translated prayer among Muslim jurists. He belongs to the small minority who maintained that prayer is permissible in languages other than Arabic, although he stresses more than once that this applies to cases of necessity, making it undesirable but not forbidden. Ibn Bilal is possibly the only scholar who dedicated an entire work to argue for this opinion using logical and legal arguments. His main authority is Abu Hanifa, the only one of the "Four 
Imams" (founders of the main legal schools of Sunni Islam) to have permitted prayer in Persian when Arabic in not possible. In fact, Abu Hanifa's reported opinion was something of an embarrassment for many later scholars, who usually cited it to refute it for several reasons, including the claim that he retracted from it, which is rejected by Ibn Bilal.

In his effort to refute the more popular opinion, Ibn Bilal examines several issues on the translation of the Qur'an, making some interesting distinctions. His discussion of the nature of Qur'anic translation is based on the meaningutterance dichotomy, which was central to the debates of $i^{\prime} j \underline{j} \underline{z}$ and the (im)possibility of its translation. While he recognizes the inextricability of meaning and utterance as evidence of the Qur'an's inimitability, he objects that prayer only requires the meaning, since its purpose is spiritual fulfilment. The utterance, on the other hand, is tied to the meaning only in $i^{\prime} j \underline{j} z$, where it is necessary for the purpose of "challenge and refutation," but not the correctness of the prayer.

Consequently, Ibn Bilal concludes that "sameness" is not impossible as such, as maintained by those who reject the translation of the Qur'an. For he argues for a limited type of equivalence that accommodates only the meaning, to be distinguished from the (impossible) full equivalence of $i^{\prime} j \underline{j} \underline{z}$, which holds only in Arabic. With this division of equivalence into two levels, one of which could be sufficient depending on the conditions and purpose of communication, Ibn Bilal deviates from scholars who saw equivalence on the single level of complete sameness, which is doomed to impossibility.

Nevertheless, while Ibn Bilal advocates a form of meaning preservation as acceptable for prayer, he proposes some constraints that would keep it within the realm of translation proper, as opposed to paraphrase or adaptation. We can see this in his response to the twelfth argument. Al-Razi has found meaning translation inadequate, reasoning that, when rendered in the other languages, Qur'anic verses would not go beyond the basic senses which may be found in any text of religious nature. As a result, the language of prayer would lose its distinctive character. In response, Ibn Bilal distinguishes two types of translation, conducted by a "primary" or an "auxiliary" method. The first, as can be ascertained from the context, is a direct form of translation, where the meanings are rendered into the second language from the text of the Qur'an. In the latter, indirect type, these meanings are mediated through a secondary source that quotes words, phrases, or passages in ways that deviate from the original; these would be Qur'anic terms and paraphrased statements used in a sermon, for example, as opposed to direct quotations. What we have, in other words, is the difference between a method that takes meaning as the unit of translation, but still maintains the basic features of the original, and another where the original "configuration" of the text, to use al-Hanafi's term, is practically indistinguishable, as only the basic ideas are retained.

\section{Tarek Shamma}




\section{Notes}

1 Most likely the Ottoman sultan Suleiman I (r. 1520-1566).

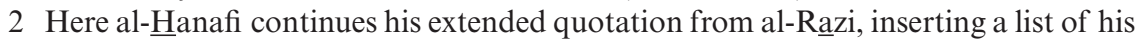
fifteen arguments, to which he responds with a list of 15 correspondingly numbered rebuttals in the following section. We have found it more convenient to attach Ibn Bilal's responses to al-Razi's arguments one by one without making any other changes to the text.

3 The original has the "former," which is almost certainly an error.

4 Islamic law divides actions in terms of their permissibility into five categories: obligatory (wajib), desirable (mustahab), permissible (mub $\underline{a h})$, undesirable (makr $\underline{u} h)$, and forbidden (ma $\underline{h} d h \underline{u} r)$.

5 As writers of these highly specialized texts could rely on their readers' full knowledge of the Qur'an and Hadith, they often abbreviated their citations, leaving implicit key aspects of their significance. In some of these cases, we have found it useful to provide some of the larger context of the citations.

6 In Islamic theology the miraculous nature of the Qur'an, reflected, among other things, in its "inimitability," i.e. the impossibility of producing its likeness, as seen in some of the verses cited by al-Razi, which challenge the enemies of Islam to produce its likeness.

7 Al-Razi here provides a loose rewording of the Qur'anic chapter. His point is that any version in another language would be limited to a paraphrase of the basic meanings, leaving out the distinctive Qur'anic style (reflected in its rhythm, rhymes, and figures of speech) and the unique Qur'anic terms with their associations and connotations.

8 The Qur'an challenged humans to emulate it. 


\title{
25 Translation of Ulugh Beg's Astronomical Tables (c. 1543)
}

\author{
Yahia Ibn 'Ali al-Rifá $i$
}

We have very little information about the writer of the introduction, who translated this work from Persian, except that his full name is Yahia Ibn 'Ali al-Za'ami al-Rifa'i al-Shafi'i. The attribution to the Shafi'i school of Islamic law may indicate a judge or a jurist. The translation was commissioned by Shams al-Din Muhammad Ibn Abu al-Fath al-sufi, a mathematician and astronomer who died in 1543. His surviving works include astronomical works on the moon, as well as a zij (a book of astronomical tables) in his own name.

Attached to this work is another manuscript which starts on page 43, and contains a translation of another part of this $z i j$ (dated around 1607) by Hasan Ibn Muhammad al-Fasihi al-Nidhami, an astronomer known as Qạdi [i.e., Judge] Hasan. The last section of the manuscript was written by yet another person who completed the sixth part of the original, left untranslated

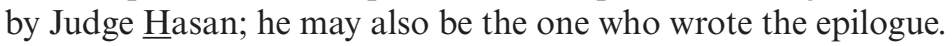

The excerpts below are taken from a manuscript at the Egyptian National Library and Archives in Cairo, using the digital version at the World Digital Library. ${ }^{1}$ The title page bears the seals of previous owners, including one 'Uthman al-Finawi, a judge from Cairo, and Muhammad'Ali Pasha, governor of Egypt (1805-1848).

\section{[SCIENTIFIC TRANSLATION AFTER THE “GOLDEN AGE”]}

These are the astronomical tables of the fortunate Sultan, the $\operatorname{martyr}^{2}[\ldots]$ Ulugh Beg Khan Ibn Shahrukh Ibn Taimur Gurkan, of Samarkand, Hanafi by jurisprudence school. May he rest in peace. Amen.

God will surely reward him for how scholars are benefiting from his work. These tables will benefit him and his fellow scholars in this field who do not have them.

\section{In the Name of God, the Beneficent, the Merciful}

Nothing is easy, save what You have made it so. 
This poor servant of God, Yahia Ibn 'Ali al-Rifạ'i al-Shafi'i, says:

Our shaikh and teacher, the learned scholar, the accomplished polymath, the Sibawaih ${ }^{3}$ of his age, the Ptolemy of his contemporaries, now the imam of the scholars of his time, the expositor of the geometric, arithmetic, and other sciences, our master shaikh, the sun of religious and worldly disciplines, Shams al-Din Abi al-Fath al-Súfi [...]

Having, by his kind offices, brought forth from his precious treasures the astronomical tables of the Sultan, son and grandson of sultans, the fortunate, the martyred, Ulugh Beg, may God favor him with His mercy and satisfaction, which were written in Persian, he presented the tables to my humble self, whereupon I translated them from Persian into Arabic, abiding by what the author said without any addition or verbosity, as much as it was possible.

I modestly hope that the worthy reader will regard what we have said with satisfaction, and will mend any oversights or mistakes of my pen he may find therein. For I cannot but confess to my imperfections and failings.

I beseech God for inspiration to guide us to the right path, and to benefit seekers of knowledge with this book. He is all-powerful and all-hearing [...]

[From the epilog]

This concludes the Samarkandi astronomical tables with the help and grace of God [...]

[From the second manuscript]

\section{In the Name of God, the Beneficent, the Merciful}

Here we copy the translation of the sixth chapter from another manuscript, as Judge Hasan did not translate it [...]

[From the epilog]

This concludes the book of New Astronomical Tables by the fortunate king Mirza Ulugh Beg, the martyred, may God bless his secret and place him in the highest rank of paradise. May God reward him generously on our behalf, and may he on the Day of Judgment be summoned among the best people of early and later generations.

This book has been fully translated into Arabic, conveyed in the most eloquent high idiom, with no omissions or alterations, additions or abridgements. We have preserved the meanings of the original, and avoided anything that deviates from it.

The translation was conducted by [...] our shaikh and master Judge Hasan Ibn Muhammad al-Fasihi al-Nizami, known as "Judge Hasan." By the intersession of Muhammad and his family May God reward him and shower him with his blessings [...]

This copy, based on the manuscript of the translator (May he rest in peace), was completed on blessed Friday, 28 Rajab, 1126 Hijra [July 30, 1714]. 


\section{COMMENTARY}

A $z i j$ is an astronomical handbook with tables used to calculate the positions of the stars and planets. An indispensable tool for astronomers, it "constitutes a major part of the history of Islamic astronomy" (King and Samsó 1986: 496). The $z i j$ in question was prepared in Persian by Ulugh Beg (1394-1449).

A notable feature of these translations is their late date, completed in the fifteenth, sixteenth and the early seventeenth century respectively-a long time after the end of the flourishing of translation in the early Abbasid age. Therefore, it seems that scientific translation did not fully come to an end in later periods. Astronomy perhaps continued to command attention due to its practical uses and, especially, the importance of zijs in building the calendar. According to the introduction, the first translation was commissioned by the astronomer Shams al-Din al-Misri (d. 1543), who used the tables to study the geographical coordinates of Cairo. Furthermore, the surviving manuscript, having been completed in 1741, was in demand for a long time afterward, as indicated by the names of the several owners, up to the nineteenth century. Still, the question of translation in later stages warrants further research.

Retranslation was not an uncommon practice in the past "golden" age of translation. Its main purpose then was the improvement of the first translations, either with corrections and revisions through comparison with the source text or by refining and polishing the style of the target text (see Hunain Ibn Ishaq, Chapter 3, and Ibn Abi Us aibi'a, Chapter 16). Yet, there is no professed reason for retranslation in this case, especially that the second version does not have paratextual material that usually provides this kind of information.

In terms of translation methods, both versions show keen concern with accuracy and faithfulness to the original, as would be expected in technical translation. This primary goal is emphasized in the introduction and epilog, with the latter adding the secondary consideration of eloquence.

\section{Tarek Shamma}

\section{Notes}

1 www.wdl.org

2 Ulugh Beg (r. 1447-1449), was a Timurid Sultan, as well as an accomplished astronomer. He was deposed by his son and assassinated upon his orders in 1449 .

3 An eminent linguist of the eighth century; one of the founders of Classical Arabic linguistics. 


\section{The Holy Scriptures in Arabic (1671)}

Sarkis al-Rizzi

\section{Sarkis Ibn Musa al-Rizzi (c. 1572-1638)}

Born in Baqufa (Mount Lebanon), he enrolled in the Maronite School of Rome in 1584. In 1600, he was ordained Bishop of Damascus for the Maronite community. In 1621, he moved to Rome, where he worked on scholarly projects at the service of the Papal institutions, including the printing of a Syriac grammar and the Arabic translation the Bible. He died in Rome.

\section{Al-Kutub al-Muqaddasa bi al-Lisan al-'Arabi (The Holy Scriptures in the Arabic Tongue)}

The work on the translation of the Holy Scriptures began at the initiative of al-Rizzi, who requested permission to do so from the Pope Urban VIII (1623-1644). The translation project was launched in 1625, conducted by a team of linguists and theologians under al-Rizzi's supervision. Work on the translation continued for several decades, during which al-Rizzi died in 1638. The completed translation was printed in three volumes in Rome in 1671.

\section{[THE FIRST MISSIONARY TRANSLATION OF THE BIBLE]}

\section{Introduction}

Praised be God, the creator of the heavens and the earth. To Him we extend our deepest gratitude and glorification, our thanks and veneration. For it is with His charity and His blessings over people that He sent down His noble words to His pure messengers and chosen prophets, as the perfect law for the truth of religion and a trusted guide to the straight faith.

Now when God Almighty, in His rightful providence and far-reaching judgment, suffered most nations to go astray from the path of justice, thus deviating into different forms of egregious error and corrupt, misguided ways, He nonetheless did not allow those books that hold His words, and are recognized by all people as containing the straight doctrine and the 
path toward salvation and bliss, to be completely lost in any community. If God had not sent down to His pure servants His words in the holy scriptures as a certain sign and truthful proof of the pure faith and the true religion, people would accept as religious signs power and good fortune; or the ornaments of physical attributes, good manners, and natural goodness; or the display of false signs and deceptive miracles with which devils make mockery of man.

These words sent down by God Almighty were first written by the prophets and messengers in their languages, each in the language of his own country or people. Then the words of God were translated into different languages, so that all nations would know what God had revealed for the salvation of them all. While the accepted copies contain word differences, such as local variants or multiple meanings in the original, in truth these words still have the same interpretation, and carry no contradiction to the truth. This is especially the case in this well-known version, commonly used by the One Holy Roman Apostolic Church, which agrees with the original text - that is to say the Greek and Hebrew - not only in meanings, but also in most words. All this notwithstanding, you may find lacks or corruptions in some copies of these books, be it among the Roman Catholics or other denominations, as a result of scribes' oversight or translators' want of diligence. Small deficiencies or minor mistakes may be found in the Hebrew and Greek originals as well. For there is hardly a book, no matter how complete and authentic, that is free from error or omission, but it would not be right for anyone, for this reason, to say that it is a completely unacceptable, corrupt book.

As for the copies of the Holy Scriptures, they are as numerous as languages and peoples. In ancient times, the Arabic version was also famous for its completeness of words and truthful meanings when the faith of Christ flourished in the regions of the East, and conditions had not yet fallen into confusion, following the deep schisms and heresies in those lands. ${ }^{1}$ However, when learning and faith went into decline, so did the said version, of which only few codices have remained, and even these suffering from numerous errors and deficiencies, caused by the dearth of scribes and scholars and the prevalence of dimness and ignorance.

It is this reason that moved the venerable Father, renowned for his piety and goodness, and recognized for his learning and wisdom, Sarkis the Maronite of the House of al-Riz [hence al-Rizzi], the Patriarch of Damascus, to serve and fulfill the needs his community to the best of his ability, concerning the wishes they had expressed to some eastern bishops and patriarchs to seek the permission of our lord Pope Urban VIII to mend the Arabic version and publish it in Great Rome for the benefit of their churches and congregations. The said Pope, having bestowed his consent to their request, appointed for this purpose the venerable preeminent lords, the cardinals at the head of the Holy College for the Propagation of Christian Faith [Pontificio Collegio Urbano de Propaganda Fide]. On their part, they entrusted Patriarch Sarkis, mentioned above, to assemble in his house a bevy of theological scholars-bishops, 
monks, and laymen - and teachers of Hebrew, Greek, Arabic, and other languages, so that he could mend the Arabic version with them.

They embarked on this task with great diligence in the year of our Lord 1625 , by the support and disposition of God Almighty. They selected what they found to be most correct, adequate, and consistent with the Hebrew and Greek sources. They supplied what was missing, mended what was corrupt, following the said source and the translation in common use by the Roman Church. Thus, to the best of their ability, they restored to the eminent Arab community, and other communities who use the Arabic language, the Holy Scriptures as they used to have them in ancient times. Surely, in this great enterprise, all effort and industry are too light and too little. This is why the Holy College ordered the Latin text to be published in this translation opposite the Arabic text, so that everyone will have a faithful law by which to recognize and correct whatever deficiencies or errors have remained in the Arabic, unbeknownst to the translators and revisers.

Now you should know, dear reader, that in this correction of ours we did not always follow the original word for word, but observed the practice of past translators. We often preserved the message alone, disregarding the number and order of words. When the difference of the message between the Latin and Arabic did not impair the truth, we chose not to change it; we kept the interpretation in deference to our predecessors. For the people of the East have been long so accustomed to it that change would be distasteful to them. Besides, the original text may admit the two readings equally, as they are different but not contradictory, attesting to the same things.

We also bring to your attention that we have followed the letters of the Hebrew writing with the names of people and places, except when the common practice in the Arabic language demanded otherwise, as in "Ibrahim" instead of "Abraham," "Sulaiman" instead of "Shlomoh," and "Urshalim," instead of "Yerushalim." As for the names of stones, trees and other plants, animals, and the like, when there is doubt or dispute about their meanings, or disagreement among translators about their interpretation, we left them in the Arabic text unchanged.

Now in this Arabic translation you will find expressions that are inconsistent with - indeed contradictory to - the rules of language, such as the masculine instead of the feminine gender, the singular instead of the plural, the plural instead of the dual, ${ }^{2}$ the nominative instead of the objective in nouns, wrong

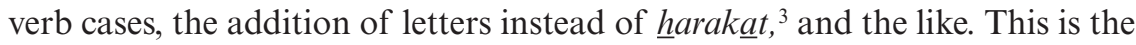
reason for the naivety of the Christians' Arabic writings, such as has become a mode of expression unique to them. However, not only in Arabic, but also in Latin, Greek, and Hebrew, did prophets, messengers, and early fathers disregard linguistic measures, for it was not the intention of the Holy Spirit to limit the vastness of the divine word to the narrow confines of grammatical rules. Thus, He presented heavenly secrets to us without eloquence or stylistic ornaments, in clear, easy words, so that humanity's great, marvelous salvation, and the world's entering the religion of Christ, would not be attributed to 
their own human abilities and enterprise, but only to God Almighty's power and wisdom - so that praise and glory would be given not to humans, but to God, the Lord of all worlds.

You should also know, dear reader, that this Arabic translation lacks harakat and the distinguishing grammatical signs that scholars have invented for ease of reading, except what we used in some places out of necessity. For it is not the custom of the Eastern Churches to employ these signs in the Holy Scriptures or the books they use in the divine service. Nevertheless, if someone were to be add these signs in all the relevant places in the Holy Scriptures, then that would be a good thing.

In these books, errors were made that are specific to the Arabic text, due either to the scribes' or printers' oversight, or inattention on part of the translators and revisers. For this reason, we have placed at the beginning of every volume a list of the serious errors with their corrections, leaving the minor ones to your discernment, wherewith you can correct them on your own. Some errors were corrected by the revisers after some of the pages had been printed. Hence, you may find in these pages errors that were not included in the list; contrariwise, you may find errors in the lists that are not in the pages printed afterwards, for we could not read all the printed copies, which exceed 1,500 in number.

Now we want to bring to your attention that in these Holy Scriptures we have only included those books accepted by the One Apostolic Roman Church, in the tradition of the Apostles, the Councils, and the early Fathersbeing the true word of God, as decided by the Trent Council.

\section{Translated by Tarek Shamma}

\section{COMMENTARY}

By the nineteenth century, the most widely circulated and officially recognized version of the Bible in the Arab East was the Catholic translation published in Rome in 1671. Mostly an indirect translation, the Catholic version was based more on the Latin Vulgate, the official Bible of the Catholic Church, than on the original Greek and Hebrew. Besides the canonical Vulgate, the translators drew on the long history of Arabic translations of the Bible; as the introduction explains, they consulted the available Arabic translations, reconstructing "the holy scriptures, as [the Arabic community] used to have them in ancient times." Overall, the introduction provides a useful account of the translation methods and the underlying intellectual assumptions.

Two points merit special attention. The translators (following the practice of past translators, who were more inclined to domesticate the scriptures into their Arabic environment through Islamic-sounding terms) deliberately avoided a "word for word" literal approach. In their deference to the prevailing tradition, the translators also preserved their predecessors' terms, as well as 
their interpretations, even in cases of deviations from the Latin canon, where the "truth" was not compromised. However, this avoidance of literalism vis-àvis previous translations is largely relative, an issue that bears further inquiry.

The other aspect of the translation strategy concerns one of the most important and controversial questions in the Arabic translation of the Bible. Many Christian and Jewish works of the Classical period, and into the nineteenth century, were written in what is termed "Middle Arabic." These writers and translators did not speak Arabic as a first language, and were not integrated into the religiously infused dominant idiom like, for example, their Persian counterparts who converted early on to Islam. Besides, their style was often influenced by the Bible and other religious texts in languages such as Syriac and Hebrew. As a result, their Arabic showed remarkable deviations from the norms of Classical Arabic in terms of rhetorical style and grammatical structures (as explained in the introduction to this translation). However, it is noteworthy that the authors stress that deviations from the norm are not confined to Arabic, but are common to Bible translations in other languages. In attributing this phenomenon to the influence of the Holy Spirit, who did not want "to limit the vastness of the divine word to the narrow confines of grammatical rules," the authors echo what can be called a Christian ideology of translation, whose norm was meaning transferin contradistinction to the common Islamic ideology, in which meaning and utterance where an inseparable unity (see, for example, al-Kindi and al-Hashimi; Chapter 5, and al-Shatibi, Chapter 20). At any rate, this issue (the Arabic Bible's unorthodox usage) would play a significant part in the nineteenth-century Arabic translations of the Bible.

Overall, this translation can be seen as a transition between the ancient translations, which relied mostly on domestication to the receiving environment to the point of echoing the Qur'anic style, and most later versions, starting especially in the nineteenth century, whose literalism was rooted in a deliberate effort to avoid Islamic terminology (see, for example, al-Shidiaq , Chapter 34, and The Protestant Translation, Chapter 31). Al-Rizzi's translation was also the first to be supported with European official patronage in the form of the Catholic Church. This is another aspect in which it anticipated the major Bible translation projects of the nineteenth century.

\section{Tarek Shamma}

\section{Notes}

1 Following the "Great Schism" in 1054, the church split into denominations: the Roman Catholic, based in Rome, and the Eastern Orthodox, based in Constantinople.

2 Arabic has a dual, as well as singular and plural numbers.

3 In Arabic, short vowels are not written; they are represented, when necessary, with harakat, special diacritical marks. 


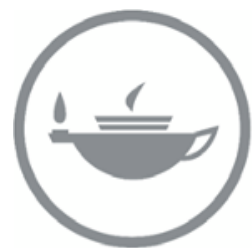

Taylor \& Francis Taylor \& Francis Group http://taylorandfrancis.com 


\section{The Nahda Period (1800-1918)}




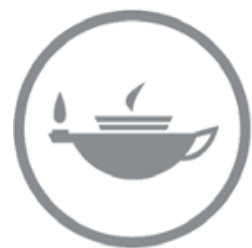

Taylor \& Francis Taylor \& Francis Group http://taylorandfrancis.com 


\title{
27 The History of Al-Jabarti (c. 1822) \\ 'Abd al-Rahman al-Jabarti
}

\begin{abstract}
'Abd al-Rahman al-Jabarti (1753-1825)
Generally considered the first major historian in modern Arabic, he was born to a wealthy family of 'ulama (religious scholars). He was educated at the famous al-Azhar University in Cairo, where he spent his life as a scholar. He was appointed in the National Diwan established by Jacques-François de Menou, Chief General of the French Expedition to Egypt (1798-1801), which was led by Napoleon Bonaparte until August of 1799. His works are among the foremost historical sources for the period.
\end{abstract}

\section{'Ajạ ib al-Athar fi al-Tarajim wa al-Akhbar (Marvelous Compositions of Biographies and Chronicles, or The History of al-Jabarti)}

Al-Jabarti's major work, for which he is remembered today, often known as "The History of Al-Jabarti." It chronicles the history of Egypt beginning from 1694 to 1820 , shortly before his death. The book provides the bestknown chronicles of the events of the French occupation of Egypt and the subsequent ascension of Muhammad 'Ali. Besides political events, al-Jabarti describes the cultural, religious, and social life in Egypt during that time.

\section{[CHRONICLES OF TRANSLATION DURING THE FRENCH OCCUPATION OF EGYPT]}

\section{[from Part 4]}

\section{[August 2, 1798]}

The commander of the army Bonaparte called the shaikhs for a general meeting. As they came together, Bonaparte went up to the front and came back, holding in his hand pieces of cloth, all of which had three stripes of white, red, and dark blue. He put one of these cloths on the shoulder of Shaikh al-Sharqawi, who threw it straight to the ground, and asked to be excused. [Napoleon's] face changed color, and his features hardened. The 
interpreter said: "Dear Shaikhs, you are now the allies of the Commander in Chief, which is why he wishes to honor you with his emblem and insignia. Your prestige will be high amongst the military and the common people, and you now will have a place in their hearts." They said: "But we would lose our place with God and our Muslim brothers."

[Napoleon] became enraged at these words and spoke in his own native tongue. The translators communicated that he thought that al-Shaikh alSharqawi was not fit for command, and things of this nature. But the others placated him and asked to be excused. He then said: "If this cannot be, one of you has to pin the emblem on his lapel - an insignia which is called a 'rosette'." So they said: "Please give us time to consult together on this," and they came to an agreement after twelve days had passed - at which time Shaikh al-Sadat, arriving upon request, came across them taking their leave. When he took his seat, the Commander in Chief, smiling at him, paid him compliments in words translated into Arabic by the interpreter. A diamond ring was gifted to him, and he was requested to attend again the following day. The rosette was brought out and pinned upon his robe. He fell silent and went along, then got up and left, whereupon he lifted it away. However, this [i.e., wearing the rosette] is not a religious violation.

On the 18th of the same [Hijri] month [August 19, 1798], a group of running footmen employed by the French began to demolish stone edifices on graves within the cemetery situated in al-Azbakiya [a central district in Cairo], flattening them to the ground. When news of this got out, the owners of the land came out from all the sides [...] a horde of people screaming and crying. They all congregated at the house of the Commander in Chief. The interpreters came down the steps and apologised to them, saying that the Commander had no idea that this destruction was taking place, and that he had not given the order for it. What he had ordered was that no more be buried there. They returned to their homes and the destruction of the edifices was halted [...]

\section{[in August of 1798]}

There was a man called al-Hajj Muhammad Ibn Qimu al-Maghrebi, a trader from Tripoli [in North Africa]. There was competition between him and some of the Christian Syrian translators, who communicated to the French higher authorities that he was in possession of great wealth, and that he was the partner of 'Abdullah al-Maghrebi, who was a follower of Murad Bey. ${ }^{1}$ They sent out a group to search for him, which first went to the house of al-Shaikh Abdullah Al-Sharqawi as the two men were related [...] Two men, al-Mahdi and Al-Duwākhli, went to the Commander in Chief and told him about the whole issue, and how the man had fled already. The Commander asked: "But why did he flee?" They replied: "He was afraid of what would happen to him." He replied, incandescent with rage, "If he had not committed a really serious crime, he would not have run away, and you have hidden him." They addressed the translator with compliments and reassurances, so he talked to the Commander in Chief, whose anger dissipated. Then the Commander 
asked them about the location of the house [of the trader], and his store, and so they told him. He said: "You will be accompanied there by someone who will put a seal on them until he turns up there tomorrow. So rest assured."

[November 10, 1798]

One of the most important events in this month happened on the well-known hill, Tal al-'Aqarib in al-Nasiriya [neighbourhood], where they dug trenches and built turrets for use by the French troops and to store their armaments. The French also began demolishing the houses of some of the princes, taking away the rubble and marble to use it for their own buildings. They took out the works of astronomers, people of mathematical knowledge, as well as engineering, astronomy, engraving, painting, writing, accounting, and composition and moved them to al-Nasiriya, where the new pathway was being built.

Large amounts of books were moved there, which then became repositories of knowledge and sources of reference used by those pursuing their studies. Students of their kind used to gather every morning opposite the repositories where the books were stored, all on chairs lined up in rows alongside each other. When someone, even the lowliest of uneducated soldiers amongst them, wished to look up something, the guardian of the repository would bring it to him so he could leaf through it, look up references and write it down. Even if Muslims came to have a look, they did not forbid them entry into what was clearly a place of great value to them, but rather greeted them with smiles and actually seemed very happy to see them, particularly those who were educated and were seeking knowledge [...]

Many Islamic books were translated by them into their language. I saw amongst them al-Shifa' [The Remedy] by Judge 'Aiyad (titled "Honourable Remedy" in their language), and al-Burda poem by al-Busairi. I saw some of them who knew verses of the Qu'ran by heart. I noticed that they had an eager thirst for knowledge, in particular mathematics and languages, and great commitment to learning languages and logic. They toil night and day to learn, and have many books dedicated to the explanation of different languages - their conjugations and morphology — so that it is easier for them to transmit what they wish of these languages into their language as rapidly as possible $[\ldots]$

[May 14, 1799]

A Christian Syrian man passed by the Mausoleum of al-Husain [the Prophet Muhammad's grandson] riding on a donkey. The interpreter for the neighborhood officer, called al-Saiyd 'Abdullah, saw him and ordered him to dismount out of respect for the Mausoleum, as is the custom. When he refused, he [the interpreter] set upon him, hit him, and hurled him to the ground. So this Christian man went to the French to lodge a complaint against al-Saiyd 'Abdullah. So they [the French] brought him and imprisoned him [...] 
[December 18, 1799]

News of the [Ottoman-French] Truce became known, and a party from the side of the Ottomans, including the treasurer and the chief secretary, came to conclude the truce. Both parties agreed to desist from war and causing more bloodshed. The French showed compliance until the day that the truce of 22 conditions was signed, sealed and printed on a large sheet of paper. A sense of goodwill pervaded Egypt, and the people were pleased and joyful. The French Commander in Chief [Jean Baptiste Kléber, who had replaced Bonaparte in August] sent a report of the situation to General Charles Dugua, and people in the Diwan perused it.

When the written truce with details of the conditions arrived, they translated it into Arabic and made many copies of it, and displayed it in many places for all eyes to see in the markets and streets.

Below is a literal copy of the clauses and conditions, aside from the translated version of the lines written there in French:

This is a copy of the conditions of the handover of Egypt effected between Divisional General Desaix and his Excellency Poussielgue, the general director of the borders, distributed between them the complete authority to negotiate as representatives of the Commander in Chief Kléber, and

His Excellency Mustafa Rashịd Effendi, Treasurer, and Mustafa Rasisa Effendi, Chief Secretary, with complete authority to negotiate [on behalf of the Ottoman Authorities] [...]

Validated and affirmed by our military seals, according to the procedure established [in the city of] al-'Arish, in the month of Pluviôse, year 8, of the French Republican Calendar, the $24^{\text {th }}$ of January of the Western year of 1800 , and $28^{\text {th }}$ of the month of Sha'ban, 1214 Hijri.

Signatures: Divisional General Desaix and his Excellency Poussielgue, general director of the borders, whose complete authority as representatives of the Commander in Chief Kléber is shared between them and between His Excellency Mustafa Rashịd Effendi, Treasurer and Rasisa Effendi, Chief Secretary, with complete authority to negotiate [on behalf of the Ottoman Authorities]. Transmitted from the original version, which is identical to the French one sent to the Ottoman delegates, rather than the version which was sent in Turkish. Signed by Desaix and Poussielgue, authorized by Commander in Chief as revised at the end of the Turkish year [in the Ottoman Fiscal Calendar], which remains in the keeping of the Ottoman Ministry.

I the Commander in Chief of the French Army in the Egyptian Territory, the undersigned, validate and attest to the conditions of the above-named Treaty, the receipt of what was completed in terms of work, format and design, although it is necessary that I ascertain that the twenty two conditions set out up until now are still dependent upon this version being proofed in the French language, as signed by the authorized representatives of the Ottoman Ministry as directed by its Highest Order, 
the translation of which undoubtedly calls for constant re-evaluation if, for whichever reason, differences arise which could lead to problems.

Validated and affirmed in the General military headquarters at al-Salihiya [Cairo] on the $8^{\text {th }}$ of the month of Pluviôse, year 8, of the Republic Calendar. Signed: Kléber, from the original version, Divisional General, Commander of the French army. Signed: [General FrançoisÉtienne de] Damas.

End of the copied text. Errors and distortions are in the original version printed by the French press in the Arabic language. I have altered nothing of it $[\ldots]$

[On the trial, on June 15-16, of Sulaiman al-Halabi, who had assassinated General Kléber, the Commander in Chief of the French Expedition, on June 14, 1800]

The French arranged the court proceedings according to their system of retributive law. They condemned to death three persons cited as being with the assassin, and released Mustafa Effendi ${ }^{2}$ al-Busili in that was not informed [by al-Halabi] of his intentions [...] The trial came to this conclusion and recorded on paper the outline of the proceedings and how they took place. They printed many copies of these in three languages, French, Turkish, and Arabic.

I had demurred from citing all of the proceedings due to their length and awkwardness of grammar which was due to the weakness of the [Arabic] language version. Then I observed that many took great interest in the account - what it tells of the event and how the court was run [...]

Here is a copy of the translation of these papers ${ }^{3}$ :

\section{The first interrogation of Sulaiman al- $\underline{H}$ alabi}

[...] The accused was seen by members of the French military in the area of Giza, where he was found crouched in the same garden where the assassination occurred. In the very same garden, the dagger which was used to attack the General was also found. The interrogation was carried out in the presence of General Menou, who, as the most senior of his peers in the army, took over the authority for the city of Cairo. The interrogation took place via Khawaja ${ }^{4}$ Bracewich, the private secretary and translator for the General, and written down by secretary Sartelon, brought by General Menou for the said accused [...]

The interrogation took place in the presence of the General Menou, in the presence of senior officers at the house of the Commander in Chief. All of it was sealed and signed off by General Menou and the secretary Sartelon on the afore-mentioned day, month and year, and then read out to the accused, who then signed it in his own handwriting in Arabic: Sulaiman.

Signatures of: General 'Abdullah Menou; ${ }^{5}$ General Damas; General Valentin;GeneralMorand;GernalMartinet;NavalGeneralLeroy; Scretary 
Sartelon; Translator: [Jean Baptiste] Lhomaca; Translator: Jean Renno; Private Secretary and translator for the General: Damien Bracewich [...]

He was asked: Did al-Saiyd 'Abdullah al-Ghazi know him also? He answered: "Yes." He was told that it was established that yesterday Sulaiman had spoken with him at length, which was witnessed by many. So he answered: "Yes, this is true." He was then asked why he had said in the beginning that he had not seen him. And he answered that his guess was that he had not said that, and that the translators had made a mistake $[\ldots]$

This interrogation took place in the presence of the military generals gathered by General Menou. Secretary Sartelon wrote down everything in his own hand on the orders of General Menou. After it was read out to the accused, they wrote their names down in Arabic, on the day, and in the month and year cited above: three signatures in Arabic, alongside the signatures of General Menou; Secretary Sartelon; Translator Lhomaca; General Menou, Supreme Commander of the French armies in Egypt [...]

After the completion of the above-mentioned interrogation, I, Sartelon the prosecutor, asked the four accused to choose one to speak on behalf of all of them before the judge and advocate for them. The accused said that they did not know whom to choose. For this reason, we presented to them the translator Lhomaca in order to assist them in this regard [...]

We read out to Sulaiman and Mustafa Effendi these proceedings, and they stated that this was what had come to pass, nothing more and nothing less. Then they signed it in the presence of the translator [...]

Signatures of the two accuseds, signatures of Lhomaca the translator [...]

\section{[October 20, 1800]}

They started to re-order the council board in a different way from the first one. Now it was made up only of nine elders, ${ }^{6}$ with no Copts, Ottoman officers, or Syrians [...] It consisted of the following nine chiefs: Shaikh al-Sharqawi, the head of the Council Board; al-Mahdi, its Private Secretary; Shaikh alAmir; Shaikh al-Sawi and his secretary; Shaikh Musa al-Sarsi; Shaikh Khalil al-Bakri; Saiyd 'Ali al-Rashidi, father in law to the Commander in Chief; Skaikh al-Fayumi; Judge Shaikh Ismail al-Zarqawi; al-Saiyd Ismạ'il alKhashab, chronicler; Shaikh 'Ali, Arabic secretary; Qasim Effendi, foreignlanguage secretary; Father Rafa $\underline{\text { il }}$ [Zakhur ], senior translator; Elias Fakhr the Syrian, junior translator; Commissaire [Joseph] Fourier, called "head of legal judgements"; a corporal; and five footmen. They chose the house of Rashwan Bey for them, which was in the 'Abidin neighborhood [...] To make a new and honorably furnished seating area for the Council Board, they refitted, repainted and refurnished the harem quarters of this house, so they could meet there for sessions, ten times a month.

Fourier and his attendants moved to the house and allocated to the translators and secretaries in French a space where they could sit at all times, including outside of the Council Board meeting session, for when 
they translated details of events and where records were to be kept in special cabinets. Next to this house, they opened up another house, refurnished it and called it a court for commercial matters. They arranged for Christian and Muslim merchants to meet there to consider cases relating to the laws of trade. The sessions were headed by Fourier, and all such matters were only conducted there.

On the 15th day of this month [of Jamada the Second] [October 20, 1800], the Council Board sessions began. It was designed that when the shaikhs met for a session, Fourier would attend, accompanied by translators. They would rise to meet him, and he would sit with them, while the senior translator Rafa'il would stand by. Litigators would stand behind the screen situated at the back of the Council meeting room. This screen was made of latticed wood, and had a door guarded by an usher, who prevented people other than litigators from entering and showed them in one after the other.

A plaintiff would have then to put forward his case, and the translator would translate for him. If the case concerned legal matters, the head judge for the Council would then call upon the experts in law to consider it or would refer to the head judge in a court of law if it required the pleas to be written or for the records to be taken out and consulted [...]

They arranged for each of the nine shaikhs of the Council to receive fourteen thousand pieces of silver each month, that is four-hundred and a half pieces of silver for each day. The head judge, the registrar, the Arabiclanguage secretary, the translators and other people serving received varying amounts, and enough to prevent them from the possibility of bribery.

[December 18, 1800]

In this month they completed the building which they had founded in alAzbakiya, at the place known as Bab al-Hawa. It is what they call in their language "al-komedi." It was where they would meet one full evening, every ten nights. They would watch a game that a group of them would play for the purpose of enjoyment and amusement for four hours a night, all in their language. None could enter this place without a specific card and being of a certain position.

[March 16, 1801)

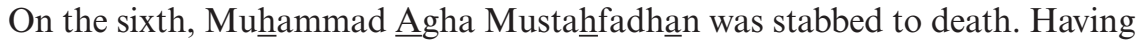
been ill on Saturday, he died on Sunday night [...] No ceremony nor gathering took place for him. They quarantined his home and locked up its residents, and no one was appointed to replace him. However, they permitted 'Abd al-' $\underline{\mathrm{Al}}$ to ride in his place, and this with the help of Nasralla, the Christian translator.

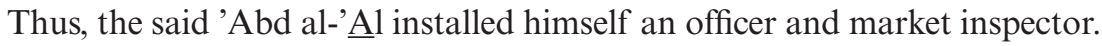

This was a unique event of its kind and a lesson to learn from. For this 'Abd al-' Al was one of the lowest of the low, as he was a paid servant to a Christian Syrian from Khan al-Hamzawi neighborhood. He came to have influence with Mustafa Aggha through knowing some Christian interpreters, 
then rose through the ranks through this connection until he was awarded the title of Agha and was made into his deputy and manager. When Muhammad Agha replaced Mustafa Agha in his post, 'Abd al-'Al attached himself to him, as was the case with Mustafa Agha. But he was in a lower status than before, as the murdered Muhammad Agha was a man of integrity. When he died, the post was left for 'Abd al-'Al to occupy, as the French were busy with more consequential matters, such the outbreak of war, the plague, and so on.

[Shortly before the departure of the French army from Egypt]

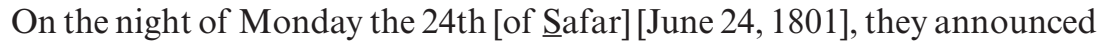
in the markets that cannons would be fired in the morning.

On Wednesday the 19th [June 19, 1801], people traveling with the French went out [of Cairo] to al-Rawda and al-Giza [suburbs] with their belongings and women. They were a large group of people, including Coptic Christians, Frankish merchants, translators, and some Muslims who interacted with them and were afraid for themselves. There were many Christian Syrians and Greeks, such as Yeni, Bartalmin [Barthelmy], Yusuf al-Hamwi, and 'Abd al-'Al Agha too, who had divorced his wife, sold his belongings, furniture, and anything of his possessions and weapons too heavy to carry. As he sold each item, he would send someone to force the buyer to bring him the price immediately. He only took with him the lightest and most valuable items.

\section{Translated by Ruth Abou Rached}

\section{COMMENTARY}

Al-Jabarti's chronicles of the French invasion of Egypt is a vital historical source on the political, cultural, and social conditions of Egypt in the late eighteenth/early nineteenth century (Murphy 2014). In his chronicles, alJabarti records how translators-mostly from the Levant (Greater Syria) took on a crucial role of mediation with tangible political ramifications for the local communities in Cairo. As a member of the 'ulama', the scholarly religious class, al-Jabarti was in a unique position to observe his contemporaries exercising their influence alongside the elites of the Mamluk military and Ottoman governors. As the different representatives effectively ruled Egypt by making decisions based on resolutions of confrontation, they were reliant on translators before and after the Napoleonic invasion of 1798 for security and trade between different political/religious communities and specialized traders to function.

Through the day-to-day political events recorded in the chronicles of Al-Jabarti, Arabic speakers are described often as "Shami" (i.e., Syrian, Levantine), originally from outside of Egypt and needing the financial renumeration from translating day-to-day workings of the Ottoman Empire in a province of relative prosperity. Al-Jabarti describes the involvement 
of translators in drafting written contracts and testifying to agreements reached between different representatives of the community. Underpinning these agreements was a tradition of long-established communities arriving at consensus, as well as an emergent recognition that conflict and instability in a now modern era of trade was unconducive to economic prosperity and political influence. According to al-Jabarti, the ensuing stability of Egypt making it the most prosperous province in the Ottoman Empire (1822, IV: 35), conversely encouraged the French to invade and thus also benefit from its resources (ibid.). In this way, this chronicle sheds light on how the lived micropraxis of translation, carried out by men within different networks of power and patronage operating one macro-system of colonization (Ottoman), reverberated - and perhaps contributed - to another (French) macro-system, which did not replace the previous one, but operated alongside it.

Al-Jabarti is the first, if not only, scholar writing in Arabic to chronicle the day-to-day "practicalities" of translation during the late nineteenth century as an act which happens by individuals with corporeal bodies. He records in great detail how translators were physically placed behind wooden barriers to witness everything of high-level discussions between local leaders of influence. His account uniquely shows how translators themselves discuss and decide to keep their translated papers as administrative records in specific shared spaces of work, particularly where they were sworn to keeping particular testimonies secret. Al-Jabarti also describes translation as a commercially and politically competitive profession, sometimes playing out along sectarian lines. The microsituations between different translators described by al-Jabarti foreground the translator (Chesterman 2009) as well as translation itself as intersecting site of mediation, loyalty, and conflict in eighteenth-century Cairo. In this "early modern" Ottoman era most Arabs identified with religious and geographical provenance, rather than nationality, in marked contrast with many Nahda discourses centering Arabness as point of departure nearly a century later.

Interestingly, al-Jabarti also describes how each statesman during the French era had their own personal interpreter positioned in hierarchal order of precedence to relay information alongside other interpreters assigned to other statesmen. This phenomenon reflects translation and interpreting as an issue of trust on one hand, as well as a prototype of interaction between nation states in the not too distant future. At the same time, we see evidence of political stakeholders, in the face of encroaching French influence, considering translation as a conduit for educating and thus equipping the younger generation from all backgrounds in the fields of mathematics, engineering and surveying. A school was set up where books were translated, which resulted in translators becoming teachers but only by virtue of language skills to relay what was already written in each text. The establishment of this school raises questions on the fluid status of translators and the acquisition of "new" knowledge via the medium of translators at that time. Formerly recording translators as mediating verbal and written transmissions, al-Jabarti's narrative shows what could be described as a potential "rupture 
between habitus and field" (Abdallah 2014: 120): a dissonance between the role of translators as a profession and what political leaders decided they needed in terms of skills of use.

This potential dissonance resonates with the question on "motivation" of translators (Chesterman 2009: 17) as embodied individuals with skills and qualities to offer in an "early modern" Ottoman Empire: how and why did translators move to Cairo whose migratory communities were typically "organised within ethnic, professional and religious organisation of space [...] working in specialised trades"? (Ghazaleh 2010: 138). This raises questions on how the "profession" of translation was "lived" by translators outside the elite milieus of governance. Al-Jabarti's accounts of micro individual actions offer a rare insight — and invite further research — on "non-elite" translator agents whose physical presence was crucial for mediating the prosperity of the city on which each trade, and its politics, operated.

\section{Ruth Abou Rached}

\section{Notes}

1 The former governor of Egypt who was secretly agitating against the French.

2 A general term of respect of Turkish origin, which was used into the early twentieth century, for men of social status (usually educated).

3 The proceedings of the trial were published by the press of the French Expedition in 1800, along with Arabic and Turkish translations. Al-Jabarti copies from this book with minor corrections of the "awkwardness" of the Arabic.

4 Then a general term for a foreigner in Egypt.

5 Jacques-François Menou, who had converted to Islam in 1799 upon marrying the daughter of 'Ali al-Rashịdi, a notable from Rosetta, a city in northern Egypt (see below).

6 Known in Arabic as 'mu'ammimin', literally those wearing turbans. 


\title{
28 Document for Appointing Rifa'a al-Tahtawi (1831)
}

\author{
Promotion of Al-Tahtawi to the Rank \\ of Amiralay (1846)
}

Muhammad'Ali Pasha

\section{Muhammad 'Ali Pasha (1770-1849)}

Muhammad 'Ali Pasha was the de facto ruler of Egypt (under nominal allegiance to the Ottoman Sultan) between 1805 and 1848. He was born in Kavala, a city in Greece today, to an Albanian family. He came to Egypt after the French occupation as head of the Albanian battalion sent by the Ottoman Empire. He came to power in 1805 after the popular revolt over Khurshid Pasha, the new governor under the reasserted Ottoman rule. Muhammad 'Ali undertook a massive modernization program of Egypt on all levels, part of which included sending Egyptian students to study in Europe. His rule is generally considered the start of the Nahda (renewal) period in Egypt. His descendants continued to rule Egypt until 1952, when the monarchy was abolished and the republic was declared.

\section{Rifa'a al-Tahtawi (1701-1873)}

Translator, educator, intellectual, and administrator, widely considered a founder of the intellectual and scientific renaissance in modern Egypt and the Arab World. He was born in Tahta in Southern Egypt, then moved to Cairo and received traditional religious education at al-Azhar University. In 1826, the Egyptian government sent him as an imam (cleric) on an educational mission to Paris. However, he decided to pursue further secular education on his own; he studied French, geography, and history, and specialized in translation. Upon his return to Egypt in 1831, he was the key figure in several "modernizing" projects, including the School of Languages, where he trained generations of translators, the first Arabic-language newspaper, and massive educational reforms (including Arabization of school curricula on all levels, and extending education to women). His translations include books from French on geography, history, law (including the French Civil Code),

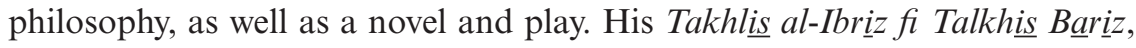
about his experience in Paris, is one of the first accounts of Europe in modern Arabic; it had a great influence on modern reformers in Arabic, and is still 
discussed and studied today. An English translation was published in 2004 as An Imam in Paris: Al-Tahtawi's Visit to France 1826-1831.

\section{Rifa'a al-Tahtawi's appointment as a teacher at the Medical School in Abu Za'bal}

This is the only text in this anthology that was not originally written in Arabic, as it was translated from Ottoman Turkish (then the official language of administration). It has been included here not only due to its importance, but also because translations used as official documents (as was the case here) must be considered parallel, rather than target texts (Hermans 2014: 8ff).

\section{[MUHAMMAD 'ALI PACHA SIGNALS THE START OF THE TRANSLATION MOVEMENT]}

[May 22, 1831]

From: Muhammad 'Ali

To: Mahmud Bey, Minister of the Military

Your excellence, Dear Brother, Mahmud Bey, Minister of the Military

I have discussed with one of our great physicians, Gaetani, that the Council considers, and decides, whether it would be in order to arrange for the shaikh

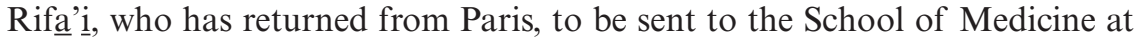
Abu Za'bal to teach French to the students there. However, I fail to see any mention of this in the minutes of the council. I wonder whether you were not informed or whether you forgot to discuss it.

It remains that the matter is still outstanding, and now I have the following idea: As it is imperative for this Rifa' $i$ to undertake the translation of books, if he were to be appointed to the School in Abu Za'bal and teach French, twenty-five or thirty translators could graduate every year.

I therefore ask that you appoint the above-mentioned shaikh at the School of Medicine in Abu Za'bal and pay him an appropriate salary.

The seal: Muhammad 'Ali

\section{[THE OFFICIAL PATRONAGE OF TRANSLATION]}

\section{Dossier 2: Orders to the Department of Schools}

Your excellency Adham Bey, Director of Schools

Since I assigned to Colonel Rifa'a Effendi, the principal of the School of Languages, the rank of Brigadier with the half-year pay [bonus] and all the benefits for this rank, implement this from the date of my decision and appoint him to the rank of Brigadier. 
14 Thu al-Hijah 1262 H. [December 3, 1846]

Muhammad 'Ali

\section{COMMENTARY}

In the first document, translated from the Arabic version of a Turkish document, the Governor of Egypt, Muhammad 'Ali, orders that the translator Rifá'a al-Tahtawi, referred to as Sheikh Rifá $i$, be appointed as a language instructor in order to teach French and translation, a clear indication of how Muhammad 'Ali placed translation and access to foreign knowledge at the heart of his modernization program.

But there is little appreciation here of what translation entails, above linguistic competence. Priority is given to the way returnees from the student missions in France can be employed in the modernization and nation-building project, and translation is seen as one of the necessary conditions for the program to be implemented. From these short official documents, we can also understand the huge efforts that al-Tahtawi devoted to the development of his translation skills, when in Paris, as a personal initiative beyond his official mission as a religious guide and mentor to the other students, and then with regard to the implementation of a translation program in Egypt.

The second document requests that al-Tahtawi's remuneration be increased in view of his efforts. This was an important juncture in the career of al-Tahtawi, who was soon to play a key role in the modernization and development of public education in Egypt.

Finally, the above documents offer a glimpse of the 'formalization' of translation in the early Arab renaissance.

\section{Myriam Salama-Carr}




\title{
29 Speech Delivered at the Staging of The Miser (1848)
}

\author{
Marun al-Naqqash
}

\section{Mạun al-Naqqạsh (1817-1855)}

A playwright, poet, and stage director, generally considered the founder of modern Arabic theater. He was born in Sidon, but grew up in Beirut, where he studied French and Italian. He traveled to on business trips Europe, where he familiarized himself with modern theater. When he returned to Beirut, he produced the first plays in Arabic, including al-Bakhil (The Miser) (1848),

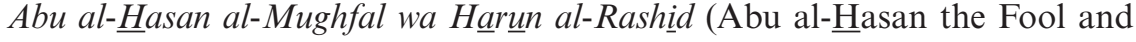
Harun al-Rashid) (1850), and al-Has $\underline{u} d$ al-Salit (The Envious Railer) (1853).

\section{Speech delivered at the staging of The Miser, from Arzat Lubnan (The Cedar of Lebanon)}

The book was written by Salim al-Naqqash in honor of the memory of his brother Marun after his premature death at 38. Besides Marun's biography and his collected works, it contains the speech that introduced his first play, The Miser, which he wrote, produced, and directed.

\section{[Between Translation and Authorship]}

The speech that he (May He Rest in Peace) delivered upon introducing his first play in February of 1848

We thank You Who have disseminated wisdom and prudence through tales and traditions. You have instructed your servants in serious wisdom and moral lessons by the means of humor and plays. It is the thanks of someone who has traveled the world with the love of his homeland in his heart, and sought the gift of wit from Your graciousness, for You are the true helper and benefactor, the only consoler.

Now this poor servant of God, with his humble ability and intelligence, needful for the succor of his Master, Marun Ibn al-Yas al-Naqqash, May God replenish his soul with the rains of his aid and rejuvenation, having observed that the people of our land are embarked upon the first steps of success, and 
are progressing day after day toward accomplishment, I was convinced that the merciful God has bestowed upon them His timeless care [...]

And here I come forward on your behalf, bearing potential blame in your stead. To these esteemed and distinguished gentlemen, with their remarkable knowledge and singular, lucid minds, who are the eminent figures of this age - indeed the cream of the learned and adept in this country-I present literary theater: Frankish gold cast in Arabic molds.

For during my travels in European countries, passing through Frankish lands, I saw at first hand, amongst other useful pursuits that are means for edifying character, sites where they play quaint games and narrate marvelous tales. In the narratives they use, and the plays on which they are founded, one can discern that, beneath the overt metaphors and humor, lie covert truth and reform - so much so that kings are attracted from the top of their thrones to attend and gain in good judgment and entertainment.

These theaters are divided into two types, both of which are pleasing to the viewer. One is called "prosa,"1 which is divided into comedy, drama, and tragedy. These are presented plain without poetry, and not set to the tunes of musical instruments. The second type they call "opera," which could be serious, sad, or cheerful, and is luxuriant with music.

Now it would have been more important and more expected for me to be translator and author of the first, rather than the second type; for the former is easier and more accessible for a start. However, I have been compelled to violate this principle, with its consequent difficulties, for two reasons. Firstly, I have found the second type more pleasurable and enjoyable - more pleasant and resplendent. A man usually does not excel except when practicing that to which he is inclined; likewise, an author's imagination would flourish, and his mind thrive, wherever his hopes are at stake. Secondly, as one cannot divine other people's thinking but through his own, I have been guided by my opinion, desire, and enthusiasm, to believe that the second type would find more favor among my folks and community. Therefore, I have fixed my intention upon imitating the worthy kind of the musical theater, which I appreciate highly [...]

What theater we have so far seen in our country is merely a token, like a shadow to the real thing. However, considering that this production is the first of its kind, besides the lack of resources at our disposal, we do not consider our work inferior to those of Europe. Indeed, even the Europeans who have seen our plays have acknowledged their merits. Notwithstanding their ignorance of the language, they have managed to understand them well enough to enjoy them, which is the best testament to their craft and the skill of the pupils who performed them. Nevertheless, we do hope that in time our lands will reach the highest level of civilization and prosperity, whereupon this art will gradually multiply and flourish just as it does in Europe.

\section{Translated by Tarek Shamma}




\section{Marunn al-Naqqash}

\section{COMMENTARY}

Marun al-Naqqash is generally recognized as the founder of the modern theater in Arabic (Berg 2016). So this text can be seen as the first step in a process of integration, in which translation played a significant role. The first encounter of Arabic literature with Western ("Aristotelian") theater was Matta Ibn Yunus's translation of Aristotle's Poetics (see Ibn Rushd, Chapter 12), where "comedy" and "tragedy" were radically adapted into the terms of Arabic poetry. As a result, the Poetics was incorporated into literary, and especially philosophical, debates that inevitably remained outside the literary genre that it exposited. Aside from the ongoing debate since the nineteenth century about the potential existence (or lack thereof) of theatrical forms in Arabic literature, it is well established that theater in its Western classical form was introduced into Arabic only in the nineteenth century by pioneers such as Marun al-Naqqash, who is undoubtedly the founder of theatrical production, if not necessarily composition. ${ }^{2}$

Translation was instrumental in introducing new literary forms into the traditional Arabic canon. This was especially the case with the novel and the theater, although the European influence in the latter was mediated through first-hand contact. Thus, the first account of the modern theater in Arabic is found in al-Jabarti's history (see al-Jabarti, Chapter 27). In his account, cited above, in 1800 the French constructed a theatrical stage, for which he found no Arabic equivalent, so he used a transliteration of the French comédie (كمدي). This was followed by first-hand experience of staged plays in Europe, the first of which in Rifa'a al-Tahtawi's account of his stay in Paris (18261831), published as Takhlis al-Ibriz (1834). Al- Tahtawi used "tiatr" (تياتي), an Arabic transliteration of the French théâtre to describe the plays he watched in Paris, which he divided, like al-Naqqaash, into two types: "While the opera is the largest tiatr, the smallest is called the komet" (1834: 89).

When native Arabic theater began to emerge, it had to rely on the imitation of European models. A businessman whose travels took him to several European countries, including Italy where he experienced the classical theater, al-Naqqash decided to start an Arabic theatrical tradition based on the same principles. It is generally agreed that the new genres entered Arabic literature in stages that started with several types of translation before original authorship. But one important element that is often overlooked is the considerable overlap between translation and authorship in this transitional period, where the boundaries between them were frequently blurred. For alNaqqash does not seem to establish a clear distinction between his roles as translator and author in the effort to produce "Frankish gold cast in Arabic molds"; they seem to him be two parts of a continuum.

We can see this gradual trajectory from translation to authorship in alNaqqash's theatrical experience, which mixed translation, authorship, and adaptation. The title of his first play-The Miser, for which this speech was written — seems to echo Molière's $L$ 'Avare. Indeed, several scholars have argued 
that it is based on a translation of the French play, albeit with great liberties, including changing the characters' names (e.g., Starkey 2006: 34). Even those who argue that The Miser is predominantly an original composition recognize that it was at least inspired by L'Avare, and that "al-Naqqash wrote it after he had read and acquainted himself with Molière's play" (al-Takriti 2002: 78). In addition, al-Naqqash's short dramatic career drew on the other major source of intellectual and literary renewal in al-Nahda: the revival of Arabic Classical heritage. His second play, Abu al- $\underline{H}$ asan the Fool and Harun al-Rashidd, was an adaptation of a story from the Arabian Nights. Then his final play, The Envious Railer, a contemporary comedy of manners, was an original work. It was staged in 1853, two years before his death.

\section{Tarek Shamma}

\section{Notes}

1 Al-Naqqash's terms are taken from Italian.

2 See Bugruh (2003) and Moreh and Sadgrove (1996: 45), who argue that the Algerian Abraham Daninos published a play of his writing in 1847, the year before al-Naqqash's first play was produced. 


\title{
30 Translation of Robinson Crusoe (1861)
}

\author{
Butrus al-Bustani
}

\section{Butrus al-Bustani (1819-1883)}

Linguist, encyclopedist, lexicographer, translator, poet, and major figure of the Nahda. Born in Dibbiye in Mount Lebanon, he attended national and missionary schools, where he studied Arabic, Syriac, Italian, English, and Latin. He is the author of the first modern Arabic encyclopedia Da irat alMa'arif (The Circle of Knowledge), completed after his death by his son Salim. He founded the nationalist newspaper Nafir Suria (The Clarion of Syria), as well as three literary magazines, most notably al-Jinan (The Gardens). He established the National School in 1863. His dictionary Muhit al-Muhit (The Ocean of Oceans), the first modern dictionary in Arabic, was published 1870. $\mathrm{He}$ also contributed to the Protestant translation of the Bible (1865).

\section{Al-Tuhfa al-Bustaniya fi al-Síra al-Krüziya (The Bustanian Gem of the Crusian Biography)}

In the introduction to Daniel Defoe's Robinson Crusoe, al-Bustani states that the significance of the novel is that it was based on real events, emphasizing the realism of the plot, as well as the ethical value of the work. This, however, was not the first Arabic translation of Robinson Crusoe. It was preceded by an anonymous translation (of very poor quality), published in Malta in 1835 - perhaps the first published novel in Arabic, translated or otherwise (Duma 2015: 7).

\section{[Translation and the New Reading Public] \\ The Book of \\ The Bustanian Gem of the Crusian Biography \\ Or}

The Voyage of Robinson Crusoe

Translated, Refined, and Printed by Master Butrus Al-Bustani

What pleases me most of all

One strives for things he will never achieve is a man striving on, unknowing of his destiny

For the soul is one and concern for all is plenty

As long as one lives, hope extends ahead The eye's sight only ends at life's boundary

DOI: $10.4324 / 9781003247784-33$ 


\section{THE TRANSLATOR'S INTRODUCTION}

This enchanting story is about the journey of Robinson Crusoe, and about all the terrors and dangers he encountered on land and sea, about what he braved and the tools and means he made recourse to in order to survive and to make his life more comfortable. For those in the West, it is considered one of the most extraordinary, captivating and exciting stories of all time, and one which stands out from its contemporaries for the following reasons:

Firstly, it is constructed as a sincere, and believable story. Secondly, the events in this story are, in their delivery, believable and reasonable to have occurred. Thirdly, it is refined in style and free from frivolous and licentious language. Fourthly, its contents impart wisdom and decent moral messages, with entertaining incidents relating to the particular and universal, to adults as well as children. Fifthly, it has many illustrations which make the story easy to understand.

Themes in this story, moreover, are varied, its style aesthetically pleasing and the Arabic clear and easy to read. This being the case, and as its language is familiar and the content entertaining, there is no fear of becoming bored when leafing through its pages. It is thus one of the best books to be read in elementary schools, as a way of strengthening the learning of children. As a book refined in style and content, it is more acceptable for readerships in this age when the portals of knowledge are now open to those of the feminine sex, for whom attention is needed to the purging of literary salons, and Arabic books and collections, from inappropriate words and references, so that due propriety and decorum can be preserved and maintained for them.

With this as a consideration, I undertook the translation, refinement, and printing of this work, which was completed in what scraps of time were available over five months, a period full of pressures, trials and tribulations which give cause for me to offer my excuses and apologize for any errors, lapses and oversights. Clearly time can be adapted to the ebb and flow of pressures in relation to one's endeavors. And such times that many spend in places of entertainment and in a state of idleness can be spent in producing works of benefit to them and to the children of their homeland.

When someone is of no benefit to any other, Losing or gaining him, for me, does not matter.

\section{Translated by Ruth Abou Rached}

\section{COMMENTARY}

From his life and times to the present day, the eminent scholar Butrus alBustani (1819-1883) occupies a unique place in the field of translation and literature in the Arab world. Known, with a measure of hyperbole, as the 
"father of the Arabic Renaissance," or al-Nahda (Luce 2016), al-Bustani played a unique role in revitalizing, and adapting Arabic as a vehicle of communication, educational reform, "acculturation" to modernity and East/ West knowledge exchange during the Ottoman era. Believing that Arabs should learn from "Western" science and civilizations, al-Butrus left an impressive legacy working to that end: his vast-ranging Arabic dictionary (1870) and the first six volumes of an encyclopedia, starting in 1876.

Al-Bustani played a significant part in the American Protestant Mission's Bible Translation project (Hall 1885), which published the first Protestant version of the Old and New Testament in Arabic (1865). Al- Bustani made a huge contribution to the translation of European literature into Arabic during the Nahda era, of which this Arabic version of Robinson Crusoe is a prime example. As noted by Hanna (2016), in contexts of Arabic versions of Shakespeare, it is important to note that the act of translating literary works from "the West" into Arabic in this era held varying degrees of prestige, depending on the genre of the work translated, its intended audiences and the perceived "embodied cultural capital" (2016: 38) of the translator himself. In other words, "the range of knowledge, skills, cultural, artistic and political preference" (ibid.) the translator was perceived to have denoted not only the status of the translated work, but its intended audiences and the translator's authority to use particular strategies for its translation. For scholars such as al-Bustani, the praxis of incorporating outside (Western) knowledge tailored to local audiences was embodied in their translation strategies of focusing on content rather than form. The contemporary common practice of adapting or rewriting foreign works instead of straightforward translation (Patel 2013: 176) involved high visibility for the translator, sometimes reinforced in the peritextual material. Translator prefaces, footnotes, and epigraphs were employed by Nahda literary translators, of which al-Bustani made overt and extensive use when setting forth his version of Robinson Crusoe.

On the title page, al-Bustani puts forward two titles which separate and overlap the prestige of the translator with the prestige of the translated novel itself: The Bustanian Gem of the Crusian Biography and The Voyage of Robinson Crusoe. The first title situates the work as part of al-Bustani's iconic literary status; the second is an explanatory, near literal, translation of the English title ("Adventures of Robinson Crusoe"). In the epigraph, al-Bustani presents himself as "master," teacher and someone responsible for-as well as in charge of - all stages involved in this work's production, alluding to the status of accountability for a literary translator of his stature. He uses three terms to describe his role: he translated or interpreted the book, he "made it polite or "refined" it" for particular audiences, and, on a commercial/practical level, he oversaw the processes of printing production.

His presentation of himself as central to the work-with no mention of the novel's English language author-foreshadows two critical aspects of his translation strategy set out in his preface: one, his cultural competence to select as well as translate canonical texts from the "West" into Arabic, 
and, two, how his translation strategies connected to focus on education and women's access to reading in the Nahda era. The three verses on this inner cover-which come from the early Islamic poet Ka'b Ibn Zuhair (d. c. 647) - could be read as al-Bustani's assertion of his own personal agency alongside a recognition of humanity as "one soul" with shared concerns: he poetically communicates that this work is for the present and the future, its reception in either unpredicted, so not universally catered for.

In contrast to the poetry on the title page, al-Bustani's preface sets out a much clearer, more unequivocal stance towards his act of translating this work, which he describes as five months of agonizing deliberation: that the presence of this work in Arabic will benefit the homeland for educational and cultural reasons, as it will appeal to both school age children, girls as well as boys. Significantly, al-Bustani makes particular reference to the presence of adult women in Arab world readerships, as well as girls in schools, to justify his translation strategy of "refining" the Arabic work. Of particular note is how he frames his strategy of refinement within wider literary scenes: removing "inappropriate words and references," for the benefit of "those of the feminine sex, for whom attention is needed." Not only is al-Bustani here ensuring the novel's content was suitable to women as well as "children of the homeland" within the expanding world of Arabic readerships; he also explains why he took full charge of the translation and the printing. His supervision of the whole process of the book's production alludes to his own sense of authority in ensuring the correct register of Arabic was disseminated within wider established and emergent reading publics, under the auspices of his literary prestige. At the same time, his unwillingness to entrust any aspect of the task to anyone else alludes to the sense of risk he felt towards exposing new readerships to different literary works.

For al-Bustani, along with other Nahda intellectuals, literary translation was one way of facilitating the Arabic language to become a viable vehicle of learning and cultural exchange. A printed book, then, was for him more than a novel: it represented a political ideal working to find its way to its target audiences via an emergent publishing and printing industry, whose multiple (and usually commercial) stakeholders held different priorities.

\section{Ruth Abou Rached}




\title{
31 The Bible, that is the Old and New Testaments, Newly Translated from the Hebrew and Greek Languages [The Protestant Translation of the Bible] (1865)
}

\author{
Eli Smith, Cornelius Van Dyck, Nasif al-Yaziji, \\ Butrus al-Bustani
}

\section{Eli Smith (1801-1857)}

American missionary and translator who was born in Connecticut. He graduated from Yale University in 1821, the Andover Theological Seminary in 1826, then moved to Malta for missionary work in the same year. He was fluent in Greek, Latin, and Hebrew. He traveled to Beirut to learn Arabic and returned to Malta in 1827. He went on a 16-month expedition with Harrison Dwight in Anatolia, Georgia, Persia, and Armenia, described in the two volumes of Missionary Researches in Armenia. The American Syrian Mission in Beirut commissioned him to direct the project of translating the Bible into Arabic, to which he dedicated the last ten years of his life. Following his death, the task was completed by Cornelius Van Dyck. Sometimes his name is Arabized as 'Ali (literally "high").

\section{Cornelius Van Dyck (1818-1895)}

American missionary and physician. Born in Kinderhook, New York, he graduated from Jefferson Medical College in 1839. In the following year, he was sent as a physician to the Levant, beginning by traveling to Beirut and then on to Jerusalem, during which time he began to learn Arabic. Upon settling in Beirut, he studied Arabic language, grammar, and literature under the tuition of Nasif al-Yazji and Yusuf al-Asir. He also founded the 'Abeih Village school and compiled a number of textbooks in the Arabic language. After the passing of Eli Smith, he headed the project of the Arabic translation of the Bible. Van Dyck wrote a number of books in Arabic, including Usul alKinim $\underline{y} \underline{a}^{\prime}$ [The Principles of Chemistry] and Usul al-Hai' a fi 'Ilm al-Falak [The Principles of the Science of Astronomy] as well as translating the book The History of the Reformation in the Sixteenth Century into Arabic. 


\section{Nasif al-Yaziji (1800-1871)}

Poet and linguist. Born in Kfarshima, Mount Lebanon. At a young age, he was employed as a secretary to Prince Bashịr al-Shihabi II, governor of Mount Lebanon, for 12 years. Then he moved to Beirut, where he dedicated his time to writing, teaching, and composing poetry. He worked alongside Butrus Al-Bustani on editing the first part of his dictionary Muhit al-Muhit. His wrote several books on linguistics and rhetoric, as well as a collection of poetry.

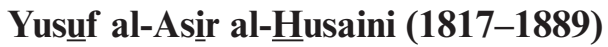

The only Muslim contributor to the Protestant translation. Born in Sidon in 1817, he studied in Damascus and Cairo, where he graduated from the eminent al-Azhar University. He was a scholar, poet, educator, and editor of two literary magazines, as well as the official Jaridat Lubnan (Lebanon Newspaper). He also served as a teacher at the Teachers College in Istanbul and as the Mufti of Acre.

\section{Butrus al-Bustani}

See Chapter 30.

\section{Note on the Protestant Translation}

The first edition of the translation was published in 1865 without prefatory material on the translation, and has been known since as the "Smith-Van Dyke" version. However, this name disregards the substantial contribution made by the other, Arabic-speaking participants in all the stages of the translation, as can be seen in the texts below. In fact, modern Arab Biblical scholar Ghasan Khalaf argues that the role of Smith and Van Dyke was primarily administrative, besides revising the translation for theological principles. The bulk of translation, he argues, was handled by al-Bustani, while Nasif al-Yaziji revised the work for grammar and style (Khalaf 2009: 5; see also Jessup 1900: 2ff). Therefore, Khalaf argues that the translation would be more aptly called "al-Bustani-Van Dyke." 


\title{
32 The Seekers' Guide to the Precious Bible (1869)
}

\author{
Simeon Calhoun
}

\section{Simeon Calhoun (1804-1876)}

Born in Boston, he graduated from Williams College in 1829. Although he did not attend a seminary, he studied theology under the tuition of theologians at Williams College. Calhoun was ordained in 1836, then left the United States to become a missionary. He studied Arabic while residing in Syria as part of the Mission of the American Board, and after two years, was able to give sermons in Arabic. The British Commissioner in Beirut appointed Calhoun as his counsel in the wake of the religious violence in Mount Lebanon in 1860.

\section{Murshid al-Talibin ila al-Kitạb al-Muqaddas al-Thamin (The Seekers' Guide to the Precious Bible)}

Written by Calhoun and a "select group" of theologians, this book is made up of three parts. The first is an account of the Bible and the beneficial principles of its reading. The second provides details on specific books of the Bible. The third covers a range of themes, including the manuscripts of the Bible in different languages, especially Hebrew and Greek, and its translations of into other languages, including Arabic. The first edition was published in 1840. We have cited the third, expanded edition (1869), in which Calhoun discusses the recent Protestant translation.

\section{[THE VERACITY OF THE BIBLE AND ITS UNIVERSAL NATURE]}

\section{Part 1: Chapter 6: on the authenticity of the Holy Bible}

The Books of the Holy Bible provide us with the clearest, strongest and most certain of proofs in its authenticity and its faultlessness. The Books of the Old Testament were written and compiled with great care and attention by its God-inspired prophets, a care also made manifest by its translation into Greek nearly three hundred years before the Advent of Jesus Christ, for the benefit of the Jews living in towns where this language was in use. Also borne witness

DOI: $10.4324 / 9781003247784-35$ 
to in the Old Testament read by the Jews in Hebrew is the Coming of Our Redeemer, the citations of which are written in books of the New Testament, particularly in the Greek translation that supports and relays the words as written in its ancient form. Its authenticity becomes more apparent when we see how the Jews have preserved the Old Testament, as the most holy of their Holy Books, with and despite the various prophesies alien to their infidelity, and which promote, spread and make victorious Christianity. Importantly, these prophecies still remain present, despite their fierce opposition to the call [to Christianity] and the fact that their enmity was prophesied.

All of the books recounting the events taking place in the New Testament were written and distributed by people who had lived during these times. Each book is named after the person who had written it. The proof of its authenticity is further fulfilled, firstly by the sequential manner in which the Christians compiled these Books during the times of these prophets until this time we live in today. Secondly, the absolute conviction in the authenticity of the Holy Bible is shared by all denominations of Christianity. A third Proof of its authenticity is how enemies of the Christian Faith, amongst them scientists, attest to the Holy Bible.

No reasonable mind can deny that the books known to us as the GospelsMatthew, Mark, Luke, and John - were written by those to whom they have been attributed. Wherever these books have been read and distributed, all Christian scholars are agreed on their source of origin. We also have firm proofs and sources of reference showing that these books, and events on the sayings and works of Jesus Christ related within them are fully true and correct. Matthew and Mark were Disciples of Our Redeemer and were dedicated to Him throughout the duration of His time of service on earth, and so were eyewitnesses to the events they cited, and what they heard of His sermons.

Although Mark and Luke were not of the Twelve Disciples, they wrote Epistles, and were familiar with whomsoever witnessed what they write in their Books. Many believe that Luke was one of the 70 Apostles called on by the Lord to spread the Good News in the Holy Gospels. For this reason, they must have been as well acquainted with Jesus Christ as were the Twelve Disciples, and were, in any case, close companions of St. Paul for many years $[\ldots]$

Aside from these accounts, these Apostles of Christ wrote what is in the Holy Gospels of Jesus Christ through being inspired and moved by the Holy Spirit, which delivered them from all error and lapses in the writing of these true Holy Books in order to teach the nations and all future generations of followers, and to redeem and sanctify them.

By the power of the same Spirit, the Apostles were moved to write Epistles to the newly founded Churches, according to what was promised by their Teacher, Jesus Christ. It is in the first of this second generation of followers that the majority of the books of the New Testament were compiled into one book. In the first instance, it was the Epistles and Gospels which were 
compiled via different Churches, far away in distance from each other, so it was not clear which version was true and correct. Because so many Books attributed to the Apostles were in fact fakes, and had been spread in many different regions, many churches were doubtful of accepting the Epistle of Saint Paul to the Hebrews, as well as the Second Epistle of Saint Peter, the three Epistles of Saint John, the Epistle of Saint Jude and the Book of Revelation. When these Epistles were closely examined, however, it became manifestly clear that they were truly compositions of the Apostles of Jesus Christ and inspired by Him. In this way, these were accepted by all churches like the other books of the New Testament.

Concerning preservation, the first versions of the Bible were lost. The Books of the New Testament were preserved, however, without falsification or any fundamental lapses, meaning that they were kept exactly as they were when written by their first writers in all of their different circumstances. Clearly, however, in the copying of the Books, errors occurred over time, due to the absence of printing in those times, which has led perhaps to some omissions, changes and misrepresentations of some of the letters or words in some versions. No error exists in relation to the fundamental teachings, nor the dates mentioned in them at all. This is because at the time when the original versions were distributed, many proselytizing traveling priests made copies to take to different churches. At the time, they took it upon themselves to translate the Bible into various languages, and so it became distributed far and wide, with many Christians devoting themselves to reading it at their gatherings, even learning full passages of it by heart. Many historians would cite and reference them in books of learning of many different forms, including those offering knowledge inspired by the Bible itself. [...]

There are many versions of the Holy Books with errors stored and gathered on all manner of bookshelves in all lands where Christians reside. Men of knowledge have meticulously examined about five hundred of such books and have accepted them after extensive editing and refinement. Many versions of the Holy Book go back to the eighth, seventh, sixth, and even the fourth centuries. It is in this way that we come back to the time of the Apostles who first spread these books. The sheer number of such books, and the geographical distance between different countries where they are found, as well as how their meanings and contents concord with the citations of their forefathers across such different times is another proof of the authenticity of these books. Scholars have stated that even if the New Testament had been fully lost, its content could be re-compiled through the citations taken from it, existing in the books of the first four generations of the Church. For much of the Word is still to be found in these very versions [...]

\section{Part 1: Chapter 8: of the translation of the Holy Bible}

Something which further confirms the authenticity of the Torah is its translation. We do not know of any translation existing before the Septuagint 
version was translated from the Hebrew to the Greek in Egypt, circa 280 в . [...] This is the first translation [...]

\section{THE SIXTH: THE ARABIC TRANSLATION}

We do not now know when the New Testament was first translated into Arabic. The four Gospels may have been translated during the seventh century, and the by the eighth or nineth generation, from which many other translations were made. Some of these translations came from the Greek, some from the Syriac and some from the Coptic. The Four Gospels were first printed in Rome in 1591, in Holland in 1616, in Paris in 1645 and in London in 1657. It is thought that these last three versions of the Four Gospels were translated from the Greek, and the others from the Syriac or the Greek.

The translation that was circulating in recent times is not modern, in that it emerged from amongst the seventeenth-century Christians. Sarkis al-Rizzi, the Bishop of Damascus, requested permission from the Pope to create a printed version of the Holy Bible, as the versions present among them at the time were full of errors, and the Pope granted permission. In 1620, this same Bishop began with a number of scholars to gather the various Arabic versions of the Book and compare them to the Hebrew and Greek versions, and in particular with the Latin version, known as the Vulgate. In 1671, they presented the printed Arabic version to Rome in the form of three books bound alongside the Latin version. Many copies of this version, with the apocryphal books ${ }^{1}$ removed, were printed in London before the new Arabic translation in Beirut was published $[. .$.

As for the new version, newly translated in Beirut, we can make more detailed mention of it here in that we know the people involved in it, and the means and ways by which they did so. What we can say is that many of the Arabic translations of the Bible existing before this version were found, upon close examination, to be completely lacking and at extreme variance from each other, with the majority of them not being translated from the original languages of the Holy Book. For this reason, it was decided that the entire Old Testament be translated from the Hebrew, and that the New Testament be translated from the Greek.

Father 'Ali Smith from the Mission of the American Board undertook this work in 1837 [...] and in 1848, Father Smith embarked on the translation with the help of Lebanese scholar Butrus al-Bustani, and they both worked on it together until the passing of Father Smith on the 2nd of January in 1858. By this time, they had produced a translation of the five Books of Moses, the New Testament and various sections of prophets, and had begun printing the Old Testament.

After the passing of Father Smith, Father Cornelius Van Dyck, another American missionary, took up the work, checking and proof-reading all of the books which Father Smith and Butrus al-Bustani had translated, then he translated the remaining parts. The full translation of the Holy Bible was 
completed on the 23rd of August, 1864, and the first print was made on the 29 th of March 1865. However, the New Testament had been completed before this date and printed several times, the first print in March 1860.

It can be reliably said that this was the work of Father Smith in the first instance, followed by Father Van Dyck, in that they both showed great care and diligence in producing a perfect translation and in printing and compiling it in the most exact way possible. And it was due to their care and diligence that they sent off thirty proofs before the final version was made public to the most eminent of scholars, Muslim, Christian, Arab, and foreign (non-Arab) alike, residing in different areas of the world, including Syria, Egypt, Lebanon, and even Germany, in order to receive critique on the translation and the use of Arabic language, and to write down on the margins in terms of God-inspired commentary and opinion. After all these drafts [with comments] were sent back to them in Beirut, the center of this project, they were refined, and polished; those found to be pertinent and acceptable were implemented - meaning that many brilliant minds of Arab and foreign scholars truly contributed to the compilation of this important work. One scholar whose knowledge they particularly drew on to refine the Arabic grammar and make the prose of the translation read more elegantly was Shaikh Nasif [alYaziji] the Lebanese and Shaikh Yusuf al-Asiri al-Azhari.

As the people mentioned above who created this translation are all alive today aside from one, we have held back from describing them and mentioning their vast knowledge, outstanding language skills, and fidelity to this work because their fame precedes them. What we can say, in short, for the benefit of the eminent scholars currently residing further afield, is that all people involved endured many trials and tribulations for its sake for a great number of years, which is why we are completely certain that this Arabic translation of the Bible is the truest and most accurate version amongst all the other translations, and will be a source of reference and sustenance in years to come. We pray to God that He render this Book as a benefit to all.

Lastly, we must mention that the Holy Bible was translated into Armenian during the earlier times of the Fifth Generation of the Church. It was translated into Persian in olden times, according to Saint John Chrysostom. It was first translated into French around 1160, Spanish c. 1380, Austrian c. 1460, and English 1380. We can see that the Mercy of Godly Beneficence has been made manifest in all of these scholars being available to translate the holy books, so that now there are around 200 languages in which God's commands are read, with more than 150 of these receiving the translation of the Book during our current century.

\section{Translated by Ruth Abou Rached}

\section{COMMENTARY}

This book is written by a scholar who learnt Arabic as an adult while carrying out Protestant missionary work in the Levant under the patronage of ABCFM 
(American Board Committee of Foreign Missions). Like many written records by missionaries in the region, this publication sheds light on prevalent commentaries and discourses on Bible translation as a source of knowledge and community building within Arabic-speaking Christian communities during late Ottoman times. Their commentaries also give insights into how the American missionaries saw their role in the lands of the Ottoman Empire, a role which has been cited as an example of "evangelical piety" and "disinterested benevolence" (Grafton 2015: 2). This particular work by Calhoun reads as a "reference guide" as well as historiography to reading the 1865 translation. Although clearly associated with the ABCFM, Calhoun makes no mention of his denomination: instead, he sets out a history of the Bible's translation and then frames the 1865 version as a source of knowledge for all denominations of Christianity. To further emphasize a politics of commonality, Calhoun emphasizes the Torah (or the Old Testament) and the writings of John Chrysostom as two foundational texts in the history of Christianity.

In view of controversies arising from the 1865 Arabic version of the Bible - including the status of the Arabic speakers working with the American missionary translators Smith and Van Dyck (Binay 2012: 83) Calhoun's decision to write this work in Arabic is significant. Writing in Arabic directed his commentary to specific target readerships: literate Arabic readers who had the means and time to read and engage with notions of historiography connected to faith as a "tool" by which craftsmen show the quality of their work. The history of the Arabic Bible's translation found in Calhoun's commentary is reiterated almost word for word by Van Dyck in his 1883 correspondence with Isaac Hall (1885) which suggests a prevalent "narrative" involving "translation" on a number of levels. First, an American missionary was "translating" a version of denominational unity. Second, Calhoun's account of the Arabic Bible's historiography "translates" a belief structure the Protestant missions prioritized within the Ottoman Empire: detailed knowledge of the Bible, rather than baptism or being born to a Christian, did not count for making the Church fit for receiving converts (Murre 2008: 464). Thirdly, his writing in Arabic, not English, was a crossing of his own unspoken boundary: he was addressing Arabic readers, not the personnel of the ABCFM. In this way, Calhoun seems to be supporting the "silent" cross-border work enacted by all involved with the 1865 version of the Arabic Bible detailed by Grafton (2015): all of the translators, American and Arab, had to contend with potential tensions from their own religious group, be it ABCFN in the case of Smith and Van Dyck, different Christian denominations in the case of al-Bustani and al-Yaziji, different Islamic perspectives towards the Protestant Bible for al-Asir (Grafton 2015: 234). In retrospect, Calhoun's solidarity with this cross-border work via the Arabic language provides a c/overt response to past and future accusations levelled at the 1865 Protestant Bible as adding (yet) another sectarian discourse to an already sectarian area of the Ottoman regions (Tibawi 1966: 48) (see also The Jesuit Translation, Chapter 35). 
When telling the Arabic Bible's history of translation, Calhoun focuses on three crucial aspects of the Old and New Testaments which testify to its "proof": first, the prophets of the Old Testament were inspired, thus making the Old Testament free from fault or blemish, be it in Hebrew or translated from Hebrew into Greek; second, the New Testament was written by those living at the times of events; three, despite the best efforts of the enemies of Christianity, no scientific thought has been able to disprove anything in the Bible. The first and second aspects of the Bible's "proofs" echo the lines of argument made by Jewish and Christian scholars during the classical era towards Muslim scholars' accusation of tahrif (distortion) (LazarusYafeh 1992). The third aspect refers to more contemporary debates on the relationship of science and religion prevalent in the 19th century.

After explaining how moral rectitude precluded doubt, Calhoun reiterates the Bible's veracity by confirming how the texts were "closely examined" to explain how the first "pure" version can be verified. For this reason, any mistakes or errors occurring in copies of the "true" Bible could be attributable to human error. In this light, Calhoun states the Bible has no fault in its fundamentals, and then lists the languages and locations of various translations of the Old Testament throughout ancient and contemporary history.

In his listing of the books in the Old and New Testament, Calhoun makes no direct reference to denominational differences between books included by the Catholic and Orthodox and excluded by Protestant churches. When citing the first translations in European countries, he makes no reference to the tempestuous times of the Christian Reformation in Europe either. He simply cites the first Bible translated into Italian in 1591, and printed elsewhere. In terms of the Arabic version, Calhoun presents its current translation as inspired by localized Christian fellowship connected to Rome throughout history. He recalls how the Bishop of Damascus called on Rome for assistance in 1630 to clear the Arabic versions of the Bible from all mistakes. Calhoun thus situates the subsequent exclusion of "apocryphal" books from the Bibles available in the Arab world as non-denominational and localized decisions. And from this basis, the current 1865 version of the Bible carried out under the auspices of the ABCFN emerges.

When describing the 1865 version, the focus of Calhoun's commentary switches from the historiography of texts to a description of translators: he refers to Smith working alongside al-Bustani, then Van Dyck finishing the work, following Smith's death, alongside Muslim scholar al-Asir. Calhoun frames his refusal to write of the individual attributes of the translators for one reason: they are still alive at the time of his writing. This glosses over what Isaac Hall in 1885 cites Van Dyck as describing in terms of a practical difficulties faced: Smith working from more than one Greek version of the New Testament; Van Dyck being ordered to translate the whole New Testament from scratch (Hall 1885: 279) - discourses of conflict with the ABCFM. 
Like Van Dyck, Calhoun elucidates more information on the real practical difficulties of producing this Bible, then swiftly explains how the book was translated into Armenian and other Eastern language to reach 150 languages in the world. In this way, he seemingly promotes a message of one Bible existing via many different historiographies and languages as mirroring the narrative of the disciples disseminating the Word of Christ in different languages via the Holy Spirit. Yet, unlike earlier accounts of the Holy Spirit (such as alKindi's), Calhoun presents the "modern" narrative with minimal focus on the human agencies at play in the Arabic translation. And while referring to practical difficulties faced by Smith and Van Dyck, Calhoun makes no mention of any difficulties faced by al-Yaziji, al-Bustani, and al-Asị working alongside them. In other words, Calhoun reiterates the silent "narrative" in the paratexts of the 1865 version itself to Arabic readers: he only cites the names of Smith and Van Dyck.

However, in view of the evidence presented by Grafton (2015) and Hall (1885), translator co-collaborator cannot be discounted in this respect, particularly in light of the extremely charged sectarian contexts of Lebanon at this time (Al-Jaburi and Al-Jabiri 2015). Foregrounding the names of Smith and Van Dyck in the production of the 1885 version may have been a collective decision taken on by all translators involved, not necessarily one of "disinterested benevolence." Calhoun's narrative respects this decision and, in his Arabic, reiterates silent solidarity with them. In this respect, this Apology "translates" something of Calhoun and his long-term commitment to his habitus in Lebanon by his decision to translate himself, articulating his core beliefs wholly in Arabic.

\section{Ruth Abou Rached}

\section{Note}

1 i.e. the books recognized by the Catholic Church, but not by the Protestant Church. 


\title{
33 Proofs of the Fundamental Truth of Christianity (1877)
}

\author{
James Shepard Dennis
}

\section{James Shepard Dennis (1842-1914)}

Born in Newark, New Jersey, he studied at the Princeton Theological Seminary, where he received a $\mathrm{PhD}$ in theology. He taught at the Beirut Theological Seminary, where he wrote three books in Arabic for use in classes. He returned to the United States in 1891, and wrote several books on missionary work. His works include Christian Missions and Social Foreign Missions after a Century, and a contribution to Progress World Atlas of Christian Missions.

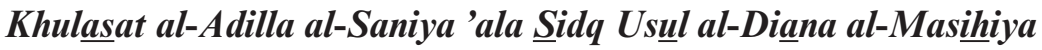 (Summa of Supreme Proofs of the Fundamental Truth of Christianity}

In this book James Dennis brings together proofs of the veracity of the Christian faith, in response to critiques prevalent at the time. In this chapter, he defends the translation produced by the American Mission in Beirut.

\section{[ON THE ACCURACY OF TRANSLATION]}

Concerning the Arabic translation of the Bible newly translated and printed in Beirut by the American Missionaries, we can confirm to the reader that there is no other more accurate or correct translation existing in the world. The New Testament has been carefully translated from the famous version printed by Robert Stephanus in 1550, which was the outcome of the great efforts of Erasmus, [Theodore] Beza, and the aforementioned Stephanus, who were amongst the most famous scholars who meticulously studied the New Testament in its original language, and who, besides relying on the labors of those going before them, went about gathering hundreds of versions and exerted much effort to establish a version that was true and free from all mistakes and errors. Their efforts were so successful that the text they printed remains under the title given to it then, viz. "The Received Text" [Textus Receptus]. This text has been accepted by the two world-renowned 
American and British Missions, as well as others, and has been the basis of the many translations made at their expense in many other languages. All of the knowledge produced by eminent scholars of renown and piety across the generations since this version first became well known confirms its accuracy in every aspect of all its fundamental attributes. The consensus is that any errors present in this version are trifling, and are not considered to be anything that would prevent the light of faith from reaching us in the form in which it was originally given to the world.

As for the Old Testament, it has been translated from the Masoretic text (named after the Jewish scholars [the Masoretes] who were dedicated to verifying the authenticity of the Hebrew text, and who divided it into verses and paragraphs), which is certainly the authentic text preserved from the days of Ezra until this day through the care and devotion of the whole Jewish community the world over. This text has been translated into Greek and Latin, as well as other languages, and the matching of these translations ascertains their authenticity.

However, we would not venture to say that any error in this [American Mission] translation is impossible to find, in the same way, that we would not venture to say this concerning the translation of any other text in the world. But at the same time, we know that there is no other translation in another language better and more correct than this one. Moreover, there is also commentary concerning all possible readings of particularly important passages and opinions worthy of mention on the meanings that are other than that which is recorded in the text in the margins of this version, which alert the reader to this.

Let the reader rejoice at finding the Book of God as true and accurate to this extent,

And let him divest from his mind, in this respect, all doubts and fears.

\section{Translated by Ruth Abou Rached}

\section{COMMENTARY ON THE PROTESTANT TRANSLATION}

The Protestant Arabic Bible was one of the most influential translation projects in a period that can rightly be called an age of translation. The controversies it sparked in the Arab East reverberated through the local Christian communities and beyond. Competing translations soon appeared under the patronage of rival churches (similarly financed by European missionary institutions), most notably the two Catholic translations: the first patronized by the Dominican Fathers in Iraq (1871-1875), and the more famous one by the Jesuit missionaries in Beirut (1876-1881; see Chapter 35). The resulting disputes, involving translators and Christian scholars on all sides, were so intense that they escalated to ad hominem attacks and accusations of manipulation, distortion, and heresy. 
Early Protestant missionaries in Ottoman Syria relied on the Catholic al-Rizzi translation, ${ }^{1}$ but only after removing Biblical books that are not recognized by the Protestant Church (Hall 1885: 278), which "caused turmoil and contentions throughout Syria" (al-Tibawi 1968: 334). It should be noted that the omitted deuterocanonical books, while accepted by both the Catholic and Orthodox churches, are not as highly revered by the latter. The term "deuterocanonical" (i.e., "of the second canon") designates secondary authority among Orthodox Christians, but only a chronological one among Catholics (as these books were canonized later than the rest of the Bible). This is perhaps why the disputes occasioned by the Protestant Bible, and the translation projects that emerged in response, came predominantly from Catholic quarters.

The initiative for a new, full Arabic translation of the Bible was taken by the American Protestant Mission in Syria (based in Beirut). The project was headed from the beginning by Eli Smith, who had arrived in Syria 1826 and been in charge of the mission's Arabic press. In preparation for the formidable enterprise, Smith took Arabic lessons with local instructors, especially the renowned scholar Nasif al-Yaziji. Under Smith, a printing press with a new Arabic type was brought in from Malta for the purpose of the translation (alTibawi 1971: 752-755).

Translation proper started officially in January 1847. Smith was appointed to this task by the Syrian Mission, and the necessary resources were made available to him, based on a proposal submitted by a committee headed by himself; the other committee member was Cornelius Van Dyck, who would later play a crucial role in the translation.

Previously in 1844, Smith had submitted a report in which he had stressed the necessity of producing a new translation of the Bible, as the version circulating in the country was "reprinted from the edition of the Romish propaganda, which appeared in 1571. ${ }^{2}$ That edition was corrected from an ancient translation, the origin of which I do not know" (qtd in Jessup 1900: 1). Smith criticized al-Rizzi's version for following the Latin Vulgate, and also because the "structure of the sentences is awkward, the choice of words is not select, and the rules of grammar are often transgressed" (ibid.). In fact, Protestant missionaries had "been ashamed to put the sacred books of our religion, in such a dress, into the hands of a respectable Muhammedan or Druze" (ibid). He concluded that "we cannot expect a strong thirst for the Scriptures to be created in the public mind, nor that much effect will be produced by them, until we present them in a purer form" (quoted in Jessup 1900: 2). Smith fully realized the magnitude of the objections that the proposed project would face. Interestingly, he anticipated that they could help promote the new translation: "we have no doubt that its appearance would raise a great clamor against us from our enemies, which might go far towards assisting it at the outset" (quoted in Jessup 1900: 3).

Smith undertook the translation in collaboration with Nasif al-Yaziji and Butrus al-Bustani, another major Arabic scholar. A main principle of 
the translation method was to give the text a "native coloring" by "bringing into it the terms and phrases in common and good use to express the ideas of the original" (Jessup 1900: 8). This was the task of the native "helpers." With regard to the general style of the translation, it was agreed "to adopt a simple but pure Arabic, free from foreign idioms, but never to sacrifice the sense to a grammatical quirk or a rhetorical quibble or a fanciful tinkling of words" (Jessup 1900: 28). As to whether the translation should use Islamic or Qur'anic terms, "All naive Christian scholars decidedly objected to this" (ibid.).

Upon the death of Smith in 1857, the continuation of the translation was entrusted to Van Dyck, who enlisted another native "helper," the Muslim scholar Yusuf al-Asiri, an Arabic teacher and a graduate of the renowned al-Azhar University (al-Tibawi 1968: 337). The complete translation of the Bible was published by the American Mission's press in 1865, under the title The Holy Bible, that is The Old Testament and The New Testament, Newly Translated from Hebrew and Greek.

Notwithstanding the "native coloring," accuracy was undoubtedly the Protestant missionaries' primary concern. Thus, affirmations of accuracy and fidelity to the original texts are the main commendations for the new translation repeated consistently in the secondary literature produced by members of the Mission, as we have seen with Simeon Calhoun, who was in close personal contact with the translators, and James Dennis, who was also affiliated with the Mission. Hence Dennis's emphatic statement that "there is no other more accurate and correct translation existing in the world."

\section{Tarek Shamma}

\section{Notes}

1 We found this to be the most convenient (in fact, the only feasible) term for this translation, even though al-Rizzi, the initiator and early driving force, died before the translation was completed.

2 Al-Rizzi's translation was actually published in 1671 (see al-Rizzi, Chapter 26). Smith refers to him as "Sarkịs al-Rur, a Maronite bishop of Damascus" (ibid.). 


\title{
34 Revealing the Hidden Arts of Europe (1866)
}

\author{
A $\underline{h}$ mad Faris al-Shidiaq
}

\section{Ahmad Faris al-Shidiaq (1803-1887)}

Linguist, journalist, and man of letters of wide interests, and a major figure of the Nahda. Born in 'Ashqut in Mount Lebanon, he moved to Egypt when he was 20, then spent his life traveling in Europe and the Near East. He lived in Malta for several years, where he ran the American missionary printing press. Then he moved to Europe, living for extended stays in England, where he became a British citizen, and France. He moved to Tunisia upon the invitation of the governor to work as a newspaper editor. There he converted to Islam (having converted in his youth to Protestantism from Maronite Catholicism)

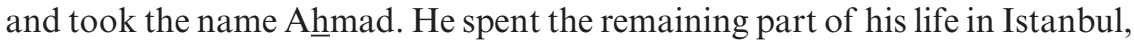
where he established and edited the Arabic magazine al-Jawa $i b$. Some of his best-known works are accounts of countries he visited-Malta, England and France, and Europe in general - characterized by erudite, and sometimes whimsical wit. His linguistic works include encyclopediac studies of Arabic dictionaries and an exposition of English grammar.

\section{KASHF AL-MUKHABBA 'AN FUNUN URUBA (REVEALING THE HIDDEN ARTS OF EUROPE)}

A personal account of the author's life in Europe, especially in England and France, dealing with his scholarly pursuits as well as providing penetrating accounts of social life in these countries. Like many contemporary Arab scholars, al-Shidiaq analyzes the causes of Europe progress, and potential lessons for an Arab renaissance.

\section{[L-SHIDIAQQ ENGLISH TRANSLATORS]}

\section{The English pursuit of fame}

The Englishman is by nature keen to distinguish himself from his fellows by whatever expedient comes to hand, especially in matters of learning. Give an Englishman a smattering of Arabic, Persian, or Turkish, and let him write a 
book. He will fit into it all the words he knows in every tongue but his own, so that his readers may think him a prodigy in languages; yet he cares not a whit if he writes those words well or ill. The first page of his book offers a clanging parade of high-sounding titles, proclaiming the author a fellow of this or that learned society, the epitomist of such-and-such a volume, the author of one or another essay, the deacon of such-and-such a parish, and so on. But take up the volume and wring it out: not a drop of useful learning will trickle forth. This is because its author, innocent of instruction by native speakers, tosses off whatever explanation happens to suit him; and furthermore propounds this misinformation with no trace of embarrassment.

Consider Richardson, author of a work that embraces the Arabic and Persian languages as well as his own. ${ }^{1}$ As God is my witness, he knows our language not half so well as I know his. And yet he thought himself suited to the task of compiling a grammar of Arabic! ${ }^{2}$ The result is a comedy of errors. To illustrate the possessive construction, he gives us qadahun faddatin, "a cup of silver or a silver cup," mulkun Kusrin, "the kingdom of Cosroe or Cosroe's kingdom," ra'sun ammanin, "the head of an ideot [sic] or an ideot's head,"3 al-ghalibu 'ajami and ghalibu 'ajami, "the conqueror of Persia," kitabun Sulaimanin, "a book of Solomon,"5 nasira 'Aqabahi, "two assistants of Akbah," nasiru 'Aqabahi, "assistants of Akbah," and al-nasira 'Aqabahi, also "assistants of Akbah." In his citation of the Arabian Nights story about the witless fellow who imagines himself wed to the daughter of the vizier, he translates the sentence "I will be treated with the respect I deserve" as "I will not give liberty to my soul (spouse) but in her apartments." ${ }^{8}$ In the sentence "I will continue in this manner until her unveiling is complete," he misreads jalwah (unveiling) as jald (flogging), and translates: "I will not desist thus until I complete her distress." In a comment on the phrase "all those present" (kull man $\underline{\text { had }}$ ar), he declares that " $\underline{h}$ adhar and the feminine $\underline{h} a \underline{d} a h$ " are analogous to "majesty, highness, excellency, \&c, with us." 10 These instances should suffice to condemn the entire work.

When an Englishman translates a book, he covers it with patches of his own invention, and recasts it to suit the mold of his language. I have read many of their translations from Arabic, and found them to be recast in a manner utterly alien to the notions of the original author. So it is that I have read, in the English rendering of a proclamation in which the Sultan urges his subjects to take up arms, the following: "The worshippers of Muhammad cannot attain salvation in this world or the next except by pursuing the jihad against the infidel." 11 Now then: does a Muslim describe himself as "worshipping" the Prophet? Nor have I seen any steer clear of this sort of travesty, except Mr. Sale, translator of the Qur'an; Mr. Lane, translator of A Thousand and One Nights; and Mr. Preston, who has Englished twenty-five of al-Hariri's Maqamat. Sale lived among the Arabs for many years and learned his Arabic from them, eventually gaining sufficient mastery to translate the Qur'an. So says Voltaire, at any rate; though I have my doubts, as Sale's introduction seems to say that he never lived on familiar terms with speakers of Arabic. 
Whatever the case, he rendered the text accurately. As for Lane, he dwelt long in Egypt, and was on intimate terms with local scholars and men of letters. Preston, similarly, traveled to the Levant, and befriended some of the natives. With the exception of these three, the English translate as if guided by the poet 'Aqil Ibn 'Alqama, who once said to the caliph 'Umar Ibn 'Abd al-'Aziz (717-720):

You take the high road

And I'll take the low road:

All roads reach Harsha eventually.

That is to say, it is a matter of indifference to them in what style a meaning is rendered. Should he come across an exclamation like "You and your religion can go to blazes," the English translator will understand that a man is being praised for the ardent, white-hot fervency of his belief, which burns up all other faiths - that is, sweeps them aside, by virtue of being the one true faith, much as God is called "a consuming fire."12 For them, knowledge of our language is merely a means of clarifying some oddment of another tongue, such as Hebrew or Syriac, both of which they hold in greater esteem; to say nothing of the fact that the professor of Hebrew at Cambridge receives a thousand pounds a year while the professor of Arabic receives only seventy. As soon as they learn a bit of our language, they compare it some feature of another, and are satisfied with having illuminated only the latter $[\ldots]$

[On his collaboration with Samuel Lee on an Arabic translation of the Bible, begun in 1848 and published in 1857 $]^{13}$

In the course of our work together, there arose certain disagreements, which I will presume upon the reader's patience to relate for the light they shed upon the Englishman's knowledge of Oriental idiom, especially as concerns Arabic. One argument arose because he endeavored to use the phrase huwa dha everywhere he found "lo and behold" in the Hebrew original. Nothing could deter him from saying things like "because lo and behold," "while it is lo and behold," and "he was, lo and behold, a man." He did not believe that "there is" or "there was" (itha) in sentences like "I went out and there at the door was Zaid" did the work of "lo and behold." He also wanted to do away with phrases like "a certain captain," which Arabic prefers to "a captain." Another dispute broke out because he wanted to retain the original by inserting "saying" after "said" in expressions such as "he said, saying." The latter is poor style in English too, which is why the English Bible often has "he spoke, saying," instead of "he said, saying." In figurative expressions like "to put forth a parable" (daraba mathalan, "to coin a parable") he would replace daraba with "to say," all because he had translated the word daraba to himself as "strike," which for him meant only "to cause pain by hitting." ${ }^{14}$ In "he saw their faith" ('alima i'tiqudahum) he would substitute ra'a for 'alima ${ }^{15}$ saying 
it better conveyed the sense; and he would argue that i'tiquad (conviction) was no synonym of iman (faith) - all because i'tiquad is derived from 'aqd (knot), which to his mind did not convey the sense of "belief." ${ }^{\prime 6}$ He would change "the water of the sea" to "the waters of the sea," 17 which is admissible, but only a maniac would insist on it. He was certain that ma yakunu lana was a better translation of "What shall we have" than ma 'asa an yakuna lana, ${ }^{18}$ and that min thamma meaning "hence" was a little-used phrase and could not do duty for "therefore" (wa-li-hatha). He also refused to believe that the word mu'jizat ("miracles") was a Christian term until we found it in a Greek Orthodox text.

Most of all, he was obsessed with avoiding, to the greatest extent possible, the use of rhymed prose and of elegant turns of phrase. He insisted that kharajtum ilaiya bi-'usiyin ka-lis $\underline{\text { s }}$ ("you came out against me with staves, like a thief" $)^{19}$ was rhymed prose. He tried to change it but could not, and let it remain as it was, but with a very ill grace. His fevered imagination said the same of nilta khayrataka fi hayatika ("thou in thy lifetime receivedst thy good

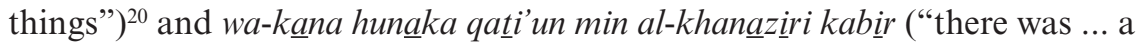
great herd of swine"), ${ }^{21}$ which, he said, was the sort of rhyme one must avoid placing in the mouth of God Almighty. Every time a period ending in - $\underline{u} n$ or -in caught his eye, he would declare it a mimicry of the Qur'an, and change it. Even the sentence wa-antum 'ala hatha shuhud ("you are witnesses to this") he said, "ends like a passage from the Qur'an," and so changed it to wa-antum

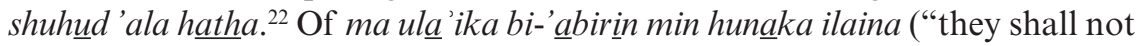
pass from thence unto us") he said, "That expression is too elegant," and put in ya'burun ("they pass") for 'abirin ("they shall pass"). I was not at all surprised at his meddling, but I was astonished that he had noticed the elegance of the original expression. He would claim that "there was a man whose name was So-and-so" was a more concise expression than "there was a man named Soand-so." Should the original contain an unnecessarily long-winded sentence, he would say "It is there for emphasis"; when he found a passage so garbled as to be nonsensical, he would call it "a rhetorical omission." He would try using expressions like "to be said" and "it chanced that he said" and "it so happened that he thought." I told him that "it so happened" cannot be used with verbs that refer to actions that take place as expected: you cannot, for example, say, "So-and-so came to see me and it so happened that he sat down," since sitting down upon coming to see someone is quite the ordinary occurrence. "But then," he replied, "you have not kept the original wording." Besides being, as far as I could see, too zealous a partisan of the Torah, he lived in fear of being censured by his rivals, of whom there were many.

In any event, no course is more foolish than to translate from one language to another using the same words and phrases, for it is inconceivable that one tongue should express itself in the same way as another. In Hebrew one may say of God that "there went up a smoke out of his nostrils," 23 and in Greek one speaks of "the bowels of God"; 24 now just try to say those things in Arabic!

When I pointed out to several learned Englishmen that such expressions are unworthy of being applied to God Almighty, all of them drew a comparison 
with "the face of God," 25 the eye of God, ${ }^{26}$ and "the hand of God," 27 failing to acknowledge the distinction between the higher and the lower organs.

\section{Translated by Michael Cooperson}

\section{COMMENTARY}

Known for his sharp wit, al-Shidiaq provides one of the earliest evaluations of Western orientalism in modern Arabic. His targets include their knowledge of Arabic and their methods in translation and linguistic analysis. Inspired sometimes by his own personal interactions with these scholars, alShidiaq's incisive comments could give us an outsider's informed, though unapologetically personal, view of the status of Arabic studies in some of the major English universities of the time.

Within this larger context, al-Shidiaq lends special attention to these scholars' excessively liberal translations, in which, as he puts it, they add patches of their own invention, and recast the original into the molds of their language. Of these generalizations, he makes exception for three of the most prominent English Orientalists of the time: George Sale, translator of the Qur'an (Alcoran of Mohammed, 1734), Theodore Preston, translator of the picaresque tales of al-Hariri (d. 1122) (Makamat or Rhetorical Anecdotes, 1850), and Edward William Lane, translator of the Arabian Nights (1839) and author of the 8-volume Arabic-English Lexicon (based on Arabic dictionaries, particularly the encyclopedia Taj al-'Aruss).

Especially prominent in al-Shidiaq's account is the contrast between the liberal translations of most orientalists and the literalist approach espoused so resolutely by Samuel Lee (1783-1852) in the Arabic translation of the Bible. The two collaborators approach translation from different angles. AlShidiaq adopts the common-sense view that "no course is more foolish than to translate from one language to another using the same words and phrases, for it is inconceivable that one tongue should express itself in the same way as another" (notwithstanding his rejection of the excessively adaptive methods of other English Orientalists). By contrast, Lee's literalism may have been influenced by the dominant English translation of the Bible, the then official King James Version. We can perhaps detect a direct instance of this influence in Lee's persistence, to al- Shidiaq's derision, in repeating the Arabic formulaic phrase اتفق ("it so happened"), which seems to echo the English "it came to pass." One of the most frequent, and stylistically distinctive features of King James Version (especially the Old Testament), it was usually employed as the English equivalent of the Hebrew ויהי, where it is primarily a discourse marker, and so is left out in most modern versions (van der Merwe 1999: 84).

Yet, this approach gains an added significance in the historical context of the Arabic Bible, as it marks the literalism that began to dominate translations since the mid-nineteenth century, represented most notably in the Protestant translation of 1865 (see above), and, to a slightly lesser extent, the Jesuit 
translation of 1881 (see below), which remain the most influential and widely circulated to this day.

The underlying motivation was (sometime explicitly, as in the Protestant Translation, Chapter 31) to fashion a distinctive Biblical style in Arabic, free from Islamic influences, even at the expense of deviating from idiomatic expressions, and sometimes grammar. So much so that some Arabic litterateurs have objected to these versions from a purely aesthetic perspective. For example, Taha Husain (one of the most influential literary figures of twentieth-century Arabic literature) expressed his frustration quite forcefully:

I do not know how to describe the pain that rises in me when listening to their prayers recited in broken Arabic, the least to be said about which is that it does not befit the dignity of any religion, or the type of linguistic education that Egyptians should all possess. Unable to contain this exasperation, I have sometimes expressed it candidly to some eminent Copts, on whom I impressed the necessity of giving due regard to a pure, correct translation of their holy books into Arabic.

(Husain 1938: 268). ${ }^{28}$

Mustafa Sadiq al-Rafi'i, another well-known Egyptian scholar from that period, criticized the Jesuit translation as "Arabized foreign jargon" written in a "twisted turn of phrase" (1924: 22-27).

Still, this new style prevailed: it became practically the standard recognizable idiom of the Arabic Bible, leaving a lasting imprint on the entire Christian discourse in Arabic (including creative writers and poets). This marked a departure with most approaches long common in Biblical translation, which had employed a "domesticating" strategy without attempting to stay clear of Qur'anic style. In fact, some translations deliberately borrowed expressions, characteristic phrases, and rhetorical devices from Islamic texts, in an attempt, it seems, to emphasize the links with the larger Islamic majority (see, for example, Sa'diya, Chapter 8, and Abu Sa'id, Chapter 14). One, rather extreme, but not untypical example

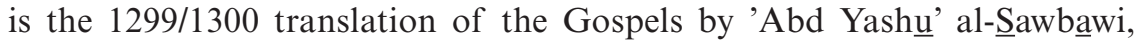
which employed rhymed prose unmistakably reminiscent of the Qur'an (see Hanna 2018: 21-33). As Samih Hanna explains, "the mechanisms of 'sacred Biblical knowledge' production and the identity construction of the receivers through translation cannot be understood except against the background of the Qur'anic text as the central sacred text in Arabic-Islamic culture" (2018: 18).

\section{Tarek Shamma}

\section{Notes}

1 A Dictionary, Persian, Arabic, and English (1777), by John Richardson (1740/ 41-1795). 
2 John Richardson, A Grammar of the Arabic Language (1776). In what follows I have put al-Shidiaq's citations back into Richardson's original English.

3 Richardson 1776: 180. These examples not only contain misvowelings but incorrectly vocalize the first noun in each pair as indefinite (though this would be correct in the first case if the expression were adjectival and not possessive).

4 Richardson, Grammar, 181. Richardson is actually pointing out that the first of these is wrong, but then the second and supposedly correct form is wrong too.

5 Richardson, Grammar, 179. Both words have incorrect endings.

6 Richardson, Grammar, 181, where he is trying to cite the forms nasira 'Uqbah “'Uqbah's two helpers” and nasiru 'Uqbah, "'Uqbah's [many] helpers," but instead produces four imaginary expressions.

7 wa-la ukhalli ruhi illa fi mawdi'iha.

8 Richardson, Grammar, 204-205.

9 Wa-la azalu ka-thalika hatta tatimma jalwatuha.

10 Richardson, Grammar, 206-207.

11 This back-translated excerpt apparently comes from a call to jihad issued by the Ottoman Sultan ("the King"), perhaps during the Crimean War (1853-1856) or the Greek War of Independence (1821-1830).

12 Hebrews 12:29.

13 Al-Kutub al-Muqaddasah [The Holy Books] (London, 1857), hereinafter KM. In what follows I will give the English of the Bible passages in the King James version.

14 See, e.g., Matthew 13: 24, where the King James Version has "Another parable put he forth unto them." Al-Shidiaq must have won this argument, as $K M$ reads $w a$ daraba lahum mathalan akhar.

$15 R a^{\prime} a$ means to see with the eyes, literally; 'alima means to become aware of, realize, perceive, or learn.

16 Lee must have won the argument: see, e.g., Luke 5: 20, where $K M$ has $\mathrm{ra}^{\prime} a$ imanahum.

17 See, e.g., Exodus 15: 19.

18 Matthew 19: 27. $K M$ follows Lee, whose preferred phrasing is not wrong but sounds abrupt. The addition of 'asa would shade the sense toward "What might we have?"

19 Al-Shidiaq is misremembering Matthew 26: 55, which reads: "Are ye come out as against a thief with swords and staves?" Despite what al-Shidiaq says above, $K M$ seems to reflect Lee's preference: a-kharajtum 'alaiya kama 'ala lis $\underline{s}$ bi-suy $\underline{u}$ fin wa-'usiiy?

20 Luke 16: 25. The passage in $K M$ is the same as what al-Shidiaq has here.

21 Mark 5: 11. KM has qatíun kabirun min al-khanaziri yar'a, evidently reflecting Lee's preference.

22 Evidently Luke 24: 48, where the final wording, though it differs slightly from alShidiaq's recollection of it, seems to be Lee's emended version: wa-antum shuhud 'ala hathihi al-ashia'.

23 Psalms 18: 8.

24 Evidently Philippians 1: 8, "the bowels of Jesus Christ."

25 E.g. Qur'an, al-Baqara 2: 115.

26 Qur'an, Taha 20:39 (God speaks of "my eye").

27 Qur'an, al-Má ida 5:64; 48:10.

28 Husain's reference is most likely to the Protestant ("Smith-Van Dyke") translation, which was adopted officially by the Egyptian Coptic Orthodox Church. 


\section{The Holy Bible (the Jesuit translation) First Edition (1876-1881) Second Edition (1897)}

Augustin Rodet, Ibrahinim al-Yazziji

\section{Augustin Rodet (1828-1906)}

Born in France, he studied Arabic in Algeria, then joined the Jesuit mission in Syria. He headed a school in Ghazir in 1868, before being transferred to Beirut. He contributed to the translation of the Bible from Hebrew and Greek into Arabic with Ibrahịm al-Yazziji.

\section{Ibrạhịm al-Yạziji (1847-1906)}

Linguist, literary critic, and translator. Born in Beirut, he received intensive linguistic and literary education by his father Nasif al-Yaziji (see Chapter 31). He taught Arabic language and literature at the Patriarchate School in Beirut. In 1884, with Drs. Bishara Zalzal and Khalil Sa'ada (see Chapter 48), he founded the magazine al-Tabib (The Physician), where he contributed to scientific translation and terminology. In 1897, he founded the magazine al-Baian (Expression) with Dr. Bishara Zalzal. In 1894, he moved to Cairo, where he founded the magazine al-Dia' (Light), which he edited for the rest of his life. In 1872, he was invited by the Jesuit mission in Syria to join the Bible translation project, for which he studied Syriac and Hebrew.

\section{[INTRODUCTION TO THE FIRST EDITION]}

\section{The translators' preface}

It is no secret that, since they have entered the land of Syria, members of the sect of Protestant innovators have been bent on showing their enmity to the Catholic faith, as evidenced by their actions in every town which they have entered. They have churned out books jampacked with slander against the Holy Church, contradicting its true, pure teachings with numerous smears and calumnies. They did not stop at that, however. They have tampered with 
the holy books through distortions and omissions. They have published their Arabic translations of the scriptures in this condition in all parts of Syria, and in other countries. They tried to appeal to people with fine printing and attractive designs. They have also offered these books for low prices, so as to tempt the innocent who are oblivious to the pernicious snares that lie therein - just as someone may admire the beautiful ornaments of a glass without knowing that it contains deadly poison.

For this reason, the principals of the Holy Church in the East have been greatly chagrined, as they were aware of the perdition of souls that lies along this path. They have repeatedly pleaded with the general head of the Jesuit mission in this region to lend attention to the creation of a truthful, flawless Arabic version of the Glorious Book, rendered from the original, for the protection of the believers from the schemes and corruption of the heretics. Having consented to their request and recognized its urgency, he still had to postpone the start of this project for consultation with the Holy Synod, whose permission should be obtained for such a weighty undertaking. In the meantime, he spared no effort in combating those innovators and refuting their lies and fabrications. For in their insolence with the Book of God Almighty, they have deleted verses, removed entire books, and tampered with what was left by distorting words and corrupting meanings, especially the passages on which Catholic doctrines rest. If this were not impertinence enough, they had the audacity to traduce those books, claiming that the deuterocanonical books are not part of the Holy Book, but human fabrications containing nothing but lies and superstition. Indeed, they have written books on these and similar matters, which they printed and distributed among the people, spreading misinformation and propagating errors.

As no one in Syria then could respond to these defamations of theirs and uncover their perverse distortions of God's verses, the head of the Mission mentioned above instructed one of his monks to write responses to them. Thus were published two books. Exposing the Sophistic Fallacies Committed against the Holy Books included clear demonstration and undisputed proofs that the Catholic version of the Book of God and the deuterocanonical books are true in text and faithful in testimony, free from interference or corruption. The second book, Exposing the Manipulations and Distortions in Tampering with Verses of the Noble Book, details the verses which the Protestants have manipulated, taking them out of their context to conform to their doctrine.

In the meantime, the reply came from Great Rome, wherein Cardinal Alessandro Barnabò, addressing the Patriarch of Jerusalem and the general head of the Mission, expressed the approval of the Holy Synod concerning the request it received for the translation of the book of God Almighty into Arabic, in the way explained above, to resist the Protestants who are spreading corruption in the lands of Syria. He commanded the work to be implemented under the patronage of His Eminence the Patriarch mentioned above and published under his support. ${ }^{1}$ 
As for the translation of the Book, it has been conducted from its original Hebrew and Greek, in which the Good Book was written. To the original text we added the old versions held by the Church for comparison: the Latin and Syriac translations, as well as the Greek one, known as the Septuagint. However, when disagreements arose about verses that concern faith or manners, we have relied on the Latin version, which we have adopted as our authoritative reference, as it has been the standard in the Church of God for a long time, and was adopted by the Council of Trent.

Before embarking on this endeavor, we consulted His Eminence Patriarch Giuseppe Valerga, in observance of the message of Cardinal Barnabò, as stated above. The Patriarch approved this method, and continued to encourage us to apply our effort and attention toward accomplishing this enterprise, until he passed into the mercy of God. His successor on the Jerusalem Seat, His Eminence Giovanni Bracco, was a great source of assistance for us with his apostolic jealousy. He has followed the example of his predecessor in characteristic good will, perfect zeal, and high-minded ambition. He has never ceased to extend his paternal attention and apostolic patronage until we completed the translation of the book to the highest level of quality and excellence that we could muster.

Endeavoring to produce a satisfactory translation, and paying the necessary tribute to the glory of God and the honor of the Church, we have not spared an effort in revising the translation and refining its phrase as necessary to protect against the charges that heretics have been directing at the Holy Church. We have provided the translation with full diacritics ${ }^{2}$ in order to clarify its meanings and avert any ambiguities that may be seized by innovators as pretexts to take meanings out of their contexts. For it is no secret that diacritics leave no doubt about intention and no place for misleading pedantry. This is why diacritics are observed carefully by superb practitioners of eastern languages (Arabic and others) in the Holy Book and other weighty compositions to signify their distinction and elucidate their intended meanings. Hence, with the Grace of God, this translation has met all desiderata and fulfilled all hopes, obviating any excuse for preferring the version of the heretics. It has become thus incumbent upon all to obey our superiors in this serious matter on which hangs the salvation of souls.

In truth, this mighty undertaking, with its heavy toils and considerable expenses, would have been beyond our powers, had not God Almighty, who looks after His Church and arranges all things with his guidance, graced us with His unfathomable care and facilitated the means for us to glorify Him and seek His satisfaction. For He, hallowed be His Majesty, has sent to these lands one who is equal to this great endeavor, viz. Father Ambrosius Monnot, the general head of our mission, who shouldered the labors of this task, to which he dedicated his utmost attention and consideration. He has spared no effort so that the Good Book would appear in the most attractive and graceful aspect in the eyes of the elite and the commoners. 
We had earlier agreed to publish the book in a different typeface from the one used here, and had prepared all the necessary printing equipment. We were on the verge of commencement when we received books printed in Constantinople in a typeface so exquisite that experts agreed unanimously to select it in preference to all the typefaces commonly used thus far by Arabic printing presses. When we conveyed the matter to Father Monnot, he postponed the printing immediately; he established communication with Constantinople for this typeface and all necessities thereof to be fetched for the purpose of this venture. Thereby the merits of the book were completed, which is to be counted among the many accomplishments of this honorable father which should be recognized with great commendation and gratitude in these pages.

\section{Translated by Tarek Shamma}

\section{COMMENTARY}

Like its Protestant predecessor, this translation was a joint enterprise between European missionaries and local scholars. The main collaborators included Augustin Rodet, a French Jesuit priest who worked and died in Syria, and Ibrahim al-Yaziji, son of the same Nasif who contributed to the Protestant translation, a well-known scholar and a teacher at the Jesuit College (later University of Saint-Joseph) in Beirut.

The introduction to the first Jesuit edition (published in 1876 by the Mission's press in Beirut) shows that Eli Smith's predictions were wellfounded, at least when it comes to the outcry that the prospective translation would provoke. The objections to the Protestant version go beyond the original bone of contention (the omission of the deuterocanonical books) to accusations of distorting terms and corrupting senses, especially in areas of doctrinal differences between the Catholic and the Protestant Churches.

The two pamphlets mentioned in the introduction as responses to the perceived attack on the Catholic faith were both written by Joseph van Ham, a Dutch Jesuit who lived in Syria and wrote in Arabic (Shekho 1910, I: 154). The full title of the first book is Exposing the Sophistical Fallacious, in Response to What Was Recently Published by a Servant of the Protestants against Some Divine Books (1870), where Van Ham argues against the omission of the deuterocanonical books. The second, Exposing the Manipulations and Distortions in Tampering with Some Verses of the Noble Book (1872), is a detailed critique of how the Protestant translators deliberately manipulated Biblical verses to refute Catholic doctrines and confirm their own. Van Ham wrote yet a third polemical pamphlet about the same translation: Exposing the Illusions of the One Who Is Riddles with Arrows (1873), a rebuttal to an anonymous article entitled "Aiming Arrows at the Jesuit Van Ham," which 
was published in 1872 in al-Nashra al-Usbu'iya (The Weekly Bulletin) of the American Mission in Beirut (al-Khuri 1995: 31).

\section{Tarek Shamma}

\section{[THE JESUIT TRANSLATION]}

\section{Introduction to the second edition}

Our superiors, the principals of the Church in the East, having recognized a want in these lands for the books of the two Testaments to be published in a faithful and capable translation, communicated continually on this matter with the general head of the Jesuit Fathers in Syria. They sought his judgment in fulfilling this need and repairing this flaw. With typical chivalry, he heeded these pleas for help, while realizing the travails, hardships, adversities, and labors involved in this undertaking. However, commencement was delayed until the matter was remitted to the Apostolic See, whose authorization must be sought for such a task.

The reply from Great Rome expressed endorsement of the project to assure that the Catholic doctrines remain in a state of health and splendor with the Eastern denominations. Cardinal Alessandro Barnabò commanded the translation to be implemented under the patronage of His Eminence the Patriarch of Jerusalem and published under his support.

As for the translation of the Book, it has been conducted from its original Hebrew and Greek, in which the Good Book was written. To the original text we added the old versions held by the Church for comparison: the Syriac translation, the Greek one known as the Septuagint, but especially the Latin version, which has been the standard in the Church of God for a long time, and was adopted by the Council of Trent.

Before embarking on this endeavor, we consulted His Eminence Patriarch Giuseppe Valerga, in observance of the message of Cardinal Barnabò stated above. The Patriarch approved this method, and continued to encourage us to apply our effort and attention toward accomplishing this enterprise, until he passed into the mercy of God. His successor on the Jerusalem Seat, His Eminence Giovanni Bracco, was a great source of assistance for us with his apostolic jealousy. He has followed the example of his predecessor with characteristic good will, perfect zeal, and high-minded ambition for the completion of the translation of the book to the highest level of quality and excellence.

Endeavoring to produce a satisfactory translation, and paying the necessary tribute to the glory of God and the honor of the Church, we have not spared an effort in revising the translation and refining its phrase as necessary. Accordingly, the meaning has been transferred into Arabic with no loss but its foreign mantle. While observing the principles of eloquence, we 
have not deviated from the style of the book as to the naivety of phrase. To clarify meanings and avert misleading interpretations, we have provided the translation with full diacritics. For it is no secret that diacritics leave no doubt about intention and no place for wrongful interpretations, as is the practice of Easterners with precious books.

In order to spare no opportunity in our capacity to pay the respect befitting the word of God, we have exerted our best abilities, be it labor or expense, to exhibit the book of God in the most luxuriant aspect, as becoming of its status. Therefore, we have utilized the best Arabic typeface in the experts' unanimous opinion, viz. the Constantinople Typeface, which is now familiar in most places.

Furthermore, it is no secret that the verses of the Good Book contain parts that may be hard to understand for many people, who may thus be confused about their true meaning. For this reason, we have appended notes at the end of the book which uncover the different facets of the intention. In these notes we have relied on other verses of the divine books, as well as the teachings and exegeses of the holy fathers.

Now it would not be fitting for us to express an opinion in praise of the task we have accomplished in fulfillment of our superiors' commands. Yet, it was to our great delight that the translation has met the satisfaction of His Eminence the Patriarch of Jerusalem, and all the other patriarchs and bishops of the east, as evidenced in their commendations, which we took as testimony that (the Lord willing) the labors we have extended have not been in vain. In fact, the phrase of this translation has been complimented by a number of Muslim scholars. As for those who pursued the translation in search of weaknesses to attack, they have not made any comments in the beginning or the end; their silence is testimony to the fidelity of the translation.

In fine, we have not saved an effort to make this translation the most satisfactory to respected priests, beneficial for clerics and believers, and reverent of God's magnificent glory.

\section{Translated by Tarek Shamma}

\section{COMMENTARY}

The second edition of the Jesuit translation, also published by the Jesuit Mission's press, had a briefer introduction, reiterating the collaborative nature of the enterprise and the support it had received from the Vatican and its local representatives. Conspicuous by their absence are the heated controversies and accusations that were advanced in the first edition as the main rationale for the translation.

Having explained the background of the project in the first edition, the collaborators have more to say now about the translation itself. Particular emphasis is placed on accuracy and faithfulness, particularly in reliance on 
the target texts in their original Greek and Hebrew. However, the Vulgate remains a primary standard; its position in the Arabic Catholic translations had been established since al-Rizzi's translation. In fact, it was employed here as the final reference for settling any disagreements.

Accuracy is not the only criterion. The Jesuit translators seem to have given more attention to producing as much a polished and idiomatic a translation as possible. Yet, they are careful to follow the standard already introduced by al-Rizzi, i.e., not to mitigate "the naivety of phrase," which had become a distinctive feature of Arabic Biblical translations.

Still, the Jesuit translation was generally recognized for its literary character and attention to idiomatic Arabic, in contrast to the more literal approach of the American missionaries' version. For example, Louis Shekho, a respected Arabic scholar as well as a Jesuit priest himself, explains that the American Protestant version achieved "wide popularity, but only until the arrival of the Jesuit fathers' translation [...] which was more accurate in translation, more comprehensive in content, and more eloquent in expression" (Shekho 1910, I: 75). While Shekho may not be the most impartial judge on a translation produced with the support of his own church, the same opinion was expressed by other contemporaries. For example, Jurji Zaidan, editor of the highly influential Egyptian magazine al-Hilal, summarized the differences between the two translations as follows:

We have no doubt that the two translators had the best intentions, each wanting his own translation to be correct and completely identical to the original. But they followed different methods. The Americans were apparently keen for their translation to be purely literal, regardless of what ambiguity or ambivalence may arise in the process, due to the different ways of expression in the two languages. The Jesuits, on the other hand, relied on sense translation, striving to cast meanings into a fluent Arabic mold, even if they were compelled as a result to add a word or a passage that does not exist in the original Hebrew, with the aim of clarifying and perfecting the meaning [...] On the whole, the American translation is literal, while the Jesuit is meaning-based, and each has its own virtues and flaws. The American translation has the advantage of preserving the Hebrew original literally. It leaves the judgment on the exact intended meaning to the discretion of the reader, who may be left uncertain due to the meaning being ambiguous to him; in fact, he may understand a phrase in a way different from its intended meaning. The Jesuit translation has the advantage of being eloquent and wellformed in phrase, as well as easy to grasp and accessible to the reader, who is never in doubt about the meaning. Its flaw is the disposal of the Hebrew phrases according to the translator's own comprehension of their meanings, while some of these may be amenable to meanings other than what he has decided.

(Zaidan 1894: 593-594) 
However, judgments about the eloquence and idiomatic nature, or lack thereof, of these competing translations must be seen as relative, based on the comparison of the two versions alone. As it happened, both seemed relatively lacking in elegance to some contemporaries, especially those who objected to the "naiveties" of expression as impurities and deviations from correct Arabic usage (see, e.g., Mustafa Sadiq al-Rafi i, Chapter 34).

Perhaps what distinguishes the position of the translators in this edition most from its predecessor is the effort to expand the scope of reception, which now included Muslim scholars, whose commendation is cited as indicating the wide acceptance of this version in its larger cultural context. This concern was already apparent in the first edition, which used Qur'anic terms in condemning the Protestant translation who "change words from their context" (see al-Qur'an, al-Nisa ${ }^{6} 4:$ 46). The Jesuits (and generally Catholic) missionaries were keen on emphasizing their longer history in the region and their deeper links to the local population, in contrast with the Protestants, who were portrayed as arrivistes, both in the general history of Christianity and in the region itself.

\section{Tarek Shamma}

\section{Notes}

1 Emphasis in the original.

2 Marking short vowels. Short vowels are not written in Arabic, sometimes leaving ambiguities that have to be resolved from the context. 


\title{
36 Official Documents about His Service as a Translator (1887-1896)
}

\author{
A $\underline{h}$ mad Zaki Pasha
}

\begin{abstract}
Ahmad Zaki Pasha (1867-1934)
Translator, historian, and public official. Born in Alexandria, he graduated from the School of Law (later the College of Law, Cairo University). He worked as a translator, then secretary, to the Egyptian cabinet (then under British occupation). His non-official translations include works on history, geography, and Islam, all from French. He was also a well-known scholar of Classical Arabic literature. His works include Dictionary of Ancient Geography and Encyclopedia of Arabic Sciences (in Arabic and French). He proposed the first systematic punctuation system in Arabic in 1911.

The following are official documents (mainly correspondence) concerning his 27-year service as a translator at different ranks at several government offices in Egypt.
\end{abstract}

\section{[TRANSLATION AS A GOVERNMENT PROFESSION]}

\section{Document 1}

Translation of the Technical Committee's memo submitted to the Cabinet

Date: March 6 (date and number as per the Committee's communication) With reference to the letter of the Interior Ministry of February 18, no. 4141, referred to the Technical Committee concerning the results of the examination conducted on the 24th of last February for the position of translator at the

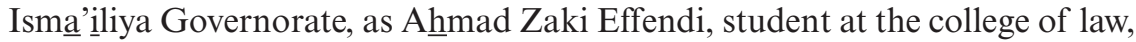
won the first rank in the examination, and since according to the bylaws of the School of Law, students are prepared for administrative, as well as legal jobs, the Financial Committee has approved the appointment of the said Ahmad Zaki at a monthly salary of 13 Egyptian Pounds. We forward this decision to the Cabinet for their kind confirmation.

Remark from the Head of the Cabinet Office to the Interior Ministry, on March 9, 1887

The Cabinet has ratified the above in its meeting of Monday, March 7, 1887. 


\section{Cabinet Head}

Signature

Nubar [Pasha]

\section{Document 2}

From the Office of the Cabinet Head to the Ministry of the Interior

Considering the need to engage one translator at the Office of the Cabinet Head who is fully competent in French and Arabic and capable of translating from one language to the other, we previously notified the Education Ministry to publish an announcement on their behalf in the official gazette for this position at a monthly salary of twenty pounds, to appoint a date for the applicants' test, and to communicate the results to us. We have just received the Education Minister's letter of November 28, 1889, to the effect that the highest score in that test was achieved by Ahmad Zaki Effendi, First Translator at the editorial management of the Interior Ministry's Official Gazette. Accordingly, the Interior Ministry is requested to issue a release notice for the said effendi, effective November 1889, and send a notice of the same to the Prime Minister's Office, so that he will be registered in this position at the above-mentioned salary, effective December 1, 1889. We have written to the Finance Ministry regarding the necessary procedures.

On November 31, 1889

Seal: Mustafa Riad, Cabinet Head

\section{Document 3}

To the Cabinet

Ahmad Zaki Effendi, head of the translation unit at the Cabinet, was promoted, beginning with January 1, 1896, to the position of department head at the Office of the Cabinet Head at a monthly salary of 35 pounds, the minimum for this rank. As he has been performing his duties to the highest levels of quality, and has been on the third rank since June 1894, we are of the opinion that he deserves the Supreme Consideration for the second rank, in recognition and encouragement of his diligence. It is our hope that the request for promotion to the said rank receive the gracious approval of the high Khedive Eminence. ${ }^{1}$

\section{Document 4}

To the Human Resources Department, Cabinet Head's Office

Following our decision to create a department deputy position in the Cabinet Head's Office's budget, effective 1896, and promote Ahmad Zaki Bey, ${ }^{2}$ head of the translation unit, to that position at a base monthly salary of 35 pounds, effective January 1, 1896, we forward the above for adoption.

On January 19, 1896 


\section{Cabinet Head}

Mustafa Fahmi (seal)

\section{Document 5}

The Office of the Cabinet Head

Brief Summary of Service, through December 31, 1914

Name: Ahmad Zaki Pasha

Position: Secretary at the Office of the Cabinet Head

Salary: 1200 Pounds

Educational Qualification: BA in Law

Foreign languages: French and Italian, little Latin and English

Permanent Service Start Date: 12 March, 1887

Service Duration: 27 years, 9 months, 20 days

\section{Summary of Service Duration and Positions}

Appointed as translator in the Directorate of Isma'iliya at a monthly salary of 13 pounds, starting 12 March, 1887, following an exam for this position, as approved by the Cabinet in its 27 March, 1887 meeting, following the recommendation of the financial committee as per memo no. 178, the 6th of the same month. Upon his appointment, he had been a student at the School of Law, and had been given the permission to take the final exam at the end of the year.

October 5, 1888, appointed translator, first rank, at the publication unit, Ministry of the Interior, at a monthly salary of 14 pounds. Endorsed by the Cabinet in its meeting of the 22th of the same month, following the financial committee's approval.

December 1, 1889, appointed translator at the Cabinet at a monthly salary of 20 pounds, after winning the exam instituted for this position at the discretion of the Ministry of Education.

December 1, 1894, promoted to translation unit head, at a monthly salary of 28 pounds, then department deputy at a base monthly salary of 35 Pounds, starting December 1, 1896.

In the 1897 budget, appointed Second Secretary to the Cabinet. Then his salary was raised to 37 Pounds and 500 piastres on January 1, 1898.

His salary was raised to 500 Pounds per year, starting January 1, 1901, then 560 Pounds, starting January 1, 1904, then to 620 Pounds, starting January $1,1907$.

In its April 18, 1908 meeting, the Cabinet endorsed the awarding of an incentive bonus of 120 Pounds per year, not to be included in salary, starting January 1, 1907.

Starting January 7, 1911, appointed Secretary to the Cabinet, replacing the retired Qustantin Qitta Pasha. His salary was raised to 1000 Pounds per year, then to 1200, starting April 1, 1914. 
Awarded the third rank in 1894, and the second rank in 1896, the Rank of Excellence in 1908, the rank of Mirmiran in 1911, and the Order of the Nile of the Second Class in 1915.

His Excellence was awarded the rank of Pasha in 1918.

\section{Translated by Tarek Shamma}

\section{COMMENTARY}

Extending from 1887 to 1914 , these documents illuminate several aspects of the practice of official translation in government service during this period. As a government position, translation was obviously a highly structured and regulated profession, with translators selected through officially administered tests and given ranks based on experience and ability. The fact that the appointments had to be ratified by the highest level of government (while in part the result of centralized bureaucracy) is certainly indicative of the importance given to the position of the translator.

It would be also useful to examine Zaki's salaries over the period extending from the late nineteenth through the early twentieth centuries. This data, seen in the context of average remuneration for other government, or nongovernment jobs, as well as the general standard of living in Egypt during this period, would be an important contribution to the study of the financial conditions of translators.

The documents are also significant when considered against the political background of the time. They span a crucial period in the history of modern Egypt, starting in 1887 (five years after the British occupation of Egypt) until 1914, when Egypt had officially become a British protectorate. To what extent did these political developments, if any, cause any changes in the nature of the translators' positions and employment? Zaki translated from French, the predominant foreign language of translation throughout the nineteenth century (see Appendix 2), and his continuous advancement is evidence of constant demand for it. One question, not discernable in these documents, is whether the stakes of English rose in official translation departments, as certainly happened in other fields, such as education.

\section{Tarek Shamma}

\section{Notes}

1 'Abbas II, Khedive (ruler) of Egypt, 1892-1914.

2 A title of nobility, just below Pasha. 


\title{
37 Edifying Plays in the Art of Tragedy (1893)
}

\author{
Muhammad 'Uthman Jalal
}

\section{Muhammad 'Uthman Jalal (1829-1898)}

Poet, journalist, translator, and pioneer of Arab theater. He studied French and Arabic at Dar al-Alsun (The House of Tongues), Cairo, under Rifáa al-Tahtawi. He taught French at the Khedive Diwan (Ministry of the Interior). Then he was named head of translators at the Maritime Bureau in Alexandria, and the translation office at the Ministry of the Interior. His works include translations from Molière and La Fontaine and a book on the grammars of Arabic and French.

\section{Al-Riwayiat al-Mufida fi 'ilm al-Tarajịda [Edifying Plays in the Art of Tragedy]}

This book combines verse translations of three plays by Jean Racine: Esther, Iphigénie, and Alexandre le Grand.

\section{Al-Amani wa al-Minna fi Hadith Qabull wa Ward Jinnah (Hope and Gratitude: The Tale of Qabul and Ward Jinna)}

A translation of Paul et Virginie, a pastoral novel by Jacques-Henri Bernardin de Saint-Pierre about innocent love. Jalal adapted the names of the characters into Arabic, and employed saj' (rhymed prose characteristic of Classical Arabic literature and still in use at the time) and Classical Arabic poetry.

\section{EDIFYING PLAYS IN THE ART OF TRAGEDY}

\section{In the name of God the Beneficent, the Merciful.}

After extending praise to God, and prayer and peace upon the Prophet, the translator of this book says that among the plays performed in Europe is what they call "la tragédie," which consists of historical incidents dealing with war or love. In France, a man named Racine became famous for this art. He lived in the age of Louis XIV, who supported the dissemination of learning and patronized poets and authors in their fine creations and affecting innovations. 
I have selected three plays from his works under the title Edifying Plays in the Art of Tragedy. They are most similar to the genre of relief after distress, ${ }^{1}$ treating of the fulfillment of hopes after long denials. Following the versified original, I made its verses understandable to the general reader. For the common language is most appropriate in this regard and more stirring for the elite and the commoners.

I followed the translation with the family tree of the illustrious Khedivial Dynasty, which may serve as a historical example at all times. I have dedicated the translation to His Grace, the distinguished pasha, the lord and prince, Muhammad Ratib Pasha, grandson of the late Ratib Pasha the Elder. For he has graciously sponsored its printing and the dissemination of its benefit. May his house remain prosperous and showered with blessings, and may his family be always regarded by his monarch and his children protected in God's care. Amen.

\section{Translated by Tarek Shamma}

\section{COMMENTARY}

The inclusion of drama into the Arabic literary repertoire constitutes an important site for the dynamics of diglossia and cultural politics, in terms of the choice of language varieties, in this case classical Arabic versus the vernacular. Translating European plays into Arabic has also been alternatively seen as a wholesale introduction of a new genre (see al-Naqash, Chapter 29), or a revival of local dramatic forms (for instance folk shadow theater, farces, etc.). In this short text 'Uthman Jalal, whose translation work focused on seventeenth- century French classical production (Boileau, Corneille, La Fontaine, Molière, and Racine), introduces the genre of the "tragedy" to the readers, and more particularly the work of the canonical playwright Jean Racine. Three of Racine's plays are selected as particularly edifying, significant and suited to translation. The use of the Egyptian vernacular (تصصير, literally "Egyptianizing") to translate the French tragedies, is an adaptation justified by 'Uthman Jalal as more likely to stir the audience and establish an emotional connection with the play, and can be seen as an innovative approach which marks the beginnings of popular and vernacular drama production in Egypt and combines carrying over "the cultural prestige and authority of the French culture" (Bardenstein 2005: 1) as well as "assert[ing] indigenous cultural capital and prestige" (ibid.). The reference to the overall context in which the translation is undertaken and performed, i.e., the support of the khedive and his entourage, points once again to the importance of patronage.

\section{Myriam Salama-Carr}

\section{Note}

1 A genre of morality tales in Classical Arabic literature, in which characters overcome dangers and tribulations, usually through piety and divine grace. 


\section{The Tale of Qubul and Ward Jinna (1912)

\author{
Muhammad 'Uthman Jalal
}

\section{In the name of God the Beneficent, the Merciful}

Praise be to Him, who made tales in his Book the best admonition and commendation. We thank Him who tests his good servants and has prepared for them Gardens under which rivers flow ${ }^{1}$ to reward them for their patience and award them a high status [...]

Now as books of literature are required in primary schools for the pupils' moral instruction, and as the most accessible of these are introduced through diverting tales and narratives, I have selected one of the most famous books in the French language and translated it into Arabic. For it is a model for this purpose. It is indeed to be emulated for those seeking refinement of character, considering the maxims, parables, and instructive lessons that it contains, which are like legitimate magic and sweet, fresh water. I have poured it into glasses of crystalized phrases, choosing the easiest of luminous words, so that it would be readily accessible, trusting that its beauties will shine through without embellishment. I have also extracted it from Frankish temperaments and converted it into the manners of the Arab nation. Yet, I have only changed the names, which I paired with the appropriate referents, leaving the rest as it is $[\ldots]$

Those who peruse it with a critical eye will find it to be a perfect match; those who measure it for correspondence and compare it [with the original] from beginning to end will recognized it as a twin-a proper translation indeed $[. .$.

I have named this work Qabul and Ward Jinna, as the two names are close in articulation and identical in pronunciation in the two languages. ${ }^{2}$

I present this book to His Eminence, the model of grandeur and lordship, the master of the pen and the sword, the son of the most honorable Khedive, our Effendi Muhammad Tawfiq Pasha. ${ }^{3}$

\section{Translated by Tarek Shamma}




\section{COMMENTARY}

'Uthman Jalal's interest in literary translation was not limited to classical French plays. In this short extract he discusses his choice of text, Paul et Virginie, the famous novel of Bernardin de Saint-Pierre (1737-1814), published in 1788, a novel for which Arabic translations were also produced by key figures of the literary Nahda, Farah Antun (1874-1922), and Mustafa al-Manfaluti (1876-1924). The translator stresses the edifying and instructive value of the novel, the latter provided by the number of references to nature and geography, justifying its adaptation into Arabic to tune it to the readership's sensibilities, both moral and literary. The translation arabicizes the names of the main characters in the novel while staying as close as possible to the phonetics of the original names, uses rhyming prose and inserts a few philosophical considerations. Describing his efforts as a way of taking the novel out of its French mold to adapt it to an Arabic one, the translator uses a number of innovative translation techniques. Translation for him is both "translation" and "writing" (see al-Naqqash) and contributes to the moral and esthetic development of the readers, and thus to progress.

\section{Myriam Salama-Carr}

\section{Notes}

1 A reference to a common Qur'anic description of paradise.

2 Compare "Qabul" and "Ward Jinna" to "Paul" and "Virginie."

3 Ruler of Egypt (1879-1892). 


\section{9 "Arabization" (1895)}

Khalill Baidas, Jurji Zaidan

\section{Khalil Baidas (1874-1949)}

Writer, translator, and educator. Born in Nazareth (Ottoman, later Englishmandate Palestine), he studied at a Russian (Orthodox) missionary school and Teachers' Training Center. He was a director of several Russian schools in Syria and Palestine and worked as teacher in Jerusalem. He founded the magazine al-Nafá is al-'Asriya [Modern Masterpieces], where he serialized the Russian novels he translated. After the 1948 Arab-Israeli War, he moved to Amman, then to Beirut, where he spent the rest of his life. His many translations from Russian comprised mostly fiction, but also historical and political books, including works in other European languages (such as Italian and German) through their Russian translations. He also published a novel, a collection of short stories, and books on education.

\section{Jurjị Zaidann (1861-1914)}

Historian, literary critic, novelist, journalist, and translator, and an influential figure of the Nahda. Born in Beirut, he studied medicine for a year in Beirut, before leaving for Egypt to work at al-Zaman (Time) newspaper. In 1885 he accompanied the British expedition to Sudan as a translator; returning to Beirut, he joined the Eastern Academy and studied Hebrew and Syriac. He finally settled in Egypt, where he worked at al-Muqtataf magazine, before founding al-Hilal [The Crescent] in 1892, for which he was the sole editor until his death. One of the most influential journals of its time, al-Hilal is still published in Egypt. He is remembered today mostly for a series of historical novels based on Arab-Islamic history, some of which were translated into other languages (see discussions of copyright below). He also wrote the pioneering, though controversial (see Rida, 'Abdo, al-Nu'mani, Chapter 42), Tarikh al-Tamaddun al-Islami (The History of Islamic Civilization), and translated literary works from English. 


\section{[THE LIMITS OF TRANSLATION]}

\section{Arabization}

\section{(Nazareth) Khalil Effendi Ibrahin Baidas}

If a person Arabizes a European novel and transfers its meanings into pure Arabic expression from which one could not scent Arabization, doing with the novel as they wish while maintaining the historical events according to their origin along with the names (because Arabic proper nouns in such a novel are like an alaja $a^{1}$ patch on a robe made of taffeta). In sum, if he were to read a foreign novel, implementing and writing it according to his genius using Arabic expressions and poetic spices, the words of the Arabs and their manner of speaking, then should his work be called an Arabization, a composition, or what?

(al-Hilal) Every book, article or statement is necessarily composed of two essential things - meaning and expression. The meaning is essential, while the expression is accidental. So whosoever has transferred a book from one tongue to another has changed the expression and he is a translator. There is nothing significant in his having transferred the foreign novel to the Arabic tongue unless one can catch in it the scent of Arabization because that is the most important of his tasks. Arabization is the transfer of the meaning from a foreign expression to Arabic expression but not word to word-for if the Arabic expression is marked by non-Arabic expression, then it shows that the Arabization is deficient. As for the Arabic poetry and proverbs he puts into it, if he changed nothing of their meanings then the work is Arabizationit could be called an embellished Arabization or enhanced Arabization. If he changed something of their meanings, for example by abbreviating some events, deleting or adding others, then it is free Arabization. That work is not called literary composition unless it was creative from its origin, that is to say that the writer is the one who generated the original idea, shaped the context of the story and organized its events. If he collected its events from various novels, then his work is that of authorship. But they have agreed to call all writing other than translation authorship, so literary composition and authorship according to their terminology are one thing while, in origin, they are two distinct things as you have seen.

\section{Translated by Neil Sadler}

\section{COMMENTARY}

This short text, a response to a letter to the editor of al-Hilal, reveals some of the principles underpinning the conception and practice of translation during al-Nahda, in particular the extent to which a translator can deviate from, or take liberties with the original. 
Jurji Zaidan, an eminent Nahda intellectual and translator himself, bases his argument on the meaning-utterance dichotomy, which played a crucial role in formulating positions on translation in Arabic in all ages. A reformer who saw the emulation of European civilization as at least one important source of modernization, Zaidan posits a hierarchy between meaning and form, of which the latter is only one manifestation. As we have seen (e.g., Matta and al-Sirafi, Chapter 7), this position leads to an endorsement of free translation, as long as one preserves the meaning, with varying perspectives on the acceptable limits of this freedom. While Zaidan acknowledges the preservation of meaning as a necessary requirement, he confines it to the bare minimum, expanding the translator's scope of discretion to any textual changes that fall short of full authorship.

Otherwise, all changes are permissible, including addition, omission, reformulation, and even introducing Arabic verses and proverbs to the original. All these textual practices can still be classified as translation, if under qualifiers such as "embellished." In fact, such alterations may become necessary, since one of the most important tasks of the translator is to recast the original, so that the target text does not smack of translation. This remains a popular view among translation readers, and practitioners, in Arabic and other languages, although excessive liberties (of the magnitude described in this text) are generally less tolerable. Fidelity, in different forms and interpretations, has become practically indispensable in evaluating translation, even when mitigated or dismissed as a secondary consideration.

Zaidan's views can fairly be said to represent the predominant conception and practice of translation during al-Nahda, and well into the twentieth century. In fact, Khalil Baidas, the author of the inquiry, later became an established translator from Russian, and he clearly followed Zaidan's recommended methods in his practice. In his introduction to The Horrors of Tyranny, his 1927 translation of Aleksey Tolstoy's Prince Serebrenni (Kнязь Серебряный), he explains that the source text has undergone "additions, omissions, changes, substitutions, and divisions in order to be appropriate for Eastern taste" (Baidas 1927: 6-7). Baidas's shifts include inserting a "chapter about Moscow, another about Russian kings, and one more about King Ivan IV, one of the protagonists of this novel, in addition to other cases of explanation and description which are necessary to acquaint the Arabic reader with the conditions of the Russian nation in most periods of its history" (ibid. 7). He adds that he did not change names, as "they were all real" (ibid.).

\section{Tarek Shamma}

\section{Note}

1 An expensive variety of corded lace originating from Turkestan. 


\title{
40 "Language and this Age" (1897)
}

\author{
Ibrạhim al-Yaziji
}

\section{Ibrahim al-Yaziji}

See Chapter 35.

The article was published in al-Baian magazine, which was edited by al-Yaziji, on June 1, 1897.

\section{[ARABIC AND THE CHALLENGES OF MODERNITY]}

There is no writer, nor any person involved in publishing in this nation, who is unaware of what has become of our language in our current era concerning its falling short of being fit for the purposes for its peoples, and its sterility in terms of fulfilling the needs of its users. Its vocabulary seems narrow in the face of the demands made by writers and grammarians of Arabic. Writing in this language has become a task of endurance and a doorway to toil. Its limitations are only increasing while different permutations of civilization become broader and the proliferation of their many inventions and features of modernization multiply to the extent that it could be said that it has all but been cast away into the corners of negligence, joining the languages in bygone centuries. We have to sense the need to tend to its affliction before its final death-rattle $[. .$.

This is the language described in all times as the richest in vocabulary, the most expressive in its capacity to be configured for different meanings, and the most evocative. But if the writers of today only took the time to look into their own bedrooms, they would find a limited resource in all that this treasury of language offers to them, not to mention describing the palaces of kings and nobles, the houses of those living in the lap of luxury and their streets, their embossed furniture, furnishings and the like, as well as the different types of utensils and cosmetic instruments for which there is no name in this language. An Arab in these cases can only make recourse to wan, stammering phrases and inexplicit language to render the real meaning of words that cannot be articulated, and where there in no way of pronouncing them. It is as if they were segments which describe attributes for which there is no place between

DOI: $10.4324 / 9781003247784-43$ 
his jaws to articulate and no possibility for them to flow between his lips and uvula, rendering him a mute who can see and distinguish things but cannot express anything about them except through pointing or miming. [...]

Now a language is nothing more than a mirror reflecting the circumstances of its people, a picture of their civilization, as well as their mores and morals. It should also be a record of what they have achieved in the field of sciences, manufacturing, crafts and literature. It should be able to serve the needs of the nation in terms of expression, and to represent their thoughts, and the many feelings residing within the meaning of their words. It is well-known that the Arabs who created this language were people of the desert, their houses made of animal hair [...] How far removed they are from the modern modes of civilization and scientific explorations ever expanding alongside the many genres of household wares, furniture, and decoration, and everything else in our societies and ways of living, not to mention advancements in science and industry - all of which is alien to their time, except what was introduced when Islam was at its height, and of which much has disappeared and what little has remained is hardly sufficient.

Whatever the situation of those people [in ancient times] - the limitedness of their lives and societies and the poverty of their terminology which falls short of modern conditions - we cannot hold on to the fallacy that there is an inherent incapacity within this language's range of expression which has become a handicap in today's competition among different tongues. The incapacity proper in a language arises when its users encounter meanings which its words cannot express, then its structures prove too narrow to produce new words for these meanings which become a lack afflicting this language, which only worsens over time. Thus, the language becomes incapable of providing the tools of expression that its users need, or it becomes unfit for their purposes. The only solution then would be to abandon this language, or to draw on another to fill the gaps, which alters the fundamental fabric of the language and obscures its distinctive style, until its features change over time and it becomes another language altogether.

It is undeniable that what we have described, according to the opinions of many, is akin to what we witness happening to our language in the present day. We have been lamenting its limitations to respond to our modern demands. However, if you look further into the reasons for this, and probe into the depths of this language and evaluate the extent to which it can be adapted in multiple ways, you will discover that there is nothing inherently lacking within it. I am of the strong belief that this language is at the height of its youthful vigor, that it is still growing, with great capacity for current use, which allows it to compete with the broadest of languages in terms of range and vocabulary. What has impeded the development of this language is its users and their backwardness in relation to modern civilization and urbanity. For a language is as youthful or as infirm as its users, in that it represents their interactions between each other; their tongues only represent their thoughts, and their words are only images of what occurs in their minds. It goes without saying 
that the lexicon of any language is not created in one fell swoop but rather in an accumulative way according to the needs of its speakers. What distinguishes this language is the rare quality that most of its expressions are derived either by coining new words through morphological rules or by extending the meanings of existing words, which is why it has continued to develop in ways barely matched by any other language. For while it is one of the smallest languages in terms of its basic structures, it is one the richest in constructions and formulations, which is why it enjoys this astonishing capacity. This not to mention its many permutations of metaphorical expression which have continued to diversify $[\ldots]$

Consider what we have mentioned previously of the circumstances of the language during the pre-Islamic and early Islamic times in comparison with the era of the Abbasid Caliphate, after invasions and conquests had settled, and people were awakened to the needs of science and new ways of civilization. So they took Arabic out of the harshness of Bedouin existence into the most advanced permutations of civilization and society of that era, scarcely adding any foreign terms ${ }^{1}$. During this era of old, the people did not make recourse to new structures, but rather used the same structures to derive words previously known to the Arabs, so that they mastered the craft of the Persians and the knowledge and science of the Greeks. They did incorporate the terminology of peoples that they encountered, be they in the west or the east, and derived words for themselves according to context and absorbed all they brought into this language without its own resources being depleted. We do not read of anyone at that time complaining of any incapacity or limitation.

However, times changed, and the trepidation of destiny halted their progress at that stage, so language ceased at the level we find in what books have come to us from them, while many invasions befell its peoples, resulting in the destruction of sources ensuing, and the traces of their civilization becoming obliterated, their knowledge of sciences dispersed into the wind. Thus, many of the words in this language vanished, as their signification was lost, so that what remains of it today is no longer fit to serve an increasingly modern and urban society, and it does not reach the daily lives of its peoples. Therefore, if there is feebleness, it is not within the language itself, but in its people, their mental faculties, and the backwardness of their conditions. For if this people had, perchance, remained as they had within the era of their forefathers in terms of civilizational development and their contribution to knowledge, they would not have left new phenomena pass them by until this present time.

For hundreds of years, this language has not added to its vocabulary even one new letter that does not relate to matters of the needs of the household and marketplace - and even these are shrinking [...] As long as meanings are nonexistent, then the words expressing them would not be available. For words only express innermost thoughts, and so they would necessarily be limited to them. This situation was further aggravated by the burning of books written 
by our predecessors, one example being the Library of Cordoba [...] as well as much looting and pillaging, where looters do not care for what they have stolen, due to their ignorance of its value. This is how we can easily see that many examples of such works are now in the libraries of foreigners, many of which have been bought from us with gold pieces [...] No wonder then that in such circumstances, this is what has befallen our language, so that even when we are putting our efforts into its revival, vowing to renew and revitalize it, we will not find many works of value in our lands, aside for tomes relating to religious knowledge, which are almost the only works that the people of these lands have been able to preserve.

\section{Translated by Ruth About Rached}

\section{COMMENTARY}

This article can be said to situate al-Yaziji's calls for Arab nationalism, which were part of his intellectual career, in more practical terms: highlighting the crucial nexus of translation as a bridge and as a source of knowledge in the Arab world. Here al-Yaziji summarizes the practical, political and psychological challenges Arabic as a language was facing at that time as a medium of communication. Although he contextualizes much of his argument by drawing on histories of the past, he is clear in calling two stakeholders of the present to account: writers and publishers.

He begins by stating that no one can neglect that Arabic has become a language notable for its deficiency in serving its users. From this point, he gives a succinct but comprehensive summary of the Arabic language's political historiography, from a language of the desert to the language of an Empire, and now at a point where the Arabs resort to institutions of knowledge in languages completely different from their own, which shapes not only how Arabs conceptualize their world now, but how they will do so in the future.

Crucially, al-Yaziji situates the reasons for this "deterioration" as not the fault of the language or its peoples, but a series of political disasters which have resulted in Arabic not progressing from the time of the Abbasid caliphs. Recalling when Arabic was a linguistic nexus by which knowledge and translation were disseminated inside the Arab world and later to Europe, al-Yaziji's article deals with a crucial issue of debate in the whole Nahda period: how Arabic could incorporate new fields of knowledge into its historical linguistic heritage during an era of intersecting colonial discourses and languages? With discourses of linguistic conservativism during the Nahda going beyond boundaries of historical and religious identities (Patel 2013: 22), al-Yaziji's article clearly situates his "politics of translation" within a "conservative" frame of linguistic reform: linking normative translation practices of the (Classical Abbasid) past to the prosperity and progress of the Arab people. 
At the same time, al-Yaziji was not calling for scholars to revive a lost past. He frames Arabic's uniqueness in terms of its complexity and its capacity to accommodate and innovate. Alongside its traditions of poetry and metaphor, we see that al-Yaziji's vision of Arabic is of a language with youthful potential to create and conceptualize the present and future by its own inherent strength. This is an important point which situates the Arabic language beyond the historical episodes of the Arab world's unhappy ends to many of its most valuable knowledge resources, the burning of books, libraries and remaining valuable books owned by foreigners.

Committed to drawing on the resources within Arabic, it becomes clear why al-Yaziji foregrounds the role of translation in Arab world history as key to this process, although he does not use the term itself. What he does, however, is make reference to translation strategies. Al-Yaziji reminds the reader that at no point do we read about translators of the Classical Abbasid age expressing a complaint for not finding a suitable new term in Arabic. The reason can be attributed to the translators of the Abbasid era coining new Arabic words from old Arabic roots according to Arabic patterns. Al-Yaziji used this method himself when suggesting new lexical terms for foreign" concepts such as "car," "photo" and "telegram" by using Arabic forms in his contributions to several journals. As we see in the commentary on Hafidh Ibrahim below, this praxis was received with both favor and resistance during the Nahda. But it was used in many Arab countries in response to rapidly changing modern language environment and terminology. In this sense, it is not surprising that this article is considered seminal in Arabic scholarship, and continues to be referenced in modern times.

In this article, al-Yaziji enacts and articulates a view of Arabic language preservation which expands, rather than changes, aspects of Arabic grammar in a modern age. His article nonetheless conceptualizes one of the first - and most impacting - links made by Nahda intellectuals between the status of standardized Arabic language and its connection to Arab peoples' sense of lived reality.

\section{Ruth About Rached}

\section{Note}

1 Exceptions are books of medicine, where many foreign names of medications and illnesses were permitted in their foreign forms, as no synonyms had been found in Arabic, and some had no synonyms among the Arabs. Names of gemstones and similar artefacts are mostly rendered only through loan words. [footnote in the original]. 


\title{
41 Copyright of authorship and translation (1899-1905)
}

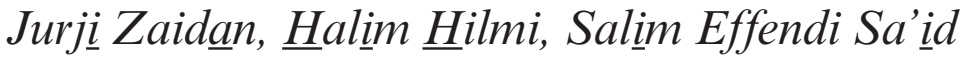

\section{Jurịi Zaidan}

See Chapter 39.

\section{Articles on the rights of translator and authors}

The discussion on the subject began with an article by Jurji Zaidan, the editor of al- $\underline{H}$ ilal, in 1899. Using examples from translations published in Egypt, he raised the issue of novels translated without the permission of their authors, besides omitting the authors' names in the published editions. He argued that the author's permission and mention of his name are moral as well as legal responsibilities. Two issues later, the magazine published a response from $\underline{H}$ alim Hilmi, one of the translators criticized in Zaidan's article. Hilmi defended his omission of the author's name, citing several reasons, to which Zaidan gave his own response. Discussion on the matter was renewed in 1905 with an inquiry from Salim Sa'id, to which Zaidan replied with a detailed article.

Throughout his editorship of al-Hilal, Zaidan would publish notices, from time to time, about upcoming translations of his literary and historical works into different languages. These were usually accompanied by a letter requesting permission for the translation from the author. In response, the request is accepted with an emphasis on the translator's commitment to completing the translation, or rejected if a translation is already underway. The first of these notices appeared in 1895. We have included selected samples of them.

\section{The translation of Armanusa the Egyptian into Russian}

Esteemed founder of the illustrious al-Hilal,

While I was leafing through your trailblazing al-Hilal, I came across the novel Armanusa the Egyptian and, being delighted by its abundant benefits, wished to translate it into Russian in order to make them widely available to the public. Nonetheless, I first wished to seek your permission in this matter. So 
I request that you honor me with a response including your respected wish. You remain among the most excellent of men.

(Nazareth) 'Assaf Girgis Wahba

(Al-Hilal) We thank you for your desire to publish our novel Armanusa the Egyptian for readers of the Russian language. Nonetheless, it will not be unknown to you, sir, that the novel has not yet been published in its entirety, owing to its appearance in installments in the issues of al-Hilal. If you wish to translate those installments as they are published, then there is nothing to prevent you from being granted permission to do so, beyond the condition that you persist in this work until its conclusion. For it may be that a reader is intent on translating the novel into the aforementioned language but that he would cease this work upon learning of your intention, with the consequence that, if you are not persistent in translating it to its end, it would hinder the publication of the novel.

In this connection, the two writers previously authorized to translate the novel al-Mamluk al-Sharid [Mamluk on the Run] into the English and French languages were subject to the same condition.

\section{The translation of Armanusa the Egyptian into the French language}

Esteemed founder of the radiant al-Hilal,

We submit to you the request that you permit us to translate the novels Armanusa the Egyptian and Fatat Ghassan (The Maid of Ghassan) into the French language. With the request in this letter, we commit to you that we will exert the utmost effort to show it in that language wearing the finest garb. We ask you to give your view on this matter, for we stand ready to begin the work. You are most excellent.

(Alexandria)

Muhammad Mutwalli, clerk at Port Customs

Mustafa Ibrahim, at the General Administration of the Egyptian Postal Service

\section{Praise and Criticism Section}

\section{(The Rights of Translation and the Rights of Authorship)}

The literary market has spread widely. Thanks be to God. As there are many readers of novels and other literary and historical books, those working in the service of knowledge have been active in publishing them. Most of those that have been published were Arabized from foreign languages because foreigners began working on this art long before us. Most of what is translated are literary or historical novels because they are the most popular books, and few have embarked on authoring them. Translation is not without benefit, and translators must be greatly esteemed for bringing those benefits from foreign languages into the Arabic tongue. Nonetheless, we reproach them for 
a practice which we see frequently and which most of them commit: omission of the author's name from the Arabized novel. We do not see the wisdom in doing so: if they were to claim authorship of the novel, then we would have said that they wished to arrogate it to themselves. But they acknowledge that they are translators of the novel, so what would harm them if they gave the name of the author who melted down his intellect, spent wearying nights searching and delving, and made himself a target for the arrows of criticism and rebuke. Perhaps upon the publication of the novel, he spent money, yet he does not profit from it. So, is the right of authorship not reserved for him in the same way as we reserve for ourselves the right of printing by stating on the first page of any novel which we Arabize "right of printing reserved to the Arabizer?"

The established convention in the translation of books is that whosoever wishes to translate a book ask for the permission of its author before commencing the translation and that he may pay a monetary price for that right. Nonetheless, the gates have been flung open for no one to ask permission and no one to give it. So, we Arabize novels without feeling embarrassed or being censured by anybody, and without anyone asking us for a fee or permission. Should we not, therefore, at the least retain the name of the author on that which he has authored since it is a legal right resulting from his being the author? We have recently been reminded of this by a number of Arabized novels gifted to us by the pens of writers who have neglected the names of their authors. Let us not need to descend into this issue again. God is the lord of all things.

\section{The Rights of Translation and the Rights of Authorship}

\section{(Halfa) Halim Effendi Hilmi, teacher at a Government School}

I hold in my hands the ninth issue of your al-Hilal, turning its pages and reaping its benefits. When I reached the Praise and Criticism section, I found what you wrote under the title "The Rights of Translation and the Rights of Authorship," in which you repeatedly condemn the Arabizers of novels who omit the names of their authors. I was reading it in the knowledge that its arrows were aimed at me, something confirmed to me when I read your statement that our novel 'Awaqib al-Taish [The Consequences of Recklessness] was "among the novels in which their Arabizers omitted the names of their authors."

My goal in these lines is not to absolve myself of this criticism, but I consider that you have gone too far in your reproach and disapproval and, perhaps, if you were to have been just, you would not have been so strong in your condemnation because the matter is not so exceptional as to deserve such censure. On the contrary, it is a simple error, and I would be very appreciative if you were to refer to it without casting aspersions towards the Arabizers who spent their nights and the edges of their days (and translation is no easier 
than authorship, as you know) searching for European authors who began working in this area long before us, as you have mentioned.

I said that omitting the name of the author of the novel is not considered exceptional because the purpose in mentioning his name is not to ensure appreciation of himself since he is not known among the speakers of the language into which the novel was translated. Rather, the purpose is to acknowledge that it is not from the creativity of the writer but rather authored by a foreign writer. Nonetheless, suppose the author is extremely famous, such as the Frenchman Alexandre Dumas or the Englishman Shakespeare. In that case, the names of authors such as these should be mentioned since their great fame demonstrates the superiority of the book, and mentioning one of their names on the book serves to praise and honor it. If the author is unknown outside his nation or beyond the speakers of his language, it makes no difference whether his name is mentioned or not. Nevertheless, I wished to speak to you and did not compose these lines for a reason other than to demonstrate that Arabizers omitting the names of the authors of foreign novels does not deserve this censure. I offer my profound thanks for your valuable counsel, and I shall follow it if I am to be so fortunate as to translate additional novels in the future, God willing.

(Al-Hilal) We do not deny the hardship endured by Arabizers in bringing foreign books to the Arabic tongue, and it may be that, in some circumstances, it is more difficult than composition. It may seem to some readers if they read an article brought over from a foreign tongue that its translator suffered nothing in writing or knew nothing. They may not realize that genuine translation on a topic demands extensive knowledge of that topic and the greatest care in applying Arabic expressions precisely to the desired meaning. So, we do not underappreciate the value of translators, but nor do we agree with your view that the "purpose in mentioning his name is not to ensure appreciation of his person because he is not known among the speakers of the language into which the novel was translated. Rather the purpose is to acknowledge that it is not from the creativity of the writer" because the author in literary matters, and especially in novels, expresses his morality in them, or at least affirms his view on good and evil morals, so they are an image of his morals and manners. Whosoever reads the writing of an author studies the condition of that author, and it has been said that "you have not read the writing of a man without knowing the scope of his mind from it." Europeans say that if you have read a poet or an author's writing, then "you have read somebody," rather than saying that you have read somebody's writing. The relationship between the writer and his writing is like the relationship between a man and his shadow, so how can they be separated?

The fame or lack of fame of the author amongst us is irrelevant because it is not what we are concerned with investigating; rather, we seek affirmation of his excellence. On the other hand, if we look to the fame of foreign writers among us, then we see that it depends upon what of their work has been published, causing it to be spoken of and become known among the people. 
Alexandre Dumas did not become well known among us for any reason other than because those who translated his work mentioned his name on their translations. If they had paid heed to his lack of renown among us at that time and followed your opinion, then they would have omitted his name, and he would have remained unknown among us even as he was famous among his own people.

The author has two rights in his work, one literary and one material. With regard to the first, it is the relationship between what he writes and his morals and manners. So, it is necessary for the author's name to be linked to his writings so that the reader knows that he is reading the person who wrote that book when he reads a book. As for the material right, it consists in reaping the fruits from what he has sown, and it will not be hidden from you, sir, that fame is a major part of the profits of authors, and perhaps all of it. Some authors may spend long years and great sums of money in authoring and publishing a book with no desire other than that people will benefit from it and acknowledge him. If we translate his writing without mentioning his name, we rob him of all his material right, whether he be known or unknown among Arabic readers. On the contrary, we see his lack of fame among them as demanding the publication of his name so that people who currently do not know his excellence can come to know it. It is also valuable to include a brief account of his life history at the start of the book so that the translation can be a channel for understanding between the author and the Arab readers. As for a famous and well-known author, if his name is not mentioned in some of his works, it will reduce his renown.

The people of the cultured world who know the value of authorship and the rights of authors are not satisfied with simply mentioning the author's name on the books that they translate but rather do not translate any book, or it is not permissible to them to translate any book, without first asking for the permission of its author as we have mentioned elsewhere.

So, you will see from what has been presented that what we said about this matter in the ninth issue of al-Hilal did not go beyond the limits of fairness and that the purpose of including the author's name in his writings is an affirmation of his excellence and not merely a recognition that the book was a translation of his work.

\section{The Translation of The Virgin of Quraish into English}

\section{(Request for permission)}

\section{Esteemed founder of the innovative al-Hilal}

I have read your historical novels published in your wondrous al-Hilal, and the path you followed was so truly excellent that I wished to reproduce these novels in English. Given that others beat me to the translation of Maid of Ghassan and Armanusa The Egyptian, I will content myself now with 'Athra 
Quraish [The Virgin of Quraish], so I request that you permit me to translate it so that I can give it as a gift to the readers of the English language. Many thanks to you in advance.

(Nazareth) Mary Hicks

(Al-Hilal) We are delighted that the esteemed Mrs. Mary Hicks has embarked on the translation of The Virgin of Quraish into the English language, and we are thankful for her care in that and hope that it will be published soon, adorned with English dress.

We request that those who have favored us by translating our other novels into English, French, Russian, Turkish, Hindi, Persian, or other languages write to us with details of what they have translated, for it may be that one of them has turned away from translation for private reasons. No-one else has embarked on translating that novel due to his knowledge that we had permitted its translation, in the pages of al-Hilal, to someone else, for if someone requests our permission to translate one of those novels, we cannot grant it due to our considering it under translation.

\section{The Rights of Printing and Translation in Egypt}

\section{(Alexandria) Salịm Effendi Sa’ịd}

In the third issue of al-Hilal this year, I read a paragraph concerned with the transfer of some of your writings into Urdu, Persian, English, and other languages, saying that the translators of the first two languages did not seek your permission, but that did not prevent them translating and publishing them. How did that happen when countries have laws for publications which protect the rights of authors, with the consequence that one cannot embark on the translation or publication of a book without the permission of its producer? Is Egypt not a party to these laws? What are these rights, and what did you do with regard to those who translated your books without permission?

(Al-Hilal) Every author has literary rights and material or legal rights. Literary rights are governed by common opinion and the ethics of writing and necessitated by the interests of the translator. It may be that the author himself is engaged in transferring his writing to the language to which the translator wishes to transfer it, so his exertions would be in vain. As for material rights, they pertain to financial gain. The author of a book is its owner; the book is the product of his genius and fruit of his mind, so he owns it in the same way as a landlord owns his property. If someone else sought to benefit from it without his permission, it would be considered a breach of his rights.

For this reason, the civilized countries have enacted laws that protect the author's rights, termed by the English "copyright." Among its conditions are that the author who publishes his work during his lifetime retains his rights 
to it so long as he may live. The rights remain with his inheritors for seven years following his death, provided that the period from the publication of the book for the first time until the end of the seven years previously mentioned is not less than 42 years. On the other hand, if the book is published after the death of its author, the right to publish the book passes to the author's inheritors after the conclusion of 42 years from the date of first publication. Authors have risen to demand the modification of these laws because the mandated period which protects those rights scarcely benefits the inheritors of the author who may see no benefit from the publication of the book until after the end of that period.

As for Egypt, it has no special law relating to publication and translation, but authors' rights are protected there as the rights of manufacturers and businesses are protected. If their rights are infringed by the arrogation of their products or business, the government requires the damage to be compensated once it has been proven. Egypt has not enacted a specific law relating to the rights of publication due to the recency of its entry into the world of authorship, lack of authors, and the torpor of the book market - it is rare for someone to embark on the publication of a book out of fear that it will lose the cost of its publication. Additionally, freeing printing and publication has a role in promoting science and literature and, until recently, the government spent money from its treasury to encourage authors by purchasing their books even if it did benefit from buying them.

Now, on the other hand, this renaissance of ours has matured, journalism has developed, and a number of important publications have emerged, so it behooves the Egyptian government to establish a specific regulation for printed materials specifying the rights of authors to make it unnecessary for them to prove the occurrence of damages caused by others having the insolence to benefit from their works and to make it so that the mere fact of someone's embarking on the printing or translation of a book written by another is a breach of the law indicating the occurrence of damage of one kind or another. We see in this not a frustration of vigor but rather the protection and maintenance of rights. Egypt should join relevant international treaties connected with this to protect those rights abroad, for it is not appropriate for Egypt, having emulated the greatest civilized kingdoms in its administrative, political and judicial systems, for the rights of printing and publication in the country to remain in chaos.

Although the author is delighted by his writing spreading and by people competing to translate and print it, he is saddened when it is done without his knowledge, with him only discovering it by chance, as happened to us with the translation of Tarikh al-Tamaddun al-Islami (The History of Islamic Civilization) into Urdu and Persian and some of our novels into Persian, as we have previously mentioned. We know now, again by chance, that some of our Islamic novels were translated into Urdu by our counterpart, the editor of the Indian newspaper al-Wakil, translator of The History of Islamic Civilization, while others were translated by the editor of the newspaper Biza Akhbar. We 
learned this from Mr. Muhammad 'Umar, a student of medicine in Lahore, who wrote to us about some related matters and mentioned by chance that he had come across the novels The Maid of Ghassan, The Virgin of Quraish, Armanusa The Egyptian in the Urdu (Hindustani) language. We wrote to him seeking greater clarification and requesting that he send examples of those translations, and his response arrived yesterday saying that one of our novels had been translated by the office of the newspaper Biza Akhbar in the city of Lahore and that Armanusa The Egyptian had been translated by the office of the newspaper al-Wakil along with the first part of The Maid of Ghassan, while the second part had been translated but needed revision, a task with which he had been entrusted.

We have already reproached our counterpart, the editor of the newspaper al-Wakil, because he translated The History of Islamic Civilization without our knowledge. Then, we received a letter from Mr. Muhamad Effendi Halim al-Ansari, one of the editors of Avadh Akhbar daily in Lucknow, including the translator's apology for this matter. He wrote:

I have translated, over two years, under the direction of his Excellency Janab Munshi Shaikh Ghulam Muhammad, the honorable director and editor of the newspaper al-Wakil in Amritsar in Punjab, the following of your works:

The first part of The History of Islamic Civilization and the first part of the novel The Maid of Ghassan. Currently, we are translating the second part of the book The History of Islamic Civilization, and I have reached page 120 . The publication of these books was initiated by the aforementioned esteemed Amritsari, with the first two already published and the third in press. After printing these books, a translation of the novel Armanusa The Egyptian has also been published. The right to translate it was taken from me, although I had been asking for it for years.

(Lucknow, India) 3 March 1905-Muhammad ㅌalim al-Ansari

So, it is evident that our colleague, the editor of the newspaper al-Wakil, was content with al-Ansari's permission before reaching out further with other translations, so he is excused, and we merely demanded from him our literary rights.

As for the Persian translations, in issue 8 of al-Hilal, we published what we had learned from Mr. Ja'afar Ibn al-Hajj 'Ali Akbar Khaminah that Prince 'Abdul Husain Mirza translated Ghadat Karbala ' [The Young Woman of Karbala ] into the Persian language under the order of Princess 'Ezzat al-Daula, aunt of the current Shah. The History of Islamic Civilization was translated by Zoka-ol-Molk, owner of the newspaper Tarbiat. The aforementioned Mr. Ja'afar sought our permission to translate the novel Abu Muslim al-Khurasani, which we are writing this year. In our response, we mentioned our reproach of the translators and gave him permission to translate the novel. Yesterday I received a letter from His Highness the 
above-mentioned Prince, explaining the reason which led to his translating the novel and saying that he is engaged in translating the novel Abu Muslim, even if we have given permission to someone else to translate it. Here is the text of his letter in which he was generous and humble:

Your humble servant 'Abdul Husain Mirza Ibn Mu'aiyd al-Daula Ibn Daula Shah Ibn Fatahali Shah al-Mabrür says to Mr. Jurji Zaidan peace be upon you. I saw in the third issue of al-Hilal of this year your response to the letter from Tabriz regarding the translation of Ghadat of Karbala ${ }^{\text {‘ }}$ into Persian in which you mentioned the name of your humble servant as 'Abd al-Hai Mirza. As we Iranians had no life, it would not be right for us to be called 'Abdul $\underline{\mathrm{H} a i},{ }^{1}$ so perhaps the writer of the letter erred in writing it. In any case, this servant is devoted to you and I benefit from the overflowing of your pen. I felt sorrow for the people of the Persian tongue, deprived of your writing, so I translated the following: The Young Woman of Karbala', The 17th of Ramadan, Armanusa The Egyptian, and al-Hajjaj bin Yusuf. All have been printed, and I have now begun translating the novel Abu Muslim (even if the writer of the letter sought permission to translate it). I have translated the parts of it that appeared in al-Hilal, so I ask of you the generosity of sending the novel, if possible, so that I may translate the remainder of it.

We say: as for the remainder of the novel, there is no possibility of obtaining it before the end of the year because we have written no more of it than that which appears al-Hilal, issue by issue. We extend to His Highness the duty of thanks for his care in bearing these writings into the Persian tongue and praise the kind words in his letter. He shimmers with the virtues of kings and the attributes of the best of men.

While writing these lines, we received a letter from our counterpart Zokaol-Molk, owner of the newspaper Tarbiat in Tehran, in which he said that he only wished to summarize The History of Islamic Civilization into Persian, so that he could publish it in his newspaper. Having looked at some of what he has published, we thank him for it and see no harm in publishing it as a single volume if he saw there to be some benefit in doing so for the readers of the Persian language.

\section{The Novels of al-Hilal}

\section{Their Persian translations and omitting the author's name}

We have spoken elsewhere of those of our novels that Persian writers have translated into their tongue and published. We thank them for their good intentions but were nonetheless perturbed by the fact that some of them omitted the name of the author entirely, not mentioning it either on the cover 
of the book or in its introduction, as we saw with the translator of Fath alAndalus [The Conquest of Al-Andalus], Mirza Ibrahim Khan, secretary to the French embassy in Tehran. We wrote a letter to Mr. Ja'afar Ibn al-Hajj 'Ali 'Akbar Khaminah, who informed us of this translation and sent us a copy of it, in which we tasked him with communicating our reproach to the translator. His response reached us yesterday, saying that the aforementioned Mirza Ibrahim Khan apologized for omitting the name of the author, attributing it to an error that occurred during his absence from the printing press and saying that he would correct it.

Mr. Mirza Ja'afar mentioned in the letter to which I have alluded that he had begun translating al-'Abasa, the Sister of al-Rashid into Persian and published the parts that he had translated in the newspaper Habl al-Matin, which is distributed in Calcutta. We looked at some of it, and he did not omit the name of the author. We then received a letter from him with that appended, sent from Mashhad in Khurasan.

\section{Translated by Neil Sadler}

\section{COMMENTARY}

These selections from the al-Hilal are connected by the common thread of intellectual property rights of translation, concerning both the translator and the original author. It seems that Zaidan's interest in this issue was sparked by the letters, duly published in al-Hilal, which he received from time to time, asking for permission to translate his historical novels into various languages. This recognition of the author must have contributed to his protest against the not uncommon practice of the time of translators disregarding the name of the original author, even when the work is explicitly presented as a translation. Zaidan first tackled this problem in the regular feature "Praise and Criticism," in which he reviewed the latest publications, specifying particular titles where the original author was ignored. Piqued by what he saw as a personal attack, the translator of one of these titles wrote to al-Hilal, explaining his reasons for the omission, to which Zaidan responded with a detailed rebuttal.

Zaidan, obviously preoccupied with the question of intellectual rights, returned to it, albeit briefly, in later issues of the magazine, either when unauthorized translations of his works were published in other languages or in response to readers' inquiries. Outside the magazine he edited, Zaidan revisited this question in his later book A Journey to Europe (1912), where he counts among the "signs of intellectual advancement" in France the societies established to "promote science and literature, or to guard the rights of authors and translators" (22).

In a chapter on copyright in his The Scandals of Translation (1998: 54-55), Lawrence Venuti argues that there are two sides to intellectual products that 
are referenced, separately or together, when discussing the author's right in the translation. On the one hand, one may highlight the efforts that authors exert in the creation of their works, which consequently become products of labor subject to the same laws that apply to manufactured goods, including ownership and sale. An intellectual product can also be seen as an extension of the author, enjoying the same inviolable rights of his/her own person, so that the unauthorized usage of any of these works would be a violation of the author as a person.

These two arguments are employed in al-Hilal for different purposes. In the first article, $\underline{\text { Halim }}$ and Zaidan value the great efforts that the authors and translators put into their work, which entitles them to rights that should be respected. Zaidan, identifying a financial dimension to these rights, adds a moral one arising from the symbiosis between the author and his work, which is "an image of his morals and manners." As result, the author is entitled not only to recognition, but also to financial remuneration.

The author's rights, in particular, seem to have been a constant concern of Zaidan's. While well-practiced in the two fields, he was more known as an author than a translator. It is also possible that the little financial, or even moral, reward of translation made its intellectual rights a less pressing issue.

The discussion of rights naturally invokes the legal frameworks required to protect them, a question that Zaidan raised in 1905 along the same lines, with a special focus on the financial side. The English law he referenced is the Copyright Act of 1842, which was still in effect in the United Kingdom, but had not been applied in Egypt despite its position then as a "veiled protectorate." In fact, Zaidan emphasizes the lack of any law that protects the rights of authors in Egypt.

It is worth noting that the conditions which occasioned Zaidan's discussion of intellectual rights - the flourishing publishing industry and book marketare practically the same that led to the emergence of copyright laws in modern times. No more an expensive and labor-intensive manuscript circulated among the elite (a situation that compelled many authors to seek patronage), the book became a commercial product that brings direct financial revenue and may allow the possibility of being a full-time, self-funding author. However, Zaidan disregards an important point in this connection, and one that may provide a different perspective specifically on translation copyright. As Hilmi points out, the different circumstances between and Europe, the birthplace of modern copyright laws, and Egypt, where (despite a relative boom) authorship and translation remain scarce, should allow some leniency in the application of copyright laws. It seems unreasonable, on this view, to apply the same laws effective in Europe to countries whose modern literary traditions are still nascent.

Zaidan may have been implicitly addressing this very point when he asserted in his 1905 article that Egypt had "emulated the greatest civilized kingdoms in its administrative, political and judicial systems." Still, this question certainly 


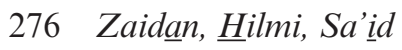

merited more discussion and analysis. For the same international laws that Zaidan espoused had recognized these differences among nations. The most significant of these in that time was the Berne Convention of 1886, which made special provisions for "developing" countries.

\section{Tarek Shamma}

\section{Note}

1 A pun on the name 'Abdul $\underline{H}$ ai, which literally translates as "servant of the Living [God]." 


\title{
42 Translation in Islamic history (1900-1912)
}

\author{
Rashịd Rida, Shibli Nu'mani, Muhammad'Abdo
}

\section{Rashid Rida (1860-1935)}

Islamic reformer, scholar, and educator. Born and raised in Qalamun, near Tripoli in the Levant, he moved to Egypt in 1898 to study under Shaikh Muhammad 'Abdo. In the same year, he issued the magazine al-Manar [The Lighthouse], which was a platform for his advocacy of Islamic reform. He went to Syria during the reign of King Faisal, after independence from Ottoman rule, where he was elected president of the Syrian National Congress, but returned to Egypt in 1920, following the French occupation of Syria. Al-Manar, a major voice in moderate Islamist reform, was Rida's major intellectual outlet; he continued as its editor until his death in 1935.

\section{Muhammad 'Abdo (1849-1905)}

One of the most influential Islamic reformers in the modern era. Born in Beheira, Egypt, he studied at the famous al-Azhar University, then worked as a history teacher. He was active in the 'Urabi Revolution against the Khedive and British/French influence in Egypt (1879-1882), for which he was imprisoned, then exiled to Beirut for a period of three years. He joined the prominent reformer Jamal al-Din al-Afghani in Paris, where they founded the journal al-'Urwa al-Wuthqa [The Firmest Bond], which called for Islamic reform and denounced colonial intreventions in Muslim countries. He was allowed to return to Egypt in 1888, and was appointed as a judge, then became Grand Mufti of Egypt in 1899. His works include Risalat alTawhid (A Treatise on Monotheism) and Al-Rad 'Ala Hanotaux (Response to Hanotaux).

\section{Shibli Nu'mani (1857-1914)}

Indian Islamic scholar, historian, and educator, born in the state of Uttar Pradesh. He worked at Aligarh Muslim University and collaborated in establishing Darul Uloom Nadwatul Ulamain (House of Knowledge and Assembly of Scholars University), an Islamic institution in Lucknow, India. 
He published books on Islamic theology in Urdu, and articles in Arabic in alManar magazine, as well as in al-Hilal.

\section{MUL्HAMMAD RASHID RIDAA}

\section{THE CIVILIZATION OF THE ARABS}

\section{(Third overview)}

Reasons for the late engagement with secular science in comparison with the age of the al-Rashidun Caliphs. Science and the Abbasids. Who else supported science in the east. Science in al-Andalus and Egypt. Astronomy and the Arabs. Astrology and divination. The reason why Muslims practiced astrology despite religious opposition. Science before Islam [...] Science into praxis. Science from praxis to theories. Famous astronomers. Muslim discoveries and inventions.

Nothing appears in the universe without a necessary cause, provided an absence of deterrence, and the religion of Islam is the greatest cause of sciences, arts and material and literary achievements. As for its literary achievements, they shone from the start so that the personal and social manners of people today are nowhere near [as civilized] as those in the first century of Islam. As for the mathematical and natural sciences and the discovery of the mysteries of the universe and the subsequent material works, they were not found amongst the Muslims until after the second condition (the absence of deterrence) was met.

At the dawn of Islam, Muslims were in opposition to the temporal world which they had undertaken to refine and develop. Their lives were threatened together with their message. Once security and confidence prevailed, and the message of Islam spread and took hold, the seeds of knowledge and wisdom sowed by the Qur'an could grow in people's minds. This is something we have already mentioned, and on which we will not expatiate further.

The Abbasid Caliph Abu Ja'far al-Mansur [r. 754-775 CE] triggered the interest in the secrets of nature and in revealing the mysteries of creation. Other Caliphs followed, amongst them al-Ma'mun [r. 813-833 $\mathrm{CE}$, who was key to this movement and played a shining part in it. His successors followed in his steps. But al-Ma'mun's was the leading light, and seeking knowledge was steeped in the religion of Islam itself. The quest for knowledge persisted throughout the earth-shattering upheavals of the Abbasid rule [...]

This is with reference to the East [of the Muslim Empire], but the Muslim West was no less splendid and productive. The Arabs and the Umayyad Caliphs of al-Andalus opened the floodgates of science. They raised the edifice of knowledge and dazzled Europe with their scholarship. [The cities of] Seville, Cordoba, Granada, Murcia, and Toledo hosted the secrets of wisdom 
and promoted literature and trades. Sciences also traveled to the land of the Berbers $^{1}$ where Tangiers, Fez, and Marrakech boasted centers of learning for scholars who rivaled those of the capitals of al-Andalus. As for Egypt, the treasure chest of the Muslim countries past and present, it followed the same pattern. The Ubaidids [Fatimid dynasty of the tenth-twelfth centuries] were great patrons of science, and if the light and influence of the House of Wisdom had somehow diminished, Al-Azhar stood steadfast through time and its vicissitudes [...]

This is a summary of the civilization of the Arabs. If you need further details, here they are:

\section{Astronomy}

[...] At the advent of Islam, science and knowledge were dwindling everywhere. Some learning, however, remained among Christians who were employed by the Arabs to translate the books of the Greek philosophers, such as Aristotle, Socrates, Galen, Euclid, Ptolemy, and others. [The Caliphs] al-Mahdi [775$785 \mathrm{CE}$ ] and al-Rashid [786-809 CE] were generous to these translators, then good translators were found amongst the Muslims. But these translators were not knowledgeable in the sciences they translated into Arabic, hence the numerous errors that occurred. Later on, Arab scholars corrected these translations, together with many of the errors made by the Greeks. We will find out more later.

The first one we know of the outstanding Muslim scholars is the astronomer Masha'alla [Ibn Athari] with his work on the astrolabe and its copper dial and Ahmad Ibn Muhammad al-Nahawandi. The first to master translation was Hijazi Ibn Yüsuf, ${ }^{2}$ who translated Euclid into Arabic. The Arabs had obtained those books from people who were destined to preserve such invaluable riches and the legacy of a long-gone generation. But the vestiges of science they had were incoherent and repetitive. It was the Arabs who had the vision to use knowledge in practice, following the noble hadith "Whoever acts upon what he has learnt will be rewarded by God with knowledge that he has not had before" $[\ldots]$

Then came the enlightened al-Ma'mun, who promoted sciences and arts. This leader obtained knowledge for his people from Athens and Constantinople, and strengthened links with the Greek [Byzantine] kings. He spent generously on the translation of the books brought from Byzantium, or from what could be found in Egypt and Alexandria. During his reign, the geometry works of Euclid, Theodosius [of Bithynia], Apollonius, Hypsicles, and Menelaus were translated, and commentaries of Archimedes' on the sphere and the disc, and others, were produced. Yahia Ibn Mansur compiled an astrological almanac with Sanad Ibn 'Ali who had observed the stars with [the astronomer] Khalid ibn 'Abd al-Malik al-Maruzi in the years 217-218 [c. 832-833 CE]. These two [scholars] had traced the meridian, with 'Ali Ibn 'Isa and 'Ali Ibn al-Buhturi between [the cities of] Raqqa and Palmyra. Ahmad 
Ibn 'Abdullah Ibn Habash composed three almanacs on the motions of planets. These scholars measured lunar and solar eclipses, comets and others, together with sunspots. They observed the spring and autumn equinox and estimated the inclination of the zodiac. As per al-Ma'mun's orders, they corrected Ptolemy's Almagest, which had been translated during the reign of his father, al-Rashid.

\section{MUHAMMAD 'ABDO}

\section{ISLAM AND CHRISTIANITY WITH SCIENCE AND CIVILIZATION}

\section{(The third article by this wise guide and erudite teacher)}

The results of these fundamental principles and their influence on Muslims

Where did the nature of Islam lead Muslims? And what was its impact on their forefathers?

'Amr Ibn al-'As, God be pleased with him, conquered Egypt and his army took Alexandria - six years according to one account, or nine years according to another, after the Prophet (PBUH) joined the Most Kind. Islam then was in its dawn, only beginning to send forth its light.

A survivor from the bygone times was a Jacobite Christian named Yuhanna al-Nahwi. ${ }^{3}$ He used to be a sailor, helping people to cross the sea with his boat. He was interested in science and when some of his passengers were men of knowledge, he listened to their debates. His interest in science grew to the extent that he left being a sailor to acquire knowledge at the age of 40 and surpassed some who were acquainted with science from their youngest age. He excelled in various branches of knowledge and became famous as a philosopher, logician and physician in his time.

Many Western Muslim historians report that 'Amr Ibn al-'As [governor of Egypt] heard of him and respected and honored him, and that this affection grew between the two men. This led a Western philosopher to say:

The affection that developed between 'Amr Ibn al-'As, the conqueror of Egypt, and John the Grammarian shows how the Arab mind can elevate itself to free thinking and high opinions. As soon as it had liberated itself from Pre-Islamic idolatry and joined Mohammedan monotheism, it became quite prepared to explore all philosophical and literary branches.

The Muslims mixed with the people of Persia, Syria, and the rural areas of Iraq and involved them in their state affairs, and their religion did not prevent them from employing them. In fact, their state registers were in Greek in Syria, and they were only written in Arabic decades later. This meant encounters of 
ideas and the tolerance of their religion led Muslims to the study of sciences, arts, and trades.

\section{The interest of Muslims in literary, and then logical knowledge}

[...] The literary acumen of the Arabs, encompassing knowledge of Arab history, poetry, and eloquent prose, reached its peak during the Umayyad period at a pace unsurpassed in other nations. The Umayyad Caliphs gave great importance to literature, and thus high status to poets, orators and biographers. The influence of the sciences of logic was felt at the end of their rule, and a number of philosophical and technical treatises were translated before the end of the first century $[718 \mathrm{CE}][\ldots]$

\section{Their establishment of scientific schools and methods of teaching}

The Muslims were full of enthusiasm for the different branches of astronomy and for all aspects of literature, including legends and stories and social accounts. They started to acquire knowledge from Greek and Syriac, translating the books of the ancients from those languages into Arabic, and this with accuracy. At the beginning, their translators were Christians, Sabeans, and others. Then, many Muslim scholars learnt Greek and Latin and compiled dictionaries for these languages. This in order to acquire knowledge from its sources and transfer it into their own language as their knowledge progressed. At first, those who taught the sons of the powerful were Christians and Jews, then colleges were founded and the teachers came from every sect and creed. They taught what they excelled in.

\section{The sciences and discoveries of the Arabs}

To begin with, the science of the Arabs was Greek, but it became Arab within a century. The Arabs did not want to remain as students of Aristotle, Plato, Euclid or Ptolemy for as long as the Europeans did, that it to say ten whole centuries of Christian history.

\section{CRITIQUE OF THE HISTORY OF ISLAMIC CIVILIZATION}

\section{SHAIKH SHIBLI AL-NU'MA NI}

\section{4}

[...] The Umayyads were the first to introduce a minting house in Islam and they used it to glorify Islam, obviating the need for Byzantine, Persian, and other foreign coins [...] They are the ones who arranged for the diwan and state registers to be translated from Persian, Greek, and Coptic into Arabic, which 
helped disseminate the Arabic language and increase its influence. It did not take long for these countries to become Arab with regard to their tendencies and language. The Umayyads were the first to build a hospital in the land of Islam, in Damascus in the year eighty eight [706-707 CE]. They brought physicians to it and ordered for lepers to be kept and paid wages [...]

\section{The dissemination of knowledge and science}

[...] The Umayyad monarchs showed great interest in the chronicles of past events and countries. [The historian] Al-Mas'udi wrote: [The caliph] Mu'awiya [661-680 CE] [...] summoned the renowned scholar 'Ubaid Ibn Sharba from Sanaa in Yemen, and asked him about the chronicles of the past, foreign kings, and the cause of the confusion of tongues and the scattering of people in countries. He asked him to record what he had learnt and 'Ubaid lived until the reign of 'Abd al-Malik [685-705 CE] [...] [the Umayyad caliph] Hisham [724-743 CE] was interested in chronicles and history and some translated for him the biographies of the Persians, from Persian into Arabic. The translators were ordered by Hisham to translate the book on the history of the Persian kings, the laws of their empire and the biographies of their notable men. This was an illustrated book, translated in the year 113 $[731-732 \mathrm{CE}][\ldots]$

With regard to the philosophical sciences, including medicine and chemistry, their translation into Arabic had good effects. Ibn Athal translated, for Mu'awia, medical treatises from the Greek language, and this was the first translation in Islam. At the time of [Caliph] Marwan Ibn al- $\underline{H}$ akam [r. 684685], there was, in Basra, a skilled Jewish physician who knew Arabic, whose name was Masarjaway and he translated the Pandects of the Presbyter Aaron Ibn A'yan of Alexandria from Syriac into Arabic. When [Caliph] 'Umar Ibn 'Abd-al-'Aziz [r. 717 -720] came to power, he found the book in the libraries of Syria, so he had it taken out and disseminated.

Khalid Ibn Yazid Ibn Mu'awia, the scholar of the Umayyad dynasty, is the first to have sought philosophical knowledge in Islam. He was said to have the ambition to be caliph. But when Marwann [Ibn al-ㅍakam] seized power, Khalid turned to the quest for knowledge and brought a group of Greek philosophers from Egypt (one of whom was Marianus, who taught medicine and chemistry) and ordered them to translate from Greek and Coptic into Arabic, and they translated for him. Khalid wrote on chemistry and medicine [...] Also, Salim, the scribe of Hisham [Ibn 'Abd al-Malik] [...] translated the epistles of Aristotle to Alexander.

Thus, on the basis of what we have said above, the Umayyads are the first to have invited and welcomed philosophers into Islam. They are the first to have ordered the translation of sciences into Arabic, and the first to establish libraries in Muslim lands.

\section{Translated by Myriam Salama-Carr}




\section{COMMENTARY}

The great interest throughout the Nahda in translation in Arab-Islamic history combined the two main intellectual sources of the period: translation and the revival of Arab heritage. In fact, many contemporary intellectuals (and not only Islamic revivalists like Rashịd Rida) looked back to the golden age of translation, especially in the early Abbasid Caliphate for inspiration and models to apply to the present. Thus, we find Abbasid translation as an example to emulate and learn from in one of the foundational texts of Nahda, Rifa'a al-Tahtawi's Takhlis al-Ibrizz, mentioned above. As he ponders the declining state of knowledge in Arabic, al-Tahtawi looks at the Abbasid Caliphate as a cultural zenith, which he attributes to the patronage of the caliphs, including their support of translation (1834: 7-8).

In these articles, published in the Islamic reformist magazine al-Manar in the late nineteenth century, the Abbasid translation movement is interpreted through the Islamic revivalist perspective which Rashid Rida adopted as the official line of al-Manar. In his two articles, he elaborates on the scientific, literary, and cultural renaissance during the time of the Islamic Caliphate, emphasizing its supremacy over European civilization and the caliphs' patronage of scholars and translators.

Rida seems especially anxious to stress the involvement of Muslims themselves in the translation practice. Even though the first translators were non-Muslims (or non-native speakers of Arabic), Muslim scholars, he argues, soon caught up: they learnt foreign languages from their original sources, which actually enabled them to correct, not only the mistakes of previous translators, but of the original Greek scholars and scientists. As part of his emphasis on the originality and creativity of Islamic civilization, Rida explains that the translated works were assimilated by Muslim scientists, who soon were able to discern and remedy their weaknesses, then establish new sciences on their foundation.

The role of translation in the transmission of science remains a current issue in Arabic today, with the Abbasid example often presented as a model for translation as a vehicle for the transmission of knowledge for scientific, literary, and intellectual renewal. Yet, the translation movement (specifically the transmission of Greek philosophy) has also been subject to ideological manipulation and revision, among Nahda scholars, as well as such ancient

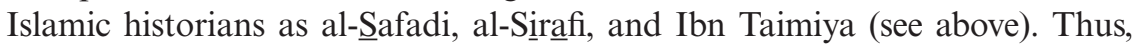
while positive evaluations are more prevalent, especially among translation scholars (see Salama-Carr 2020: 287), divergent views have pointed to negative effects of importing foreign ideas that presumably led to freethinking skepticism, argumentation, and dispute. While these objections were made by contemporary traditionalists, they have been reiterated by some modern scholars in Arabicwether literally (e.g., 'Allal 2018: 7-17), or within more sophisticated theoretical frameworks (e.g., 'Abd al-Rahman 1995: 364ff; 2006: 51ff).

\section{Tarek Shamma}


284 Rida, Nu'mani,'Abdo

\section{Notes}

1 Or Amazigh, the indigenous people of North Africa, west of Egypt, who converted to Islam after the Islamic conquests.

2 The same as al-Hajjaj Ibn Matar (see Ibn al-Nadim, Chapter 10).

3 John the Grammarian, or John Philoponus (of Alexandria), c.490-c.570. 


\title{
43 Translation of Les Misérables (1903)
}

\author{
Hafidh Ibrahin
}

\section{Hafidh Ibrahịim (1871-1932)}

Major Egyptian poet of the Classical school. Born in Asyut, Southern Egypt, but moved to Cairo at a young age. He graduated from the military academy in 1891, and served as a lieutenant officer for several years. He left the army to work as a civil servant, and in 1911 he was appointed director of the literary section in the Egyptian National Library, then assistant director, a position he held until his retirement in 1932. He wrote many nationalist poems, which earned him the title the "Poet of the Nile." He translated literary works from French, and collaborated with the poet Khalil Mutran in translating Précis d'économie politique by Paul Leroy-Beaulieu as al-Mujaz fi 'Ilm al-Iqtisad (Brief Introduction to Economics).

\section{Translation of Les Misérables by Hugo}

Ibrahim published his translation in two parts (in 1903 and 1922), which in total covered the first out of the five volumes of the French novel.

\author{
[UNITY WITH THE ORIGINAL] \\ Les Misérables \\ Written by Victor Hugo \\ and Translated by Muhammad Hafidh Ibrahim
}

(Part 1)

To the Great Teacher [Muhammad 'Abdo]

You are the succor for those living in poverty and despair. You are also the recourse for the dispossessed. This book is full of the pain of all those living in poverty and wretchedness, and the life of the miserable. The book's author Victor Hugo has encapsulated the issues at hand, and by titling it "The Miserable Ones," he has rendered it an epitome of the wisdom of the adage "Mercy before Justice."

I devoted much time and labor to render this story into Arabic as the very life that I myself have lived and the life lived by those in poverty and misery 
come from the same source. I made some amendments through abridging some sections of the story. I consider that I have been able to raise it to your high standards and esteemed opinion by adding three elements of worthfirstly, your high renown and the honor of your association; secondly, the joy of raising this book to a level suitable for a man who appreciates the skill of words and subtleties of understanding; and thirdly, to extend a bridge between the wisdom of the West and that of the East, by dedicating what a wise man of the West wrote to a wise man of the East.

May this great man accept this book from this young son, God preserve him in this world and in His Faith. May He aid me in the rendering of this book for Arabic readers.

\section{In the Name of God, the Merciful, the Compassionate}

\section{Introduction}

\section{On the rendering of this book into Arabic}

This book, Les Misérables, is one of the best works produced in this era. The author is amongst those who live in misery, and he who rendered it into Arabic is of the miserable himself. In this way, the original version and the Arabic version come together, as when we look at a beautiful woman and see her reflection in the mirror at the same time. He, one of the most outstanding poets of the West, wrote his version of the story whilst in exile. This writer here rendered it into Arabic while living within the bosom of its very laurels.

If I had drunk from the cup which this great man had drunk from, the level of my knowledge would have been akin to him and every drop of ink flowing from his pen. If I had had a pen honed from the trees of Paradise, one of "the scrolls of Abraham and Moses" [Qur'an, al-A'la 87:19], and the gift of all aspects of eloquence, having extracted out all of its juices to take all that I need, I would not have had the courage to render this book into Arabic, had it not been for our unity in pain and similarity of hardship.

I pored over this work like an astrologer examining the calendar, seeking God's help in surmounting its difficulties. When my thought penetrated into what was behind its lines, and led me to the depth of its wisdom, the Mother of All Languages called upon me to balance between the beauty of the East and the maid of the West, bringing the two ladies together in a way which fulfills the eloquence of the Arabs and that of the French. For if one side seemed to shine and tempted me to it, I exercised the authority of the intellect to tame this temptation, just as a wayfarer tames a rough terrain, so that she eventually sat serenely by her sister's side. It is oftentimes that I had to intervene between the two sides, like kohl between one lid and another, as if I were a wiseman seeking to mediate between one people and another, until the desires and needs of both intertwined, and the two spirits mixed, their 
two suns shining in one halo. The former endowed the latter with its majesty, while the latter lent the former its glow and loveliness. The meaning of the French emerged, polished with this eloquent tongue and reclothed according to Eastern taste, and so became situated within Arabic meanings.

Speakers of the Arabic language have never to this day come across any work by this wise man, and they are in the direst need to know the secrets of life and grasp the depth of his ideas which I consider at times as akin to moving across the astral plain, while also tracing the steps of even the minutest of creatures, such as the ant; residing between the summit of scientific knowledge and the heights of the most stately palace, whilst between the depths of the ocean and bottom of the river [...]

All writers from all nations are earnestly petitioning to make what inspires them comprehensible to others by bringing into their works wisdom and sayings as their way of warding off evil via their pens in the same way that Arabs would ward off rain by using incantations. These authors rain wisdom from the heavens [via their pens] to let it fall on the pages of their works. They laud these pieces of wisdom as they tell their stories which invoke such calls to moral rectitude and transport the soul away from the pathways of base temptations. Amongst such stories is this book which I have sweated blood in order to render into Arabic. This author relates to us the fairest of stories. ${ }^{1}$ And as he has often said himself, a story like this is akin to a gold mine whose raw ore or essence cannot be fully grasped and its richness immeasurable.

God bestowed upon me the opportunity to render this story into Arabic. I undertook much labor to do this, and all that I dedicated to this story was given back to me by it. I had to hone the equivalent of twelve crescents [i.e., months] to render this story into Arabic in the way that you receive it today. I tried to renew the relation which the hand of the commercial translator has torn between us and those men who dedicated themselves to the Arabization of ancient myths and rendered them skillfully, then clothed them in a lovely apparel which pleases the language and its users.

Have you not seen the book Kalila wa Dimna? Would you yourself be able to realize while you savor the sweet nectar of its construction and the fluidity of its style that 'Abdullah Ibn al-Muqaffa' translated it into Arabic from Persian, if you had not been told that? Sustained by such pens rendering such works into Arabic, I have rendered this story into Arabic. Woe to this language that is now caught between a foreigner calling for its burial and an Arab who plots against it.

Whoever considers the books which have been translated today sees that this beauty of the East is on her deathbed, bemoaning a sanctum violated by pens, and a privacy breached by misconceptions. They have, in these books, opened up a grave for her, her burial shroud their newspapers, their pens the wood for her pyre. All is needed is for Westerners to make their call and her own family and relations make haste to attend the funeral.

God knows that we are the source of her ailment, and we have the skilled doctors. We have heard her call, and we have the saviors [...] 
How could it be that Arabic today has so many masters of eloquence and kings of elegant words when I have but a few names for all these flowers, old and new-when I can hardly describe one palace, one instrument or one invention but what the Arabs of that bare Peninsula saw and what the heights of their civilization in al-Andalus reached? What kind of man the author of Les Misérables had to be, what drops of rain succored him and what air sustained him, so that he could bring into his language words beyond count and take a brave stand against those in opposition until they retreated in defeat? Are our men not able to do together what this one man did alone? [...]

So we find ourselves in a predicament when dealing with many things to which we are referring, but for which we have no names in the language or equivalents to render their meanings.

To all those with the abilities and capacity to reform this language, do so and consider how your forefathers integrated many words from Persian.

The Book of God is there, granting permission to what I am advocating. For the doors of morphological derivation ${ }^{2}$ and blending are, by the grace of God, still open, unlike that of independent judgement in theology. So enter them in security. ${ }^{3}$

\section{Translated by Ruth Abou Rached}

\section{COMMENTARY}

From the first lines of the preface, Ibrahim links himself and Hugo with one discourse on "similarity" as a literary figure in erratic material circumstances, and another discourse on "civilizational transformation" brought about by the medium of writing in Arabic connected to contemporary discourses of the Nahda. In terms of similarity, Ibrahim writes of his and Hugo's experience of "wretchedness" and as a fellow poet with varying fortunes of patronage. It is Ibrahim's sense of shared experience which gave him, according to the preface, the insight to how Hugo's ink flowed. On the other hand, Ibrahim's civilizational task of "Arabizing" Les Misérables does not involve rendering the Arabic version as different from the French version; he describes his process of translation as bringing the "Eastern" and "Western" beauties together, showing the charm of each alongside the other.

Ibrahim justifies how and why this translation took twelve months for a number of reasons. His role of mediating between different people and civilizations by "living through" Hugo was a connective one which could only be experienced by Hafez in its own time. The second reason was due to décallage on two levels: the first between words of the nineteenth century in French and Arabic, and the second between levels of literary/political awareness of Hugo's readerships and the Arabic readerships of Ibrahim several decades later. 
As did other writers of the Nahda era, such as Butrus al-Bustani and Ibrahim al-Yazzji, Hafidh Ibrahin drew on normative translation practices of the past to justify his translation practices. The novel is annotated with numerous footnotes to explain complex terms or to justify his changing of some passages to keep the novel "relevant" to Arab readerships. In his preface, Ibrahim also critiques the practices of "commercial" translations whose processes of importing "foreign" words, he fears, risks "killing" Arabic. Linking his critique to the charged dynamics of colonial discourses in Egypt, he cites Western critics" praise for "foreign" words in Arabic as a ruse for her own family and relations to "attend the funeral." For this reason, Ibrahim took an approach to the Arabic version based on drawing on older Arabic word roots to create for the Arabic version a deeper meaning.

Ibrahim's modes of translation initially appear akin to a politics of translator-writer "simpatico" described by Venuti (1991), as a translator's shared sense of "common sensibility" with the author increasing "the fidelity of the translated text to the original" (1991: 3) - but considerably reconfigured and reconfigurable by the politics of the Nahda and Ibrahim's own experience of language and translation. For although Ibrahim clearly admired the work and identified with the theme of "misery" expressed as text and paratext, his mode of translation is not about making the Arabic text a reflection of the source text. Rather through it, Ibrahim is working to reflect something of the Arabic language of old back to readerships via the French novel as frame. As explained by Mustafa Sadiq al-Rafi'i account of Ibrahim's translation, the reader encounters three levels: "in the language of translation, in the rhetorical eloquence of the language, and then in the strength of that eloquence" (1937: 323). Several decades later, Taha Husain critiques the complex register of language (as well as inaccuracies, omissions and exegesis) in the Arabic version, making the work no longer "a translation of Hafiz but a book of his which holds no benefit for us" (1933: 92). The thrust of Husain's critique is that Ibrahim's eloquent register, so suitable for Arabic poetry, does not resonate as a register of translation for a novel aimed at readers of a modern era: it is, as he argues, "written in a different age" (1933: 85). Although in jest, Husain recalls his own suffering when reading the novel in Arabic due to its highly complex register (1933: 87). He puts forward an important counterpoint for eminent Nahda writers justifying translation strategies from a sense of "simpatico" towards an author or text: one writer's sense of identification with one author cannot stand in for-and be transmuted to - whole readerships. In other words, the personal ideology of the translator should not exclude emergent readerships in Egypt in dire need of new relevant ideas in order to imagine differently.

Taha Husain nonetheless describes Ibrahịm in a different article as a poet who saw his own suffering in the Egyptian people, who also saw themselves in him: "Ibrahim's genius was his ability to imagine and represent the pain of the people" (1933: 160). Thus, despite his critique of Ibrahim's translation of Les 
Misérables, his commentary here sheds light on why his translation should not be discounted as reflecting only a (misplaced) sense of identification on the part of Ibrahim with Hugo. As noted by $\underline{\text { Hu} u s a i n ~ h i m s e l f, ~ I b r a h i m ~ w a s ~ s e e n ~ b y ~}$ his contemporaries as embodying the "downtrodden" of Egypt by the subject matter of his writing poetry and his mode of living his writing in ways which went beyond "similarity" to connectivity. Arthur Arberry, quoting Husain notes, "He was not an individual living by himself for himself: all Egypt, nay, all the East, nay, all humanity was at times living in this man, feeling with his senses" (Arberry 1937: 45). This sense of connectivity is apparent when Ibrahim likens Arabic to the "water" of its people, and the deterioration of Arabic to the onset of a "funeral": the preservation of Arabic shared by him and his people is literal lifeblood, which he sets out to preserve for him and his compatriots, however they understand it, in poetry and in this new translation.

By these words, Ibrahim is situating his translation strategies within a framework of collective conservation of Arabic alongside a presentation of individual identification. He thus ends his preface with a lack of apology for his translation decisions, asking the reader to keep the "doors" or options of word coinage open. These final words thus frame any difficulty in reading "The Miserable Ones" as expected, and serve as testimony to the seepage of Arabic language in centuries of neglect and occupation.

\section{Ruth Abou Rached}

\section{Notes}

1 Compare the Qur'an, Yusuf 12: 3.

2 The process of coining new words using standard roots and morphological rules, contrasted here with blending, where a new word is created by combining two or more existing ones without any pre-established principles.

3 See the Qur'an: "Enter you into Egypt, if God will, in security" (Yusuf 12: 99). 


\title{
44 Homer's Iliad (1904)
}

\author{
Sulaiman al-Bustani
}

\section{Sulaiman al-Bustani (1856-1925)}

Poet, translator, and politician. Born in Bkheshtin, Mount Lebanon, he studied at Butrus al-Bustani's National School, then worked as a teacher there. He knew several languages, including Turkish, English, French, Syriac, and Greek. He published his articles in magazines, including al-Jinan and contributed to Butrus al-Bustani's encyclopedia. He traveled in Asia and Europe on business trips. Upon his return, he served as a member of the Ottoman Senate, then as a minister of finance. After the start of World War I, he resigned and left for Switzerland, where he stayed for five years. He passed away in New York, where he had spent the last years of his life.

\section{The translation of Homer's Iliad}

Besides al-Bustani's extensive introduction, the book includes illustrations of scenes from the epic, historical maps of the geographical background of the action, as well as indexes of poems (by rhyme), terms, subjects, and names.

\author{
[INTRODUCTION TO THE TRANSLATION OF THE ILIAD] \\ Homer's Iliad \\ Translated in Verse \\ With historical, literary explanations \\ Including an introduction about Homer and his poetry, \\ and the literature of the Greeks and the Arabs, \\ A general glossary, and indexes \\ By Sulaiman al-Bustani
}

This is Homer's Iliad, which I present to the Arabic readers, resplendent in Arabic poetry. I have expended my best efforts in its versification and formulation in the hope of producing a successful translation, free from foreignisms and infelicities.

I have furnished the translation with an introduction in which I discussed his compositions, his status among the ancients, views of him among the 
moderns, and what has been written in Arabic about his poetry. I explored the Iliad - its themes, means of transmission before being written, its collection and committal to writing, and its freedom from distortion, notwithstanding the few additions, omissions, repetitions, and obscurities. I undertook to analyze and dissect it, expounding on its benefits in literature, history, and various other sciences, arts, and industries. I explained the reasons that made the Arabs in early Islam neglect to translate it into their language.

I also discussed the translation, including the history of the translator in composing this book. I ventured into the methods of the Arabs in rendering foreign books, and the ways on which translators should depend. Consequently, I looked at poetic translation, then versification as such, including poetic meters and rhymes, and the relative effect of each as to the meaning, as well as cases of poetic license - familiar or disagreeable - and other issues specific to this art.

Then I compared the Iliad to Arabic poetry. I started the discussion with ancient poetry - its origins and the reasons for its extinction - the debates at 'Ukadh Souq, ${ }^{1}$ where the dialect of Quraish was paramount, and what we owe to the Qur'an in putting together the fragments of Arabic, thereby unifying it and perfecting its rhetoric in composition and verse. Here I compared the Mudari ${ }^{2}$ of Quraish with the Ionic of the Iliad. Detailing the historical phases of Arabic poetry, I identified the various categories of poets, from pre-Islamic times down to this day. For every category, I identified its characteristics, duration, and distinguished representatives, including when possible some of the gems of their poetry. Then I indicated the foibles of Arabic poetry; the poetic themes, techniques, and styles of later poets; and the history of the sciences of the Arabic Language. I concluded with the reasons for the weakness and decline in modern poetry, and the efforts of the eminent minds of this age to remedy these flaws and amend poetic methods. I dedicated a section to epics, or narrative poetical compositions, that resemble the Iliad. Then I indicated the forms of poetry among the Franks, comparing foreign epics with those of pre-Islamic poetry and Jamharat Ash' $\underline{\text { ar }}$ al-'Arab. ${ }^{3}$

After an excursion into the two ages of paganism - of the Arabs and the Greeks - and the epics of the moderns, I returned to poetic inquiry with discussion of truth and figurative language. I discussed variation on poetic meanings through metaphor, simile, metonymy, and ornaments; problems of imitation, plagiarism, and coincidence of ideas; as well their changes due to differing modes of civilization. In this regard, I touched on poetic styles in other languages, emphasizing the relative advantages of Arabic in some cases.

The introduction concludes with a coda on language and poetry, contrasting Arabic and Greek. Herein I explore the immensity of the Arabic language, reflected in the richness of its ancient treasury, its numerous synonyms, the multiplicity of meanings for single utterances. I also explain the benefits and harms of these properties. While identifying the reasons for the want in conveying meanings that have emerged in modern times, I indicated the Arabs' methods of expanding linguistic usage and convention. I conclude with 
a brief summary of what seems to me to be the illness and the medication, the modern renaissance, and the future of language and poetry.

I added explanatory comments which I intended to be both useful and diverting. These were interspersed with about a thousand verses in which Arab poets treated of meanings or events similar to those of the Iliad, including what should be known of the manners of the Arab nation "in their paganism, nomadic state, and civilized phases; their famous myths and rituals; their traditional mores, and customs; the methods of their poets and literati; the famous/landmarks of their kings, princes, politicians, and leaders"; in addition to other issues that I explained in the Translator's Personal Account. I used full diacritical marks [shakl] for the poetic text. in addition, I inserted into my explanations many figures illustrating gods and other figures that are worth viewing.

Finally, I appended an index of the illustrations and rhymes, a glossary of terms, and two more glossaries that cover all the contents of the book: personages, history, science, industry, manners, customs, and so on.

These, on the whole, are the contents of this book. If the work to which I dedicated my effort be successful, then this would be the fruit of arduous labor. Otherwise, it would suffice that I opened a door through which may pass those who God guides to success.

\section{INTRODUCTION}

\section{[...]}

The Arabs' Disinterest in Translating it into their Language

The Arabs were among the nations most distinguished for their devotion to literary disciplines, dedication to memorizing poetry, and fondness for verse. One may wonder why the Iliad remained beyond their reach, when it is so widely spread among the nations of the earth-indeed having been composed in a Semitic language like theirs, ${ }^{4}$ and chanted by literati in their very midst during the Abbasid Caliphate. However, if we ascertain the reasons, we will no longer marvel at this inattention to the book in the past - with the evidently dire need to translate it in the present [...]

\section{The Iliad and Islam}

What we said about Christianity in its nascence applies to Islam in its early phases. For the leaders of the nation, assuming they had had any knowledge of the contents of the Iliad, would undoubtedly have been uneasy about it being spread among the common people, lest it might be corrupting to their faith.

In addition, no sooner were the Arabs out of the Bedouin wilderness than they took possession of vast lands, spread in many countries, and established great kingdoms. As soon as the Umayyads had secured their monarchy in Syria, they realized the need to obtain books of science. Likewise, when the 
foundations of the Abbasid State had been laid in Iraq, the caliphs assembled councils of translators to render the sciences of past nations: Persians, Indians, and Greeks. They perceived that they needed science more than poetry or literature - most of all medicine, and, for the defense of their religion, kalam. So they embarked on the translation of the medical and philosophical works of Hippocrates, Aristotle, and similar scholars, ignoring the Iliad and other works of literature.

Additionally, no language in the world rivals Arabic in the body of poetry or the number of poets, all of whom are passionately loyal to their art. Like devoted votaries, they could not conceive the possibility that there might exist poetry in any other language which emulated the eloquence, harmony, precision, and excellence of their poetry. This was another reason why they neglected to partake of foreign poetry, being content in their possession of the gems of that vast sea. I do believe, however, that if the glorious age of the Abbasid Age had lasted longer, or if al-Ma'mun ascension to the caliphate had been delayed by two generations, some of the passages of the Iliad would now be recited in literary forums. The fact that the later State of al-Andalus patronized literature does not diminish the truth of this statement. For the Andalusian Umaiyads, while innovative in literary arts and exceedingly accomplished in poetry, in no way matched the Abbasids of Baghdad in their interest in importing the philosophy of other nations and having their books translated.

After these states, no Arab state emerged that showed similar commitment to accumulating sciences from their treasure troves and seeking literary arts from their fountainheads. For the Fatimid State of Egypt and those of alMaghreb were engaged in other concerns - not to mention the paucity of translators in those times who were proficient in foreign languages besides their own.

\section{Arabic translators}

Two natural barriers which were also substantial impediments to the poetic translation of the Iliad in the early eras [of Islam] may be no less-perhaps even more - serious than religious ones.

First, the caliphs' translators, such as Ibn al-Khasi, Ibn Hunain, and the Bakhtshu' Family, were not Arabs, even though they had been educated in Arabic at the hands of its masters. It would not have been easy for them to compose Arabic poetry. To the Arabs, they were men of science, not literature - even if they had cherished the literatures of their own languages, so much so that they had bedecked Syriac with the jewel that is the Iliad, composed in poetry that they used to chant in their assemblies. The only exception to this rule was a small number of Persians who so dedicated themselves to the arts of Arabic that they excelled to the point of distinction, and these were not poets either. 
Second, Arab poets themselves did not know Greek, so none of them was suited to this task. If it is objected that the inability to compose Arabic poetry should not have prevented the Iliad from being translated into prose, just as Ferdowsi's Shahnameh was translated [from Persian], we can point out that the links between the Arabs and the Persians were a lot stronger than those between the Arabs and the Greeks. How different, indeed, the authors of the Iliad and the Shahnameh! The one is an idol worshipper; the other a Muslim litterateur. And even then, the Shahnameh did not find an Arab translator until a king who understood both Arabic and Persian was so enthralled by recital of the original that he wanted his own nation to be enthralled by recital of the translation; whereupon he generously patronized a man whom he had found to be qualified for the undertaking. It is hard to imagine this event under different circumstances. ${ }^{5}$

Furthermore, it is no secret that when poetry is translated into prose, its loveliness is lost and its elegance faded. It seems that this rule applied to the Shahnameh and caused it to be consigned to oblivion. Otherwise, it would not have been lost to us, becoming no more than a memory. We read about it in history books, but no author has given any account worth mentioning of it.

In fine, whatever barriers may have thwarted men of letters from translating the Iliad and revealing it to the common reader are no more present in our time. Indeed, is a necessity of this age to dress the Iliad in an Arabic garb, in which our language can emulate those of civilized nations. This is especially the case since the myths of pagan religions depicted therein are now extinct. Thus, it is incumbent now that their relics remain as examples to be admonished by.

\section{THE TRANSLATION}

\section{The translator's personal account of his translation of the Iliad}

A great number of my literary friends have asked me how I translated the Iliad and what motivated the translation. Thus, I wrote the following chapter, which I hope will be of use to those who have face a similar challenge.

Since childhood I have been enamored of reading narrative poems, especially those treating of fantasy and ancient creeds. As our language is almost devoid of this kind of poetry and my time was consumed with school responsibilities [...] I would put together what I could glean from my teachers' incidental conversation or examples cited in textbooks [...]

When I came of age and had full power over my leisure time, I realized how little I knew, notwithstanding my previous illusions of wide knowledge. So I wound up where I should have started. Now I approached these verse compositions, of which none, except Milton's Paradise Lost, I had properly read. I read every one of these books that I could obtain - in its own language when I could read it, or in a translation in a language that I knew. 
With every verse composition I read, ancient or modern, I would admire the Iliad even more. For while it is the oldest, it is still the clearest, widest of breadth, most modern of appeal, impressive of energy, and eloquent of them all. Poets have emulated it as a model but could not scale its heights. They abated their thirst from its waters, and they had their fill, but it was not any the less for it.

So I said to myself: how fitting it is for our Arabic language to obtain an instance of this unique gem! It has a greater claim to it than other civilized nations that have partaken of it. Indeed, neither the Europeans' languages, nor their poetry, have the resources that would render the Iliad in a lovelier guise than those of our language. For the poetry of the Greek is in a language that is close to original nature like ours, set in a time of paganism similar to ours. No poets in any nation have handled the topics of wisdom and poetic description in a manner identical to the that of the Iliad like our early poets.

Therefore, I entertained the hope of translating the Iliad, despite my knowledge of the enormity of the undertaking, the harshness of the terrain, and the long path ahead [...] Having composed the first line of it, I was determined not to cease until I had completed the last.

\section{Translating the original}

I instituted a plan for myself whereby I would compose random samples of the Iliad and show them to men of letters-probing their reactions and locating the flaws of my work. This, I thought, would be the wise course of action before I delve into the work. With my mind thus set, I tackled a French translation of the Iliad in my possession, and placed it alongside an English and an Italian translation. I opened the French translation a third of the way through to find Achilles and Agamemnon in argument [...]

Then I put together my draft translations of the three poems and presented them to poets and literary men that I visited or was visited by, including those familiar with modern poetry and others long accustomed to old poetry. They expressed approval and compliments, which only enhanced my zeal. However, I sensed doubt and worry in some of them lest I might suffer boredom and discouragement, considering the strenuous toil involved in this tremendous task, and the enormous costs to be incurred if the book were to be printed. For Arabic readers and those who seek this kind of book would not risk incurring the exceeding cost, labor, and time. Yet, this was the least of my worries: I had not embarked on this endeavor coveting profit; indeed, I had resigned myself to loss if need be. It was not that I despised financial gain; I was driven by a passion that despised hardship.

Now I told myself that it was the time to start. So I returned to Book 1 , and continued the translation uninterrupted until I completed this book and versified half of Book 2. During the composition, I would compare the various translations, sometimes finding differences that made it difficult to opt for one version over the others. Consequently, I stopped my composition, and 
decided that I had to go back to the Greek original. For no correct translation can be made except from the original.

My knowledge of Greek then was completely unsatisfactory, limited to basic reading, besides a handful of words and rules which were barely sufficient. Looking for a teacher for this purpose, I was guided to a Jesuit scholar who I was told was as competent in Greek as he was in French. As I knew that the Jesuit Fathers were not allowed to give private tutoring outside their schools, it became necessary, besides the teacher's acceptance, to secure his superior's permission. Having fortunately achieved these two goals, I expressed my gratitude to these gentlemen for their generosity. Now my teacher taught me the principles of the language and explained the books of the Iliad to me, while I was intent on my study, dedicated to its benefits. After I spent several months with the teacher, I learned from him that I could continue my study on my own and translate the Iliad from the original, relying on language books and guides, so I left him in gratitude. After a period of time which I spent in painstaking reading, I resumed the translation.

I still was not fully satisfied with what I had translated in Books 1 and 2. When I re-examined these parts and compared them to the original, I found flaws that necessitated revisions and corrections. I did not hesitate to alter a verse or two; indeed, I would rewrite entire stanzas. However, I did not need to make such revisions in the remaining books, apart from substituting a word or a hemistich, or replacing a rhyme with another-issues that all versifiers encounter. Otherwise, I would toil to craft every verse as much as possible before writing it down.

No sooner had I settled in Egypt than I was called upon by the necessity of travel that had pursued me since my early youth. I left Cairo in 1888, stricken with longing and fondness for it [...] The Iliad was my companion in all my travels. I would scrape together whatever bits of time I could manage; whenever I was finished with a duty, I soon hastened back to the book. Weeks and months would pass with the Iliad kept away, until suddenly I would bring it out of its slumber and resume work on it. This often happened on mountain tops, as well as aboard ships and trains. In this respect, this work came into life in the four corners of the earth.

In all the places to which I traveled, I was keen to draw on the support of local scholars. This was especially the case in Istanbul, where, as my good fortune had it, I got in touch with Greek men of letters who were passionate admirers of Homer and his Iliad, such as Stavridis [?], translator at the British embassy, and Karolidis, professor at the Halki seminary in Istanbul. Some of these could read Arabic, so, benefiting from their generosity, I consulted them about ambiguous or inscrutable parts. When I read out to them parts of my Arabic compositions, they would be enraptured with the delight at prospect of the Arabic translation of their greatest poet. I continued to work thus fitfully until the early summer of 1895 [...] when I was eventually finished with the labors of translation. 


\section{Writing the explanations}

From the beginning, my aspirations went beyond composition. For if the Iliad were to be presented to Arabic readers devoid of explanation, they would think of it merely as a poetic construction, of no more benefit than the numerous volumes of poetry widely available in our language. Hence, I found it advisable to write explanatory comments on the translation following a new, unprecedented style. My intention was to encourage the Arabic reader to look back at the manners of his nation in its paganism and parts of its civilized history - its famous myths and creeds, established customs and mores, the methods of its poets and litterateurs, and the memorable deeds of its kings, princes, politicians, and leaders. He would thus admire the vastness of his language in its capacity for all natural meanings, notwithstanding its present inability to fulfill some modern meanings. I also describe relevant aspects of the conditions, language, and social life of the Arabs. All this in comparison and contrast with counterparts in ancient nations, especially those of Greece.

For the benefit of the foreign reader who knows of our language, a portal will be opened that no one, I believe, has entered before. He will be able to search, plumb, and explore, thus being acquainted with all types of subjects to which we have been mostly oblivious.

For this purpose, I had to read pages upon pages - weighty volumes in Arabic and foreign languages on literature, poetry, and history. If you look over the poetic citations in the glossary at the end of the book, and find that I had to quote two hundred Arabic poets in all ages, not to mention quotations from foreign poets, you will excuse me for the time I expended in explaining the book. At times, I had to read a poet's entire oeuvre in quest of one verse. If you put together the time I spent on poetic composition, it will be hardly half the time I spent on writing the explanations [...]

\section{Principles of translation}

Many those who have translated European languages into Arabic have followed self-invented principles, with which they have mostly gone astray. They gave their pens unrestrained leeway to go wherever they would take them, regardless of the author's intention. Some took liberties with the meaning, adding and omitting as they wished-in the process corrupting the transmission and losing the original. Others could not in their haste spare some moments of their time to verify the authors' intention: misunderstanding a statement, they would convey it based on their first impression, thereby reversing the meaning inadvertently. Others would distort the translation by clothing it in whatever garb they fancied; they so transformed meanings in line with their own intentions and plans that no trace was left of the original. And there are those who exerted themselves to the utmost, but were unqualified to sail this ocean, no matter how hard they tried. 
Then these writers have no qualms about calling their productions "translations." They would better call them "quotations," "summaries," "imitations," or "distortions." Yet, even less deserving of excuse and forgiveness are the imposters and frauds - those who appropriate books, translating all or part of them, then turn them out to the public as the products of their own minds. However, we still have a fair number of those with learning and honesty who are committed to truthfulness. With precision and rigor, they skillfully deliver truthful productions. When they translate, they acknowledge the translation; when they take liberties, they explain the purpose thereof; if they enclose quotations, they indicate the reason; and if they imitate, they say what the imitation is for. It is these, provided we can trust their competence, whose transmission should be believed and whose example should be followed.

\section{Arabic translators}

Looking back at the early translators, we can see that a large number of them belonged to that latter class. Varied as their mastery was in conveying the intention, they all aimed for actual benefit and maintained truthfulness and accuracy. They followed one of two methods of translation, as described by Baha' al-'Amili in his al-Kashk $\underline{u l}$, citating al-Safadi [see Chapter 19]:

Translators follow one of two methods. The first is that of Yuhanna Ibn al-Bitriqu, Ibn Na'ima al-Himsi, and others. Here the translator considers every individual Greek words individually in terms of its meaning it signifies, finds an individual word in Arabic that is synonymous in signifying this meaning, and adopts it. Then he moves to the next word in the same manner, until he has completed what he wants to translate. This method is flawed for two reasons. For you will not find Arabic words that correspond to all Greek words. This is why many Greek words were left as they were in this kind if translation. On the other hand, structural features, and syntactical relations in one language are not always identical to those of another. In addition, errors could result from figurative uses, which are abundant in all languages. The second method of translation is that of Hunain Ibn Ishaq, al-Jawhari, and others. Here the translator approaches a sentence, comprehends its meaning, then expresses it in the other language with a corresponding sentence, regardless of whether individual words are equal. This method is superior. It is for this reason that Hunain's books did not need revising, expect in mathematics, in which he was not versed. Contrariwise, his translations in medicine, logic, physics, and divinity, did not require any correction.

These two approaches indicated by al-Safadi six centuries ago are still the ones on which to depend in translation to this day. No third method exists for true translation. As he said, the first method is a bad one if aimed at obtaining the gist of the meaning; but it also completely obliterates the 
elegance of expression. This type of translation is not appropriate for books meant for wide circulation, be it among the common readers or the elite, none of whom would be pleased with it. Indeed, you seldom find a reader who could complete one page of this kind of translation. Still, it is useful for those who seek the utterance, rather than the meaning-for which reason some European authors have used it in works intended for language teaching, as well as in many books of literature and poetry, such as the compositions of Homer and Virgil, when meant to benefit those interested in Greek or Latin, rather than in the Iliad or the Aeneid. For this method to achieve its true benefit, two conditions should be met. First, the original should be enclosed in its own language, together with its counterpart in the translated language. Second, it should be accompanied alongside by another translation in the second approach, that of Hunayn, so as to clarify the import; otherwise, the reader would be confused about the meanings and would miss the force of expression. Since what should be pre-posed in one language should be postposed in another, what must be explicitly stated in the original has to be implied in the translation, and so on, then sentences translated with the first method would have flawed constructions and inverted structures: no elegance, precision, correct grammar, or harmony.

The second method is the one which is trusted by the majority, as it secures the intended benefit, viz. transmitting meanings and formulating them in correct constructions agreeable with the language of the translation and the tastes of its readers. A book translated in this way would read like one in Arabic - not in a foreign language, as in the former case. Thus, it can be said that our method is that of Hunain Ibn Ishaq and al-Jawhari.

\section{The translator's approach to translating The Iliad}

It can be seen from the above that the translator has been careful to render the original with truthfulness, while heeding the texture of language. For further clarification, I assert that I have been determined not to add to, or take away, from the meaning, not to pre-pose or post-pose save when required by linguistic structure. I would take a statement—spanning a verse or two, sometimes more or less - and formulate it into an Arabic mold, whose elegance I strove to polish to the best of my ability. Only when I was convinced that I had fully refined this statement would I move to the following one.

As Arabic poetry varies in length depending on the meter used, it was inevitable for the number of verses to be different between the original and the translation. Greek poetry is not comprised of verses with hemistiches as in Arabic; each hemistich in it is a full verse [...] Besides, two verses in Greek may be linked in such a way as cannot be implemented in Arabic. Therefore, it has not been always possible to translate a Greek verse into an Arabic verse or a hemistich [...] As a result, Arabic verses amounted to between ten and eleven thousand verses, translated from an original of sixteen to seventeen thousand verses. 
In my readings of European translations, I rejected things which I would hate others to reject in my translation. So I steered clear of them. For example, some translators would take peculiar liberties with the original, substituting a sense or a word with another on the most trivial excuses (as explained at relevant parts in the commentary). More peculiar still are audacious omissions and additions; in some places I found many verses that they had condemned to omission and others that they had been tempted to add. One of them wove four into 34 verses, enclosing meanings that did not cross Homer's mind.

\section{Preserving the original}

I was most concerned not to commit such an injustice. I did not take any liberties with the meanings, preserving the words when possible. When a word has been deleted, it is either a repetition that is agreeable in the original language, but not in ours; a word that can be deduced from the drift; or a title or epithet that does not have to be mentioned at all times. When I added a word, it was either required by the context of Arabic expression, or a rhyme that does not augment or diminish the meaning. Pre-positions or postpositions were limited to short stretches, as demanded by the Arabic cast of expression - which was the greatest restriction I imposed on myself.

\section{Avoiding the inelegant and arcane}

I avoided to the best of my ability inelegant and arcane expressions, hoping that mine would not be contemptible to the elite or incomprehensible to the commoners. When I had to use a specialized term, this was for coinage that cannot be replaced with another, a rhyme that cannot be abandoned, or an expression with no superior in familiar usage [...]

\section{Versification in translation}

$[\ldots]$

Rhymes

\section{Greek and European rhymes and meters}

For an Arab, "poetry" denotes composition in rhymes and rhythms; to his mind, rhyme is as intrinsic to poetry as rhythm is. This cannot be generalized onto other languages. Greek and European languages do not have meters based on a specific set of rhythmical patterns, as is characteristic of the language of the Arabs and other Easterners who followed their example, such as the Syriacs, Persians, and Turks. For Westerners have their own measures and rhythms $[\ldots]$

Rhyme, on the other hand, is not a poetic prerequisite in all languages: in French, rhyme is essential for poetry, while English has rhymed as well as 
unrhymed poetry, as so does Italian and German. For this reason, the Iliad has been rendered into some European languages in rhymed verse, as in Pope's version, as well as in blank verse, as in Monti's. As for the Greek original, it has rhythm, but no rhyme [...]

Rhymes in Arabic

In Arabic poetry, rhyme is indispensable. For Arabic is a sonorous, highly regular language, in which measure and resonance should be observed. Arabic abounds with so many corresponding rhymes as would hardly be found in any other languages; one cannot be excused for showing it unadorned when it is possessed of such lovely gems. If a European confines himself to composing poetry in couplets each having the same rhyme, from which he moves to others $[\ldots]$ before he is forced to repeat the same rhyme after a while, or if he chooses to compose poetry that is bare of rhymes entirely, we cannot blame him. For this is how his language was created; indeed, no matter how hard he exerts himself in many places, he cannot bolster two rhymes with a third. The Arab poet is in the opposite position: rhymes of many kinds pour upon him like rain; if they run dry, it is only due to his own lack of ingenuity, his pursuit of a narrow path, or persistence in a poem too long to be composed in one rhyme.

\section{Translated by Tarek Shamma}

\section{COMMENTARY}

Al-Bustani's Arabic translation of Homer's Iliad was published in 1904 and is widely held as a masterpiece in which literalism, in Berman's sense of 'fidélité à la lettre' (Berman 1984), and stylistic flair are married. This translation is considered to be one of the best translations of poetry into Arabic where attention to rhythm and rhyme are combined with meaning accuracy. In the translator's preface, al-Bustani explains that he has strived to present Homer's Iliad as Arabic poetry for his readers. It can be argued that this approach corresponds to a form of domestication. Here an ancient and iconic text is adapted to a new readership.

Al-Bustani's approach is interesting in that he relied on a French version of the Iliad, which he contrasted with an English translation of Homer's book, as his knowledge of Ancient Greek was somewhat limited. Indeed, indirect translation was not uncommon during al-Nahda. The most translated languages by far were French and English (the latter at a considerable distance), apart from some limited exceptions (including Russian, which was linked to the missionary and diplomatic presence of Imperial Russia in Palestine, and Ottoman Turkish in the first half of the nineteenth century). Consequently, translators often resorted to second-hand translations when rendering works from other languages, such as German and Italian (see also Sa' $\underline{a} d a$, Chapter 48). 
In addition, the introduction serves to locate the translation within the wider narrative of translation into Arabic. Al-Bustani draws on the history of translation in the Arab World, with specific reference to the approaches used by earlier medieval translators and the much cited classification of translators proposed by al-Safadi. He also addresses issues such as the lack of equivalence between languages, the need to preserve the meaning of the source text, and reflects on his own practice: The translation itself includes a number of annotations and explanatory notes.

The publication of this Arabic translation was celebrated with an official launch in Cairo attended by high officials and men of letters from Egypt and abroad (see below). In fact, al-Bustani's Arabic version of the Iliad was a literary event in that it can be said to have paved the way for innovative and creative writing at the time of the Nahda.

\section{Myriam Salama-Carr}

\section{Notes}

1 A famous market in pre-Islamic Arabia, where literary competitions were held.

2 Quraish, Muhammad's clan belonged to Mudar, the main tribal alliance of Northern Arabia.

3 A major anthology of Arabic poetry, complied by Abu Zaid al-Qurashi, who lived in the tenth century CE.

4 Al-Bustani has mentioned earlier that the Iliad was translated into Syriac by Theophilus of Edessa (695-785).

5 Ferdowsi's Shahnameh was translated into Arabic prose by al-Fath Ibn 'Ali alBaghdadi al-Assahani for the great king 'Isa Ibn al-'Adel Abi Bakr al-Ayubi. The translation was completed in 679. [Footnote in the original] 


\title{
45 Celebrating the translator of the Iliad (al-Muqtataf magazine) (1904)
}

\author{
Various authors
}

\section{[PERSPECTIVES ON TRANSLATION IN THE NAHDA]}

In the middle of last month, Cairo witnessed a scene the like of which it had never seen previously: a celebration attended by around a hundred of its greatest thinkers and writers with a sumptuous banquet at Shepheard's Hotel. The entrance of the hotel was adorned with multi-colored electric lights and its garden and trees decorated with electric lanterns. Throughout the garden, tables were laid at which the various hosts and guests sat to eat delicious food. A card was placed in front of each of them with a drawing of the pyramids and Sphynx, the symbols of Egypt, and Mount Lebanon and the cedar, the symbols of Syria. Above them both rose the sun of knowledge, casting its rays upon them, with these lines beneath:

Long live the nation, hearts' desire every corner of its land, and with it, souls' delights

The sun of knowledge rising above joins every corner and them both unites

Its rays shine among the cedars' boughs and over the pyramids they fly

Inside the card the names of the dishes were written in Arabic and French. The celebration committee had asked one of the founders of this magazine ${ }^{1}$ to represent them in welcoming the guests and to introduce the investigation which motivated the organization of the party. So, once the food was finished, he stood up to speak. He began by appealing to the audience to excuse him for failing to introduce the topic in the way it deserved, and then quoted an Arab saying mentioned to him by his grace Tawfiq al-Bakri, Naqib al-Ashraf, ${ }^{2}$ who was sitting beside him, about inadequate oratory: "this speech is after dinner or before bed." He then said: This celebration of ours may be the first of its kind in the lands of the Mashreq. I hope it is the first of many celebrations held to honor knowledge and esteem the worth of those who strive for it.

I do not know for certain to whose mind this thought first occurred. But I am certain that everyone in attendance welcomed it and was glad to participate, not on account of his connection with a specific person, even if 
this person holds an elevated position in our estimation, nor on account of his connection with a specific issue, even if this issue is considered important by the masters of writing and the luminaries of rhetoric who gave to Homer the highest position among the painters of imagination in the same way as they gave to Da 'irat al-Ma'arif ${ }^{3}$ the highest position in the Arab encyclopedia. Our esteemed friend, the celebrated Sulaiman Effendi al-Bastani, has demonstrated a new spirit which has emerged in the sons of the East, which we previously either did not know or paid scant attention to, which truly values the benefits of science and literature. But he is not new to this domain: rather he has worked in it for many years. He has worked in the service of knowledge for more than thirty years and the outpourings of his quill appeared in the Da'irat al-Ma'arif before they appeared in Homer's Iliad. He studied under the guidance of his master al-Bastani the Elder, instigator of the encyclopedia Muhit al-Muhit, Qatr al-Muhit and Da'irat al-Ma'arif, the newspapers al-Janin and Janna, and the textbooks Muftah al-Misb $\underline{a h}$ and Kashf al- $\underline{H i j} \underline{a} b$ as well as other widely circulating books. He was the founder of the National School and the Syrian Association, a man of action and determination, productive and eloquent, a gifted writer, and an incisive politician. The second al-Bastani was his son Salim Efendi, editor of the numerous sections of al-Janin and Da 'irat al-Ma'arif, intimate friend of the arts, elegance, and eloquence which have been scarce in our era. His tender branch was rent and he died while still in the primacy of his youth. The third al-Bustani is Professor Abdullah, the scholar of language and Bedouin poet. But who of the sons of the Mashreq has recognized the glory of those people with a public celebration like this? The blame goes not to them, nor to the leading thinkers of the past century such as al-Asir, al-Ahdab, al-Yazji, al-Naqqash or the other scholars of the Levant; nor to the scholars of Egypt, who number in the hundreds and played a key role in everything written in poetry or prose, thought and passed on, even if we fail to celebrate them. No, the blame is ours because this kind of appreciation was not known to us. So I congratulate you for it, esteemed friend, because you saw among your brothers those who realized the value of your work, whether in Da irat al-Ma'arif or Homer's Iliad, as I congratulate those to whom this idea first occurred and who are the first to every triumph.

As for Da 'irat al-Ma'arif, al-Bustani the Elder began working on it around 30 years ago and prepared many of the tools for it. Six parts were published before he was taken by the hands of his Lord and his eldest son Saleem Efendi took on the task. Yet death did not tarry in coming to him, so he completed two sections before passing this heavy burden to his two younger brothers and their cousin: the subject of our celebration today. He was a partner in the task from the first and made, along with the brothers, an outstanding contribution as the sections of Da 'irat al-Ma' arif make clear.

The Iliad is historical Greek poetry and among the oldest and most extensive poetic works in which they poured forth their knowledge; its central theme is the description of some of the events of the Trojan war. The poet was expansive in describing and narrating events so his poem is considered an 
encyclopedia of his time since it mentions the nature of people, their habits, their manner of worship, and the level of culture they attained. It is clear from the poem that the Greeks at that time, as well as before it, were a people of agriculture, industry, commerce, science and philosophy. It is also clear that in those aspects, as well as in the erection of fortresses, the deployment of armies, the construction of battleships and the enactment of legal provisions, they reached a level which was not surpassed by the peoples of Europe who followed them until the past century. It is likely that, even at the present time, they still have not been outdone in sculpture, statuary, and metalworking.

It is a substantial text, precisely researched, greatly sophisticated and was consulted by the Arab scholars when they translated the writings of the Greeks. ${ }^{4}$ They revered it but did not translate it. This was not because they abhorred the translation of narratives or because they were unfamiliar with this kind of poetry for they proposed that the story of 'Antara ${ }^{5}$ and its events resembled those of the Iliad and that they shared a single style - a concise historical basis, adopted by the genius of Homer in the Iliad and by the genius of al-'Asma'i in the story of 'Antara, ${ }^{6}$ upon which they constructed glorious edifices. It is clear that they refrained from translating it due to its inclusion of many distinctively western symbols and inaccessible meanings, because of its extensive references to the gods of the Greeks and their religious rites, or due to other reasons.

Homer remained locked away from the sons of the Arabic language. Their writers hoped for it to be possible for one of them to pull back the curtain from him and bring him to their language as he had been brought to the European languages or as he had been previously brought to Syriac, a fact that Sulaiman Effendi has confirmed). ${ }^{7}$ However it was impossible for any man to set himself to this dangerous work other than one who: had studied the Greek language in order to read Homer in the original; knew several European languages so that he could read commentary on Homer written in them; was of flexible genius to ease the crafting of thousands of lines; was eloquent of expression so that his words would be of the same standard as those which he translated; of great memory and widely read so that it would be easy for him to compare Homer's lines with their equals from the Arab poets; had unflinching endurance so as not to tire from shaping line after line, poem after poem, year after year to give the time for him to write poetry when it obeyed him and to set it aside when it disobeyed him. It goes without saying that all these qualities are brought together in al-Bustani-he seized Homer in his grasp and did not release him until he had clothed him in Arab dress.

If his work had stopped at this point, it would have been not merely great but among the greatest of works. Yet he did not stop there but rather strode on toward that which is greater still, for many of the meanings of Homer are closed and he references many matters the meanings of which cannot be comprehended except by one with extensive knowledge of history, geography and mythology. So, for this work of poetry to be understood, there is no escaping explanatory commentary to fill its margins - and this is what 
al-Bustani did. Yet he did not stop there, but rather to the meanings of Homer he added the meanings of the Arab poets, especially those of the Abbasid 'Antara, that is to say Abu Sa'id al-Asma'i, ${ }^{8}$ author of the story of 'Antara. He showed that most of the ideas used by Homer and which were familiar to the Greeks were also known to the Bedouin Arabs.

The Arabization of the Iliad came to around 1,000 pages, around half or a third of which comprise precise commentary, so it is as if he composed a great book of commentary in which he brought together hundreds of testimonies from the Arabs as well as practical investigations.

Al-Bustani is an ally of ambition, and how honorable, exulted, and beneficial is legitimate ambition, for most great works have emerged from it! He did not wish to publish the Iliad with its commentary but otherwise decapitated, without an introduction. And what an introduction! One of the scholars of the English defined the introduction as the part of the book which is not read, but our friend al-Bustani gave the Iliad an introduction which fills 200 pages and which the reader will not tire of reading on account of the benefits and fine writing he will find in it. It equals Ibn Khaldun's 'Introduction'9 in the diversity of its topics, the eloquence of its expression and the number of its benefits. I trace its lineage to Ibn Khaldun's 'Introduction' with regard to the precision of its research because its position in the science of today is like that of the 'Introduction' in the era of Ibn Khaldun. It is also like it in the solidity of its expression, to the extent that it is only right that it should serve as a model for eloquent writing. It occupies 200 pages in which the writer goes against the norms of introductions by dividing it into numerous chapters so that the reader wishes to read them and does not tire as the reader of introductions which are not divided into chapters tires.

This introduction is a work of literature and science into which the author pours the result of his long years of study and investigation. In our celebration of the book's publication, we celebrate the publication of three large books: the organized poetic text, the harmonious commentary and comprehensive introduction. Three books in a single book filling around 1,150 pages to which are further added more than 100 pages of indices and glossaries which required significant exertion to produce; the author's gift was to exert himself once so that each reader of his book should not exert himself. Profuse thanks are owed him in every respect.

In brief, at this celebration of ours, we, and your esteemed excellencies who have honored us by accepting our invitation, have expressed a desire to honor literature and appreciate its masters. I am certain that our friend al-Bustani is equally as delighted as ourselves not because our appreciation is directed toward him, for he would be the last person to seek the limelight, but because his work is being honored because it deserves to be honored. So, I congratulate you for it, esteemed friend, for the fully-deserved respect you have earned from your brothers. I congratulate you on behalf of those who organized this celebration for you as I congratulate you on my own count. Furthermore, I reiterate the extension of profound thanks to you, esteemed gentlemen, 
who graced us by accepting our invitation. You remain in the vanguard of the nation's leaders and the champions of virtue. Permit me, in conclusion, to thank you and all the other respected guests because you honored me by listening to these words. And if I have fallen short in description and in expressing by mind, then the blame falls on those who fed me before calling me to speak, for my speech came 'after dinner and before bed."

When he had finished speaking, 'Abdelkhaleq Bek Tharwat stood up and read a letter sent by his excellency Shaikh Muhammad 'Abdo, Mufti of Dạr al-Ifta ${ }^{6}$ al-Misriya ${ }^{10}$ and head of the Association for the Invigoration of Arab Sciences. It said:

Our friends invited me to join you at the hour of your being celebrated for the success of that literary work to which you have dedicated a number of years. They invited me to join them in thanking you for your toil, for applying yourself with patience to the difficulty of research, and for your exhaustion on account of having chosen the paths of writing in order to gift to the sons of your Arabic language one of the greatest and most beautiful literary works ever seen.

I would have been the first to respond to the invitation were it not for the issue which prevented me, like a censorious man to a lover of beauty, from being gladdened by your company. Nonetheless, it did not prevent me from joining in thanking you.

You have translated the Iliad, by the most outstanding of the Greek poets, the famous Homer. Your genius has woven the style of that book into the translated book. For if it is a square in which our Arabic language raided its Greek counterpart, then its virgins have been taken captive, its jewels plundered, and it has returned to us wearing the garb of Arabic literature, bearing nourishment to the intellect from its marrow. How beautiful that conquest is in a time when the Arabs have weakened in their desire to study literature, both that which is close at hand and that which is attained with difficulty. You deserve the thanks of every man who understands the value of the effort you put into realizing it because you have filled a void in the fabric of Arab science which has been there for ten centuries. Our people raided the treasures of Greek art in the third hijra century ${ }^{11}$ and the years that followed, spreading what had been stored away and distributing among the people that which had lain buried. They left nothing opaque without clarifying it and nothing distant without bringing it near. Through their work the Arabic language acquired what it did not previously have, and it became the language of science and industry as it had been the language of religion and wisdom.

It is as if those first masters saw that this was what truth demanded of them with regard to science, in which the East does not differ from the West and about whose facts the speakers of Arabic and other languages do not disagree. But they thought that the habits of other people, which lie beyond science, did not accord with their own habits on account of the distance between their lineages and their own. So, they did not extend their gaze to the poetry and writings of the master rhetors written in Greek and the Greek language did not receive their care in the way that the Persian and Hindustani languages 
did. Their hope for the Arabic language was that they would not deprive it of the valuable contributions devised by the Greeks while they adorned it with the beauty invented by the Indians and Persians. That hope remained in place, through the murk of time, until you came to raise the curtain on it and say to the people that "I have completed in the nation of 'Abbas ${ }^{12}$ that which was not done during the reign of the Abbasids." How delighted the Arabic language was with having its request acceded to and with the appearance of that which was waiting to be spread widely. I hope that your book receives the reception, and provides the benefits, which befit your efforts and that it inspires others to follow in your footsteps.

Then, Mr. Farid Bek Babazughli stood up and read a telegram from Dr Apostolides, translator of the Iliad from Ancient to Modern Greek in which he praised its esteemed translator into Arabic and apologized to the committee for his being unable to travel from Alexandria. He was followed by Mr. Dawud Bek 'Amun who read a letter from Dr. Shabli Shmail in which he apologized for not attending due to his poor health and wished those celebrating well on account of their coming together for the highest social purpose which is the acknowledgment of genuine excellence. He also congratulated the subject of the celebration for his having successfully completed the translation of the Iliad. After this, Mohammad Effendi Mas'ud, one of the editors of alMu'ayid, read a letter from his excellency Shaikh 'Ali Yuusuf, proprietor of al-Mu'ayid, in which he praised the subject of the celebration for his 'service not only to the Arabic language but to the arts and sciences' as well as those celebrating, on account of their having "put the matter in its place." He also apologized for not attending on account of his being in Alexandria.

Then, Mr. Rashid Rida, founder of the garb al-Manar, stood up and made an eloquent address in which he explained the reasons which, in the past, had prevented the Arabs from translating the Iliad and expounded on the appropriateness of its translation at this time. He was followed by the lawyer Mr. Akhnukh Effendi Fanus who gave an elegant address in which he explained the value of literary prowess and concluded by praising the translator of the Iliad for his having given the prime of his life to bestowing upon the sons of the Arabic language the most eloquent poetry of the Greek nation, doing so without greed for monetary or material gain. After him rose Mr. Ibrahim Bek Ramzi, proprietor of al-Tamuddun, to expound on the excellence of the Greeks and their learning. Then, the translator of the Iliad rose and gave the following speech:

\section{Esteemed gentlemen}

I stand here, in this position, because of your excellence. Every word, no, every gesture, no, every glance in this gathering of the noblest and most excellent men grants me such kindness that I am left unable to fulfil the duty of thanks. With regard to the commendation bestowed by the eloquent speakers in

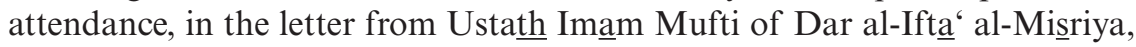


as well as the other absent scholars, I see myself compelled to take refuge in silence, in both pride and acknowledgment that I was but a mirror in which their honorable characteristics, so exemplarily shown, were reflected.

If I be permitted to take pride in a piece of work, then I take pride in an achievement in which I had no hand and which did not even enter my mind. Rather it emerged from the beauty of your industry - the organization of this gathering. I cannot single out an individual to praise for I see no-one amongst you who is not a dear friend who does for his friend many times what he does for himself, who is not a generous scholar who esteems the smallest amount of effort from everyone other than himself, and who pays no regard to the years of his life spent in the service of knowledge. I see writers of poetry and wise prosaists who take delight in every new note in the songs of literature, even if they be imperceptible in comparison to what is bestowed by their skill.

All my Syrian brothers are equal in their excellence and there is nothing but fervent zeal in their hearts. So, it is God who destined that this zeal be directed to my humble person. As for the generosity of the Egyptians, to their zeal and innate goodness is added the virtue of collaboration. This is not the first time that Egypt has taken the arm of her sister, Syria, and extended to her the hand of love and loyalty to work together in elevating the position of literature and writers.

Gentlemen, those of you who have read the Arabization of the Iliad will know that I did my utmost to compare and bring together the literature of the Arabs and the Greeks, knowledge of the two nations, their histories and morals. Permit me to do the same in drawing connections between the Iliad and this celebratory gathering.

The Iliad 's publication in an Arab garb is the product of free time which made it possible for a seeker of knowledge to become besotted with its beauty, to cleave to it with the commitment of the lover to their beloved irrespective of his tiredness or fatigue. He earned his reward with that which pleases the eye in the physical world, exercises the soul in the gardens of imagination and from the reverberations of the abundant works made available to the hearts of those interested in literature at a time like this. Nonetheless, your approval is greater still, for what reward is more valuable than this?

As for this gathering of ours, its meaning is still more illustrious and its benefit greater. Before looking to the truth of its significance, I ask your permission to bring forward evidence from the Iliad for the purposes of amusement.

Some dear people have said that feasts are not how a worker should be rewarded for his work. But Homer had already shown the deficiency of these words and it is as if the dear friends who called for this celebration were inspired by his spirit, emulating it with their modesty. It suffices for me to direct your attention to the word "feast" in the Iliad's glossary: there you will see that it was the reward sought by the great Greek kings before Homer's era 
and then by the Arabs. For both, it had an illustrious meaning as something for which people competed and in which they took great joy.

I have said that the meaning of this gathering, with regard to literature, is greater than the publication of the Iliad. That is because it is the result of a new spirit of life seeping into the veins of the sons of the Arabic language; they have set into motion a flourishing which they drive forward with the excitement of being reunited with someone after a long absence. They all desire true life and know that the life of a language is the life of the nation: a language cannot survive without its nation and a nation cannot survive without its language.

There is no doubt that the publication of the Arabic Iliad has happened at an auspicious time; otherwise it would not have enjoyed the reception from you that it has received. How many of you outstanding men, and of those who have carried us forward in this century, having spent your lives in the service of literature, are more deserving of your affection than this friend of the Iliad. Do you all not see in attendance a tribe, yes a tribe, of those who spent their youth and middle age among pens and inkwells. The Arabizer of the Iliad, and those like him, borrowed from their incalculably valuable writing and thinking, so they are more deserving of a glittering celebration like this than he. If the Iliad has a distinguishing quality in relation to the jewels that came before it, then that quality is but a reflection of your light; it emerged because it was encouraged by fortune. The germ of literature has matured in the breasts of men after lying hidden for an age. You have welcomed the Iliad and esteemed it beyond its value, encouraging those like its Arabizer and announcing to all that this language remains in the fullness of its youth regardless of the passage of the ages. It shall remain on the highest plane or rise still further beyond it, for it is like the triumph of Homer and only rendered more wonderful and beautiful by the passage of time.

That, gentlemen, is one of the good things of this gathering. But there is also another which is no less good: the feeling of the Syrian and the Egyptian that they are collegial partners in the language in which they were raised and that there is no way for this partnership to be dissolved so long as blood pulses through their veins. For if one of them succeeds in his business, the profits go to both partners; and if they are destined to go bankrupt, God forbid, then they go bankrupt together. Muhammad 'Ali Pasha had the foresight to establish schools, and so built a solid foundation for his descendants. Students graduated and made great strides in the language but were the benefits of those efforts restricted to the sons of Egypt, or did not their Syrian brothers also reap their fruits, continuing to taste their sweetness?

The Syrians awoke in the middle of the last century, with a group of them importing the wellsprings of knowledge and literature. Did they keep them for themselves or was not every step taken by one of the sister nations followed by the other; the two of them striding together, supporting one another as if they were two inseparable, conjoined twins.

Wise men say that knowledge has no nation, for it is the honoured guest wherever it may be; a citizen in his homeland does not hesitate to provide 


\section{Various authors}

for the visitor. If a man of the west plants a tree, then a man of the east may harvest its fruit simply by standing up and reaching out his hand to it or take a cutting to plant in his own land which, with effort, will bear tender fruit because knowledge flourishes in every country on God's earth.

With literature this statement is not true at all. The greater the distance between tongues, the less harmonious are the ties which bind them. Egypt and Syria are joined with all the countries of the world in the community of knowledge if they so wish. Nonetheless, there is a special connection between them which cannot be unstitched, even if they wished it. If the issue at hand here is not the clarity of the air, the region and its rights, people's origins, morals and ways of life, then should we also turn our gaze away from language, the strongest of ties? All this means that Egypt and Syria must join their literary bloodlines - an excellent lineage. Every connection is more readily frayed than language, and every bloodline more vulnerable to disruption than that of virtue and literature. In the words of the poet al-Sharif al-Radi in the eulogy of al-Sabi:

Virtue joined our blood for neither my kin nor my birth equaled his You may not be of my family or tribe but you are dearer to me in my affection

Gentlemen, if we were to count the speakers of Arabic then we would find that they do not number less than the speakers of many languages of the civilized West. If we measured the area of our lands, we would see that they would accommodate several countries from the civilized world. Our language is alive despite the exaggerated claims of some. All these countries naturally support the renaissance of literature, but it is essential for there to be a public fountain sending streams of fresh water to every corner. In our time, there is nowhere better placed to build this fountain than the nation of Egypt. We are in a time of wakefulness and progress, so this is an outstanding opportunity and it is a wise man who seizes an opportunity. I see you all as nothing less than an army, striving toward and focused on this goal, in the knowledge that this is a time in which ideas are pulled forward by the powerful current of science. This current, which has truly swept our nation onward, has broken dams and overcome barriers. The sons of the Arabic language have learned that there is no one to help them to realize their ambitions but themselves. If they are of pure intention and steadfast then, God willing, nothing will prevent them achieving them.

There is no doubt that they have turned the wheel once again in these late times, springing forth in a new way. So, let this springing forth bear fruit and let it continue with your grace, until, God willing, it is possible for us to say:

We build as the best of us did you build and we do as they did

Then, his excellency Shakur Pasha stood up and spoke in French, praising the Iliad's translator on behalf of Egypt "the mother of civilization and source 
of inspiration for the Greek poets from the ancient times. Egypt, whose youth is not blemished by weakness or old age however much time may pass. Egypt is the sister of affection, hospitality, munificence, and generosity." He was followed by Monsieur Povidas, master of the [Greek] 'Ubaidi School, with an address in French and by Mr. Aveyronnais [?] with an address in Greek. The hosts and guests departed unanimous in their praise for the literary celebration and hoping that it be the first of others like it so as to strengthen the capabilities of men of science and virtue and encourage industry in science and literature. They thanked the man who first thought of the idea and served as head of the celebration's organising committee, 'Abdullah Bek Safirr, as well as the other members of the committee who worked with him.

\section{Translated by Neil Sadler}

\section{COMMENTARY}

Periods of transition and renewal in the history of national literatures are often marked by the central position of translation, which affords an effective way of introducing new genres or methods and renewing existing ones. It should not be surprising, then, that translation was instrumental in the intellectual, as well as material, renaissance of Arab societies during the Nahda. The translation of European literature contributed directly to the modern development of the Arabic language and the emergence of new literary genres. Yet, the impact of translation was not limited to literature and language. Similarly to movements of modernization in several nonEuropean countries (such as China and Japan), new "modernizing" ideas were introduced through translation from European languages.

Al-Bustani's translation of the Iliad was widely celebrated by his contemporaries at the illustrious Shepheard's Hotel. An uncommon practice at the time, this "book launch" party is a testimony to the crucial importance that Nahda intellectuals placed on translation. The list of attendees includes some of the most recognized and influential figures of the time in various fields: besides writers, scholars, educators, and journalists, several high-placed officialsincluding the current prime minister, the minister of education, and two future prime ministers, as well Greek diplomats in Cairo - either attended the event or sent letters of congratulation (Mitri 1905: 5-7). Significantly, the enthusiastic reception of this ancient work of Greek mythology was not limited to "liberal" figures: among those extending their approbation were leading Islamic scholars, including Rashịd Rida, editor of al-Manar (see Rida and Sa'ada, Chapter 48), and the grand Mufti of Egypt, the eminent Islamic reformer Muhammad 'Abdo, whose letter was recited to the gathering (ibid. 6). As the head of the "Committee for the Renewal of the Arabic Language," Abdo found the celebration of the translator "an opportunity to highlight the commendable efforts of this Committee to renew our noble tongue" (ibid.). 


\section{Various authors}

The speeches delivered on this occasion are important, not only as indicating the status of translation among the educated Nahda elites in all fields, but also as a sample of contemporary views of its methods, importance, and social impact. They figure some of the most widely debated questions of translation during that period, especially its prime necessity for reviving the Arabic language, and modernization, that is catching up with the civilized (i.e. European) world. While al-Bustani himself, as explained in his introduction, followed a balanced translation approach, most speeches advocated a liberal method that domesticates the original, sometimes in radical ways. This can be seen clearly in Sarruf's praise of the translator, who "seized Homer in his grasp and did not release him until he had clothed him in Arab dress," and even more emphatically in 'Abdo's metaphor of translation as a battlefield on which Arabic "raids" the foreign language and brings back spoils and female captives. This analogy between translation and conquest (sometimes imbued with sexual overtones) ${ }^{13}$ is not uncommon in Arab or other cultures. ${ }^{14}$ This general trend of liberal translation was prevalent to varying degrees during the Nahda period.

\section{Tarek Shamma}

\section{Notes}

1 A reference to al-Muqtataf, the magazine in which this article was published.

2 A senior government position found in several territories of the Ottoman Empire.

3 An influential Arabic encyclopedia produced by Butrus al-Bustani.

4 A reference to the "Translation Movement" in which a large volume of Ancient Greek texts were translated into Arabic. The movement was at its height in the eighth to the tenth centuries and centered on Baghdad, then capital of the Abbasid Caliphate (see Introduction).

5 A reference to the pre-Islamic warrior and poet 'Antara Ibn Shaddad, whose life and exploits in the sixth century $\mathrm{CE}$ are described in an epic poem considered one of the seven "mu'allaqat," highly influential early Arabic poetic works.

6 A reference to the account of 'Antara's life found in the poetry of al-Asma'i, an Abbasid-era poet and scholar. Al- Asma'i is traditionally regarded as one of the Arabic language's most outstanding poets.

7 See al-Bustani's introduction.

8 In referring to al-Asma'i as an "Abbasid 'Antara," the speaker implies that his poetry is of the same caliber as that of 'Antara himself, who was a major preIslamic poet.

9 A reference to the "Muqaddima" or "The Introdcution" by the medieval Arab scholar Ibn Khaldun, a highly influential text discussing a wide range of issues including sociology, economics, history and theology.

10 An institution established in 1895 for the study of Islamic jurisprudence which offers guidance on religious and everyday matters through the issuing of fatwas.

11 i.e., the tenth century CE.

12 A reference to 'Abbas II Helmi, Khedive of Egypt 1892-1914. 
13 See, for example, Hafidh Ibrahim in this volume. Thus, in his introduction to his Takhli s al-Ibrizz (one of the first accounts of Europe in modern Arabic), Rifáa'a al-Tahtawi aimed to "unveil the face of [Paris], which is said to be the bride of the world" (1834: 5). Shaden Tageldin (2011) analyzes this issue with special reference to Nahda intellectuals. For a discussion of the sexual overtones of translation as conquest in the context of English, see, for example, Lori Chamberlain's seminal essay "Gender and the Metaphorics of Translation" (1988).

14 See Shamma 2020. 


\title{
46 Europe's Crime Against Itself and the World (1906)
}

\author{
A hmad Fahmi
}

Little information is available about the author of this novel. In his encyclopedic bibliography of the Arabic novel (2005, V: 2440), Hamdi Sakkut mentions a novel entitled $\underline{\text { Aiat }}$ al-'Ibar (Epitomes of Examples) published in 1899 by an author with the same name.

\section{[TRANSLATION AND MORALITY]}

\section{A word on authorship and translation}

In its common usage, authorship is writing on a topic that the writer weaves with the hands of his idea, knits with the fingers of his intuition and adorns as much as his ability of cleverness and eloquence allows him with an ornamentation that the reader either admires and welcomes with enthusiasm or dislikes and leaves with dissatisfaction. Translation, on the other hand, is the transfer of a phrase from a foreign language to Arabic. The effort of the translator is limited to the perfection of the transmission, the adornment of expressions and the betterment of composition according to his ability without touching the essence of the subject. Anything more than that would be considered taking liberties. Therefore, authorship is more important and useful than translation, and an author is expected to be more knowledgeable, prolific, and higher in status than a translator.

An author usually casts his composition in a mold that appeals to his nation and obtains its approval. Often, authorship serves the people for whom the authored work was intended, either to urge them to do some good or to draw their attention to an opinion or to deter them from an ugly practice.

It is known that what is desirable for one group of people may be despicable for another, and vice versa, what is necessary for one nation is unnecessary for another, what is essential for one country is renounced by another, and so on. For this reason, it should be of no interest to transfer a book from one language to another except in general subjects or only to the extent of the need of the nation to whose language a work is transferred. That is mostly the case in political or scientific books, but even those books undergo some 
amount of liberty-taking that makes their subjects acceptable to the receiving readers.

Consequently, it must be known that authorship in Arabic by its speakers is better than translation in many respects, particularly in the present day, and even more particularly in Egypt, where we need the pens of writers who write what corresponds to our customs, morals and conventions. We need what brings our hearts in harmony, unites our opinions, cultivates our faculties, educates our intellects and strengthens us. We need what establishes our position in the world, advances us and pushes us forward to the best ranks of men so that we stand among the leaders of this civilized era and acquire what others have enjoyed in terms of prestige, pride, high status, power, influence, freedom, independence and many other advantages. We know our illnesses more than anyone else, and we are more capable of diagnosing our diseases than foreigners. They are far from us and write for their own people what agrees with them. It must be then an immense shame that we only transfer their writing to us and not write for our own people what agrees with us.

What is unfortunate and deserves to be rebuked, besides our writers' indulgence in translation, is that they do not master a subject, but rather spend their precious time and exhaust their valuable minds in translating any book they happen to find in their hands without careful selection or consideration of whether or not that book is in agreement with us. Yet I do not blame translators for that because they have an excuse; they would not embrace it fully unless they witness how the readers among us welcome anything translated and turn away from anything authored in Arabic. It is the luck and privilege of the foreigner that we suffer from. It is the ugliest thing that we might be inclined to accept. It is as though the foreigner were king and his work honorable even if he were the devil and his work disgraceful.

Does the Egyptian not know that, in his love for everything foreign, he has only alienated his brother from him and weakened his fortitude, if not killed it? It is indeed a great loss and a grave misfortune. The love for translation and anything translated has caused men of letters to become tardy and abandon authorship, eventually getting lost and disappearing from the ranks of the powerful and the intelligent. The Egyptian has become known for his weakness, ignorance, and lack of enlightenment. Yet this is such a misguided judgment, because if the Egyptian opened his arms to his brother, welcoming his writing and accepting his books, and discarded what is translated, the field of composition and writing would be crowded, the sea of authorship would overflow with boats of eloquence and the neck of literature would be adorned with pearls of rhetoric. Egypt would become a modern version of the old 'Ukadh Souq, exhibiting modern literary books of its own. But how can this wish be fulfilled when we are divided by discord? Rather, when shall we love the good of the nation when we are in dissonance and strife? God, may You reconcile our hearts and hasten endearment and harmony!

If I say that what is desired by a certain group of people might be despised by another and vice versa, I must present evidence of that. I believe that I do 
not find this difficult, as it is something that belongs to the world of today and not far away. Whoever reads some of the translated novels that have been successively published in Egypt would notice the harm of translation in its clearest manifestations. They would notice how the conventions, morals, and preferences of foreigners are in disagreement with our own conventions, morals, and preferences. We do not have to go as far as reciting to the reader all the translated novels in order to prove our claim and reinforce our evidence. Instead, it is sufficient for us to take a brief glance at one or two of the most recent novels. Take Whims of the Youth and The King's Mistress, ${ }^{1}$ for example.

We have read Whims of the Youth and understood that the novel ends with shame, scandal, immorality, corruption of morals, lack of decorum and politeness, dishonor, lack of education, breach of privacy, and oath breaking. Such are deeds at whose mention the face of our Oriental girl would redden and that we fear lest they corrupt our morals and the minds of our youth.

The story of The King's Mistress (whom we already encountered in Whims of the Youth, where she had several lovers) begins with killing honorable emotions, the death of honor, the distortion of the face of chivalry, the sacrifice of nobility and valor, and deserting pride and dignity - all for the sake of mortal money. These are deeds that even the lowest Oriental would not commit nor would a ragged ruffian from Egypt accept. Does a translator, by translating this novel and the likes of it, attain pride, popularity and approval, or something else? However, we are blind to the faults of the foreigner, and this is one of his privileges in the Orient.

If translation is something necessary and unavoidable, and if we cannot but resort to foreign sources, should we not write a novel, or at least put a word at the end of every such novel, in which we abhor the likes of these ugly matters and highlight the sins present in the novel? In this way the youth and school children would pay attention to those sins when they read about them, so that their minds do not accept those faults. But if the intention is to represent the vices of the Franks and condemn them, which does not appear to be the intention of the translators, then we have not reached the level of high philosophy and correct education ...

Here is a section from The King's Mistress:

Comte du Barry said to his brother (they are among France's most noble and distinguished men): "There is a beautiful girl whom we want to be married to you through a legal marriage contract, but it's impossible that you are going to actually wed."

Guillaume sat on a chair next to his brother and said: "I want to see the girl. She might not occupy a place in my heart."

"Do not say that she did not appeal to your eyes, or the king will throw you in the darkness of the Bastille."

"What are you saying, brother"?

"Listen to me a while."

(After a long reproach, the Comte said to his brother): 
"Do you not know that if you marry a girl whom the king loves and prefers to Paris's most beautiful girls, and agree to attach her name to our family's, you will be showered by clouds of bounty and you will return to your home as one of the richest people"?

"But do you not know, brother, that our family is noble? How can I agree to marry a girl whom I will leave in the lap of the king and go back home satisfied with some riches"?

"What an ignorant idiot you are"!

"You are insulting me, bother."

"Yes. Because you are closing a door to a prosperous, lively future."

"Have you forgotten, my brother, that I'm wed to a woman graceful in form and mind"?

"I still think that you are an ignorant idiot. You say that you are married and that is what prevents you from accepting the girl whom the king asks you to marry. But you miss that wealth in this age is honor and glory. There is no value to a human being without it."

"But wealth is not enough."

"What else would you want besides it"?

"I want a high title of honor."

"Had you not disagreed, I would have told you that the king, may God prolong his life, would grant you the title of general governor of one of his colonies."

As such, the Comte's brother accepted to be a husband on paper to the king's mistress - we learn from his own words that he is married; what is greater crime against honor and religion? - and not to consummate their relationship, but to leave her in the king's arms, because she is his beloved and he is the king's procurer, in return for mortal money and empty worldly titles that do not come from anybody in the Orient, be it the lowliest wretch or the greatest prince. This brief example shows many aspects of hideousness and vice, and if we follow the story from beginning to end, we will see scandal, immorality and the killing of virtue and gallantry. Is it appropriate for us to translate these novels, like Napoleon's Love, ${ }^{2}$ for example, and publish them ourselves while we are at the start of our renaissance and the beginning of our learning? Do we not need what guides us to pride and self-esteem, not to what teaches us that wealth is honor and glory, that is, to kill honor and slaughter glory with the knife of meanness and lowness for the sake of wealth? There is no power and no strength except with God!

Someone might say that the Translator perhaps wanted to describe the tyranny of Europe's past. To them I would say there is no benefit we can procure from such action, and that the authors themselves only published their novels among their people because they were aware of the completeness of their people's knowledge, freedom, education, civility, and progress. Thus, they wanted to represent the heinous situation for their people to compare their past to their bright and prosperous present. Moreover, the authors were 
not afraid that their people would be corrupted by those novels or imitate the behaviors they included. As for us, on the contrary, we must now be reminded of our bygone glory and incite us to the dignity of our fathers and grandfathers, and moreover to what the Orient has achieved in ancient times and experienced in the days of trial and tribulation. We do not need to be taught evils and vices, lest anything stick in our memory and then defile our morals while we are in our preparatory schools of progress, and lest our children think that these are the modern civilized teachings to be followed and acted upon.

But if we want to provoke our people's vigor with the nascent pride and modern sovereignty the West has acquired, then that should be done in a template that we accept and that is in accordance with our conventions, morals and sentiments of work, determination, and diligence. This can only be achieved by authorship, not translation.

Another example, more vile than the previous one, is what can be found in The Immortal Magician and The Massive Revenge. ${ }^{3}$ I have too many objections to these two novels to be mentioned here, but suffice it to say that the novels do not suit Muslims, and Egyptians in particular, especially when considered in light of their harm to the ideas of schoolchildren and their disturbance to their minds. In sum, these novels were not worthy of translation and publication, and if we have to have something like them, then the tales of The One Thousand and One Nights are better crafted in composition, closer to the mind, more interesting to the soul and more abundant in magic, magicians and the jinn than what Forster has told of himself.

Since this has been decided and we know now the benefit of authorship, we ask our youth to give up their inclination towards Arabization, and we appeal to them to be patriotic, to strengthen the case of authorship by helping authors and promoting their books, thus serving their homeland and fellow citizens, and they have the thanks of humanity, the country and the people.

\section{Translated by Ali Almajnooni}

\section{COMMENTARY}

Besides modern theater, and quite possibly ahead of it, the novel is the most significant literary product of the translation movement of the Nahda period. As a new genre that was introduced, at least in its classical form, through translation from European languages, the novel occupied an ambiguous position among the educated elites, despite its immensely growing popularity with the reading public in the second half of the nineteenth century. Perhaps reminiscent of its dubious status upon its emergence in Europe, the novel was associated with the "masses" and often condemned as appealing to popular, and uncouth taste (Sakkut 2005: 8-9). 
Influenced by the style first adopted to translate European novels, fiction writers (most of whom were translators themselves) used a simpler, more mundane language, often approaching the vernacular, breaking with the idiom of late classical literature, which by the nineteenth century had descended into stilted, formulaic prose, relying on artificial rhetorical devises and stylistic flourishes. Furthermore, some novelists tried to experiment with popular and folk forms (such as The Thousand and One Nights), usually looked down upon by belletrists. Many critics complained that novels used the colloquial, a plain, inartistic Arabic, or a mixture of both, that their writers did not have a strong literary background, and that they had less artistic "value" than poetry (al- Khatib 1990: 70; Sakkut 2005: 32-33). In addition, fictional works were often seen as immoral, exposing the readers to the customs and manners of foreign nations.

However, even the severest critics did not reject the novel as a genre in itself. Its supremacy in European literature meant it was a harbinger of modernity, and its immense popularity with readers stimulated even some of its detractors to try their hand at it. However, critics insisted that this new form had to be refined in terms of style and should serve a higher purpose than popular entertainment. In fact, the novel's concern with immediate everyday reality (in contrast with poetry, the epitome of Classical Arabic literature) made it an arguably effective vehicle for social reform, a major concern for all Nahda intellectuals. Moreover, with its translated status, the novel was often a site of encounter with the Other; the questions of West and East, the Arab World and the Europe, were a main concern of Arab novelists and storywriters.

Thus, in something of a literary manifesto, Ahmad Fahmi calls for a home-grown novel that respects the native customs and cultural specificity of Egyptian and Muslim readers, one which can, in fact, propagate moral values and contribute to the renewal of society. This new form of literary practice cannot be achieved through translation, which, he laments, was prevalent at the time. For only native authors are aware of the ills of their community, and so his aim of social reform can be delivered only through authorship. In this respect, the introduction is a protest against translation inasmuch as it is call for original production. The author's objection to translated European novels is chiefly ethical: they are rife with customs and practices that are inconsistent with "eastern" ethics, thus leading to moral corruption and depravity.

Fahmi's complaint that translated fiction stunted original production in Arabic was not new. Fifty years earlier, the first original novel in Arabic

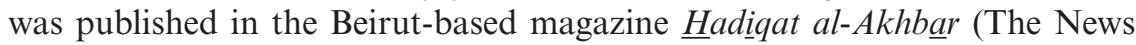
Garden) under the same rationale. After a series of translated novels that started with the first issue of the magazine in 1858, the editor Khalil al-Khuri inaugurated a new age of original production with a novel of his own writing in the October 1859 issue: "If, dear reader, you have grown bored of reading translated fiction and count yourself an astute person, then do not hesitate to 
read this new composition called Alas,- then I'm not a Frank!" (in Ibrahim 2008: 533-534).

Moral considerations were also prominent in many writings about fiction. For example, in 1882, Habib Bannut echoed the concerns of many readers in an article entitled "The Harms of Amorous Novels and Poems," published in the Egyptian magazine al-Muqtataf, condemning the questionable morality of translated fiction. While, unlike Fahmi, he did not consider translations inferior to original works, Bannut argued that writing in Arabic should take priority when possible, as it allows the authors to employ their knowledge of local customs, represented for reformist or satirical purposes. Still, he did not reject translation out of hand, but called upon translators to select works that do not clash with local mores, and to highlight the ethical lessons in translated fiction. But Fahmi's attitude is more radical. The ethical standards he adopts are not intended to encourage a more careful selection of translated works, but to dismiss translation altogether, with the possible exception of scientific works. For cultural and social differences among nations render what is acceptable in some detestable in others, and vice versa.

It should be noted that Fahmi does not, as one might at first assume, hold an extreme view of the reflective function of literature; nor is his position anti-European in principle. He concedes that the representation of practices that are immoral or inconsistent with local customs may be a means to expose corruption and incite reform. However, as part of the narrative of progress that permeated virtually all the writings of Nahda intellectuals, he objects that these methods would be effective only in countries with mature levels of "knowledge, freedom, education, civility and progress," unlike Egypt and the East, which are still in "preparatory schools" of progress.

\section{Tarek Shamma}

\section{Notes}

1 Both translated by Fu'ad Salim.

2 Translated by Amin Taqi al-Din.

3 Muhammad Lutfi Jum'a's translations of works by Guy Boothby. 


\title{
47 Guide for the Modern Translator (1906)
}

\author{
Muhammad al-Saiyd, Muhammad Awad \\ Ibrahim, W. H. Stevens
}

Muhammad al-Saiyd: Principal of Dạr Al 'Ulum School (for Arabic and Islamic studies), Cairo Muhammad Awad Ibrahim: Inspector at the Ministry of Education, Egypt W. H. Stevens: Lecturer at Higher Teachers College, Cairo

\section{Murshid al-Mutarjim al- $\underline{\text { Hadith }}$ (Guide for the Modern Translator)}

This book, which is addressed to students at Egyptian high schools, provides exercises and practices in translation between English and Arabic. It covers rules of English grammar deemed useful for students in translation, as mentioned in its introduction. The first part of the book includes 65 grammatical rules-focused on differences in usage between Arabic and English in cases such as pronouns, conditional sentences, and word orderaccompanied by illustrative examples and sample sentences to apply the respective rule in translation. The second part provides selected texts on various topics from the two languages to serve for translation practice.

\section{[ON THE METHODS OF TEACHING TRANSLATION]}

In the name of God and the Beneficent, the Merciful

Thanked be God who created man and endowed him with the gifts of thought and expression, and prayer and peace upon our Master Muhammad and all prophets.

Now as the art of translation is the highest aim for the language learner, and the fruit that the student reaps for understanding communications, so that he would benefit and be beneficial to others, we have written a book on translation for students taking the High School exam, intended to help them in translating from their own language into English, and vice versa. However, we have confined the rules of this book to those that help the students translate the idioms of this language, leaving out the rest of the rules that they study in depth in the grammar classes. For the same reason, we have avoided the linguistic rules of Arabic. 
Students may believe that the language lessons of Arabic and English are enough by themselves to develop their capacity in translation from one of these two language into the other. This belief is faulty, however. There has to be a book that compares the idioms of the one language with those of the other. For there is no doubt that a wide gulf and plain differences exist between them.

Students may be assisted by their teachers who could explain fully the rules included in the introduction to every exercise. As for students studying the language on their own, these can forgo assistance with these same exercises, for their numbers, as they will find, have been made to match those of the rules to be applied.

Of the extracts selected for translation at the end of the book, 50 have been accompanied with glosses explaining some words and constructions that could be beyond the capacity of the average student, followed by another fifty extracts without glosses. We advise the students neither to translate these extracts literally, nor to take excessive liberties with them, but to pursue a middle way between the two courses, and to preserve the original in their translations to an extent that does not harm the language into which they translate. Therefore, they have to read the entire extract once in the beginning for comprehension, then sentence by sentence, so that they can translate it in a way that demonstrates their comprehension of the idioms and mastering the constructions. In addition, the students should heed the necessity of using conjunctions that serve the purpose of punctuation marks in English when translating from English into Arabic, ${ }^{1}$ and vice versa when translating from Arabic into English.

As (written) Arabic tends more toward elegance and embellishment than English, we should call the students' attention to the fact that Arabic metaphors and similes are often very hard to translate into English in a way that meets the intended purpose. Therefore, students should not translate these instances literally, but based on the intended meaning, except when they are certain that the same metaphor or simile is used in English.

It should be noted here that the inclusion of translation in the school curriculum was the subject of heated debate among modern language professors in Europe. In fact, a quarter a century ago some of them have called for this subject to be removed from school curricula, based on the argument that the best way to study modern languages is the natural one, whereby children learn their native language, to which translation would be a barrier. This idea was soon found to be erroneous; the prevailing opinion today is that the systematic and scientific learning of translation facilitates studying foreign languages and saves the student considerable time.

\section{Translated by Tarek Shamma}

\section{COMMENTARY}

This brief text can give us a rare glimpse into the methods of teaching translation and foreign language in Egyptian schools, which followed a British system 
of education during the English occupation of Egypt (1882-1952). While translation (not untypically for the time) was used as a method of teaching English as a foreign language, it is significant that the authors see it also as an end in itself. This is especially apparent in the book's methodology, which expounds only grammatical rules that help the student with the translation process, with the understanding that grammar instruction is a separate activity.

The authors thus advance the relatively sophisticated view of translation as an independent skill, which cannot be mastered through linguistic competence alone, due, as they argue from a still narrow perspective, to idiomatic expressions that transcend the rules of grammar. Besides, the "middle way" they recommend promises a more balanced approach than the highly domesticating translation methods common during the Nahda. The caveat against excessive liberties may be due to the educational function of the book, as an element of accuracy is inevitable for the purpose of evaluation in translation curricula, especially in comparison with translation practice in professional fields. However, broad guidelines like "liberty," "literalism," and "accuracy" vary widely in their range of applications. Thus, a contemporary review of this book complimented the translation samples supplied by the authors, especially proverbs and aphorisms, specifically because "it is difficult to distinguish the translations from the originals" (Muqtataf, 1906, 1016). In other words, prevalent perceptions may govern the reception of translation beyond the translators' methods, and even professed intentions (see Sulaiman al-Bustani, Chapter 44).

In the final section of the introduction, the authors seem cognizant of the latest developments in pedagogical theory. The potential function of translation in language teaching remains a hotly debated issue today. The reliance on translation as the main tool of language instruction led to a backlash in some later communicative pedagogies in which translation was excluded completely from the teaching process. Yet, some modern approaches argue for a productive role for translation in language teaching, though certainly not as the primary method (see, e.g., Cook 2007: 17; Tsagari and Floros 2013: vii).

Some of these contemporary debates are discussed in the introduction. The call a quarter a century before the book's publication to remove translation from school curricula is certainly a reference to the "Reform Movement," which emerged in the late nineteenth century in several European countries (especially in France and Germany, and to a lesser extent in Britain) in reaction to the grammar-translation method. As the established approach to teaching foreign languages since the Middle Ages, the grammar-translation method was based on instruction in the grammatical rules of the foreign language, which were then applied through a literal, word-word-for-word translation of the foreign text (Howatt 1997: 131ff.).

An illustrative example of the grammar-translation method in the Arab World in that period can be found in a book published earlier in Egypt. Published during the height of the state-sponsored translation movement during the reign of Muhammad 'Ali (1805-1848), Necklaces of Pearls for the Benefit of the Translator (1850) was written by Khalifa Bin Mahmud, a 
graduate of the famous School of Tongues (founded in 1835 as "The School of Translation"), where he was "the head of the unit for translating literary books" (Bin Mahmud 1842: 1). The book treats translation and language teaching as one and the same. While the title defines the book as directed to translators, the introduction explicitly states that it is "a book designed for the teaching of the Arabic, [Ottoman] Turkish, and French languages" (ibid: 5). In content, the book is in three parts: a glossary of basic terms from the three languages; a list of common phrases in them, together with sample conversations; and a brief summary of French syntax and morphology in the three languages, with further explanations on Arabic and Turkish. Necklaces of Pearls can be seen as a representative of the translation instruction methods at the School of Tongues, which was the main supplier of translators during that early stage. In fact, this is how the school is described by Bin Khalifa himself in his introduction to his 1842 translation of the French version of the first volume of William Robertson's History of the Reign of the Emperor Charles V, with a View of the Progress of Society in Europe: an institution "where learning languages is of high quality" (Bin Mahmud 1842: 1).

In response to such approaches, the Reform Movement advocated the more "natural" "Direct Method," which is more concerned with verbal, contextsensitive communication than grammar, with the aim of creating a learning environment that simulates the original setting of language acquisition. In this context, the reliance of translation was one of the most fundamental objections to the traditional method; so much so that it many argued that no translation or any interference from the first language should be allowed, with the foreign language being used as the sole medium of communication. It was not long, however, before the extreme side of this approach was challenged, especially in Britain, where the Direct Method was not as influential as in France or Germany (Van Essen 2004: 395). Hence, while the dependence on translation as the primary method of teaching had become obsolete in the early twentieth century, many educators, as the authors explain, still found grammar to be conducive to language learning, and that translation could contribute to this process. This moderate position was represented most notably by Henry Sweet, an influential British linguist and educator of the late nineteenth and early twentieth centuries. We can see the potential impact of this approach to foreign language teaching in the authors' emphasis on "understanding communication" and the sentence, rather than the word, as the unit of language comprehension and translation (Atherton 2004: 854).

\section{Tarek Shamma}

\section{Note}

1 Classical Arabic did not use punctuation marks. At the time punctuation marks had not been standardized in modern Arabic. Translation from foreign languages played an important part in this process. 


\section{The Gospel of Barnabas (1908)}

Khalil Sa'âda, Rashịd Rida

\section{Khalil Sa'ada (1857-1934)}

Khalil Sa'ada was a physician and writer born at Choueir, Mount Lebanon. He studied medicine at the Syrian Protestant College (later the American University of Beirut). He was a regular contributor to the magazine alTabib [The Physician]. He moved to Cairo to work in the fields of medicine and writing; there he published studies on medicine and politics in the daily newspaper al-Ahram. He then emigrated to Argentina where he published the magazine al-Majalla [The Magazine], and founded the Syrian Press Trade Union and the Syrian University. He finally settled in Brazil, where he was editor in chief of 'al-Rábita [The League] journal, published by the Syrian National League in São Paulo; he was honorary president of the League until his death. His works include Sa'ada Dictionary of Arabic and English (1911), which is still used today, and Syria from War and Famine to the Peace Congress, as well as medical writings. He also wrote a novel in English, Caesar \& Cleopatra: An Historical Romance, published in London in 1898.

\section{Rashịd Rida}

See Chapter 42.

\section{Translation of the Gospel of Barnabas}

Sa'ada translated the Gospel of Barnabas into Arabic from the English translation of an Italian version which is kept in the Imperial Library of Vienna. In his introduction, the translator kept the discussion to the historical and scientific, rather than the religious, aspects of the text. Among other things, he discusses the Spanish translation of the Gospel of Barnabas, and differences between the Spanish and Italian versions. 


\section{The Translator's Introduction}

I have undertaken to translate the book titled the Gospel of Barnabas fully aware of the heavy responsibility that I have placed upon my own shoulders. I am assuming this work as an act of service towards history, and out of a love for a language which is the most deserving to have this work rendered into. This is the first time that this Gospel appears in Arab apparel. This Gospel has evoked differing opinions amongst scholars and diverse schools of historians who have worked to distinguish between error and guidance and to grasp its truth between the lines of logic and prejudice, while seeking to examine traces and trajectories and explain the minute details, in order to prevail over it to cure their ills and slake their thirst.

The only known version of this work existing today in the world to be translated from is the Italian version in the Imperial Library of Vienna. It is considered one of the most valuable treasures and historical documents, containing two hundred and twenty-five pages [...] The first person to discover this Italian version who has not disappeared from the annals of history is Cramer, a counsellor to the King of Prussia, who was residing in Amsterdam at the time. In 1709, he took it from one of the most famous and well-known public figures of this town to whom he referred only by obscure pseudonyms. Nothing is known about this particular figure except that he deemed this specific version of the work to be very valuable indeed and that Cramer lent it to [John] Toland and then after four years gifted it to Prince Eugène de Savoie, a man who, despite the many wars, battles, and projects with which he had been engaged, was extremely passionate about historical sciences and artefacts. In 1738, this work was moved from Prince Eugène's library to the Imperial Library of Vienna, where it remains until this day, as we explained above.

There is, however, another Spanish version found at the beginning of the eighteenth century, made up of 222 chapters and four-hundred and 22 sheets, which unfortunately perished and disappeared without a trace. It had been studied, and Reverend Holme from Hedley (a village in Hampshire, England) lent it to the famous Orientalist George Sale. After Sale, Reverend Doctor Monkhouse, one of the members of the Queen's College in Oxford, took it and translated it into English. Then in 1784 he sent on the translation with the original version to Doctor White, another eminent scholar.

The aforementioned Dr. White discussed this version of the Gospel with his pupils in his lectures and cited excerpts from it. I examined these excerpts and compared them to the English version rendered from the Italian version that is still in existence today in the Imperial Library of Vienna and found that the Spanish version is a word-for-word translation with no difference that I can see, aside from two things. The Italian version states that when Judas the Betrayer came with the Romans and handed Jesus over, Jesus was praying in the garden next to the room where the Disciples were sleeping. Upon hearing the soldiers coming, He went into this room. God, when He saw the eminent 
danger, then sent four angels to carry Jesus from out of the window to the Third Heaven. When Judas the Betrayer entered the room, God altered Judas' appearance and voice to resemble that of Jesus. The Disciples then awoke and saw Judas and had no doubts that he was Jesus Himself. The Spanish version uses the exact same wording except for adding the two words "except Peter," that is Peter was the only one to differ from the other Disciples who all believed Judas to be Jesus. When the name Azrael, one of the angels carrying Jesus from the window, is stated, the following words "Ereal in Italian" are added. There are some other minor differences which we deem as not worth mentioning.

What can be taken from Sale's commentary on the Spanish version is that it was a translation from the Italian version and was penned by a Muslim of Aragonese descent called Mustafa al-'Arandi, ${ }^{1}$ published with a prologue in which the discoverer of the Italian version - a Latin monk called Fra Marino - tells the story of how he had found it. He said that he had found the epistles of Irenaeus, one of which denounced Saint Paul. As Irenaeus had based his denunciation of Saint Paul on the Gospel of Saint Barnabas, the aforementioned Fra Marino was very interested in finding this Gospel. He happened at that time to be very close to Pope Sixtus V. It happened that they were both inside the Papal library whilst His Holiness was napping at the time. To kill some time, Marino had begun perusing which books until the Pope arose from sleep, and the first book that he laid his hands upon was the Gospel itself. He nearly jumped for joy at this discovery and after hiding this valuable work within the folds of his habit, made his excuses to the Pope to leave once he had risen and then left with this treasure. When he perused this book, he read it with great excitement, and as a result embraced the Islamic faith.

This is the story of Fra Marino as recorded in the Spanish version, according to what the Orientalist Sale wrote in "The Preliminary Discourse" to his translation of the Holy Qu'ran. This, along with what was shared by Reverend White in his lecture, is the only source relating to the Spanish version that still remains to us. Nothing of how this version came to disappear or become lost is known except that Dr. Monkhouse was appointed to translate it, and that, once he gave it to Dr. White, it disappeared, all traces of it erased from existence.

This brings us to a question: is the Italian version in existence the one which the monk Marino stole from the library of Pope Sixtus V or another version? We cannot gauge this without considering when it was written. For when examine the dates, you find that the time of Pope Sixtus V is around that of the sixteenth century, and that the type of paper used for it is of an Italian kind whose origin can be known from its watermark, a reliable indication of the date of the Italian version. Based on the above, the date that scholars estimate the version to be in existence is between the mid-fifteenth or midsixteenth century, so it is very possible then that the Italian version could well be the same version stolen by Fra Marino from the library of the Pope. 
When knowledge about the existence of the Gospel of Barnabas emerged at the beginning of the eighteenth century, much debate and discussion arose at academic and religious forums, particularly in England. Much controversy ensued, and many scholars bitterly clashed in opinion, ranging from the wildest of realms of fancy and delusion to solid scientific research. In the first instance, scholars were pre-occupied with issues relating to the Italian version, and whether this version had been rendered from another or was the original version of monk Marino who claimed to have stolen it from the library of Pope Sixtus V.

It is peculiar that it did not occur to these scholars to solve this question by looking at the comments and phrases in the margins of this version written in Arabic, which prove to us that the translation was faithfully rendered and had followed the original to the letter. As the truth of the matter could be found in the Arabic phrases located in the margins of the Italian version, I must comment upon this in detail because the experts on the Italian version have not shown engagement with the Arabic glosses nor have made any references to them. Even eminent Orientalist Margoliouth only mentioned this issue in passing. The only thing that he said about these marginal notes was that [Bernard de] La Monnoye had believed them to be correct and well written. Denis however has not failed to observe their clumsy constructions and abundance of grammatical errors.

However, if you closely examine these margins closely and read them in more detail, you will see that some of them are correct and well written, but have been marred and distorted by the pens of scribes, while others are clumsy of construction in the first place, their meanings either decipherable with considerable mental exertion or indecipherable at all. You also find that clumsy constructions and awkward phrasing have occurred when the scribe has carried out a literal word for word translation to render its meaning in the most narrow and ridiculous of ways [...] something which no Arabic writer under the sun would ever do. And this does not occur only within the margins where we find translations of paragraphs of the Gospel into Arabic, but also in the margins written by him with no correspondence in Italian $[\ldots]$

If we consider what I have put forward to you above, we can conclude that that the Arabic commentary in the margins must have had more than one writer: the original version being the correct one, and the others written upon it by copyists who had various shortcomings in their level of Arabic. Much of the original Arabic version by the first scribe became distorted with many erroneous expressions and awkward phrasing of writing with no discernable sense. This leads me to deduce that the Italian version from the Imperial Court of Vienna was taken, no doubt, from another version, and that we cannot consider it to be the first original version.

If this then is the case, the difficult question of what the original version is, from which the Italian version was taken, arises. It is one which is difficult, but not impossible to answer. Considering what has been commented on concerning what befell the Arabic commentary in its margins, we can 
deduce that the original version was not Arabic, as whomsoever had enough knowledge of Arabic to translate this Gospel into another language would not make those nonsensical grammatical mistakes that we see in the margins [...] all of which indicate that this language could have been Latin, or Old Italian. This deduction is consistent with what the experts, after examining it closely, have said about the font type used in the Italian version now in the Imperial Court of Vienna. For they have come to the conclusion that its scribe was of Venetian descent, and that he copied it in the sixteenth century or beginning of the seventeenth century. It was likely taken from a Tuscan version or from a version in the Venetian language where Tuscan terminology was used. This is the opinion of the two scholars Lonsdale and Laura Ragg after they drew on the opinions of Italian experts specialized in this realm of knowledge to support their arguments.

The two afore-mentioned scholars conclude that this version was created around 1575, and that the scribe of this Gospel was likely to have been monk Marino who is mentioned in the prologue to the Italian version referred to above. Then they state (and I translate):

Whatever the case may be, we can conclude with certainty that this Italian book of Barnabas is a composition, whether by a priest, secular, monk or lay-man, with an impressive knowledge of the Latin version of Torah equal to Dante's, and that like Dante he had special familiarity with the Psalter. It is the work of a man whose knowledge of Christian scriptures greatly surpassed that of his knowledge of the scriptures of Islam, meaning that it was probable that he was apostate from Christianity.

The inspiration for the comparison of this Gospel to the work of the famous poet Dante derives from there being many expressions of the Italian version that are similar to those in the poetic works of Dante, where he describes scenes of heaven and hell. In this Gospel, there are seven circles to hell, each level with a torture different and corresponding to whichever of the Deadly Sins had been committed. There are also nine Heavens, the zenith (i.e., the tenth) being paradise. Some believe therefore that the writer of this Gospel came after Dante and took some of his descriptions from him, or that he was a contemporary of Dante and so mentioned, like him, views that were prevalent at the time.

It first occurred to scholars that the Italian version was taken from an Arabic original, something which Cramer alluded to upon the publication of the Italian version which he gifted to the Duke of Savoy, which he prefaced with a few lines stating that this Muhammadian Gospel had been translated from Arabic or another language. He was followed in this by $\mathrm{La}$ Monnoye, who said: "Baron Huhndorf, who combined noble ancestry, high manners, and wide knowledge, showed me a book which the Turks claim was by Saint Barnabas, apparently translated into Italian from Arabic.” By the 


\section{Khalil Sa'a ${ }^{\prime} d a$, Rashịd Rid $a$}

term "Turks" he meant the Muslim and Arab nations, a term which is still commonly found in many books by foreign scholars to the present day.

Then Dr. White mentioned in 1783 that "the original Arabic version still exists in the East." However, close examination reveals that White's claims are based on the writings of the Orientalist Sale published half a century earlier in his so-called "The Preliminary Discourse." There in the context of discussing the Qur'an, he wrote:

The Mohammedans have also a Gospel in Arabic, attributed to St. Barnabas, wherein the history of Jesus Christ is related in a manner very different from what we find in the true Gospels, and correspondent to those traditions which Mohammed has followed in his Korân.

However, he then confesses in his introduction to the Qur"an that "I had not seen the Gospel of St. Barnabas when I referred to it in the Preliminary Discourse,"2 meaning that his previous statements were based on word of mouth, and what he had spoken of was based on what he had heard, as he himself had not seen this Arabic version [...]

I must explain however after all the above that I am inclined to believe that there may have been an Arabic version of this work, rather than in any other language. The fact that this version has never been found is not an argument that it has never existed. Otherwise, we must assume the Italian version to be the original, as no other version has been found aside from the Spanish one whose introduction says that it has been translated from the Italian. The Eastern reader can see from the first instance that the writer of the Gospel of Barnabas had a strong knowledge of the Qur'an, to the extent that many of its paragraphs appear to be a literal translation of Qur'anic verses. I say this with the full knowledge that I go against the opinion of most Western scholars who have delved into this matter. For when we look at the research of Lonsdale and Laura Ragg, they claim that this writer had little knowledge of Islam. They deny that this book could be of Arabic origin for a number of reasons. Yet there are paragraphs corresponding [...] to Qur'anic verses in the Gospel of Barnabas, as well as references to Hadith and scientific proofs known only to ancient Arabs. For despite the large number of Orientalists and Westerners specializing in the Arabic language and the history of Islam you can find nowadays, there are not amongst them any real scholars of $\underline{\text { Hadith }}[\ldots]$

However, to argue for an Arabic version of the Gospel, it does not follow that writer had to be an Arab in origin. I rather believe that the author was an Andalusian Jew who had embraced Islam after becoming Christian and studying the Gospels. For if you look at this Gospel, you will see that its author has an astonishing knowledge of the books of the Old Testament of the like never found amongst the followers of Christianity, aside from those dedicating their life to studying religion, such as theologians. It is rare however to find even amongst these theologians the knowledge of the Old Testament 
equivalent to that who wrote the Gospel of Barnabas. It was a well-known fact that there were Jews in Andalusia who had excellent proficiency in the Arabic language and were considered amongst the literati of Arab literature and were as familiar with the Qur'an and the Prophetic Hadith as the Arabs themselves $[\ldots]$

There are others who go with the view that the Gospel is Italian and existed from the earlier Middle Ages and believe that the writer was Italian as the Gospel and its expressions reflect the spirit of that time and depict words about harvest and songs relating to Tuscany and Tino in Italy [...] What can be said is that the same descriptions applicable to Italy are equally applicable to Andalusia.

Whether the author of this Gospel was Jewish or Christian in origin, there is no doubt that he was a Muslim. This is why it is such a tragedy that the Spanish version was lost, particularly as no scholars with access to it carried out the detailed scientific research which has been carried out on the Italian version. This is especially the case as we know nothing about its translator, Mustafa al-'Arandi, because the biography of a Muslim who had mastery over both Italian and Spanish, the languages in which the Gospel of Barnabas emerged, is of no small importance [...]

Before I conclude, I must point out that I have taken on the translation of this Gospel relying on the simplest of words and the easiest of styles, avoiding the ornamentation of expression and the embellishment of words in favor of faithfulness in translation. I maintained simplicity of expression rather than eloquence and fluency whenever they deviated from the original in any way. This version is identical to the English translation, which was taken from the Italian version, aside from the numbers which I added to aid in reference to particular parts when needed.

I give my deepest of thanks, praise and appreciation to the scholar Lonsdale Ragg, the Deputy Bishop of the Church of England in Venice, and to his wife, the gracious Laura Ragg, for her editing. Both granted me permission to translate this Gospel into Arabic from the English version which itself has been recently translated from the Italian original. In the service of history, I make mention of their great service and give praise to all the work and care they have given to the accuracy of its translation, and the preservation of its original version. This work is one of great toil, which only someone who has undertaken similar work can fully appreciate. I dedicate my thanks to the head of Clarendon Press in Oxford who agreed to print this Gospel and distributed to its readerships a rare book, and this was done due to this printer's commitment to the service of scientific knowledge.

In conclusion I have to emphasize that I committed myself in this introduction to cover the historical and scholarly perspectives only because I translated this book, as I set out in this introduction, to carry out a service to history. For this reason, I avoided going into the finer details of religious debate which I leave to those much more capable than myself.

Cairo, March 15, 1908, Khalil Sa'ada 


\section{The Publisher's Introduction}

In the Name of God, the Merciful, the Compassionate

Praise be to Allah, and blessings and peace upon the Prophet of God Muhammad, upon Jesus who was supported by the Spirit of God, and all of the prophets and messengers and whomsoever has been rightly guided by them towards the Day of Resurrection.

We note that the Christian historians are in accord that many Gospels were in existence in the first centuries following the coming of Jesus Christ, and that clergymen selected four of them and rejected the rest. Their followers amongst their people accepted their choice without further inquiry, and this would be the case for many like them, until God wills otherwise. However, whosever in any community values knowledge and wishes not to be a blind follower will look toward the origin of his faith and its history, even if it means consulting the rejected gospels, and looking to everything concerning them, after weighing up and evaluating the proofs that are manifest to him even if they are not manifest to clergymen.

If all of the Gospels had remained, the founts of historical knowledge on the faith's origins and precepts would have been more abundant and the wisdom and insights from them could have been studied by the scholars of this era using modern scholarly methods strengthened by the shield of freedom of will and independence of opinion, neither of which were characteristic of the clergymen who chose the Four Gospels but had refused all others [...]

Many centuries passed, and generations followed, and no one heard mention of this Gospel until a version of it was discovered in Europe 200 years ago. They considered it to be an invaluable treasure. Had anyone found it during the Middle Ages, those of the darkness of intolerance and ignorance, it would never have come to light. How could anything emerge in darkness, for light is the condition of visibility?

This version emerged in the vivid light of freedom in these lands and has been a source of great interest for scholars. Careful research and desire to discover new knowledge led to two prominent English researchers translating it into English last year, making it available in publication. Having received a copy of it upon publication, we concluded that the readers of Arabic should be no less fortunate that the readers of English. So we proposed the idea to our friend Dr. Khalil Sa'ada, and we came to an agreement to create a literal translation of it in Arabic. We published it after comparing it to the original for further accuracy in correction.

The research carried out by scholars of Europe and their long chapters and treatises on it have been summarized by Dr. Sa'ada in his Introduction. Amongst their findings, are detailed and painstaking studies on the type of parchment it was scribed upon, its binding and its language. Other opinions are conjectures and suppositions, as in speculation on the original author and the time of its composition, in which approach they have been followed by the editors of al-Hilal and al-Muqtataf $f^{3}[\ldots]$ 
There remains the issue which the scholars of this gospel most repudiate, from a scientific not religious perspective, that is the explicit reference to "The Prophet Muhammad" (PBUH). They say that it is inconceivable that this book was written before the emergence of Islam, as religious prophecies are typically delivered though allusions and tropes [...] It cannot be discounted that the translator of Barnabas into Italian could have used "Muhammad" as a translation, and that in the original the name was mentioned using a term that conveys its meaning, such as "the Paraclete." Such laxity in translation is not untypical for Christians, as demonstrated by Shaikh Rahmat Allah using many examples from their books [...] in his Revealing the Truth [...]

The Muslim reader should not assume that scholars from Europebesides some scholars from our countries, such as Dr. Sa'ada and the editors of al-Hilal and al-Muqtataf - cast doubt on this Gospel whose teachings are consistent with Islam due any fanaticism for Christianity. The time of intolerance that drove scholars to bury historical facts has now passed. The scholars of Europe have carried out research on the Four Gospels and have shown that it is still not known when any of the four were written, in which language, with some of them saying that their writers are not known at all. Some say that Paul wrote the majority of them, as can be seen in the French Encyclopedia and other works. It is even claimed that their basic teachings were taken from the pagan religions.

The vast majority of scholars in this age are free and independent in their research, aside from those who follow religious teachings or try to curry favor with religious people. Don't you see that the English Dr. Margoliouth is the one who refuted the claim that this gospel has an Arabic original and that it was written by Muslims? It is Dr. Sa'ada who disproved the claim that the book was written during the Middle Ages [...] The editors of Muqtataf believe that there is an original from which the Italian version was translated, which they call upon scholars to seek. The opinions of scholars such as these are to be respected, even when they are not supported with clear proof or manifest explanation.

It is noticeable that some priests have made the noble moral teachings in the Four Gospels the main pillar of Christianity. Reading the Gospel of Barnabas, one can distinguish its high status in terms of divine and moral teachings. For aside from its historical relevance, and its support of Islam in the three main issues of controversy - the Unity of God, the non-crucifixion of Christ, and the prophecy of Muhammad (PBUH) — we have enough motive for publication, along with historical value, in its guidance, wisdom, morals, and high-minded teachings.

May Allah rightly guides whom He wills on the Straight Path.

Cairo March 24, 1908.

Muhammad Rashid Rida Al- $\underline{\text { Hu}}$ usaini,

Founder of al-Manar

Translated by Ruth Abou Rached 


\section{COMMENTARY}

Translated into Arabic by Khalil Sa'adda from an English translation of a supposedly Italian translation, this Gospel has an elusive provenance. Many Islamic scholars, such as Rashid Rida, have presented the Italian Barnabas as a translation of a lost "source" gospel suppressed from the Biblical canon by earlier generations of Christian scholars due to its references to the Prophet Muhammad. According to Rida in his introduction, this Arabic version is a translation of at least two chains of translation from a "lost" original. In this sense, Rida publishing this Gospel could be read as simply re-launching Christian-Muslim polemics of the past, based on the claims of naskh (Islam abrogating religious laws of previous Abrahamic faiths), tahrif (the corruption of Old and New Testaments), and lack of tawatur, or reliable transmissionto then resituate them in the Nahda contexts. And certainly this text's ensuing high profile within some Islamic scholarly circles (Goddard 1996; Leirvik 2002) has led to questions about its status as translation or pseudotranslation: was Barnabas an Italian text written by an excommunicated Franciscan monk (Sox 1984) or a Carmelite monk converted to Islam (Pulcini 2001)? Is the Italian version a translation of a source Syriac text compiled in an ancient monastery (Cirillo 1977)? Or is it an exegesis of a source Spanish version by an Andalusian Muslim forced to convert to Christianity (Pons 1995; Leirvik 2002)? Or is it the work of a Jewish Andalusian convert to Islam, the conclusion deemed as more probable by the Christian Arabic translator Dr. Khalil Sa'ada?

Although the Gospel of Barnabas is clearly a rich and abundant source of debate, the preface of Rashid Rida, alongside the translator's own introduction, should not be overlooked. For Rida's preface represents a dynamic (and at times a dilemma) faced by many Islamic intellectuals in Egypt, such as Muhammad 'Abdo at this time: the combat of two negative influences on Muslim communities, colonization and religious reactionism holding Egypt back from progress. For this reason, Rida's preface as a paratextual part of this gospel offers fruitful insights into the politics of an Islamic scholar known for his reformist views publishing and translating a polemical Christian text into Arabic.

In Rida's preface, he sets out many points to frame this gospel as a source of valuable historical and theological knowledge in both localized and globalized frames: first, its presence in Arabic brings back to believers "original" sources of knowledge previously obscured by corrupt religious authority figures for centuries; second, Rida states he wishes to ensure "that the readers of Arabic should be no less fortunate that the readers of English"; third, Rida demonstrates how the Christian translator's own meticulous research using many sources brings forth rational lines of thought on its provenance regardless of faith background. By making his own remarks on the Italian version's style and Arabic annotations in the margin Rida demonstrates how Islamic scholarship contributes to rational debate by specialized knowledge 
of Classical Arabic and of the Qur'an. It is this final point in particular by which Rida condemns the tradition of blind imitation of previous religious teachings and the benefit of, and need for, "rational" and "independent" thinking in a world created by a God in His Unity (Skovgaard-Petersen 1997).

In many ways, Rida's introduction is a strong example of "paratranslation," of what is a text which many scholars deem a "pseudo-translation" (Toury 1984). His paratexts (Genette 1997) actually also "translate" the text itselfalongside Sa'ada's English-Arabic work - to new target audiences for particular ideological purposes (Garrido 2005: 31). For although Rida frames Barnabas as affirming notions of the Trinity, Crucifixion and Second Coming of Christ in ways compatible with Islam, he is not calling for Arabic readers to embrace Islam on the basis of Barnabas alone.

Dominating Rida's preface rather are arguments on why and how the book should be debated "for its historical value" and from different perspectives, all of which make his remarks on translation important. For when Rida draws attention to the debates on the text's status as a "real" or "pseudo" translation, he is clearly enacting (as well as promoting) the ability and need of Arabic readers to engage with polemical debates using "rational and independent" thought. Rida asks, for example, what would have happened to the text if it had been discovered in the dark ages? which could be read in many ways: as a rhetorical reference to the dangers of imitation, or as a provocation or challenge to elicit different perspectives, and thus inspire further debate. His decision to publish one introduction by a Christian translator and his own as a prominent Islamic scholar is a significant "paratext" in itself for the Nahda era still relevant to current scholarship: Rida paratranslates how differing opinions on a contentious religious text's past and present status as a translation can coexist and enrich knowledge and debate if rational and "independent" modes of interpretation, not techniques of imitation, are respected.

A silent or invisible paratext of Barnabas is its absence from Arabic versions of the Bible (see above) published for the most part under the auspices of Christian missionaries speaking the languages of European colonizers. Its visible paratext was its presence in the work of an Islamic reformist ideas with visions of the Islam as a global unifying force for progress and reform (Skovgaard-Petersen 1997: 97) despite European colonial domination in Muslim majority lands. According to Rida, rational methods deduction guides all scholars. So while he believed that European empires owe their progress to Arabic translations of knowledge disseminated in the Classical Islamic era in the first place (Skovgaard-Petersen 1997), the Arabic translation of scholarship published in European languages is helpful for Arabs to orientate themselves and their histories (Rida 1899: 62). It is not surprising then that he presents the Arabic Barnabas as a resource for both the Islamic community and Christian Arabs unfamiliar with a gospel absent/ed in their versions of the Bible. In this way, the text presents a clear challenge toward the influence of Christian missionaries in Islamic lands and traditions of blind imitation in 
any faith in the Nahda era. The Arabic translation by a Christian translator presented by an Islamic scholar as enacting overtly reformist Islamic thought thus paratranslates (intentionally or otherwise) in it a politics of authority resistance somewhat similar to that of its earlier mediaeval Italian or Andalusian settings.

\section{Ruth Abou Rached}

\section{Notes}

1 Also named as Mustafá de Aranda (Bernabé Pons 1998: 58). C.f. Joosten 2010: 203.

2 This is a rephrasing of Sale. The original reads: "of the Gospel of St. Barnabas (which I had not seen when the little I have said of it in the Preliminary Discourse, and the extract I had borrowed from M. de la Monnoye [...] were printed off) I must beg leave to give some further account" (Sale 1734: viii). This note comes in the introductory "To the Reader," which was apparently written after the Preliminary Discourse had already been printed.

3 Well-known Egyptian contemporary journals which were apparently the first to refer to the Gospel of Barnabas in Arabic: al-Hilal in 1896 and al-Muqtataf in 1907. The editors were Jurji Zaidan and Ya'qub Sarruf respectively.

4 Some Islamic apologists hold that the term "Paraclete" in the Bible refers to the prophet of Islam.

5 A contemporary Muslim apologist. 


\section{9 “Copyright Law" (1910)}

Anonymous

The terms of this law were first published in Arabic in Istanbul-based al- $\underline{H}$ adara newspaper, and later printed in a separate booklet. It was also published in several Arabic periodicals of the time, including the Beirut-based Rawdat alMa'arif, the Damascus-based al-Muqtabas, from which this text was taken, and the Egyptian al-Manar, edited by Rashid Rida, although the provisions of the law did not apply to Egypt, which was then under British rule.

\section{[THE FIRST TRANSLATION LEGISLATION IN ARABIC]}

\section{The Copyright Law}

Article 1: The owner of every kind of intellectual and scientific production holds a right that is called copyright.

Article 2: Intellectual and scientific production includes all kinds of books, drawings, plates, calligraphy, scrapbooks, figures, plans, maps, planes, architectural, geographical and topographic representations, artistic sculptures, hymns and musical notes.

Article 3: Copyright includes the printing and publication of these works, trading in them, translating them into another language or conveying them into a dramatic production. This applies to lessons, sermons, speeches and evening discussions launched for educational or entertainment purposes. As for speeches delivered in the councils of delegates and other notables, in public courts, or in public meetings, everyone has the right to collect and publish them. The right to transcribe, collect and print sermons of a preacher or lessons of a teacher belongs to the owner of those sermons or lectures.

Article 4: If the articles and drawings published in daily newspapers and periodicals are restricted by a phrase expressing that "their right is reserved and their publication and translation is forbidden to anyone other than their owner," then their right is reserved. Unrestricted articles, drawings and daily news are not protected by copyright, provided that their source is indicated. 
Article 5: It is not permissible to use the titles of newspapers, collections, correspondences and books that are already in use. Everyone may use titles that are available for the public for their own writings.

Article 6: An author enjoys copyright during his life, and after his death the copyright is owned by his children and spouses for a period of thirty years from the date of his death. Then, it goes to their parents. Then, it goes to their grandchildren, equally. Therefore, it is not permissible to print and publish those books or translate them to another language during this period of time by anyone other than their author or his inheritors.

$[\ldots]$

Article 10: It is not permissible to adapt a prose or verse novel or part of it without the permission of its author. The right to publish and print such works does not include the right to stage them.

Article 11: The performance of prose or verse works in gatherings organized by non-profit private offices and societies is not included in copyright.

Article 12: It is permissible to take some parts from any work for necessity or benefit, for literary or scientific work, school books, or criticism, provided that the author's name is indicated or mentioned.

Article 13: Correspondences may not be published without permission from their owner if he is alive or from his family if he is deceased.

Article 14: A book may be translated by one or more translators within the provisions of this law. Effective from the death of the translator, the copyright of each translator to their translation is like the copyright of the author.

Article 15: The copyright in the works published by official departments and associations officially known to the government belongs to those departments and associations.

Article 16: If a work is authored or translated by one or more persons without agreement or contract, the right of authorship or translation belongs to all of them equally. When one of the partners dies, the right to benefit from the parts he published until the date of death and the drafts he prepared for publication is passed to his inheritors. A thirty-year term for the right of authorship and a fifteen-year term for the right of translation are determined starting from the death of the last partner. If there is an agreement or contract between the partners, its provisions are to be honored. If there is a dispute, it is taken to court.

Article 17: If there is no owner of the book left, such as in the case of the death of an author who dies without an inheritor, then every person has the right to print or translate that work.

[...]

Article 25: Within the legal duration or period, the owner or translator of the work, the beneficiary or inheritors, may sell or waive the right of authorship or privilege permanently or temporarily, with something or nothing in return, to another. The buyer or acquirer of the right enjoys the same position as the owners within the agreed conditions, so that if he dies before completing the period, his inheritors are considered owners of the right in the remaining period. $[\ldots]$ 
Article 29: The unlicensed printing and adaptation of a book in the legal duration constitutes an imitation. So is the performance of a prose or verse work during the legal duration without the permission of the copyright owner. The reproduction of musical notes, the copying of maps, paintings, drawings and calligraphy, through photography or other media, as well as the creation of plates or molds for literary and musical works is considered an imitation. Imitators are prosecuted as stated in Article 32.

Article 30: The attribution of authored works in literature and arts to anyone other than their owners is considered plagiarism. Whoever rearranges the phrases of a book, musical lyrics or font letters or styles, benefiting from them in a way that the origin is recognized and attributes it to themselves is considered a plagiarizer.

Article 31: Criticism, explanations and footnotes are not considered plagiarism. Likewise, the use of some sentences and paragraphs from one book in another and mentioning the source does not constitute plagiarism.

$[\ldots]$

Article 35: The provisions of Article 32 of imitators shall also apply to plagiarizers.

\section{Translated by Ali Almajnooni}

\section{Commentary}

The first recognition of copyright in the Ottoman Empire can be traced to Encümen-i Daniş, Consultation Council established in 1850, whose duties included, among other things, regulating the publication of books (Surmeli 2011: 45). In the new law, an author was afforded copyright based on an examination that proved the work's originality (and also served as a form of veiled censorship) (ibid.: 46). The copyright recognition was seen as part of an incentive reward system, also including financial remuneration and the author's name on an inscription panel or a medal (ibid.). As the main goal of Encümen-i Daniş was to promote Turkish letters (and translation into Turkish), ${ }^{1}$ these regulations had no impact in the Arab World, especially that the council was disbanded in 1862. When the Berne Convention for the Protection of Literary and Artistic Works was adopted in 1886, the Ottoman State did not join it (Suthersanen and Gendreau 2013: 88).

The law at issue here, approved in 1910, was adapted from French, and to lesser extent German, laws of the nineteenth century (ibid), and based on Western notions of authorship (Birnhack 2012: 84). Here the authors' right to their work is established as a form of ownership, making it necessary to acquire their permission for any kind of reproduction, including translation. Just like material property, intellectual products can be traded and passed on to the authors' heirs.

While Article 10 does not list translated works among those requiring the permission of the producer, the last part of Article 6 prohibits the translation 


\section{Anonymous}

of any work into other languages without this permission. In addition, Article 14 recognizes the translators' right to their products and gives it the same duration as that of the author. Finally, Article 16, on collaboratives works, covers both translation and authorship, though it gives authorship twice the term as that of translation. In view of Article 14, it is not clear why translation is treated differently here.

This law can be regarded as the first recognition of translation, as well as authorship, copyright in the Arab countries under Ottoman rule. However, there is no indication that it was put into practice anywhere in the short period of its duration, i.e., until 1924, which saw the end of the Ottoman Empire and the establishment of the modern republic of Turkey (Suthersane and Gendreau 2013: 89; Birnhack 2012: 86). This was especially the case in the Arab region, which passed out of Ottoman rule before the end of World War I. Thus, the significance of this law remains chiefly historical.

\section{Tarek Shamma}

\section{Note}

1 In fact, it was decided to establish a committee whose aim would be "to prepare a Turkish dictionary which was independent of Arabic and Persian" (Surmeli 2011: 46). 


\title{
50 "Poetry and Poets" (1910)
}

\author{
Amin al-Rihani
}

\section{Amin al-Rihani (1876-1940)}

Amin al-Rihani was a critic, historian, translator, and travel writer, and one of the few major anglophone writers and translators in the Arab Nahda. He was born in Freike, Mount Lebanon. In 1888, he was sent by his father to the United States, where he studied at New York Law school in 1897, but returned the following year to Lebanon due to his illness, and worked there as an English teacher. Later he returned to New York and issued several books, including the first and second parts of al-Rihaniyat (his collected essays). He lived between his birthplace and the United States throughout his life. In 1922, he traveled around the Arab world and wrote several travel books about his experience. He was an author and translator in both Arabic and English. His works include The Kings of the Arabs and al-Rihaniyat. In English: The Book of Khalid (considered the first Arab-American novel), Around the Coasts of Arabia, The Path of Vision: Pocket Essays of East and West, and translations (in two volumes) of the poet Abu al-'Ala' al-Ma'arri (973-1057).

\section{Al-Rihaniyat (al-Rihani's collected essays)}

In this four-volume book, al-Rihani tackles literary, philosophical, religious, and social issues. The titles of his essays suggest the diversity of the topics: "Prayer," "On the Rooftops of New York," "What is Happiness?" "Ibn Sahl the Andalusian Poet," "Poetry and Poets," "The Spirit of Revolution," "Tolstoy," "The War and What Follows it."

\section{[THE LOCAL AND THE GLOBAL]}

There are two types of poets: One who writes for his people and is limited to topics of his time, and one who writes for the world, whose poems are fit for all times. When the first is translated into a foreign language, the translation rarely qualifies to be considered poetry. The opposite can be said of the second type. Nevertheless, the first type's writing can still be found in the work of the latter. His mastery may overpower his genius in cases where 
the acquired emerges victorious over nature. The first type of poet may have a bird's view of things, where he looks on from a summit with clear skies. This view, however, is not panoramic; the horizon is out of sight, and tunnels and dead ends are plenty. This poet sees the roots and heads of things, but not their branches and ends. Arab poets, except [Ibn] al-Farid ${ }^{1}$ and [Abu al-'Ala $\left.{ }^{\prime}\right]$ al-Ma'arri, fall under this category because in their poems' real poetic craft prevails; thus they produce poetry that is strictly Arabic, not poetry in its most infinite sense.

Al-Farid and al-Ma'arri almost transcend all this, each in his own way. Their souls lay bare, free off surface-level, shallow matters-namely the traditions of their people and the spirit of their time. It might appear strange that I chose these two poets as if they were two trees stemming from one root when they seem to have different methods and approaches. However, it seems to me that, upon closer inspection of their poetry and lives, they are fundamentally and considerably similar. In the works of both, there is no particular quality that is special to one nation or to one period of time. In fact, their poetry is all-encompassing and comprehensive, written under a universal sky, not an Arab one. Their poetry does not follow a Hijri nor a Gregorian calendar. In both their lives are intertwined ropes of piety and perplexity alternating between skepticism and certainty; the mind rises above the soul in "the Captive of Two Prisons" 2 while the soul rises above all sensible and tangible in "The Poet of [God] Seekers" [i.e., Ibn al-Faridi]. We can go further in saying that Abu Al-'Ala ' [al-Ma'arri] is, in some of his works, a Sufi and that Al-al-Farid is, at some point, a materialist. Abu Al-'Ala' produces poetry that is like a prism: clear but cold. The truth about life is reflected through it, thus gaining color and eventually bursting into flames that light up the subjects he addresses. Al-Farid's poetry is a spark of the soul that illuminates the flowers of love and the birds of eloquence chirping around a throne of secrets.

It is true what is said that poetry is the product of emotion. ${ }^{3}$ Emotions, at times, are very delicate, so they overflow. At other times, they are so intricate that they become mysteries for those that have never plunged into their depths. Emotion intensifies until it bursts, then burns, then illuminates. It is said that some emotions are instinctive, while others are acquired. If acquired, they would have an air of pretense about them. If instinctive, however, they would be overly sentimental or obsessive. A philosopher once said: "poetry is the beginning of obsession; the most beautiful verse is the result of adoration and obsession," and, to me, the poet of the soul should not be a logician nor a philosopher. I see that obsession, adoration, or extreme emotional inclinations reflect the voice and sighs of the soul; their tunes can be melodious, joyous, or noisy, depressing. In all cases, a soul's tendencies are the light and salt and wine of poetry, without which a poem is stale, pale, and sickly.

During such extreme fits of intense inclinations, a poet is not subject to worldly, shallow matters of the mind. His words and rhyme become manifestations of what the poet may deem a work necessity and a condition for excellence. Such inclination may become intense to the extent of turning 
into a form of madness where the intentions of poets different both in appearance and form align. For al-Farid's obsession with secrets flirts with their mysteries in the same manner in which Abu al-'ala' was obsessed with logic and the love poems he wrote for mortality and decay. Abu al-Atahia ${ }^{4}$ was similar in his devoutness until it became synonymous with lunacy in his poetry. Nevertheless, exaggeration is a natural quality in a poet since his emotion is an accumulation of the people's. If we may compare a human community to the human body, poets would be the nervous system of this figurative living body. Most poets belong to this category-poets of their people who write for their times.

A great poet, however, is a poet of the world and writes for all times; for he is the heart and the mind of the world. When a poet experiences a refinement, a sudden fragility of emotion, he wanders aimlessly or perhaps with a superficial aim to find himself entertained by the lovely appearance of things. On the other hand, he who is overtaken by the intensity of emotion plunges into the bottom of the ocean, bringing back gems and pearls. Finally, he who experiences the intricate depths of emotion may find himself forging through its dark mysteries; the only light at the end of the tunnel lies, for him, within the mind and the soul. Every truth has a dark, invisible ray of light. A true poet strolls among the shadows of this truth, following the path of its rays until the very end. There, he finds more of life's truths, as the rays of light to the sun. That being said, I do not think that all these qualities can be found together in one Arab poet.

Al-Mutanabbi, ${ }^{5}$ for instance, is rarely refined or intricate of emotion. It may be true that Abu al-Taiyib [Al-Mutanabbi] often purposefully plays on the element of mystery; yet he provides us with cold puzzles. On the other hand, in the poetry of Abu al-'Ala $\underline{a}^{6}$, we can barely hear the voice of the heart, except what comes through strained and belabored. Al-Farid , too, writes dense forests for poems - forests in which brides are holding luminous candles, running ahead of us to light our path towards paradise. But these candles are soon extinguished in the middle of the forest, and the brides sing as they fade into the darkness - and that is the best description that can put the secrets of love and the divinity of secrets into words. Now these three qualities that were divided equally among three of our own poets can be found, combined, in Homer, the poet of the Greek, and Shakespeare, the poet of the English.

\section{Translated by Sahar Othmani}

\section{Commentary}

Poetic translation is generally recognized among the most difficult challenges a translator could face. American poet Robert Frost defined poetry as "what gets lost in translation." What distinguishes poetry, even from other literary genres, is the inseparable symbiosis of content and form: all the components of the poem-meaning, structure, imagery, rhythm - are combined into an integrated whole that is intertwined with the linguistic, literary, and cultural 
context in a unity that is practically impossible to convey as is in a different cultural/linguistic context (see, e.g., al-Jahidh, Chapter 4). Thus, poetry, in the words of American poet Clement Wood, "cannot be translated; it can only be recreated in a new language" (quoted in Landers 2001: 97).

However, Amin al-Rihani in his ardent pronouncements about poetry (including some sweeping judgments of Arabic poetry and its potential universal horizons) argues for the opposite position: true poetry, to him, is what is actually preserved in translation, as it encompasses some kind of a timeless transcendent message that, surpassing the limitations of time and place, can be conveyed into any language/culture. His argument is based on a distinction between those poets whose vision is confined to the limits of their own age, language, and culture ("the traditions of their people and the spirit of their time") and those whose vision encompasses a universal scope that is so "all-encompassing, and comprehensive" that it resonates with humanity everywhere. On this view, al-Rihani advocates for poetry in its "infinite sense," as opposed to the kind that is tied to its own local circumstances (under which he classifies almost all Arabic poetry). The universal dimension that enables the true poet to function as the "nervous system" for the human community derives from genuine, pure emotion and unsullied nature which allows the poet to connect with readers as humans everywhere. This is contrasted with poetry that relies more on acquired craft, which is by necessity local and the product of its own age.

Al-Rihani's preoccupation with the general human dimension of poetry as the foundation for translation, and the yardstick of its success, especially what he calls "the infinite sense," is reminiscent of Ibn Rushd's quest for "totalities" in Greek poetry (see Ibn Rushd, Chapter 12), with the ultimate aim of uncovering universal laws that apply to all nations, as opposed to what is specific to Greek literature in its local environment. It should be noted, however, that the Andalusian philosopher did not see "totalities" as the property of some poets, or literary traditions, over others, but as dispersed, so to speak, among nations and poets throughout the world.

The theoretical background that governs al-Rihani's conception of poetry is arguably European romanticism: its celebration of the spontaneous expression of emotion vs. the rationalism of classicism, of nature vs. craft, and of the poet's inner life. In particular, al-Rihani (who published original works and translations in English and was deeply familiar with literature in this language) seems to have drawn on the English Romantics of the early nineteenth century. His article shows, it can be argued, the direct influence of William Wordsworth's preface to the Lyrical Ballads (1802), ${ }^{6}$ generally regarded as the foundational statement of English romanticism. Many of al-Rihani's pronouncements echo Wordsworth's principles: the definition of the object of the poet as "truth, not individual and local, but general, and operative; not standing upon external testimony, but carried alive into the heart by passion" (Wordsworth 1802: xxxii), and of poetry itself as "the image of man and nature" (ibid.); his exhortation, for these purposes, that the poet address the reader not within the limits of his own philosophy, profession, 
or place, "but as a Man" (ibid.: xxxiii); and his celebration of the universal appeal of poetry, so that in spite of all differences "of soil and climate, of language and manners, of laws and customs [...] the Poet binds together by passion and knowledge the vast empire of human society, as it is spread over the whole earth, and over all time" (ibid.: xxxvii).

Applied to translation, this humanist perspective usually inspires adaptive, "domesticating" approaches that eschew literalism and exacting accuracy. Such is Rihani's own view of translation, as expressed in a different article entitled "The Spirit of Language." In discussing the differences between Arabic and English, and his style in each, he rejects "metaphors tied to the surface morals, customs, and traditions of one nation, which, for the most part, can be understood, and admired, only by its own people," concluding that "literal translation from one language to another is graceless and disagreeable" (1923: 73).

However, seen especially from a modern perspective, al-Rihani's views seem simplistic and reductive. How realistic, it may be asked, is it to ascribe the reception of literary works in other cultures, and the international recognition of particular authors, to the intrinsic qualities of literary works, regardless of the standards and reading practices dictated by tastes prevailing at particular times and countries? Can we separate cultural and literary relations in the international market from political and economic ones? This awareness of the intertwined links between literary works and their sociopolitical contexts is one of the major contributions of modern cultural studies, as reflected especially in postcolonial approaches. Modern critiques of classical humanism have shown that what are often presented as universal human values are, at root, the products of societies with the political, financial, and military power to present their own worldviews, and even manners and modes of behavior, as general human traits that transcend time and place. One may also note that, while such practices are regularly linked today to Western centers of power, they have parallels in other cultural and linguistic contexts throughout history. In fact, a similar view governed intercultural transfer and translation in Classical Arabic: as Islam was the religion of original human nature, its basic principles could be identified in texts from other cultures. In this regard, it was the function of translation to recover some basic commonalities in foreign texts as a condition of their acceptance in the target culture (see, e.g., Matta and al-Sirafi, Chapter 7). ${ }^{7}$

Al-Rihani's standards are so Eurocentric that he finds all three qualities of great poetry as he sees it in two canonized Western poets (Homer and Shakespeare), while Arab poets of any recognition (a mere three) get only one quality each. It is significant, therefore, that the characteristics which supposedly distinguish al-Ma'arri and Ibn al-Farid from all Arab poets and endow them with some universal appeal ("piety and perplexity alternating between skepticism and certainty") reflect the "fin de siècle" in some European countries, with its pessimism and disillusionment with entrenched beliefs and grand causes, which extended into the early twentieth century, and was only exacerbated following the horrors of World War I. 
In a pertinent context, the remarkable success of the English translation of Rubáiyát of Omar Khayyám (1859) resulted from the ability the translator Edward FitzGerald to adapt the Persian quatrains to the concerns of his contemporaries (skepticism and world-weariness), who were "living in a season of outworn faith and restless satisfaction" (qtd. in Yohannan 2004: 6).

The translation and reception of al-Khayyam's poetry can help further illuminate al-Rihani's views on translation and intercultural communication. For al-Rihani tried consciously to replicate FitzGerald's experience in translating the Persian poet through his own translation of Abu al-'Ala ${ }^{6}$ alMa'arri, the same Arabic poet he singles out here for his humanist outlook.

In 1903, he published The Quatrains of Abu'1-Ala, his translation of a selection of al-Ma'arri poems, reformulated as quatrains from the original couplets. His introduction to the translation shows a consistent and deliberate effort to approximate the Arab poet to the cultural horizon of English readers. He calls al-Ma'arri "the Lucretius of al-Islam, the Diogenes of Arabia and the Voltaire of the East" (Rihani 1903: vi), who attacked the superstitions and the false traditions of religions" (v). Further, al-Rihani stresses the intellectual affinity between al-Ma'arri and al-Khayyam. In fact, he argues that the latter is the former's disciple and imitator (xviii), for "the skepticism and pessimism of Omar are, to a great extent, imported from Marrah [alMa'arri's hometown, to which he is attributed]" (xix).

Al-Rihani's translation strategy is naturally the same as FitzGerald's. $\mathrm{He}$ rejects adherence to the letter, which results in works that are "insipid, dull, and even ridiculous at times" (Rihani 1903: xvii). Translation, he says, is a "process of transformation," in which "the outer garment at times must necessarily be doffed" (xvii), but he still "adhered to the spirit and preserved the native imagery where it was not too clannish and grotesque" (ibid.).

\section{Tarek Shamma}

\section{Notes}

1 A well-known Sufi poet who lived in Egypt (1181-1234).

2 Al-Ma'arri, who was blind almost since birth, lived an ascetic life, confined to his home in northern Syria; blindness and home confinement were his two prisons.

3 Considering that the Arabic word for poetry (shi'r) is a cognate of shu'ur (feeling).

4 A seventh-eighth-century poet known for his ascetic poetry.

5 Abu al-Taiyb al-Mutanabbi (c.915-965) is widely considered one of the greatest poets in Arabic. His poetry is known mostly for wisdom and epic accounts of battles.

6 The Lyrical Ballads was first published in 1799, prefaced by a short "advertisement." Wordsworth's poetic principles were laid out in full in the extended preface to the third edition of 1802 , which we have used here.

7 For a discussion of the universalizing tendencies of Islamic translators see Shamma 2009: 83; Hanafi 2000, I: 319. 


\section{1 “Translation Lessons" (1912) 'Ali 'Umar al-Mišri}

(1870-1931)

'Alị 'Umar al-Missri was an Egyptian educator and school administrator. He received his education in Egypt and England. In 1919 he was exiled to Rafah, Palestine, as a result of his participation in the nationalist movement against the English occupation. Upon his return to Egypt, he served as an inspector at the Ministry of Education. In the twenties, he was Secretary General of the Egyptian University (now Cairo University).

\section{Hidaiat al-Mudarris li al-Nidhạm al-Madrasi wa Turuq al-Tadrịs (The Teacher's Guidance to the School System and Teaching Methods)}

The book from which the article was taken includes discussions of, and instructions on teaching methods. It covers topics such as what education is, its factors, habits and their formation, and the principles of teaching. The book also provides some guidelines for teaching specific subjects, including translation.

\section{[THE METHODS AND BENEFITS OF TEACHING TRANSLATION]}

Translation lessons entail a great deal of benefits in terms of both discipline and practice; they carry the combined benefit of grammar and composition lessons, since they bring together these two subjects. It is also no secret that translation hones the skill of precision in thought and phrasing, as it requires the translator to adhere to the intended meaning of the original author. It is, furthermore, one of the most prominent mediums for exchanging knowledge, ideas, inventions, and more.

The teaching of translation in schools aims to achieve two things: the first, to broaden students' horizons in terms of the depth of both languages. The second is to compare both languages' grammatical rules and terminology to pinpoint both similarities and differences between them. 
If the purpose of teaching is to enhance the students' vocabulary, the teacher must prepare the words around which the lesson revolves. He ought to compile words according to one theme and find their counterparts in the other language, not forgetting to provide collocations of said words according to context and to his students' levels. He should bear in mind that the source should first be English, and then Arabic, alternatively.

If the purpose, however, is finding parallels in grammar and terminology, he must indicate what he intends to teach.

At any rate, the following should be implemented:

1 The lesson objective must be indicated and written clearly in the lesson plan.

2 The issues that he intends to teach must be clearly explained in a manner that allows students to be prepared for the lesson. Simple examples must be provided, too.

3 The teacher should prepare in advance a set of oral exercises to ensure the clarity of meaning, which in turn leads to concluding facts upon which students can build as much new knowledge as they can.

4 The teacher should write on the blackboard, in clear handwriting, the sentence that he wants his students to translate orally.

5 If a sentence requires explanation, it must be explained in the same language in which it is written.

6 The teacher must choose one student to translate that sentence.

7 The teacher must not hasten to reject a student's answer merely for being incomplete or wrong. Instead, he should point out the mistake and ask the other students to correct it, not forgetting to commend any good effort.

8 If the sentence is noteworthy, the teacher must ask his students to write it down in their notebooks.

9 The teacher must write the second sentence on the blackboard, repeat the same set of instructions, and then move on to the third and the rest until he is finished with the exercise.

10 When the teacher is certain that his students comprehend the subject of the lesson, he must prepare a written exercise on small slips of paper. $\mathrm{He}$ should give it to students to solve it in their notebooks, practicing what they learned. He should know that the dictation of the sentence to his students is a waste of time.

11 Students must write the date and translate each sentence on their notebooks carefully and in clear, fair handwriting.

12 Students must be asked to write in Arabic using calligraphy reed pens and in English using suitable pens.

13 There must be more Arabic-into-English translation exercises than the other way round.

14 Each student must work on their own without help. 
15 Once they are done with their translations, the teacher must collect notebooks to mark them [...]

16 When marking notebooks, the teacher must have a notepad at hand where he writes down major and common mistakes in order to warn his students not to make them [...]

17 If the students' translations indicate that most of them did not truly grasp the lesson, the teacher must explain it once again and give them another exercise.

18 The teacher must periodically test his students' knowledge by giving them a written quiz to translate sentences that match their past learning. It would be beneficial to include sentences they have already translated to motivate students to revise past lessons, which would firmly root these lessons in their minds, thus rendering the teaching of translation fruitful.

A teacher must know that teaching translation can only be productive if planned comprehensively at the beginning of the academic year. This plan must include all the themes the teacher sees fit for the level of his students, putting effort into inserting a parallel number of lessons on English and Arabic grammar. He must always remember that he is meant to work through comparing the languages in terms of both terminology and grammar and not teach each one in isolation, because that is the job of a language teacher.

\section{Translated by Sahar Othmani}

\section{Commentary}

In this didactic book, published in 1911 in Egypt, and aimed at school and college teachers, a specific section is dedicated to translation, alongside sections on grammar and writing. The author stresses the centrality of translation to communication and knowledge exchange across languages and cultures, beyond its usefulness as a tool in language teaching, hence its promotion in the school curriculum. The practical value of translation as a mode of teaching foreign languages, and the English language in particular, is foregrounded with reference to the acquisition of vocabulary, terminology, grammar and phraseology. This approach is anchored in the grammar-translation tradition, which was still widely used in educational contexts at the time even if debated (see al-Saiyd, Ibrahim, Stevens, Chapter 47).

The author also stresses the importance of a methodological approach to the application of translation as a teaching tool, and the need to take into account the competence of the learners and their preparedness and willingness. Understanding the original text is seen as a pre-requisite to translation which cannot be reduced to transcoding and the search for equivalences but necessitates accuracy and "faithfulness" to the source text. 
Translation here is more than a practical tool. It is seen as contributing to the cultural and academic development of the students, which explains the pivotal role it played in educational programs in Egypt, and elsewhere in the Arab World at the beginning of the twentieth century, Finally, the discussion resonates with similar uses of, and challenges to the grammar-translation method in more recent contexts.

\section{Myriam Salama-Carr}




\title{
52 "La Marseillaise' \\ History of the French National Anthem and its Translation into Arabic" (1918)
}

\author{
Ernest Ni'matalla
}

Ernest Ni'matalla was a poet, musician, and translator of Syrian origins, who lived in Egypt in the early twentieth century. He published several poems in al-Hilal magazine, the last of which in 1929. His remaining works are lyrics that focus on national themes.

\section{The Arabic Translations}

Three aspects must be taken into account when translating La Marseillaise: first, to transfer the intended meanings without any addition, nor omission; second, to craft the expressions so that they arouse emotions; third, to ensure that the meter and the musicality are preserved in their entirety.

The first to translate La Marseillaise into Arabic was Rifa'a Bey al-Tahtawi, who took excessive liberties with the translation. Besides, he did not heed the meter and the musicality [of the original], which means that his Arabic version cannot be sung. Here is the first stanza $[\ldots]^{1}$

More recently, a good translation was written by Khalil Effendi Haslab, who followed the French original as much as possible with some liberties taken with the meaning. But this version cannot be sung. Here is the first stanza $[\ldots]^{2}$

We now have access to a third translation, yet to be published, composed and signed by Ernest Ni'matalla Bey, who put great effort in conveying the intended meaning in an expressive, arousing Arabic style, whilst preserving meter and musicality. This was a challenging task which required artistic flair and great precision.

We asked Ni'matalla, Bey, to describe the style of his translation, and he commented as follows:

The Arabic version is my translation articulated upon particular feet which match the tune perfectly and are repeated in all seven stanzas. Beyond observing the constraints of meter and musicality, and preserving the structure and meaning of the original, I also strove to find an equivalence in Arabic for the two French rhymes: the rime masculine and the rime feminine ${ }^{3}$, through the use of the consonant and vowel rhymes. 
This means that the anthem can be sung in the same way as the French version. Taking out the vowelization of the last letter in the vowel rhymes allows for recitation; whilst fixing it allows for singing, bearing in mind that every hemistich in the Arabic text corresponds exactly to one verse in the French text.

\section{Translated by Myriam Salama-Carr}

\section{COMMENTARY}

It is clear that the French Revolution of 1789 played a significant symbolic role in the construction of a concept of the nation at the time of the Nahda in the Arab World, and more specifically in Egypt. The present article, published in 1918 in al- $\underline{H}$ ilal, examines the historical origins of the anthem and the life of its author, Rouget de Lisle. It then moves on to discuss different Arabic translations of La Marseillaise whereby the translations are compared and contrasted in terms of accuracy and style.

The first translation examined here was carried out by the wellknown translator, reformer, and educationalist Rifa'a al-Tahtawi (see the Introduction), who had not focused on the rhyme and balance of the song. The second translation was that of the poet Khalil Effendi Haslab (1836-1907), who aimed at faithfulness to the original. As for the third version, written by Ernest Ni'matalla, it is said to show great care in conveying the intended meaning in eloquent and enthusing language, whilst ensuring rhythm and balance.

This discussion of three different Arabic versions of La Marseillaise provides an interesting example of the way translation and its requirements and challenges, such as equivalence or lack thereof, pragmatic effect and semantic accuracy were widely discussed. But, perhaps more importantly, the article shows the centrality of translation to the national dialogue and the part it played in awakening and stirring national consciousness when Egypt was under the British occupation. In fact, this translation was published when the nationalist movement was at a zenith, just before the Egyptian Revolution of 1919, which eventually led in 1922 to England's recognition of the independence of Egypt and the first constitution and national government in 1923.

\section{Myriam Salama-Carr}

\section{Notes}

1 The Arabic translation stays close to the meaning of the original and maintains a rhyme in Arabic.

2 This translation resorts to shorter hemistiches (Classical Arabic poetry, which was used by the first two translators, is composed in rhymed couplets).

3 In French in the original. 


\section{Bibliography}

\section{References in Arabic}

\section{A. Primary Sources}

[Anonymous]. [Treaties in Arabic]. In I Diplomi Arabi del R. Archivio Fiorentino [Arabic Documents of the Royal Florentine Archive], Michele Amari. Florence: Le Monnier, 1863.

'Abdo, Muhammad. 1902. "Al-Islam wa al-Nașraniya ma' al-'Ilm wa al-Madaniya [Islam and Christianity with Science and Civilization]." Al-Manar 5(13): 481-495.

Al-'Asqalani, Ibn Hajar. 1986. Fath al-Bari, Sharh Sahih al-Bukhari [Explanation of al-Bukhari's Collected Hadiths], Muhammad Fu'âd 'Abd al-Baqqi, et al. (eds.). Cairo: Dạr al-Raiyan li al-Turath.

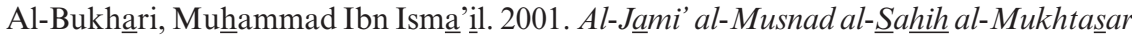
min Umür Rasul Allah ( $\underline{\text { Sahih }}$ al-Bukhari) [The Authentic, Abridged, ChainSupported Collection of the Traditions of the Messenger of God], Muhammad Zuhair al-Nasir. Beirut: Dar Tauqq al-Najat.

Al-Bustani, Butrus (trans. \& ed.). 1861. Al-Tuhfa al-Bustaniya fi al-Asfar al-Kuruziya [The Bustanian Gem of the Crusian Biography]. Daniel Defoe, Robinson Crusoe. Cairo: Matba'at al-Ma'arif.

Al-Bustani, Sulaiman (trans. \& ed.). 1904. Al-Iliatha [The Iliad]. Homer, The Iliad. Cairo: Matba'at al-Hilal.

Al-Fayumi, Sa'dia (Gaon). 2015. Tafsir al-Tawrat bi al-'Arabiya [Explanation of the Torah in Arabic].' Sa'idd 'Atiya Mutawi' and Ahmad 'Abd al-Maqsud al-Jundi (eds.). Cairo: National Center for Translation.

Al-Hạshimi, 'Abduallah Ibn Ismáil and 'Abd al-Masih Ibn Ishaq al-Kindi. 1885. Risalat 'Abduallah Ibn Ismáil al-Háshimi ila 'Abd al-Masih Ibn Ishaq al-Kindi [Letter by 'Abduallah al-Hashimi to 'Abd al-Masih al-Kindi]. London: Society for Promoting Christian Knowledge.

Al-Jabarti, 'Abd al-Rahman. 1822. 'Ajáib al- $\underline{\text { A }}$ thar fi al-Tarajim wa al-Akhbar [The Marvelous Compositions of Biographies and Chronicles]. Cairo: Matba'at alAnwar al-Muhammadiya.

Al-Jahidh, Abu 'Uthmann. 2002. Kitab al-Haiawan [The Book of Animals], Ibrahin Shams al-Din (ed.). Beirut: Sharikat al-A'lami li al-Matbu'at.

al-Kafawi, Abu al-Baqa'. Al-Kuliyat [Totalities], edited by 'Adnan Darwish and Muhammad al-Masri. Beirut: Mu'asasat al-Risala, 1998.

Al-Mas'údi, Abu al-Hasan. 2005. Muruj al-Thahab wa Ma'âdin al-Jawhar [Meadows of Gold and Mines of Gems], Kamal Hasan Mar'i (ed.). Beirut: Al-Maktaba al-'Assriya. 
al-Misiri, 'Ali 'Umar. 1912. Hidaiat al-Mudarris li al-Nidham al-Madrasi wa Turuq al-Tadris [The Teacher's Guidance to the School System and Teaching Methods]. Cairo: Matba'at al-Wa'idh.

Al-Naqqash, Marunn. 1869. "Khutbat Masrahiyat al-Bakhill" [Speech Delivered at the Staging of The Miser]." In Arzat Lubnan [The Cedar of Lebanon], Salim AlNaqqash (ed.). Beirut: Al-Maktaba al-'Umümiya.

Al-Nu'mani, Shibli. 1912. "Naqd Tạrikh al-Tamaddun al-Islami" [Critique of The History of Islamic Civilization]. Al-Manar, 15(5): 342-352.

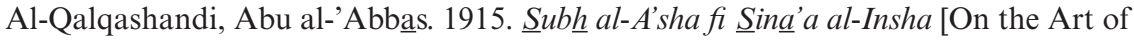
Composition]. Cairo: Dar al-Kutub al-Misriya.

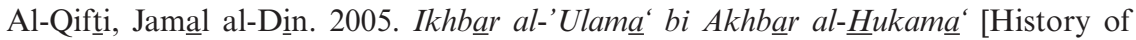
Wise Men], Ibrahim Shams al-Din (ed.). Beirut: Dạr al-Kutub Al-'Ilmiya.

Al-Razi, Fakhr al-Din. 1999-2000. Mafat $\underline{\text { h }}$ al-Ghaib [The Keys to the Knowledge of the Unseen], or Al-Tafsír al-Kabị [Great Exegesis], Vol. 1. Beirut: Dạr Ihia' alTurath al-'Arabi.

Al-Rifâ'i, Yahia Ibn 'Ali. Ta'rịb Zij Ulukk Bek [Arabization of Ulugh Beg's Astronomical Tables]. Manuscript. Cairo: Dạr al-Kutub wa al-Watha 'iq alQawmiya. www.wdl.org/ar/item/3951.

Al-Rihani, Amin. 1903. "Al-Shi'r wa al-Shu'ara ' [Poetry and Poets]."Al-Rihaniyat [Al-Rihani's Collected Essays], vol. 3, Beirut: Al-Matba'a al-'Ilmiya.

Al-Rizzi, Sarkịs Ibn Músa, et al. 1671. Al-Kutub al-Muqaddasa bi al-Lisan al'Arabi [The Holy Scriptures in the Arabic Tongue]. Biblia Sacra Arabica: Sacrae Congregationis de Propagnada Fide. Rome: Typis eiusdem Sacrae Congregat, de Propaganda Fide.

Al- $\underline{S}$ afadi, Salah al-Din. 2003. Al-Ghaith al-Musajjam fi Sharh Lamiyat al-'Ajam [Commentary on the L-Rhymed Poem]. Beirut: Dar al-Kutub al-'Ilmiya.

Al-Saiyd, Muhammad, Muhammad Ibrahim, W. H. Stevens. 1906. Murshid alMutarjim al- $\underline{H}$ adith [Guide for the Modern Translator]. Cairo: Matba'at al-Ma'arif.

Al-Shatibi, Ibrahim Ibn Músa. 1997. Al-Muwafaqat [The Reconciliation (of the Fundamentals of Islamic Law)], Abu 'Ubida Al Salaman (ed.). Riyadh: Dar Ibn 'Affan.

Al-Shidiaq, A Ahmad Faris. 1881. Kashf al-Mukhabba 'an Funun Urubba [Revealing the Hidden Arts of Europe]. Istanbul: Matba'at al-Jawa 'ib.

Al-Sirafi, Abu Saíd and Matta Ibn Yunus. 2004. In Abu Haiyan al-Tawhidi. AlImta ' wa al-Mu'anasa [Enjoyment and Companionship], Haithm al-Ta'ími (ed.). Beirut: Al-Maktaba al-'Assriya.

Al-Tabari, Ibn Jarịr. 1879-1901. Tarikh al-Rusul wa al-Muluk [History of the Messengers and Kings], Michael Jan de Goeje (ed.). Leiden: Brill.

Al-Waqqidi, Abu 'Abdullah. 1997. Futuh al-Sham [The Conquests of Syria], 'Abd alLatif 'Abd al-Rahmann (ed.). Beirut: Dạr al-Kutub al-'Ilmiya.

Al-Yazziji, Ibrahịm. 1897. "Al-Lugha wa al-'Assr [Language and the Age]." Al-Baian 1(4): 145-150.

Al-Zarkashi, Badr al-Din. 2010. Al-Burhan fi 'Ulum al-Qur' $\underline{a}$ [On the Sciences of the Qur'an], Muhammad Abu al-Fadal Ibrahim (ed.). Beirut: Dạr Ihia' al-Kutub al-'Arabiya.

-2007. Al-Bahral-Muhitfi Usul al-Fiqh [On the Fundamentals of Jurisprudence], Muhammad Tạmir (ed.). Beirut: Dạr al-Kutub al-'Ilmiya.

. 2000. Al-Manthur fi al-Qawa 'id al-Fiqhiya [On the Rules of Jurisprudence] Muhammad Hasan Isma’ili, Beirut: Dạr al-Kutub al-'Ilmiya. 
al-Zubaidi, Murtada. Taj al-'Arus min Jawahir al-Qamus [From the Gems of the Dictionary], Dahi abd al-Baqi (ed.), Vol. 1. Kuwait: al-Majlis al-Watani la alThaqâfa wa al-'Ulum wa al- Adab.

'Atiya, Ahmad. 2012. "Al-Baian al-Ta'sisi al-Awwal" [The First Foundational Manifesto]. Hermes 1.1: 20-34.

Baidas, Khalil. 1895. “Al-Ta'rịb [Arabization].” Al-Hilal 2(4): 62-63.

Calhoun, Simeon, et al. 1869. Murshid al-Talibin ila al-Kitạb al-Muqaddas al-Thamin [The Seekers' Guide to the Precious Bible]. Beirut: n.p.

Fahmi, Ahmad. 1906. Jinayat Uruba 'ala Nafsiha wa al-'Alam [Europe's Crime against itself and the World]. Cairo: Matba'at al-Ma'arif.

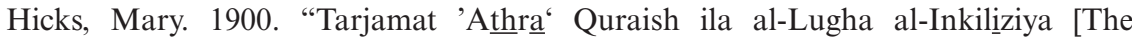
Translation of The Virgin of Quraish into the English Language]." Al-Hilal, vol. 8, no. 7.

Ibn 'Asakir, Abu al-Qạsim. 1995. Tạrikh Dimashq [History of Damascus] 'Amr Ibn Gharama al-'Amrawi, Damascus: Dạr al-Fikr.

Ibn Abi al-Husain, Abu Sa'id. Tarjamat al-Tawrat al-Samiriya [Translation of the Samaritan Pentateuch]. Manuscripts Arabe 6, Arabe 5, Arabe 7. Bibliothèque Nationale de France.

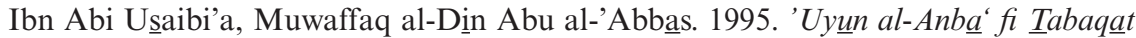
al-Atibba' [The Classes of Physicians], Nizar Rida (ed.). Beirut: Dạr Maktabat

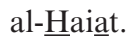

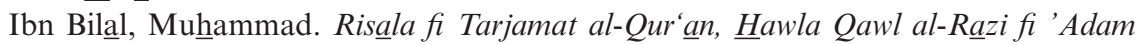

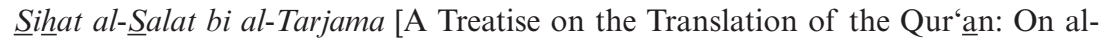
Razi's Injunction against Prayer in Translation]. Manuscript no. 304857. Cairo: AlAzhar University Library.

Ibn Hazam, Abu Muhammad. 1983. Al-Taqrịb li Hadd al-Mantiq [Approaching the Scope of Logic].” In Rasa il Ibn $\underline{H}$ azam al-Andalusi, Ingsan 'Abbas (ed.), Vol. 4. Beirut: al-Markaz ala'Arabi li al-Dirasat wa al-Abhath.

Ibn Ishaq, Hunain. 1925. Risala Ila 'Ali Ibn Yahia fi Thikr ma Turjima min Kutub Jalinus bi-'Ilmih wa ma lam Yutarjam [The Epistle of Hunain Ibn Ishaq to 'Ali Ibn Yahia Regarding What Was and Was not Translated, to His Knowledge, from Galen's Books]. In Hunain ibn Ishạq über die Syrischen und Arabischen GalenÜbersetzungen, Gotthelf Bergsträsser (ed.). Leipzig: Deutsche Morgenländische Gesellschaft.

Ibn Khaldun, 'Abd al-Rahman. 2004. Rihlat Ibn Khaldun [Ibn Khaldunn's Journey], Muhammad Ibn Tawit al-Tanji (ed.). Beirut: Dạ al-Kutub al-'Ilmiya.

Ibn Rushd, Abu al-Walid. 1953. "Talkhị Kitạb Aristu Talis fi al-Shi'r [Commentary on Aristotle's Poetics]." Fan al-Shi'r ma'a al-Tarjama al-'Arabiya al-Qadima wa Shuruh al-Farabi wa Ibn Sina wa Ibn Rushd [Poetics with the Old Arabic Translation and Commentaries by al-Farabiabi, Ibn Sina and Ibn Rushd],'Abd al-Rahman Badawi (ed.). Cairo: Maktabat al-Nahdia al-Misriya.

Ibn Taimiya, Taqi al-Din. 2005. Baian Talbis al-Jahmiya [Demonstration of the Deceitfulness of the Jahmiya], Rashid Muhammad 'Ali (ed.), Vol. 2. Medina: King Fahd Complex for the Printing of the Holy Quran.

. 1999. Al-Jawab al-Sahih li Man Baddala Din al-Masih [The Sound Refutation

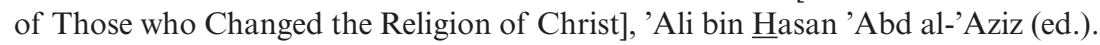
Riyadh: Dâr al-' Asima.

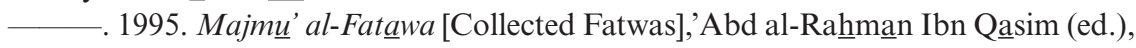
Vol. 4. Medina: King Fahd Complex for the Printing of the Holy Quran. 
Ibn Wahshiya, Abu Bakr. 1995. Al-Filaha al-Nabatiya [Nabataean Agriculture], Tawfiq Fahd (ed.). Damascus: French Institute for Arab Studies.

Ibrahim, Hafidh (trans. \& ed.). 1903. Al-Bu'asa' [The Miserable]. Victor Hugo, Les Misérables. Cairo: Matba'at al-Tamaddun.

Jalal, Muhammad 'Uthmann. 1912. Al-Amani wa al-Minna fi Hadith Qabul wa Ward Jinnah [The Tale of Qabul and Ward Jinna]. Cairo: Mustafa Taj al-Kutubi.

-1893. Al-Riwaiyat al-Mufida fi 'Ilm al-Tarajịda [Edifying Plays in the Art of Tragedy]. Cairo: Al-Matba'a al-Sharafiya.

Anonymous. 1910. "Qanun Haq al-Ta 'lif [Copyright Law]." Al-Muqtabas 5: 405-412.

Mitwalli, Muhammad and Mustafa Ibrahịm. 1897. "Tarjamat Armanúusa al-Miśriya ila al-Lugha al-Firansawiya [The Translation of Armanusa the Egyptian into the French Language]." Al-Hilal, 5(10): 377.

Muhammad 'Ali Pasha. 1846. "Tarqiat Rifá'a al-Tahtawi” [Promotion of Rifáa alTahtawi]. http://modernegypt.bibalex.org/NewTextViewer.aspx?TextID=DC_ 22101.

1831. "Ta'in Rifáa al-Tahtawi Mudarrisan bi Madrasat al-Tibb bi Abi Za'bal [Rifa'a al-Tahtawi's Appointment as a Teacher at the Medical School in Abu Za'bal]." http://modernegypt.bibalex.org/NewTextViewer.aspx?TextID=DC_20373.

Murasalat Hukumiya hawla Khidmat A hmad Zaki [Governmental Correspondence about Ahmad Zaki's Service]. Alexandria: Dạr al-Mahfudhat Maktabat alIskandariya. http://modernegypt.bibalex.org/NewDocumentViewer.aspx?DocumentID= DC_28055\&keyword http://modernegypt.bibalex.org/NewDocumentViewer.aspx? DocumentID=DC_28062\&keyword http://modernegypt.bibalex.org/ NewDocumentViewer.aspx?DocumentID=DC_28063\&keywordhttp://modernegypt. bibalex.org/NewDocumentViewer.aspx?DocumentID=DC_28065\&keyword http://modernegypt.bibalex.org/NewDocumentViewer.aspx?DocumentID=DC_ 28070\&keyword http://modernegypt.bibalex.org/NewDocumentViewer.aspx? DocumentID=DC_28086\&keyword http://modernegypt.bibalex. org/NewDocumentViewer.aspx? DocumentID=DC_28087\&keyword http://modernegypt.bibalex.org/NewDocumentViewer.aspx?DocumentID=DC_ 28088\&keyword http://modernegypt.bibalex.org/NewDocumentViewer.aspx? DocumentID=DC_28109\&keyword http://modernegypt.bibalex.org/NewDocument Viewer.aspx? DocumentID=DC_28114\&keyword http://modernegypt.bibalex.org/ NewDocumentViewer.aspx?DocumentID=DC_28137\&keywordhttp://modernegypt. bibalex.org/NewDocumentViewer.aspx?DocumentID=DC_28145\&keyword

Ni'matallah, Ernest. 1918. "Al-Marsiliaz: Tạikh al-Nashịd al-Watani al-Faransi wa Tarjamatuhu ila al-'Arabiya [La Marseillaise: History of the French National Anthem and its Translation into Arabic]." Al-Hilal, 26)4(: 321-328.

Rida, Muhammad Rashidd. 1907. "Muqaddimat al-Nashir [The Publisher's Introduction]." In Injill Barnabba [Gospel of Barnabas]. Translated by Khalil Sa'âda, edited by Khalil Sa'âda and Muhammad Rashịd Rida, Cairo: Matba'at al-Manar. 17-23.

1900. "Madaniat al-'Arab, Nabtha Thalitha [The Civilization of the Arabs: Third Overview]." Al-Manar 3)17): 385-391.

Rodet, Augustin and Ibrahịm al-Yazijị. 1897. Al-Kitạb al-Muqaddas [The Holy Bible]. Beirut: Matba'at al-Mursalin al-Yasúïin.

1881. Al-Kitáb al-Muqaddas [The Holy Bible]. Beirut: Matba'at al-Mursalin al-Yasu'iin. 
Sa'âda, Khalil. 1907. "Muqaddamat al-Mutarjim [The Translator's Introduction]." Injịl Barnába [Gospel of Barnabas]. Translated by Khalil Sa'ada, edited by Khalil Sa'ada and Muhammad Rashid Rida, Cairo: Matba'at al-Manar. 1-16.

Sa'id, Salim. 1905. "ㅂuquq al-Tab' wa al-Tarjama bi Missr [The Rights of Printing and Translation in Egypt]." Al-Hilal 13(7): 426-429.

[Various Authors]. 1904. "Al-Ihtifal bi Mutarjim al-Iliatha [Celebrating the Translator of the Iliad]." Al-Muqtataf, 29)7(. 669-677.

Wahbah, 'Assaf Girgis. 1895. "Tarjamat Armanusa al-Miśriya ila al-Lugha al-Rusiya" [The Translation of Armanusa the Egyptian into the Russian Language]. Al-Hilal 4)4): 144.

Zaidạn, Jurji. 1910. "Qanun $\underline{H}$ aq al-Ta'liff fi al-Mamlaka al-'Uthmaniya [Copyright Law in the Ottoman Kingdom]." Al-Hilal 1(19): 43-47.

. 1906. "Riwaiat al-Hilal wa Tarajamatuha al-Farisiya wa Ighfal Ism al-Mu'allif [al-Hilal Novels, their Persian Translations and the Omission of the Author's Name]." Al-Hilal 15(1): 61-62.

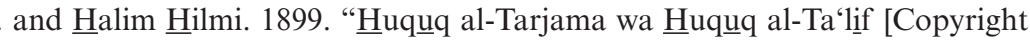
of Authorship and Translation]." Al-Hilal 7(12): 365-367.

1899. "Huquq al-Tarjama wa $\underline{H} u q u \underline{u}$ al-Ta'liff [On Copyright of Authorship and Translation (Praise and Criticism Section)]." Al-Hilal 7)9): 285-288.

\section{B. Secondary Sources}

'Abd al-Rahman, Taha. 2006. Al-ㅍaqq al-'Arabi fi al-Ikhtilaf al-Falsafi [The Arab Right to Philosophical Difference]. Second Edition. Casablanca: al-Markaz alThaqâfi al-'Arabi.

_ 1995. Al-Falsafa wa al-Lugha [Philosophy and Language]. Casablanca: alMarkaz al-Thaqại al-'Arabi.

'Ali, Jawad. 1993. Al-Mufassal fi Tarikh al-'Arab qabl al-Islam [Detailed History of the Arabs before Islam]. Second Edition. Baghdad: University of Baghdad.

'Allall, Khalid Kabịr. 2018. Muqawamat Ahl al-Sunna li al-Falsafa al-Yunnaniya khilal al-'Asr al-Islami [Sunni Resistance to Greek Philosophy during the Islamic Age]. Amman: Mu'assasat al-Warraqq.

Abu Shawk, Ahmad. 2017. "Al-Tạrikh al-'Arabi al-Islami Unmuthajan [Arab Islamic

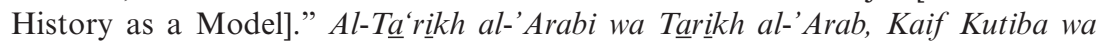
Kaifa Yuktab [Arab Historiography and the History of the Arabs: How It Was Written and How It Is Written]. Doha: Arab Center for Research and Policy Studies.

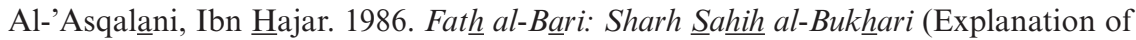
Al Bukhari's ㅂadith Collection), Muhib al-Din al-Khatib (ed.), Vol 13. Beirut: Dar al-Ma'rifa.

Al-Bairuni, Abu al-Raihan. 1983. Tahquiq ma lil Hind min Maqula (Investigation of What Indians Recount), 'Ali Safa (ed.). Beirut: 'Alam al-Kutub.

Al-Bustani, Butrus. 1906. "Tarikh al-Tarjama fi al-'Arabiya [History of Translation in Arabic]." In Majali al-Ghurar li Kuttáb al-Qarn al-Tási' 'Ashar [The Writers of the

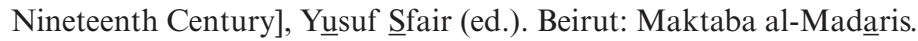

Al-Dibbi, al-Mufaddal. 1930. Dịwan al-Mufaddaliyat [Al-Mufaddaliayt Poem Collection], Karlos Ya'qüb Laial [Charles James Lyall], (ed.). Beirut: Matba'at alAba $\underline{A}^{6}$ al-Yasu'iin. 


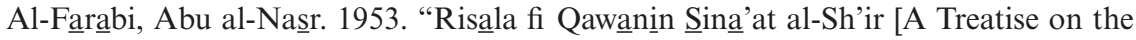
Laws of the Art of Poetry]. " Fan al-Shi'r ma'a al-Tarjama al-'Arabiya al-Qadima wa Shuruh al-Farabi wa Ibn Sina wa Ibn Rushd [Poetics with the Old Arabic Translation and Commentaries by al-Farabi, Ibn Sina and Ibn Rushd], 'Abd alRahman Badawi (ed.). Cairo: Maktabat al-Nahdia al-Misriya.

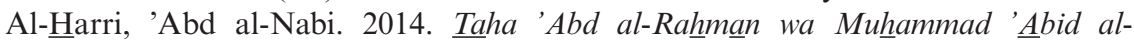

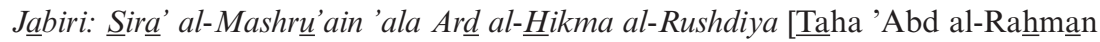
and Muhammad 'A bid al-Jabiri: The Struggle of the Two Projects against the Background of Ibn Rushd's Philosophy]. Beirut: Al-Shabaka al-'Arabiya li alAbhath wa al-Nashr.

Al-Hawi, Ilia (ed.). 1983. Sharh Dịwan al-Farazdaq [Explanation of Diwan of alFarazdaq], Vol. 2. Beirut: Dạr al-Kitạb al-Lubnani.

Al-Jabiri, Muhammad 'Abid. 1993. Tawkin al-'Aql al-'Arabi [The Formation of the Arab Mind]. Casablanca: Al-Markaz al-Thaqąi al-'Arabi.

Al-Jaburi, Karim, and Muhammad Al-Jabiri. 2015. "Al-Hamla al-'Askariya alFaransiya 'ala Jabal Lubnan 1860-1861 [The French Military Campaign in Mount Lebanon 1860-1861]." Majallat Markaz Bábil li al-Dirasat al-Insaniya [Journal of Babylon Center the for Humanities] 5(2): 39-49.

Al-Khafaji, Ibn Sinan. 1982. Sirr al-Fasaha [The Secret of Eloquence]. Beirut: Dạr al-Kutub al-'Ilmiya.

Al-Khatịb, Muhammad Kạmil. 1990. Takwịn al-Riwáia al-'Arabiya [The Formation of the Arabic Novel]. Damascus: Wizarat al-Thaqa fa.

al-Khuri, Yussuf. 1995. Al-Bustani wa al-Kitạb al-Muqaddas [Al-Bustani and the Bible]. Beirut: Baisan lil Nashr.

Al-Maqrīzī, Taqi al-Din. Al-Mawáiidh wa al-I'tibar [Instructive and Edifying Examples], Vol. 1. Beirut: Dar al-Kutub al-'Ilmiya.

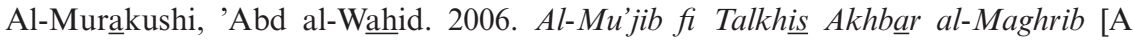

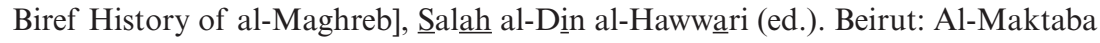
al-'As sriya.

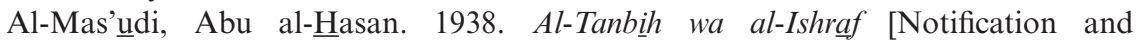
Verification],'Abdullah al-Sawi (ed.). Cairo: Maktabat al-Sharq al-Islamiya.

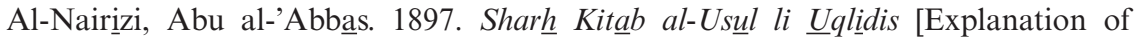
Euclid's Elements]. In Euclidis Elementa ex Interpretatione Al-Hadschdschadschii cum Commentariis Al-Narizii, Besthorn Olsen and Johan Heiberg (eds.), Vol. 1. Copenhagen: Libraria Gyldendaliana.

Al-Nu'mani, Shibli. 1912. "Al-Intiqą 'ala Kitabb al-Tamaddun al-Islami [Critique of The History of Islamic Civilization].” Al-Manar. 15:5: 342-352.

Al-Rihani, Amin. 1923. "Ruh al-Lugha [The Spirit of Language].” In Al-Rihaniyat [Al-Rihani's Collected Essays], Vol. 3. Beirut: Al-Matba'a al-'Ilmiya.

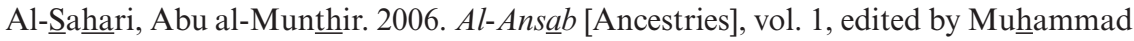
Ihsan al-Nass. Muscat: Ministry of National Heritage and Culture.

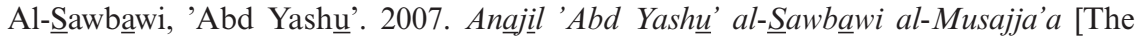

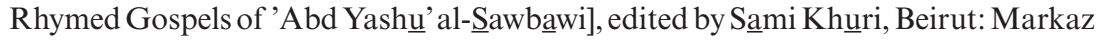
al-Turath al-'Arabi al-Masihi.

Al-Shaffi'i, Muhammad Ibn Idris. 1990. Kitáb al-Umm [The Exemplar]. Beirut: Dạr al-Ma'rifa.

Al-Shahrastani, Abu al-Fath. 1968. Al-Milal wa al-Nihal [Sects and Creeds],'Abd al-

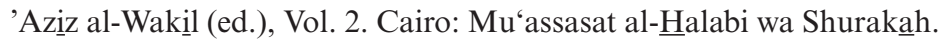


Al-Shaiyal, Jamal al-Din. 1951. Tarikh al-Tarjama wa al-Haraka al-Thaqafiya fi 'Ahd Muhammad 'Ali. [The History of Translation and the Cultural Movement in the Reign of Muhammad 'Ali]. Cairo: Dar al-Fikr al-'Arabi.

Al-Shatibi. 1992. Al-I'tisam [Taking Refuge], Salim al-Hilali (ed.), Vol. 1. AlKhobar: Dạr Ibn 'Affan.

Al-Suyuti, Jalal al-Din. 1980. Al-Muhththab fi ma Waqa'a fi al-Qur'an min al-Mu'arrab [On Arabized Terms in the Qur'an], al-Tuhami al-Hashimi (ed.). Rabat: $\underline{\text { Sanduqq }}$ Ihia' al-Turath al-Islami al-Mushtarak.

-1974. Al-Itqan fi 'Ulum al-Qur'an [On the Sciences of the Qur'an]. Muhammad Abu al-Fadl (ed.), Vol. 1. Cairo: al-Hai'a al-Misriya al-'ㅅamma lil Kitab.

- 1964. Al-Lughat fi al-Qur'an [Languages in the Qur'an], $\underline{\text { Salah }}$ al-Din alMunjjid (ed.). Cairo: Matba'at al-Risala.

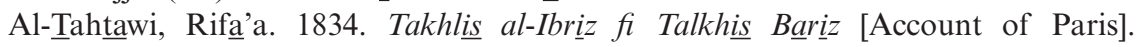
Cairo: Bulaq Press.

Al-Takrịti, Jamil Nasif. 2002. Al-Masrah al-'Arabi, Riada wa Ta'sis [Arab Theater: Pioneering and Founding Efforts]. Baghdad: Dạr al-Shu'un al-Thaqafiya al-' $\underline{\text { Amma. }}$.

Al-Tawhidi, Abu ㅂaiyann. 1992. Al-Muqabasa $\underline{t}$ [Borrowed Lights], ㅂasan al-Sandubi (ed.). Kuwait: Dạr Su'ad al-Sabah.

Al-Tibawi, 'Abd al-Latif. 1971. "Al-Qass Ilai Smith [Reverend Eli Smith].” Majallat al-Majma' al-'Ilmi al-'Arabi fi Dimashq [Journal of the Arabic Academy of Damascus], 46(4): 753-787.

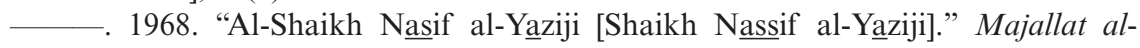
Majma' al-'Ilmi al-'Arabifi Dimashq [Journal of the Arabic Academy of Damascus], 43(2): 326-340.

Al-Tirmithi, Muhammad. 1998. Al-Jami' al-Kabị [The Great Compendium], Bashar Ma'ruff (ed.), Vol. 4. Beirut: Dạr al-Gharb al-Islami.

Al-Yussi, Nür al-Dinn. 2006. Al-Muhadarat [The Lectures]. Muhammad Hajji and Ahmad al-Sharqawi Iqbạl (ed.). Beirut: Dạr al-Gharb al-Islami.

Ashtiani, 'Abbas Iqbal. 2004. 'Al Nawbakht [The Nawbakht Family],'Ali al-Asadi (trans.). Mashhad: Majma' al-Buhuth al-Islamiya.

Baidas, Khalil (trans. \& ed). 1927. Ahwal al-Istibda d [The Horrors of Tyranny]. Aleksey Tolstoy, Князь Серебряный. Cairo: Al-Matba'a al-'Assriya.

Bannut, Habib. 1882. "Darar al-Riwaiat wa al-Ash'ar al-Hubbiya [The Harms of Amorous Novels and Poems]." Al-Muqtataf, 7)3): 174-175.

Bin Mahmud, Khalifa. 1850. Qala iid al-Juman fi Fawa'id al-Turjaman [Benefits for the Translator]. Cairo: Bulaq Press.

- 1842. Ithaf al-Mulukk al-Alibba bi Taqaddum al-Jam'iyat fi $\underline{\text { Urubba [The }}$ Progress of European Socieites]. Cairo: Bulaq Press.

Bin Thair 2014. "Manhajiyat al-Ta'rikh li al-Adab al-'Arabi" [The Metholodologies of the Historiography of Arabic Literature]. Dirasat 39: 25-53.

Bugruh, Makhluf )ed.(. 2003. Abraham Daninos: The Trip of the Infatuated and the Sighs of Love-Stricken in the City of Tiriaq in Iraq. Algiers: Al-Sanduq al-Watani li Tarqiat al-Funun wa al-Adab.

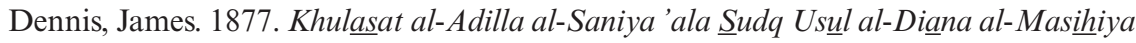
[Summa of Supreme Proofs of the Truth of the Fundamentals of Christianity]. Beirut: Matba'at al-Amerkan.

Doha Historical Dictionary of Arabic. www.dohainstitute.edu.qa 


\section{Bibliography}

Duma, Khairi (ed.). 2015. Robinşon Kruzzi (1835) [Robinson Crusoe]. Cairo: alMarkaz al-Qawmi lil Tarjama.

Hanafi, $\underline{H}$ asan. 2000. Min al-Naql ila al-Ibda ' [From Transmission to Creation], Vol. 1. Cairo: Dar Qibá'.

Hanna, Samih. 2018. "Intaj al-Ma'rifa wa Tashkil al-Hawiya fi Tarjamatain li al-Kitạb al-Muqaddas ila al-'Arabiya [Knowledge Production and Identity Formation in Two Arabic Translations of the Bible]." Alif: Majallat al-Balagha al-Muquarana [ALIF: Journal of Comparative Poetics] 38: 11-45.

Husain, Taha. 1997/1938. Mustaqbal al-Thaqafa fi Misr [The Future of Culture in Egypt]. Second Edition. Cairo: Dạr al-Ma'arif.

- 1933. Hafidh wa Shawqi [Hafidh and Shawqi]. Cairo: Maktabat al-Khanji.

Ibn 'Abd Rabbih. 1983. Al-'Iqd al-Faridd [The Unique Necklace],'Abd al-Majịd alTarhini (ed.), Vol. 4. Beirut: Dạr al-Kutub al-'Ilmiya.

Ibn 'Arabi, Muhiy al-Din. 1985. Al-Futuhat al-Makkiya [Meccan Revelations],'Uthman

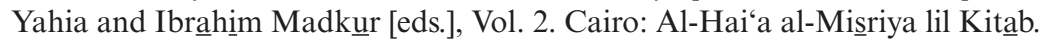

Ibn al-Nadim, Abu al-Faraj. 1997. Al-Fihrist [The Index], Ibrahin Ramadan (ed.). Beirut: Dạr al-Ma'rifa.

Ibn $\underline{H}$ azm, Abu Muhammad. 1996. Al-Fas l fi al-Milal wa al-Ahwa wa al-Nihal [On Religions, Sects, and Creeds], Muhammad Ibrahin Nas r and 'Abd al-Rahanman 'Amira (ed.), Vol. 1. Beirut: Dar al-Jill.

Ibn Khaldunn,'Abd al-Rahnman. 1988. Al-Muqaddima, Dịwan al-Mubtada' wa alKhabar fi Tarikh al-'Arab wa al-Barbar wa man 'Asarahum min Thawi al-Sultan al-Akbar [Introduction, to the History of the Arabs, non-Arabs, and Berbers, and Their Powerful Contemporaries], Khalil Shahada (ed.), Vol. 1. Second Edition. Beirut: Dar al-Fikr.

Ibn Munqith, Usama. 2003. Al-I'tibạ [Learning by Examples].'Abd al-Karịm alAshtar (ed.). Beirut: Al-Maktab al-Islami.

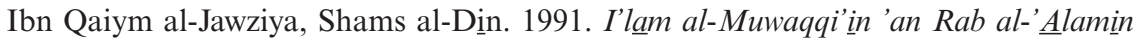
[Guidelines for Those Who Implement the Rules of God], edited by Muhammad 'Abd al-Salam Ibrahịm, Beirut: Al-Maktaba al-'Ilmiya.

Ibn Qutaiba (Al-Dainuri), Abu Muhammad. 2014. Ta'wil Mushkil al-Qur án [Interpreting the Difficult Passages of the Qur'an], Ibrahim Shams al-Din (ed.). Beirut: Dạr al-Kutub al-'Ilmiya.

1992. Al-Ma'arif [The Branches of Knowledge], edited by Tharwat 'Akasha, Cairo: General Egyptian Book Organization.

Al-Rafi'i, Mustafa Sadiq. 2000/1937. Wahi al-Qalam [The Inspiration of the Pen]. Vol.

3. Beirut: Dâr al-Kutub al-'Ilmiya.

—. 1924. "Al-Jumla al-Qur'aniya [The Qur'anic Sentence]." Al-Zahrạ́. 6(1): 353-359.

Ibn Sina, al-Husain Abu 'Ali. 1953. "Fassl fi al-Shi'r, min Kitab al-Shifạ ' [Chapter on Poetry, from Healing]. Fan al-Shi'r ma'a al-Tarjama al-'Arabiya al-Qadina wa Shuruh al-Farabi wa Ibn Sina wa Ibn Rushd [Poetics with the Old Arabic Translation and Commentaries by al-Farabibi, Ibn Sina and Ibn Rushd],'Abd al-Rahman Badawi (ed.). Cairo: Maktabat al-Nahda al-Misriya.

Ibn Taimiya, Taqi al-Din. 1986. Minhaj al-Sunna al-Nabawiya [The Path of the Prophet's Sunna], Muhammad Rashạd Salim (ed.), Vol. 5. Riyadh: Imam Muhammad Ibn Saud Islamic University. 
Ibrahim, 'Abduallah. 2008. Mawsúlat al-Sard al-'Arabi [Encyclopedia of Arabic Narrative], Vol. 1. Beirut: Al-Mu'assasa al-'Arabiya li al-Dirasat wa al-Nashr.

Jirji, Anba. 1932. Mujadalat al-Anba Jirji al-Rahib al-Sam'ani ma' Thalathat Shuiukh Muslimin (The Debate of Anba Jirji, the Simeonite Monk, with Three Muslim Theologians). Beirut: n.p.

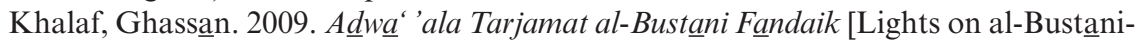
Van Dyke Translation]. Beirut: Bible Society Lebanon.

Khalil, Samir. 1983. "Madkhal ila al-Turath al-Masihi al-Qadim, Part 3. [Introduction into the Ancient Christian Heritage]." Sadiq al-Kahin 23: 3-4: 195-210.

Miskawayh, Abu 'Ali. Al- $\underline{H}$ ikma al-Khalida [Timeless Wisdom].'Abd al-Rahman Badawi (ed.). Beirut: Dạr al-Andalus.

Mitri, Najịb. 1905. Hadiyat al-Iliatha [The Gift of the Iliad]. Cairo: Matba'at al-Ma'arif.

Najm, Wadi'a Taha. 1985. Manqulat al-Jahidh min Arstu fi Kitáb al- $\underline{\text { Haiawan }}$ [alJahidh's Borrowings from Aristotle in The Book of Animals]. Kuwait: Ma'had alMakhtutat al-'Arabiya.

Rida, Muhammad Rashid. 1890. "Tarikh al-Mashriq [History of the East]." Review. Al-Manar 1(2): 62

Sa'id al-Andalusi, Abu al-Qạsim. 1912. Tabaqat al-Umam [The Categories of Nations],

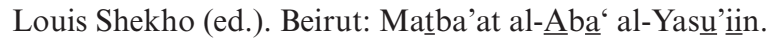

Saliba, George. 1998. Al-Fikr al-'Ilmi al-'Arabi: Nasha'atuhu wa Tatawuuruh [Arab Scientific Thought: Its Emergence and Development]. Beirut: University of Balamand.

Sarruf, Ya'qubb. 1906. "Murshid al-Mutarjim" [Guide for the Translator] (Review). Al-Muqtataf 31)12(: 1016.

Shekho, Louis. 1910. Al- $\underline{\text { Adab }}$ al-'Arabiya fi al-Qarn al-Tasi' 'Ashar [Arabic Literature

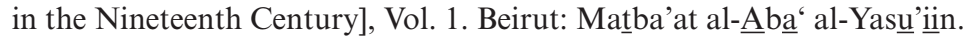

Tarabishi, George. 2006. "Man Qatala al-Tarjama fi al-Islam?" [Who Killed Translation in Islam?]. In Hartaqąt: 'An al-Dínuqratiya wa al-'Almaniya wa alHadatha [Heresies: On Democracy, Secularism, and Modernism]. Beirut: Dâr al-Saqqi.

[Unknown Author]. 1996. Akhbar al-Zaman wa man Abadahu al- $\underline{\text { Hadathan }}$ [Chronicles of Time], 'Abduallah al-Sawi (ed.). Beirut: Dar al-Andalus.

Van Ham, Joseph. 1873. Kashf al-Awham 'amman Mazzaqathu al-Siham [Exposing the Illusions of the One who Is Riddles with Arrows]. Beirut: Matba'at al- $\underline{A b}^{6}$ al-Yasu'iin.

-1872. Kashf al-Talánub wa al-Tahrif fi Mass Ba'd Aiat al-Kitab al-Sharif [Exposing the Manipulations and Distortions in Tampering with some Verses of the Noble Book]. Beirut: Matba'at al-Ába' al-Yasu'iin.

1870. Kashf al-Mughalatat al-Safsatiya, Raddan 'ala Ma Ashharahu Hadithan A $\underline{h}$ ad Khadmat al-Burutastantiya Didda Ba'ad al-Asfar al-Ilahiya [Exposing the Sophistical Fallacious, in Response to What Was Recently Published by a Servant

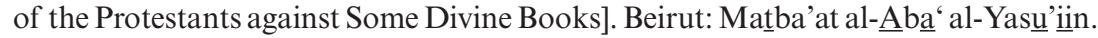

Zaidan, Jurji. 1894. "Tarjamat al-Tawra [The Translations of the Torah]." Al-Hilal 2(19): 593-600.

al-Zirkli, Khair al-Dinn. 2002. Al-A'lạm [Notable Figures]. Beirut: Dar Al-'Ilm lil Malaiin. 


\section{Bibliography}

\section{References in English and Other Languages}

Abdallah, Kristiina. 2014. "The Interface between Bourdieu's Habitus and Latour's Agency." In Remapping Habitus in Translation Studies, Gisella Vorderobermeier (ed.). Leiden: Brill. 111-132.

Abdulla, Adnan. 2021. Translation in the Arab World: The Abbasid Golden Age. London \& New York: Routledge.

Abdul-Raof, Hussein. 2013. Qur'an Translation: Discourse, Texture and Exegesis. London \& New York: Routledge.

Alexander, Philip. 1992. “Targum, Targumim.” In The Anchor Bible Dictionary, David Freedman (ed.), Vol. 6. New York: Doubleday. 320-331.

Al-Musawi, Muhsin Jasim. 2015. Medieval Islamic Republic of Letters. Notre Dame, IN: University of Notre Dame Press.

Arberry, A. J. 1937. "Hāfiz Ibrāhim and Shauqī." The Journal of the Royal Asiatic Society of Great Britain and Ireland 1: 41-58.

Aristotle. Poetics. 1995. Stephen Halliwell, et al. (trans., eds.). Cambridge, MA: Harvard University Press.

Atherton, Mark. 2004. "Sweet, Henry." In Routledge Encyclopedia of Language Teaching and Learning, Michael Byram (ed.). London \& New York: Routledge.

Baer, Brian James. 2020. "On Origins: the Mythistory of Translation Studies and the Geopolitics of Knowledge”. The Translator 26(3): 221-240.

Baker, Mona and Gabriela Saldanha (eds.). 2020. Routledge Encyclopedia of Translation Studies. Third Edition. London \& New York: Routledge.

Baker, Mona. 2014. "Translation as Re-narration.” In Translation: A Multidisciplinary Approach, Juliane House (ed.). Basingstoke: Palgrave Macmillan.

Bardenstein, Carol. 2005. Translation and Transformation in Modern Arabic Literature: The Indigenous Assertions of Muhammad 'Uthmān Jalāl. Wiesbaden: Harrassowitz Verlag.

Behrens-Abouseif, Doris. 2004. "European Arts and Crafts at the Mamluk Court." In Essays in Honor of J. M. Rogers, Doris Behrens-Abouseif and Anna Contadini (eds.). Leiden: Brill.

Berg, Lovisa. 2016. "Al- Naqqāsh, Mārūn." In The Routledge Encyclopedia of Modernism. Routledge, online. www.rem.routledge.com/articles/al-naqqash-marun1817-55.

Berman, Antoine. 1992/1984. The Experience of the Foreign: Culture and Translation in Romantic Germany. Albany: State University of New York Press.

Binay, Sara. 2012. "Revision of the Manuscripts of the 'So-called Smith-Van Dyck Bible'." in Translating the Bible into Arabic: Historical, Text-Critical and Literary Aspects, Sara Binay and Stefan Leder (eds). Würzburg: Ergon Verlag. 75-84.

Birnhack, Michael. 2012. Colonial Copyright: Intellectual Property in Mandate Palestine. Oxford: Oxford University Press.

Bosworth, C.E. 1986. "Tardjumān.” In Encyclopaedia of Islam, Second Edition, P. Bearman et al. (eds.), Vol X. Leiden: Brill. 236-238.

Bourdieu, Pierre. 1996. Physical Space, Social Space and Habitus. Oslo: Institutt for sosiologi og Samfunnsgeografi, Universitetet i Oslo.

Brody, Robert. 1998. The Geonim of Babylonia and the Shaping of Medieval Jewish Culture. New Haven: Yale University Press.

Butterworth, Charles (ed.). 1977. Averroës' Three Short Commentaries on Aristotle's "Topics," "Rhetoric," and "Poetics". Albany: State University of New York Press. 
Cachia, Pierre. 1990. An Overview of Modern Arabic Literature. Edinburgh: Edinburgh University Press.

Chamberlain, Lori. 1988. "Gender and the Metaphorics of Translation." Signs: Journal of Women in Culture and Society 13.3: 454-472.

Chesterman, Andrew. 2014. "Translation Studies Forum: Universalism in Translation Studies.” Translation Studies 7:1. 82-90.

- 2009. "The Name and Nature of Translator Studies." Hermes - Journal of Language and Communication in Business 22(42): 13-22.

Cheung, Martha. 2009. "On Thick Translation as a Mode of Cultural Representation." In Across Boundaries: International Perspectives on Translation Studies, Dorothy Kenny and Kyongjoo Ryou (eds.). Newcastle: Cambridge Scholars Publishing. 22-36.

- 2006. Anthology of Chinese Discourse on Translation. Manchester: St. Jerome Publishing.

Cirrillo, Louis. 1977. L'Évangile de Barnabé: Recherches sur la Composition et l' Origine. Paris: Editions Beauchesne.

Cook, Guy. 2007. "A Thing of the Future: Translation in Language Learning." International Journal of Applied Linguistics 17(3): 396-401.

D’Hulst, Lieven. 2014. Essais d'histoire de la traduction. Avatars de Janus. Paris: Classiques Garnier.

Davidson, Roderic. 1973. Reforms in the Ottoman Empire 1856-1876. New York: Gordian Press.

Delabastita, Dirk. 2012. "Response.” (Forum: Rethinking Methods in Translation History) Translation Studies 5(2): 246-248.

Delisle, Jean, and Judith Woodsworth (eds.). 2012. Translators through History, Revised Edition. Amsterdam: John Benjamins Publishing.

Ehinger, Jessica Lee. 2012. "Was Anyone Listening? Christian Apologetics Against Islam as a Literary Genre." The Church and Literature (48): 35-46.

Ellis, Roger and Ruth Evans. 1994. Medieval Translator IV. Liverpool: Liverpool University Press.

Fahd, T. 1986. "Nabaț." In Encyclopaedia of Islam, Second Edition, P. Bearman et al. (eds.), Vol. VII. Leiden: Brill. 831-838.

Faiq, Said. 2000. "Culture and the Medieval Arab translator." Perspectives: Studies in Translatology 8(2): 89-95.

Fawcett, Peter and Jeremy Munday. 2009. "Ideology." In Routledge Encyclopedia of Translation Studies, Second Edition, Mona Baker and Gabriela Saldanha (eds). London \& New York: Routledge. 137-141.

Fisher, Greg. 2011. Between Empires: Arabs, Romans, and Sasanians in Late Antiquity. Oxford: Oxford University Press.

Footitt, Hilary. 2020. "War." In Routledge Encyclopedia of Translation Studies, Third Edition, Mona Baker and Gabriela Saldanha (eds.). London \& New York: Routledge. 616-620.

Garrido Vilariño, Xoán Manuel. 2005. “Texto e Paratexto: Tradución e Paratradución”. Viceversa: revista galega de traducción 9: 31-39.

Genette, Gérard. 1997. Paratexts: Thresholds of Interpretation. Trans. Jane E. Lewin. Cambridge: Cambridge University Press.

Ghazaleh, Pascale. 2010. "Competing Immigrant Networks in Egypt." In The City in the Ottoman Empire: Migration and the Making of Urban Modernity, Ulrike Freitag et al. (eds.). London \& New York: Routledge. 
Goddard, Hugh. 1996. Muslim Perceptions of Christianity. London: Grey Seal Books. Gould, Rebecca. 2013. "Inimitability versus Translatability: The Structure of Literary Meaning in Arabo-Persian Poetics." The Translator 19(1): 81-104.

Grafton, David. 2015. The Contested Origins of the 1865 Arabic Bible: Contributions to the Nineteenth Century Nahda. Leiden: Brill.

Gran, Peter. 1979. Islamic Roots of Capitalism: Egypt, 1760-1840. Syracuse: Syracuse University Press.

Griffith, Sidney. 2013. The Bible in Arabic: the scriptures of the" People of the Book" in the Language of Islam. Princeton University Press.

Gutas, Dimitri. 1998. Greek Thought, Arabic Culture: The Graeco-Arabic Translation Movement in Baghdad and Early Abbasid Society (2nd-4th/8th -10th centuries). London \& New York: Routledge.

Guth, Stephan. 2017. "The Etymology of Some Language and Translation-Related Terms in Arabic." In Philologists in the World: A Festschrift in Honour of Gunvor Mejdell, Nora Eggen and Rana Issa (eds.). Sofiemyr: Novus Forlag. 141-164.

Hall, Isaac. 1885. "The Arabic Bible of Drs. Eli Smith and Cornelius Van Dyck." Journal of the American Oriental Society 11: 276-286.

Hanna, Sameh. 2016. Bourdieu in Translation Studies: The Socio-cultural Dynamics of Shakespeare Translation in Egypt. London \& New York: Routledge.

Heimburger, Franziska. 2012. "Of Go-Betweens and Gatekeepers: Considering Disciplinary Biases in Interpreting History through Exemplary Metaphors." In Translation and the Reconfiguration of Power Relations: Revisiting role and Context of Translating and Interpreting, Beatrice Fischer and Matilde Jensen (eds.). Zurich: Lit Verlag.

Hermans, Theo. 2014. The Conference of the Tongues. London \& New York: Routledge. . 2006. Translating Others (ed.). St. Jerome Publishing.

Heyworth-Dunne, J. 1938. An Introduction to the History of Education in Modern Egypt. London: Luzac \& Co.

Hirschler, Konrad and Sarah Bowen Savant. 2014. "What is in a Period - Arab Historiography and Periodization.” Der Islam 91(1): 6-19.

Howatt, A. P. R. 1997. A History of English Language Teaching. Oxford: Oxford University Press.

Hung, Eva Tsoi, and Judy Wakabayashi. 2014. Asian Translation Traditions. London \& New York: Routledge.

Islam, Riazul. 1986. "Kâtib.”. Encyclopaedia of Islam, Second Edition, P. Bearman et al. (eds.), Vol IV. Leiden: Brill. 754-760.

Jessup, Henry. 1900. Brief Documentary History of the Translation of the Scriptures into the Arabic Language by Rev. Eli Smith, D.D., and Rev. C.V.A. Van Dyck, D.D. Beirut: American Presbyterian Mission Press.

Joosten, Jan. 2010. "The Date and Provenance of the Gospel of Barnabas." Journal of Theological Studies 61(1): 200-215.

Kaegi, Walter Emil. 1992. Byzantium and the Early Islamic Conquests. Cambridge: Cambridge University Press.

al-Kafawi, Abu al-Baqa'. Al-Kuliyat [Totalities], edited by 'Adnan Darwish and Muhammad al-Masri. Beirut: Mu'asasat al-Risala, 1998.

Kahle, Paul. 1960. The Cairo Geniza. New York: Praeger.

Kaye, A. S. 1986. "Sudan, Biląd Al-." In Encyclopaedia of Islam, Second Edition, P. Bearman et al. (eds.), Vol IX. Leiden: Brill. 752-761. 
Kaye, Jacqueline. 1985. "Islamic Imperialism and the Creation of Some Ideas of 'Europe'." In Europe and Its Others, Francis Barker, Peter Hulme, Margaret Iversen, and Diana Loxley (ed.), Vol 1. Colchester: University of Essex. 59-71.

King, D.A. and J. Samsó. 1986. “Zidj.” In Encyclopaedia of Islam, Second Edition, P. Bearman et al. (eds.), Vol XI. Leiden: Brill. 496-508.

Koningsveld, P.S. van. 2004. "The Apology of Al-Kindi." In Religious Polemics in Context, T. L. Hettema and A. van der Kooij (eds.). Assen: Royal Van Garcum.

Kuenen, Abrahamus. 1851. Arabica Pentateuchi Samaritani Versione. Lugduni Batavorum. Leiden: Brill.

Landers, Clifford. 2001. Literary Translation. Clevedon: Multilingual Matters.

Lazarus-Yafeh, Hava. 1992. Intertwined Worlds: Medieval Islam and Bible Criticism. Princeton University Press.

Lefevere, André. 1992. Translation, Rewriting and the Manipulation of Literary Fame. London: Routledge.

Leirvik, Oddbjørn. 2002. "History as a Literary Weapon: The Gospel of Barnabas in Muslim-Christian Polemics." Studia Theologica-Nordic Journal of Theology 56(1): 4-26.

Lipiński, Edward. 1997. Semitic Languages: Outline of a Comparative Grammar. Leuven: Uitgeverij Peeters.

Luce, Mark. 2016. “Al-Bustani, Butrus.” In The Routledge Encyclopedia of Modernism. Routledge, online. www.rem.routledge.com/articles/al-bustani-butrus-1819-83

Mamdani, Mahmood. 2017. "Reading Ibn Khaldun in Kampala." Journal of Historical Sociology 30(1): 7-26.

Montaigne, Michel de. 1580/1993. Montaigne: Complete Essays. Trans. M. A. Screech. London: Penguin Classics.

Montgomery, Scott. 2002. Science in Translation: Movements of Knowledge through Cultures and Time. Chicago: University of Chicago Press.

Moosa, Matti. 1997. The Origins of Modern Arabic Fiction. Boulder: Lynne Rienner Publishers.

Moreh, Shmuel and Philip Sadgrove. 1996. Jewish Contributions to Nineteenth-Century Arabic Theatre: Plays from Algeria and Syria . Oxford: Oxford University Press.

Murphy, Jane. 2014. “Al-Jabarti.” In Encyclopaedia of the History of Science, Technology, and Medicine in Non-Western Cultures, Helaine Selin (ed.). Dordrecht: Springer.

Murre-van den Berg, Heleen. 2008. "The Middle East: Western Missions and the Eastern Churches, Islam and Judaism." In The Cambridge History of Christianity. vol.8. Sheridan Gilley and Brian Stanley (eds.). Cambridge: Cambridge University Press.

Patel, Abdulrazzak. 2013. The Arab Nahdah: The Making of the Intellectual and Humanist Movement. Edinburgh: Edinburgh University Press.

Pellat, C. 1986. "al-Mas'udi”. In Encyclopaedia of Islam, Second Edition, P. Bearman et al. (eds.), Vol VI. Leiden: Brill. 784-789.

Pons, Luis Bernabé. 1995. El Evangelio de Bernabé: Un Evangelio Islámico Español. Alicante: Publicaciones de la Universidad de Alicante.

Pulcini, Theodore. 2001. "In the Shadow of Mount Carmel: The Collapse of the Latin East and the Origins of the Gospel of Barnabas." Islam and Christian-Muslim Relations 12(2): 191-209.

Pym, Anthony. 1998. Method in Translation History. Manchester: St. Jerome Publishing. 
Rafael, Vicente. 2015. "Betraying Empire: Translation and the Ideology of Conquest." Translation Studies 8(1): 82-93.

Ricci, Ronit. 2011. Islam Translated: Literature, Conversion, and the Arabic Cosmopolis of South and Southeast Asia. Chicago: University of Chicago Press.

Richardson, John. 1777. A Dictionary Persian, Arabic, and English. Oxford: Clarendon Press.

. 1776. A Grammar of the Arabic Language. London: J. Murray.

Rihani, Ameen. 1920. "Preface." In The Luzumiyat of Abu'l-Ala. Trans. Ameen Rihani. New York: James T. White.

Robin, Christian Julien. 2012. "Arabia and Ethiopia." The Oxford Handbook of Late Antiquity, Scott Fitzgerald Johnson (ed.). Oxford: Oxford University Press. 247-332.

Robinson, Douglas. 1997. Western Translation Theory: From Herodotus to Nietzsche. Manchester: St. Jerome Publishing.

Rose, Marylin Gaddis (ed.). 2000. Beyond the Western Tradition. Binghamton: State University of New York.

Rundle, Christopher. 2011. "History through a Translation Perspective." In Between Cultures and Texts: Itineraries in Translation History, Antoine Chalvin et al. (eds.). Frankfurt Am Main: Peter Lang.

Ryding, Karin. 2005. A Reference Grammar of Modern Standard Arabic. Cambridge University Press.

Sakkut, Hamdi. 2005. The Arabic Novel: Bibliography and Critical Introduction, 18651995. Cairo and New York: The American University in Cairo Press.

Salama-Carr, Myriam. 2020. "Mapping an Arabic Discourse on Translation." In The Routledge Handbook of Arabic Translation, Sameh Hanna, Hanem El- Farahaty, and Abdel-Wahab Khalifa (eds.). London \& New York: Routledge. 285-296.

2000. "Medieval Translators into Arabic: Scribes or Interpreters?" In Beyond the Western Tradition: Translation Perspectives XI, Gaddis Rose, Marilyn (ed.). Binghamton: State University of New York. 99-105.

- 1997. "Translation as Seen by Al-Jahiz and by Hunayn Ibn Ishaq." In Across the Mediterranean Frontiers - Trade, Politics and Religion 650-1450, D. Agius and I. Netton (eds.). Turnhout: Brepols Publishers. 385-393.

Sale, George. 1734. The Koran Commonly Called The Alcoran Of Mohammed: Translated into English Immediately from the Original Arabic, with Explanatory Notes Taken from the Most Approved Commentators to which is Prefixed a Preliminary Discourse. London: J. Wilcox.

Santoyo, Julio-César. 2006. "Blank Spaces in the History of Translation.” In Charting the Future of Translation History: Current Discourses and Methodologies, Georges Bastin and Paul Bandia (eds.). Ottawa: University of Ottawa Press.

Santoyo, Julio-César. 2006. "Blank Spaces in the History of Translation”. In Charting the Future of Translation History, Georges Bastin and Paul Bandia (eds). Ottawa: University of Ottawa Press. 11-44.

Savage-Smith, Emilie et al. (eds.). 2020. A Literary History of Medicine. Leiden: Brill. Schleiermacher, Friedrich. 1813/1997. "On the Different Methods of Translating." In Western Translation Theory: from Herodotus to Nietzsche. Douglas Robinson (ed., trans). Manchester: St. Jerome.

Shamma, Tarek. 2021a. "In Search of Universal Laws: Averroes' Interpretation of Aristotle's Poetics." In World Literature: Premises and Problems. Luiza Moreira (ed.). Albany: SUNY Press. 9-28. 
2021b. "Universal Wisdom, Islamic Law: Translation Discourse in Classical Arabic." In The Routledge Handbook of Translation History, Christopher Rundle (ed.). London \& New York: Routledge.

2020. "Conquest." In Routledge Encyclopedia of Translation Studies, Third Edition, Mona Baker and Gabriela Saldanha (eds.). London \& New York: Routledge.

- 2009. "Translating into the Empire: The Arabic Version of Kalila wa Dimna." The Translator 15(1): 65-86.

Shehadeh, Haseeb. 1989. "The Arabic Translation of the Samaritan Pentateuch." In The Samaritans, Alan David Crown (ed.). Tübingen: Mohr Siebeck.

Skovgaard-Petersen, Jakob. 1997. Defining Islam for the Egyptian State: Muftis and Fatwas of the Dar al-Ifta. Leiden: Brill.

Sox, David. 1984. The Gospel of Barnabas. London: George Allen and Unwin.

Starkey, Paul. 2006. Modern Arabic Literature. Edinburgh: Edinburgh University Press. Subrahmanyam, Sanjay. 1998. "Notes on Circulation and Asymmetry in Two Mediterraneans, c. 1400-1800." In From the Mediterranean to the China Sea: Miscellaneous Notes, Denys Lombard et al. (eds.). Wiesbaden: Otto Harrassowitz Verlag.

Surmeli, Gungor. 2011. "The Enforcement of Intellectual Property Rights (IPR) in Turkey in the EU Accession Process: A Perception Analysis of the Police Officers Dealing with IPR Crimes.” Ph.D. Dissertation. Durham University.

Suthersanen, Uma and Ysolde Gendreau. 2013. A Shifting Empire: 100 Years of the Copyright Act. London: Edward Elgar.

Tageldin, Shaden. 2011. Disarming Words: Empire and the Seductions of Translation in Egypt. Oakland, CA: Univ of California Press.

Tibawi, Abdul Latif. 1966. American Interests in Syria, 1800-1901: A Study of Educational, Literary and Religious Work. Oxford: Clarendon Press.

Toury, Gideon. 1984. "Translation, Literary Translation and Pseudotranslation." Comparative Criticism 6: 73-85.

Troupeau, G. 1986. “Al-Kindi, 'Abd Al-Masīh B. Isḥaḳ.” In Encyclopaedia of Islam, Second Edition, P. Bearman et al. (eds.), Vol V. Leiden: Brill. 120-121.

Tsagari, Dina and Georgios Floros. 2013. Translation in Language Teaching and Assessment. Newcastle: Cambridge Scholars Publishing.

Tymoczko, Maria. 2014. "Response.” (Forum: Universalism in Translation Studies) Translation Studies, 7:1, 104-107.

- 2007. Enlarging Translation, Empowering Translators. Manchester: St. Jerome.

- 2001. "Difference in Similarity." In Similarity and Difference in Translation: Proceedings of the International Conference on Similarity and Translation, Stefano Arduini and Robert Hodgson (eds.). Rome: Ed. di Storia e Letteratura. 27-43.

- 1999. "Post-Colonial Writing and Literary Translation." In Post-Colonial Translation: Theory and Practice. Susan Bassnett and Harish Trivedi (eds.). London \& New York: Routledge. 19-40.

Vagelpohl, Uwe. 2012. "Abbasid Translation Movement in Context: Contemporary Voices on Translation.” In Abbasid Studies II: Occasional Papers of the School of Abbasid Studies, John Nawas (ed.). Leuven: Orientalia Lovaniensia Analecta.

Van der Merwe, C. H. J. 1999. "The Elusive Biblical Hebrew Term ויהי: A Perspective in Terms of its Syntax, Semantics, and Pragmatics in 1 Samuel." Hebrew Studies 40: 83-114. 
Van Essen, Arthur. 2004. "History: From the Reform Movement to 1945 Europe." In Routledge Encyclopedia of Language Teaching and Learning, Michael Byram (ed.). London \& New York: Routledge.

Venuti, Lawrence. 2008. The Translator's Invisibility: A History of Translation. Second edition. London \& New York: Routledge.

-1998. The Scandals of Translation: Towards an Ethics of Difference. London \& New York: Routledge.

_. 1991. "Simpatico." SubStance 20(2): 3-20.

Versteegh, Kees. 2014. Arabic language. Edinburgh University Press.

Vollandt, Ronny. 2015. Arabic Versions of the Pentateuch: A Comparative Study of Jewish, Christian, and Muslim Sources. Leiden: Brill.

- 2011. "Christian-Arabic Translations of the Pentateuch from the 9th to the 13th Centuries: A Comparative Study of Manuscripts and Translation Techniques." Ph.D. Dissertation. University of Cambridge.

Wakabayashi, Judy. 2009. "An Etymological Exploration of 'Translation' in Japan." In Decentering Translation Studies: India and beyond, Judy Wakabayashi and Rita Kothari (eds.). Amsterdam: John Benjamins.

Wolff, Anne. 2003. How Many Miles to Babylon? Travels and Adventures to Egypt and Beyond, 1300 to 1640. Liverpool: Liverpool University Press.

Wordsworth, William. 1802. Lyrical Ballads. Third Edition. London: Longman.

Garrido Vilariño, Xoán Manuel. "Texto e Paratexto.” Viceversa: Revista Galega de Traducción 9(10): 31-39.

Yohannan, John. 2004. "The Fin de Siècle Cult of FitzGerald's Rubaiyat of Omar Khayyam." In Edward FitzGerald's The Rubáiyát of Omar Khayyám, Harold Bloom (ed.). Philadelphia: Chelsea House Publishers.

Zewi, Tamar. 2015. The Samaritan Version of Saadya Gaon's Translation of the Pentateuch. Leiden: Brill. 


\section{Appendices}

\section{Abbreviation list}

\begin{tabular}{ll}
\hline Subjects & Languages \\
\hline Eng: & English \\
Fre: & French \\
Per: & Persian \\
Tur: & Turkic/Ottoman \\
Grk: & Greek \\
Lat: & Latin \\
Rus: & Russian \\
Heb: & Hebrew \\
Syr: & Syriac/Aramaic \\
Ind: & Indian \\
Oth: & Other \\
Lit: & Literature \\
Lan: & Language \\
Geo: & Geography \\
Phi: & Philosophy \\
His: & History \\
Sci: & Science \\
Off: & Official/legal \\
Rel: & Religion \\
Oth: & Other \\
\hline
\end{tabular}




\section{Appendix (1): Statistical Tables for the Classical Period}

Eighth Century

Number of Texts: 6

Written Translation

\begin{tabular}{|c|c|c|c|c|c|c|c|c|c|c|c|c|c|c|c|c|c|c|}
\hline Total Number & \multicolumn{18}{|c|}{6} \\
\hline Location & \multicolumn{9}{|c|}{ Independent Source } & \multicolumn{9}{|c|}{ Translation Paratexts } \\
\hline Number & \multicolumn{9}{|c|}{5} & \multicolumn{9}{|c|}{1} \\
\hline Subject & Lit & Lan & Geo & Phi & $\mathrm{H}$ & & & Sci & Oth & Lit & Lan & & & $\mathrm{Ph}$ & & Rel & Sci & Oth \\
\hline Number & 3 & & & & 2 & & & & & 1 & & & & & & & & \\
\hline Language & Grk & Lat & $\mathrm{H}$ & $\mathrm{P}$ & & Syr & & ad & Oth & Grk & Lat & & $\mathrm{He}$ & & Per & Syr & Ind & Oth \\
\hline Number & 1 & & 1 & 1 & & 2 & & & 1 & & & & & & 1 & & 1 & \\
\hline
\end{tabular}


Ninth Century

Number of Texts: 23

Written Translation

\begin{tabular}{|l|l|l|l|l|l|l|l|l|l|l|l|l|l|l|l|l|l|l|l|}
\hline Total Number & \multicolumn{10}{c|}{ Independent Source } & \multicolumn{8}{|c|}{ Translation Paratexts } \\
\hline Location & \multicolumn{10}{|c|}{} \\
\hline Number & \multicolumn{10}{|c|}{17} & \multicolumn{8}{|c|}{2} \\
\hline Subject & Lit & Lan & Geo & Phi & His & Rel & Sci & Oth & Lit & Lan & Geo & Phi & His & Rel & Sci & Oth \\
\hline Number & 2 & & & & 7 & 6 & & & & & & & & & 2 & \\
\hline Language & Grk & Lat & He & Per & Syr & Ind & Oth & Grk & Lat & He & Per & Syr & Ind & Oth \\
\hline Number & 1 & & & 1 & & & & 1 & & & & 1 & & \\
\hline
\end{tabular}

\section{Interpreting}

\begin{tabular}{|l|l|l|l|l|l|l|l|l|l|l|l|l|l|l|l|l|}
\hline Total Number & \multicolumn{10}{|c|}{ 6 } \\
\hline Subject & Lit & Lan & Geo & Phi & His & Rel & Sci & Oth & Lit & Lan & Geo & Phi & His & Rel & Sci & Oth \\
\hline Number & & & & & 3 & 2 & & 1 & & & & & & & & \\
\hline
\end{tabular}


Tenth Century

Number of Texts: 19

\begin{tabular}{|l|l|l|l|l|l|l|l|l|l|l|l|l|l|l|l|l|l|l|}
\hline Total Number & \multicolumn{10}{|c|}{ Translation Paratexts } \\
\hline Location & \multicolumn{10}{|c|}{} \\
\hline Number & \multicolumn{10}{|c|}{} & \multicolumn{10}{|c|}{4} \\
\hline Subject & Lit & Lan & Geo & Phi & His & Rel & Sci & Oth & Lit & Lan & Geo & Phi & His & Rel & Sci & Oth \\
\hline Number & 1 & 1 & & 1 & 7 & 2 & & & & & & 1 & & 1 & 2 & \\
\hline Language & Grk & Lat & He & Per & Syr & Ind & Oth & Grk & Lat & He & Per & Syr & Ind & Oth \\
\hline Number & 7 & & 3 & 7 & 3 & 2 & 6 & 2 & & 1 & & & & \\
\hline
\end{tabular}

\section{Interpreting}

\begin{tabular}{|l|l|l|l|l|l|l|l|l|l|l|l|l|l|l|l|l|}
\hline Total Number & \multicolumn{10}{|c|}{ 3 } \\
\hline Subject & Lit & Lan & Geo & Phi & His & Rel & Sci & Oth & Lit & Lan & Geo & Phi & His & Rel & Sci & Oth \\
\hline Number & & & 1 & & 2 & & & & & & & & & & & \\
\hline
\end{tabular}




\section{Eleventh Century}

Number of Texts: 24

\section{Written Translation}

\begin{tabular}{|l|l|l|l|l|l|l|l|l|l|l|l|l|l|l|l|l|l|l|l|l|}
\hline Total Number & \multicolumn{10}{|c|}{ Translation Paratexts } \\
\hline Location & \multicolumn{10}{|c|}{} \\
\hline Number & \multicolumn{10}{|c|}{ Independent Source } & \multicolumn{10}{|c|}{4} \\
\hline Subject & Lit & Lan & Geo & Phi & His & Rel & Sci & Oth & Lit & Lan & Geo & Phi & His & Rel & Sci & Oth \\
\hline Number & 1 & 3 & 1 & 4 & 5 & 4 & 1 & & 1 & & & 2 & & 1 & & \\
\hline Language & Grk & Lat & He & Per & Syr & Ind & Oth & Grk & Lat & He & Per & Syr & Ind & Oth \\
\hline Number & 5 & 2 & 2 & 4 & 2 & 2 & 1 & 2 & & 1 & 1 & & & \\
\hline
\end{tabular}

\section{Interpreting}

\begin{tabular}{|l|l|l|l|l|l|l|l|l|l|l|l|l|l|l|l|l|}
\hline Total Number & \multicolumn{10}{|c|}{1} \\
\hline Subject & Lit & Lan & Geo & Phi & His & Rel & Sci & Oth & Lit & Lan & Geo & Phi & His & Rel & Sci & Oth \\
\hline Number & & & & & 1 & & & & & & & & & & & \\
\hline
\end{tabular}


Twelfth Century

Number of Texts: 17

Written Translation

\begin{tabular}{|c|c|c|c|c|c|c|c|c|c|c|c|c|c|c|c|c|}
\hline Total Number & \multicolumn{16}{|c|}{13} \\
\hline Location & \multicolumn{8}{|c|}{ Independent Source } & \multicolumn{8}{|c|}{ Translation Paratexts } \\
\hline Number & \multicolumn{8}{|c|}{12} & \multicolumn{8}{|c|}{1} \\
\hline Subject & Lit & Lan & Geo & Phi & His & Rel & Sci & Oth & Lit & Lan & Geo & Phi & $\mathrm{H}$ & Rel & Sci & Oth \\
\hline Number & 1 & 3 & & 3 & 2 & 3 & & & & & & 1 & & & & \\
\hline Language & Grk & Lat & $\mathrm{He}$ & $\mathrm{P}$ & & & Ind & Oth & Grk & Lat & $\mathrm{He}$ & & & Syr & Ind & Oth \\
\hline Number & 2 & & 1 & & trat & & & & 1 & & & & & & & \\
\hline
\end{tabular}

\section{Interpreting}

\begin{tabular}{|l|l|l|l|l|l|l|l|l|l|l|l|l|l|l|l|l|}
\hline Total Number & \multicolumn{10}{|c|}{ 4 } \\
\hline Subject & Lit & Lan & Geo & Phi & His & Rel & Sci & Oth & Lit & Lan & Geo & Phi & His & Rel & Sci & Oth \\
\hline Number & & & & & 3 & 1 & & & & & & & & & & \\
\hline
\end{tabular}


Thirteenth Century

Number of Texts: 22

Written Translation

\begin{tabular}{|l|l|l|l|l|l|l|l|l|l|l|l|l|l|l|l|l|l|l|l|}
\hline Total Number & \multicolumn{10}{c|}{ Translation Paratexts } \\
\hline Location & \multicolumn{10}{|c|}{ Independent Source } & \multicolumn{10}{|c|}{4} \\
\hline Number & \multicolumn{10}{|c|}{16} & \multicolumn{10}{|c|}{} \\
\hline Subject & Lit & Lan & Geo & Phi & His & Rel & Sci & Oth & Lit & Lan & Geo & Phi & His & Rel & Sci & Oth \\
\hline Number & & & & 2 & 6 & 8 & & & & & & & 1 & 2 & 1 & \\
\hline Language & Grk & Lat & He & Per & Syr & Ind & Oth & Grk & Lat & He & Per & Syr & Ind & Oth \\
\hline Number & 3 & & & 3 & 1 & & & 1 & & 1 & 1 & & & \\
\hline
\end{tabular}

\section{Interpreting}

\begin{tabular}{|c|c|c|c|c|c|c|c|c|c|c|c|c|c|c|c|c|}
\hline Total Number & \multicolumn{16}{|c|}{2} \\
\hline Subject & Lit & Lan & Geo & Phi & His & Rel & Sci & Oth & Lit & Lan & Geo & Phi & His & Rel & Sci & Oth \\
\hline Number & & & & & 2 & & & & & & & & & & & \\
\hline
\end{tabular}


Fourteenth Century

Number of Texts: 33

\begin{tabular}{|l|l|l|l|l|l|l|l|l|l|l|l|l|l|l|l|l|l|l|l|l|}
\hline Total Number & \multicolumn{10}{|c|}{ Translation Paratexts } \\
\hline Location & \multicolumn{10}{|c|}{} \\
\hline Number & \multicolumn{10}{|c|}{ Independent Source } & \multicolumn{10}{|c|}{1} \\
\hline Subject & Lit & Lan & Geo & Phi & His & Rel & Sci & Oth & Lit & Lan & Geo & Phi & His & Rel & Sci & Oth \\
\hline Number & & 2 & & 5 & & 16 & 1 & & & & & & & 1 & \\
\hline Language & Grk & Lat & He & Per & Syr & Ind & Oth & Grk & Lat & He & Per & Syr & Ind & Oth \\
\hline Number & 5 & & 3 & 4 & 2 & & 1 & & & & & & & \\
\hline
\end{tabular}

\section{Interpreting}

\begin{tabular}{|l|l|l|l|l|l|l|l|l|l|l|l|l|l|l|l|l|}
\hline Total Number & \multicolumn{10}{|c|}{$\mathbf{8}$} \\
\hline Subject & Lit & Lan & Geo & Phi & His & Rel & Sci & Oth & Lit & Lan & Geo & Phi & His & Rel & Sci & Oth \\
\hline Number & & & 1 & & 3 & 4 & & & & & & & & & & \\
\hline
\end{tabular}


Fifteenth Century

Number of Texts: 11

Written Translation

\begin{tabular}{|c|c|c|c|c|c|c|c|c|c|c|c|c|c|c|c|c|c|}
\hline Total Number & \multicolumn{17}{|c|}{8} \\
\hline Location & \multicolumn{8}{|c|}{ Independent Source } & \multicolumn{9}{|c|}{ Translation Paratexts } \\
\hline Number & \multicolumn{8}{|c|}{6} & \multicolumn{9}{|c|}{2} \\
\hline Subject & Lit & Lan & Geo & Phi & His & Rel & Sci & Oth & Lit & Lan & Geo & $\mathrm{Ph}$ & & His & Rel & Sci & Oth \\
\hline Number & & & & 1 & & 4 & & 1 & & & & & & & 1 & 1 & \\
\hline Language & Grk & Lat & $\mathrm{He}$ & $\mathrm{Pe}$ & & Syr & Ind & Oth & Grk & Lat & $\mathrm{He}$ & & Per & & yr & Ind & Oth \\
\hline Number & 2 & & & & & 1 & & & & & & & 2 & & & & \\
\hline
\end{tabular}

\section{Interpreting}

\begin{tabular}{|l|l|l|l|l|l|l|l|l|l|l|l|l|l|l|l|l|}
\hline Total Number & \multicolumn{10}{|c|}{ 3 } \\
\hline Subject & Lit & Lan & Geo & Phi & His & Rel & Sci & Oth & Lit & Lan & Geo & Phi & His & Rel & Sci & Oth \\
\hline Number & & & & & 2 & 1 & & & & & & & & & & \\
\hline
\end{tabular}


Sixteenth Century

Number of Texts: 9

\begin{tabular}{|l|l|l|l|l|l|l|l|l|l|l|l|l|l|l|l|l|l|l|l|}
\hline Total Number & \multicolumn{10}{|c|}{ Translation Paratexts } \\
\hline Location & \multicolumn{10}{|c|}{} & \multicolumn{8}{|c|}{0} \\
\hline Number & \multicolumn{9}{|c|}{ Independent Source } \\
\hline Subject & Lit & Lan & Geo & Phi & His & Rel & Sci & Oth & Lit & Lan & Geo & Phi & His & Rel & Sci & Oth \\
\hline Number & & & & & 2 & 6 & 1 & & & & & & & & \\
\hline Language & Grk & Lat & He & Per & Syr & Ind & Oth & Grk & Lat & He & Per & Syr & Ind & Oth \\
\hline Number & 2 & & 1 & 2 & & & 1 & & & & & & & \\
\hline
\end{tabular}




\section{Seventeenth Century}

Number of Texts: 12

\section{Written Translation}

\begin{tabular}{|l|l|l|l|l|l|l|l|l|l|l|l|l|l|l|l|l|l|l|l|l|}
\hline Total Number & \multicolumn{10}{c|}{ Translation Paratexts } \\
\hline Location & \multicolumn{10}{|c|}{ Independent Source } & \multicolumn{8}{|c|}{} \\
\hline Number & \multicolumn{10}{|c|}{} \\
\hline Subject & Lit & Lan & Geo & Phi & His & Rel & Sci & Oth & Lit & Lan & Geo & Phi & His & Rel & Sci & Oth \\
\hline Number & & & & 2 & 1 & 6 & & & & & & & & 2 & & \\
\hline Language & Grk & Lat & He & Per & Syr & Ind & Oth & Grk & Lat & He & Per & Syr & Ind & Oth \\
\hline Number & 3 & 2 & 1 & 3 & & & & 1 & & & & & & \\
\hline
\end{tabular}

\section{Interpreting}

\begin{tabular}{|l|l|l|l|l|l|l|l|l|l|l|l|l|l|l|l|l|}
\hline Total Number & \multicolumn{10}{|c|}{1} \\
\hline Subject & Lit & Lan & Geo & Phi & His & Rel & Sci & Oth & Lit & Lan & Geo & Phi & His & Rel & Sci & Oth \\
\hline Number & & & 1 & & & & & & & & & & & & & \\
\hline
\end{tabular}


Eighteenth Century

Number of Texts: 7

\begin{tabular}{|l|l|l|l|l|l|l|l|l|l|l|l|l|l|l|l|l|l|l|l|l|}
\hline Total Number & \multicolumn{10}{|c|}{ Translation Paratexts } \\
\hline Location & \multicolumn{10}{|c|}{} & \multicolumn{10}{|c|}{5} \\
\hline Number & \multicolumn{9}{|c|}{ Independent Source } \\
\hline Subject & Lit & Lan & Geo & Phi & His & Rel & Sci & Oth & Lit & Lan & Geo & Phi & His & Rel & Sci & Oth \\
\hline Number & & 1 & & & & 1 & & & & 1 & & & & 3 & 1 & \\
\hline Language & Grk & Lat & He & Per & Syr & Ind & Oth & Grk & Lat & He & Per & Syr & Ind & Oth \\
\hline Number & & & & & & & & 1 & 3 & & & & & \\
\hline
\end{tabular}


Total Number of Classical Texts

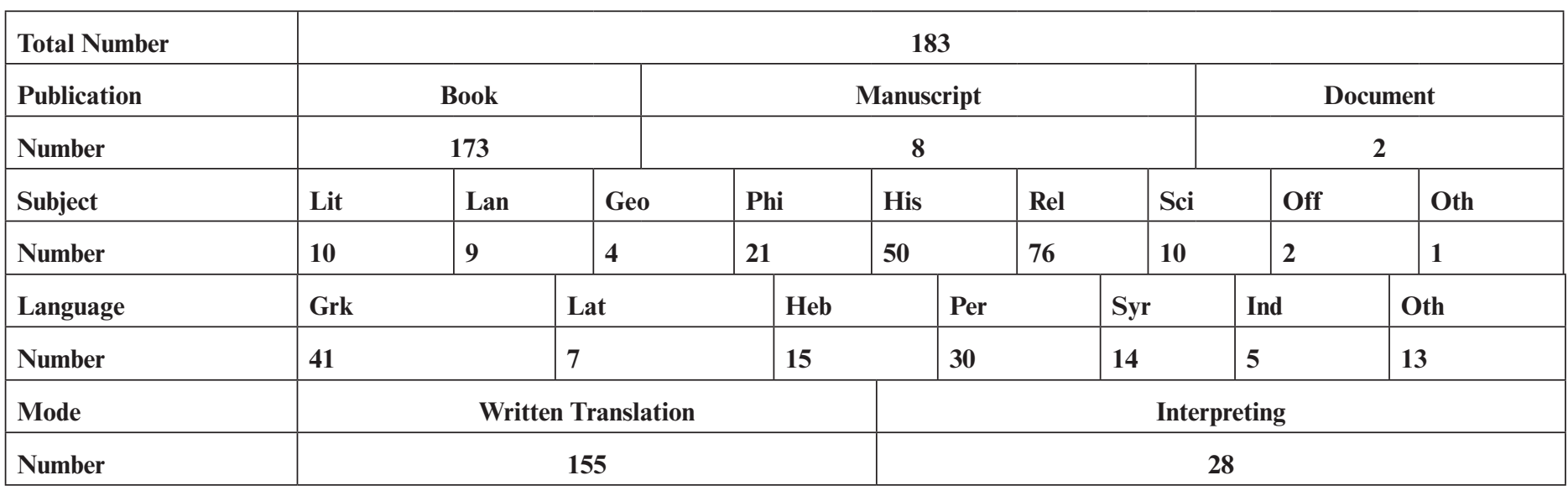




\section{Appendix 2: Statistical Tables for the Nahda Period}

1800-1830

Number of Texts: 2

\begin{tabular}{|c|c|c|c|c|c|c|c|c|c|c|c|c|c|c|c|c|c|c|c|}
\hline Total Number & \multicolumn{19}{|c|}{2} \\
\hline Location & \multicolumn{9}{|c|}{ Translation Paratexts } & \multicolumn{10}{|c|}{ Independent Source } \\
\hline Number & \multicolumn{9}{|c|}{1} & \multicolumn{10}{|c|}{1} \\
\hline Form & \multicolumn{2}{|c|}{ Book } & \multicolumn{2}{|c|}{ Periodical } & \multicolumn{3}{|c|}{ Manuscript } & \multicolumn{2}{|c|}{ Document } & \multicolumn{2}{|c|}{ Book } & \multicolumn{3}{|c|}{ Periodical } & \multicolumn{3}{|c|}{ Manuscript } & \multicolumn{2}{|c|}{ Document } \\
\hline Number & & & & & 1 & & & & & 1 & & & & & & & & & \\
\hline Subject & Lit & Lan & Geo & Phi & His & Rel & Sci & Off & Oth & Lit & Lan & $\mathrm{Ge}$ & & Phi & His & Rel & Sci & Off & Oth \\
\hline Number & & & & & 1 & & & & & & & & & & 1 & & & & \\
\hline Language & Eng & Fre & & er & Tur & Grk/ & & Rus & Oth & Eng & & re & Per & & Tur & Grk/I & & Rus & Oth \\
\hline Number & & & & & & & & & 1 & & & & & & & & & & \\
\hline
\end{tabular}


1830-1839

Number of Texts: 10

\begin{tabular}{|c|c|c|c|c|c|c|c|c|c|c|c|c|c|c|c|c|c|c|}
\hline Total Number & \multicolumn{18}{|c|}{10} \\
\hline Location & \multicolumn{9}{|c|}{ Translation Paratexts } & \multicolumn{9}{|c|}{ Independent Source } \\
\hline Number & \multicolumn{9}{|c|}{7} & \multicolumn{9}{|c|}{3} \\
\hline Form & \multicolumn{2}{|c|}{ Book } & \multicolumn{2}{|c|}{ Periodical } & \multicolumn{3}{|c|}{ Manuscript } & \multicolumn{2}{|c|}{ Document } & \multicolumn{2}{|c|}{ Book } & \multicolumn{2}{|c|}{ Periodical } & \multicolumn{3}{|c|}{ Manuscript } & \multicolumn{2}{|c|}{ Document } \\
\hline Number & \multicolumn{2}{|c|}{6} & & & \multicolumn{3}{|l|}{1} & & & \multicolumn{4}{|l|}{3} & & & & & \\
\hline Subject & Lit & Lan & Geo & Phi & His & Rel & Sci & Off & Oth & Lit & Lan & Geo & $\mathrm{Ph}$ & His & Rel & $\mathrm{Sc}$ & $\mathrm{O}$ & Oth \\
\hline Number & & & 2 & 1 & & 1 & 3 & & & & & 1 & & 2 & & & & \\
\hline Language & Eng & Fr & $\mathrm{P}$ & & Tur & Grk & Lat & Rus & Oth & Eng & & re & Per & Tur & Grk/I & & Rus & Oth \\
\hline Number & & 5 & & & 1 & 1 & & & 1 & & 1 & & & & & & & \\
\hline
\end{tabular}


1840-1849

Number of Texts: 11

\begin{tabular}{|c|c|c|c|c|c|c|c|c|c|c|c|c|c|c|c|c|c|c|}
\hline Total Number & \multicolumn{18}{|c|}{11} \\
\hline Location & \multicolumn{9}{|c|}{ Translation Paratexts } & \multicolumn{9}{|c|}{ Independent Source } \\
\hline Number & \multicolumn{9}{|c|}{9} & \multicolumn{9}{|c|}{2} \\
\hline Form & \multicolumn{2}{|c|}{ Book } & \multicolumn{2}{|c|}{ Periodical } & \multicolumn{3}{|c|}{ Manuscript } & \multicolumn{2}{|c|}{ Document } & \multicolumn{2}{|c|}{ Book } & \multicolumn{2}{|c|}{ Periodical } & \multicolumn{3}{|c|}{ Manuscript } & \multicolumn{2}{|c|}{ Document } \\
\hline Number & \multicolumn{2}{|l|}{9} & & & & & & & & 1 & & & & & & & \multicolumn{2}{|l|}{1} \\
\hline Subject & Lit & Lan & Geo & Phi & His & Rel & Sci & Off & Oth & Lit & Lan & Geo & Phi & His & Rel & $\mathrm{Sc}$ & & Oth \\
\hline Number & 2 & & 2 & & 2 & & 3 & & & & 1 & & & & & & 1 & \\
\hline Language & Eng & $\mathrm{Fr}$ & $\mathrm{P}$ & & Tur & Grk & & Rus & Oth & Eng & $\mathrm{F}_{1}$ & re & er & Tur & Grk/ & & Rus & Oth \\
\hline Number & & 8 & 1 & & & & & & & & & & 1 & & & & & \\
\hline
\end{tabular}


1850-1859

Number of Texts: 9

\begin{tabular}{|c|c|c|c|c|c|c|c|c|c|c|c|c|c|c|c|c|c|c|}
\hline Total Number & \multicolumn{18}{|c|}{9} \\
\hline Location & \multicolumn{9}{|c|}{ Translation Paratexts } & \multicolumn{9}{|c|}{ Independent Source } \\
\hline Number & \multicolumn{9}{|c|}{2} & \multicolumn{9}{|c|}{7} \\
\hline Form & \multicolumn{2}{|c|}{ Book } & \multicolumn{2}{|c|}{ Periodical } & \multicolumn{3}{|c|}{ Manuscript } & \multicolumn{2}{|c|}{ Document } & Boo & \multicolumn{3}{|c|}{ Periodical } & \multicolumn{3}{|c|}{ Manuscript } & \multicolumn{2}{|c|}{ Document } \\
\hline Number & \multicolumn{2}{|l|}{2} & & & & & & & & 4 & \multicolumn{3}{|c|}{1} & \multicolumn{5}{|c|}{2} \\
\hline Subject & Lit & Lan & Geo & Phi & His & Rel & Sci & Off & Oth & Lit & Lan & Geo & $\mathrm{Ph}$ & His & Rel & $\mathrm{Sc}$ & & Oth \\
\hline Number & & & & & & & & & 2 & & 1 & 1 & & & 3 & & 1 & 1 \\
\hline Language & Eng & Fre & $\mathrm{P}$ & & Tur & Grk/ & & Rus & Oth & Eng & $\mathrm{F}$ & & er & Tur & Grk/ & & Rus & Oth \\
\hline Number & & 2 & & & & & & & & & 1 & & & 1 & & & & \\
\hline
\end{tabular}


1860-1869

Number of Texts: 12

\begin{tabular}{|c|c|c|c|c|c|c|c|c|c|c|c|c|c|c|c|c|c|c|c|}
\hline Total Number & \multicolumn{19}{|c|}{12} \\
\hline Location & \multicolumn{9}{|c|}{ Translation Paratexts } & \multicolumn{10}{|c|}{ Independent Source } \\
\hline Number & \multicolumn{9}{|c|}{8} & \multicolumn{10}{|c|}{4} \\
\hline Form & \multicolumn{2}{|c|}{ Book } & \multicolumn{2}{|c|}{ Periodical } & \multicolumn{3}{|c|}{ Manuscript } & \multicolumn{2}{|c|}{ Document } & \multicolumn{2}{|c|}{ Book } & \multicolumn{3}{|c|}{ Periodical } & \multicolumn{3}{|c|}{ Manuscript } & \multicolumn{2}{|c|}{ Document } \\
\hline Number & \multicolumn{2}{|c|}{7} & & & \multicolumn{3}{|l|}{1} & & & \multicolumn{2}{|l|}{4} & & & & & & & & \\
\hline Subject & Lit & Lan & Geo & Phi & His & Rel & Sci & Off & Oth & Lit & Lan & G & & Phi & His & Rel & $\mathrm{Sc}$ & Off & Oth \\
\hline Number & 2 & & & & 2 & 3 & 1 & & & 1 & & 1 & & & & 2 & & & \\
\hline Language & Eng & $\mathrm{Fr}$ & $\mathrm{P}$ & & Tur & Grk & & Rus & Oth & Eng & & Fre & Per & & Tur & Grk/ & & Rus & Oth \\
\hline Number & & 4 & & & & 2 & & & 1 & & & & & & & & & & \\
\hline
\end{tabular}


1870-1879

Number of Texts: 11

\begin{tabular}{|c|c|c|c|c|c|c|c|c|c|c|c|c|c|c|c|c|c|c|c|}
\hline Total Number & \multicolumn{19}{|c|}{11} \\
\hline Location & \multicolumn{9}{|c|}{ Translation Paratexts } & \multicolumn{10}{|c|}{ Independent Source } \\
\hline Number & \multicolumn{9}{|c|}{4} & \multicolumn{10}{|c|}{7} \\
\hline Form & \multicolumn{2}{|c|}{ Book } & \multicolumn{2}{|c|}{ Periodical } & \multicolumn{3}{|c|}{ Manuscript } & \multicolumn{2}{|c|}{ Document } & \multicolumn{2}{|c|}{ Book } & \multicolumn{3}{|c|}{ Periodical } & \multicolumn{3}{|c|}{ Manuscript } & \multicolumn{2}{|c|}{ Document } \\
\hline Number & \multicolumn{2}{|l|}{3} & & & \multicolumn{3}{|l|}{1} & & & \multicolumn{2}{|c|}{5} & \multicolumn{3}{|c|}{1} & & & & \multicolumn{2}{|l|}{1} \\
\hline Subject & Lit & Lan & Geo & Phi & His & Rel & Sci & Off & Oth & Lit & Lan & $\mathrm{G}$ & & Phi & His & Rel & $\mathrm{Sc}$ & & Oth \\
\hline Number & & & & & 1 & 1 & 1 & & 1 & 1 & & & & & 1 & 5 & & & \\
\hline Language & Eng & $\mathrm{Fr}$ & & & Tur & Grk & & Rus & Oth & Eng & & Fre & $\mathrm{Pe}$ & & Tur & Grk/l & & Rus & Oth \\
\hline Number & & 1 & & & 2 & & & & & & & & & & & & & & \\
\hline
\end{tabular}


1880-1889

Number of Texts: 14

\begin{tabular}{|c|c|c|c|c|c|c|c|c|c|c|c|c|c|c|c|c|c|c|c|}
\hline Total Number & \multicolumn{19}{|c|}{14} \\
\hline Location & \multicolumn{9}{|c|}{ Translation Paratexts } & \multicolumn{10}{|c|}{ Independent Source } \\
\hline Number & \multicolumn{9}{|c|}{7} & \multicolumn{10}{|c|}{7} \\
\hline Form & \multicolumn{2}{|c|}{ Book } & \multicolumn{2}{|c|}{ Periodical } & \multicolumn{3}{|c|}{ Manuscript } & \multicolumn{2}{|c|}{ Document } & \multicolumn{2}{|c|}{ Book } & \multicolumn{3}{|c|}{ Periodical } & \multicolumn{3}{|c|}{ Manuscript } & \multicolumn{2}{|c|}{ Document } \\
\hline Number & \multicolumn{2}{|l|}{7} & & & & & & & & 1 & & \multicolumn{3}{|l|}{5} & \multicolumn{3}{|l|}{1} & & \\
\hline Subject & Lit & Lan & Geo & Phi & His & Rel & Sci & Off & Oth & Lit & Lan & $n$ & eo & Phi & His & Rel & $\mathrm{Sc}$ & Off & Oth \\
\hline Number & & & & 1 & 1 & & 3 & & 2 & 2 & 5 & & & & & & & & \\
\hline Language & Eng & $\mathrm{Fr}$ & & er & Tur & $\mathrm{Grl}$ & Lat & Rus & Oth & Eng & & Fre & $\mathrm{Pe}$ & er & Tur & Grk/ & & Rus & Oth \\
\hline Number & 1 & 5 & & & 1 & & & & & & & & & & & & & & \\
\hline
\end{tabular}


1890-1899

Number of Texts: 44

\begin{tabular}{|c|c|c|c|c|c|c|c|c|c|c|c|c|c|c|c|c|c|c|c|}
\hline Total Number & \multicolumn{19}{|c|}{44} \\
\hline Location & \multicolumn{9}{|c|}{ Translation Paratexts } & \multicolumn{10}{|c|}{ Independent Source } \\
\hline Number & \multicolumn{9}{|c|}{6} & \multicolumn{10}{|c|}{38} \\
\hline Form & \multicolumn{2}{|c|}{ Book } & \multicolumn{2}{|c|}{ Periodical } & \multicolumn{3}{|c|}{ Manuscript } & \multicolumn{2}{|c|}{ Document } & \multicolumn{2}{|c|}{ Book } & \multicolumn{3}{|c|}{ Periodical } & \multicolumn{3}{|c|}{ Manuscript } & \multicolumn{2}{|c|}{ Document } \\
\hline Number & \multicolumn{2}{|l|}{6} & & & & & & & & 4 & & \multicolumn{3}{|c|}{34} & & & & & \\
\hline Subject & Lit & Lan & Geo & Phi & His & Rel & Sci & Off & Oth & Lit & Lan & $\mathrm{G}$ & & Phi & His & Rel & $\mathrm{Sc}$ & Off & Oth \\
\hline Number & 1 & & & & 2 & 2 & & & 1 & 8 & 5 & 1 & & & 3 & 14 & 1 & & 6 \\
\hline Language & Eng & Fre & $\mathrm{P}$ & & Tur & Grk & & Rus & Oth & Eng & $\mathrm{F}$ & & $\mathrm{P}$ & & Tur & Grk/ & & Rus & Oth \\
\hline Number & 1 & 4 & & & & 1 & & & & & & & & & & & & & \\
\hline
\end{tabular}


1900-1909

Number of Texts: 103

\begin{tabular}{|c|c|c|c|c|c|c|c|c|c|c|c|c|c|c|c|c|c|c|}
\hline Total Number & \multicolumn{18}{|c|}{103} \\
\hline Location & \multicolumn{9}{|c|}{ Translation Paratexts } & \multicolumn{9}{|c|}{ Independent Source } \\
\hline Number & \multicolumn{9}{|c|}{4} & \multicolumn{9}{|c|}{99} \\
\hline Form & \multicolumn{2}{|c|}{ Book } & \multicolumn{2}{|c|}{ Periodical } & \multicolumn{3}{|c|}{ Manuscript } & \multicolumn{2}{|c|}{ Document } & \multicolumn{2}{|c|}{ Book } & \multicolumn{2}{|c|}{ Periodical } & \multicolumn{3}{|c|}{ Manuscript } & \multicolumn{2}{|c|}{ Document } \\
\hline Number & \multicolumn{2}{|l|}{3} & \multicolumn{2}{|c|}{1} & & & & & & 14 & & \multicolumn{2}{|c|}{85} & & & & & \\
\hline Subject & Lit & Lan & Geo & Phi & His & Rel & Sci & Off & Oth & Lit & Lan & Geo & Phi & His & Rel & Sci & Off & Oth \\
\hline Number & 3 & & & & & & & & 1 & 11 & 36 & 10 & 2 & 4 & 20 & 4 & & 12 \\
\hline Language & Eng & $\mathrm{Fr}$ & $\mathrm{P}$ & & Tur & Grk & Lat & Rus & Oth & Eng & & Fre & Per & Tur & Grk/ & & Rus & Oth \\
\hline Number & 1 & 2 & & & & & & 1 & & & & & & & & & & \\
\hline
\end{tabular}


1910-1919

Number of Texts: 144

\begin{tabular}{|c|c|c|c|c|c|c|c|c|c|c|c|c|c|c|c|c|c|c|c|}
\hline Total Number & \multicolumn{19}{|c|}{144} \\
\hline Location & \multicolumn{9}{|c|}{ Translation Paratexts } & \multicolumn{10}{|c|}{ Independent Source } \\
\hline Number & \multicolumn{9}{|c|}{20} & \multicolumn{10}{|c|}{124} \\
\hline Form & \multicolumn{2}{|l|}{ Book } & \multicolumn{2}{|c|}{ Periodical } & \multicolumn{3}{|c|}{ Manuscript } & \multicolumn{2}{|c|}{ Document } & \multicolumn{2}{|c|}{ Book } & \multicolumn{3}{|c|}{ Periodical } & \multicolumn{3}{|c|}{ Manuscript } & \multicolumn{2}{|c|}{ Document } \\
\hline Number & \multicolumn{2}{|l|}{3} & \multicolumn{2}{|l|}{17} & & & & & & 18 & & \multicolumn{3}{|l|}{106} & & & & & \\
\hline Subject & Lit & Lan & Geo & Phi & His & Rel & Sci & Off & Oth & Lit & Lan & $\mathrm{Ge}$ & & Phi & His & Rel & Sci & Off & Oth \\
\hline Number & 17 & 1 & & 1 & & & & & 1 & 40 & 28 & 6 & & 2 & 9 & 10 & 3 & & 26 \\
\hline Language & Eng & Fre & & & Tur & Grk & & Rus & Oth & Eng & & Fre & Per & & Tur & Grk/I & & Rus & Oth \\
\hline Number & 4 & 10 & & & & & & & 1 & & & & & & & & & & \\
\hline
\end{tabular}


Total Number of Nahda Texts

Number of Texts: $\mathbf{3 6 0}$

\begin{tabular}{|c|c|c|c|c|c|c|c|c|c|c|c|c|c|c|c|c|c|c|}
\hline Total Number & \multicolumn{18}{|c|}{360} \\
\hline Location & \multicolumn{9}{|c|}{ Translation Paratexts } & \multicolumn{9}{|c|}{ Independent Source } \\
\hline Number & \multicolumn{9}{|c|}{68} & \multicolumn{9}{|c|}{292} \\
\hline Publication & \multicolumn{2}{|l|}{ Book } & \multicolumn{2}{|c|}{ Periodical } & \multicolumn{3}{|c|}{ Manuscript } & \multicolumn{2}{|c|}{ Document } & \multicolumn{2}{|l|}{ Book } & \multicolumn{2}{|c|}{ Periodical } & \multicolumn{3}{|c|}{ Manuscript } & \multicolumn{2}{|c|}{ Document } \\
\hline Number & \multicolumn{2}{|l|}{46} & \multicolumn{2}{|l|}{18} & \multicolumn{3}{|l|}{4} & & & \multicolumn{2}{|l|}{54} & \multicolumn{2}{|c|}{232} & \multicolumn{3}{|l|}{1} & \multicolumn{2}{|l|}{5} \\
\hline Subject & Lit & Lan & $\mathrm{Gec}$ & Phi & His & Rel & Sci & Off & Oth & Lit & Lan & Geo & $\mathrm{Ph}$ & His & Rel & Sci & Off & Oth \\
\hline Number & 25 & 1 & 4 & 3 & 9 & 7 & 11 & & 8 & 63 & 76 & 20 & 4 & 18 & 55 & 8 & 3 & 45 \\
\hline Language & Eng & $\mathrm{Fr}$ & & Per & Tur & Grk & & Rus & Oth & Eng & $\mathrm{F}$ & re & Per & Tur & Grk/I & & Rus & Oth \\
\hline Number & 7 & 41 & & & 4 & 4 & & 1 & 3 & & 2 & & & 2 & & & & \\
\hline
\end{tabular}


Total Number of Nahda Texts by Means of Publication

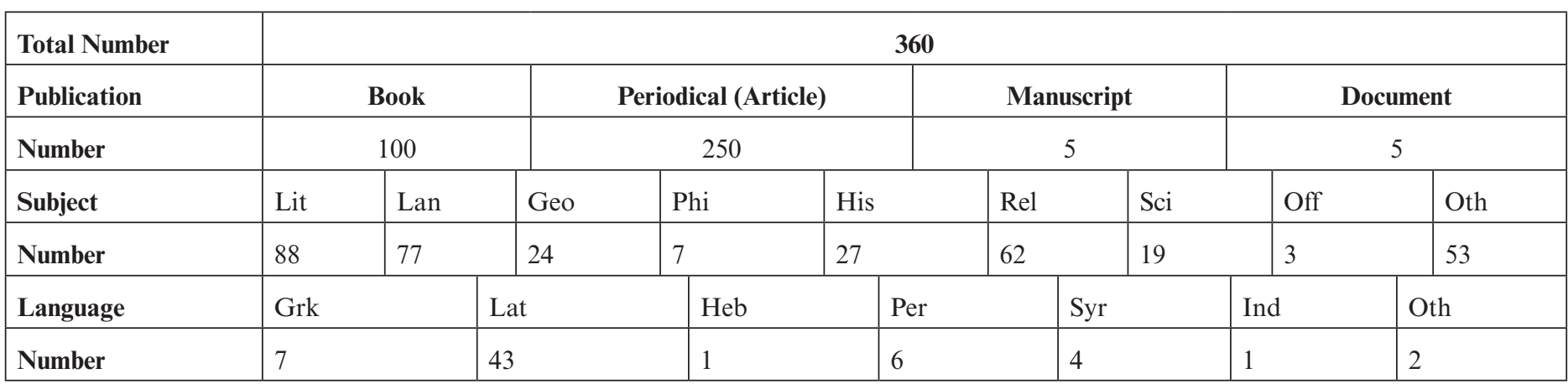

Total Number of Texts for the Two Periods

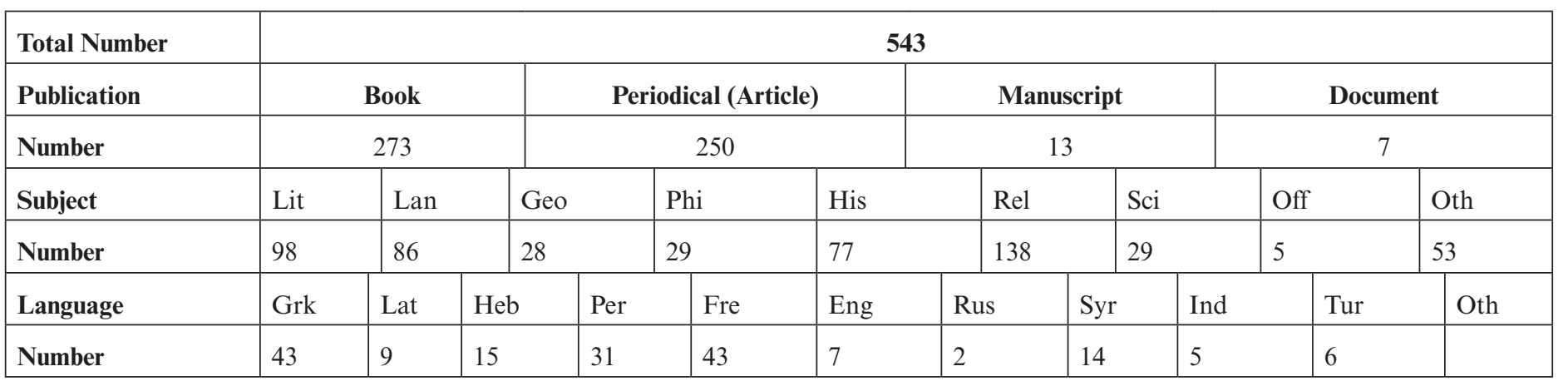




\section{Index}

al-'Abbadi, 'Udai Ibn Zaid 3

Abbasid caliph al-Mutawakkil 153

Abbasid period 23, 88-89

'Abd al Rahman Ibn Khaldun 171

'Abdo, Muhammad 277

'Abdo, T. 9

Abdulla, Adnan 6

Abu 'Abdullah al-Shafi'i 33

Abu 'Abdullah Al-Wạqidi 39

Abu al Baqa' al Kafawi's Al-Kuliya $t$ (dictionary) 25

Abu al-Hasan Al-Mas'udi 88

Abu al-'Abbas al-Qalqashandi 175

Abu al-Hasan the Fool and Harun al-Rashid (play) 215

Abu al-Walid Ibn Rushd 105

Abu Bakhr Ibn Wahshiya 67-74

Abu Ishaq Ibrahim al-Shatibi 157

Abu Jarir Al-Tabari 39

Abu Muhammad 'Abdullah 135

Abu Sa'id al-Sirafi 75

Abu Sa'id Ibn Abi al-Husain 118

Abu Shahram 95

Abu 'Uthman al-Jahidh 56

Abu al-'Abbas Ibn Abi Usaibi'a 124

Akhbar al-Zaman 121

Aleppo 42, 44, 47n6, 111

Alexandria 172

Armanusa the Egyptian 265

Ancient Books 62

Anthology of Chinese Discourse on

Translation (2006) Cheung 14

Apollonius the Carpenter [of Perga] 114

Apostles 62

Arabic history 1

Arabic poetry 292

Arabic translation, rules 193

Arabization 155, 209, 310

Arabizers 268, 288
Arberry, A. 290

Aristotle 57, 101, 105; logic 125;

Categorias 112

arithmetic 95

al-Ashtar, Malik 44

astrology 57, 90

astronomical tables 186

astronomy 279

'Athra' Quraish (The Virgin of

Quraish) 269-70

al-Azhar University 221

Babel 122

Baghdad 56, 111

de Bagno, Ranieri 133

Battle of Yarmuk 42

battles in Palestine 42

Bible: Arabic versions (ninth century)

66; Jesuit translation 241; King James

Version 238; translation 27; Vulgate 194, 225, 232, 234

British Library 12

al-Bustani, Butrus (The Levant

Herald) 24

al-Bustani, Sulaiman 291

Byzantine 112, 129

Caesar 40, 41

Calhoun, Simeon 222

Caliphs 29n2

calligraphy 175

chronological vs. thematic organization 16-17

Classical age 10, 18

Classical Arabic 1, 4, 10

copyright 265,270

Copyright Act (1842) 275

Copyright Law 339; Article (10) 340

Cramer, John Frederick (1709) 328 
Damascus 124, 171

Dante 331

Delabastita, D. 22

Dennis, James Shepard 230

deuterocanonical 232, 242

diacritical marks (shakl) 293

digital databases 12

Dioscorides of Anazarbus 130, 131

díwans (government departments) 19, 25, $98,133,180$

drugs 130,131

Edifying Plays in the Art of

Tragedy 254

Egypt 7, 28, 85, 93, 111, 118, 199;

modernization 209; women's

education 209

Egyptian National Library and Archives 12, 188

Egyptianizing 254

Encümen-i Daniş 341

English as a foreign language 325

English pursuit of fame 234

Erasmus 230

Europe 97, 238

Fagioli, Giovanni 133

Fahmi, Ahmad 316

Farrokhzad, Rostam 40, 46n1

fatwa 34, 36, 141

al-Fayumi, Sa'diya (Gaon) Ben Joseph 85

Al-Fihrist (The Index) 91

Al-Fikr al-'Ilmi al-'Arabi: Nash'atuhu wa Tatawuuruh (1998) Saliba 8

figh (Islamic jurisprudence) 33, 105

Florentines 138

Footitt, H. 45

Fra Marino 329

French occupation of Egypt 199

Frost, R. 345

Futuh al-Sham (The Conquests of Syria) 39

Galen 124; The Catalogue 49; The Causes of Breathing 53; On the Pulse 48; Sects in Medicine 49

Galen on the therapeutic method 51 gate keepers 45 geography 175 geography and history (Arabic) 88 geometry 57,95

Al-Ghaith al-Musajjam 155

Gospel 62; of Barnabas 327; missing (Barnabas) 65
Gould, R. 24

government profession 249

Greek and European rhymes and meters 301

Greek philosophers 48, 108; see also Aristotle; Plato

Greek poetry 110

Greek Thought: Arabic Culture (1998) Gutas 8

Greek/Arabic 156

Griffith, S. 2

Hadiquat al-Akhbar (The News Garden) 321

Hadith (sayings/actions of Prophet Muhammad) 33, 157

al-Halabi, Sulaiman: interrogation 203

harakat 194

Al-Hashimi's letter to al-Kindi 62

Heimburger, F. 45

heresy 192, 231

hijra 2

al-Hilal 247

Hippocrates 48, 50, 125

Hippocrates' Oath 115

Hirschler, K. and Savant, S.B. 18

history 175,291

The History of al-Jabarti 199

The Holy Bible, that is The Old

Testament and The New Testament,

Newly Translated from Hebrew and Greek 233

holy books (200 languages) 226

The Holy Scriptures in Arabic 191

Holy Spirit 64

al-Husaini, Yusauff al-Asiri 221

Ibn 'Asakir, History of Damascus 40

Ibn Abi Usaibi'a, Abu al-'Abbas 124

Ibn Battuta 25

Ibn Biląl, Muhammad 181

Ibn Fadlan 25

Ibn Hajar al-'Asqalani 33

Ibn Hazm al-Andalusi 100, 103

Ibn Ishaq, Hunain 48; Epistle 24; patronage 55

Ibn Juljul 130

Ibn Khaldun, 'Abd al Rahman 171

Ibn Munqidh, Usama (Learning by

Examples) 25

Ibn al-Munthir 35

Ibn al-Nadim, Muhammad 91

Ibn Qaiym al-Jawziya 33

Ibn Rushd, Abu al-Walid 105 
Ibn Shaiban, Tariq 44

Ibn Sina 109

Ibn Taimiya, Taqi al-Din 141

Ibn Wahshiya, Abu Bakhr 67-74

Ibn Yunus, Matta 59, 105; and Abu

Sa'id al-Sirafi (debate) 21

Ibrahim, Hafidh 285

i'jaz 27

Iliad (Homer) 291

Imams (religious leaders) 33

Imperial Library of Vienna 328

intellectual property rights 274

interpreters in wars 40

interpreting 25

Islamic empire 2, 120

al-Jabarti 199

Al-Jahidh 59

al-Jahidh, Abu 'Uthman 56

Jaridat Lubnan (Lebenon

Newspaper) 221

Jesuit missionaries 231

Jewish scholars 87

Jews 37, 85; in Andalusia 333

jihad 235

Joachim (governor of Aleppo) 44, 47n6

katib 180

The King's Mistress 318

Kitáb al-Haiawan (The Book of

Animals) 56, 59

knowledge, universal 74

al-Kushtaj 92

L-rhymed poem 155

Lefevere, A. 55

Levant 7, 206

librarianship 175

logic 75-84, 100, 104

al-Maghreb 172

Al-Mas'uddi, Abu al-Hasan 88

Mamluk period 26

marginalia 330

La Marseillaise 353

mathematics 57, 58

meaning 156

medicine 95; see also Galen;

Hippocrates; physicians

metaphors and similes 324

methodology 11,24

minting house 281

The Miser 212

Les Misérables 285
al-Mișri, 'Ali 'Umar 349

modern Arabic theater 212; prosa, opera 213

modernization 7

morality 316

Muhammad, Prophet of Islam 2, 36, $101,144,335$

Muhammad 'Ali Pasha 8, 20, 209

al-Muqaddima (The Introduction) 173

al-Muqtataf (magazine) 304

Murshid al-Mutarjim al-Hadith 323

Murshid al-Talibin ila al-Kitáb al-

Muqqadas al-Thamin 222

music 57, 95, 212

Muslim-Christian polemics 61

Nabataean Agriculture 67-74

Nahda (renaissance) 7, 10, 18

al-Naqqạsh, Marun 212

Ni'matalla, Ernest 353

novels 268, 320

novels of al-Hilal 273

Nu'mani, Shibli 277

Old Testament, Jewish scholars 231

Ottoman Empire 10

Ottoman French Truce 200

panegyric 106, 107

patronage, The Epistle (Hunain) 55

periodization 18

Peter of Toledo 61

philosophy 94, 95

Physical Space, Social Space and Habitus

(Bourdieu) 173, 174

physicians 124-132; Syriac 128

Pisans 134

Plato 57

poetry $56,331,343,354 \mathrm{n} 2$; universal laws 105

Pope Sixtus V 329

Pope Urban VIII 191, 192

Porcellino, Neri 135

prayers 181

primary sources 11

printing press 232, 234, 244

Prophet Muhammad (PBUH) 2, 36, 101, 144, 335

Protestant Translation of the Bible 220

Ptolemy Philadelphus 116

al-Qalqashandi, Abu al-'Abbạs 175

al-Qarawiyyin 171

Al-Qiftị, Jamal al-Dinn 111 
qiyas 38n5

Qur'an 39, 63, 147, 332; meaning/ utterance dichotomy 186; translation 27,181

“The Received Text" [Textus Receptus] 230 religion, to err in 58

religious doctrine 74

Richardson, J. 235

Rida, Rashid 277

al-Rifa'i, Yahia Ibn 'Ali 188

rights of printing and translation in Egypt 270

"The Rights of Translation and Rights of Authorship" 267

al-Rihani, Amin 343

rime masculinelfeminine 353

al-Rizzi, Sarkis Ibn Musa 191

Rodet, Augustin 241

Rundle, C. 21

Sa'ada, Khalil 327

al-Safadi, Salah al-Dimn 155

al-Shafi'i, Ābu 'Abdullah 33

al-Shatibi, Abu Ishaq Ibrahim 157

al-Sirafi, Abu Sa'id 75

The Scandals of Translation (Venuti) 274

Schleiermacher, F. 97

School of Medicine at Abu Za'bal 210

School of Oriental and African Studies

(SOAS) library 12

secondary sources 11

The Seekers' Guide to the Precious

Bible 222

Shahnameh 295

Shakespearean drama 9

Shami (Syrian, Levantine) 206

Shari'a law 10

al-Shidiaq, Ahmad Faris 234

Sibawaih 189, 190n3

Siege of Aleppo 42

similes and metaphors 324

Smith, Eli 220

sociology $171,173,174$

Stephanus, Robert 230

Subh al-A'sha fi Sina'at al-Insha 175

Sunni Islam 33

Syriac 113, 117, 122; physicians 128
Taghribirdi 139, 140

Al-Tabari, Abu Jarir 39

al-Tahtawi, Rifa'a 210

Tarjamat al-Tawrat al-Samiriya (The Translation of the Samaritan Torah) 118

tarjama (translation) 3, 25

teaching translation, benefits 349

tiatr (theater) 214

Timur's siege of Damascus 171

tongues $64,121,122$

Torah 85-87, 118

translation: commercial/political 207; methods 156; as profession 133; teaching 28

translator-writer simpatico 289

Translators Through History (Delisle and Woodsworth) 1

treaties between the Mamluk state and Italian cities 137

Ulugh Beg 190

Al-Um (The Exemplar) 33

Umayyad: Caliphate 8; period 281

universal knowledge 74

'Uthman Jalal , Muhammad 253

Van Dyck, Cornelius 220

Venuti, L. 97, 289

Vulgate Bible 194, 225, 232, 234

al-Wakil 272

Al-Wạqidi, Abu 'Abdullah 39

Western orientalism 238

Whims of Youth 318

women's education (Egypt) 209

Wood, C. 346

al-Yaziji, Ibrahim 241

al-Yaziji, Naisif 221

Zaidan, Jurji 247, 265

zakat (Islamic alms giving) 87

Zaki Pasha, Ahmad 249

$z i j$ (astronomical handbook) 190

al-Zobah 63, 66n3

zoology 56 


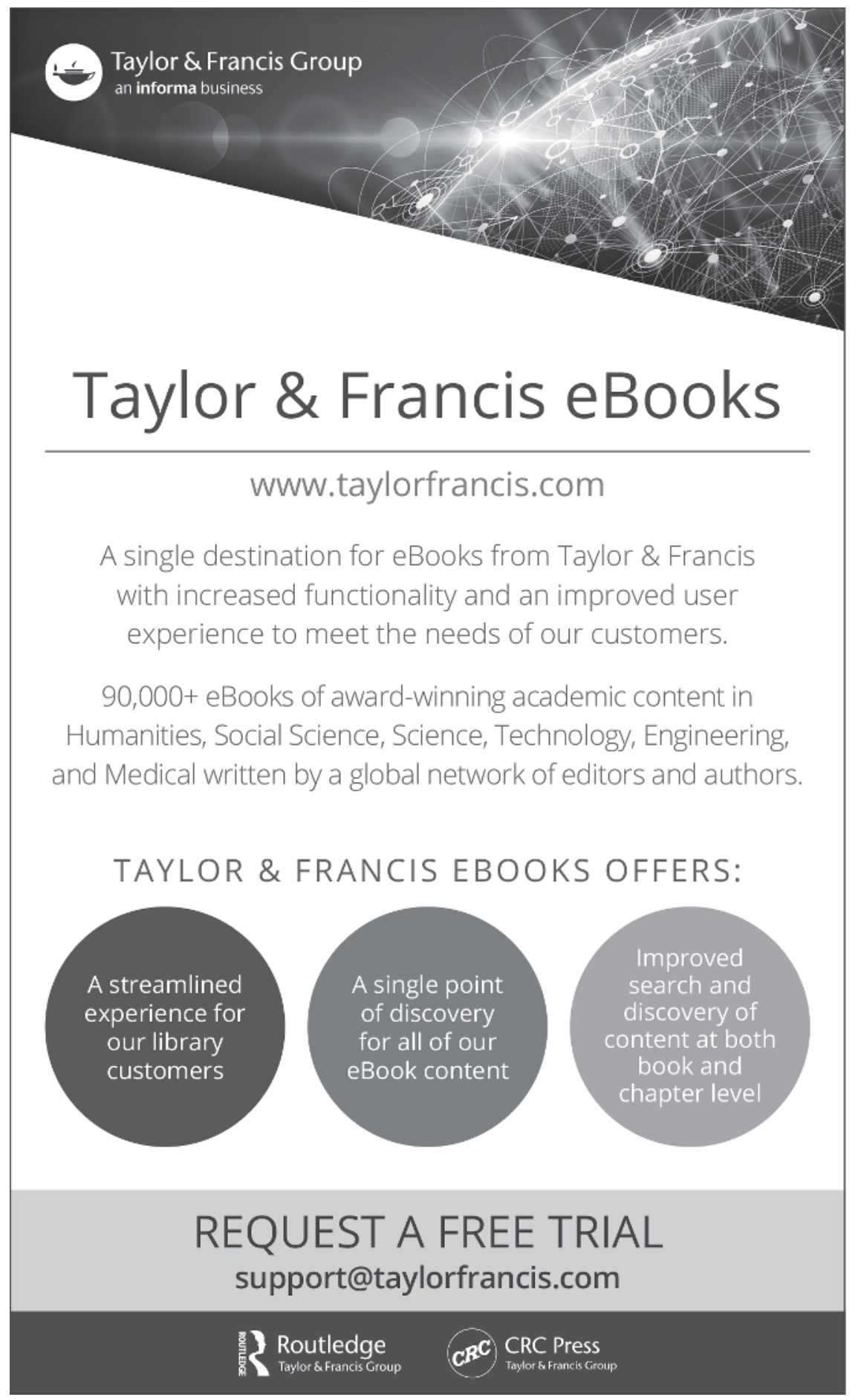

